\title{
ESSENTIALS IN HISTORY
}

$$
\text { BSSENTIALS IN }
$$

\section{AMERICAN HISTORY}

\section{ALBERT BUSHNELL HART}



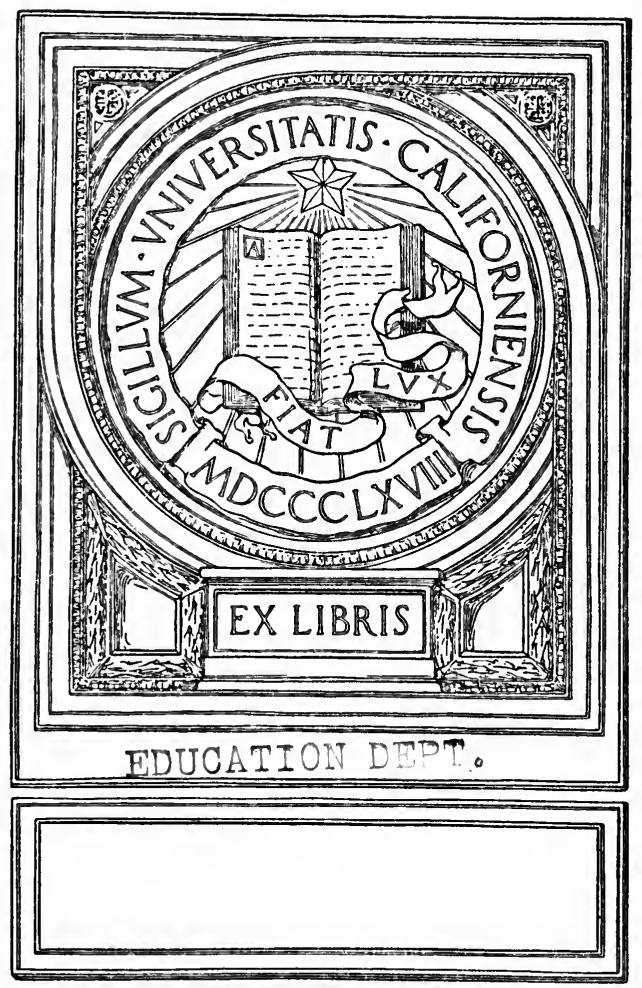
toharles H. Jhompen. Section II Rour 6 Seat 10 Hatory 7 .

S. R.H.S. 



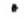




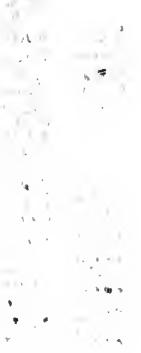




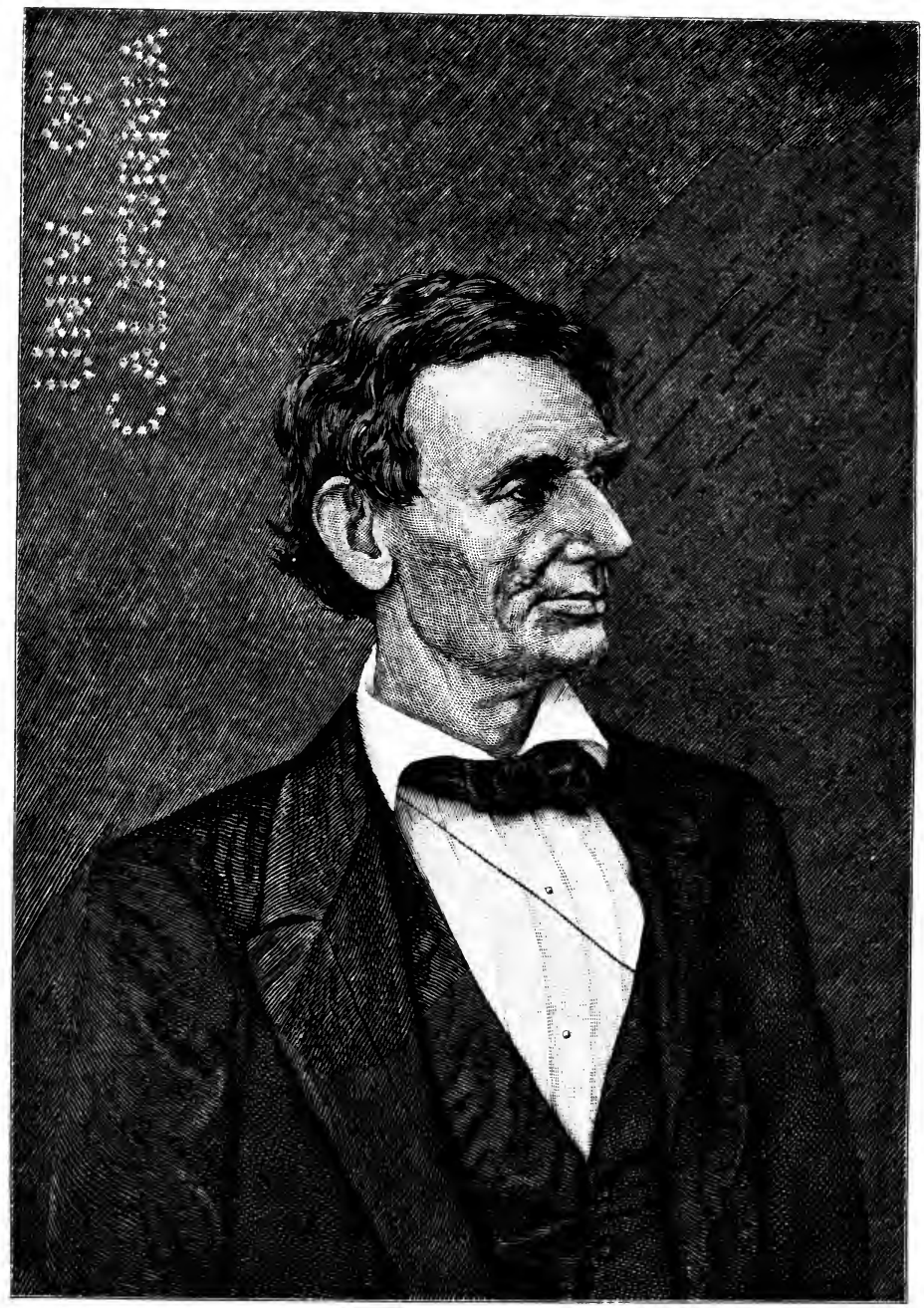

Abraham Lincoln in 1860. 


\section{ESSENTIALS IN HISTORY}

\section{ESSENTIALS}

IN

\section{AMERICAN HISTORY}

(FROM THE DISCOVERY TO THE

PRESENT DAY)

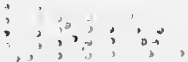

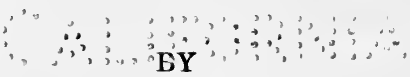

ALBERT BUSHNELL HART, LL.D.

PROFESSOR OF HISTORY, HARVARD UNIVERSITY

NEW YORK •:• CINCINNATI •:• CHICAGO

AMERICAN BOOK COMPANY 


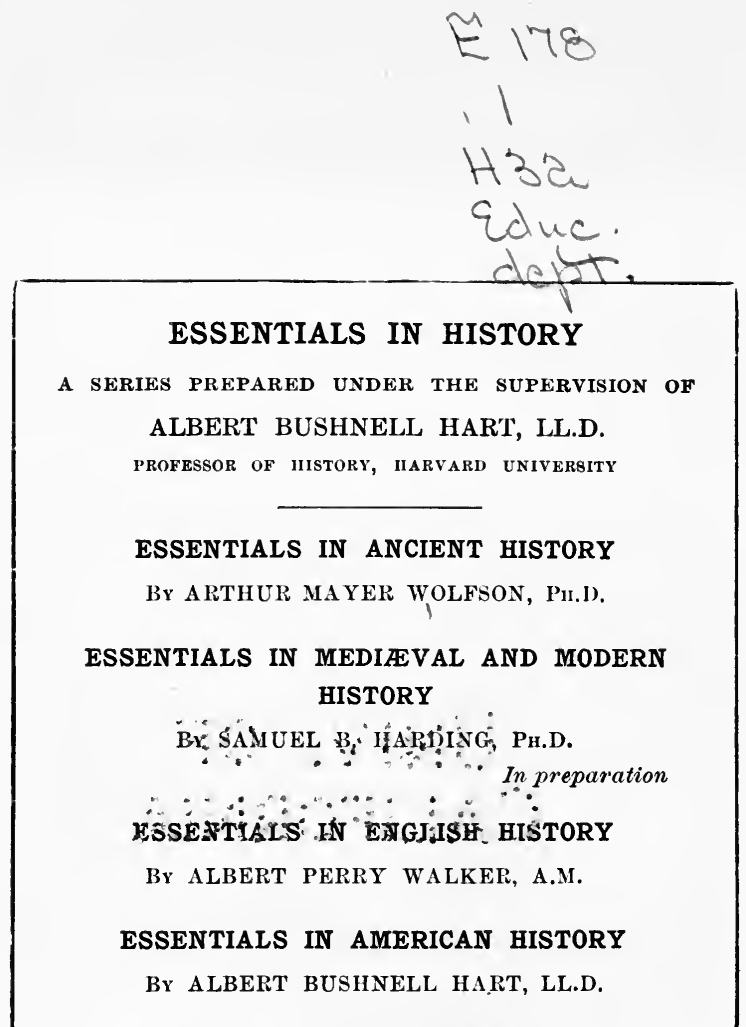

\section{EDUCATION DEPT,}

Copyright, 1905, ву

ALBERT BUSHNELL HART.

Entered at Stationerg' Hall, London.

EBSEN. AMER. HIBT.

w. P. 3 


\section{THE AUTHOR TO THE TEACHER}

THE simple system of study and teaching, which this book is intended to make easy, may be summarized as follows:-

(1) The text-book should be carefully read and studied by the pupils, so that they may have a sense of the movement and proportion of the history of their country and may know a body of useful facts. The names, events, and dates which seen to the author essential go directly into the text; dates in parentheses are of less importance and are inserted merely to show the progress of events.

(2) Class exercises will necessarily be based upon the text-book, with such methods of question, "quiz," "fluents," "cards," and the like as the teacher may feel inclined to use; but he should always aim to recall previous lessons which have a bearing on the day's subject and to enlarge on the text when possible.

(3) Reading outside of the text-book is requisite for any good course in history. The whole story of the nation's development can not be told in five hundred pages. The rules of arithmetic are true, but they need practical illustration; in like manner history is apt to seem dry without the additional interest of reading about some things in more detail than can be included in one brief book. The number of reference books necessary for a school to provide is not large. The reading references at the end of each chapter are intended to serve both teacher and pupil, by sending them to a few selected and brief readings. Exact titles of most of the books mentioned will be found in Appendix B. Besides formal histories, the bibliographies include "Illustrative works," that is, narratives, novels, poems, and like literary illuminations of the subject.

(4) Written work has become one of the effective adjuncts of historical study in secondary schools: it may take the form of essays, based on secondary authorities; of reports, based in whole or in part on sources; of brief "judgment questions," set during class ; of "written recitations;" or one of many other forms. The list of books at the end of each chapter will facilitate such work. The "Suggestive topics" can all be prepared from the text-book, plus a few general histories, biographies, encyclopedias, and like accessible books. 
The "Search topics" are more specific, and require the use of a larger range of secondary writers, and in many cases of sources. Of course a school pupil's use of sources is a very different thing from the long accumulation of material and the weighing of all available evidence which characterize the historian's research; but "sources" are simply records made at or near the time of events by people in a position to know what was going on. Well-selected sources are valuable to pupils because they bring home to the mind the realities of history, they emphasize the human element, they vitalize. Such books as Bradford's Plimoth Plantation, Franklin's Autobiography, Lincoln's Works, reveal great men and also characterize great times. Besides the separate sources and collections of sources in the lists, the marginal references in the text are in all cases to the source of some quotation there printed.

(5) Geography and map work, oral and written, are aided by the abundant maps in the text, and by references at the end of the chapters to a few authorities on the historical geography of the United States.

In using this book, then, the author hopes that the text will be found interesting enough to carry students along from week to week ; that it will be the background of class exercises; that through the lists of references, and still more through the expert direction of the teacher, the pupil will add intelligent collateral readings; that some written topics will be prepared on subjects suggested at the ends of the chapters or provided by the teachers, including the use of sources; and that the book will be a basis of geographical study.

The point of view of the volume is that a complete history of the United States must include all things memorable in the upbuilding of the country, and that a text-book must so fully describe several different classes of memorable things, as to be serviceable where there is no opportunity for additional reading or written work: (1) Political geography is, of course, the background of all historical knowledge; it is a special topic throughout this book, and should be the basis of the teacher's work. (2) While trying to make perfectly clear what were the aims and the main incidents in our various wars, the treatment includes only the most significant battles, sieges, campaigns, and military and naval movements. (3) The development of government has been treated as evidence of the purpose and spirit of our ancestors and also to connect the study of history and of civil government. (4) Foreign relations and the diplomatic adjustment of controversies have received special attention. (5) Social condi- 
tions and events have been freely described, because they are among the most important causes in national development. (6) Much attention has been given to economic data, as, for example, the discovery of gold in California, the invention of the reaper, the perfection of the trolley car. (7) All sections of the Union have helped to make the Union; and all sections, North, South, West, and far West, have been included in the plan of this volume. (8) Since what makes a nation great is the greatness of its people, this book aims to make distinct the character and public services of some great Americans, the details of whose lives are briefly set forth in special sections of the text. (9) Toward the end, a chapter sums up the services of America to mankind.

The illustrative material has been gathered from many places, and includes no map or picture which does not add to an understanding of the subject. With the exception of reproductions of a few famous paintings, to show an artist's conception, the pictures are all realities, intended to put before the pupil in visible form the faces of public men, the surroundings of famous events, and some of the great statues and buildings. Additional pictures are suggested in the lists of books at the ends of the chapters. Besides a series of general maps, showing the progress of discovery and settlements, the territorial claims of European powers, and the creation and suldivisions of the United States, there are many special maps illustrating boundary controversies, campaigns, etc.

For the teacher's use and as a guide to the pupil's reading and written work, the Brief List of anthorities noted in Appendix A is especially commended; and the work of teaching and studying will be made easier and pleasanter by the purchase of the twenty-fivedollar library there described. A school library ought also to have a judicious selection out of the long list in Appendix B.

The dates and statements of fact throughout the volume have been verified by Mr. David M. Matteson.

Whatever the lack of skill in combining into a unity the broad and manifold phases of a great nation's life, I have at least tried to write about things that count, to describe events which give us pride in being Americans, to set before my young countrymen ideals that have made for national greatness.

ALBERT BUSHNELL HART. 


\section{CONTENTS}

\section{BEGINNINGS}

I. Foundations of American History . . . . 13

II. The Century of Discovery (1492-1605) . $\quad$ - $\quad$ - 31

\section{COLONIAL ENGLISHMEN}

III. The English in America, 1607-1660 . . . . $\quad 45$

IV. Rivals of England, and the Great West (1603-1689) $\quad 65$

V. Expansion of the English Colonies, 1660-1689 . . 77

\section{COLONIAL AMERICANS}

VI. Colonial Life $(1700-1750)$. $\quad$. $\quad$. $\quad . \quad$. 91

VII. Internal Development, 1689-1740 $\quad . \quad$. $\quad . \quad \cdot \quad \cdot \quad \cdot 107$

VIII. Wars with the French $(1689-1763)$. $\quad . \quad$ • $\quad$ • $\quad$. 122

\section{REVOLUTION}

IX. Quarrel with the Mother Country (1763-1774) . . 135

X. Birth of a New Nation (1774-1776). $\quad$ • $\quad$. $\quad .149$

XI. The War for Independence (1776-1783) . . 165

\section{FEDERATION}

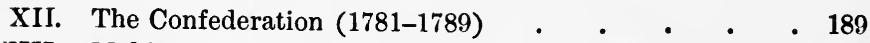

XIII. Making the Federal Constitution (1787-1789). $\quad . \quad 206$

\section{ORGANIZATION AND EXPANSION}

XIV. The American People from 1780 to 1800 . . . 220

XV. Organizing the Government (1789-1793). . . . . 235

XVI. Federalist Policy (1793-1801) . . . . . . 249

XVII. Expansion of the Republic (1801-1809) . . . . . 261

XVIII. War with Great Britain (1809-1815) . . . . 277 


\section{NATIONAL DEVELOPMENT}

XIX. Settling the West (1800-1820) . . . . . $\quad \begin{gathered}\text { PAGE } \\ \mathbf{2 8 9}\end{gathered}$

XX. The New National Spirit (1815-1829) • . . . 303

XXI. New Political Issues (1829-1841) • . . . . 316

\section{SECTIONALISM}

XXII. Social and Sectional Conditions (1831-1841) . . . 338

XXIII. Renewed Expansion (1841-1847) . . . . . . 353

XXIV. Results of the Mexican War (1848-1853) . . $\quad$. 369

XXV. Foreshadowing of Civil War (1853-1859) . . . . 383

\section{CIVIL WAR}

XXVI. The Crisis (1859-1861) • . . . . . . 401

XXVII. North and South in 1861 . $\quad . \quad$. . . . . 419

XXVIII. Period of Uncertainties (April, 1861-December, 18(i:) . 433

XXIX. Emancipation and Military $\Lambda$ dvance (1862-1863) . . 455

XXX. End of the War (1864-1865) • . . . . . 470

\section{REORGANIZATION}

XXXI. Reconstruction of the Union (1865-1875) . . . 491

XXXII. New Foundations (1875-1885) . . . . . 511

XXXIII. Economic and Social Issues (1885-1897). . . $\quad \vdots 525$

\section{THE NEW REPUBLIC}

XXXIV. The Spanish War and its Results (1897-1903) • . 551

XXXV. What America has done for the World . . . . 565.

XXXVI. The Twentieth Century . $\quad$ • $\quad$ • $\quad$ • $\quad$ • $\quad$ • 579

\section{APPENDICES}
A. Brief List of Books
B. General Bibliography
C. Declaration of Independence, 1776
D. Constitution of the United States, 1787
E. Proclamation of Emancipation, 1863
F. Joint Resolution for Intervention in Cuba, 1898
G. States of the Union

$$
\begin{aligned}
& \text { - } \mathbf{i} \\
& \text { - Iif } \\
& \text { xxix } \\
& \text { Xxx }
\end{aligned}
$$$$
\text { - } x i
$$$$
\text { - xiv }
$$$$
\text { xxvii }
$$ 


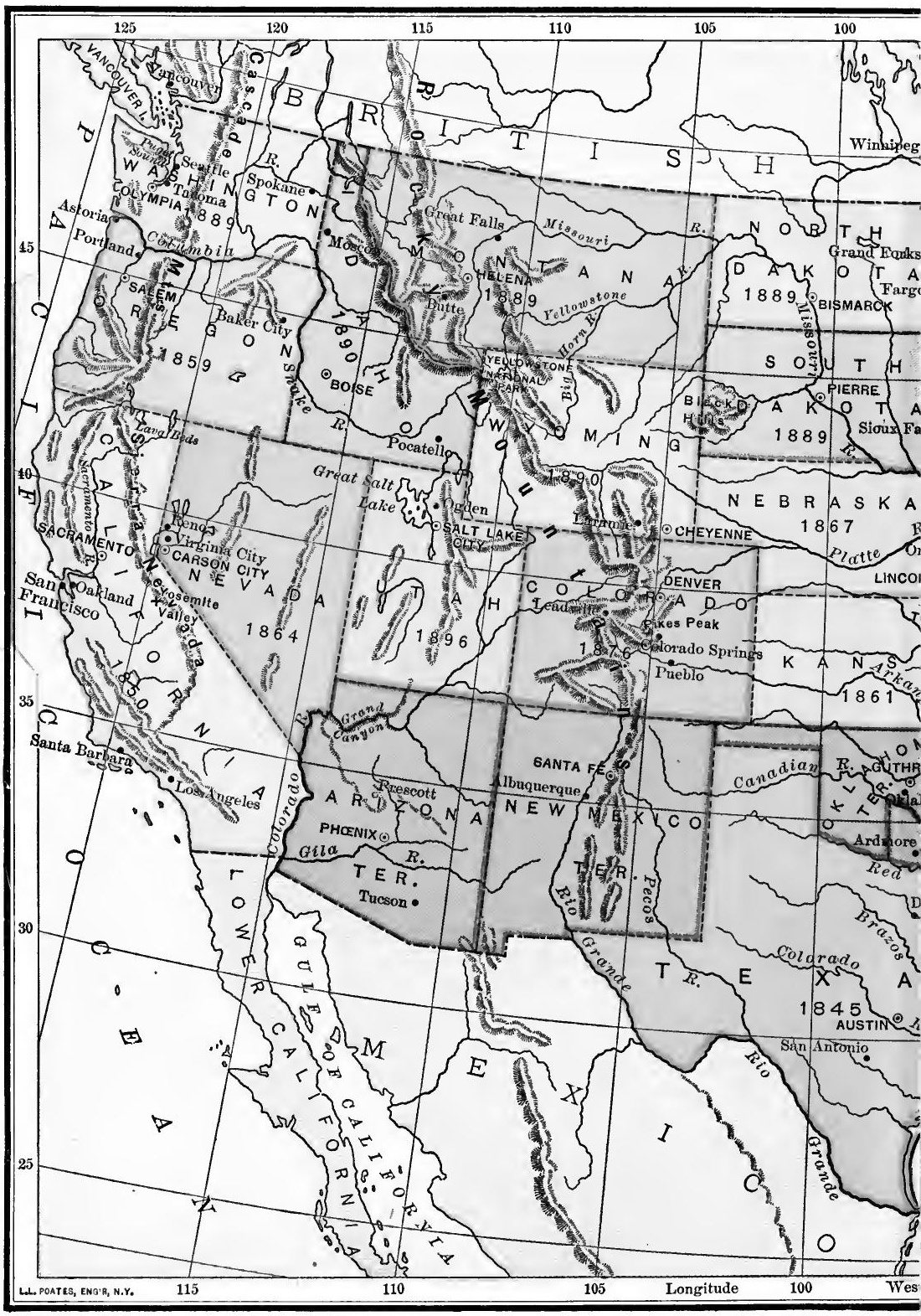




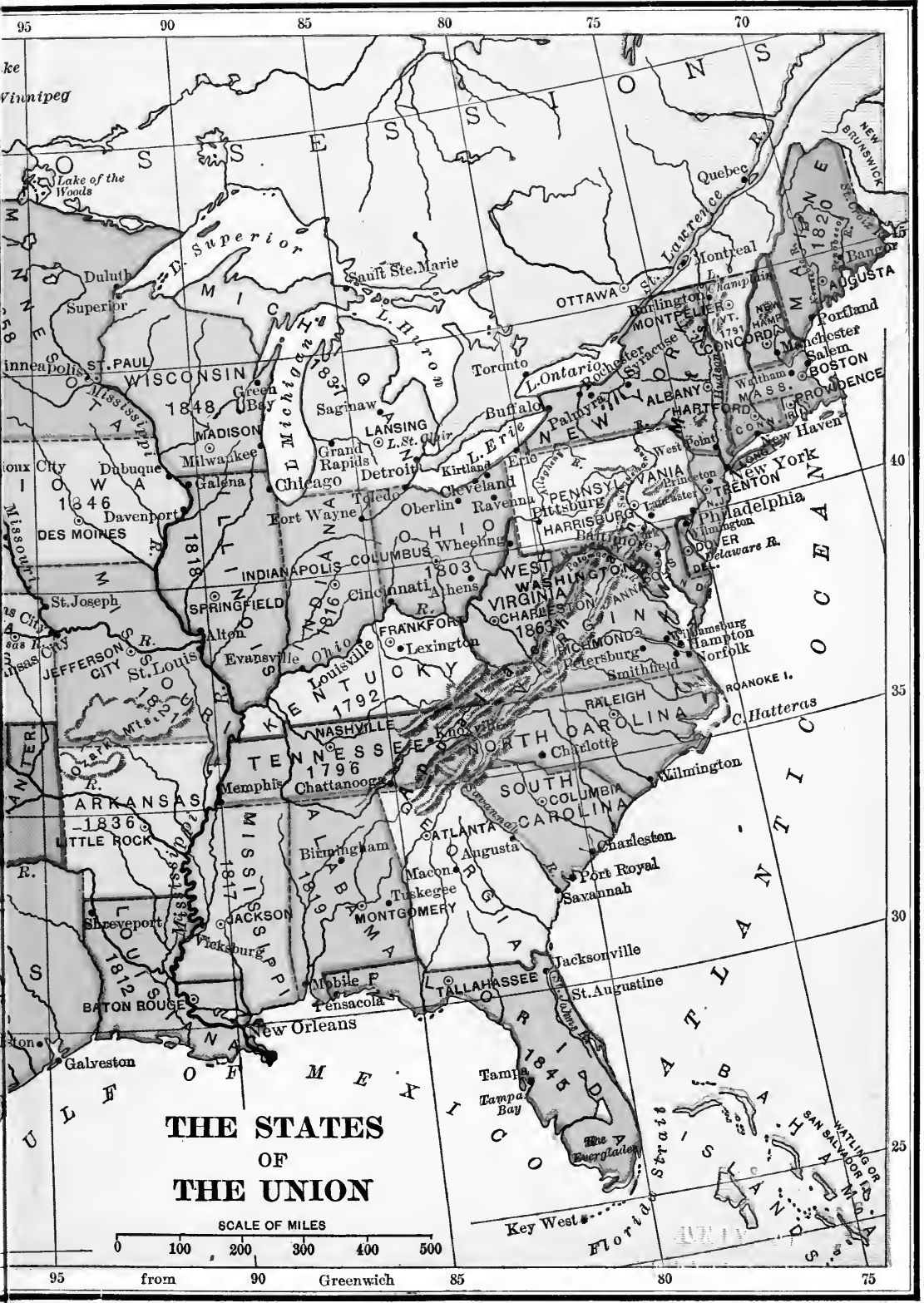




\section{REFERENCE MAPS}

PAGES

The States of the Union (at present) $\quad$ - $\quad$ - $\quad$ - $\quad$ • $\quad$ - 10,11

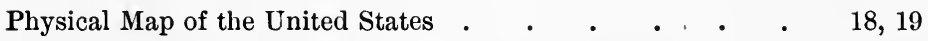

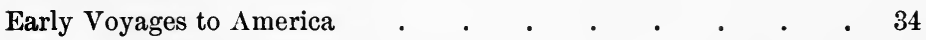

French and Indian War, showing Chain of French Forts, 1754,

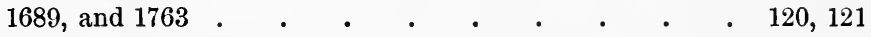

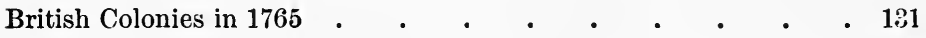

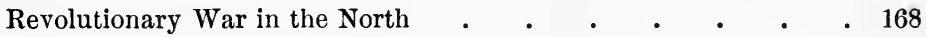

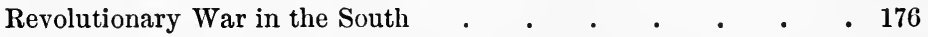

The United States, 1783 ; State Claims to Western Lands 190

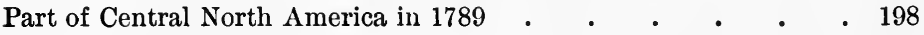

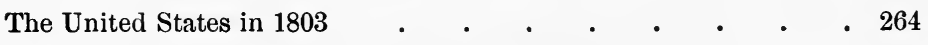

Roads and Waterways to the West in 1825 . $\quad$ • $\quad$ • $\quad$ • $\quad 291$

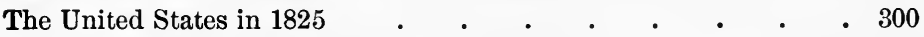

Railroads and Waterways of the United States in $1850 \quad$ • $\quad$ • 324, 325

The United States in 1850 •

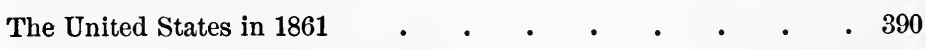

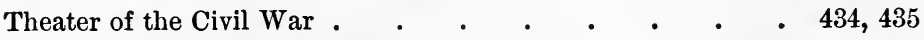

Principal Railroads of the United States, $1885 \quad$ • $\quad$ • $\quad$ • $\quad$ • 516

Territorial Development of the Continental United States, 1776-1866 567 


\section{ESSENTIALS IN AMERICAN HISTORY}

\section{CHAPTER I. \\ FOUNDATIONS OF AMERICAN HISTORY}

Where does American History begin? The true fathers of America are the men of various European countries, especially of England, who, three centuries ago, had the courage to voyage unknown seas, and the persistence to plant colonies across the ocean. They brought with

1. Dawn of American history them the religion, language, laws, and methods of government to which their ancestors were accustomed; and hence the early history of America was really a part of European history; the first American colonists were simply Spaniards, Portuguese, or Frenchmen in America; and the English settlers who, to better their condition, removed over seas, looked upon themselves as still a part of the English people. When that bond was broken by the Revolution of 1775 , the United States became at once one of the family of civilized nations; and by commerce, by the immigration of foreigners, by the sharing of the world's literatures, by interchange of inventions and principles of government, our history has always been inextricably connected with that of Europe.

The discovery of America was a result in great part of that new spirit of interest in the past, and curiosity about the world, which we call the Renaissance. When, about the year 1300, men began to go back to the beauty and power of ancient writers and the ancient works of art,

2. Spirit of enlargement interest in nature and the desire to know her secrets sprang up again with passionate force. Hence, when a new commercial route to India was needed, men were willing to take great 
risks, to penetrate into the unknown western ocean, and to explore a land as yet undreamed of.

A new spirit speedily showed itself in improvements in navigation, and especially in two inventions (both previously known in Cinina) which helped discovery and exploration: (1) guxpoúder, ferhaps discovered in Europe by Roger Bacon, and first used in war about 1350, enabled the invaders of America to beat the savages; (2) printing with movable types, probably first used by Gutenberg in 1450, served to spread the fame of the new world.

The art of navigation was steadily advancing. Sea-going ships had keels and single rudders, were fitted with heavy 3. Seafar- spars and square sails, and for defense from the seas and ing

from enemies were provided with high bulwarks, forecastles, and aftercastles. There was little distinction between merchantmen and war ships: in time of war the trader took

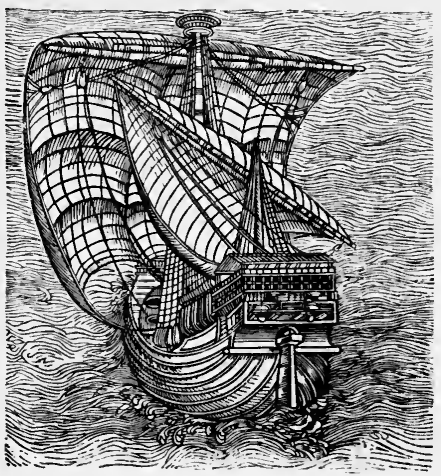

ShIP of ABOUT 1450.

From a drawing ascribed to Columbus. on a few more guns and men and became a fighting cruiser. Naval science was immensely aided by four inventions, which by 1450 were widely used : (1) The wondrous art of sailing on the wind, discovered by the Norsemen, gave confidence to men on long voyages. (2) The magnetic compass was a guide far ont of sight of land, and when the stars were not visible. (3) The astrolabe enabled the mariner roughly to estimate his distance from the equator. (4) The portolano, or sea chart, assembled what was known about the seas and coasts.

The prelude to American history was the attempt to establish new relations between Europe and Asia. In 1450 Europe 


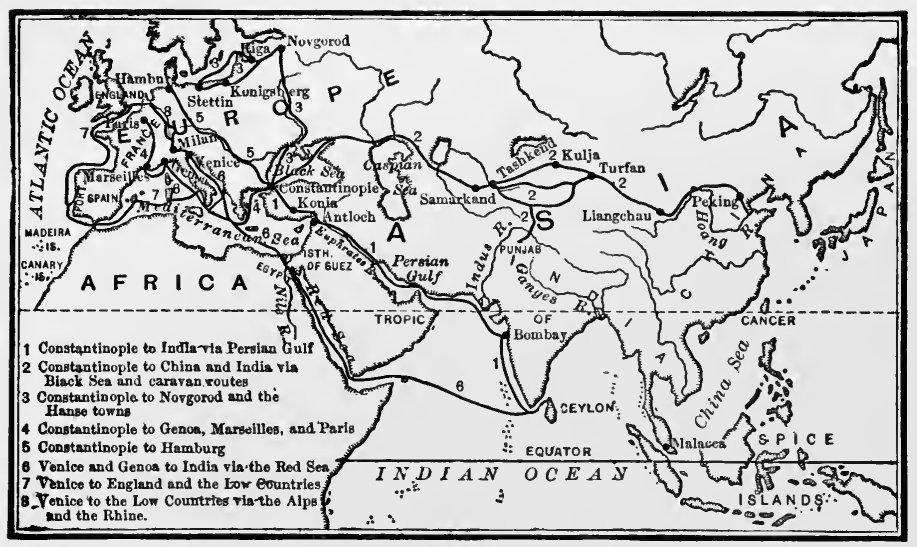

Mediaval Trade Routes.

had no direct intercourse by sea with India, China, and Japan; eastern products found their way westward only by transfer across the Isthmus of Suez, or by a slow and expen-

4. Europe and the

East sive caravan journey across Asia, over routes which were broken in two by the fierce Turks when they took Constantinople in 1453. Where were Europeans thenceforward to get the carpets and the silks, the pearls and the cotton goods, the sweet white powder that men called sugar, the gums, and the pepper that sometimes sold for its weight in gold dust?

One European, Marco Polo, actually crossed Asia and

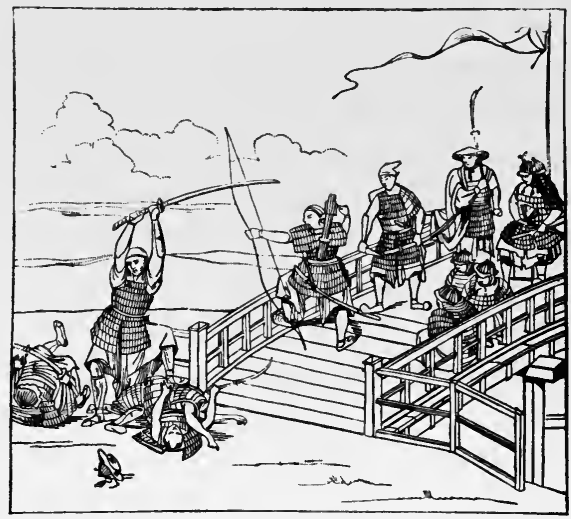

Battle of Japanese and Chinese in Marco Polo's Time.

From an ancient Japanese drawing. 
reached the Chinese coast about 1292, and thus reported: "And I tell you with regard to that Eastern Sea of Chin, Yule, Polo, according to what is said by the experienced pilots and II. 246 mariners of those parts, there be 7459 Islands in the waters frequented by the said mariners. ... And there is not one of those Islands but produces valuable and odorous woods ... and they produce also a great variety of spices." In course of time the question began to be asked, Why might not the Spice Islands and Japan be reached by sea from western Europe? - hence attempts were made to find a water passage around Europe by the Arctic Ocean, and around Africa by the Atlantic Ocean.

Moreover the learned men of the Renaissance discovered that the ancients believed that the world is round. A strange book of wonders, called the Travels of Sir John Mandeville, which is dated 1322, says, "For when the sun is east Pollard, in those parts towards paradise terrestrial, it is then Mandeville, midnight in our parts of this half, for the roundness of 249

the earth. For our Lord God made the earth all round in the midplace of the firmament." By 1470 the Florentine astronomer Toscanelli actually figured out the circumference of the earth at almost exactly its true length. If the world was really round, why might not India be reached by sailing westward instead of eastward?

Such a question could best be solved by the maritime nations of western Europe - by Spain, France, England, and Portugal. 5. The colo- The adventurous Portuguese by 1450 had already disnizing nations covered the four groups of the Canary, Madeira, Cape Verde, and Azores or Western Islands. Under the direction of Prince Henry the Navigator, they pushed down the west coast of Africa; but on his death (1460) they had reached no farther south than Sierra Leone.

The neighbor and great rival of Portugal was Spain; in 1469 the marriage of Ferdinand of Aragon with Isabella of 
Castile brought under one sovereignty the Christian parts of that land. In 1492, by the conquest of the Moorish kingdom of Granada, the way was opened for a great Spanish kingdom. Twenty-seven years later Charles V., king of Spain and ruler of the Netherlands (grandson of Ferdinand and Isabella), by his election as German Emperor, brought Spain into the heart of European politics. Spain built a powerful navy, and organized an infantry which could defeat knights in armor, and was almost invincible by other footmen; for many years Spain remained the strongest state in Europe.

The immediate theater of American history lay unknown beyond the Atlantic. The Europeans of the fifteenth century thought of the world as consisting of only three parts Europe, Asia, and Africa. It required a generation of 6. America; the Atlantic explorers after 1492 to evolve the idea that North slope America is not part of Asia; more than a century elapsed before men generally began to think of it in its true proportions, and its true relations to the rest of the world. Nevertheless the physical character of the land constantly had a controlling effect on the course of discovery and colonization; and therefore it must be considered among the essentials of American history.

The Atlantic coast of North America abounds in deep and sheltered bays and estuaries which make fine harborage, and helped the early settlers in their seafaring. The coast is bold and rugged as far south as Cape Ann; and the country inland, as far south as the Hudson, is hilly and stony and abounds in waterfalls. Farther south lies a low coast plain which gradually widens till it reaches Georgia, and thence stretches westward along the Gulf of Mexico to Texas. Its sandy coast is fringed with shallow lagoons, partly inclosed by long, narrow islands.

Up to the foothills of the Appalachians the south country is flat and fertile, and well adapted to agriculture. The water powers at the head of navigation on the sluggish rivers afford 


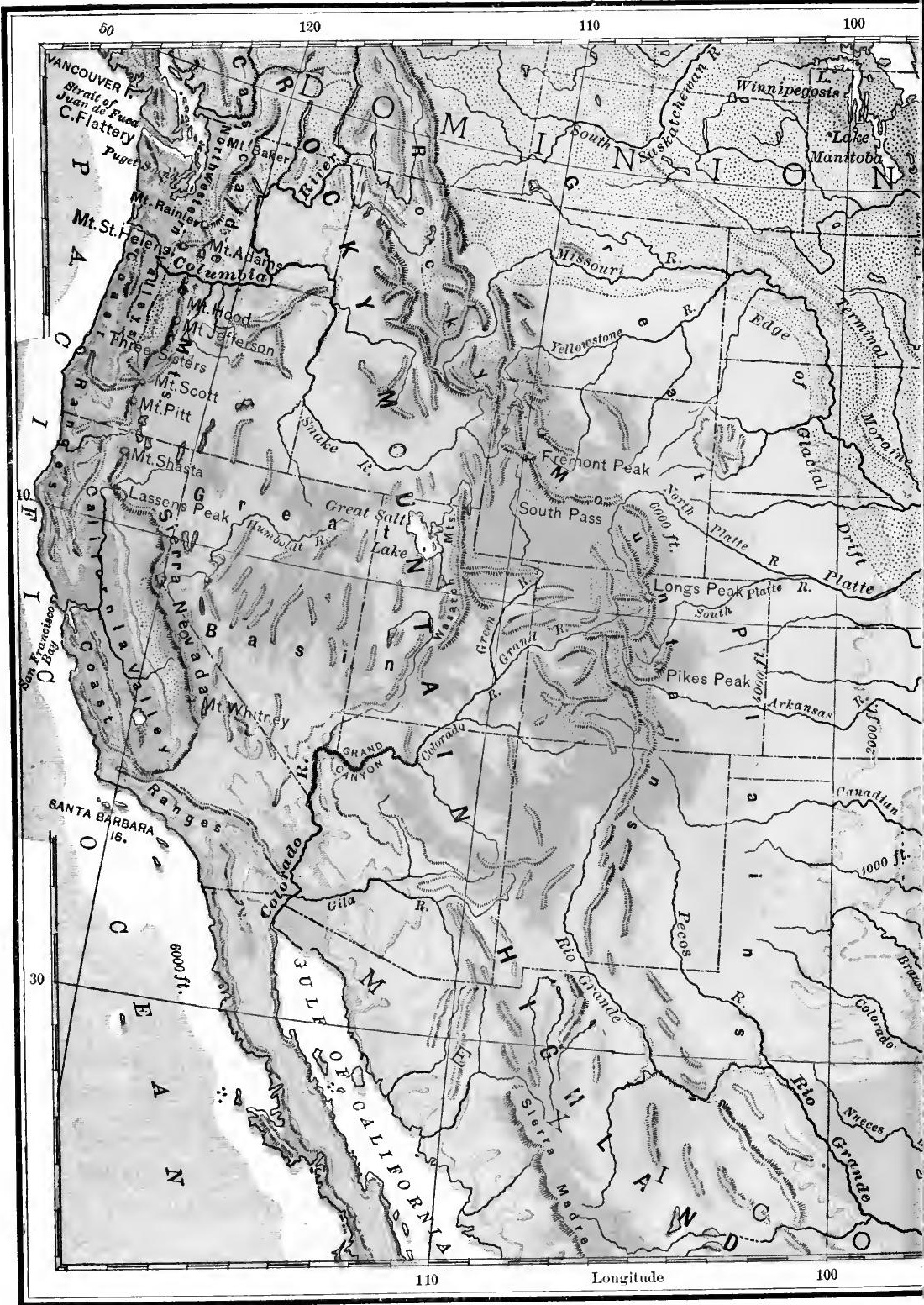




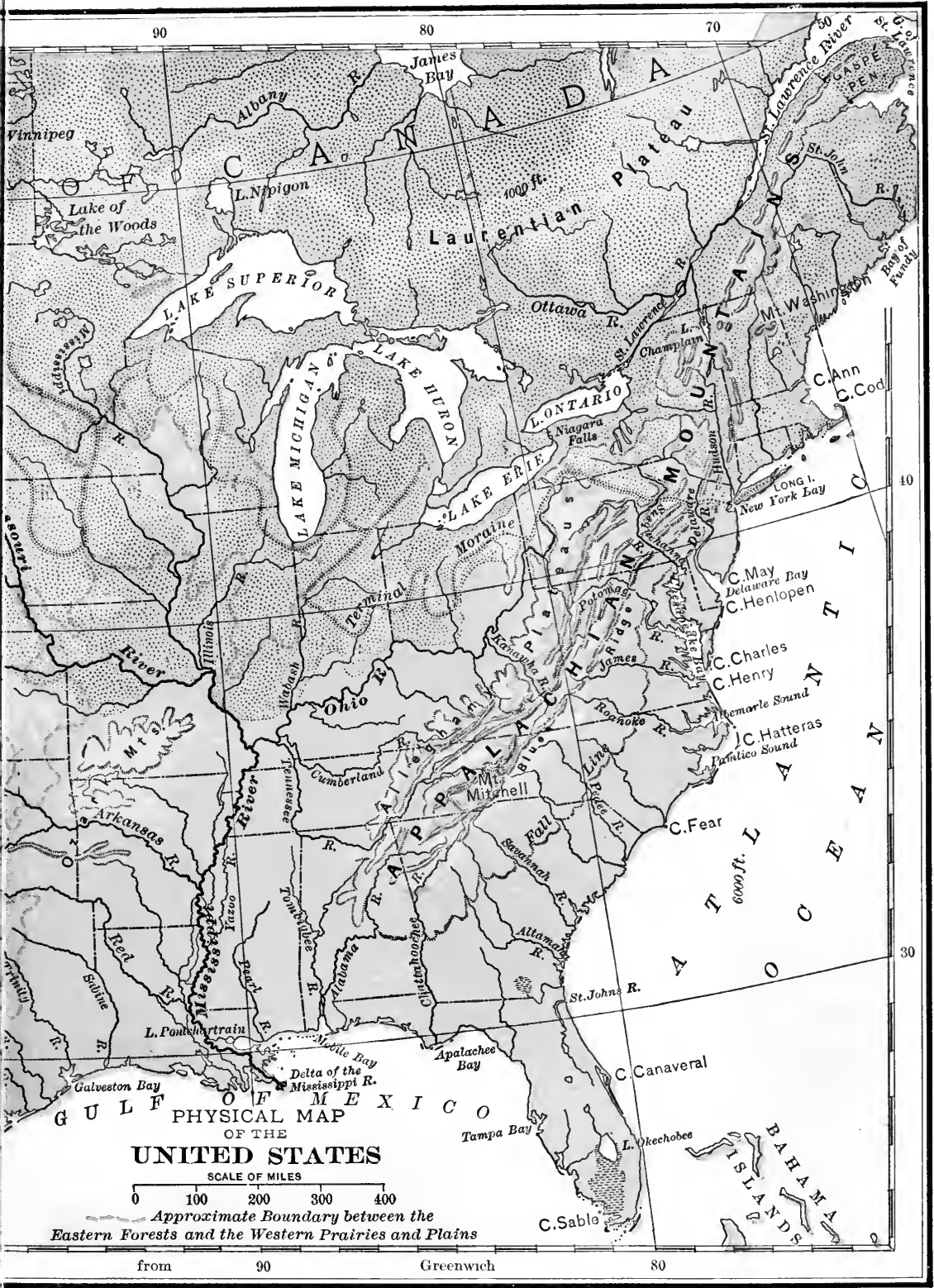


natural advantages which determined the location of a line of towns and cities, such as Trenton, Richmond, Petersburg, Raleigh, Columbia, Augusta, and Macon. The very flatness of the Atlantic coast gave rise to one disadvantage: inuumerable swamps and fresh-water ponds bred mosquitoes; when our forefathers sickened with fevers, they little guessed that it was this insignificant enemy which brought disease, death, and often the ruin of a colony

Inland the Atlantic coast plain terminates in the Appalachian Mountain system, which extends in a belt about a hundred miles wide from Gaspé Peninsula in the Gulf of St. Lawrence 1600 miles southwestward to northern Alabama. The average elevation is about 2000 feet, the passes from 1500 to 3000 feet; though Mt. Washington and the North Carolina ranges rise above 6000 feet. The eastern half of the system consists of long, parallel, and steep-sided mountain ridges; the western half is an upland plateau which declines gradually to the west and is deeply trenched by the steep-sided valleys of the streams. Like the lower coast lands, this whole highland region was originally clothed with forests which concealed the lurking savage.

The west slope of the Appalachian plateau merges into a vast low plain, which is drained partly northeastward to

7. Interior of North America
Hudson Bay and the Gulf of St. Lawrence, but chiefly southward through the Mississippi River system to the Gulf of Mexico. The whole region is characterized by a smooth surface and gentle slopes, a little broken by the bluffs along the streams. The northern belt, and the southern as far west as the Ozark Mountains, were originally forest-covered; but the central part from Indiana westward abounded in treeless, grassy prairies, which expanded westward until they covered all the land excepting fringes of timber along the water courses.

This St. Lawrence and Mississippi valley is the most exten- 
sive tract of highly fertile land in the world. "When tickled with a hoe, it laughs with a harvest ;" and it has almost every variety of soil and product. The numerous streams furnish alluvial "bottom land"; north of the Missouri and Ohio rivers most of the country is covered with glacial deposits Nature's wheat fields; the vast prairies grow all kinds of crops, especially corn. Yet this interior was a lonely wilderness up to the close of the Revolution; it became the chief area of settlement from that time to the Civil War, and is to-day the home of about fifty millions of prosperous people.

Beyond the Mississippi River the land rises imperceptibly into a treeless plateau, which, west of the 100th meridian, is called the Great Plains and is so dry that farming is almost impossible without irrigation. The bunch grass of these plains once supported countless herds of wild bison, and now is the pasturage for beef cattle.

The Great Plains form the eastern part of the Rocky Mountain Highland, which extends to within 150 miles of the Pacific coast, with a general elevation of 5000 feet; from it rise the Rocky Mountain chain in the eastern part, and the Sierra Nevada and Cascade chains on its western margin. The high region between these chains, which may be called the Interior Highland, has been settled chiefly since the Civil War.

The lofty and complicated ranges of the Rocky Mountains occupy a belt of country from 200 to 300 miles wide, made up of mountains extremely rough and rugged. Their summits reach to nearly 15,000 feet, though the chain may be crossed at elevations not greater than from 6000 to 8000 feet. Among these mountains the Indians found large game for food, and small fur-bearing animals. From the sheep which now range the region the white man still draws material for clothing; while in the upheaved and dislocated strata he finds our richest stores of gold, silver, copper, and lead. 
Rough and broken surfaces characterize the Interior Highland: the region is very dry, some places having no rain for

8. Great Basin and Pacific slope months or even years. The triangular region between Snake and Colorado rivers and the Sierra Nevada is called the Great Basin, because its meager rainfall collects in pools and salt lakes and then evaporates without reaching the sea.

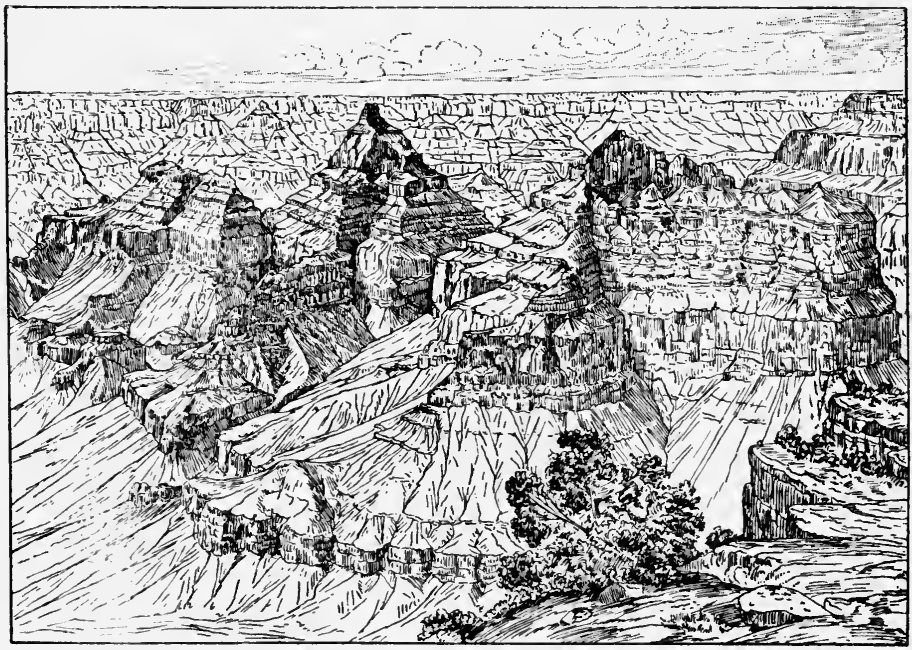

Grand Canyon of the Colorado.

Showing erosion in a region of little rain.

West of the Interior Highland rises the precipitous escarpment of the Sierra Nevada and Cascade chains, which sink away again in a long western slope, abundantly watered in winter by moist winds from the Pacific, which clothe it with thick forests of valuable trees. These chains are scarcely more than seventy-five miles wide, but they rival the Rocky Mountains in height and ruggedness. West of the crest of the Sierra Nevada and Cascade chains, and beyond a series of long lowland valleys, is the crest of the low Coast Ranges, which rise 
steeply from the Pacific Ocean. These ranges are broken down to the sea at three places only - the Bay of San Francisco, the gorge of the Columbia River, and the Strait of Juan de Fuca, which leads to Puget Sound. Through these breaks are drained the fertile Pacific valleys; and near them are the principal Pacific ports.

Through the forests and across the mountains were two systems of primeval routes of travel, footpaths and waterways : (1) Throughout the continent, buffalo paths and Indian trails, sometimes only six inches wide, led through prairie of trade and and forest; they often followed the divides between the travè streams, as being free from fords. (2) Rivers and lakes made a network of water routes, on which plied the dugout and in the north the Indian birch-bark canoe, one of the best inventions of any savage race; easy to make, swift to paddle, and light to " tote" over a carry from one system of rivers to another.

For long east and west journeys the Atlantic streams could

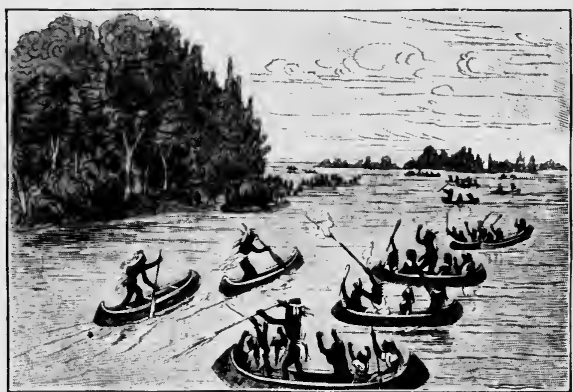

Indian Birch-Bark Canoe Race.

Sketched by an eyewitness about 1830 . be followed up to the divides separating them from the tributaries of the Great Lakes or of the Ohio River. The routes across the Appalachian chain ran for the most part on the same lines as the present trunk-line railroads, especially the gaps at the heads of the Mohawk, Susquehanna, Potomac, and James rivers. By carries or portages known to the Indians, one could also pass from the Great Lakes to Hudson Bay, or to the upper Mississippi, or to the Ohio. Examples of such transfer points are Ravenna, Ohio, between the Cuyahoga and 
Mahoning rivers; Fort Wayne, Indiana, between the Maumee and the Wabash; and Chicago, between Lake Michigan and the Des Plaines branch of the Illinois. At such places in many instances a white man's town eventually grew up.

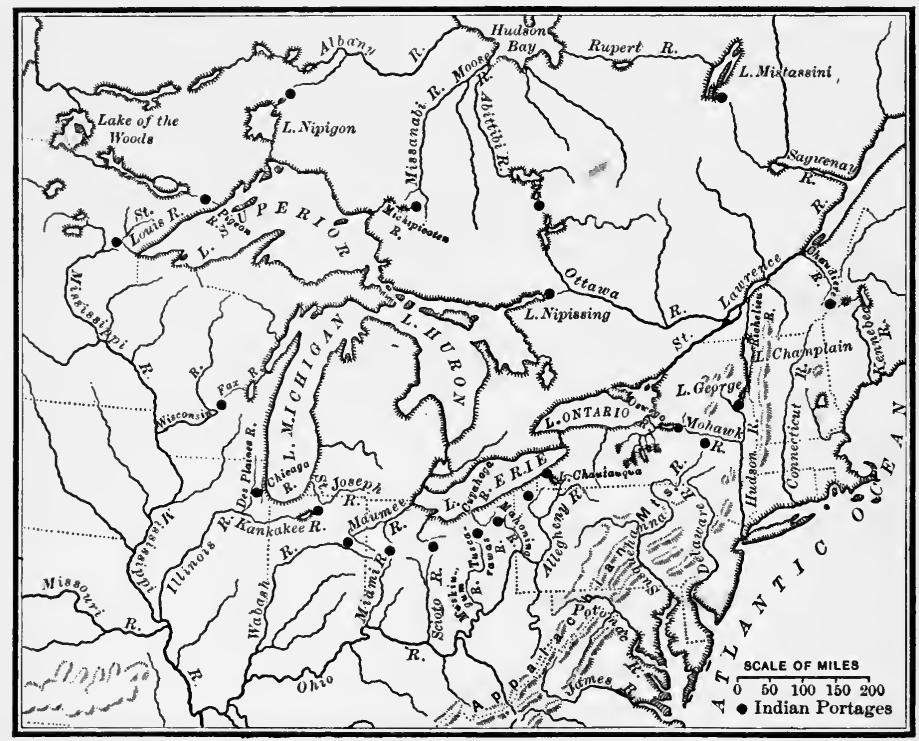

Important Indian Portages.

The whole land originally abounded in wild animals. The deer and the bison, commonly called buffalo, furnished meat 10. Ameri- for the hungry, clothing for the cold, and a roof for the can prod- family; the game birds, of which the turkey and the ucts

pigeon were the most plentiful, increased the food supply; and the coast waters and streams abounded in fish and in fur-bearing animals. The earth furnished to the savage fruits and berries, corn, pumpkins, squashes, and maple sugar for his diet, tobacco for his luxury, herbs and simples for diseases and wounds, wood for his fires and even for houses. 
Later colonists found a valuable resource and profit in the timber and the iron ores; their descendants discovered coal and oil, and precious metals; but almost the only things the Indian had to sell that the white man coveted were deerskins and furs, especially that of the beaver. Still America yielded three products not then known to the old world: (1) Corn was the plant most widely sown and harvested by the Indians, "a grain of general use to man and beast." (2) The potato, native of South America, in the course of time became the chief food of millions of Europeans. (3) Tobacco, everywhere much prized by the Indians, grew wild or was negligently cultivated.

The native inhabitants of America, called Indians by Columbus because he supposed he had reached the Indies, were throughout of one race, though their origin is a puzzle for ethnologists. To be sure, throughout central North America exist a great number of mounds, some sepul-

11. Native civilization in America chral, some village sites, some defensive, some built in the outline of animals; but there is no reason to suppose that the "mound builders" were different from the ordinary Indians.

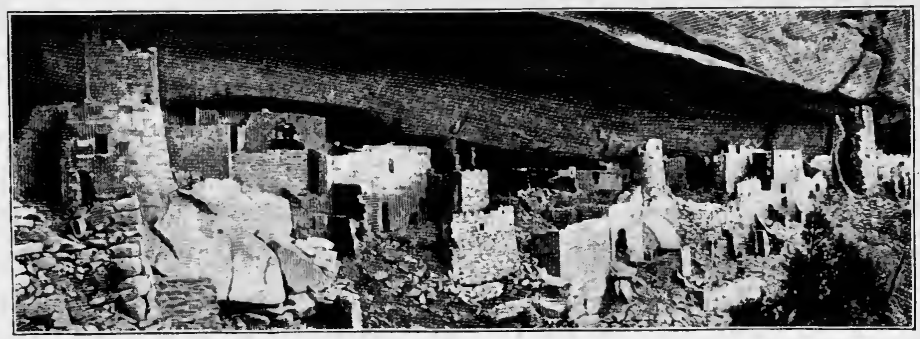

INdian Cliff DWhllings. (Near southwest corner of Colorado.)

From Georgia to Arizona most tribes raised plenty of food and lived in fixed towns, some southwestern peoples in cliff dwellings. The descendants of some of these tribes, as for instance the Zuñis, still live in the same communal villages UART'S AMER. HIST, -2 


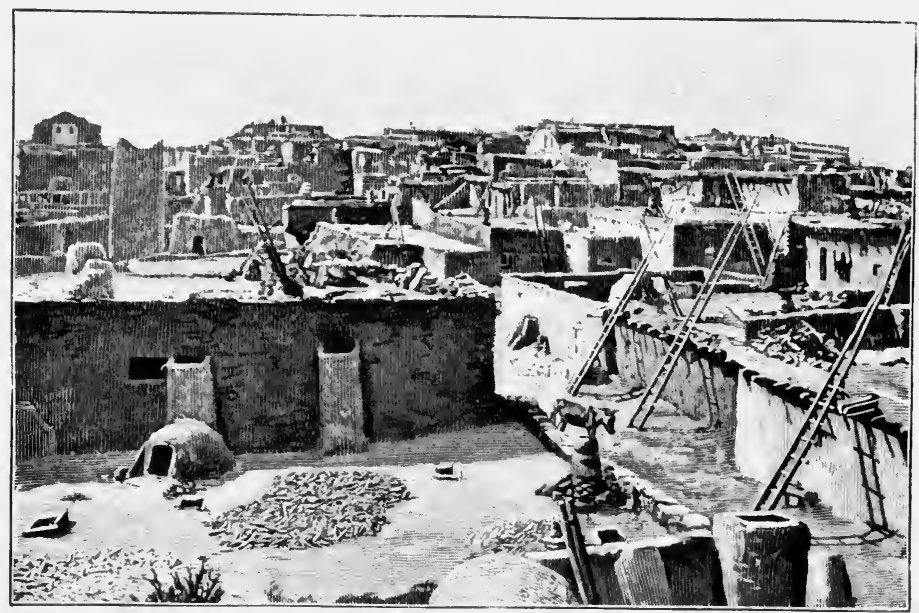

Interior of Zũ̃i Pueblo.

About the same as in $\mathbf{1 4 9 2}$.

or pueblos, and carry on much the same life as their forefathers.

Farther south, in the communal city of Mexico, were the Aztecs, men of war who lived on tribute or plunder from neighboring tribes, and reveled in human sacrifice; they had the arts of making pottery, of working in soft metals, of weaving and of feather work, and even of a kind of picture writing. In Mexico and Central America ruined stone cities mark a higher civilization, already decaying when the white man came. These abound in elaborately carved stone walls, stairways, and monoliths, extraordinarily like certain temples and idols in eastern Asia. In South America native civilization reached its highest point in the empire of the Incas in Peru, who had an organization far above that of the ordinary Indians; for they built roads and stone towns, used llamas for beasts of burden, and had a system of records made by knotted cords. 
The Indians who most disturbed the English colonists were three groups : (1) along the northern Atlantic coast the Algonquin family; (2) inland, between Lake Erie and the 12. Indian Hudson, the "Five Nations" of Iroquois; (3) between the Mississippi and the southeast coast the powerful Cherokees, kin to the Iroquois, and the Muskogee family, including the intelligent, numerous, and warlike tribes of Choctaws, Creeks, and Chickasaws. All these Indians were vigorous and hardy people, well built, tall, and handsome. Their clothing was chiefly of deerskins, supplemented after the whites came by the "matchcoat," or blanket. They gathered into villages, living for the most part in wigwams of bark or skins; though some tribes had "long houses" - rows of continuous wooden dwellings.

The main occupations of the Indians were fishing and hunting and fighting, but nearly all the tribes had cornfields, and some of them plots of tobacco and vegetables, all tilled by the women. The Indians were fond of gayety, lively conversation, dancing, and open-air games. Real religion they had none; the early discoverers said that they worshiped stones and the devil. Their priests were medicine men who sang, shook their rattles, and circled about the fire ten or twelve hours together, "with most impetuous and interminate clamours and howling." In many ways the Indians showed remarkable inventive skill. They strung bows, fashioned stone arrowheads, clubs, and hatchets, contrived snowshoes, made rude pottery, tanned skins, executed beautiful designs in beads and porcupine quills, manufactured maple sugar, plaited nets, carved pipes, had a currency of wampum made from seashells, and, above all, invented the graceful and serviceable bark canoe.

In war the Indians were among the greatest fighting men of all history. Their weapons were the bow and arrow, club, tomahawk, and stone knife; and they quickly took over the white man's musket and steel axes and knives.

13. Indian warfare and government Swift and silent in movement, their favorite attack was sur- 
prise; if once beaten back, they were likely to give up and go home for the time, rather than lose many men. Their custom of killing or enslaving men, women, and children alike, was too often imitated by their white enemies, who also learned how to seize the scalp locks of their savage adversaries. The narratives of white captives are full of fearful tortures.

Fortunately for the whites, the Indians were broken up into small political fragments. The so-called "tribes," often including many villages, were united by the loosest of ties; they fought among themselves, and the fundamental idea of the Indian was that every meinber of every other tribe (unless bound by friendly treaty) was his enemy; and he looked on all Englishmen as members of one hostile tribe. Indeed, the whole Indian conception of government and society was different from the English. The tribes were subdivided into clans, or "totems," and families, and the tribal councils were mere "powwows," for the decision bound nobody; yet discussion and decision were backed up by a powerful public opinion. The tribal lands were usually only the territory over which the tribe habitually ranged; nobody "owned" land in the English sense.

The chiefs were not hereditary, but in part members of distinguished clans and families, in part simply able men who pushed themselves forward. They had no recognized power to compel obedience, and hence treaties with the English were always hard to enforce. Few Indians have come down in history as leaders of their people. Wahunsonacock, commonly called Powhatan by the Virginians, George Guess who invented an alphabet, King Philip in New England, Pontiac and Corn Planter in the West, and later Tecumthe, Chief Joseph, and Geronimo are almost the only great names.

From about 1450 to 1500 the conditions in Europe were especially favorable for discovery and commercial adventure. 
Europe was ready for new fields of activity; and by 1500 each of the foir nations on the western sea front-England, France, Spain, and Portugal - had a consolidated royal power, capable of directing new enterprises. Each had also an eager, seafaring people, acquainted with new arts of navigation. The closing of the overland route to Asia by the Turks aroused the people to the necessity of a route by sea; and a belief that the world is round suggested a western voyage to India.

But between Europe and India, all unknown and undeveloped, lay the two Americas, occupied by savage tribes, who were skilled in the warfare of the woods, and ready to contest with all their might any attempt to set foot. upon their territory. Yet the central belt of this broad land that stretched from the 25th parallel to the 49th, and through fifty degrees of longitude, had the soil and climate which have later made possible the cotton of Texas, the wheat of Minnesota, the corn of Indiana, the Maine potato, and the olive groves of California.

\section{TOPICS}

(1) What made Spain a great nation? (2) When and how did the Renaissance reach England? (3) When and where was gunpowder first used in European warfare? (4) What are some of the earliest printed travels? (5) How did the mariners' compass come into use? (6) What are the best waterways (with portages) from the Atlantic to the Pacific? (7) Name the principal peaks of the Appalachians. (8) What are the easiest passes across the Appalachians? across the Rocky Mountains? (9) The principal "carries" from the Great Lakes to the tributaries of the Mississippi. (10) Indian remains in your neighborhood.

(11) Life in a present-day pueblo.

(12) Adventures of Marco Polo. (13) Who wrote the Travels of Sir John Mandeville? (14) Career of Prince Henry the Navigator. (15) First European visitors to Niagara Falls. (16) First European explorations in the Appalachian Mountains. (17) How to make a birch-bark canoe. (18) Introduction of tobacco into Europe. (19) The Serpent Mound. (20) Ancient stone buildings and monuments in Mexico and Central America. (21) Peruvian roads and buildings. (22) Modern cities on the sites of Indian villages. 


\section{REFERENCES}

Geography

Secondary authorities

Sources

nlustrative works

Pictures
See maps, pp. 10, 11, 15, 18, 19, 24 ; Brigham, Geographic Influences; Epoch Maps, no. 1; Cheyney, European Background; Farrand, Basis of American History.

Thwaites, Colonies, §§ 2-5; Fisher, Colonial Era, 1-11 ; Fiske, Discovery of America, I. 1-147, II. 294-364; Doyle, English in America, I. 5-17 ; Winsor, America, IV. i-xxx ; Farrand, Basis of American History; Shaler, Nature and Man. in America, 166-283, - United States, I. 1-272, 417-517 ; Cheyney, European Background; Higginson, Larger History, 1-26; Hinsdale, How to Study and Teach History, 174-203; Morgan, American Aborigines.

Hart, Source Book, § 9, - Source Readers, I. §§ 8, 19-33, 3744, III. \$§ 57-69; Old South Leaflets, nos. 30, 32. See Channing and Hart, Guide, $\$ \S 21-21 b, 77-80$; New England History 'Teachers' Association, Syllabus, 167, 168, 29:, - Historical Sources, § 65.

Longfellow, Hiawatha; Whittier, Bridal of Pennacock; C. G. Leland, Algonquin Legends of. New England; C. F. Lummis, Strange Corners of our Country.

McKenney and Hall, History and Biography of the Indian Tribes; Catlin, North American Indians; Winsor, America, I.

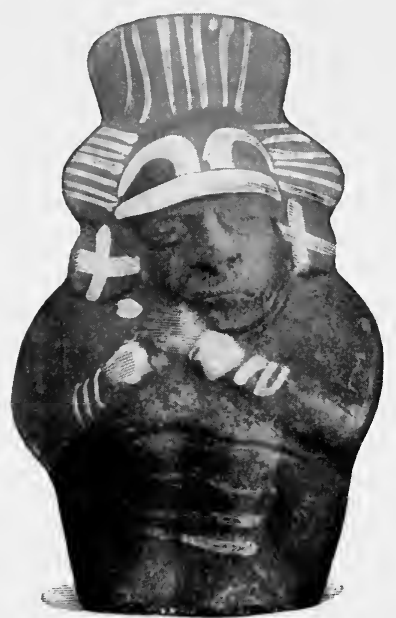

Ancient Peruvian Jar

Perhaps a portrait. 


\section{CHAPTER II. \\ THE CENTURY OF DISCOVERY (1492-1605)}

The existence of a Western Continent was till about 1500 undreamed of in Europe, although there was in far-off Iceland a "saga,"or document based on memorized tradition, showing how, in the year 1000, Leif Erikson - "Leif the Lucky" runnings of - reached the mainland of North America; and how in (1000-1492) 1007 one Karlsefni landed there in a fine country (which has never been identified) abounding in flat stones and grapes, and fierce natives. No evidence has ever been found to show that Leif's discovery was known to Italian or Spanish navigators. Their incentive to western voyages was the hope of finding a direct western route to India, especially after Bartholomew Diaz of Portugal reached the Cape of Good Hope (1487) and saw a broad sea beyond, promising a practicable indirect route.

To Christopher Columbus, born (about 1446) in the Italian city of Genoa, is due the credit of applying the science of his time to the problem of reaching India. Before he was thirty years old he formed a plan of sailing westward to Asia, which he calculated to be twenty-five hundred miles distant from Europe. Directly, or through his brother Bartholomew, he appealed to the kings of Portugal, Spain, England, and France to fit him out; and all declined the splendid opportunity. Finally, he turned again to Spain and appealed to the missionary zeal of Queen Isabella in behalf of the distant heathen, and held out to her counselors the rich results of conquest and power. In behalf of her kingdom of Castile, Isabella at last agreed to fit out an expedition. 
Furnished with the queen's money and armed with her authority, Columbus got together three little vessels, the Santa 16. Colum- Maria, Niña, and Pinta, carrying 90 men in all. He

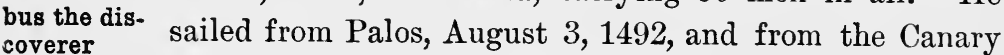
(1492-1506) Islands five weeks later; thenceforward his sole reliance was his own unconquerable will. As the crews grew muti-

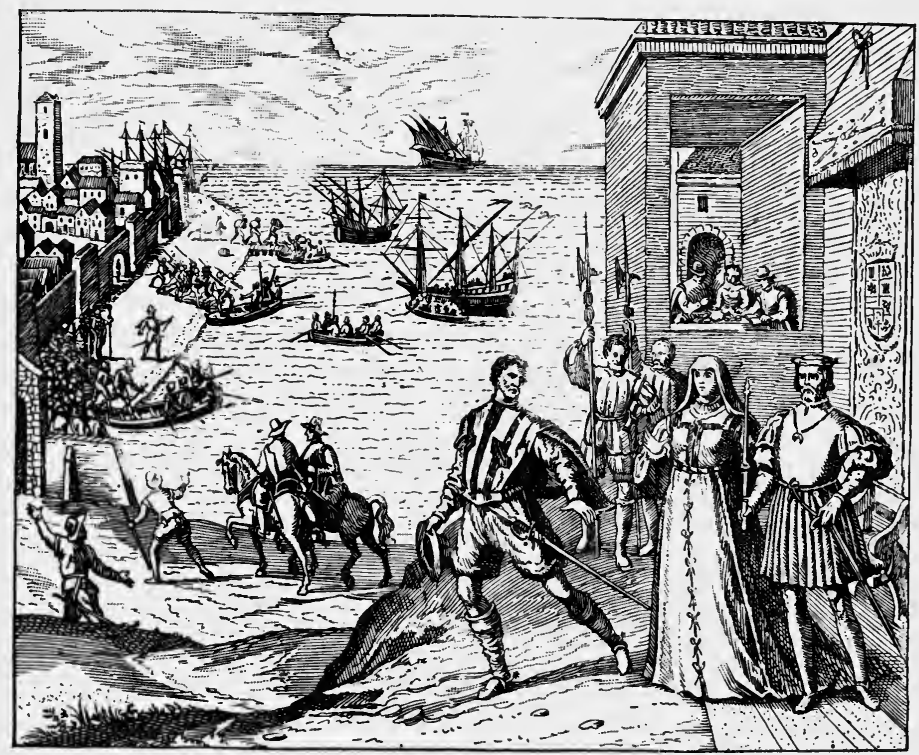

Departure of Columbus.

From De Bry's Voyages, 1590.

nous the admiral cajoled and threatened, and even understated the ship's daily run.

On Friday, October 12, 1492 (old style), thirty-three days after losing sight of land, and distant 3230 nautical miles from Am. Hist. Palos, the caravels came upon an island, to which, says Leaflets, Columbus, "I gave the name of San Salvadore, in comno. 1

memoration of his Divine Majesty who has wonderfully granted all this. The Indians call it Guanahan." This land- 
fall was probably Watling Island of the Bahama group. A few days later Columbus reached the coast of Cuba, and then Hispaniola, or Haiti. He was deeply disappointed not to find towns and civilized communities, for to the day of his death Columbus supposed that he had hit on the coast of Asia. Thus was America discovered, as an unforeseen incident in the voyage of one of the most extraordinary men in history.

In September, 1493, Columbus set out a second time with 17 vessels and 1500 men, founded Isabella in Haiti, the first city of Europeans in America, set up a government there, and discovered Porto Rico, Jamaica, and some of the Lesser Antilles. On a third voyage (1498), he reached South America, and discovered the mouth of the Orinoco. His colony in Hispaniola, including the permanent city of Santo Domingo, fell into confusion, and Columbus was sent home in chains, and for a time was in disgrace. He made, however, a fourth voyage (1502), in search of a water passage to India, which carried him to the coast of Honduras, and to the Isthmus of Panama. Four years later he died in Spain, and his bones, after wanderings in the West Indies, now rest in the Cathedral of Seville.

Meantime the Portuguese were trying to reach the gold and spice islands by sailing eastward, and they claimed a monopoly of the discoveries that they might make. In May, 1493, 17. Porthe Pope issued a bull in which he assumed the authority tuguese disto divide the non-Christian world between Portugal and (1493-1500) Spain, by a north and south line through the Atlantic. A year later, in the treaty of Tordesillas, made directly between Spain and Portugal, it was agreed that the line of demarcation should run "from pole to pole, 370 leagues west from the Cape Verde Islands." The rivalry foreseen by Harrisse': Diplomatic History, $\% 8$ the treaty was realized in 1497 when the Portuguese Vasco da Gama passed the Cape of Good Hope, and shortly reached India; soon Portuguese trading ports were established in Asia. Then Cabral, one of the Portuguese voyagers to India, hit on 


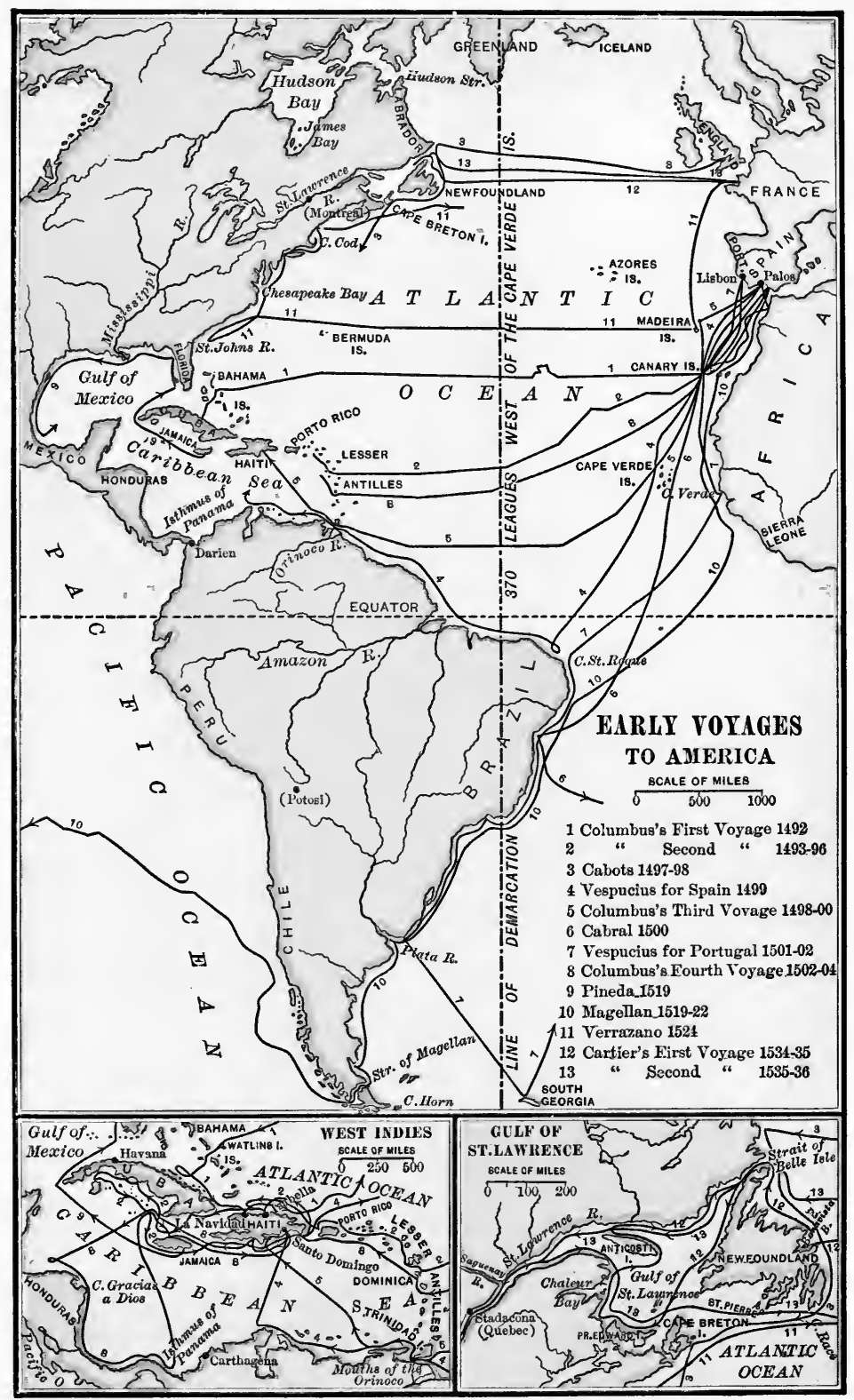


the coast of Brazil (1500), which he thought was an Asiatic island; later it was found that the line of Tordesillas ran to the west of the Brazilian coast, which was therefore left to the Portuguese to settle.

The announcement that Columbus had reached Asia aroused new national rivalries, and it was followed by many western voyages. Henry VII. of England never regarded the papal bull of 1493 or the treaty of Tordesillas as binding 18. The Cabots and him; and in 1496 he gave authority to the Venetian navi- (1497-1507) gator John Cabot and his three sons "to sail to all parts, regions, and waters of the eastern, western, and southern seas, and to discover any heathen regions which up to this time have remained unknown to Christians." Though this voyage later became the basis of the English claims to North America, we know only that Cabot came back in 1497 and reported "that 700 leagues hence he discovered land, the territory of the grand Chan. He coasted for 300 leagues and landed [probably on the island of Cape Breton] and found two very large and fertile new islands." The next year Cabot's son Hart, Contemporaries, I. 69 Sebastian is supposed to have mads a voyage farther south, probably as far as the coast of Virginia; but of his discoveries, if he made any, we have no contemporary accounts.

The Venetian Americus Vespucius coasted large parts of South America from 1499 to 1507 in behalf of Spain and then of Portugal. He published several letters describing his discoveries and, apparently without his own expectation, furnished a name which gradually supplanted the term "New World" used by Columbus and others. An Alsatian geographer, realizing that a new continent had been discovered, suggested in 1507 that the new fourth part of the world be called "Amerige, that is, the land of Americus, or America." This suggestion, intended to apply to the eastern part of South America, was gradually extended to all of South America, and then to the entire western continent. 
By the year 1514 most of the islands of the Caribbean Sea, and the coast from Mexico to the Plata, had been visited; 19. Spanish so that the Spaniards began to realize that wherever they discoveries sailed far enough west, they struck land, perhaps a conand conquests tinuous continent. The region about Darien failed to (1513-1532) disclose a strait, and in 1513 Balboa crossed the narrow Isthmus of Panama, and looked upon the Pacific Ocean. Failing to penetrate directly westward, the Spaniards in 1519 sent Magellan with a small fleet to coast America southward; he discovered and traversed the strait to which he gave his name, entered and named the Pacific Ocean, and then sailed up the west coast of South America, and westward until he reached the Ladrones and the Philippine Islands (1521). One of Magellan's vessels got home to Spain via the Cape of Good Hope - the first circumnavigation of the globe. At last the true Indies had been reached by sailing west, and the Philippines speedily became a Spanish colony, regularly communicating with the home country across the Isthmus of Panama.

An era of Spanish exploration and conquest within North America began with a fruitless expedition by Ponce de Leon in Florida (1512), and a voyage by Pineda, who skirted the north coast of the Gulf of Mexico (1519). The first permanent lodgment was the romantic occupation of Mexico by Hernando Cortez in 1519 . With 450 men and 15 horses he marched up and took the stronghold of Mexico, smashed the rude political organization of the Aztecs, and set up the Catholic religion.

In 1532 a Spanish force of 200 men and 60 horses, under Francisco Pizarro, penetrated and conquered Peru, and looted a large quantity of gold; here also the native government was overthrown and a permanent Spanish viceroyalty set up.

The Spaniards sent several expeditions to explore the southern part of what is now the United States, and thus they secured a first title to that region. (1) De Ayllon attempted to found a colony on Chesapeake Bay (1526). (2) Narvaez 
with a party explored the land north of the Gulf coast, and passed the mouth of the Mississippi, probably the first white man to see that river (1528). (3) Ferdinando de Soto, with a force of 620 men, marched inland from the coast of Florida; and in 1541 penetrated to and then beyond the Mississippi. (4) In 1540 Coronado, incited by tales of seven rich and wonderful "cities of Cibola," went north-

20. Spanish explorations farther north (1526-1592) ward from Mexico, but found the cities to be only Indian pueblos, of which some are standing yet; he penetrated to the country of Quivira (Kansas) which abounded in "crook-backed cows" (buffalo). The expedition led to the founding of the town of Santa Fé in 1572. (5) From 1533 to 1592 the Pacific coast was visited by Spaniards as far north as Puget Sound.

The West Indies, as the Spanish possessions in the new world were generally called, made the Spanish kingdom the richest of all European countries and enabled the Spaniards for a century to take the leading place in Europe. The gold of Mexico and Peru was quickly swept up and spent; but in 1545 the enormously rich silver mines of Potosi, in Peru, were opened, and later good silver mines were found in Mexico. By 1550 Spanish colonies were established in Mexico and Central America, on the west and north coasts of South America, and on the lower Plata.

Meanwhile, about twenty years after Columbus's first voyage, a mighty change was begun in Europe through the Protestant Reformation. In the end, the peoples of northwestern Europe became mostly Protestant, while those of the south remained Catholic. France, however, as well as England

21. French discovery (1524-1565) ignored the papal division of 1493 and the treaty of Tordesillas. In 1524 King Francis I. dispatched Verrazano, a Florentine, with a fleet which crossed the Atlantic and explored an unknown coast including New York Harbor, a bay, he said, in "a very pleasant situation among some steep raries,I. 105 hills, through which a very large river, deep at its mouth, 
forced its way to the sea." Much farther north the French captain Jacques Cartier found islands, firm land, and a river (1534), and the next year "a goodly great gulf, full of islands, passages, and entrances," which he named St. Lawrence; thence he entered "the great river Hochelaga and ready way to China." His progress was stopped by the rapids later dubbed Lachine ("Chinese"), near a hill which he called Mount Royal, now Montreal.

France had a Catholic king, but a body of French "Huguenots," or Protestants, with the consent of the king planted an unsuccessful colony under Jean Ribault at Port Royal, now in South Carolina (1562). Two years later, under Laudonnière, the French returned and built a second Port Royal on the "River May" (St. Johns) in Florida. This was a flat defiance of the Spaniards, who founded (1565) the frontier town of St. Augustine to confront the French ; this town, still in existence, is the oldest within the mainland boundaries of the United States. Menendez, the Spanish governor, then uprooted the French colony ; and the French never regained the opportunity of settling the southern Atlantic coast.

The monopoly of American trade and colonization by Spain aroused the spirit of the English, especially when under Philip 22. English II. (1556-1598) Spain became the great Catholic power of traders and Europe. Nominally at peace, English vessels constantly (1566-1580) traded with Spanish colonies against the will of the Spanish government, and preyed on Spanish commerce in the western seas. The feeling of rivalry with Spain was expressed in a charter granted by Parliament in 1566 to Sir Humphrey Gilbert and his associates in a company to open a northwest passage around America to India, and to discover new lands, which were to be an English colony. Ten years later Sir Martin Frobisher made three voyages on the same quest, penetrating as far as Hudson Strait. For nearly three centuries the English never quite abandoned the idea of a short water route to Asia. 
nne of the boldest adventurers and bravest fighters was Sir John Hawkins, who made several profitable voyages to the Spanish colonies with African slaves. His five ships were caught in the Mexican port of San Juan de Ulloa by thirteen Spanish ships; he fought them all and escaped with two vessels (1568). One of Hawkins's captains was Francis Drake, who in 1572 sailed off again to prey on Spanish commerce. Pirate-like he harried the Spanish mainland, captured Spanish vessels and mule trains, and carried off gold, silver, and merchandise. Nevertheless, on his return to England Drake was pardoned by Queen Elizabeth and held in favor.

The slow downfall of Spain may be said to have begun when the Netherlands revolted and formed a union of the provinces against the Spanish (1576). The English government sympathized and aided; then individual Englishmen took an active part in the pulling down of Spain. In 1577 with the queen's approval, though without a royal commission, Drake set off with a little fleet; he rounded South America, passed through the Strait of Magellan with his one remaining ship, and was the first to see Cape Horn, and to find the open sea to the south of it. The story of Drake's next exploits sounds like the Arabian Nights, and is gemmed with such phrases as "thirteene chests full of royals of plate, foure score pound weight of golde, and sixe and twentie tunne of siluer." He sailed Hart, Contemporaries, I. 85 up the unfortified west coast of South America, capturing coasters, terrifying towns, taking one prize worth a million dollars on its voyage from the Philippines, and throwing the Spaniards into a panic.

Running far to the north, in hope of finding a passage through or around America to England, he put into a bay just north of the harbor of San Francisco to repair his ships, and called the country New Albion. 'Thence he struck boldly westward across the Pacific, sailed through the Philippines and the Spice 
Islands, and then home again (1580) around the Cape of Good Hope, the first Englishman to circumnavigate the globe. Queen Elizabeth formally knighted him, and thus proclaimed him an English hero fighting for his sovereign.

The next step towards colonization was a vain attempt at planting an English settlement in Newfoundland under a new

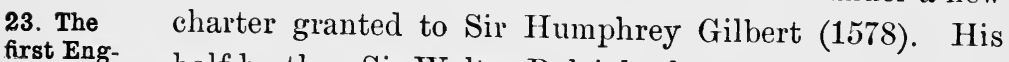
first Eng-
lish colonies half-brother, Sir Walter Raleigh, then got from the queen (1578-1587) a new "patent," or grant of lands (1584), authorizing Poore, him to colonize "remote heathen and barbarous lands
Charters and Consti- ... not actually possessed of any Christian Prince." tutions, 1379 Forthwith he sent out two vessels, under Amidas and Barlowe, to find a proper place for a colony, and they fixed on

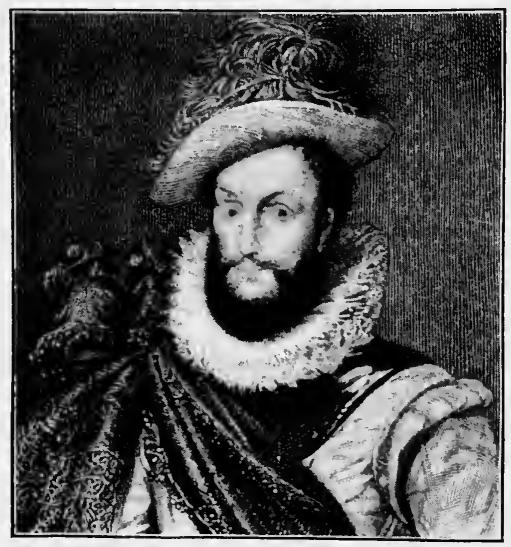

Sir Walter Raleigh, about 1590. Roanoke Island. On their return and favorable re. port Queen Elizabeth coyly named the new land for herself, "Virginia."

Thrice did Raleigh send out actual colonists to Roanoke. A settlement of 1585 with 100 men failed and the settlers came back; a smaller settlement of 1586 disappeared; in 1587 he sent out a colony commanded by John Type of the English gentleman of his time. White, with 150 people, including seventeen women, one of whom gave birth to Virginia Dare, the first English child born on American soil. All the members of this colony who remained in America disappeared in 1588, and their fate to this day is uncertain.

The harrying of the commerce of Spain inevitably led to war, and the crisis came in 1587 when Philip II. resolved to 
invade England and destroy the plague of English sea rovers at its source. The proposed invasion took the form of a religious crusade by a mighty Spanish fleet called the Invincible Armada. The Armada sailed from Corunna in 1588, 149 vessels, carrying 30,000 men, - and made its way

24. War with Spain (1587-1604) in half-moon formation up the English Channel. It was beset by an enemy as brave as the Spaniards and much more nimble; for the English received their guests with 197 ships and 16,000 men, mostly trained seamen. The English finally sent fire ships among the Spaniards, and drove them out into the North Sea, where many of the fleet were burned, taken, or sunk. The demoralized remnant made off to the

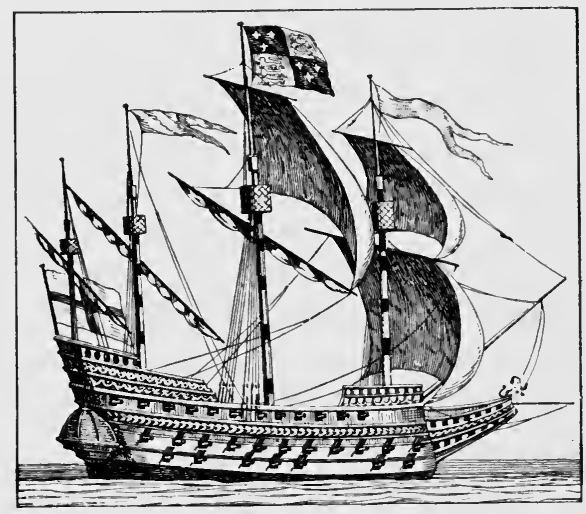

ENGLish WAR Ship of 1588.

From tapestries in the old House of Lords. northward in order to return to Spain around Scotland. Fearful tempests drove many vessels on the coasts, where the wild inhabitants massacred most of the survivors. The commander in chief arrived in Spain at last; and gradually 67 ships out of the fleet crept into port.

The war meanwhile had extended to the colonies, and it lasted for seventeen years. Drake took and plundered the city of Santo Domingo, the richest in the new world, and also the city of Carthagena, the capital of the Spanish West Indies.

The new king of Spain, Philip III., and the new king of England, James I. (1603), both desired peace; but the Spaniards long insisted that the English should agree to keep 
Englishmen from traveling to the Spanish colonies, or settling in territory claimed by Spain. On both points the English stood firm; and in 1604 a treaty of peace was made without either of the desired pledges. Thus the way was opened for the foundation of the later United States in territory then claimed by Spain.

By the year 1600 the geography and conditions of North America became clearer, especially through the diligence of 25. Rival Richard Hakluyt, an English gentleman who published claims to America a famous collection of narratives of voyages; and the (1584-1605) various nations began to bring forward arguments for their claims to America. France talked about the effect of the voyages of Verrazano and Cartier; Spain urged the Pope's bull of 1493 and her early explorations, assuming that coasts once skirted by Spanish ships remained Spanish, and that the territories inland from such coasts were Spanish to eternity.

Against these sweeping claims Hakluyt in 1584 asserted that "one Cabot and the English did first discover the shores about the Chesapeake"; and a contemporary writer set forth the English title to Virginia as follows: (1) first discovery by the subjects of Henry VII. (1497); (2) voyages under Elizabeth "to the mainland and infinite islands of the West Indies"; (3) the voyage of Amadas and Barlowe (1584); (4) the actual settlement of the White colony (1587); (5) a Discourse of Western broad claim that the coast and the ports of Virginia had Planting

been long discovered, peopled, and possessed by many English. On the Pope's bull the writer said, "if there be a law that the Pope may do what he list, let them that list obey him."

As assertions of the English claims, three more attempts were made by individuals to plant colonies in America: (1) Bartholomew Gosnold in 1602 spent a little time on the island of Cuttyhunk; (2) Martin Pring in 1603 entered the 
Penobscot; (3) in 1605 George Weymouth visited the coast of Maine. All these efforts failed; the country was too cold for comfort, and the English as yet had too little experience of colonizing.

The discovery of America by Columbus in 1492 was an accident brought about by attempting to reach the known lands of eastern Asia by sailing west, in the belief that the earth is a globe. But to Columbus is due the credit

26. Summary of acting on his belief. The discovery of an eastern route by the Portuguese Vasco da Gama was a stimulus to further attempts to reach the Spice Islands by sailing westward; and led to voyage after voyage of Spaniards, English; Portuguese, and Frenchmen, each successful explorer enlarging the knowledge of the American coast line and the islands.

Geographers took up the course of discovery and registered it on rude maps. Before 1600 Spain alone established permanent colonies, which chanced to be rich in precious metals. The wealth of the West Indies made Spain great aud yet prepared the way for her downfall ; for the English attacked, first Spanish commerce, then the colonies, then the home country; and in 1588 established the naval supremacy of England. Thenceforth the sea was free as far as an English ship could ride, and the way was prepared for English colonization.

\section{TOPICS}

(1) What do the Icelandic sagas say of America? not Henry VII. of England send out Columbus? Columbus raise men for his expedition? (4) How did Balboa discover the Pacific? (5) How did the Philippine Islands become Spanish? (6) Cortez's capture of the city of Mexico. (7) Pizarro's treatment of Atahualpa. (8) Capture of Port Royal by the Spanish. (9) Were the Spaniards justified in fighting Sir John Hawkins at San Juan de Ulloa? (10) Why did the Invincible Armada fail ?
(2) Why did

(3) How did Suggestive topics HART' AMER. HIST. -3 
Search topics

\section{Geography}

Secondary authorities

Sources

Illustrative works

Pictures
(11) Where did Leif Erikson land? (12) Columbus's own accounts of his discoveries. (13) Was Americus Vespucius truthful? (14) What kind of people were the Mexicans? (15) Where did De Soto cross the Mississippi? (16) Present state of the "Seven Cities of Cibola." (17) The Spanish silver mines. (18) Early descriptions of New York Harbor. (19) Drake's quarrel with Fletcher. (20) Profits of Drake's voyages around the globe. (21) Accounts of the Armada by eyewitnesses. (22) Did Sebastian Cabot discover the coast of Virginia?

\section{REFERENCES}

See maps, pp. 34, 45; Semple, Geographic Conditions, 1-18; Epoch Maps, no. 2 ; Bourne, Spain in America.

Thwaites, Colonies, §§ 7-12, 14-16 ; Fisher, Colonial Era, 1229 ; Bourne, Spain in America ; Wilson, American People, I. 1-33; Larned, History for Ready Reference, I. 47 ; Sparks, Expansion, 17-35 ; Eggleston, Beginners of a Nation, 1-24; Winsor, America, II. III. 1-126, IV. 1-103, - Columbus, - Cartier to Frontenac, 176 ; Fiske, Discovery of America, I. 147-516, II. 1-293, 365-569, Old Virginia, I. 1-40; Doyle, English in America, I. 18-100; Parkman, Pioneers of France, 9-228 ; Higginson, Larger History, 26-120 ; Reeves, Finding of Wineland; Markham, Christopher Columbus; Major, Prince Henry the Navigator; Corbett, Sir Francis Drake; Creighton, Sir Walter Ralegh.

Hart, Source Book, §§ 1-4, 7, -Contemporaries, I. §§16-36, 4448, - Source Readers, I. §§ 1-9, 55, 56 ; American History Leaflets, nos. 1, 3, 9, 13; Old South Leaflets, nos. 17, 20, 29, 31, 33-37, 39, 71, 90, 92, 102, 115-120, 122 ; Higginson, American Explorers, 1228 ; Payne, Elizabethan Seamen. See N. Eng. Hist. Teachers' Ass'n, Syllabus, 293-296, - Historical Sources, §§ 66, 67.

Longfellow, Skeleton in Armor, - Sir Humphrey Gilbert ; Tennyson, Columbus ; Lowell, Columbus, - Voyage to Vinland ; R. M. Ballantyne, Erling the Bold (Iceland), - Norsemen in the West; S. Baring-Gould, Grettir the Outlaw (Iceland); Lewis Wallace, Fair God (Mexico) ; Cooper, Mercedes of Castile; Gordon Stables, Westward with Columbus ; Simms, Vasconselos (De Soto) ; Kingsley, Westward Hol (English and Spaniards); James Barnes, Drake and his Yeomen; Kirk Munroe, Flamingo Feather (Huguenots in Florida).

Winsor, America, II.-IV.; Wilson, American People, I. 


\section{CHAPTER III.}

THE ENGLISH IN AMERICA, 1607-1660

The unsuccessful experience of forty years showed that no Individual was powerful enough to found English colonies in

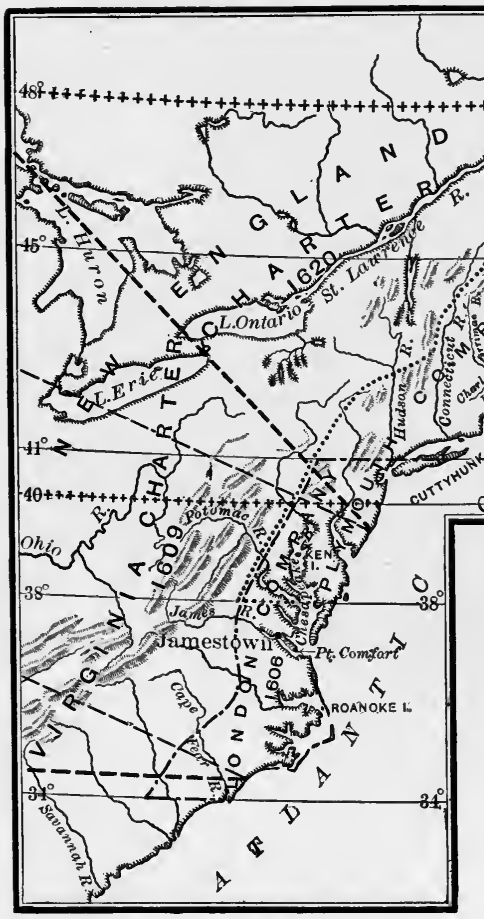

English Territorial Grants.

America. The next device was a system of colonizing companies, chartered by

27. The Vir-

the king and receiving ginia from him large grants grants of wild lands, which were treated as his personal property. The first grant was a royal charter, April 10,1606, which created two such corporations to settle the region indefinitely called Virginia: (1) the 
Plymouth Company, to make a settlement somewhere between the 38th and 45th degrees of north latitude; (2) the London Company, to colonize somewhere between the 34 th and 41 st degrees. For the government of either settlement, under this charter, it was provided that there should be a royal council in England and a local council to sit in the colony.

This charter at once involved England in a controversy with Spain, which claimed the Atlantic coast indefinitely northward, and which, with some reason, looked upon the scheme as an attempt to plant a naval station for the vexation of Spanish commerce. The Span. ish ambassador at London suggested to his master,

Brown, "It will be serving Genesis of God and Your Maj$U$. S.

esty to drive these villains out from there and hang them," but sloth, poverty, and hesitation to renew the war held back the Spaniards from anything stronger than protest.

The Plymouth Company sent out a colony 28. Settle- under the auspices

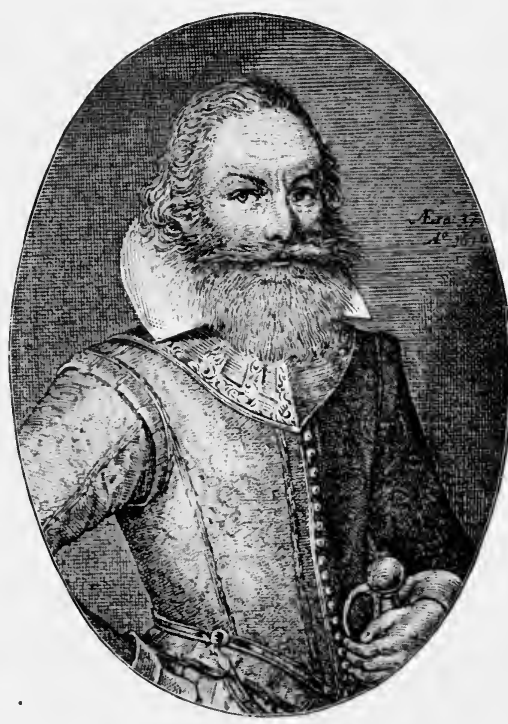

Captain John Smith in 1624.

From title-page of his Generall Historie. ment of Virginia of Chief-Justice Popham (May, 1607) which settled on (1607-1681) the Kennebec in Maine; but one severe winter broke it up, and the company never sent another. The London Company, in which Bartholomew Gosnold appears as an active promoter, in December, 1606, sent 120 emigrants, who arrived at Chesapeake Bay, and on May 3,1607, selected a peninsula 
on the James River for their settlement, which they called Jamestown. It was low and marshy, mosquito-cursed, unhealthful, and hard to defend from the Indiaus, who attacked it within two weeks. The colonists were not accustomed to hard labor, and for some years they had to be supported from England.

The most picturesque figure in these early days is Captain John Smith, who wrote two accounts of the colony: the True Relation in 1608, and the Generall Historie in 1624. In the latter he relates what was entirely omitted in the earlier story, how when he was a prisoner the Indians were about to beat out his brains; how Pocahontas (then a child of ten or twelve years), daughter of the great "Weroance" Powhatan, sprang between him and the club and saved his life. Whether this story be true or imagined, the courage and spirit of

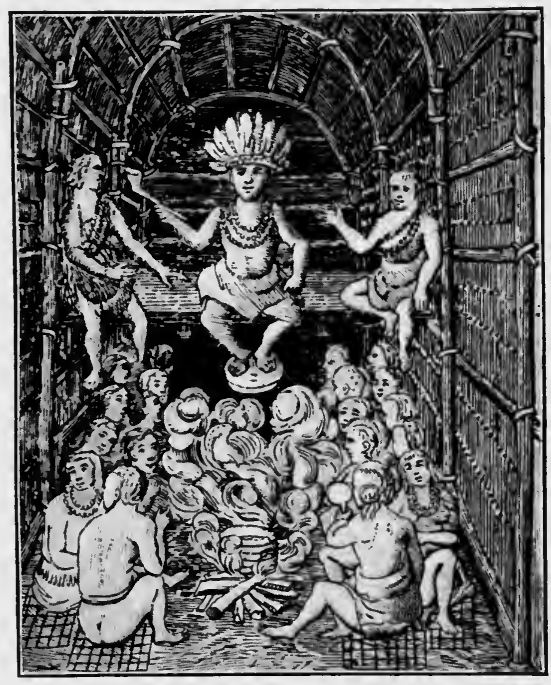

Powhatan's Lodge, 1607.

From Smith's Generall Historie,1624. Smith are undeniable. He alternately pacified and fought the Indians; he found supplies, explored the country, and was the principal man in the little government.

The beginnings of Virginia are a terrible tragedy of famine, desperation, and death; of 630 early colonists 570 died in the first two and a half years. Yet its founders did not lose courage; and the company reorganized in 1609 , and secured a 
second charter, granting a distinct territory, two hundred miles each way along the coast from Old Point Comfort and "all that Space and Circuit of Land, lying from the Sea Coast of the Precinct aforesaid, up into the Land throughout from Sea to Sea, West and Northwest." The local government, however, was a mere tyranny - under the fierce Governor Dale the colonists were little better than slaves. In 1612, by a third and last charter, the company was reorganized and received larger powers of control of its own affairs.

The turn of the tide came in 1616, when Dale departed and when the company began to assign definite tracts of land to the settlers, in strips fronting on the tide rivers, so that they had water communication with one another and with the rest of the world. Sassafras was a valued export; and in 1615 began the export of tobacco, then sold for three shillings a pound.

Yet in 1619, after at least $£ 100,000$ had been spent, there were only 400 colonists in Virginia. When the London Com29. Virginia passes pany (then often called the Virginia Company) came ginia passes under the control of liberal and public-spirited men, (1619-1650) headed by Sir Edwin Sandys, they instructed their governor in Virginia to summon a popular assembly - the first free representative government upon the western continent. Accordingly twenty-two "burgesses," elected from the various settlements of Virginia, met in the church at Jamestown in July, 1619, and drew up numerous laws for the colony. In 1621 , by the so-called "Sandys constitution," this assembly was formally recognized. The year 1619 also marks the beginning of colonial slavery. A Dutch man-of-war in Virginia exchanged twenty negro slaves for provisions; and thus began a new source of labor for the cultivation of tobacco, which quickly became almost the sole industry of Virginia.

In 1623 the Indians rose and killed nearly 350 settlers; and the tragedy gave point to enemies of the colony in England, who 
assailed it as a swampy, pestilential, ill-housed, and dreary place, where "tobacco only was the business," where of 10,000 colonists only 2000 were left alive. In vain did the company defend its management, which was manfully working to overcome the disadvantages. King James I. disliked the company, and in 1624, by the judgment of the Court of the King's Bench, the Virginia charters were held null and void. As for land titles, all grants already made to individuals were held good; and the right to make new grants within the boundaries of the old charter practically passed to the royal governor.

Under Charles I., who became king in 1625 , nominally the only government left to Virginia was the will of the king; although practically the administration went on under royal governors much as before, with frequent meetings of elected assemblies. By 1650 Virginia numbered about 15,000 people.

The second English colony in America was made by exiles cast off by their own country. During the reign of Elizabeth there grew up within the established Church of England a body of so-called Puritans, who felt that the Reforma30. Puritans and tion had not gone far enough; and out of the Puritans (1604-1620) arose a body of "Separatists," later called Independents, who would not remain in that church. Soon after James I. came to the throne in 1603 , he declared, "I shall make them conforme themselves, or I will harrie them out of the land, or else do worse." Thereupon many Puritan ministers were deprived of their right to hold services; congregations of Separatists at Scrooby and Austerfield in the east of England were broken up; and by 1608 about three hundred of these people took refuge in Holland, mostly in Leyden.

A God-fearing and industrious folk, the exiles (by this time often called Pilgrims) found themselves strangers in Holland, and feared that their children would not hold to their faith. Under the advice of their pastor, Rev. John Robinson, about two hundred of the Pilgrims made up their minds to 
seek a place of settlement in America. Their friends in England lent them about $£ 5000$, and they got from the London Company a patent for lands to be located somewhere within the general bounds of the second charter of that company.

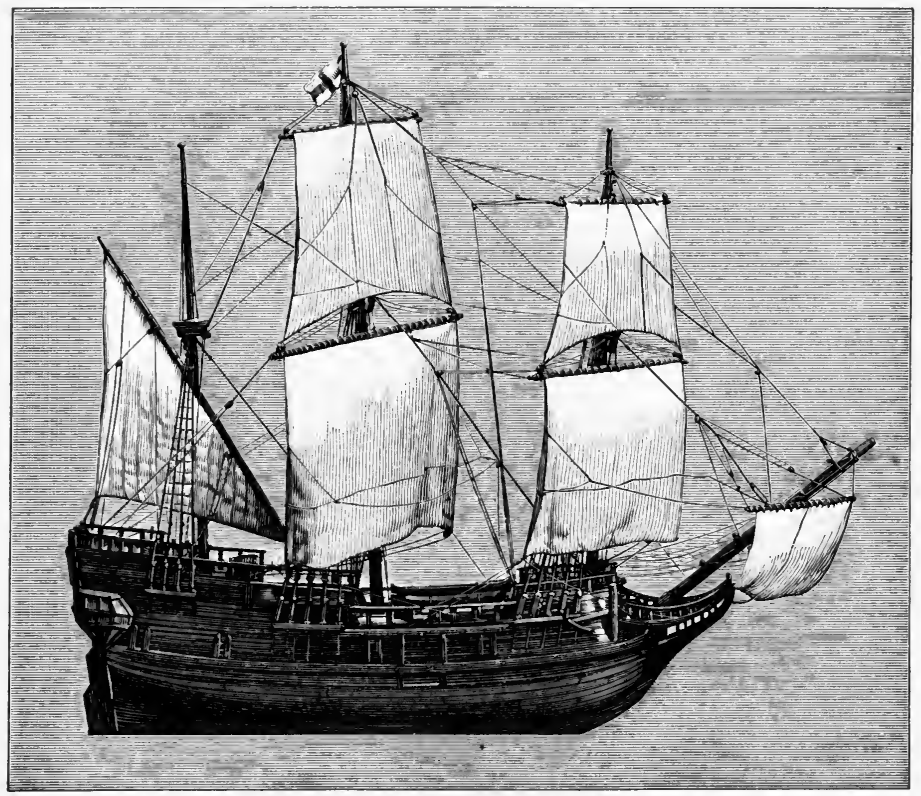

The ShIP MATFLOWER.

From a model in the National Museum, Washington.

The transfer to the new world was long and tedious. In July, 1620, a part of the Leyden congregation set sail from 31. Settle- Delfshaven to Southampton; and of these about a hunment of Plymouth dred left the harbor of Plymouth (September 6, 1620) on (1620-1640) the ship Mayflower, bound for the Hudson River country. After three months of stormy voyage they found themselves, perhaps by the bad faith of the ship's captain, hundreds of miles east of their desired harbor, just off Cape Cod, which was part of the territory of the old Plymouth Company, and 
in a region already named New England. Inasmuch as they had no patent from the Plymouth Company, the Pilgrims were under no fixed government; therefore, on board the Mayflower (November 11,1620), they drew up a brief "combination," or "compact," by which they agreed to organize as a "civil body politic" for their government after they should land; and they chose John Carver to be governor.

After exploring the coast the Pilgrims decided to settle on the bay already called Plymouth Harbor, and landed December 11, 1620 (December 21, new style), near a great bowlder Bradford, now called Plymouth Rock, "among diverse cornfeilds, $\begin{array}{r}\text { Plimoth } \\ \text { Plantation, }\end{array}$ \& litle runing brooks." The season was cruelly hard, and during the first winter half the number died from cold, poor food, and other hardships. Their pluck was decisive; the next season others came out, and thenceforward the little colony prospered. The Indians in the neighborhood were few, and the colony's military chieftain, Miles Standish, defended it well.

Plymouth remained almost an independent little republic. The people secured a patent for their land in 1621, and in twelve years paid their debt due in England, out of their fishery and Indian trading business. Under the prudent administration of William Bradford, governor for thirty years, they set up the first town meetings in America, and later organized a representative assembly (1639). To the end of its existence in 1691 , the colony never had a charter or a royal governor. Yet it hardly knew internal strife; it was at peace with its neighbors; it showed that Englishmen could prosper in the cold climate of the northeastern coast; it established in the new world the great principle of a church free from governmental interference, and founded on the will of the members. Above all, the Pilgrim Fathers handed down to later generations priceless traditions of strength, manliness, patience, uprightness, and coufidence in God. 
The Plymouth Company of 1606 in England was reorganized in 1620 by a new charter, under the name of the Council 32. Settle- for New England, and adopted the policy of dividing

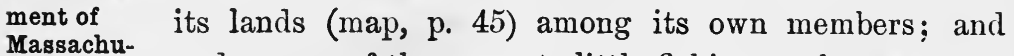
setts (1620-1635) under some of these grants little fishing settlements were Island (East Boston), and at Shawmut (Boston).

New conditions in England now led to a third permanent North American colony. The new king, Charles I., plunged into bitter quarrels with the Puritans and with Parliar

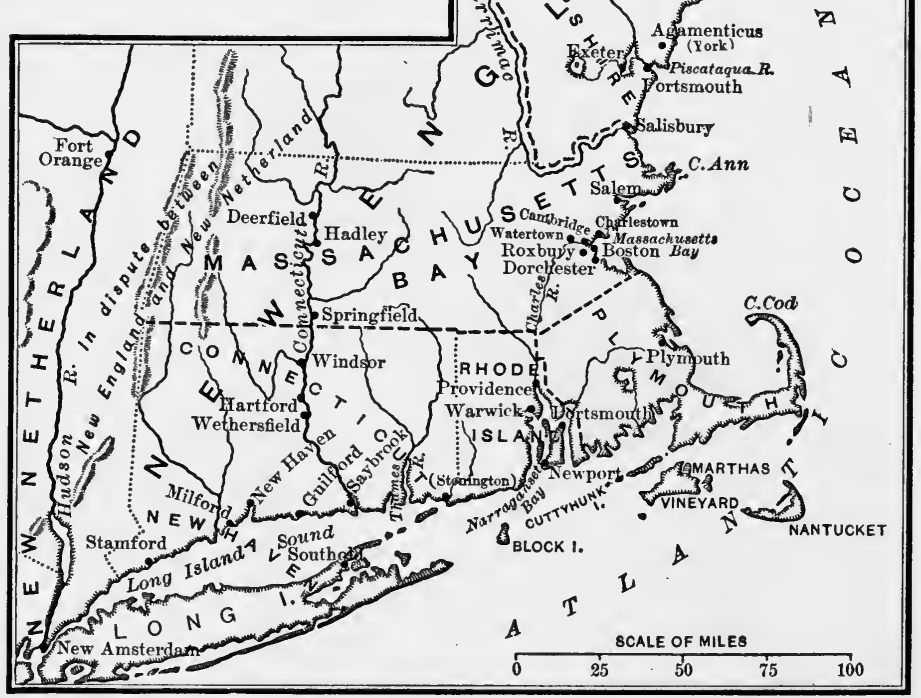

Early New England Settlements.

ment. Some merchants and country gentlemen, most of them Puritans who still accepted the service and authority of the Church of England, got a land patent from the New England 
Council. Then in 1629 they secured a royal charter to the "Governor and Company of the Massachusetts Bay in New England," covering a tract bounded on the north by a line three miles north of the Merrimac, on the south by a line three miles south of Massachusetts Bay and the Charles River, and reaching westward to the South Sea (Pacific Ocean).

The royal charter made no condition that the company should have its headquarters in England, and by a solemn "Agreement" made at Cambridge, England (August 26, 1629), fifteen members undertook to go to Massachusetts - or Massachusetts Bay, as the "plantation" (colony) was at first called. The company then voted "to transfer the government of the Plantation to those that shall inhabit it" - that is, they carried the parchment charter to Massachusetts, and exercised its privileges thousands of miles away from the too inquisitive English government.

In 1630 a thousand people crossed to Massachusetts; among them a dozen or so "freemen," or stockholders of the company, who set the government of the colony in motion by electing John Winthrop governor. The colonial government thus formed found already in existence the little towns of Roxbury, Dorchester, Charlestown, Boston, and Watertown, each of which had established a town government and begun to legislate for itself. These little undeveloped republics easily yielded to the superior authority of the colony in general measures, and accepted its right to create or alter forms of town government. Although the royal government was furious at the transfer of the charter, the colony grew rapidly, and in ten years increased to nearly fifteen thousand people. In 1635 the New England Council of 1620 gave up its charter, and the royal government made an unsuccessful effort to cancel the Massachusetts charter also.

With a strong backing in money, colonists, and protection through the Parliamentary leaders in England, Massachusetts 
had an opportunity to work out several important experiments in government.

33. Example of Massachusetts in government "Body of Liberties," enacted by the General Court in 1641.

(2) A popular government was built up. The governor was elected every year by the freemen of the company, and so were the assistants (originally a board of directors of the company). In 1634 the towns began to send "committees," or delegates, to the General Court (originally the stockholders' meeting) and thus established a representative government, in which the assistants remained as an upper house. In practice this was not a very democratic system, since freemen had to be church members, and hardly one adult male immigrant in eight was admitted as a freeman.

(3) Government and religion were closely united. In their political thoight the colonists were much influenced by John Calvin, the great Genevan divine and statesman. The Puritans very speedily abandoned the prayer book and the episcopal authority of the Church of England, and set up independent churches which called themselves "Congregational"; and the ministers, who were supported by public taxation, had remarkable influence in public affairs. One of them said that the proper government is that "in which men of God are consulted in all hard cases and in matters of religion."

Massachusetts developed statesmen of whom the best example was John Winthrop, an English country squire by birth, 34. Winthrop and the Antinomians (1636-1637) imbued with a strong sense of duty, living like a gentleman in a good house, with plenty of servants. Winthrop gave form to the commonwealth, regulated legislation, and stood as long as he could for aristocratic government; but in the end he yielded graciously to the democracy. $\mathrm{He}$ was thirteen times elected governor of Massachusetts Bay. 
The colony, led by men like Winthrop, sternly repressed people who differed from the established religion, or too much criticised the clergy. In $1636 \mathrm{Mrs}$. Anne Hutchinson of Boston, and others, who were called "Antinomians" (i.e. people not living by the letter of the law of God), set up the doctrine of the "covenant of grace," or special possession of the inspiration of God; and they asserted that most of the Boston ministers were under a "covenant of works," that is, were trying to be saved by religious observances. Then Mrs. Hutchinson began to hold women's meetings to discuss and to criticise the latest sermon - perhaps the first woman's club in America. She was tried for heresy, dismissed

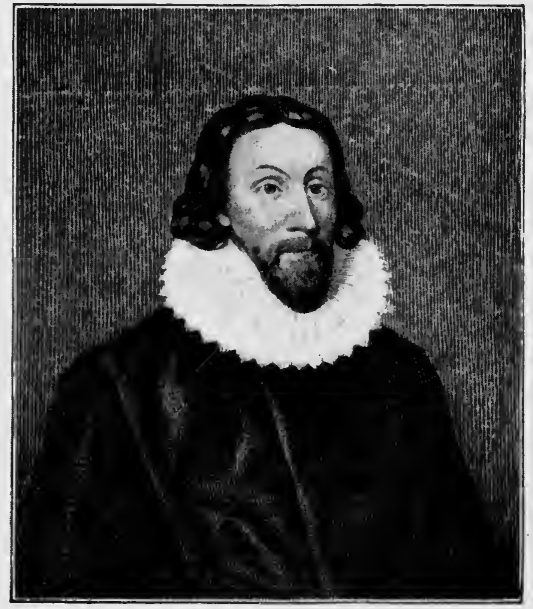

John Winthrop, ABOUt 1628.

Ascribed to Van Dyck. Dress of the Puritan gentleman.

from the church, and ordered to leave the colony (1637). This act of religious intolerance can not be denied or defended, and is in marked contrast with the gentler spirit of the people of Plymouth.

Hardly had Massachusetts been settled, when a southern colony was chartered under Catholic influence. In $1632 \mathrm{King}$ Charles granted to George Calvert, Lord Baltimore (soon 35. Settlesucceeded by his son Cecil, the second Lord Baltimore), a ment of charter for a colony called Maryland after Queen Henrietta (1632-1650) Maria. It was bounded on the north by the "40th degree," on the east by Delaware Bay and the ocean, on the south by the 
Potonac, and on the west by a meridian line drawn through the source of the Potomac.

This charter was of a new type, for both the land and the powers of government were transferred to Calvert as a "pro-

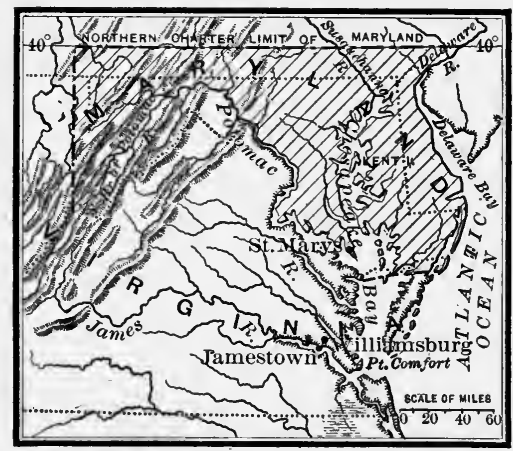

Original Extent of Maryland.

Dotted lines are present state boundaries. prietary": he had authority to make laws for the colony, provided the freemen of the colony assented. Although not distinctly so stated in the charter, it was understood that Catholics would be allowed in the province; and in 1634 a body of colonists, both Catholic and Protestant, settled first at St. Marys and then elsewhere. The Baltimore family was rich and powerful, and sent out many emigrants; the soil was fertile, tobacco soon became the main industry, and slaves were introduced.

The first excitement of early Maryland history was a controversy over Kent Island in Chesapeake Bay, with William Claybourne, who had settled it under a grant from Virginia; and a little eivil war was necessary to displace him. In an early contest with the proprietor the assembly successfully asserted its right to initiate laws. The most significant statute was the Toleration Act of 1649, which distinctly declared that "no person ... professing to believe in Jesus Christ, shall from henceforth be anywaies molested, or discountenanced . . . for his religion nor in the free exercise thereof." Under this act, though Catholies could not be persecuted for their faith, it was impossible for them to keep out Protestants, who outnumbered the Catholics; and the colony speedily became distinctly Protestant in feeling. 
The next impulse of colonization was on the Connecticut River, where several currents of settlement ran together. (1) The Dutch built a fort, called "Good Hope," on the Connecticut-in 1623, and continued to hold it thirty years. (2) The Plymouth people established a post at Windsor in 1633. (3) In 1631 the Council for New England granted to Lord Say and Seal and others a tract on

36. Settlement of Connecticut and New Haven (1623-1643) Long Island Sound, under which a settlement was made at Saybrook in 1635. (4) The principal settlements were made by some of the people of Roxbury and Newtown, now Cambridge, Massachusetts, headed by Rev. Thomas Hooker. In 1635 and 1636 they made their way across country and founded on the Connecticut River the towns of Hartford (alongside the Dutch fort), Windsor (unceremoniously annexed from Plymouth), and Wethersfield. Soon they cut loose from Massachusetts; and in January, 1639, feeling the need of a common government, representatives of these three little towns met at Hartford and drew up the "Fundamental Orders of Connecticut," the first detailed constitution made by a self-governing American community for itself.

Meantime the colony of New Haven was forming in like manner out of separate communities : Southold and other towns on Long Island; Milford, Guilford, and Stamford ; and especially the town of New Haven, founded in 1638, by Theophilus Eaton and Rev. John Davenport. In 1643 these little towns united in a common colonial assembly.

The settlement of the Connecticut valley was interrupted by an Indian war in 1637. The Pequots, a large and warlike tribe, grew threatening as they saw their hunting grounds invaded by the English. Captain John Mason, of Connecticut, with 90 armed white men and 400 Narragansetts, attacked the Pequots not far from the present Stonington, Connecticut; and stormed their fort. As the chronicler puts it, "Downe fell men, women, and children, those that scaped us, fell 
into the hands of the Indians, that were in the reere of us . . . not above five of them escajed out of our hands." This cruel and merciless massacre territied the remnants of the tribe, and gave peace for nearly forty years.

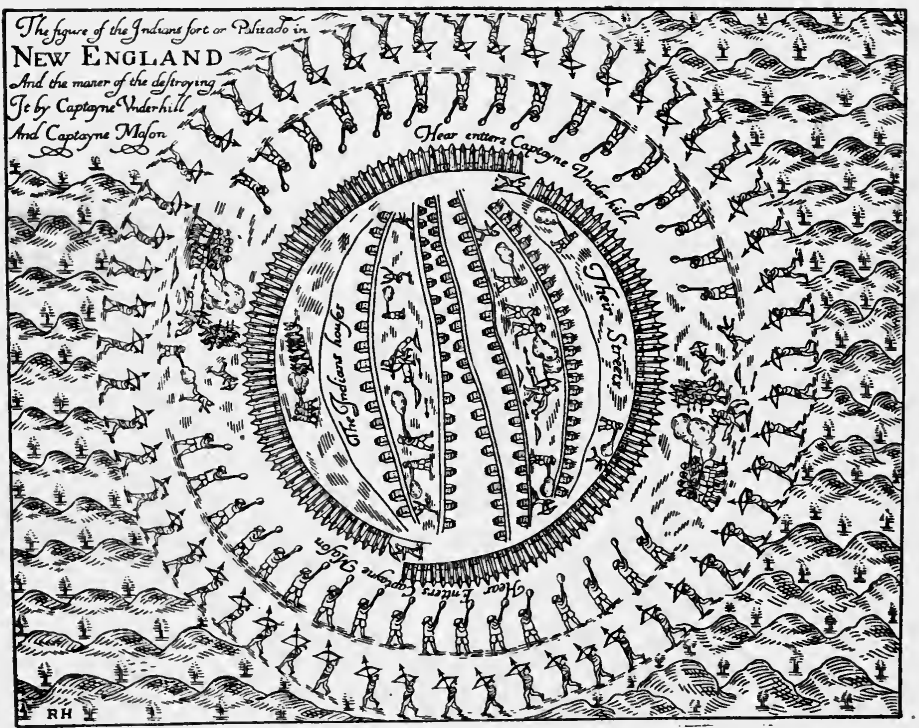

Pequot Fort, Destroyed in 1637.

Contemporary plan of the attack by whites and Indians.

Just outside the charter limits of Massachusetts another new colony was founded in 1636. The leading spirit was 37. Settle- Roger Williams, a graduate of Oxford, who for two ment of years was minister at Plymouth, and then became a Rhode Island (1636-1650) now the obvious doctrine that the civil government has nothing to do with religious acts, and that every one should have liberty to worship God in the light of his own conscience. For his denial of the right of any government to prescribe religious beliefs for its citizens, Williams was banished from 
Massachusetts (January, 1636). He betook limself to what was then the wilderness of Narragansett Bay, where he secured a tract of land from the Indians, by friendly agreement, and founded the town of Providence. Two years later he alarmed and grieved his neighbors in Massachusetts by fornally going over to the Baptist Church, which was bitterly persecuted both in England and in the colonies.

Around Narragansett Bay other exiles from Massachusetts made little settlements in 1638: the town of Warwick on the mainland, Portsmouth (founded by Mrs. Anne Hutchinson) and Newport on the island of Rhode Island. In 1644 the Earl of Warwick, in behalf of Parliament, gave a patent to the "Providence Plantations in the Narragansett Bay in New England," under which, in 1647, were loosely united under one government the four little settlements of Providence, Newport, Portsmouth, and Warwiçk. The little group of settlements attracted immigrants by its favorable situation; it even tolerated the Church of England; it had a prosperous commerce, a tumultuous assembly, elected its own governor, and was heartily disliked by its neighbors.

The settlements north of Massachusetts were obstructed by rival French claims, and hampered by a succession of confused and conflicting grants made by the Plymouth Com38. New pany and its successor the Council for New England. Hampshire and Maine John Wheelwright, a Boston minister, adopted the (1620-1650) ". Intinomian" doctrines, and was disfranchised and banished; a little company of Massachusetts people, who had already settled north of the Merrimac at Exeter without a grant, begged him to come and be their minister (1638). Other little towns were speedily settled in what is now New Hampshire, and formed a sort of confederation, not unlike the governments of Rhode Island and New Haven. Massachusetts claimed the territory; and withm five years the people accepted her jurisdiction, and remained a part of that colony most of the time to 1691 .

HAKT'S AMER. HIST. -4 
One of the members of the Plymouth Company, Ferdinando Gorges, made several efforts to build up a colony in Maine, and in 1631 founded the "City of Agamenticus" (York); but Massachusetts annexed this and other little settlements on the northern coast in 1652 .

Immigration into the colonies and especially into New England was suddenly checked by alarming difficulties in England.

39. Colonial government under Parliament (1643-1656)
After fifteen years of struggle with the king, the Puritans and Separatists at last got the upper hand in the "Long Parliament," which met in 1640. In 1642 a civil war broke out, the result of which was that, in 1649, the army under Oliver Cromwell became the virtual government of England, and Charles I. was executed. The Independents (substantially the same as the New England Congregationalists or Separatists) now became the controlling power; and the army, which was strongly Independent, supported Crom well as "Lord Protector of the Commonwealth of England, Scotland, and Ireland" from 1653 to his death in 1658.

The colonists were left mostly to themselves during the early part of this period of confusion. Cromwell, however, developed a strong and consistent colonial policy. (1) In 1651 he secured the first navigation act for protecting English colonial trade by excluding foreign shipping - a measure directed against the Dutch. (2) He sent out a fleet in 1652, which compelled Maryland and Virginia to submit to the authority of Parliament. Hostilities broke out in Maryland between the Puritans and the Catholics, but the Puritans triumphed. (3) Cromwell attacked the colonies of Holland and Spain, compelling the Dutch at last to withdraw from Hartford, and thereby practically to give up all claims to the Connecticut valley; and in 1655 Jamaica was taken from Spain and added to the previous group of English West India islands.

The pressure of the Indians and the Dutch, and the confusion in England, led Massachusetts, Plymouth, Connecticut, 
and New Haven, in 1643, to unite in a colonial union called the United Colonies of New England - the first of its kind and the prototype of our present federal union. The "Articles of Confederation," under, which the union was formed, was a little constitution, creating a government of two commissioners from each colony, " being all

40. New England Confederation $(1643-$

1655) in Church fellowship with us," and any six of the eight agreeing could bind all the colonies, although Massachusetts had more people than the other three colonies together. The Articles provided for common meetings and for common action " in generall cases of a civill nature"; and provided for the return of fugitives, servants, and prisoners.

This confederation stood for more than forty years, and by its united front rendered large service to the colonies; it concerned itself with the general improvement of the people; it made boundary settlements with the Dutch; it repeatedly checked the Narragansett Indians; it even corresponded with the French governor of Acadia. Once Massachusetts flatly denied the right of the six commissioners from the other colonies to control it (1653), and threatened secession; but peace and concord were restored.

Among the new sects which sprang up in England was that of the Friends (commonly called Quakers), founded in 1648 by George Fox as a protest against all religious forms, ceremonies, and government. Though a quiet folk of singularly blameless lives, they were harassed and often (1648-1660) imprisoned in England. They soon began to appear in the colonies. When two modest and God-fearing Quaker women reached Boston, their doctrines were officially declared to be "heretical, blasphemous, and devilish," their books were burned, and they were shipped out of the colony (1656).

Massachusetts, Connecticut, and Plymouth, as well as Maryland and Virginia, hastened to pass laws for the severe punishment of Quakers and " ranters," and prohibiting the circulation 
of their books; but mild punishments did not keep them out, nor even condemnations to be sold as slaves. In 1660 four of them were executed in Boston; and this rigor so shocked the sense of the community that a new law was passed abolishing the death penalty against the Quakers, but still banishing them. The Quaker episode is a proof that the good and pure principles of the Puritans did not keep the community from tyranny and stupid cruelty. 'The Quakers neither harmed nor seriously threatened the good order of the colonists; they were persecuted because they ventured to differ from the usual religious and political practices.

The English settlements in America in the first half of the seventeenth century are the foundation of the present United 42 sum- States, and were made under circumstances favorable to mary

high civic spirit. By the theory of English law the lands in America were the personal possessions of the crown, to be granted and to be governed according to the king's will; and both James I. and Charles I. had no larger thought than to please their favorites with immense grants of territory; and they put out of their own hands all direct colonial government, except in Virginia after 1624.

The original plan was to colonize through great companies, which were to find their profit in disposing of the lands and in trade; but the early corporations broke down. The London Company's Virginia charters were annulled in 1624. The Plymouth Company in its two forms of 1606 and 1620 practically did nothing but make land grants. The Massachusetts charter of 1629, however, was transferred to the actual settlers, and became the constitution of a nearly independent commonwealth. In Maryland there was a new form of proprietary colonial grant in 1632; but the people obtained a share in their own government. In Maine, New Hampshire, Plymouth, Rhode Island, Connecticut, and New Haven, colonies were 
founded without royal charters, and almost without royal control.

The great lesson of this early English colonization is that men of the English race were able to adapt themselves to new and inforeseen conditions. The colonists made local governments for themselves, founded representative colonial governments, and even set up a remarkable federation, during the confusion caused by the civil war in England.

\section{TOPICS}

(1) Compile a list of American colonizing companies chartered by the crown. (2) Why did the l'opham colony fail? (3) Give a Suggestiv' $\theta$ description of the weroance Powhatan. (4) Did the Indians check the growth of Virginia? (5) Was the court justified in annulling the charters of Virginia in 1624 ? (6) What were the religious principles of the Independents? (7) Why did Charles I. so readily grant a charter for Massachusetts Bay? (8) Why were the l'lymouth Company and the Council for New England failures? (9) Were the ministers wise guides in Massachusetts? (10) Was Roger Williams dangerous to the peace of Massachusetts? (11) Why did not Spain uproot the colony of Virginia? (12) What did "West and Northwest" mean in the Virginia charter of 1609 ? (13) Tobacco culture. (14) Doctrines of the Quakers offensive to the Puritans.

(15) Life in Jamestown. (16) Did Pocahontas save John Smith's life? (17) The first Virginia assembly. (18) The voyage of the Mayflower. (19) The Pilgrims and the Indians. (20) Trial of Anne Hutchinson. (21) Banishment of Rev. John Wheelwright. (22) The interest of the New England Confederation in education. (23) Was Claybourne entitled to Kent Island? (24) Cromwell's interest in the American colonies. (25) Precise date of the landing of the Pilgrims.

\section{REFERENCES}

See maps, pp. 45, 52, 56 ; Semple, Geographic Conditions, 19-35; Geography Tyler, England in America; Epoch Maps, no. 3.

Thwaites, Colonies, §§ 28-34, 48-68; Fisher, Colonial Era, 3049, 62-71, 82-146, 177-187 ; Lodge, English Colonies, chs. i. iii. Searcb topics xviii.-xxi. passim; Tyler, England in America; Fiske, Old Vir- 
ginia, I. 41-318, - Beginnings of New England, 50-198; Doyle, English in America, I. 101-229, 275-313, II. 11-319, III. 98-114; Wilson, American People, I. 34-68, 74-218 ; Gay, Bryant's History, I. 262-338, 370-428, 476-558, II. 1-114, 165-228, 373-379 ; Adams, Three Episodes; Eggleston, Beginners of a Nation, 25349 ; Bruce, Virginia, I. 1-188 ; Weeden, New England, I. 23-46 ; Mereness, Maryland; Warner, Captain John Smith; Browne, George Calvert and Cecilius Calvert; Twichell, John Winthrop; Walker, Thomas Hooker; Straus, Roger Williams.

Sources

Illustrative works

Pictures

Hart, Source Book, §§ 5, 8, 10, 13-21,-Contemporaries, I. §§ 49-142 passim, — Source Readers, I. \$§ 10-12, 20, 34-36, 45-48, 57-60 ; MacDonald, Select Charters, nos.1-21 ; American History Leaflets, nos. 7, 16, 25, 27, 29, 31 ; Old South Leaftets, nos. 7, 8, 48-51, 53-55, 66, 77, 87, 93, 121 ; Caldwell, Survey, 13, 29-32 ; Arber, Pilgrim Fathers; Bradford, Plimoth Plantation; Winthrop, New England. See N. Eng. Hist. 'Teachers' Ass'n, Syllabus, 297-305, - Historical Sources, §§ 69-71.

Longfellow, Courtship of Miles Standish,_John Endicott; Whittier, John Underhill, - The Exiles, - Banished from Massachusetts, - King's Missive; Mary Johnston, To Have and to Holl (Va.) ; J. L. Cooke, My Lady Pokahontas, - Stories of the Old Dominion, 1-64; J. G. Austin, Standish of Standish, - Betty Alden (Plymonth); L. M. Child, Hobomok (Plymouth); Motley, Merry Mount; Hawthorne, Maypole of Merry Mount, - Endicott and the Red Cross, - The Gentle Boy (Quakers), - Grandfather's Chair, pt. i. chs. i.-vii.; F. J. Stimson, King Noanett (Mass. and Va.) ; J. G. Holland, Bay Path (Connecticut valley) ; B. M. Dix, Making of Christopher Ferringham (Quaker); I. M. Thurston, Mistress Brent (Md.); M. W. Goodwin, Sir Christopher (Md.).

Winsor, America, III.; Wilson, American People, I. 


\section{CHAPTER IV.}

RIVALS OF ENGLAND, AND THE GREAT WEST (1603-1689)

Side by side with the English colonies grew up French settlements on the north, and Dutch posts in the center, which

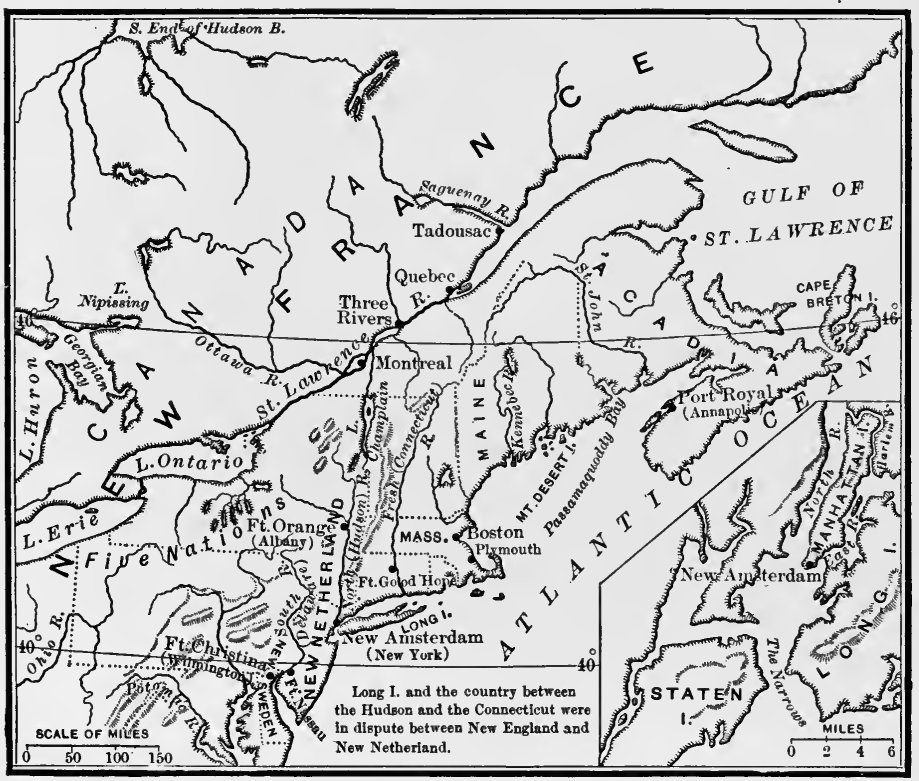

New France and New Netherlanid.

contested with the English the control of the seaboard and the best routes into the interior. Under their brilliant king Henry IV. the French revived their American claims ( $\$ 21$ ), and in 1603 he issued a royal patent, with a (1603-1632) monopoly of the fur trade, to the Sieur de Monts for the territory 
between the 40 th and 46 th degrees of latitude, under the name of Acadie.

De Monts made temporary settlements at the island of St. Croix, in Passamaquoddy Bay (1604), and at Port Royal, later Annapolis; his agent Samuel de Champlain established the first permanent French settlement in North America at Quebec (1608). Champlain was the most brilliant and most successful of French explorers and colonists. Soon after his

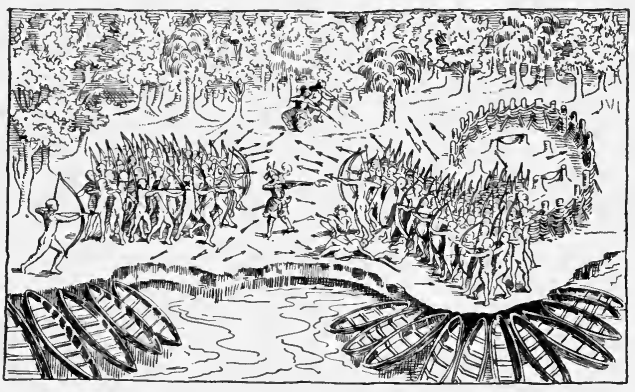

Champlain Deffating the Iroquois, 1609.

From Champlain's Voyages, 1613. arrival he and a body of Algonquin Indians went to the lake now called by his name, where they fell in with a party of fierce and hostile Iroquois. Champlain's firearms quickly dispersed the strangers in a panic, and he thus laid the foundations of hatred and dreadful warfare between the French and the Five Nations. In 1611 he founded Montreal, and a few years later was the first European to reach the shores of Lake Huron and Lake Ontario.

A settlement made by Jesuits on the island of Mount Desert in 1613 was forthwith the scene of the first armed conflict between the French and the English on American soil, for Captain Argall of Virginia descended upon it and carried away the settlers. A few years later England went so far, during a war between England and France, as to capture Port Royal and Quebec. Nevertheless, in 1632, by the treaty of St. Germain, the first European agreement as to American boundaries, the English formally acknowledged the rightful title of France to "New France, Acadia (Acadie), and Canala" (that is, to the 
present Nova Scotia and the lower St. Lawrence valley, with the country between); in return they were to be undisturbed in their Plymouth and Massachusetts settlements.

Another competitor for the best part of North America appeared on the middle Atlantic coast. The Dutch republic had now become one of the principal naval and commercial powers of Europe; and a truce with Spain (1609) gave it an opportunity for new expansion. Henry Hud(1609-1630) son, an Englishman in the Dutch service, in 1609 rediscovered New York Harbor, followed the East River to the entrance of Long Island Sound, and explored the Hudson River, thus giving to the Dutch a presumptive right to the neighboring region. Accordingly the United New Netherland Company of traders built the trading post of New Amsterdam on the site of the present eity of New York in 1614. Seven years later the Dutch government granted the monopoly of Dutch trade in America to the new Dutch. West India Company, which in 1623 sent out thirty families, part of whom settled Fort Orange (Albany).

The first permanent town on Manhattan Island was Fort Amsterdam, enlarged from the earlier post by Governor Peter

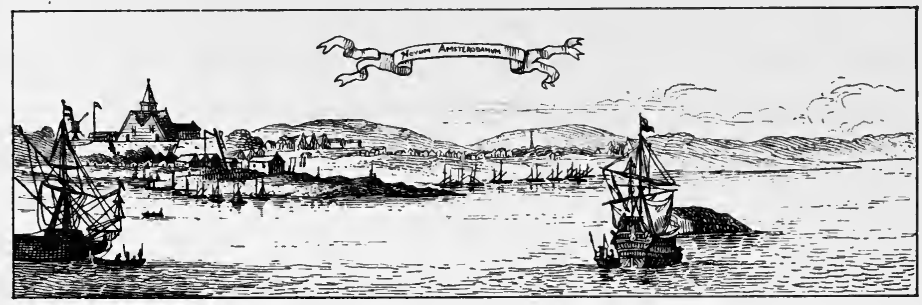

New Amsterdam, 1656. (From a drawing by H. Block.)

Minuit in 1626. The Dutch laid a broad foundation for their new colony of New Netherland by planting little trading posts on the Connecticut, on Long Island, up the "North River" (Hudson), and on the "South River" (Delaware). A change 
in the Dutch policy came in 1629, when, by a Charter of Privileges, great land grants were assigned to Dutch "patroons," gentlemen who brought out their own settlers, and established a kind of feudal system. Other people came in, and before long eighteen languages were spoken in the little town, again called New Amsterdam.

Meantime a rival power had acquired the Delaware region. In 1638 a Swedish royal colony of Swedes and Finns settled 15. The Dutch and the Swedes on the lower Delaware, near Fort Christina (Wilmington). (1638-1655) and in 1655 it was seized by the Dutch Governor Stuyvesant. While this struggle was going on, in the general European peace of Westphalia (1648) Spain had at last admitted the independence of the Dutch, including their American colonies of Guiana and New Netherland.

English, French, and Dutch alike speedily learned that the way from the coast to the interior with its valuable furs was

46. The Five Nations

held by the powerful confederacy of the Five Nations of Iroquois - the Mohawks, Onondagas, Cayugas, Oneidas, and Senecas. Their territory stretched along central New York in a succession of towns made up of $\log$ cabins called "long houses." Though they never numbered more than ten thousand people, of whom two thousand or three thousand were warriors, their war parties were a terror as far east as Boston, as far south as Virginia, and as far west as Illinois. Constantly reduced by desperate fighting and disease, they kept up their numbers by adopting prisoners. Their internal organization was weak, for there was only a loose confederation between the tribes; if the young men wanted to go to war, they made up a party, including members of one or all the tribes, and went their way.

The worst enemies of the Iroquois were their own fierceness, disease, and the white man's rum. They suffered fearfully from smallpox, which ran its course till often whole 
villages were depopulated. As to the effects of liquor, an eyewitness says: "They were all lustily drunk, raving, Contempostriking, shouting, jumping, fighting each other, and raries, I.58y foaming at the mouth like raging wild beasts. And this was caused by Christians!"

While the Dutch were pushing into the central coast, the French were steadily developing the St. Lawrence basin, but they avoided Lake Erie, which was flanked by the Five Nations. In 1634 Jean Nicolet followed up the Ottawa River, crossed to Georgian Bay, and passed through upper Lake Huron to the Sault Ste. Marie and the (1634-1669) Strait of Mackinac; he was the first European on Lake Michigan. The Catholic missionaries speedily followed, and outran the traders in zeal and courage. The Iroquois followed their French enemies northward, exterminated the Hurons because they were friendly to the French, and martyred the missionaries (1649).. In 1665 Lake Superior was discovered by the missionary Father Allouez, and before long French traders discovered an overland route from Lake Superior to Hudson Bay. Missions were soon after established at Sault Ste. Marie, at Mackinac, and at St. Xavier, on Green Bay.

Meanwhile the Jesuit missionaries were making heroic, though on the whole unavailing, efforts to Christianize the Iroquois. Father Isaac Jogues's account of his experience Contempoas a prisoner gives a frightful picture of his captors, who raries, I. 129 seemed to him like demons; they leaped upon him like Parkman, wild beasts, tore out his nails, and crunched his fingers with their teeth; his attendant Hurons were tortured on a scaffold in the midst of the Iroquois village; yet the heroic priest " began to instruct them separately on the articles of the faith, then on the very stage itself baptized two with raindrops gathered from the leaves of a stalk of Indian corn." Rescued by the Dutch, this brave and self-sacrificing man returned and plunged a second time into that misery, and died a martyr's death. 


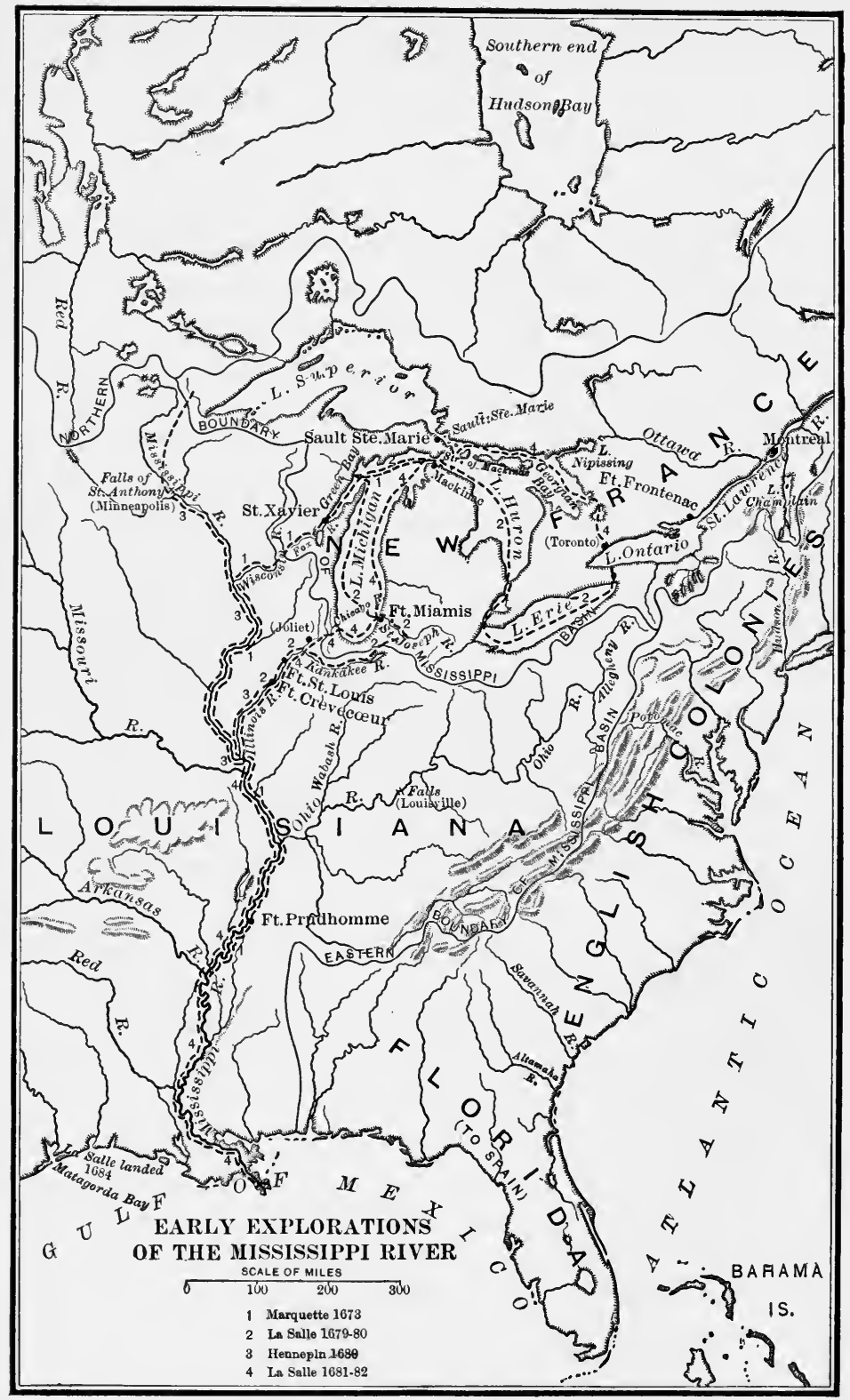


On the upper lakes the French heard vaguely of a great south-flowing . river, the "Missipi" or "Mich sipi," "Big Water," which they supposed to flow into the Gulf of California. The first man to form an intelligent plan of reaching the great river was Robert Cavalier, commonly called La Salle, a French nobleman who, in 1669,

48. Discov. ery of the upper Mississippi (1669-1680) went west as far as Lake Erie, which had just been traversed for the first time by a white man, the trapper Joliet. La Salle then disappeared southward, and reached a large river, the Wabash, or perhaps the Ohio (1670); but returned to Montreal, unable to push farther west by that route.

Before La Salle could gather his resources to start again, the Mississippi had been reached, under the direction of Frontenac, the new governor of Canada. In 1673 the missionary Father Marquette, accompanied by Joliet, passed through Green Bay, up the Fox River, across the easy portage of two miles, and down the Wisconsin, till (June 17) they entered a mighty stream, which Marquette called the River Immaculate Conception. They found very deep water, saw prairies extending east and west, and discovered quantities of fish, turkeys, and buffalo. League after league they floated down the river, hoping to reach its mouth; they passed the mouth of the Missouri, so muddy that they would not drink it. By the time they reached the mouth of the Arkansas they felt sure that they were near Spanish and hostile territory; and therefore turned back, and paddled up the Illinois River, which they called the Divine, and crossed over the site now occupied by Chicago to Lake Michigan.

Meanwhile La Salle was made commander of Fort Frontenac on Lake Ontario, and he brooded over the possibilities of establishing a trade route to the valley of the river found by Marquette. In 1678 Louis XIV. gave him a grant, authorizing him to make discoveries and to build forts, and a year later he built the Griffon, the first European vessel on Lake Erie, and 
navigated her through the chain of Great Lakes to Green Bay ; and thence in boats reached the river St. Joseph, near the head of Lake Michigan, where he built Fort Miamis. Crossing the portage to the Kankakee River, he made his way down the Illinois to a point near the present Peoria, where he built another fort, Crèvecœur, as a basis for further advance. A missionary friar, Father Hennepin, came out with La Salle and in 1680 was sent by him down the Illinois and thence up the Mississippi; he was taken prisoner by the Sioux Indians, and carried to the falls, which Hennepin named St. Anthony, at the site of Minneapolis.

Again La Salle was obliged to return to Montreal to recruit his forces. When he went west a third time, in December, 49. Discov- 1680, he found that his Fort Crèvecœur had been deery of the lower Mississippi stroyed by Iroquois and its garrison under 'Tonty had disappeared. After a hasty trip to the mouth of the Illinois (1680-1687) he returned eastward, and then began his final and successful journey in 1681. His party crossed the divide of the Chicago River, and floated down the Illinois, reaching the Mississippi February 6, 1682. Then he floated down the same stretch that Marquette had traversed. Soon after passing the mouth of the Ohio he took possession of the country with great ceremony, and set up the king's arms. A few days later, at the Chickasaw Bluffs, he founded Fort Prudhomme.

After a few weeks he passed Marquette's farthest point. April 6, 1682, he arrived at a point where the river divides into three channels. As one of the party wrote: "The water is brackish; after advancing two leagues it became perfectly salt, and advancing on, we discovered the open sea, so that . the sieur de la Salle, in the name of his majesty, took possession of that river, of all rivers that enter it, and of all the country watered by them." Thus was asserted the French title to the magnificent valley which La Salle named Louisiana, in honor of the French monarch, Louis XIV. 
On his way back La Salle founded Fort St. Louis at Starved Rock on the Illinois. His discovery made such an impression that the king sent him, in 1684, direct to the Gulf of Mexico, with a commission to plant a colony near the mouth of the Mississippi. By ill fortune he missed the river, and built another Fort St. Louis (1685) far west of the delta, somewhere near Matagorda Bay. He could not find his river; his men dwindled away; and he was murdered by his own followers in 1687. The fort was destroyed by Indians, while the Spaniards from Mexico were trying to reach it, so as to destroy the possible germ of a French settlement.

La Salle was a hot-headed, impetuous man, who planned an enterprise of colonization beyond his means and his power to command men; yet he felt more than any other Frenchman the importance of the West. He opened up a trade between the Lakes and the Mississippi, and between the upper and lower reaches of that river, and he secured for France a valid title to the Mississippi valley.

The keenness of the rivalry between European nations for the possession of North America was shown also in the West Indies, where the Dutch took several islands, and established a footing on the north coast of South America. On the other hand, as wili be seen in the next chapter, 50. International relations in America they lost New Netherland to the English in 1664. England, France, and Spain were thus left sole claimants for North America, and for a time the English showed less aggressiveness. In 1667, by the peace of Breda, the English a second time admitted the rights of the French to Acadia and Canada. By the treaty of Madrid (1670) Spain for the first time acknowledged that the English had rightful colonies in America.

A hotly disputed territory lay about Hudson Bay, discovered in 1610 by Henry Hudson for the English. This bay was a back entrance to the fur country of the northwest, and in 1670 the English Hudson's Bay Company was chartered to get a foot- 
hold there. The French, who saw their monopoly of the direct trade through the upper lakes disturbed, tried to seize Hudson Bay, and its ownership remained for many years in dispute.

By 1689 the three great colonizing powers had developed their policies toward the native Indians, toward the colonists, 51. Colo- and toward colonial trade. In all these respects Spain nial policies was the most illiberal. The natives of the West Indian
of European states islands were exterminated by the cruelty of their conquerors ; though on the mainland the Indians were more mildly treated. The Spanish colonists had no self-government, and

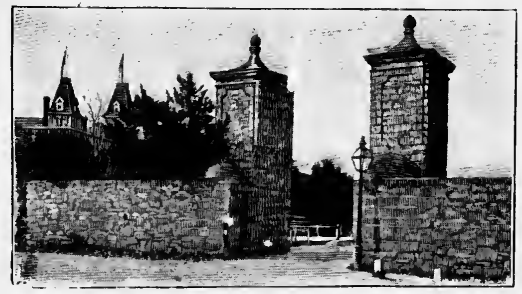

Spanish Walls and Gateway at St. Augustine.

Probably erected in the 17 th century. were ruled by governors sent out from Spain, and their commerce was regulated by the Casa de Contractacion, or House of Trade, at Seville. By a rigorous colonial system, the whole Spanish colonial trade, including that from the Philippines, was the monopoly of the merchants of the single port of Seville. It was concentrated on the Isthmus of Panama, whence year after year for more than two centuries sailed the "plate fleet" carrying to Spain gold and silver, Asiatic goods, and colonial exports.

The French got on with the savage natives better than any other power, because willing to meet them halfway. They lived on terms of peace and almost of intimacy with their Indian subjects ; and French frontiersmen often took squaw wives. Soon arose a distinct class of coureurs de bois, white men and halfbreeds who had adopted Indian dress and manner of life. Canada was substantially a big military camp, which existed chiefly for the fur trade: even the French permanent colonists were chiefly peasants, who had no ambition for self-government. 
The English despised the Indians, and eventually exterminated them or took their lands. The individual colonists had large opportunities for making a living, were of an intelligent class, and had local self-government, which in such times as the English civil war amounted almost to independence. Down to 1689 the English colonial trade was little restricted. The ordinance of 1651 , intended to take the carrying trade from the Dutch, was not enforced in America, and the colonists traded constantly in the French and Spanish West Indies, in defiance of the close colonial system of those two powers.

From 1603 to 1689 the relations of the five powers of North America were gradually defined as follows: (1) The Spaniards held undisputed possession of Mexico and Florida. (2) The French occupied Acadia and the St. Lawrence

52. Sum-

mary valley without serious opposition from any other power, and had established a good claim to the Mississippi valley by the first systematic explorations of the river: $(a)$ the central portion by Marquette (1673); (b) the upper river by Hennepin (1680); (c) the lower river and its mouth by La Salle (1682). (3) The Swedes for a time had a foothold on the Delaware. (4) The Dutch claimed the region from the Connecticut to the Delaware, actually colonized the Hudson, and annexed the Swedish settlement on the Delaware in 1655 ; but they were forced out in 1664. (5) The English gradually possessed themselves of the coast from South Carolina to Maine.

As soon as they were founded, the colonies of the various European powers began to take part in European wars; and they were directly affected by clauses in the treaties of St. Germain (1632), of Breda (1654), and of Madrid (1670). The three European powers developed different policies toward their colonies -- that of Spain being harsh at most points, that of France milder, and that of England extraordinarily liberal for the times. 


\section{TOPICS}

Suggestive topics

Search topics

Geography

Secondary authorities

Sources

Illustrative works

Pictures
(1) On what pretext did Argall destroy the settlement at Mount Desert? (2) What was Acadia? (3) What made the Iroquois so powerful? (4) Why did the Swedish colony fail? (5) What did La Salle aim to accomplish? (6) What forts did La Salle found? (7) The various names applied to the Mississippi River. (8) Did La Salle establish a good claim to Texas?

(9) Champlain's adventures in America. (10) Hudson's voyage on the Half-Moon. (11) The early public buildings on Manhattan Island. (12) Washington Irving's picture of the Dutch in New Netherland. (13) Present relics of the patroonates. (14) Methods and results of the Jesuit missions. (15) Hennepin's claim to first discovery of the Mississippi. (16) Earliest accounts of the Chicago River. (17) La Salle on the Mississippi. (18) The Spanish plate fleets. (19) Contraband trade with the Spanish colonies.

\section{REFERENCES}

Thwaites, France in America; Semple, Geographic Conditions, 24-31.

Thwaites, Colonies, §§ 13, 18-22, 83, 84, 108-110 ; Lodge, English Colonies, 205-208, 285-294; Higginson, Larger History, 120-136, 180-183 ; Larned, History for Ready Reference, I. 72, 355, 654, III. 2324; Winsor, Cartier to Frontenac, 77-342 ; Fiske, Dutch and Quaker Colonies, I. 80-242, - New France and New England, 35-132 ; Parkman, Pioneers of France, 229-454,-Jesuits in North America, - La Salle, - Old Régime,-Frontenac, 1-183, -Pontiac, I. 7-28, 46-68; Gay, Bryant's History, I. 339-369, 429-475, II. 115-164, 229-246, 499-532 ; Sedgwick, Samuel de Champlain; Thwaites, Father Marquette.

Hart, Source Book, §§ 6, 36,-Contemporaries, I. §§ 37-43, 150-159, 169-171, - Source Readers, I. \$§ 47, 59, 65; Old South Leaflets, nos. 46, 69, 91, 94, 96; MacDonald, Select Charters, no. 9; Higginson, American Explorers, 269-307. See N. Eng. Hist. Teachers' Ass'n, Syllabus, 309, 310, 315, - Historical Sources, $\$ 68$. Whittier, St. John; Stedman, Peter Stuyvesant's New Year's Call; E. P. Tenney, Constance of Acadia ; M. H. Catherwood, Lady of Fort St. John, - Story of Tonty, - Romance of Dollard (Canada); A. C. Doyle, Refugees (Canada) ; E. E. Green, Young Pioneers (La Salle); Irving, Knickerbocker's History of New York; J. K. Paulding, Konigsmarke (Swedes).

Winsor, America, IV.; Wilson, American People, I. 


\section{CHAPTER V}

\section{EXPANSION OF THE ENGLISH COLONIES, 1660-1689}

Cromwell's death in 1658 caused the downfall of the English Commonwealth, and King Charles II. entered London in 1660. The colonies fell back into the hands of the crown, which established a series of colonial councils, eventually Restoration called Lords of Trade. Parliament, as a part of its general power to regulate the trade of the empire, in (1660-1663) 1660 and 1672 renewed, with additions, the earlier navigation ordinance ( $\$ 39$ ), so as to direct colonial commerce through English ports for the profit of the English merchant.

Massachusetts, governing herself under her charter of 1629, had been since 1643 all but independent; she had even established a mint and coined "pine-tree shillings." The English government rated the colony soundly for this coinage; and required that people who were not nembers of the Congregational Church be permitted to vote and to hold office, and that the services of the Church of England be allowed. The colony also had to repeal its anti-Quaker laws, and the public insanity on that subject gradually came to an end.

The king smiled upon Connecticut, and in 1662 granted a favorable charter, - the first charter the colony ever had, with bounds extending to the South Sea. New Haven was incorporated into Connecticut, as a punishment for receiving Whalley and Goffe, two of the "regicides" who had condemned Charles I. to death. Rhode Island received a charter in 1663, giving it about its present boundaries and a liberal government with an elective governor. Plymouth got no charter, but was allowed to remain separate thirty years longer. The Baltimores were confirmed in their administration of Mary- 
land. Thus in 1663 the English had in America three chartered colonies, one proprietary colony, and two royal colonies, Virginia and Plymouth, without charters.

New Netherland, the Dutch colony which separated New England from Maryland and Virginia, was a feeble and ill-

54. Annexation of New Netherland completed (1664-1689) managed commercial community, never numbering more than ten thousand people. The Dutch West India Company was chiefly interested in the Indian trade; and though a local council of deputies was formed in 1641, it had little to do, and could not even raise money to build a schoolhouse. Ill treatment of the neighboring Indians pro-

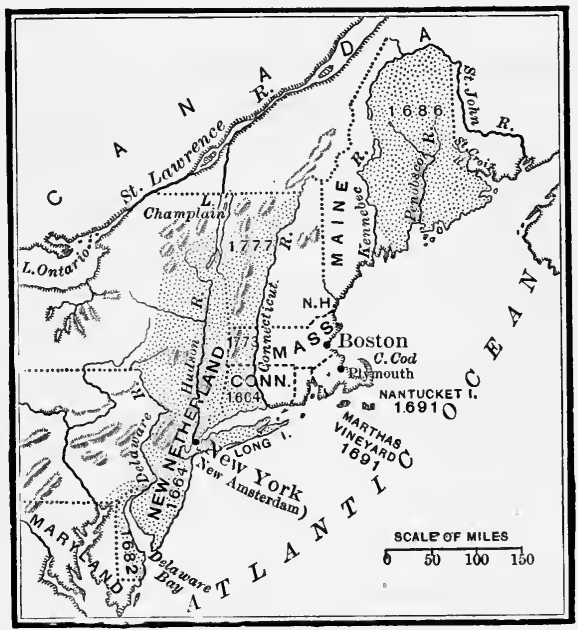

LANDS OF THE DUKE OF YORK.

With dates of cession of outlying portions. voked fierce and destructive wars along the Hudson. In 1647 the last Dutch governor, Stuyvesant, was appointed; he was a man of vigorous character, but had little means for defense and no intelligent support.

Although nominally at peace with Holland, the king of England asserted vague English claims by granting the region occupied by the Dutch to his brother, the Duke of York, and sending a fleet to capture New Amsterdam in 1664. The place surrendered (August 29), and with it the whole colony fell without a blow; and thus New Netherland became New York. Three years later the Dutch reluctantly renounced the colony, and except for a few months in 1674 they never held it again. 
Instead of giving effect to the charters of Massachusetts and Connecticut, which covered strips of territory stretching westward to the Pacific, the English government turned over to the Duke of York all the territory between the Comnecticut and Delaware rivers, together with Long Island, most of what is now Maine, and the islands of Nantucket and Marthas

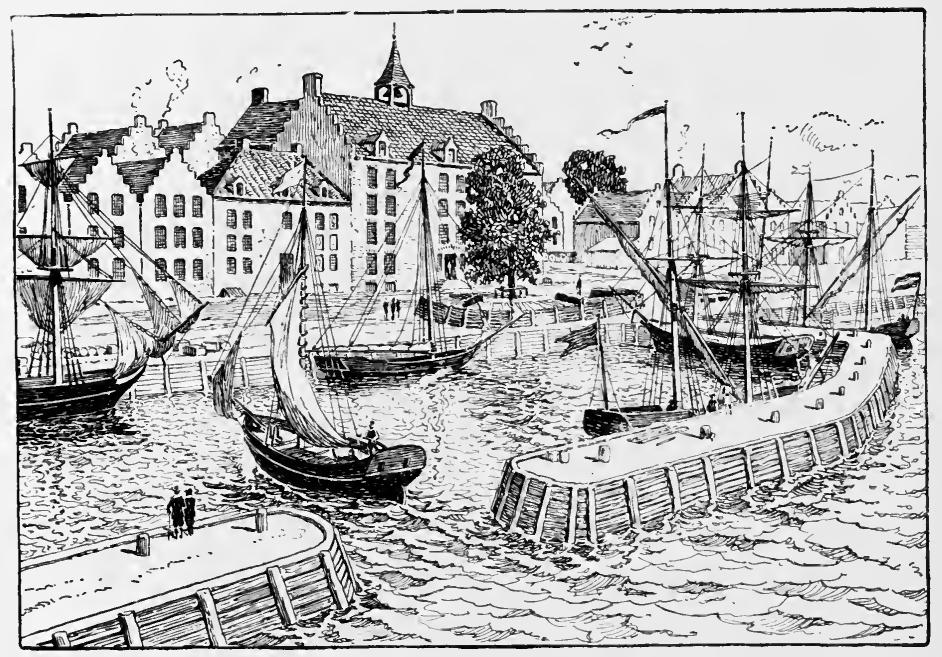

Water Front of New York City in 1673.

From a drawing by Hugo Allard.

Vineyard. But the duke soon gave up his claims beyond the present western boundary of Massachusetts and Connecticut; and his claim in Maine was transferred to Massachusetts (1686).

Under the grant to the Duke of York, all his laws for his colony had to be agreeable to those of England, but he provided for no assembly. His governor, Nicolls, therefore called a convention of Long Island towns in the colonial capital, which was now called New York, and discussed with them a code which he had drawn up and shortly put into force, called "The Duke's Laws" (1665). The city of New York received a charter 
from Governor Dongan in 1683, by which the people elected the aldermen, while mayor, recorder, and sheriff were appointed. Gradually county governments were introduced, and town government was extended beyond Long Island; but there was no colonial assembly till 1683.

Even before the duke got possession of his magnificent property, he began to cut it up into small provinces. In 1664 55. Settle- he granted to Berkeley and Carteret the tract between ment of the Hudson River and the Delaware, and they called it
Jerseys (1664-1702) Nova-Cæsaria - which is plain New Jersey. Next year they granted to their colonists the "Concessions," a kind of local constitution. In 1674 the region was divided into the separate colonies of East New Jersey and West New Jersey, each with a proprietary charter. The rich soil and the ease of access speedily attracted population. A contemporary said, Contempo- "Tis far cheaper living there for Eatables than here in raries, I.575 England; and either men or Women who have a Trade, or are Labourers, can, if industrious, get near three times the Wages they commonly earn in England." Some Swedes and Dutch were on the ground when the colony was transferred; a body of Scotch Presbyterians came to East Jersey; and New England Puritans settled Newark and other towns.

Fenwick and Byllynge, two wealthy Quakers, got control of the colony of West Jersey, in which they encouraged genuine religious toleration; and many Quakers settled here. The land grants of both the Jerseys finally fell into the hands of a body of proprietors, including William Penn ; and in 1702 they surrendered their proprietorship, and the colonies were united into the single royal province of New Jersey.

The west side of the Delaware, beyond the Duke of York's 56. Pennsyl- patent, was one of the fairest regions in the new world, vania and Delaware fronting on tide water, and abounding in arable land, (1681-1700) in forests, and minerals. In March, 1681, a royal patent was issued to William Penn for a new province in this region, 


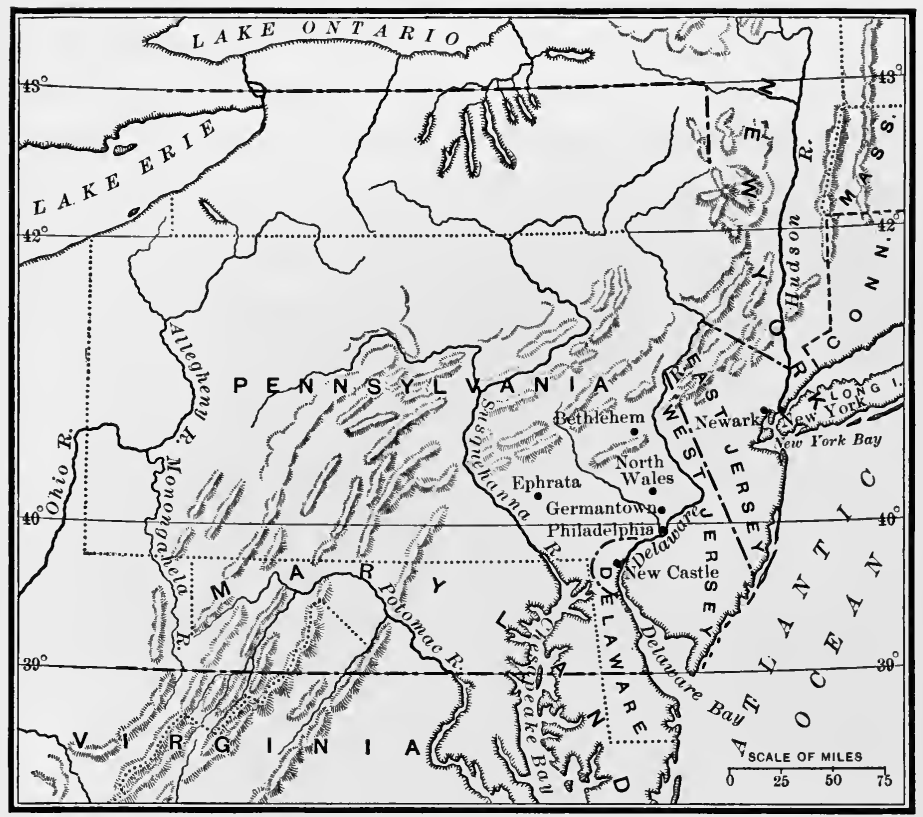

New Jersey and Pennsylvania.

named by the king, in compliment to Penn's father, Pennsylvania. The province extended westward five degrees of longitude from the Delaware River; the northern boundary was "the beginning of the three and fortieth degree of Northern Latitude;" and the southern boundary was to be "a Circle drawne at twelve miles distance from New Castle Northward and Westward unto the beginning of the fortieth degree of Northern Latitude, and then by a streight Line Westward." But this circle lies entirely between $39^{\circ}$ and $40^{\circ}$, meeting neither parallel; and thus, as will be seen later ( $\$ 80)$, arose a boundary dispute with Maryland. By a grant of 1682 from the Duke of York, Penn got also "the three lower counties," or Delaware, which he held against Maryland's claim and added to his main province. 
William Penn was rich and well educated, fond of writing, and author of many works. He was, further, an intelligent, public-spirited, and far-sighted man of affairs. Though brought up as a courtier, to the grief and amazement of his fam-

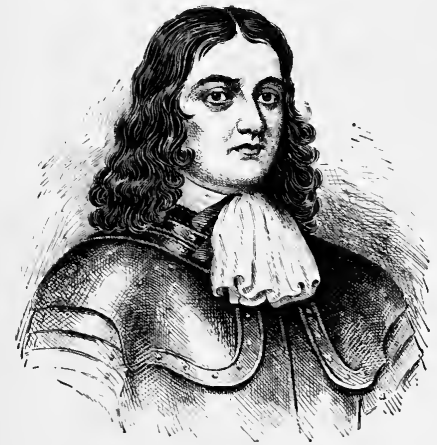

William Penn, about 1664.

Painted when a soldier in the Netherlands. ily he early became a Quaker, a member of the sect most opposed to pomps and vanities.

In all the history of the American colonies Penn's was the broadest and best-planned scheme of colonization. The first of his settlers arrived in the year 1681, and within a year three thousand came over. Peun spent two years in his colony, and laid out the city of Philadelphia (1682) on a novel and convenient checker-board plan. Among his settlers were some Welsh, who settled the town of North Wales; and in 1683 German Quakers founded Germantown; later, Moravians settled Bethlehem, Ephrata, and other places; Euglish and Scotch-Irish flocked over; and in 1700 the colony numbered about twenty-five thousand people.

More than any other colonial administrator, Penn understood how to keep peace with the Indians, on the simple principle of coming to a clear and simple understanding, and then abiding by his own promises. As he put it, "Do not abuse them, but let them have justice, and you win them."

As in Maryland and New York, the ownership of the land of Pennsylvania, and the right to provide a government, were

57. Pennsylvanian government

both vested in an hereditary proprietor. As proprietor, Penn used his power to grant a "Frame of Government" (1682), which was practically a liberal constitution. His two principles of government were "First, to terrify evil- 
doers: secondly, to cherish those that do well; ... I know some say, let us have good laws, and no matter for the men that execute them: but let them consider that though good laws do well, good men do better." The Frame of Government was much like our present state constitutions; it provided for a governor, representing the proprietor; a legislature of two elective houses (all bills, however, were to be

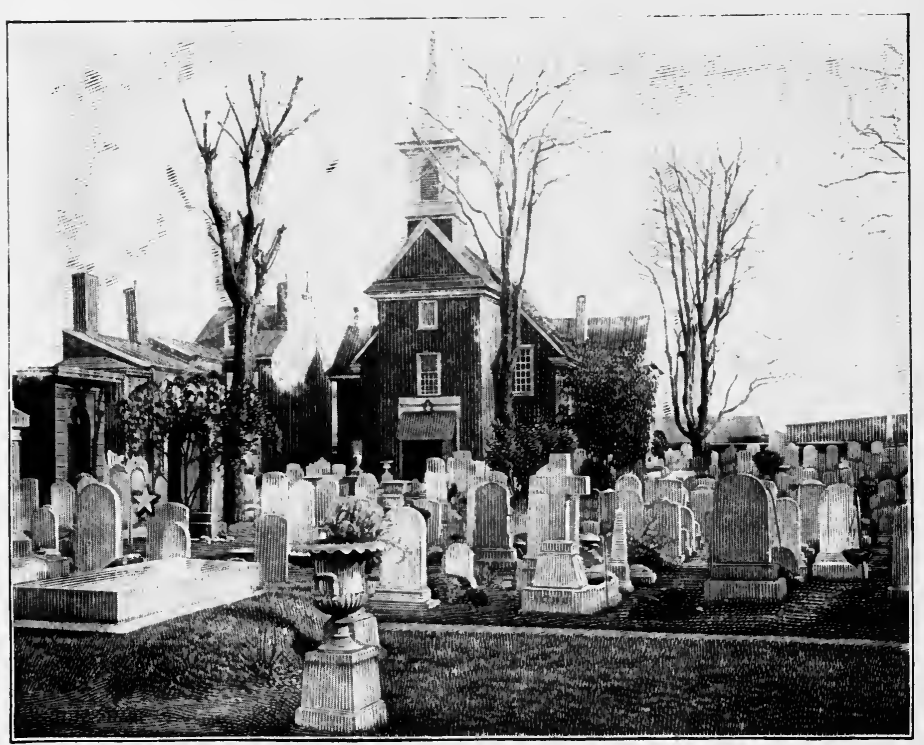

Old Swedes' Church, Piilladelphia, Built in 1700.

proposed by the governor and the upper house, the lower house having merely a veto power); judges partly elective; and vote by ballot. A city government was set up for Philadelphia in 1691 with mayor and aldermen.

Yet even in this elysium the settlers were discontented; they felt that the proprietor kept too much for himself, and began to quarrel with their governors. In 1701 Penn granted a new plan of government called Charter of Privileges, in which 
the legislature was made to consist of only one house, with enlarged powers, and the governor received the power to veto acts of this assembly; provision was made also for a separate Delaware assembly. In 1699-1701 Penn spent a second period of two years in Philadelphia. At his death in 1718 he left the rights and dignity of his proprietorship to his children, and they remained in his family down to the Revolution.

The two southern colonies grew slowly after 1655, and were rather disorderly. The very toleration of Maryland brought

58. Virginia and Maryland (1655-1689) in Quakers, Puritans, Catholics, and members of the Church of England, who could not agree; and there were war for half a century caused the massacre of three hundred settlers (1676), and the government was extravagant and harsh. When a planter, Nathaniel Bacon, headed an unauthorized expedition against the Indians, he was proclaimed a rebel by Governor Sir William Berkeley. A truce was patched up, but Bacon soon headed a formal armed insurrection, caused by the bad government of the colony, burned Jamestown, and made himself the head of an insurrectionary state (1676). He died at the height of his power, and his followers quickly melted away. To one of the rebels Berkeley remarked, "Mr. Drum"T.M." mond! you are very welcome, I am more glad to see you Bacon's than any man in Virginia; you shall be hanged in half an Rebellion, 23

hour." Drummond and thirty-five others were executed. No wonder King Charles recalled Berkeley in disgrace, exclaiming, "That old fool has hanged more men in that naked country than I have done for the murder of my father."

South of the James several small settlements were early made on Albemarle Sound and the Chowan River by wanderers from 59. Settle- Virginia, from New England, and from the West Indies. ment of the In 1663 England enlarged her dominions in North (1663-1689) America by granting land for the colony of Carolina (named for Charles II.) south of Virginia, and near the Spanish 
settlements of Florida. The first Carolina patent was granted to a body of eight noble proprietors, for a tract extending from the 31 st to the 36 th degree of north latitude, and west to the South Sea. In 1665 a second patent added strips of territory southward to the 29 th degree, and northward to $36^{\circ} 30^{\prime}$.

The English philosopher John Locke was requested by the proprietors to draw up a "Fundamental Constitution," often called "The Grand Model," which was to establish a kind of feudal system in Carolina. At the head was to be a "palatine," next to him the

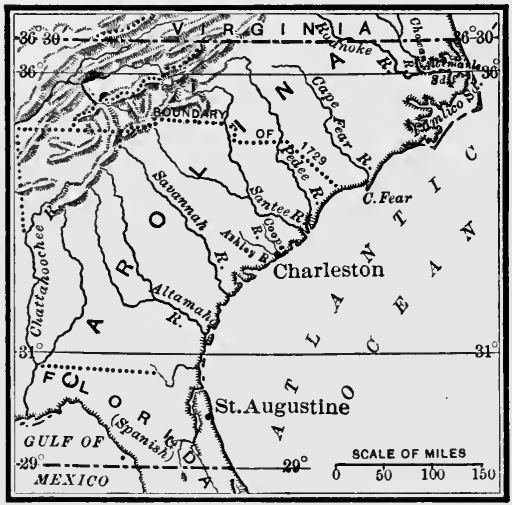

Carolina by Patent of 1665. "proprietaries," below them "landgraves," "caciques," and commons or "leetmen." This constitution never went into effect; instead, a popular assembly was organized (1669) and governors were sent out by the proprietors.

A settlement was made on the Ashley River (1670), and ten years later was moved to the present site of Charleston. Around it a separate community grew up, though united under one colonial government with the northern Carolina settlements. Scotch, Quakers, and French Huguenots came in, and the settlement was prosperous from the beginning. In the course of thirty years perhaps twenty thousand people gath. ered in the two Carolinas, including large numbers of negroes; for the rice plantations of South Carolina gave opportunity for profitable slave labor.

Of all the colonies from Maine to Carolina, the hardest to control were the New England group. Already in 1664 a royal 
commission had been sent to Boston to investigate the too independent ways of Massachusetts. 'Ten years later the home 60. The government formed a plan to withdraw all the charters New Englanders and the Indians (1664-1677) in New England and to put a governor-general at the head of one province, extending from the Delaware to the Kennebec. Edward Randolph appeared in Boston in 1675, as a royal agent to find how New Hampshire and Maine came to be parts of Massachusetts, and to investigate other irregularities; but he was interrupted by the outbreak

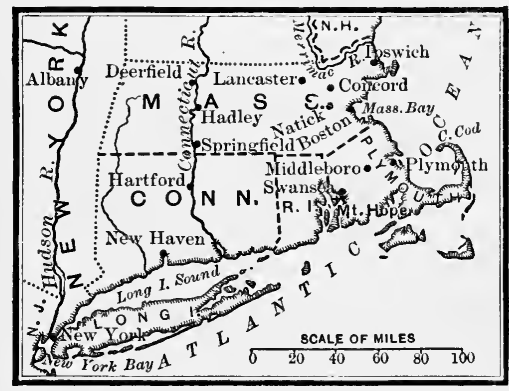

Scene of King Philip's War. of King Philip's war in Massachusetts.

The people of New England had a reckless contempt for their Indian neighbors, freely supplying powder and shot to them in exchange for furs, and fearlessly planting villages like $\mathrm{Had}$ ley, Lancaster, and Deerfield, far out in the wilderness. Some effort was made to civilize the natives. John Eliot, "Apostle to the Indians," spent his life in that work, and published the whole scriptures in an Indian tongue. Schools were established among the Indians, and an effort was made to educate some of them at Harvard College. Settlements of converted, or " praying," Indians were made, especially at Natick and at Concord, and about four thousand accepted the gospel. The good effect of such efforts was more than counterbalaneed by the brutalizing influence of the rum sold by the whites to the Indians.

In June, 1675, war broke out with the Pokanokets, settled in and near Rhode Island; their chief, Metacom, or King Philip, attacked the Plymouth frontier towns of Swansea and Middleboro. Hadley and Springfield on the Connecticut were 
attacked by other tribes, and war raged up and down the whole frontier. On both sides it was "war to the knife and the knife to the hilt." The praying Indians were attacked, and many of them massacred, by the whites. The Narragansett Indians rose, and the commissioners of the New England Confederation raised a force which killed a thousand of them.

Gradually Philip was driven to shelter in his stronghold ai Mount Hope, Rhode Island, and there while attempting to escape he was shot by an Indian (August, 1676). The colonial commander cut his body into sections and carried away his head and hands to earn a premium of thirty shillings. This King Philip's war came near annihilating the New England colonies : six hundred white men lost their lives, and a dozen villages were destroyed. The Indians lost two thousand killed and captured, of whom some - to the lasting disgrace of the white people - were sold into slavery in the West Indies.

The pressure of the home government was soon renewed, and Edward Randolph again began to report against Massachusetts. Though the colony retained Maine, by buying up the rival claims (1678), she lost New Hampshire (1679). Worse still, she lost her charter; for a decree of the Chancery Court in England (October 23, 1684) (1677-1687) declared that it was no longer in force, because its provisions had been violated.

The Duke of York came to the English throne as James II. in February, 1685; and set out to exercise unrestricted powers both in England and in the colonies. In 1686 he made Sir Edmund Andros "Governor-in-chief in and over the territory and dominion of New England," the province including Maine, New Hampshire, Massachusetts, Connecticut, Rhode Island, and Plymouth. Andros first of all reorganized Massachusetts. As there was no longer a charter, he appointed a council which, with his assent, should have power to make laws. - But when the council ordered the towns to levy taxes, the 
town of Ipswich flatly refused. Some of the principal men of that place were therefore tried and severely punished; and Andros forbade special town meetings.

In 1686, under great pressure, Rhode Island surrendered her charter. Next year Andros went to New Haven and demanded the Connecticut charter. Tradition has it that the lights were blown out and the document carried away; however that may be, Andros put an end to the charter governinent. Since he was governor also of New York and of the Jerseys, he thus almost brought about a colonial union, in defiance of the will of the people, and by violent and dangerous methods.

A revolution in England removed the pressure in Amer62. The ica. When James II. Great Revo- attempted to "dispense"
lution of 1688

with (that is, suspend) acts of Parliament, many of his subjects invited his nephew, William III. of Orange, to come to England. James fled the kingdom; and in February, 1689, the two houses of Parliament declared that he had

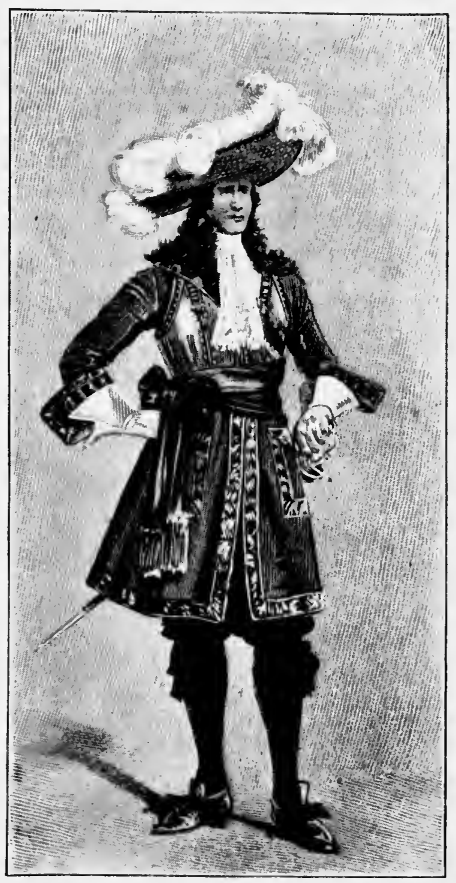

English Officer, about 1680.

Uniform of the Maritime Foot Regiment. abdicated, and that his daughter Mary and her husband, William III., were lawful king and queen of England.

The news of the revolution reached Boston in April, 1689, and two weeks later the people joyfully laid their hands on many of the royal officers. Sir Edmund Andros was forthwith 
clapped into prison; and the colonial government was reëstablished provisionally, under the old charter of 1629. In Plymouth, Rhode Island, and Connecticut the former governments were again put in force. A similar rising in New York a few days later had an unfortunate outcome. Jacob Leisler, a wellto-do merchant, took the responsibility of heading a provisional government under the self-assumed title of lieutenant governor. After a few months of this irregular administration, a royal governor was sent over; and Leisler, who hesitated to give up his authority, was found guilty of high treason and executed, though it is difficult to see that he had been guilty of a crime.

After the Restoration of Charles II. in 1660, Plymouth, Virginia, and Maryland went back to about their old relations to the home government. Connecticut and Rhode Island 63. Sumreceived charters; but Massachusetts, though she kept mary her charter twenty-four years, was obliged to stop persecution of Quakers and discriminations against the Church of England.

In 1663 began a second era of colonization. Carolina was established; then the Dutch were dispossessed in New Netherland, and five more colonies were set up - New York, East and West Jersey, Pennsylvania, and Delaware; in New England, New Hampshire was separated from Massachusetts.

Then Sir Edmund Andros was sent over to consolidate the northern colonies and to take away the liberties of Rhode Island, Connecticut, and Massachusetts by breaking down their charter governments. The Revolution of 1688 in England interrupted these plans, and prepared the way for a return to the milder type of colonial government.

\section{TOPICS}

(1) How does the navigation act of 1660 differ from that of 1651 ? (2) Who devised the rectangular plan of Philadelphia? (3) Why Suggestive topics did the settlers quarrel with Penn? (4) Was Nathaniel Bacon a traitor? (5) How did the Carolina proprietary patents differ from 
Search topics

\section{Geography} Secondary authorities

Sources

Illustrative works that of Maryland ?

(6) Quakers in New Jersey and Pennsylvania. (7) Make a list of the Duke of York's land holdings in America and tell what became of each. (8) In what condition did King Philip's War leave New England? (9) Was Goveruor Andros a tyrant? (10) What was Leisler's offense? (11) Why was the Massachusetts charter annulled ? (12) Early life of William Penn.

(13) Whalley and Goffe in New England. (14) Royal commission in Boston, 1663-1664. (15) The Duke's Laws. (16) Life in New Netherland, 1650-1660. (17) History of the "pine-tree shillings." (18) First charter of New York city. (19) Early descriptions of New York under English dominion. (20) Early accounts of New Jersey; of Pennsylvania; of Carolina. (21) Life among the New England Indians. (22) What were enumerated goods? (23) Arguments for the colonial union desired by Andros. (24) Boundary controversies under the Connecticut charter.

\section{REFERENCES}

Andrews, Colonial Self-Government.

'Thwaites, Colonies, $\$ \S 32$, 35-38, 69-72, 85-89 ; Fisher, Colonial Era, 49-56, 71-81, 146-164, 187-206 ; Lodge, English Colonies, chs. i. iii. v. vii. xi. xii. xiv. xvi. xviii.-xxi. passim ; Andrews, Colonial Self-Government; Fiske, Old Virginia, II. 45-116, 131162, 270-290, - Beyinnings of New England, 199-278, - Dutch and Quaker Colonies, I. 243-294, II. 1-61, 99-208; Doyle, English in America, I. 230-266, 314-363, III. 114-272 ; Gay, Bryant's History, II. 247-395, 401-449, 472-498, III. 1-24; Wendell, Cotton Mather, 21-87 ; Hodges, William Penn.

Hart, Source Book, §§ 22-26, - Contemporaries, I. §§ 54, 70, 71, 76-81, 116, 121-125, 132-136, 155-157, 160-167, - Source Readers, I. $\S 40,49$; MacDonald, Select Charters, nos. 24, 26, 27, 29-33, 35-41; American History Leaflets, no. 16; Old South Leaflets, nos. 21, 22, 51, 88, 95. See N. Eng. Hist. Teachers' Ass'n, Syllabus, 301, 310, 313, - Historical Sources, \$§ 70-72.

Whittier, Pennsylvania Pilgrim; M. W. Goodwin, White Aprons (Bacon); Mary Johnston, Prisoners of Hope (Bacon); M. E. Wilkins, Heart's Highway (Va.); J. P. Kennedy, Rob of the Bowl (Md.); Simms, Cassique of Kiawah (S.C.); Hezekiah Butterworth, Wampum Belt (Penn.); Cooper, Wept of Wish-ton-Wish (Philip), - Water Witch (N.Y.); Hawthorne, Gray Champion (Andros), - Grandfather's Chair, pt. i. chs. viii. ix.; W. Seton, Charter Oak ; E. L. Bynner, Begum's Daughter (Leisler). 


\section{CHAPTER VI. \\ COLONIAL LIFE (1700-1750)}

WHILE the colonies grew, the colonists had much the same experiences as people nowadays, - going to church or going to prison, working, traveling, trading, fighting, marrying, and dying, - although conditions and opportunities were very different. In population the colonies increased

64. The colonial population slowly: New England received little direct immigration after 1640 , and in 1700 numbered but 105,000 inhabitants; the southern colonies (Maryland, Virginia, and the Carolinas) together had about 110,000 ; the middle colonies 55,000 ; making a total of about 270,000 people. The largest towns were Boston, with about 7000 people, and Philadelphia, with 4000 .

The ruling element in every colony was of English descent; but there were Dutchmen in New York and a few on the Delaware; Swedes, a few Finns, and a large German element (later called Pennsylvania Dutch) in Pennsylvania; French Huguenots in several colonies, especially South Carolina; Highland and Lowland Scotch, and Scotch-Irish from the Protestant counties in the north of Ireland, principally on the western frontier. The negroes in 1700 were about 46,000 in number. The Indians were nowhere fused into the white communities.

Most of the colonists lived in the easily constructed log house, or in a frame structure, clapboarded or shingled. In Boston, New York, Phi adelphia, Charleston, and some other places there were statelier houses constructed of

65. Colonial home life brick made near the spot. Among the poorer families the HART'S AMER. HIST. $-6 \quad 91$ 


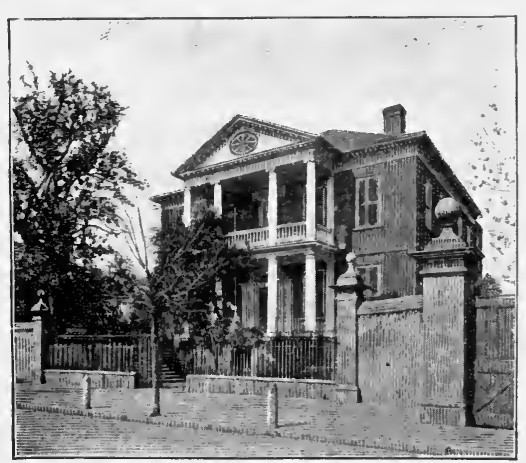

Bull-Pringle House, Charleston, BUILT ABOUT 1760. rude furniture was hardly more than floor, seats, and tables, all made of "puncheons," - that is, of split halves of small tree trunks, - with a few pewter dishes, a fireplace, and its utensils. The better houses had substantial oaken chests, chairs, and tables, and handsome clocks.

In dress our well-to-do forefathers followed as closely as they could the English fashions of elaborate suits of cloth or velvet or silk, and fullbottomed wigs. The most common materials were homespun linen and woolen, though on the frontier deerskin was used.

Food abounded: game wandered in and out of all the settlements, shellfish were abundant, and the New England coast fisheries furnished fish; Indian corn was everywhere grown, and there was plenty of wheat flour.

The colonies were swept by diseases, chiefly due to ignorance and uncleanliness : "ship-fever," "small pocks," "yellow fever"; "break-bone fever," fever and ague, and other varieties of malaria; and medical practice was lamentably unskillful.

Though England was a land abounding in schools and possessed of world-famous universities, her southern colonies in

66. ColoAmerica, broken up into separate and widely distributed nial educa- plantations, could not maintain schools. Governor Berketion

ley reported (1671) for Virginia: "I thank God there are no free schools nor printing, and I hope we shall not have these hundred years; for learning has brought disobedience, and heresy, and sects in the world, and printing has divulged them, and libels against the best government. God 
keep us from both." The New England towns established the first schools in northeastern America, though closely followed by the Collegiate School of the Dutch Reformed Church in New Amsterdam (1633). The colony of Massachusetts Bay showed its interest in education by requiring that every town of fifty families should maintain a school, and every town of a hundred families a grammar school (that is, a Latin school); but the towns too frequently avoided the responsibility if they could, and no public education was provided for the girls. In 1689 the Penn Charter school was founded in Philadelphia.

Three small colleges provided higher education for the colonies. Harvard Coilege, named from the

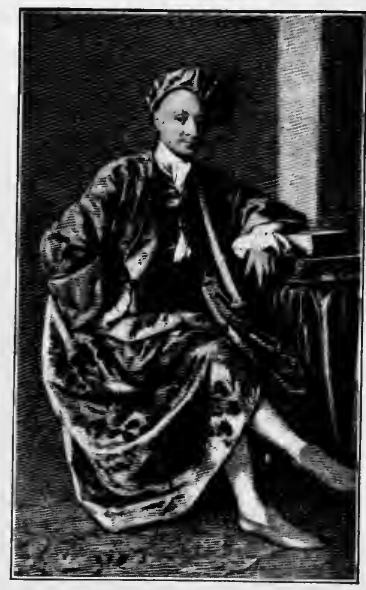

A Colonial Dandy, ABOUT 1760.

Portrait of Nicholas Boylston, merchant, Boston. Rev. John Harvard, its earliest private benefactor, was founded (1636) "to advance learning and perpetuate it to posterity." From the beginning it trained the ministers, and also had as students future men of affairs and statesmen. William and Mary College was established in Virginia (1693); King William III., the colony, and private subscribers united to give the college a home in Williamsburg. Yale College was "first concerted by the ministers" (1700), and its earliest property was forty volumes given by the founders for a library. The college was soon removed from Saybrook to New Haven, and (1718) received its name from Elihu Yale, a public-spirited Englishman who interested himself in the new institution.

The most notable colonial writers in the seventeenth century were the discoverers, explorers, and colonists who wrote enter- 
taining accounts of their experiences. Thus John Sinith and William Strachey wrote about Virginia; William Bradford

67. Colonial literature and John Winthrop each left an admirable historical account of the colony in which he was governor and leader.

In the South the chief writer of literary merit was Colonel William Byrd, who left in manuscript a charming book of trave] called History of the Dividing Line. In the middle colonies, till Benjamin Franklin came, the only man who can be called a literary light is William Penn; but the German Moravians were great printers, and issued the first Bible, except Eliot's Indian Bible, published within the colonies. The first newspaper in the colonies, the Boston News Letter, appeared in 1704 ; and the trial of John Peter Zenger in New York (1732) established the important principle that a journalist can not be convicted of libel for publishing the truth.

Works of fiction were unknown except as old writers dealt too much in neighborhood gossip; but there were several writers of poor verse. The Bay Psalm Book, the first book printed in the English colonies (1640), was made by a syndicate of ministers, whose poetic gifts may be shown by a quotation from the 63d Psalm :-

\footnotetext{
"Their poyson's like serpents poyson; they like deafe Aspe, her eare that stops. 'Though charmer wisely charme, his voice she will not heare. Within their mouth doe thou their teeth break out, o God most strong, doe thou Jehovah, the great teeth break of the lions young."
}

The favorite literature for educated men was theological and controversial. The most famous writer of this kind was Cotton Mather, a Boston minister, long the leading man of New England, who wrote an enormous and confused folio which he 


\section{The Bofton News-Letter.}

publicheo op zutbozity.

\section{- Frondondar april 17. :0 Lltonoal April :4 8704.}

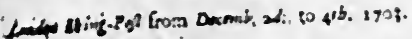
Execition Sowin brinz us the Copy of - Stacar Lesely Prioud there, latituhd, A

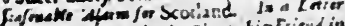

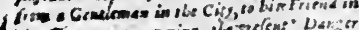

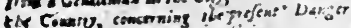

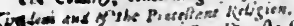

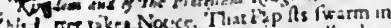
Thi, Leer rikes Noce, Thit arouredly chan an . a aivo, thartbey rratixh ante ivowedly than bivery, wod tha: of Late wy oy Scors cf Prieits \&

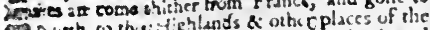
Tonorh w tha: tighlands 8 othe gplaces of the

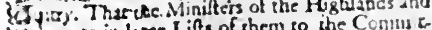
i.tes stre in Lrge Lits of thean so the Conme tete thoGenem Alembly, to be laid berotc the Fiv. Cuncil

- INikev fe oblerves, that a great Number of o. Wl. Ufoleall porions are come over frum tranct,

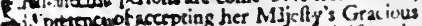
Ined rity; bero an reality, to increafe DiviGons in ine tion andro centertin a Cora fuondence witis ais: Thar tileir ill lntentions are evideft fiom - il in $^{-} \rightarrow$ their owning the Intereft of the

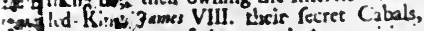
in sif cuy'ls up of Arms and Ammunicion, innt ir they can find them.

Th his bestied the late l'ritinge and . Actings offer aititendfed purfons, many of whinn i.e lor 2 Pey had ir; that feveral of ihim hive decar 7 ; the protuther embrace Popery than con. forle for the ent Government; thit they r.fufe rentign, and leen, but ufe the ambiguous word Ta Kine aneme of them pray in exprefșlyous

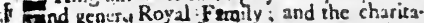
$\therefore$ h:Kindnaso Prince who has ftew'd them roc lones̀.. 'He likewile takes notice of - for latergago fourid in Cyphror, \& dirceted Tays that whouse thither from Si, Geonstains. = themlelvi: B-catelt Jucobitcs, who will not Jenow wr. by taking the Oathg to Hir Ma. Irom St. Gastie Papilts and their Cumpr. bied, colmaras fet up for the Libert, of - to ko oparyito thcic own Principles, but that iYp up a Divifion in the Nistion. He - coney egravaie thole thiggs which the - Temiplain of as to England'y refuling - to al: F-a fre:dum of Trade, Éc. and do all they in roen Divifiuns betwixt the Nations, \& to

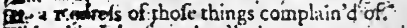
- Milrabi-cs, belays, do all they can ro per- e. Fation thut their preternded 13ing is a Hhr ha his, Hear, tho' he dares not declare is Dider the Puwer of Frenee" that he is ac. with the Miftakes of his Futher's 'Go: ser govern us more acçording to Liv Hodas im if if to his Subie fts.

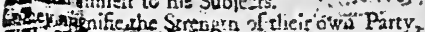

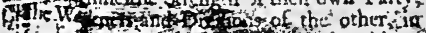

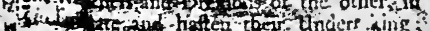

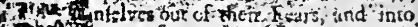

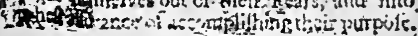

From all his be infer That the havehupes of Altilasce froos risuce, ortserwife they would nevec be fo ing pudene; and he aves Kealons for his Appritientions that the Fromch King may fend Troops thither this Winter, 8. Becaure the Englifl, \&ureb. will noc then be at Sea tu oppre: them. 2. He cap then beft fpare them, the Switun of Action biyond Sea heing over. 2. The Expeadion given hini of $\mathbf{2}$ confidcrable number to joyn then. may incourage hins eu the understhing with fower hlen, if he can but tend over 2 futirient number of Ofincers with. Arnis and Ammun tion.

He cndeavours in the reft of his Letters to an: fwer the tuolilh Preterices of the Pretender's being a Pruteflant, and that be will govern us according to $\mathrm{Lww}$. He lays, thyt b.ing bred up in the Religiun and Puliticks of Frence, he is by Education a Ituted Encmy to our Librty and thelizion. - That the Obligutions which he and his Family osve to vlie Tuenco King, mult necafiefily make him to be Wholly at his Divotion, and to fullow his Example; thes if be fit upun the Throne, the thrie Nistiuns muft be oblis d to pay the Dibt which he owes rbe Fiersb King for the Education of himlelf, and for Entertsining liis fuppoled Father and his Eumly: And fince thic King mutt nefure him by his Troops, if-crer he b- ritured, he will. tie to tecure hisown Dithe, b. fore thofe Trosps leave Britcin, The Pritender being a good Proticient in the French and Remijb. Srhools, he will never think himfelf fufficienily aveng'd. bit by the uter Ruine of his. Proteftant Subjects, both as Hereticks and Traitors. The law Queto, his pritended Mother, who in cold Blood when the wis Oueen of Britaiti, advis'd. to turn the W'it of Srocland into 3 hunting Ficld, will be then for duing fo by the greateft part of the Dation; and, no duribt, is at Pisins to have her prerended Son educated to her own Mind : Therefor: he fays, it were a great Madnets. in:the Nation tco: take a Prince brcd up in the horrid,Sctioot of Ingras ritude, Perfecution and Ctuielty, and filled with Rage and Envy. The. Facobites, he fays, both iu: Scotland and at St. Germinins, are imparient under their prefent Siraits, and knowing theip Circumb Iftances carinot be much worfe than thcy are. at prefent, are the more inclinable to the Dridert:king: He adds, That the Frivith King knows there cannot by a more, ffectuil way for himfelf to urive at the Univerfal Monarchy, and to nuine the Proteltanci Intercft, thas by ferting up the Pretender upon the "Thronc of Grest iBritrtic, he will in all prubakuitty. attempt it; ind tho be fhould be perfuded that the Defign would mifcarry in the clofe, yet he can nost bur, renp funte' Advantage by imbroiling the thriè Nations.

Frrom all this the Author concludis it to be the Inter ft of the Nation, to provide for Solf defencs sad tays; that us many bave'ialready takca the Ataten; and are furnithing themfolves with :Arass and Ammunition, the hopes the Guvcrimest wits not ontyaltow it, bur encosrage it, tisce the Nau-

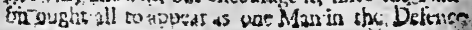


called Magnalia Christi Americana. The two most popular books in the colonies were the New England Primer, with its pious doggerel and rude woodcuts, which went through many editions; and Michael Wigglesworth's.Day of Doom, which was learned by heart by hundreds of persons, - it is a fearful description of that grewsome place

"Where God's fierce ire kindleth the fire, and vengeance feeds the flame,

With piles of wood and brimstone flood, that none can quench the same."

Wigglesworth's repulsive poem states in extravagant form the creed of the New England Puritans, who built their the68. Colonial religious life

ology on the works of John Calvin (died 1564). This great divine made his fundamental doctrine " predestination"; that is, he taught that the whole human race was doomed to perdition, except as God might "elect" a few persons to be saved. Hence good deeds, contemptuously called " filthy rags of works," could not in themselves save anybody.

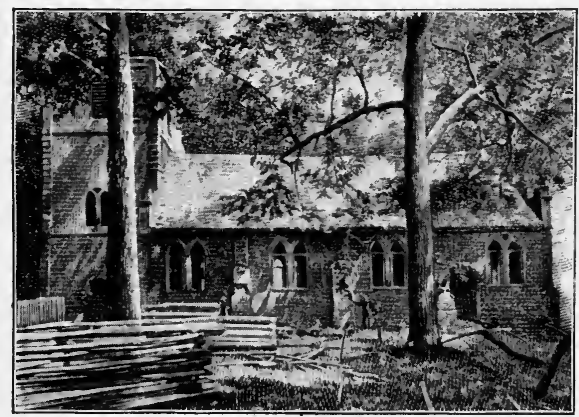

Parish Church at Smithfield, Va., BUILT ABOUT 1700.

Oldest church still standing in the South. From a view in the Virginia Historical Society.

Even such heads of the church as Cotton Mather were tor. mented by the fear that after all they might not be "elect." On the other hand, Calvin set forth the great doctrine of "free will" - of choice between good and evil, with its emphasis on personal duty and responsibility.

The Church of England, or Episcopal Church, which held milder doctrines of salvation, was now gaining ground. Al- 
ready long established in Virginia, it was made the official church, supported by public taxation, in the Carolinas and in New York, though aided also by voluntary contributions; and in 1689 the first "King's Chapel" was built in Boston as a place of Episcopal service. The Congregational Church was supported by public taxation in New Hampshire, Massachusetts (including Maine and Plymouth), and Connecticut. In Rhode Island, the Jerseys, Pennsylvania, Maryland, and Delaware there was no state church.

Side by side with the established churches lived many other religious sects. The Baptists were settled chiefly in Rhode Island; Presbyterians, English or Scotch, in the middle and southern colonies; a few Jews in Rhode Island, Georgia, and Pennsylvania; the Dutch Reformed Church in New York; Lutherans, Moravians, Mennonists, and other German sects in Pennsylvania; Catholic Scotch Highlanders in the Carolinas; English Catholics in Maryland; Quakers in most of the colonies.

Both North and South many of the church buildings were handsome and commodious. In New England the able-bodied population was required to go to service, where pews were carefully assigned according to the social position of the attendants. In the sermons - two on Sunday and a third, the "Thursday lecture" during the week - our forefathers received a good mouthful of doctrine, though two hours and a half was thought too long for a sermon. The Psalms only were sung, lined out by the minister. 'Sunday, commonly called Sabbath, lasted from sundown on Saturday to sundown on Sunday, and in strictness was as near a Jewish Sabbath as the conditions admitted.

Calvinistic theology, with its stern and pitiless logic, did not save New England from the fearful belief, then current throughout the world, that human beings could become "witches," and could make a personal compact

69. The witchcraft episode

(1692) 
with the devil which would enable them to change their shape, to travel on the wings of the wind, and especially to bring bodily harm to their enemies. Nowhere else in the civilized world did this awful delusion play so little part as in the American colonies, though there were a few cases of the execution of witches. In 1692 the children of a minister in Salem, Massachusetts, accused an Indian slave wcman, Tituba, of bewitching them. In a few weeks scores of the "afflicted" were accusing

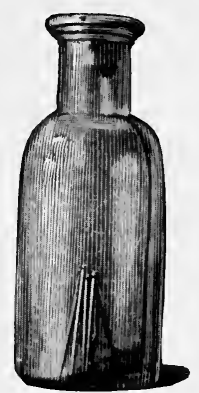

Witch Pins of 1692.

Preserved in the county court at Salem. their neighbors of the foulest crimes and most improbable orgies. The principal testimony was the "spectral evidence" - that is, the assertion of the "afflicted" that the accused people were sticking pins into them and otherwise "hurting" them. Nineteen alleged witches were hanged, and one was pressed to death by heavy weights for refusing to plead guilty or not guilty.

To save themselves, the so-called witches accused other people, and so the number rolled up till more than fifty people were so crazed that they confessed to being witches, and told preposterous stories of flying through the air on broomsticks, of taking part in "devil's sabbaths," and tormenting their neighbors. When Lady Phips, wife of the governor, fell under suspicion, the prosecutions broke down, and there were no more executions in New England, though they continued half*a century longer in Europe, where thou. sands of innocent persons suffered torture and death - often by fire - for crimes of witcheraft which no one could commit.

The basis and support of every colony was the tillage of the 70. The soil, and the most numerous class was that of the free farmer and farmers, living on almost self-sustaining farms. The the laborer forest trees furnished building lumber, ship-timber, and fuel ; corn and other grain, pork, and beef were common farm 
products, as were tobacco in Maryland and Virginia, and rice and (after 1747) indigo in South Carolina. Wagons, tools, and even furniture were made on the spot. Sheep were raised for their wool, which was carded, spun, woven, dyed, and made into clothing on the farm. Clearing new land caused an immense expenditure of human labor. The usual method was to girdle the trees and plant among the dead timber; later, people preferred to fell the trees and to roll the logs up together and burn them. Hence the collection and export of "potash" and "pearl ash" formed an important industry.

From the beginning there was a serious lack of labor. Well-to-do colonists brought with them hired servants; but a system of forced white labor began immediately. Convicts, criminals, "indented" (or " indentured") servants, prisoners in the civil wars, and children, were sent over as bond servants. Other thousands of respectable men and families came over as "redemptioners," under agreement with the shipmaster that he might sell their services for a term of years to somebody in America for money to pay their passage. Both classes were subject to the arbitrary will of their masters and were often crueliy treated. Nevertheless, many of them worked out their terms of service, became prosperous members of the community, and founded families.

Skilled laborers might earn two shillings (fifty cents) a day and their board. In the trades, such as harness making or shoemaking or bricklaying, it was common to have apprentices, who were very harshly treated. The average wage for unskilled laborers was about thirty cents a day in our specie standard; and while most provisions were cheap, imported articles were always dear.

There were slaves in every colony. Indian slaves were sullen and revengeful, and rapidly died off in confinement. Negro slaves were brought chiefly from Guinea, planter and on the west coast of Africa, to the West Indies, and 
imported thence to the American mainland. Hard was their fate - sold for life, transmitting the servile taint to their children, and if freed, still social outcasts. In most of the northern colonies slaves were few in number, but in Rhode Island, on the Hudson, and from Delaware to Carolina, they were gathered in large gangs on plantations.

For a long time masters would not allow their slaves to be baptized, because they had scruples against holding Christians in bondage; and many people held that slavery was both unchristian and stupid. Colonel Byrd, a slave owner, wrote of slaves, "They blow up the pride and ruin the Industry of our White People." A favorite devotional book, Baxter's Christian Directory, warned masters that "to go as Pirates and catch up poor Negroes or people of another land, and to make them slaves, and sell them, is one of the worst kinds of Thievery in the World." That slavery was dangerous was shown by severe laws against slave offenses, and by slave insurrections in Virginia and in South Carolina, and a supposed slave plot in New York in 1741.

The slaveholding planters of the South were among the richest men in the colonies. Among them was Colone? William Fitzhugh, a lawyer, a keen planter and slave buyer, and a capable business man, owner of fifty-four thousand acres of land. He grew flax and hemp, hay and tobacco, and put his Contempo- large profits into more land and slaves. He had a home raries, I. 306 plantation of a thousand acres, including a "very good dwelling house with many rooms in it, four of the best of them hung \& nine of them plentifully furnished with all things necessary \& convenient, \& all houses for use furnished with brick chimneys, four good Cellars, a Dairy, Dovecot, Stable, Barn, Henhouse, Kitchen \& all other conveniencys," together with an orchard, garden, water gristmill for wheat and corn, a stock of tobacco and good debts. His income was estimated at sixty thousand pounds of tobacco (about $\$ 15,000$ in money) 
per annum, besides the increase of the negroes. His tobacco he shipped direct to England from the private wharf of his own plantation, and he was accustomed to order fine clothing, silver plate, books, and other English goods.

The richest men in the middle and northern colonies were the merchants. Since there were no bankers and little subdivision of business, the same man or firm might build ships, own ships, buy cargoes to export, receive the return cargoes, and sell the imports over the counter. One of

72. The merchant and the seafarer the most famous of these merchants was IVilliain Phips, who began life as a poor boy, with one ambition - to be "owner of a Fair Brick-House in the Green-Lane of North Boston." He traded, gathered property, organized an expedition to raise the treasure of a sunken Spanish vessel, got about $£ 300,000$ in gold and silver, was knighted, became governor of Massachusetts, and got his "fair brick house."

The colonists were accustomed to the sea and got wealth out of ships in three ways. (1) The splendid forests of New England, growing close to the water's edge, furnished the best shipbuilding materials, and abounded in tall trees suitable for masts; hence ships were regularly built to sell abroad. (2) Hundreds of craft were employed in the inshore and Newfoundland Banks fisheries, and in trade from one colony to another; the New England salt fish found a profitable market in Europe and in the West Indies. (3) Other vessels were employed in trade over sea to England and elsewhere, at good freights.

A lively and profitable commerce went on all the time from colony to colony, from the continent to the West Indies, and from all the colonies to England and other European countries. The principal exports were: to the West Indies, clapboards, hoops, shingles, hay and cattle, flour

73. Colonial commerce and provisions, especially dried fish, and, later, rum; to England, tobacco, masts, wood ashes, furs, and, later, pig iron 
and indigo; to other European countries, dried fish and naval stores - pitch, tar, and turpentine.

The imports from England were manufactures of all kinds guns and ammunition, hardware, cutlery, clothing, furniture, glass, china, silverware, and tools. Tea, and later coffee and chocolate, were regular imports, often from Holland. The

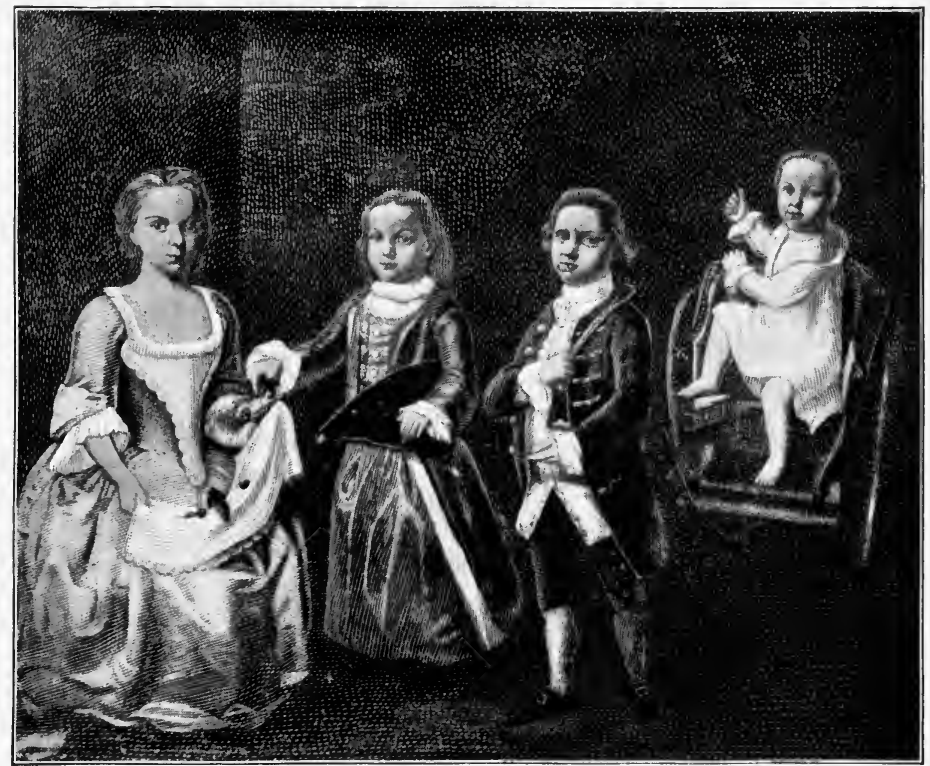

Photo. by E. C. Beveridge.

A Colonial Family - the Grimes Children.

From the picture in the Virginia Historical Society.

ladies would have their "calamancoes," or glossy woolens, their "paduasoys," or silks, their "oznabrigs," or German linen, and the much-prized pins. For the children were "poppets," or dolls, and other toys ; for the gentlemen, silks and velvets, gold lace for their best suits, and pipes of Madeira wine.

For many years the colonists freely sent and received car 
goes in trade with foreign countries; but the policy of the early navigation acts was expanded by an act of Parliament (1672) laying small customs duties on the trade from one colony to another. This was the first act of Parliament for taxing the colonies. In 1696 a more thorough-

74. Restrictions on colonial trade going navigation act was passed by Parliament and a new colonial council was created by King William III. under the name of Board of Trade and Plantations, commonly called the Lords of Trade, with the duty of supervising the colonies, instructing the governors, and executing the navigation acts.

Under these and later "Acts of Trade," the trade of the colonies was restricted: (1) Trade to and from England had to be in ships built and owned in England or in the colonies. (2) Importations had to come through English ports - that is, through the hands of English firms. (3) Exports of "enumerated goods" had to be sent only to English ports, even if intended ultimately for some other country; most of the colonial products were enumerated, but not masts, timber, or naval stores. (4) For the protection of English manufactures colonists were forbidden to make rolled iron, or to ship certain goods from one colony to another - for instance, hats. Though all these restrictions seem harsh they indirectly gave a distinct advantage to colonial shipping.

Spain, France, and Hclland had even stricter colonial systems than the English; but the English colonists, sometimes by stealth, often with the connivance of local officials, had a very profitable trade to the Spanish, French, and Dutch West Indies, especially in dried fish and lumber;

75. Smuggling and clandestine trade and they brought back sugar, tropical products, and a good surplus of hard Spanish dollars. In the same way foreign vessels often brought European cargoes into North America. Edward Randolph, the revenue detective of the English government, said in 1676: "There is no notice

Hutchinson, Mass. Bay, III. 496 
taken of the acts of navigation . . all nations having full lib. erty to come into their ports and vend their commodities."

A valuable trade, in which the French competed, was that with the Indian tribes of the interior. In time of peace, the traders circulated through the frontiers both north and south with their pack horses loaded with blankets, powder and ball, guns, red cloth, hatchets, knives, scissors, kettles, paints, looking-glasses, tobacco, beads, and "brandy, which the Indians value above all other goods that can be brought them."

Several dangers hovered over the colonial seafarer. In time of maritime war, especially after 1700 , the cruisers and priva-

76. Privateers and pirates

teers of the enemy picked up many merchant vessels. On the other hand, the colonies furnished several fleets to attack the French; and their little merchantmen were easily converted into privateers to prey on the commerce of the enemy. It was an exciting kind of gambling, for the privateer was about as likely to be taken as to take; but a successful cruise brought home plenty of captured cargoes for the owner and prize money for the crew.

Pirates abounded in all the seas, and especially in the West Indies, where they had several stations. The methods were very simple: peaceful merchantmen often turned pirates with or without the consent of the master of the ship; the boldest man was captain until some of his sailors killed him; ships were impartially plundered, the crew sometimes allowed to escape, but the passengers frequently compelled "to walk the plank." A pirate ship could live for many months at sea on its captures.

After all, piracy was a poor barbarous trade of murder and rapine, leading to a bad end. In 1718 Colonel Rhett of South Carolina sailed out and overwhelmed Captain Bonnet and his force of cutthroats. In the same year Teach, or Blackbeard, a ruffian who blackened his face and colored his beard, was visited without invitation by two cruisers sent out by Governor 
Spotswood of Virginia, which brought home Teach's head stuck on a bowsprit. Governor Fl her of New York gave commissions to pirates visiting the eity and sold protection to individual pirates at a hundred dollars apiece; but his pirate friend Captain Kidd was at last hanged in chains in London.

The thing most important to remember about the English colonists is that down to about 1700 they looked upon themselves simply as a body of English people living across the sea; but that the new conditions made their life very different from that of their brethren across the water. Land was cheap, and therefore there were no hard and fast distinctions like those in England between the aristocratic landowner, the middle-class farmer, and the lower-class laborer. Food and material for plain clothing abounded, and therefore there was no grinding poverty like that of England. Rude labor was much needed, and therefore slaves were introduced into the colonies at the time when slavery died out in England. Population was scattered, and the colonists were distant from the intellectual and literary life of the home country, and hence their literature was limited and commonplace.

Commercial life was active and eager; the colonists were good shipbuilders, bold sailors, and successful merchants. Down to 1700 the English restrictions on trade were slight, and after that time they were evaded. In general, the colonies were happy, progressive, and prosperous little communities.

\section{TOPICS}

(1) Growth of colonial population from 1607 to 1763. Suggestive (2) List of contemporary writers who described colonial industries topics and life from 1607 to 1689 . (3) Colonial writers of verse. (4) Treatment of supposed witches outside of New England. (5) Introduction of slaves into New England. (6) Phips's discovery of treasure. (7) What goods were "enumerated"?

(8) Why did the colonists smuggle? (9) Witchcraft at Salem. 
Search topics

Geography Secondary authorities

\section{Sources}

Illustrative works

Pictures
(10) French Huguenots in the English colonies.

(11) Ladies' dress in the colonies. (12) Life in some colonial college before 1750. (13) The tithing master in church. (14) Slave life in Virginia, 1619-1750. (15) A pirate's life. (16) Instances of smuggling. (17) Schools in the South. (18) List of colonial churches built before 1700 and still standing. (19) Studies and school books in early colonial times. (20) A New England Sabbath.

\section{REFERENCES}

Semple, Geographic Conditions, 114-132.

Thwaites, Colonies, §§ 23, 40-45, 75-80, 91-96; Fisher, Colonial Era, 56-61, 74, 164-176, 207-211, 313-320; Lodge, English Colonies, chs. ii. iv. vi. viii. x. xiii. xvii. xxii. ; Fiske, Old Virginia, II. 130, 116-130, 174-269, 308-369, - Dutch and Quaker Colonies, II. 62-98, 222-235, 258-293, 317-356 ; Doyle, English in America, I. 381-395, II. 1-10, III. 1-8, 14-97, 323-337, 377-395 ; Bruce, Virginia, I. 189-634, II. ; Weeden, New England, I. 47-314, 330-378, 387-447, II. 449-472, 492-606 ; Stockton, Buccaneers and Pirates; McCrady, South Carolina, I. 251-263, 341-363, 564-567, 586-623, II. 376-540 ; Tyler, American Literature (Colonial); Locke, Antislavery, 9-45; Wendell, Cotton Mather, 88-307.

Hart, Contemporaries, I. §§ 85-89, 137-149, 168, 172, II. §§ 16-18, $25,28,32,34,35,45,46,80-87,90-108$, - Source Book, §§ 11, 12, 28-35, 41, 43-47, - Source Readers, I. §§ 14-17, 22, 24, 39, 50-54, 66-83, II. 1-23, 55 ; MacDonald, Select Charters, nos. 22, 23, 25, 28, 34, 43, 50 ; American History Leaflets, no. 19 ; Caldwell, Survey, 13-22, 126-132 ; Samuel Sewall, Diary. See N. Eng. Hist. 'Teachers' Ass'n, Syllabus, 313-315, - Historical Sources, § 74.

Longfellow, Giles Corey; Whittier, Mabel Martin,-Prophecy of Samuel Sewall, - Witch of Wenham; A. M. Earle, Home Life in Colonial Days, - Child Life in Colonial Days,-Colonial Dames, - Sabbath in Puritan New England,-Customs and Fashions in Old New England, - Stage-Coach and Tavern Days, - Two Centuries of Costume, - Curious Punishments; J. de F. Shelton, Salt-Box House, 1-149 ; C. G. DuBois, Martha Corey (witchcraft); Hawthorne, Scarlet Letter, - Old News, pt. i. ; Cooper, Satanstoe (N.Y.); P. H. Meyers, Young Patroon (N.Y.); Marion Harland, His Great Self (Col. Byrd); Stockton, Kate Bonnet (pirates); Stevenson, Treasure Island (pirates); J. H. Ingraham, Captain Kyd; J. E. Cooke, Youth of Jefferson (college life).

Mrs. Earle's books mentioned above; Sparks, Expansion; Wilson, American People, I. II. ; Edward Eggleston in The Century, 1884, 1885. 


\section{CHAPTER VII.}

\section{INTERNAL DEVELOPMENT， 1689-1740}

ONE of the tasks of King William's government was to reorganize the colonies. He gave Massachusetts Bay a new charter (October 7, 1691) by which Maine was retained, Plymouth was annexed, and the governor was appointed by the king: all Christian worship except the Catholic was to be tolerated; New Hampshire, which had reunited

78. Reorganization of the colonies (16891729) itself to Massachusetts, was again separated. Connecticut and Rhode Island went back to their former liberal charters, and were the only colonies allowed to elect their governors

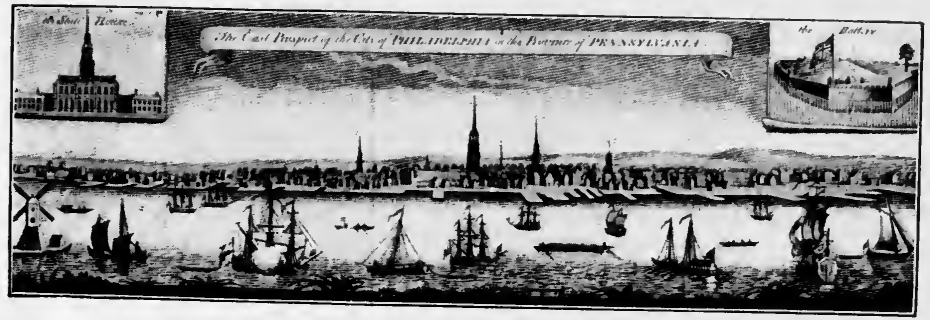

Philadelphia about 1740. (From an old print.)

In the middle colonies the proprietary charter of New York had been surrendered (1685) when the proprietor became king, and that of the combined Jerseys was yielded in 1702. Penn was deprived of his proprietorship of Pennsylvania for a year (1693-1694), and came near selling his patent to the crown in 1712. Delaware was separated from Pennsylvania in 1703, though the two still had the same governor appointed by the proprietor. 
The same policy of harassing the proprietary governments was followed in the South. Maryland in 1691 was for a time made a province, or royal colony, but the proprietorship was restored to the Baltimores later. The people of the Carolinas formed an association to oppose the proprietors, who in 1729 gave way, and sold their claims to the crown; and the British government (p. 126) thereupon organized the two separate colonies of North Carolina and South Carolina.

Between South Carolina and Florida in 1732 was set up the new chartered colony of Georgia, extending from the Savannah 79. Settle- River to the Altamaha; and from the sources of those ment of Georgia rivers westward to the South Sea. The leader of the (1732-1752) enterprise was James Oglethorpe, a man of high philanthropic spirit, whose announced purpose was to form a Christian commonwealth. The first settlement, was made at Savannah (1733); besides colonists from England, Protestant exiles came over from the principality of Salzburg in the Austrian Alps; and German Moravians, Protestant Scotch Highlanders, and Jews soon moved in.

The three fundamental principles of the new colony were that slavery should not be permitted, that rum should be excluded, and that there should be complete religious toleration. The trustees tried to start silk culture and wine making, but the crop which was most cultivated on the coast was rice, for which the planters insisted that they must have slaves; and at last, in order to compete with South Carolina, the trustees gave way. Still the colony was not prosperous; and the trustees, disappointed in both moral and pecuniary return for their investment, surrendered their proprietorship to the home government (1752).

The boundaries between the colonies were in many cases in 80. Bound. controversy. Virginia and North Carolina ran their "Diary contro- viding Line" — the present boundary — in 1728. The versies question, which branch of the upper Potomac separated 
Virginia from Maryland, was settled in 1746. The most troublesome of all these controversies was that between Pennsylvania and Maryland (see p. 81): Baltimore's grant of 1632 - " unto that part of Delaware Bay on the north which lieth under the 40th degree of north latitude"-included the whole of upper Chesapeake Bay, and even the site of Philadelphia; but Penn insisted that his grant "unto the beginning of the fortieth degree of Northern Latitude" meant the 39th parallel, and not the 40th. Baltimore had the legal advantage; Penn had the king's favor; therefore the English government gave a strip comprising Philadelphia to Penn, and the two proprietary families agreed on a compromise line, which was finally run by the surveyors Mason and Dixon (1763-1767). Later that line became also the

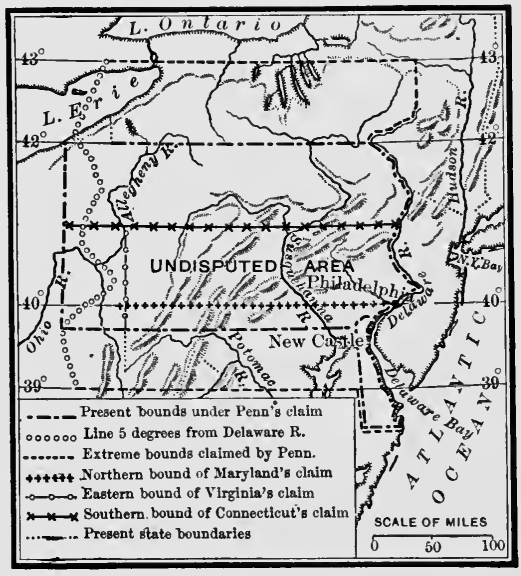

Pennsyluania Boundary Controversies.

boundary between free and slaveholding states - that is, between the North and "Dixie's Land."

New York took advantage of the Pennsylvania plea that a degree of latitude "began" at the parallel of the next lower degree, to push the northern line of Pennsylvania one degree south. In New England, Massachusetts had controversies with every neighbor, but finally came down to substantially her present bounds. The region north of Massachusetts and west of the Connecticut River was claimed by Massachusetts, settled under grants from New Hampshire, and then was assigned to New York (1764) by the British government. 
The colonies pressed their claims to territory because they felt responsible for their own future. Nowhere on earth were 81. Growth of colonial democracy

there such free commonwealths; nowhere was there so much discussion of public questions by the people at large; nowhere was there such a "fierce spirit of liberty," as Edmund Burke called it.

The foundation of this lively colonial democracy was the conviction that Americans were entitled to inborn rights, which could not be taken away by either British or colonial governments. Among them were: (1) the personal rights of Englishmen set forth in the old common law, such as speedy and open trial by jury, and freedom from arbitrary arrest; (2) rights asserted for the English by such statutes as the Petition of Right (1628), the Habeas Corpus Act (1679), and the Bill of Rights (1689); (3) the right to make statutes in local matters through town meetings and other local assemblies.

Voting was in every colony restricted to owners of real estate, or payers of considerable personal taxes - that is, to about one half or one third of the adult free men. There were no political parties in the modern sense: the usual division was between the friends of the governor and the opposition. In all the colonies the local dignitaries - ministers in New England, merchants in the middle colonies, planters in the South controlled their neighbors' votes; and the public honors fell to a small number of families of social distinction.

The colonial democracies were organized in one or another of three official forms: (1) under charters, in the three colo82. Prin- nies of Massachusetts, Rhode Island, and Connecticut; ciples of colonial

(2) under orders and grants of the proprietors, holders of government patents, in the three colonies of Pennsylvania, Delaware, and Maryland; (3) under orders and instructions to governors, issued by the home government in the seven "provinces" of New Hampshire, New Jersey, New York, Virginia, North Carolina, South Carolina, and (after 1752) Georgia. 
All these groups of colonies had governments divided into three departments :-

(1) The governors of two of the charter colonies were elective; in the three proprietary colonies they were sent out by the proprietors; in the eight other colonies they were appointed by the crown. They were paid under acts of the assemblies, and hence had to come to an understanding with their people. Associated with the governor was a small council appointed by the crown or governor, which was in most colonies both the highest court and the upper house of the legislature.

(2) The assembly (lower house of the legislature) was elected from counties or towns, as units of representation. In conjunction with the governor and council, it made laws, and had the right of voting taxes; and it appointed certain colonial executive officers and audited the accounts.

(3) In the colonial courts the judges were appointed by the governor or the crown, except in Rhode Island and Connecticut. This was the weakest department of the colonial governments; for the judges had no authority to hold that a coloniai statute was invalid. But in all criminal and most civil cases juries were used, and justice was speedy and cheap.

The freedom of action of the colonial governments was limited in several ways: (1) The colonists acknowledged the personal sovereignty of the king and the right of Parliament to legislate for all parts of the British Empire in matters of trade; and in every war the enemies of Eng.

83. Restrictions on colonial govland were the enemies of the colonies. (2) The general conduct of the colonies was subject to the supervision of the home government, exercised by instructions sent out to the appointed governors; these included the obligation to call assemblies, but also forbade the governor to sign certain kinds of bills. Most colonies had in London an agent to represent the colony there and watch its interests. (3) The legislature could be dissolved by the governor, and its acts (except in 
Rhode Island and Connecticut) were subject to his veto; and the home government or proprietor could disallow a colonial act even if the governor had signed it. (4) Appeal lay from the colonial courts to the Privy Council in England.

The colonial governments had the power to set up local governments of various kinds, and to alter or abolish them.

84. Local governments

(1) The county system, most distinct in the southern colonies, was an attempt to reproduce the English county government; there was a board appointed by the governor, and called the court of quarter sessions, or county court, which laid local taxes and made local ordinances, and, as a court, administered a crude and offhand justice for petty offenses.

(2) In Pennsylvania and New York both counties and towns were established: in Pennsylvania, the county officials were chosen as such by direct election; in New York the regular "supervisor" elected by each town or township was also a member of the county board. Both these types are now very common in the northwestern states.

(3) New York, Pennsylvania, and New Jersey set up a few city and borough governments.

(4) The smallest unit of local government in England, at the time of colonization, was the parish, often called a town. Some parishes were governed by a "select vestry," filling its own vacancies; others by a parish meeting of the taxpayers. Both these types were brought over to America: the select vestry was introduced into the so-called parishes in the South (but left no imprint on the government of the country and has long since ceased to exist); while the taxpayers' meeting was adopted for the villages (towns) of New England, and developed into the town meeting.

Once a year, and at other times if necessary, all the voters

85. Cola. nial town meetings of a New England town were summoned to a public meeting, in which most of the town business was performed. Town officers were chosen for the year, especially the 
"townsmen," or selectmen - a board of executive officers who sat from time to time during the year. Other officers were the town clerk, town treasurer, and a bewildering list of petty officers, such as constables, surveyors of the highway, overseers of the poor, pound keepers, and hog reeves.

The main business of the town meeting, however, was to legislate for the town, and it was a place for vigorous discussion, and for the development of parliamentary law and political patience; and in troubled times it was the center of protest, as when the Cambridge town meeting in the Stamp Act days instructed its repre-

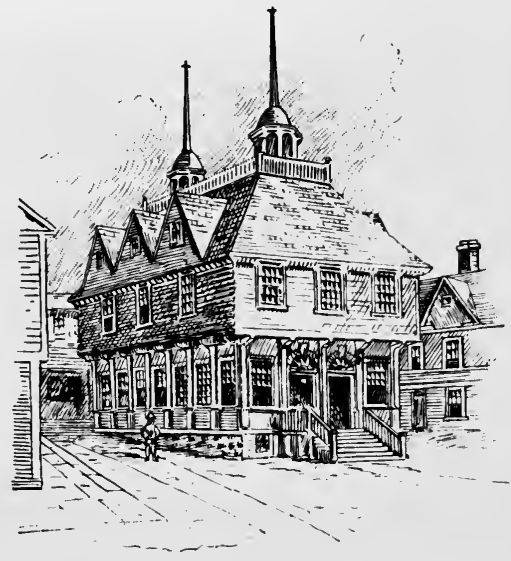

Boston Town House, 1658. sentatives that "they use their ntmost endeavours, that the same may be repealed; that this vote may be recorded in the Town Book, that the children yet unborn may see the desires that their ancestors had for their freedom and happiness."

Though officially quite distinct from one another, and connected only by common adherence to the British government, the colonies had many relations with one another. It was easy for an Englishman or a foreigner to become 86. Germs of colonial union a citizen of a colony, or to move from one to another, (1690-1750) for every colony was Protestant, every colony had the same system of laws, every colony was English-speaking.

In the period from 1690 to 1750 several intercolonial meetings were held to discuss Indian relations and other matters of common interest. William Penn even proposed (1696) an annual meeting of deputies of all the provinces, to discuss 
intercolonial questions and common defense; but distance, local jealousies, and the lack of a definite common grievance, for near a century kept the colonies from uniting.
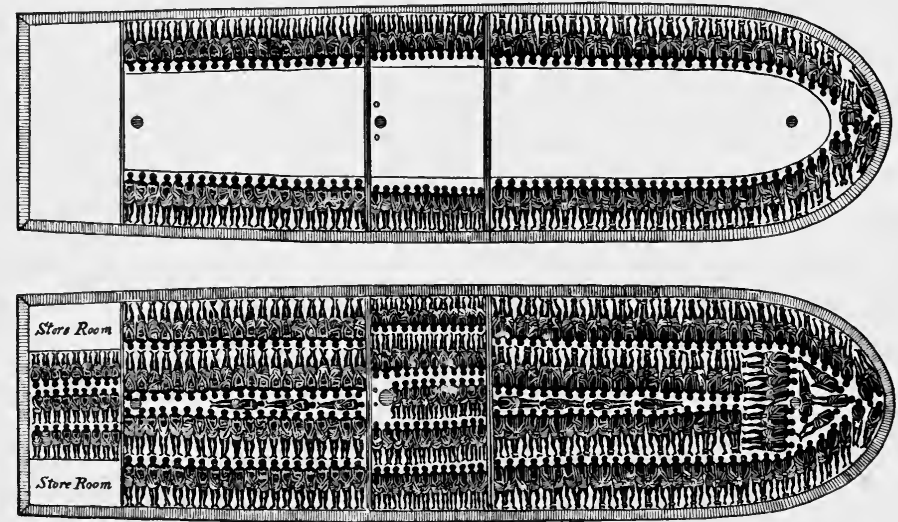

Deck Plans of a Slaver.

Showing stowage of nearly 500 persons in a 300 -ton ship; from a broadside.

Several new branches of trade developed after 1700, especially the African slave trade. Under the treaty of Utrecht 87. Devel- (1713) an English company, in which Queen Anne was opment of colonial commerce rying slaves to the Spanish West Indies. The New Englanders were quick to work up a profitable slave trade for themselves. Hardly anywhere was there protest against the trade or its shocking cruelties; and whenever the legislatures of the colonies tried to tax it for revenue, or for any other reason, the bills were vetoed in England because the trade was so profitable to the English merchant.

Eventually so many slaves were brought that the people began to be frightened, and South Carolina several times tried to lay duties on their importation. The slave traffic was connected with the manufacture of rum, which was carried to 
Africa to be exchanged for slaves; part of the slaves were carried to the West Indies on the so-called Middle Passage and exchanged for molasses ; and the molasses and the profits came home to New England to furnish raw material for more rum. In 1733 this business was much affected by the Molasses Act passed by Parliament to protect the product of the British West Indies, by prohibiting the colonists from using molasses or sugar from the French or Spanish West Indies.

Colonial trade was always disturbed because there was no uniform or steady standard of currency. Alongside the English sterling money was a medley of coins of all nations, especially the Spanish "piece of eight," or dollar. In Virginia and Maryland tobacco was a legal currency,

88. Currency and paper money even for taxes. There and elsewhere barter was very common, and people bought goods for "money" (cash), "pay" (produce), or "pay as money" (credit payable in produce).

Most of the colonies followed the bad example of Massachusetts in putting out paper notes issued to secure a temporary public loan, or lent by the colony to private individuals on the security of their lands, or lent by private "loan banks" on mortgages to the stockholders. To vote such paper issues was so easy that they ran up in amount and ran down in purchasing power. There came a time when a Rhode Island ten-pound note would not pass for more than eight shillings, or one twenty-fifth of its face, measured in gold and silver. The issue of any form of colonial paper money was discouraged by the home government; and in 1751 was prohibited by Parliament, except in emergencies.

The experiments in paper money were an evidence of a willingness to try something new, which extended even to theology. The Puritan theocracy steadily lost ground during the eighteenth century, although a new leader of thought in New England, Rev. Jonathan Edwards, worked out an 89. Intellectual and religious elaborate system of theology based on the "total deparivity" 
of human nature. He taught that the blessed in Heaven would be made happier by seeing the torments of the lost; yet he was an affectionate parent, a thrifty business man, and an acute reasoner.

Against this harsh theology and appeal to the fears of mankind, came a movement of protest which began in the attempt of John and Charles Wesley, devoted clergymen of the Church of England, to restore vital religion to that church. In their sermons, doctrinal books, and hymns, they dwelt on the love of the Savior, and the great desire of God that His children should be reconciled to Him. In 1736 both brothers, followed by Rev. George Whitefield, came out for a time to Georgia, and attempted to convert the natives and to rouse the white people. The Wesley movement ended in the founding of the Wesleyan or Methodist Church in England. In 1740 Whitefield came to New England, and by his powerful preaching brought about "The Great Awakening," the first general revival of religion in America.

The New England Congregationalists under this pressure divided into "Old Lights" and "New Lights," the latter feeling that genuine conversion must show itself by tears, groans, and convulsions, popularly called "the jerks." The outcome of the movement was the establishment of the Methodist Church in America and a great strengthening of the Baptists, while the Congregational, Presbyterian, and Episcopal churches throughout the colonies were directly or indirectly influenced to make religion less a matter of observance and dogma and more a matter of personal service.

A new intellectual interest was shown by the publication of several excellent local histories, and by the foundation, between 1746 and 1769, of five new colleges: New Jersey at Princeton; Kings, now Columbia; Philadelphia, founded by Franklin, and later reorganized as the University of Pennsylvania; Rhode Island, now Brown; and Dartmouth. 
The most distinctly intellectual man of this period, and also the greatest political leader, was Benjamin Franklin, who was born in Boston in 1706, and settled in Philadelphia in 1723. Franklin was a good printer, and the first American journalist of any continental reputation. 'Through-

90. Benjamin Franklin out his life he was interested in education, and he rendered great service to science by discovering that lightning is the same thing as the discharge of electricity produced by friction. He was also the inventor of the useful Franklin stove, a kind of little movable fireplace. He was appointed deputy postmaster-general for the colonies in 1753 and greatly improved the scrvice. In 1757 Franklin was sent to England as agent of the colony of Pennsylvania, and remained there five years. Gradually other

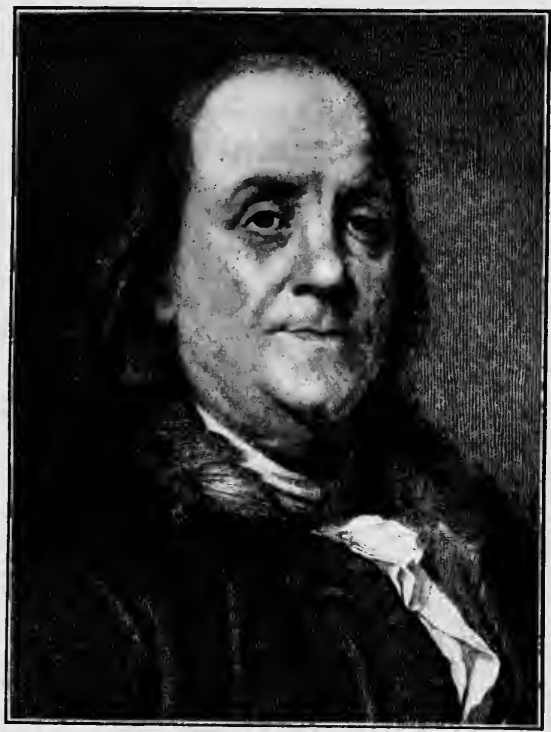

Benjamin Franklin, about 1780.

From a portrait attributed to Greuze. colonies noticed his influence with British statesmen and gave him a similar commission. He was a keen and caustic writer, and his satires on social and political matters, such as his How a Great Empire may become Small, had powerful effect; his Poor Richard's Almanac was an annual, abounding in shrewd common-sense observations, widely read in the colonies.

The chief merit of Franklin was that his great mind saw how much the colonies could do if they would only act 
together; he showed a willingness, very uncommon in the colonies, to sink local differences and interests for the common good; and in England he impressed the leading men with respect for himself and for the colonies which he represented. Franklin personified the colonist of the second half of the eighteenth century who had ceased to look upon himself as an Englishman living over seas, but was an American, with no purpose or desire but to remain a colonist.

The characteristic of the half century from 1690 to 1740 is the quiet and sound development of the colonies, and their 91. sum- experience of self-government. The colonial governmary ments were in a sense new creations, for there was nothing like them in England. The governors had large nominal powers, but were hedged about by the assemblies and by their instructions; Rhode Island and Connecticut were in all matters except foreign trade and foreign war practically independent little republics, and the other colonies were not much behind them. By force of circumstances, the English types ef parish meetings and county courts developed in America into vigorous little local governments, which did much to edueate the people in the conduct of their own affairs.

The colonists made money by trade and struck off a poor and depreciating currency with their printing presses. A freer spirit prevailed in religion, and it is at this time that religious toleration begins to be general throughout the colonies. Above all, such men as Franklin stood for a sense of common interest and responsibility which might accustom people to think of themselves, from north to south, as essentially one people.

\section{TOPICS}

(1) How did Massachusetts get the charter of 1691 ? (2) Why was New York transferred by the proprietor to the crown? New Jersey? the Carolinas? (3) Notable Germans in America before 1750. (4) Was Penn entitled by his charter to the site of Phila- 
delphia? (5) Describe the public services of some governor of a colony. (6) For any one colony compare its geographic extent in 1650 with its extent in 1690 . (7) Make a list of meetings of colonial governors, 1640-1763. (8) How could the English colonists trade with the Spanish West Indies? (9) Why was the British government opposed to paper money? (10) Spotswood's explorations west of the mountains.

(11) The Wesleys in America. (12) Whitefiell's preaching. (13) Some of Franklin's witty sayings. (14) Claims by the Search topics colonists to the rights of Englishmen, 1689-1750. (15) Origin of the "caucus." (16) A session of a colonial legislature. 17) Oddities of town meetings. (18) Conduct of the slave trade. (19) Life at Princeton College. (20) Causes of disputes with colonial governors. (21) Some notable colonial agents. (22) Instances of acts of colonial legislatures vetoed by governors.

\section{REFERENCES}

Thwaites, Colonies, §§ 24-26, 46, 81, 97, 116-130 ; Fisher, Colonial Era, 216-236, 241-286, 292-312 ; Lodge, English Colonies, chs. i. iii. v. vii. ix. xii. xiv. xviii.-xxi. passim ; Greene, Provincial America, - Colonial Governor ; Fiske, Old Virginia, Il. 3044, 162-173, 289-308, 333-337, 370-400,-Dutch and Quaker Colonies, II. 209-257, 294-317, - New France and New England, 197-232 ; Doyle, English in America, I. 266-274, 323-327, 343-350, 363-380, III. 8-14, 273-376, 395-404; Gay, Bryant's History, II. 395-400, III. 25-191, 222-253 ; Weeden, New England, I. 314-330, 379-387, II. 473-492, 607-713; Channing, Town and County Government; Dewey, Financial History, §§ 3-11; Hart, Practical Essays, 133-161; Mereness, Maryland.

Hart, Source Book, §§ 27, 42, 48-52,-Contemporaries, I. §§ 104, 126, II. \$§ 19-24, 26, 29-31, 33, 36, 38-44, 47-79, 88, 89,- Source Readers, I. \$\$ 13, 18, III. 71 ; American History Leaflets, no. 14 ; Hill, Liberty Documents, ch. xi.; Caldwell, Survey, 32-39 ; Franklin, Autobiography; John Woolman, Journal. See N. Eng. Hist. Teachers' Ass'n, Syllabus, 301, 306-308, 313-315,-Historical Sources, $\S 73$.

Hawthorne, Grandfather's Chair, pt. i. chs. x. xi., pt. ii. chs. 1.-vi. ; Cooper, Deerslayer (N.Y.); J. K. Paulding, Dutchman's mlustrative works Fireside (N.Y.) ; Mary Johnston, Audrey (Va.); W. A. Caruthers, Knights of the Horseshoe (Va.); J. E. Cooke, Stories of the Old Dominion, 82-109; Simms, Yemassee (S. C. Indians).

Winsor, America, V.; Wilson, American People, I. II.

Secondary authorities

Sources 


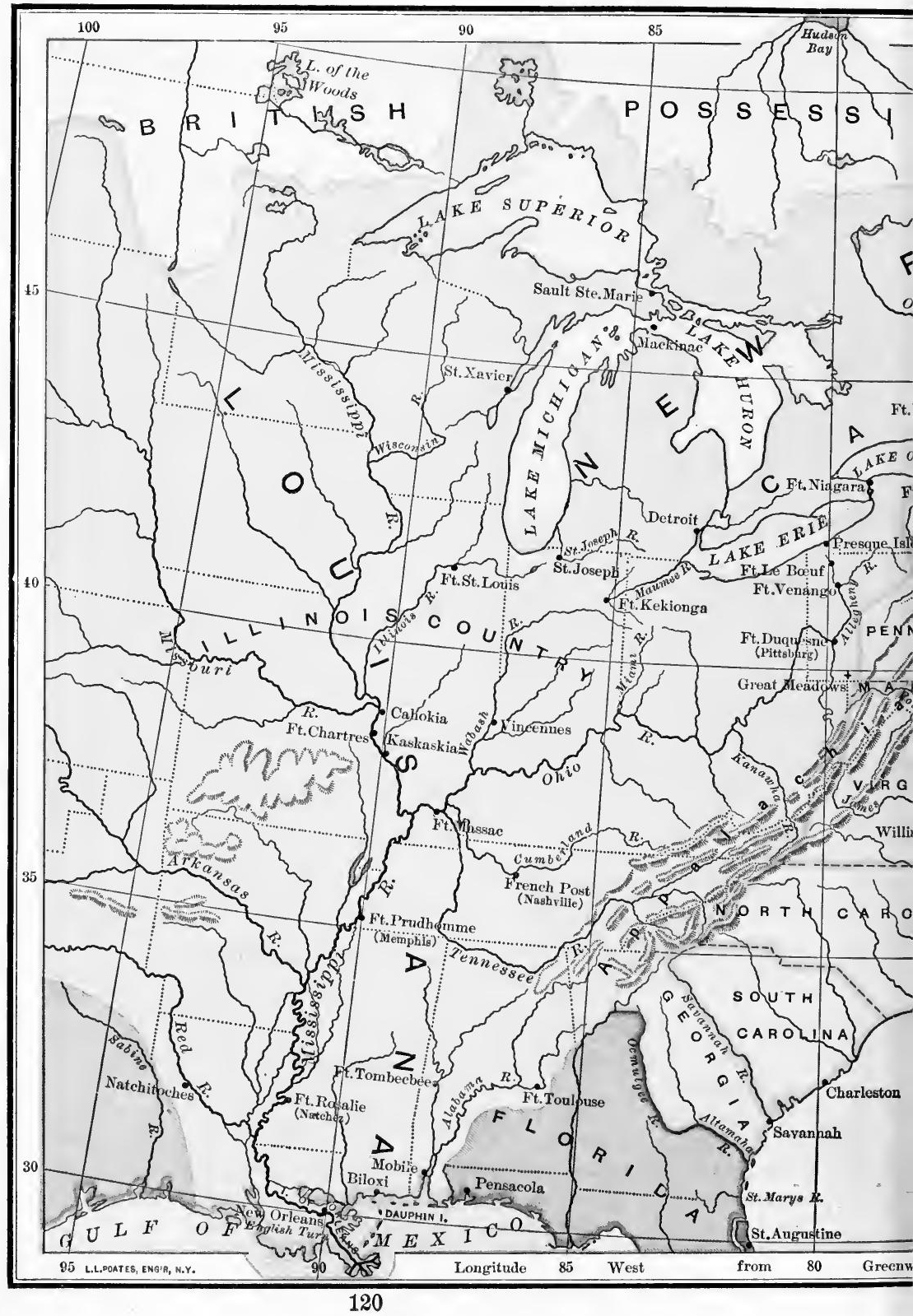




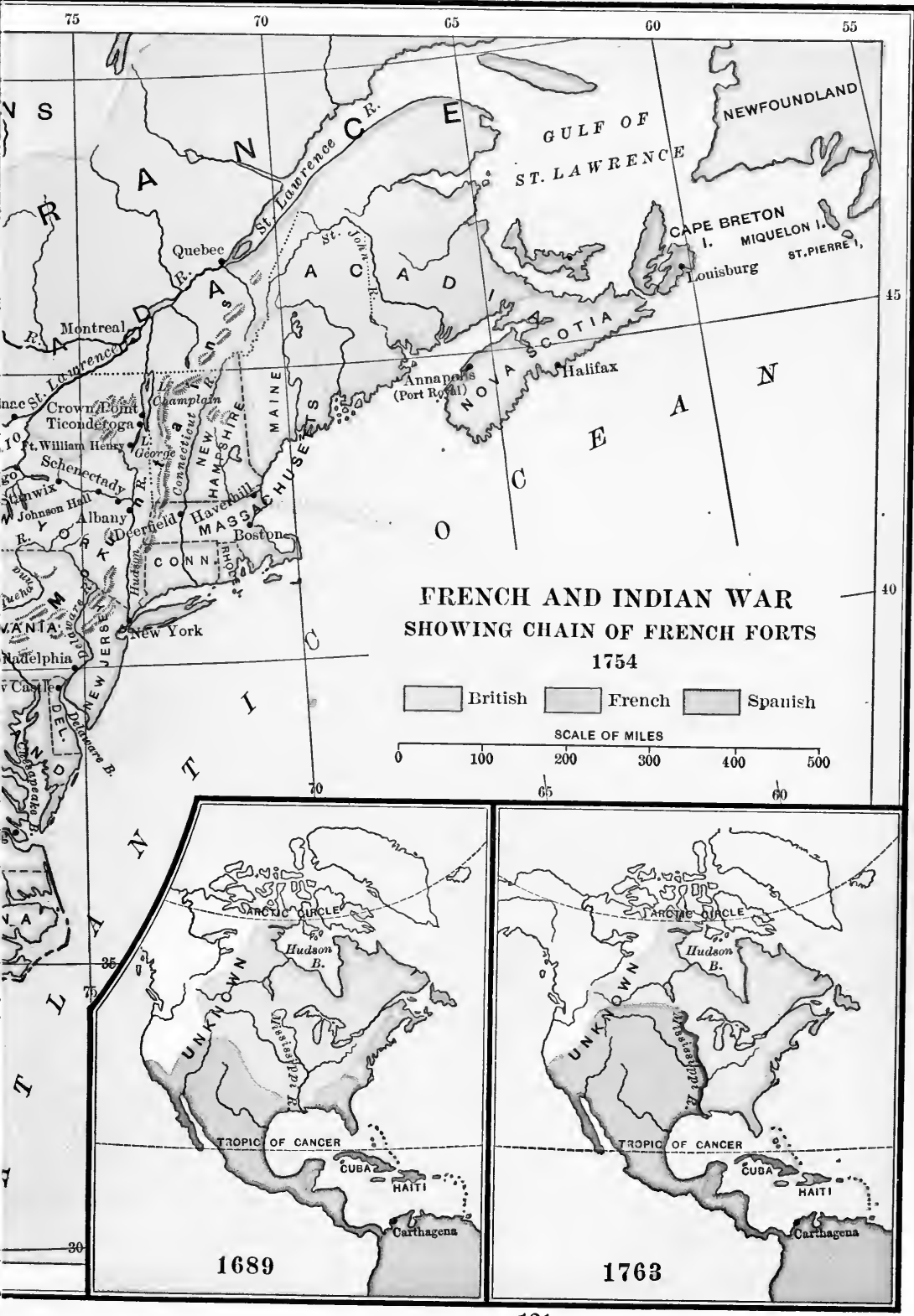




\section{CHAPTER VIII.}

WARS WITH THE FRENCH (1689-1763)

ONE of the first acts of King William III. was to declare war on France in 1689; and during the next three quarters of 92. Rivalry a century four fierce struggles by sea and land expressed of France the national hostility between England and France. and England (1689-1697) The most notable thing in these wars is the rise of the British "sea power." To protect her own colonies, scattered all over the globe, and to attack the colonies of France and Spain, England developed the best navy of the time. The unit for naval fights was a fleet of the "wooden walls of England," the great three-decker "ships of the line" of 1000 to 2000 tons' burden, carrying in two or three tiers as many as 120 guns. In time of war, often in times of peace, merchantmen sailed in "convoys," great fleets under protection of vessels of war, to keep off the enemy's cruisers and privateers.

In each of these wars the colonists fought for England by land and sea. Their first experience of invasion was from a French expedition, composed partly of Indians, which in 1690 struck the town of Schenectady, eighteen miles west of Albany, surprised it at midnight, sacked and burned its eighty houses, killed sixty people, and took thirty prisoners. In successive years half a dozen towns near the Atlantic coast were raided in the same ruthless fashion. The English struck one good return blow in 1690, when, under the leadership of Sir William Phips of Massachusetts, they captured Port Royal (now Annapolis, Nova Scotia). After eight years of what was called in America " King William's War," each power agreed by the peace of Ryswick, in 1697, to restore its conquests to the other. 
The French attack on the frontier led the English colonies to make friends with the ferocious Iroquois. The Five Nations were enlarged into the "Six Nations" by the coming of a tribe of their blood brethren, the Tusearoras (1713). Then five years later the home government appointed Sir Wil-

93. The

border

Indians liam Johnson its agent to the Six Nations. He lived among them in a great place called Johnson Hall, where he held open house for their benefit. He was an adept at those long-drawn councils which the Indians so much loved; he knew how to give belts of wampum "to dry up their tears," how metaphorically "to clear the road grown up with weeds," and to set up "the fine shady trees almost blown down by the northerly winds." This palaver, accompanied with plenty of food and rum, was very effective in preventing the French north wind from blowing down the English influence among the Iroquois.

In the South, the growth of the Carolinas led to bloody wars with the Tuscarora and Yamassee Indians from 1712 to 1716 . In 1730 the Cherokees made treaties, by which they recognized the king of Great Britain (p. 126) as their Father, and thus provided a point of opposition to the French in the Southwest; and the settlement of Georgia soon brought the whites into close contact with the Cherokees, Creeks, and other strong interior tribes.

The colonial wars were made more terrible by the Indian allies of the

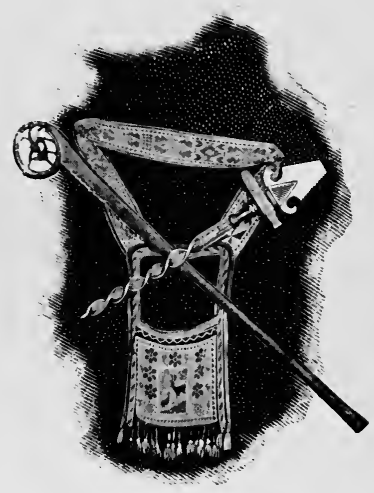

INDIAN ART.

Pipe, lacrosse stick, and pouch, procured from western Indians. French, who captured prisoners to make slaves of them, or to hold them for a ransom. Fearful was the hasty march northward after a raid; little children were brained against the trees, because too troublesome to carry; the women who fainted 
with fatigue were tomahawked and scalped to save the trouble of carrying them along. In one such foray (1691) Hannah Dustin of Haverhill, Massachusetts, was made prisoner. She had the heroism, with a nurse and a white boy, to surprise her captors, and the barbarity to kill not only two Indian men but three women and five children; by this means she escaped and reached home again to tell the tale.

During the twenty-five years after La Salle's exploration of the Mississippi, the French made various permanent settlements 94. Settle- in the new country, especially St. Joseph near the head ment of Louisiana Lake Michigan (1681), Kaskaskia (1695), Cahokia (1681-1721) (1701) near the mouth of the Missouri, and Detroit on the waterway from Lake Erie to Lake Huron (1701); and later Vincennes on the Wabash River (about 1732).

For the lower Mississippi country three nations reached out at once: (1) Spain settled Pensacola as a basis for colonies to be planted farther west; (2) the French interrupted this plan by sending a fleet of five vessels with 150 colonists, under the Sieur d'Iberville, to take possession of the coast of Louisiana in 1699; (3) the English also sent out a ship, which was driven back (1699) by the French from the bend of the Mississippi just below New Orleans, still called English Turn.

After stopping first at Dauphin Island, and then longer at Biloxi on the Gulf coast, D'Iberville founded Mobile (1702). The purposes of this Louisiana colony were to control the interior Indians, to enrich the French with their furs, and to fight the English. Notwithstanding the introduction of negro slaves Louisiana grew very slowly, for like the English coast colonies it suffered from disease and Indian enemies; so that after ten years it contained only four hundred Europeans.

In 1712 a rich banker, Anthony Crozat, got from the king of Gannett, France a grant giving him a monopoly of trade in "all ${ }_{19}^{B o u n d a r i e s,}$ the countries, territories, lakes within land, and the rivers which fall directiy or indirectly into the river St. Louis 
heretofore called the Mississippi." Crozat did little except to build posts in what is now upper Alabama and western Georgia, and after five years gave up his privileges. To them succeeded John Law and his vigorous Company of the West. The Illinois country was annexed to Louisiana; Fort Chartres was built on the Mississippi above the Ohio, and another fort at Natchitoches on the Red River; a new political and commercial center for the colony was created in the town of New Orleans, founded in $\mathbf{1 7 1 8}$ on a site chosen because the water front was elevated a few feet above the river. Law brought in German emigrants as well as French, and when his company went bankrupt a few years later 7000 persons had gathered in Louisiana.

While Louisiana was developing, England engaged in "Queen Anne's War" (1701-1713) to prevent a union of the French and Spanish European and colonial empires under the grandson of Louis XIV. In this war the Spaniards and Carolinians attacked each other's frontier towns; especially St. Augustine and Charleston. In the North

95. Renewal of intercolonial war

(1701-1713) the French incited the Indians to attack the Connecticut River town of Deerfield (1704); most of the inhabitants were killed or swept away, but the affair left deep resentment at a warfare which aimed only at destruction, with no hope of conquest. The New Englanders retaliated with the same kind of warfare on the French villages. Both Frenchmen and Englishmen often scalped their defeated enemies; and in many cases white prisoners were turned over to Indian allies to give the Indians their favorite amusement of burning them at the stake. Toward the end of the war the English colonists captured Port Royal and again attacked Quebec. By the treaty of Utrecht, which ended the war in 1713, the French gave up "all Nova Scotia formerly called Acadia," and all claims to Newfoundland and Hudson Bay. This was the first time that the English by actual conquest extended their Ameri- 
can boundaries at the expense of the French, and it was the beginning of the downfall of the French empire in America.

The period of this war was one of consolidation in England. For a century England and Scotland had been sister kingdoms, having one sovereign but two Parliaments; but in 1707, by the Act of Union, they were united into the single kingdom of Great Britain, with a single British Parliament. Ireland, however, remained a separate kingdom, with a separate Parliament, till 1801. After 1707 the Scots were on the same footing as the English in colonial trade. The union was expressed in a new British flag having the crosses of St. George and St. Andrew combined. In 1714, on the death of Queen Anne, the succession passed to the Elector of Hanover, George I.; in 1727 to his son George II.

Though the French made no proper effort to send out large bodies of colonists to Canada, they strongly fortified the town 96. Devel- and harbor of Louisburg on the island of Cape Breton, opment of as a center for their naval power in the north Atlantic; Louisiana they built forts at the mouth of the Niagara River, and (1721-1748) at Crown Point on Lake Cha:nplain; and they began to send explorers and traders into the Ohio River country. The next step was to plan a chain of posts west of the Appalachian Mountains between Canada and Louisiana.

This plan was postponed by a war called in American history "King George's War," which broke out in 1739 between Great Britain and Spain, and in 1744 between Great Britain and France. Oglethorpe raised a force of Georgians which attacked the Spanish at St. Augustine; and thousands of English colonists were sacrificed in vain attacks on Cuba and on the Spanish stronghold of Carthagena in South America (1741). Four thousand New Englanders, however, under the command of William Pepperell, a brave but untrained militia general, joined a small British fleet, and in sixteen days' siege brought Louisburg to surrender in 1745 . The 
war was ended in 1748 by the treaty of Aix-la-Chapelle, by 'which conquests were mutually restored in all parts of the world. The French reoccupied Louisburg and refortified it.

Against the French claim to the whole eastern valley of the Mississippi, the British government set itself definitely, in 1749 , by making royal grants to the Ohio Company for land on the Ohio River, in what is now western Pennsylvania and West Virginia. To forestall a settlement there, (1749-1754) Céloron de Bienville was sent out by the French. He went down the Ohio in 1749 and near the mouths of the tributaries buried lead plates, setting forth that he had taken possession of the river. To confront the French, Virginia, which claimed the upper Ohio, founded a trading post on the Miami, about twenty miles above its mouth. The French broke it up (1752) and, reviving their plan of a chain of posts from the St. Lawrence to the Gulf of Mexico, built a fort at Presque Isle (Erie), and another, Fort Le Bœuf, twenty miles farther south.

It became evident that war was at hand. Under directions from the king, Governor Dinwiddie of Virginia, in October, 1753, sent to warn the French to withdraw. His messenger, George Washington (aged 21), with one companion made his way amid threatening Indians and the dangers of the wilderness, and delivered his message at Fort Le Bœuf. He all but lost his life in the icy waters of the Allegheny River, but returned to report that the French would not yield. Instead, the French drove a little force of Virginians out of the strategic point at the Forks of the Ohio (now Pittsburg) and built Fort Duquesne on the coveted spot. George Washington, in command of a little Virginian force, thereupon collided with a body of threatening French near Great Meadows (May 28, 1754), and by his orders was fired the first shot in a great war.

At the breaking out of this fourth intercolonial struggle, commonly called the French and Indian War, the Lords of Trade tried to bring about an understanding between the Brit- 
ish colonies through a congress at Albany, assembled to make a joint treaty with the Iroquois, and representing the four New 98. Con- England colonies, New York, Pennsylvania, and Marygress of Albany (1754) land. When the treaty was completed, Benjamin Franklin of Pennsylvania presented a plan for colonial union, which is a foreshadowing of our present federal constitution. A grand council sent from the colonies in proportion to their inhabitants was to have control of all Indian affairs, frontier settlements, and taxes for common purposes. This plan was approved by the congress, and sent out to the colonies for consideration, but as Franklin said, "Its fate was singular; the assemblies did not adopt it as they all thought there was too much prerogative in it, and in England it was judged to have too much of the democratic."

At the beginning of the war the British colonists numbered about $1,300,000$, and the Canadians were about 80,000 , not 99. Three counting a few thousand savage allies. The points of years of de- contact between the French and the English were:
feat (1755-1757) (1) the north Atlantic seacoast; (2) Lake Champlain; (3) the southern shore of Lake Ontario; (4) the headwaters of the Ohio. At all four points the British attempted at the beginning of the war to strike hard, and most of the colonies contributed freely in men and money; although the Quakers in Pennsylvania held back, for they were opposed to all wars.

On the northeast there was a special danger from the 7000 French settlers who remained in Acadia (Nova Scotia) after it was ceded to Great Britain in 1713. Parkman, the best historian of this war, says, "The Acadians, while calling themselves neutrals, were an enemy encamped in the heart of the province." To prevent the danger of their rising, an officer was sent, in 1755 , with orders to remove them. He says that Contempora- the men first to embark "went off Praying, Singing \& ries, II.365 Crying being Met by the women \& Children all the way (which is $1 \frac{1}{2}$ mile) with Great Lamentations upon their Knees 
praying \&c." The Acadian families were torn from their homes, loaded on vessels, and distributed in the colonies, where many of them suffered severely before they could find a livelihood; and some families were forever separated.

In the sunmer of 1755 an expedition of fifteen hundred men under the British general Braddock, sent against Fort Duquesne, met a dramatic fate. Braddock was within seven miles of his destination, when a force of French and Indians, about one half of his strength, sallied out and totally defeated him. His regulars were brave but did not understand bush inghting, and Braddock would not allow even the militia to fight from behind trees; hence a third of his officers and men were killed, and the remainder, regulars and provincials alike, Washington says, "ran as sheep pursued by dògs."

Braddock's defeat opened a road directly to the frontiers of Virginia and Pennsylvania, which were harried by the Indians; but, through the exertions of Sir William Johnson, the Six Nations were held neutral Two campaigns followed without decisive result. The English lost Fort Oswego on Lake Ontario; and, while attempting to force the Lake Champlain route, lost Fort William Henry, where the French were unable to prevent their Indian allies from massacring the prisoners.

In May, 1756, Great Britain declared war against France, and the general European struggle began, commonly called the Seven Years' War. It extended even to India, where Lord 100. Three Clive assured British supremacy against both French and navives at the battle of Plassey, 1757. Elsewhere Great (1758-1760) Britain suffered humiliating defeats. Then the English people insisted that William Pitt, an ardent and impulsive man, a powerful speaker, and a great administrator, be put at the head of affairs; and affairs began to mend. Fort Duquesne, and Fort Frontenac on Lake Ontario, were taken in 1758; and the French were so weakened at sea that they could not prevent the second capture of Louisburg. 
To invade Canada, Pitt now selected General James Wolfe, a model commander, endowed with the English bulldog tenacity, and at the same time with the soldier's skill and dar-

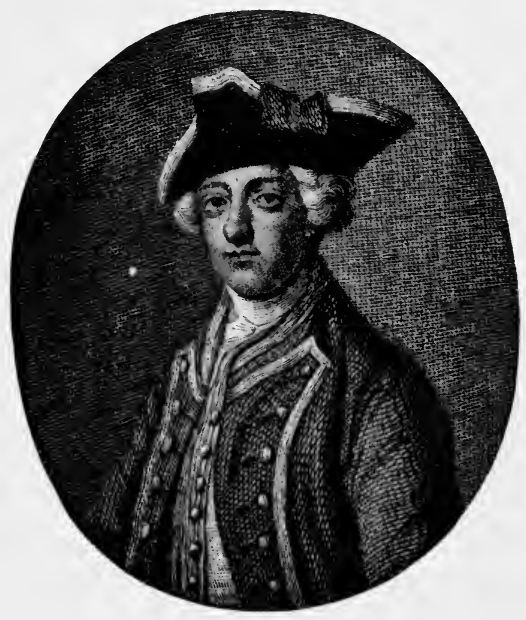

JAMES WOLFE.

From an old print. ing. With 9000 men and a fleet Wolfe besieged the strong fortress of Quebec, defended by 14,000 men ably commanded by the Marquis de Montcalm. Wolfe forced and won a battle on the Plains of Abraham, above the town (September 13, 1759), but was himself mortally wounded. " 'They run, see how they run,' cried a bystander. 'Who runs!' demanded our hero, with great earnestness. ...

The Officer answered, 'The enemy, Sir; Egad, they give way Knox, Historical Journal, 69 everywhere.' The dying general issued his orders quickly; then turning on his side, he said, 'Now, God be praised, I will die in peace.'" In a few days Quebec surrendered, and the next year Montreal fell. In 1762 Manila and Havana were captured from Spain by British fleets.

Hostilities were ended in all parts of the world by the peace of Paris (February 10, 1763). Manila was not held, and Cuba

101. Exclusion of the French from North America (1763) was given up; but the British took Spanish Florida in exchange, besides annexing Canada and Cape Breton, and the whole Mississippi valley east of the river, except the Island of Orleans. France had already transferred to Spain the part of Louisiana lying west of the Mississippi, together with New Orleans. Of all her North American pos- 
sessions, France retained only the two little islands of St. Pierre and Miquelon and some of the West Indies.

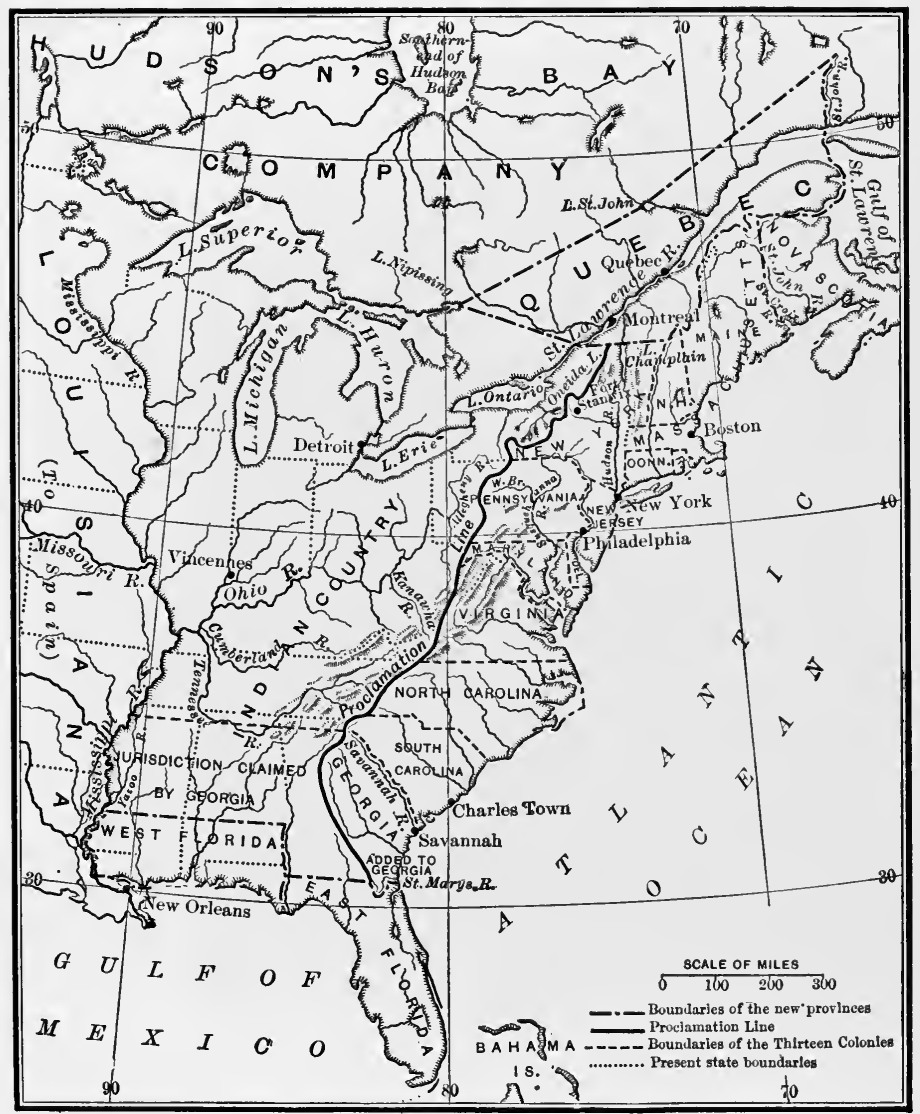

British Colonies in 1765.

The treaty left the British undisputed owners of all the territory between the Gulf of Mexico, the Mississippi River, Hudson Bay, and the Atlantic Ocean. The British government, by royal proclamation, October 7, 1763, erected three new provinces, Quebec, East Florida, and West Florida, and 
extended Georgia to the St. Marys River. Instead of adding new area to any of the other colonies, several of which had once had charters extending west to the Pacific, the proclamation cut off all the old colonies from the Mississippi basin by a clause providing that " no governor, or commander in chief of our other colonies or plantations in America do . . grant, warrant or survey or pass patents for lands beyond the heads or sources of any of the rivers which fall into the Atlantic Ocean from the west or northwest." That country was to be reserved for the occupation of the Indians. At that time the French whites and half-breeds east of the Mississippi were not more than 6000 in all; and south of the Ohio the only Europeans were a few score traders and officials.

The English began at once to mismanage the Indians. As Sir William Johnson said, they served out " harsh treatment, 102. Indian angry words, and in short, everything which can be neighbors thought of to inspire . . . dislike." When they un(1763-1768) dertook to send out garrisons to the little French posts northwest of the Ohio River in 1763, a dangerous Indian war blazed out under the leadership of the great chief Pontiac. Several posts were taken and the garrisons massacred, but the British commander, Colonel Bouquet, soon broke down the Indian rising.

By the treaty of Fort Stanwix with the Six Nations (1768), a dividing boundary line was drawn from Wood Creek, a tributary of Oneida Lake, in central New York, southward and then westward to the west branch of the Susquehanna, thence across to the Allegheny River, and down the Ohio to the mouth of the Tennessee. This was an acknowledgment that the Iroquois, already in effect wards of the colony of New York, controlled territory outside the valley of the Hudson and the New York lakes. New relations were established in the South with the five tribes of Cherokees, Chickasaws, Choctaws, Creeks, and Seminoles, who had about 14,000 "guns," or fighting men. In 
1768 the British got their first treaty of land cession from the Cherokees, and began to establish an influence in the region between Georgia and Louisiana.

From 1689 to 1763 the international history of America is the history of the downfall of the French colonial power. At the beginning France had Nova Scotia, Cape Breton, 103. SumCanada, and claims to Newfoundland and Hudson Bay; and she colonized Louisiana and asserted title to the whole Mississippi valley, though she occupied only a narrow fringe along the Gulf coast and a few settlements on the river.

The year 1713 is the great turning point, because in the treaty of Utrecht the French were obliged to cede Acadia to Great Britain. In 1754 came a trial of strength for the Ohio valley, in which for three years the French held their own. Then in 1758 came the change; one French defense after another gave way, and the capture of Quebec in 1759 broke their hold on Canada. In 1763 they were compelled to give up every square foot of their splendid empire on the mainland, and retained only the two little islands of St. Pierre and Miquelon south of Newfoundland, and their possessions in the West Indies, including part of Haiti. Thenceforward the Anglo-Saxons controlled the destinies of North America.

\section{TOPICS}

(1) Was William III. interested in the colonies?

list of wars in which the Iroquois took part.

(2) Make a

(3) Make a list Suggestive of captures and conquests of French territory in North America by the English, 1603-1750. (4) Why was Port Royal so often attacked? (5) Why did the Tuscaroras join the Five Nations? (6) What claim had the French and the English to Hudson Bay? (7) Why did the Spaniards allow the French to settle on the lower Mississippi ? (8) Make a list of attacks on English seacoast settlers by the French and Spanish, 1607-1750. (9) What claim had the English to the Ohio valley? (10) Was it necessary to deport the Acadians? (11) Why was the peace of 1763 unpopular? 
Search

topics

Geography

Secondary authorities

Sources

Illustrative works

Pictures
(12) What were the general European wars corresponding to the four intercolonial wars - and what were their causes ?

(13) Account of a fleet engagement between the English and the French. (14) Life on a British man-of-war about 1750. (15) Account of an Indian raid on a frontier town. (16) The "casket girls" in Louisiana. (17) Gerinans in Louisiana. (18) English captives taken to Canada. (19) Attack on Carthagena, 1741. (20) Contemporary accounts of Braddock's defeat; of the capture of Quebec. (21) Early New Orleans. (22) Defeat of Pontiac. (23) British war with the French in India, 1756-1763.

\section{REFERENCES}

See maps, pp. 121, 131; Thwaites, France in America; Semple, Geographic Conditions, 36-46.

Hart, Formation of the Union, §§ 12-20 ; Fisher, Colonial Era, 236-240, 286-291; Sloane, French War and Revolution, 22-115; Lodge, English Colonies, 30-36, 109-111, 223-225, 307-310, 367371; 'Thwaites, France in America; Fiske, New France and New England, 233-359; Parkman, Frontenac, 184-452, - Half Century of Conflict, - Montcalm and Wolfe, - Pontiac, I. 69-367, II. ; Wilson, American People, II. 58-61, 68-97 ; Gay, Bryant's History, III. 192-221, 251-328; Winsor, Cartier to Frontenac, 342-366, Mississippi Basin; King, Sieur de Bienville; Griffis, Sir William Johnson; Lodge, George Washington, I. 1-14, 54-118; Johnson, General Washington, 1-66. See also references to ch. iv.

Hart, Source Book, §§ 37-40, - Contemporaries, II. \$§ 22, 109129, - Source Readers, I. $\$ 42$, II. \$\$24-32, 34, 37-44; MacDonald, Select Charters, nos. 51, 52, 54 ; American History Leaftets, no. 14; Old South Leaflets, nos. 9, 73 ; Caldwell, Surveys, 39-43, - Territorial Development, 12-23. See N. Eng. Hist. 'Teachers' Ass'n, Syllabus, 316, - Historical Sources, § 75.

Eggleston, American War Ballads, I. 14-20 ; Longfellow, Evangeline; Whittier, Pentucket; Gilbert Parker, Trail of the Sword (Canada), - Seats of the Mighty (French and Indian War); William Kirby, Golden Dog (Canada); W. J. Gordon, Englishman's Haven (Louisburg); Hawthorne, Grandfather's Chair, pt. ii. chs. vii.-x., - Old News, pt. ii. ; James McHenry, The Wilderness (Ohio country); B. E. Stevenson, Soldier of Virginia (Braddock and Washington); J. E. Cooke, Stories of the Old Dominion, 110-139; C. E. Craddock, Old Fort Loudon; Cooper, Last of the Mohicans, - Pathfinder; Kirk Munroe, At War with Pontiac.

Winsor, America, V.; Wilson, American People, II.; Sparks, Expansion. 


\section{CHAPTER IX.}

\section{QUARREL WITH THE MOTHER COUNTRY (1769-1774)}

The period from 1760 to 1765 is a turning point in the history both of England and of America, for it marks the beginning of a feeling of hostility between these two parts of the British Empire. The first strong and positive sovereign since William III. was the young George III., who

104. New forces in the British Empire came to the throne in 1760 , and said, in a public address; "Born and bred in this country, I glory in the name of Briton." His mother used to say to him, "George, be a king"; and as soon as he could, he rid himself of the ministry of noble Whig families who controlled both houses of Parliament, and he began systematically to build up a personal government.

Opposed to the king's policy was a group of brilliant statesmen, of whom the most famous were William Pitt (later Earl of Chatham), Charles James Fox, and Edmund Burke; they

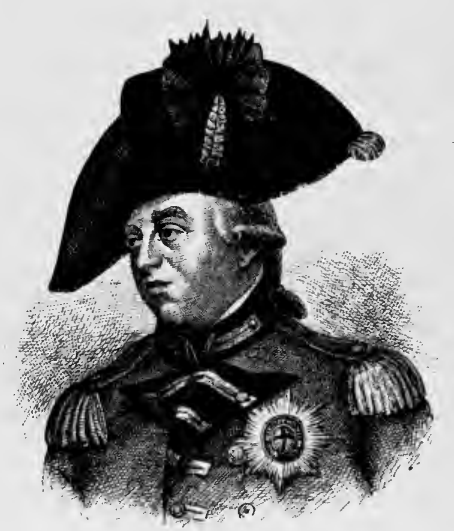

George III., ABOUT 1765.

From a painting by Sir William Beechy.

counseled wise and moderate dealing with the colonies. Notwithstanding this opposition, for a long time the king by shrewd means, by bestowing titles here, appointments there, reproofs to a third man, and banknotes where other things 
failed, was able to keep up in the House of Commons a majority, usually called "the king's friends."

On the western side of the Atlantic a new spirit began to stir among the colonists when the danger of invasion by French neighbors ceased forever in 1763. As the French statesman Turgot said (1750), "Colonies are like fruits, they stick to the tree only while they are green; as soon as they can take care of themselves they do what Carthage did and what America will do." These latent tendencies to independence were strengthened by the attempt of the home government to assert new powers of government over the colonies. The colonial officials in England resented the slowness and lack of united action shown by the colonial assemblies during the French and Indian War, and felt that it would be better for them all to pay money into one treasury, for general colonial purposes.

Up to this time the principal British control over the colonies as a whole had been exercised through the navigation acts. 105. Regu- Notwithstanding the special privileges thereby given to lation of colonial trade colonial ships, the acts caused friction, because they cut off colonial trade and profits in order to swell the trade and profits of English merchants. The home government was aware that smuggling went on, and tried to stop it; but even the little duties laid by the home government in colonial ports, to give some control over the movements of ships, were so evaded that it cost $£ 7000$ a year to collect $£ 2000$. To prevent the rise of new manufactures the British (1750) prohibited the colonists from using rolling mills and steel furnaces; and in 1774 stopped the coming in of machinery for making cloth.

In order to detect smugglers, British customs officers in the colonies were accustomed to go to the courts and ask for 106. Claim a general writ of assistance, which authorized them to of "Inalienable Rights" goods; without such searches the navigation acts could hardly be carried out. In a test case before the Massachusetts 
courts in 1761, a brilliant and able young lawyer, James Otis, argued against the writs on the novel ground that they were contrary to the principles of English law: "Reason and the constitution are both against this writ. ... All precedents are under the control of the principles of law. . . No Acts of Parliament can establish such a writ. . . A An John Acts of Parliament can establish stich a wit. ... An act against the constitution is void." John Adams said Works, II. of him, "Otis was Isaiah and Ezekiel united - Otis was a flame of fire-Otis's oration against writs of assistance breathed into this nation the breath of life."

Notwithstanding Otis's argument, the writs of assistance were again issued in Massachusetts; but his speech and his later pamphlets stated three principles of great weight in the approaching Revolution: (1) that the colonists possessed certain inalienable personal rights; (2) that there was a traditional system of colonial government, which could not be altered by Great Britain without the consent of the colonies; (3) that under that system the colonies were united to Great Britain through the same sovereign, but were not a dependent part of Great Britain, nor subject to Parliament.

In accordance with the practice of a century and a half, the home government about this time disallowed a statute of Virginia which reduced the stipends of the established clergy. A test case was made (1763), commonly called "the Parson's Cause," in which Patrick Henry got his first reputation and won the jury by an argument that there was a limit to the legal control of the mother country over colonial legislation. In a bold and significant phrase he declared that Contempora" a King, by . . . disallowing acts of so salutary a na- ries, II. 106 ture, from being the Father of his people degenerates into a 'Tyrant, and forfeits all right to his subjects' obedience."

Another danger to the freedom of the colonies came from a new spirit in the Lords of Trade. When Charles Townshend was chairman for a short time (February to April, 1763), 
he worked out a comprehensive plan for controlling the colonies. (1) Armed vessels were to be sent to the American 107. Procoast, and the naval officers were to be commissioned as posed con- revenue officers. (2) A new system of admiralty courts trol of colo- was to be set up, to deal more effectively with breaches ments (1763) of the Acts of Trade. (3) A force of troops was to be - stationed in America for common defense at the expense of the colonies. (4) Steps were to be taken to appoint and pay the colonial judges from England, so as to free them from control of the colonial assemblies. (5) For the necessary expenses a stamp duty was to be laid on the colonies. None of the proposed measures were carried out at the time.

Another danger was brought on by the activity of Lord George Grenville, when 108. Taxation and the Stamp Act he became prime minister in April, 1763. The Molasses Act of 1733, essentially a measure to protect (1763-1765) the sugar planters of the British West Indies, was by the Sugar Act of 1764 made more stringent and extended to coffee and other tropical products. In this act Grenville inserted the statement that it was "just and necessary" that a

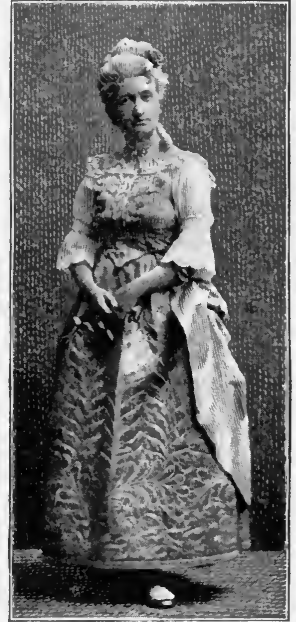

Great-grandmother's DRESS.

Abigail Bishop's dress of 1780 , worn by a descendant. tax be laid in the colonies. In 1765 he informed the agents of the colonies that he meant to lay a stamp duty unless they would suggest some other form of taxation. Without much objection, an act of Parliament was passed (March, 1765) for "certain stamp duties, and other duties, in the British colonies and plantations in America, toward further defraying the expenses of defending, protecting, and securing the same." The duties were to be imposed on all sorts of legal documents, law 
proceedings, wills, licenses and commissions, land patents, bills of sale; and also on playing cards, newspapers, pamphlets, advertisements, almanacs, and the like. The proceeds of the tax (estimated at $£ 100,000$ a year) were to go toward the expense of troops which were to be sent to America for the defense of the colonies. A few days later another cause of quarrel was provided in the Quartering Act, by which military officers were authorized to call on colonial authorities to provide barracks for troops.

Against the Stamp Act the best writers in America poured forth a flood of argument and protest.

(1) On taxation, they argued that the power of laying taxes for revenue in the colonies belonged solely to the colonial governments. As for Parliament, one writer said: If they "have a right to impose a stamp tax, they have a right to lay on us a poll tax, a land tax, a malt tax, a cider tax, a window tax, a smoke tax; and why not tax us for the light of the sun, the air we breathe, and the ground we are buried in?"

(2) On representation, they argued that the principle practiced by Parlia-

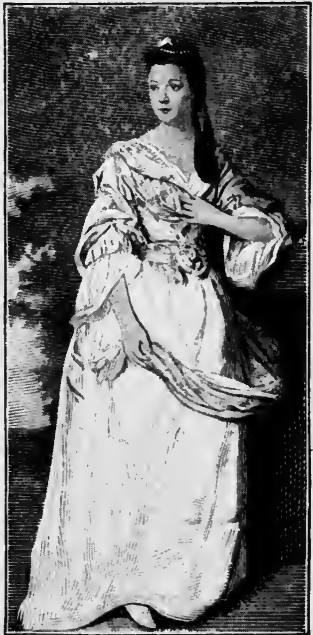

A Colonial Lady, ABOUT 1780.

Portrait of Susanna Randolph, by Copley. ment itself was "no taxation without representation," and how could they be represented in a Parliament thousands of miles away? And they scouted the British explanation that they were fairly represented by the English members of a Parliament; for their principle was that members of a legislature represented not classes or landed interests, but a body of peo ple living in some definite area.

(3) On the nature of colonial government, they maintained 
that the colonists had a traditional right not to be subject in such matters to the control of Parliament. For instance, the

John Hancock, his book, 90 Boston merchant John Hancock said, "I will never carry on Business under such great disadvantages and Burthen. I will not be a slave, I have a right to the libertys \& Privileges of the English Constitution, and I as an Englishman will enjoy them."

Opposition to the tax took several serious forms.

(1) Some of the colonial assemblies passed strong resolutions 109. 0p- against taxation; the best known are Patrick Henry's position to the Stamp Act (1765) Virginia Resolutions, which culminate in the declaration "That every attempt to vest such power in any other Frothingham, Rise of the Republic, so person or persons whatever than the General Assembly aforesaid, is illegal, unconstitutional, and unjust, and has a manifest tendency to destroy British as well as American liberty."

(2) More quiet but effective means were the organization of "Sons of Liberty," a kind of patriotic society; and an attempt to boycott British goods.

(3) In many places mobs made discussion impossible; stamp distributors were threatened and compelled to resign, or were burned in effigy before their own doors, and their property destroyed. Thomas Hutchinson, lieutenant governor and chief justice of Massachusetts, opposed the Stamp Act while it was pending; nevertheless his house was sacked and plundered, and his life and the lives of his family endangered because he proposed to execute the law. In thus forsaking an orderly government, and resorting to violence, the people who engaged in these outbreaks damaged their own cause and set a bad example for the years that followed.

(4) The most effective method was the holding of a Stamp Act Congress of delegates from nine colonies, in New York, October 7, 1765. This dignified body petitioned the British government to withdraw the act, and drew up a formal state- 
ment of "the most essential rights and liberties of the colonists, and of the grievances under which they labor." This document set forth loyalty to the crown, but stood firm on "No taxation without representation." When November 1 came, the date for putting the act in force, it was entirely ignored, and documents were simply left without stamps.

The opposition to the Stamp Act caused much perplexity in England. William Pitt warmly defended the colonists: "We may bind their trade, confine their manufactures, and exercise every power whatsoever," said he, "except that of taking their money out of their pockets without their consent." Parliament repealed the Stamp Act (March 18, 1766) before any serious attempt had been made to execute it; but eleven days earlier passed a brief act setting forth that the colonies were "subordinate unto, and dependent upon the Imperial Crown and Parliament of Great Britain [which had] full power and authority .... to bind the Colonies and People of America, subject of the Crown of Great Britain, in all Cases whatsoever."

By thus reaffirming the right to tax the colonies, the way was opened for a renewal of the trouble. Townshend again came into power, and in 1767 secured new duties on paper, painter's' colors, glass, and tea, the expected proceeds of $£ 35,000$ or $£ 40,000$ a year to be used to 110. Townshend Acts, and troops in Boston pay fixed salaries to royal colonial officers. When the (1767-1771) New York assembly refused to pass the necessary act to provide barracks and other necessities for the British troops, Townshend took the dangerous step of practically suspending the government of New York by an act of Parliament. This distinct assertion that the colonial assemblies were subject to Parliament greatly alarmed the other colonies.

Again strong protests were heard. John Dickinson of Pennsylvania, in his Letters from a Farmer, called upon his countrymen by practical and law-abiding methods to "take care of our rights, and we therein take care of our prosperity 
... slavery is ever preceded by sleep." Non-importation agreements were made in many parts of the colonies and signed by men like George Washington. The General Court, or legislature, of Massachusetts sent a circular letter to the other colonies, urging them to join in remonstrance. In June, 1768, British customhouse officials were assaulted while searching the sloop Liberty, belonging to John Hancock; and he was sued for smuggling. Soon after, two regiments of redcoats were ordered to Boston "to strengthen the hands of the government in the Province of Massachusetts Bay." As a witty Boston clergyman said, "Our grievances are now all red-dressed."

The coming of troops, intended to overawe and not to defend, incensed all the colonies. In March, 1770, there was a fight between the troops and the populace in Boston in which five persons were killed. Although the name "Boston Massacre" was applied to the unfortunate affair, John Adams was so far from sympathy with the populace that he defended the commander of the troops, who was acquitted. Two of the soldiers who had fired without orders, under great provocation, were convicted of manslaughter, and eventually were lightly punished.

The offensive Townshend duties were withdrawn in 1771, after producing $£ 16,000$. at a cost of about $£ 200,000$; but again the British government stupidly insisted on the principle of taxation by retaining a tea duty of threepence a pound.

Just about this time another grievance much disturbed the peace of mind of many good colonists. So completely sepa111. Ques- rated are church and state in America to-day that it is tion of a hard to realize how much our forefathers feared that colonial

they might be brought under the control of the Church of England by the designation of an American bishop, or bishops. The idea was not welcome to the Episcopalians of the southern and middle colonies, and was still more unpopular in New England, where the Congregational Church 
was established. When the Episcopal missionary to the college town of Cambridge built himself a large and handsome house,

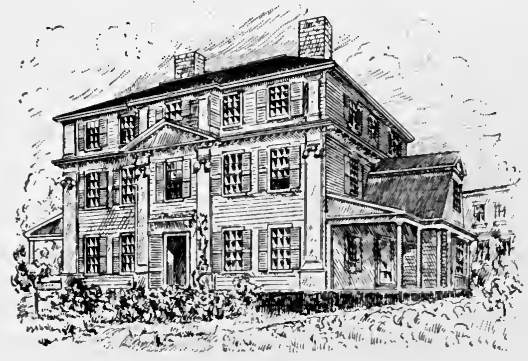

“The Bishop's Palace," Cambridge, BUILT IN 1761.

Type of the handsome colonial house. it came to be popularly known as "the Bishop's Palace." If the colonists had realized it, there was no cause for alarm; for the British government was unwilling to furnish a new cause of grievance.

While North and South were slowly combining to oppose Great Britain, a new West was opening up, on the headwaters of the southern tributaries of the Ohio (map, p. 181). After the French and

112. The

TransAlleghany movement (1768-1774) Indian War, both Pennsylvania and Virginia claimed the forks of the Ohio, where in 1765 the town of Pittsburg was founded. People poured across the mountains, and part of them drifted southward into the mountain regions of Virginia and North Carolina. Then frontiersmen, chiefly Scotch-Irish and German with a few Huguenots, ignored the proclamation of 1763 (pp. 131, 132), defied their own colonial governments, braved the Indians, and plunged into the western wilderness.

The pioneer in this movement was Daniel Boone of the Yadkin district in North Carolina, who in 1769, with five companions, started out "in quest of the country of Kentucke." For years he was the leading spirit in a little community of men who were frontiersmen, farmers, trappers, and Indian fighters all at the same time - the first settlers in Kentucky.

A second and more continuous settlement was begun in 1769 by William Beane, on the Watauga River, a head stream of the Tennessee. Soon after, the so-called "Regulators" of North Carolina protested in arms against the tedious and expensive HART'S AMER. HIST. - $\boldsymbol{\theta}$ 
methods of the courts, and in 1771 were defeated by Governor Tryon in the battle of the Alamance. Some of those who escaped crossed over to the Watauga, which they supposed to be a part of Virginia, though it proved to be within the North Carolina claims. Under the leadership of John Sevier and James Robertson, they formed a little representative constitution under the name of "Articles of the Watauga Association."

By this time the value of the West was apparent to some capitalists, who formed the Vandalia Company, a kind of successor to the old Ohio Company, and asked for a royal charter for a colony south of the Ohio. In 1774, however, Parlia. ment showed the purpose of the British government to prevent the growth of any new western commonwealth, by the Quebec Act, which added the region between the Ohio and the Great Lakes to the province of Quebec.

The conflicts between Boone's men and the Indians living north of the Ohio, for the unoccupied "Dark and Bloody Ground" of Kentucky, led in 1774 to "Lord Dunmore's War," which was aggravated by a brutal and unprovoked murder of the family of Logan, a well-known Indian chief. Dunmore, the governor of Virginia, pushed across the Ohio, a second army beat the Indians at Point Pleasant on the Kanawha, and the savages were forced to cede their claims south of the Ohio. Meanwhile the few settlers in Kentucky fled eastward.

The infant West seemed to Massachusetts people the smallest of interests; for their own struggle was all absorbing, 113. Crisis and it became almost a personal contest between Samuel in New Eng- Adams, leader of the popular party, and Thomas Hutch(1772-1773) inson, the governor. Hutchinson's letters to friends in England, urging that " there must be an abridgment of what are called English liberties," fell into the hands of Adams, who used them to persuade the people that Hutchinson was their enemy.

In June, 1772, the Gaspee, a British vessel engaged in catching smugglers, was burned in Rhode Island by a mob, against 
whom nobody would testify. Things grew so squally that Samuel Adams, in 1772, obtained from the Boston town meeting a Committee of Correspondence "to state the Rights of the colonists and of this Province in particular ... to communicate and publish the same to the several Towns in this Province and to the World." A continental committee was subsequently appointed, and eleven other colonies appointed similar committees, which kept themselves informed of public feeling and thus prepared for later joint action.

The tea duty left in force by Townshend in 1771 was not much felt, because the colonists usually drank smuggled tea; but to help the British East India Company out of financial diffculties, the home government gave it such privileges that it was able to undersell the smugglers, and in August, 1773, tea ships were dispatched to the principal colonial ports. If the tea were landed and the duty paid, the right of taxation was admitted. Hence, upon the arrival of the tea ships in Philadelphia, New York, and some other places, they were sent back without unloading. Efforts to this end in Boston were foiled; but a meeting of five or six thousand people was held in the Old South Church in Boston (December 16,1773) to make a final protest against the landing of the tea. Suddenly a war whoop was heard outside, and two hundred men boarded the ships and flung into the sea tea worth $£ 18,000$ (about $\$ 90,000$ ). An eyewitness says: "They say the actors were Indians from Narragansett. Whether they were or not, to a transient Society Proobserver they appear'd as such, being cloath'd in Blankets ceedings, with the heads muffled, and copper-color'd countenances." p. 326 Children who next morning found their fathers' shoes full of tea kept their own counsel.

To the Tory government in England, the Boston Tea Party appeared an act of outrageous violence, encouraged by the town of Boston and the people of Massachusetts, and deserving such punishment as would give warning to

114. The force acts

(1774) 
other colonies. In spite of Edmund Burke's protests against a policy "which punishes the innocent with the guilty, and condemns without the possibility of defense," a series of coercive statutes, sometimes called "the Intolerable Acts," were hastily passed by Parliament (1774): (1) The port of Boston was closed until the town should make proper satisfaction for the destruction of the tea. (2) The charter of Massachusetts was " revoked and made void," in so far that the governor received

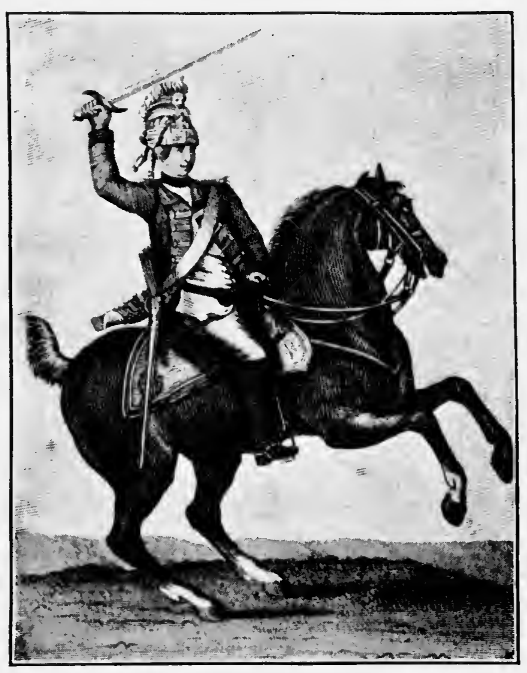

English light Dragoon, about 1778.

Type of the British cavalryman. new authority over the council and the town meetings. (3) The authority to take the necessary buildings for barracks was renewed. (4) Persons charged with murder or other capital offenses, committed in the execution of orders from England, might be transported to England for trial.

To put these measures into force, General Thomas Gage was sent over to Massachusetts; he superseded Governor Hutchinson, and attempted to establish the new government by "mandamus councillors," whom he appointed contrary to the provisions of the charter. The Salem merchants offered their wharves to their Boston brethren, and from south to north came expressions of sympathy with Massachusetts. Resistance to taxes laid by Parliament had carried the country to the verge of revolution. 
During the eleven years from 1763 to 1774 , the colonies lost their old contentment in their relation to Great Britain, and. came almost to the point of revolt. The main reasons were: (1) taxation by Parliament for revenue through the Stamp Act of 1765, the Townshend duties of 1767 , and the tea duties of $1771-1773$; (2) the execution of the navigation acts, by means of writs of assistance, or by customhouse officers as in the sloop Liberty (1768), or by naval officers as in the Gaspee (1772); (3) attempts to alter the form of colonial governments, as shown by the suspension of the New York legislature (1767), and especially by the repeal of the Massachusetts charter in 1774, - apprehension was heightened by the Parson's Cause (1763), and the supposed purpose to send over a colonial bishop; (4) a fear that those personal rights were endangered which were claimed by Englishmen in England as well as in America; (5) experience of the power of union, as shown in the Stamp Act Congress of 1765, the nonimportation agreements of 1765,1768 , and 1769 , the resolutions of sympathy or defiance in the colonial legislatures, and the committees of correspondence of 1773 ; (6) irritation at the way in which British rulers, colonial governors, and regular officers looked down on the colonists; (7) the narrowness and stupidity of George III. and other English leaders, who did not understand the colonists, and pushed the contest to a fatal issue.

\section{TOPICS}

(1) How did George III. come to be king of Great Britain? (2) What were the services of James Otis to American liberty? (3) Why ought not the colonial judges to be paid by the home government? (4) Make a list of acts of Parliament laying taxes on the colonies, 1660 to 1765 . (5) Why was the Stamp Act repealed? (6) Why should the colonists object to the Quartering Act? (7) What personal rights did the colonists have in 1765 ? (8) Why did the colonists object to control of their government by Parliament? (9) Was Governor Hutchinson hostile to the liberties of Massachusetts? (10) Was the Boston Tea Party justifiable? 
Search topics

Geography

Secondary authorities

Sources

Illustrative works

Pictures
(11) Early life of George III. (12) Predictions of American independence before 1775. (13) Account of the Parson's Cause. (14) Contemporary objections to the Stamp Act. (15) Stamp Act mobs. (16) Affair of the sloop Liberty. (17) Destruction of the Gaspee. (18) Principles of the Watanga Association. (19) Western frontier life, 1769-1774. (20) Governor Gage's "mandamus councillors." (21) North Carolina "Regulators." (22) Franklin's opinion of the Stamp Act.

\section{REFERENCES}

See maps, pp. 131, 181 ; Semple, Geographic Conditions, 46-74; Epoch Maps, no. 5.

Hart, Formation of the Union, §§ 22-30; Sloane, French War and Revolution, 116-173; Lodge, English Colonies, 476-490; Howard, Preliminaries of the Revolution; Fiske, American Revolution, T. 1-99; Wilson, American People, II. 98-192 ; Gay, Bryant's History, III. 329-376 ; Frothingham, Rise of the Republic, 158-358; Lodge, American Revolution; Trevelyan, American Revolution, pt. i. 28-193 ; McCrady, South Carolina, II. 541-732 ; Winsor, Westward Movement, 4-81, 100-106 ; Roosevelt, Winning of the West, I. 28-271 ; Tyler, Revolution (literary), I. 1-266, Patrick Henry, 1-100; Sparks, Men who made the Nation, 1-72; Thwaites, Daniel Boone, 1-112 ; Morse, Benjamin Franklin, 100203 ; Ford, Many-sided Franklin; Hosmer, Samuel Adams, 1-259, - Thomas Hutchinson.

Hart, Source Book, § 53,-Contemporaries, II. §§ 37, 130-152, - Source Readers, II. \$\$ 33, 45-51; MacDonald, Select Charters, nos. 53, 55-71 ; Hill, Liberty Documents, ch. xii. ; American History Leaflets, nos. 21, 33; Old South Leaflets, nos. 41, 68; Caldwell, Survey, 43-68; Johnston, American Orations, I. 11-23; Fithian, Journal. See N. Eng. Hist. Teachers' Ass'n, Syllabus, 318-325, - Historical Sources, § 76.

Moore, Songs and Ballads of the American Revolution, 1-64; Raymond, Ballads of the Revolution, 3-55 ; L. M.Child, The Rebels (Boston); C. C. Coffin, Daughters of the Revolution; Hawthorne, Edward Randolph's Portrait, - Grandfather's Chair, pt. iii. chs. i.-vi.; D. 1. Thompson, Green Mountain Boys ; A. E. Barr, Bow of Orange Ribbon (N.Y.); Thackeray, Virginians ; Edmund Lawrence, George Stalden; J. E. Cooke, Virginian Comedians, Fairfax, - Stories of the Old Dominion, 140-204.

Winsor, America, VI., - Memorial History of Boston, III. ; Wilson, American People, II. 


\section{CHAPTER X.}

\section{BIRTH OF A NEW NATION (1774-1776)}

THE last act of the Massachusetts House of Representatives under the old charter was to propose (June 17,1774) a colonial congress, already informally suggested in Virginia; and delegates were appointed from all the colonies, except 116. The First Continental ConGeorgia. This First Continental Congress met, Septem- gress (1774) ber 5, 1774, in Carpenter's Hall, Philadelphia, and was the most distinguished body that had ever gathered in America. Among its members were John and Samuel Adams of Massachusetts, John Jay of New York, John Dickinson of Pennsylvania, Edmund Randolph and Patrick Henry of Virginia, Charles Carroll of Maryland, and John Rutledge of South Carolina. The important action was of three kinds :-

(1) Congress protested in dignified and loyal phrases against the treatment of Massachusetts and of the colonies in general; they respectfully petitioned the king to remove their grievances, and they sent out a series of addresses explaining the situation. Except a few radicals, of whom Samuel Adams was the chief, Congress hoped and expected that Great Britain would yield to this strong and united protest.

(2) Congress drew up a Declaration of Rights which laid claim to the liberties and immunities of Englishmen, including a "Right of Representation ... in all Cases of Taxation and internal Polity, subject only to the Negative of their Sovereign"; and they enumerated various acts of Journals of Congress, Parliament which they declared were "infringements and violations of the rights of the colonists." 
(3) On October 20, 1774, Congress drew up the "Association," which was an agreement for a boycott on an immense scale: no British goods (including slaves) were to be imported or sold; and after September, 1775, no American goods were to be exported to Great Britain, Ireland, or the British West Indies. It was signed by fifty-two members and was recommended to all the colonies, most of which put it into force. Since no action by the colonies could take away the legal right of the people to buy, import, and sell British goods, the Association could be enforced only by violence. From north to south there was an era of terrorism; mob methods were called in; and he was a fortunate ship captain who, having arrived in port with a shipload of merchandise, was allowed even to sail away again with his goods on board.

Meanwhile the House of Representatives of Massachusetts broke off relations with Governor Gage, organized itself as a

117. War breaks out in Massachusetts (1775)

"Provincial Congress" (October 7, 1774), and created a Committee of Safety under the chairmanship of John Hancock, which began to collect military supplies and organize "minutemen," ready to march at a minute's notice. To break up the preparations of the colonists, during

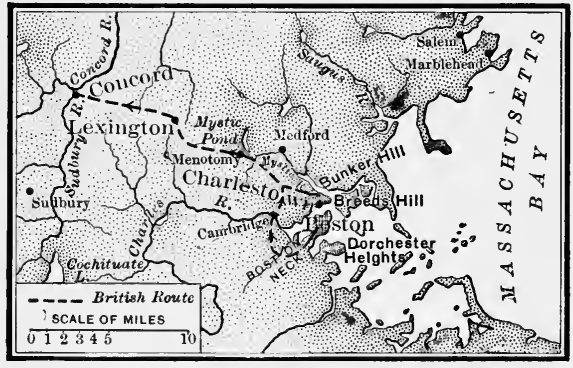

Vicinity of Boston. the winter Gage sent out and seized powder and arms at various places near Boston.

In the night of April 18, 1775, Paul Revere and other swift riders galloped off to give notice that British troops were on the march; the object was to capture John Hancock and Samuel Adams, who were staying at Lexington, and to destroy military stores at Concord. At five o'clock of the morning of 
April 19, 1775, the British van of six companies appeared on the green at Lexington and found a line of provincial militia drawn up. To this day it is uncertain just how the fight began; an English officer who was present at the battle says, "On our approach they dispersed and soon after firing began; but which party fired first I cannot exactly say, as our troops rushed on shouting and huzzaing previous to the firing."

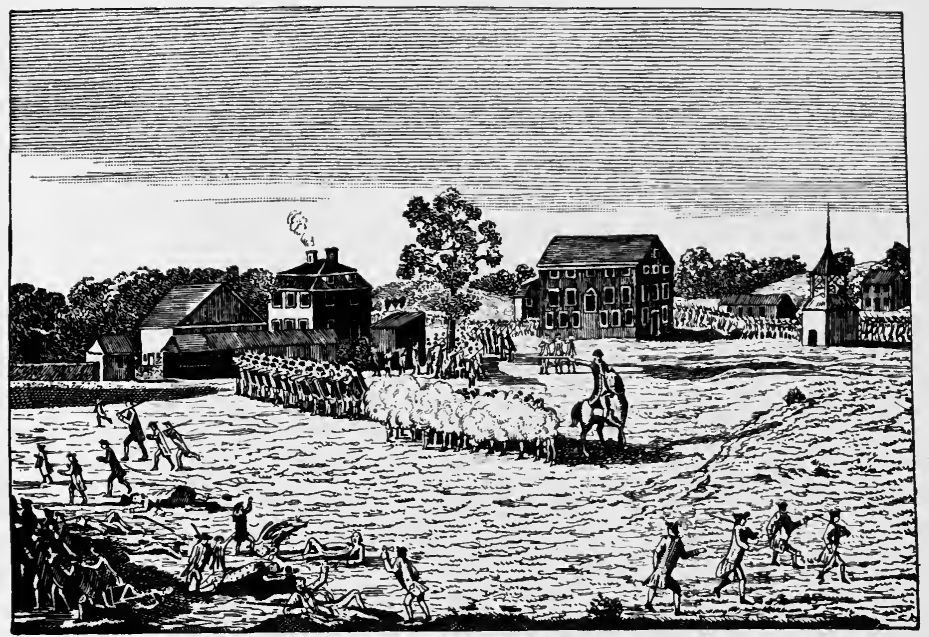

Battle of Lexington, April 19, 1775.

From Earl's drawing, made a few days later.

When the smoke cleared away, seven patriots were found killed and nine wounded. The responsibility for this outbreak of open war goes back to the king of Great Britain, who had forced matters to this issue; and is shared by men like Samuel Adams and Washington who were ready to resist the anthority of the mother country rather than yield what they felt to be their rights.

From Lexington the British marched seven miles to Concord, where a body of militia boldly marched down to oppose 
them, and beat them back at a little bridge where now stands the statue of the minuteman.

Emerson

"Here once the embattled farmers stood And fired the shot heard round the world."

As the weary British troops returned toward Boston they were followed and harassed by the militia, who ambushed them from behind the roadside walls and fences. With a total loss of 273 British to 93 Americans, the British at last reached the shelter of the guns from their ships.

The Continental Congress of 1774 called a Second Conti-

118. Onion in the Second Continental Congress (1775) nental Congress to meet in Philadelphia, May 10, 1775. It came together in what is now Independence Hall, burning with indignation over the Lexington and Concord fight; and speedily found itself the center of organization and resistance for the thirteen colonies.

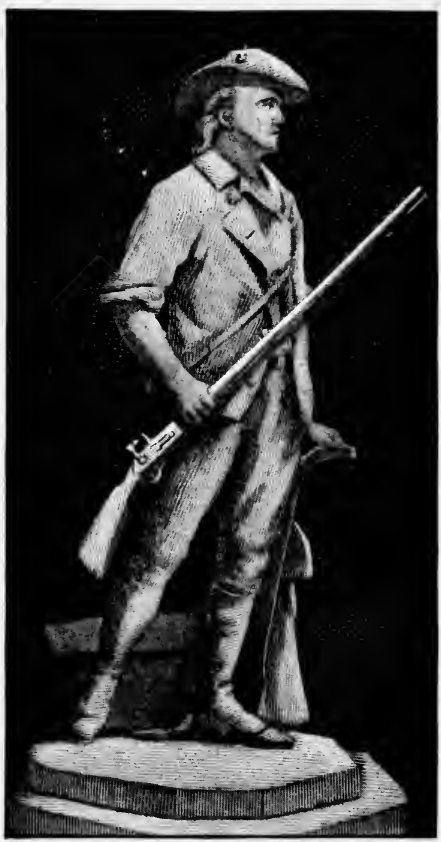

The Minuteman.

Statue by Daniel French, on site of the battle of Concord.

Without any formal authority from the colonial governments, but supported by their good will and assent, Congress made itself a national government. For example, from May to July, 1775, it forbade certain exportations, ordered a state of defense, organized a post office, voted an American continental army, appointed George Washington commander in chief, authorized bills of credit, sent a last petition to the king, and considered Franklin's scheme for a federal constitution. 
Congress also went into the minutiæ of government. For instance, on a single day it received a petition from a loyalist parson in jail; resolved to open trade with the non-British West Indies; considered a report on a French artillery Journals of officer; advanced $\$ 400$ to a Canadian prisoner; appointed Congress, a committee to investigate charges against a military off- ${ }^{-}$an. $17,17 \% 6$ cer; and fixed the pay of a regimental surgeon at $\$ 25$ a month.

Immediately after the battle of Lexington, virtual war began throughout the thirteen colonies, for the people of the middle and southern colonies showed their sympathy with Massachusetts by driving out their governors and setting up provincial congresses and conventions which

119. The issue of force $(1775)$ assumed the government. The four other continental colonies, Quebec, Nova Scotia, East Florida, and West Florida, had few English-speaking people and did not join in the revolution, though repeatedly invited to do so.

The British government met the issue of war before it came, when Parliament (February 2, 1775) declared that rebellion existed. The farthest point of conciliation offered by Parliament was Lord North's resolution, to the effect that no taxes should be laid on the colonies if they would provide a revenue of their own for the common defense. The American formal declaration of war was a vote of Congress setting forth the necessity of their taking up arms. "Our cause is just," said they. "Our Union is perfect. Our July 6, 17\%5 internal resources are great, and, if necessary, foreign Assistance is undoubtedly attainable."

After the battle of Lexington and Concord, the New England militia streamed into Cambridge, and Gage was formally besieged in Boston. Ethan Allen of Vermont, without 120. Can. waiting for anybody's authority, surprised and captured ada and the great fortress of Ticondercga (May 10, 1775), with (1775-1776) an invaluable store of powder and other munitions; and that winter forty great guns from the fort were dragged across New 
England to give indispensable aid in the siege of Boston. The road was now open directly into Canada, where the French were supposed to be ready to throw off allegiance to Great Britain. In the fall of 1775 an expedition under Montgomery took Montreal; and another under Benedict Arnold was joined by Montgomery but just failed of taking Quebec. The Canadians held off, for they did not understand this form of friendship, and had no mind to exchange distant British rulers for neighboring American masters, especially since the Quebec Act of $\mathbf{1 7 7 4}$ gave them religious freedom and an acceptable government.

The siege of Boston was enlivened June 17, 1775, by the battle of Bunker Hill. The Americans, under Israel Putnam and William Prescott, made the bold attempt to fortify the high ground back of Charlestown, commanding Boston. They fortified Breeds Hill, were ill supplied with ammunition, lost their popular general Joseph Warren, and were finally driven out of their intrenchments by the third desperate assault of the British. It was one of the dearest of victories, for the British lost over 1000 troops out of 3000 engaged, and gained no new ground.

Congress had already taken charge of the siege and appointed a new commander in chief, George Washington, who, July 3, 1775, drew up the troops on Cambridge Common, read to them his commission, and took formal command. He proceeded to reorganize the force, and, to use his own phrase, "gave a pretty good slam" to some of the militia generals. Gradually troops arrived from the middle and southern colonies. Washington seized the commanding position of Dorchester Heights, and on March 17, 1776, compelled the British army, still numbering 10,000 soldiers and sailors, to go on board the fleet; together with their loyalist friends; and presently they sailed away to Halifax.

Up to 1776 the theory of the Americans was that they were 
fighting simply to compel the British to return to the legal principles of colonial government; they still hoped for an honorable settlement of the trouble. As the war went on, they lost their habitual loyalty to the sovereign and be-

121. Ex. ponents of independence gan to accuse George III. of all kinds of gross tyranny, and to think of independence.

One of the great champions of independence was Patrick Henry of Virginia, a passionate, impulsive, fiery man, with a reputation for surpassing oratory. It is a well-founded tradition that in the Virginia Assembly in $\mathbf{1 7 7 4}$ he exclaimed, "Cæsar had his Brutus; Charles I. his Cromwell; and George III._" "Treason," shouted the Speaker. "Treason, treason," rose from all sides of the room, - " and George III. may profit by their example. If this be treason, make the most of it." As a member of the First Continental Congress, Patrick Henry foresaw independence. "Government is dissolved," said he. "Fleets and armies and the present state of things show that government is dissolved. . . . I am not a Virginian, but an American;" and in the Virginia convention of 1775 he made a magnificent speech ending with the oft-quoted passage, "I know not what course others may take; but as for me, give me liberty, or give me death."

In the North the greatest exponent of independence was the astute political leader Samuel Adams of Massachusetts, the first man to discover how much may be done in a democracy by organizing the voters and by preparing work for town meetings and assemblies througn caucuses and private meetings. He induced Boston to take strong ground in the quarrel with England; in 1768 he conceived the idea of the Massachusetts circular letter ( $\$ 110$ ), the beginning of common action among the colonies. He afterward said that at this time he had made up his mind that independence was the only remedy. In the Massachusetts legislature he invented the Committee of Correspondence in 1772 ( $\$ 113$ ), and was himself the most 
active member. Governor Hutchinson called him "Master of the Puppets." He pulled the wires which led to the Boston Tea Party; and in Congress he labored unceasingly for independence. Though he could destroy, he did not know how to build up a state, and after 1776 he lived for the most part in private, except for a brief period as governor of Massachusetts.

The first public suggestions that the Brit122. Pre- ish rule had ceased liminaries were made in of independence votes of local con(1775-1776) ventions, among them one in Mecklen-

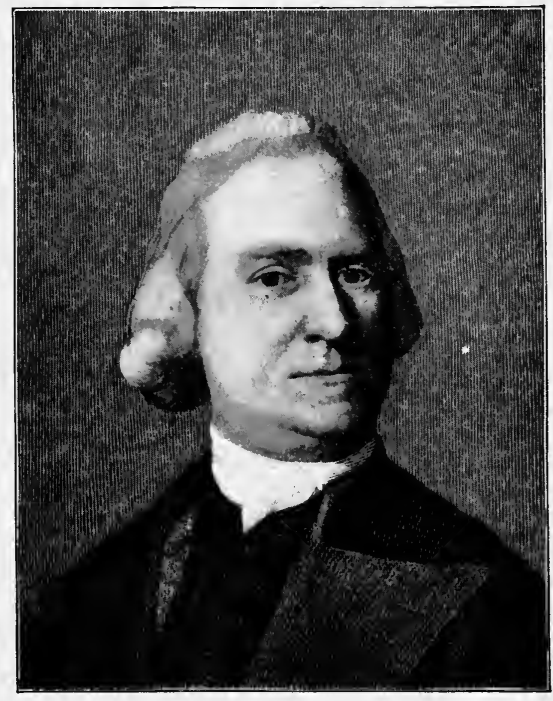

Samuel Adams, about 1780.

From the portrait by Copley. burg County, North Carolina (May, 1775). Congress waited to see the result of their appeal to the king. When news came (November 1,1775 ) that the king would not even receive it, the hope of any settlement inside the British Empire died away. In January, 1776, appeared the first widely read and effective argument on this subject - Thomas Paine's ringing pamphlet, Common Sense, an arsenal of arguments against England and against reconciliation. "The birth day of a new world is at hand," exclaimed Paine; "and a race of men . . . are to receive their portion of freedom." Congress began to take bold ground. In March, it ordered American ports thrown open to all foreign nations, issued letters of marque to privateers, and advised all the colonies to disarm the Tories. 
Rapidly the idea of a formal public declaration of independence by Congress took root; and from March to May, 1776, four provincial congresses instructed their delegates to vote for the suppression of all forms of royal authority. May 15, on motion of John Adams, Congress voted that all British authority in the colonies ought to be legally suppressed. June 7, Richard Henry Lee, under instructions from his colony of Virginia, introduced a resolution for independence, and also looking to a formal union; and two committees were appointed (June 10-12), one to draft a declaration of independence, the other to prepare articles of confederation. The question of independence was postponed, to enable delegates to receive instructions from home, for, as Franklin dryly remarked, "We must all hang together or we shall all hang Bigelow, separately."

II. 360

The first committee appointed as a consequence of Lee's resolution comprised Thomas Jefferson, a young delegate from Virginia, John Adams, Benjamin Franklin, Roger Sher- 123. Declaman, and Robert R. Livingston. To Jefferson was given the delicate task of drawing up a public statement of the ration of Independence reasons for war and separation. Fortunately he had a ready pen, and his mind was full of principles of free government, which were not peculiar to the colonies, but were the common property of the English race, and had been in part put in form by the English philosophers Locke and Hobbes. He threw his Declaration of Independence into three parts :-

(1) An announcement of political principles applying to all mankind, stated in the form of certain "self-evident truths," such as "that all men are created equal; that they are endowed by their Creator with certain unalienable rights; that among these are Life, Liberty, and the pursuit of Happiness. That to secure these rights, Governments are instituted among Men, deriving their just powers from the consent of the governed."

(1776) 
(2) A list of twenty-seven grievances, partly directed to illegal acts, but most of them charging the British government with unjustly exercising powers till then accepted as legal.

(3) The ringing statement that "These United Colonies are, and of Right ought to be, Free and Independent States."

The declaration thus prepared was reported on June 28, and was for some days debated and slightly amended. Meanwhile

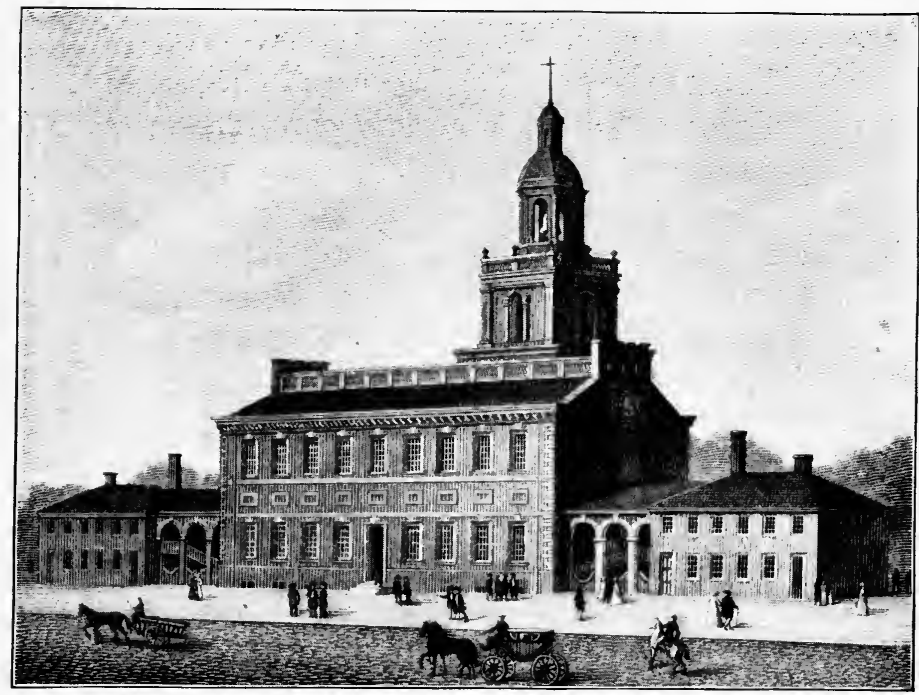

Independence Hall, Philadelphia, built in 1735.

Meeting place of the Continental Congress. From an old print.

the postponed resolution of independence ( $\$ 122$ ) was formally adopted, July 2. John Adams has left us his impressions of this momentous act. "The second day of July, 1776, will be Adams, the most memorable epocha in the history of America. . . . Works, $I X$. It ought to be commemorated, as a day of deliverance, by 420

solemn acts of devotion to God Almighty. It ought to be solemnized with poinp and parade, with shows, games, sports, guns, bells, bonfires, and illuminations, from one end of 
this continent to the other, from this time forward, forevermore." On July 4, 1776, Jefferson's draft of the Declaration of Independence was adopted as amended. On August 2, an engrossed copy (still preserved in Washington) was laid before Congress and the members then in Congress affixed their names to this document, although in the eye of English law every signer was a traitor and subject to a traitor's doom.

For a time the Declaration fell heavy on the people of America; it seemed too bold, too thoroughgoing; it shut the door of reconciliation; and nothing but hard fighting could give the proof that the colonies were really "free and independent states." Even the flag of an independent nation was not adopted until the following June. But the Declaration compelled every thinking man once for all to choose either Parliament or Congress; and it announced to foreign nations the purpose of the Americans to do or die.

"The Union is older than any of the States," said Abraham Lincoln in 1861, "and in fact it created them as States." He meant to bring out the fact that the Second Continental Congress organized a national government before new state governments came into being. The provincial congresses, from which all those who protested against the Revolution were shut out, felt that they were only

Am. Hist.

Leaflets, no. 18

124. Formation of the states (1775-1776) temporary, and several of them applied to the Continental Congress to know what to do. Congress waited till November 3, 1775 , when it advised the people of New Hampshire to establish a government; and early in $\mathbf{1 7 7 6}$ the New Hampshire convention adopted the first state constitution. Shortly after, South Carolina adopted a constitution, while Massachusetts, Rhode Island, and Connecticut thought they could get on with their old colonial charters, slightly modified.

On May 10,1776, Congress gave general advice to the states to form such governments as will "best conduce to the happiness and safety of their constituents in particular, and America in HART'S AMER. HIST. -10 
general." Thereupon the remaining eight colonies (and also Vermont) all adopted written constitutions during 1776 and 1777. Massachusetts followed in 1780 with the first state constitution submitted to popular vote. With many variations in detail these important documents agree in their general form and spirit. (1) Each contained a bill of rights - that is, a statement of the liberties of the individual. (2) Each provided for a representative republican government, including three departments, legislative, executive, and judicial. All the states except two created a legislature of two houses; in all, the legislature was the most powerful part of the system; all the states except Pennsylvania had a single governor, chosen by popular vote or by the legislature. (3) None of the constitutions were strongly democratic according to our ideas, for the suffrage was limited to property owners or taxpayers; and most of the states had also religious and property qualifications for office holders. (4) In the fear of military and centralized government, all the constitutions fixed short terms for all elective officers. (5) Several of them provided a method of easy amendment, and within ten years some of the first constitutions were entirely recast. (6) All these state constitutions directly or indirectly recognized that there would be a permanent general congress.

The idea of statehood and membership in the Union spread into the West. In 1775 Richard Henderson of Virginia, with 125. Fron- Daniel Boone as his right-hand man, set up the Transyltier commu- vania Company, and bought from the Cherokees the tract
nities (1775-1777) between the Cumberland and Kentucky rivers (map, p. 181). Boone was sent ahead and blazed out a pack trail known as the Wilderness Road, from the Holston (upper Tennessee) through Cumberland Gap to Kentucky. The new settlers founded Boonsboro and other settlements, and actually set up a government by a delegate convention. Governor Martin of North Carolina violently opposed what he called this "infamous company of land pirates"; but after his expulsion the 
settlement applied to Congress to admit it as a state. The people of the Vandalia region in 1776 also petitioned Congress to make them "a sister colony and fourteenth. province of the American confederacy." Both applications were distasteful to Virginia, which in 1776 organized Am. Hist. Review, I. 83 Kentucky County, with a county seat at Harrodsburg, and put an end to the Transylvania government.

One new community succeeded in organizing itself without the leave either of the parent state or of Congress. The people of the "New Hampshire Grants," a tract assigned by the British government to New York, revolted from New York, named themselves Vermont, set up their own constitution (1777), and kept up an independent government for fourteen years.

Never for a moment did the friends of independence expect the states to remain separate and disorganized. Already (July 21, 1775) Benjamin Franklin had propounded to Congress a plan of union somewhat resembling his old draft in 126. Articles of Confederation the Albany congress. In brief outline he proposed (1775-1778) (1) a common treasury to be supported by contributions from the colonies; (2) a Congress with representation in proportion to the population; (3) national control of boundaries, of peace, of new colonies, and of Indians. The second committee appointed as a result of Richard Henry Lee's resolution of June 7 reported (July 12, 1776) a draft of a confederation from the hand of John Dickinson; but Congress found in it many subjects for disagreement - for instance, should the states be represented in proportion to population? Should slave property be taxed? Should Congress regulate foreign commerce? Should Congress control the West?

Congress completed its draft of the Articles of Confederation November 15, 1777, and sent it out to the states for ratification; but it was much weaker than Franklin's proposition. (1) It emphasized the sovereignty, freedom, and independence of the states. (2) Each state in the confederation was to have 
one vote in Congress. (3) Taxes were to be apportioned according to the value of land in each state (a method which later proved impracticable). (4) No direct authority was given to Congress for the settlement of boundary disputes, or for the planting of new colonies.

Ratifications came in slowly: after eight months only ten states had approved; three states, New Jersey, Delaware, and Maryland, stood out because Congress was to have no power to cut down the claims of Virginia to western lands; and three years passed before they all yielded.

The change from colonies to an independent nation began in 1774 with a general feeling of wrath over the British coer127. Sum- cive acts which had been aimed at Massachusetts. The mary

First Continental Congress of 1774 expressed the common resentment, and in the Association attacked the "pocket

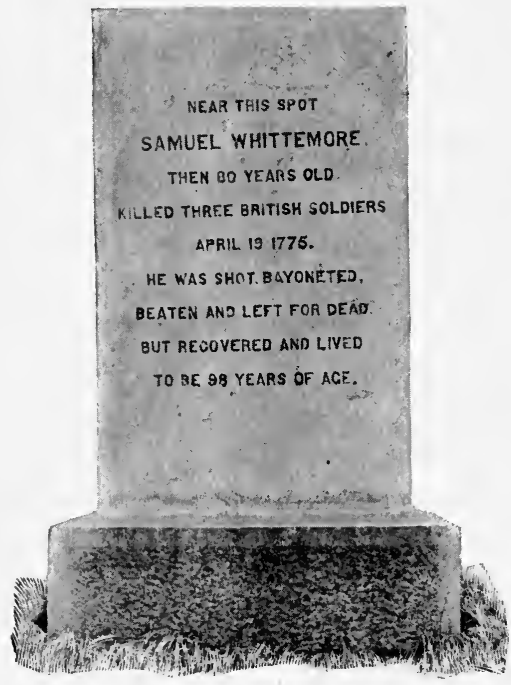

A Tough Old Patriot.

Monument in Arlington (then Menotomy). nerve" of the British merchants and made the first general regulation of commerce by America. To carry it out, however, mob violence was called in, and thus the Revolution began in disorder. The people of Massachusetts organized a revolutionary government of their own, and it was only a question of time when the two parties would attack each other.

The moment came on April 19, 1775, at Lexington. The actual shedding 
of blood by the troops and by the Americans raised an issue which the other colonies must either take up or drop, and nobly and unselfishly they took it up. While Boston was besieged and Canada invaded, the Second Continental Congress in May, 1775, began to act as a national government, and speedily organized an army and a navy, appointed a commander in chief, issued paper money, and took steps to form relations with foreign countries.

Unless the colonists were willing to yield, they had to declare themselves independent. The Declaration of Independence of July 4, 1776, was followed by a scheme of federal government, but the real beginning of the United States had been in 1775, when Congress by general consent began to legislate for the concerns of the whole people.

\section{TOPICS}

(1) Was the Association of 1774 a good method of protest? (2) How was the patriot government of Massachusetts organized Suggestive in 1774 ? (3) Make a list of previous instances of resistance by the colonists to British authority. (4) What did the Committees of Correspondence do for the American cause? (5) How did the Second Continental Congress feel about the fight at Lexington and Concord? (6) Make a list of instructions of the state legislatures to vote for independence. (7) History of the United States flag. (8) What do we know of the debate on the Declaration of Independence? (9) What objections were there to ratifying the Articles of Confederation? (10) Why did the British evacuate Boston? (11) Proceedings in Congress July 2, 1776 - also July 4. (12) Why were people ready for independence in 1776 and not in 1775 ?

(13) Revolutionary town meetings. (14) Sons of Liberty. (15) A revolutionary mob. (16) Contemporary accounts of topics the Lexington and Concord fight. (17) Enforcement of the Association. (18) Opinions of John Adams on Congress. (19) Did Washington take command of the army at Cambridge under the tree now called the Washington Elm? (20) Samuel Adams's opinions of independence. (21) Where did Jefferson get his ideas for the Declaration of Independence? (22) Hender- 
son's Transylvania Company. (23) Contemporary accounts of Bunker Hill. (24) The Mecklenburg (N.C.) Declaration of 1775. (25) Expulsion of the royal governors of the colonies. (26) Why did the invasion of Canada fail? (27) Facts which justify some of the charges in the Declaration of Independence.

\section{REFERENCES}

Geography

Secondary authorities

Sources

IIlustrative works

Pictures
See maps, pp. 131, 168, 181.

Hart, Formation of the Union, §§ 31-39; Sloane, French War and Revolution, 173-237 ; Channing, United States, 67-87; Van Tyne, American Revolution, chs. i.-v., - Loyalists ; Fiske, Revolution, I. 100-146 ; Trevelyan, American Revolution, pt. i. 193411, pt. ii. I. 1-171; Gay, Bryant's History, III. 377-450, 470-489 ; Larned, History for Ready Reference, III. 2337, IV. 2375, V. 3214, 3244, 3635; Cambridge Modern History, VII. 160-174, 207-210, 235-243 ; Greene, Revolution, 67-136 ; McCrady, South Carolina, II. 733-798, III. 1-185 ; Tyler, Revolution (literary), I. 267-521, - Patrick Henry, 101-213; Sparks, Men who made the Nation, 72-118; Morse, John Adams, 1-127, - Benjamin Franklin, 204219 ; Hosmer, Samuel Adams, 260-337 ; Lodge, George Washington, I. 128-157 ; Thwaites, Daniel Boone, 113-128.

Hart, Source Book, §§ 54-58, - Contemporaries, II. §§ 153-158, 184-192, - Source Readers, II. \$§ 51-54, 56-58, 77, 78 ; MacDonald, Select Charters, nos. 72-80, - Select Documents, nos. 1, 2 ; Hill, Liberty Documents, chs. xiii.-xv. ; American History Leaflets, nos. 11, 14, 20 ; Old South Leaflets, nos. 2, 3, 47, 86. See N. Eng. Hist. Teachers' Ass'n, Syllabus, 325-330,-Historical Sources, $\S 77$.

Matthews, Poems of American Patriotism, 8-45; Eggleston, American War Ballads, I. 23-39; Moore, Songs and Ballads of the American Revolution, 65-129, 139-149; Raymond, Ballads of the Revolution, 55-87 ; Longfellow, Paul Revere's Ride; Lowell, Concord Ode, - Ode for the Fourth of July, 1876; Bryant, Green Mountain Boys; Holmes, Grandmother's Story of Bunker Hill; Hawthorne, Septimus Felton (Concord), -My Kinsman, Major Molineux (mob), - Howe's Masquerade, - Grandfather's Chair, pt. iii. chs. vii.-xi.; Cooper, Lionel Lincoln (Boston); J. 'E. Cooke, Henry St. John, Gentleman (Valley of Virginia), - Stories of the Old Dominion, 205-218.

Winsor, America, VI., - Memorial History of Boston, III. ; Wilson, American People, II. 


\section{CHAPTER XI.}

THE WAR FOR INDEPENDENCE (1776-1783)

When war came, Great Britain seemed to have an overwhelming superiority over America in men and resources. A small and vigorous governing class, consisting only of a few hundred families of landholders, furnished almost all members of Parliament and officers of the army and

128. The rival peoples navy. In this aristocracy the central figure was King George III., who, from day to day, gave his personal directions to Lord North, the prime minister, for the management of Parliament. A good husband and father in an age of vice, a kindhearted friend, a king who meant well by his subjects, George III. was still a narrow, obstinate, and ill-informed man. The aggressive force of England was, moreover, weakened because several liberal statesmen sided with the colonies. Among them the Earl of Chatham solemnly demanded of his countrymen "a formal acknowledgement of our errors, and a renunciation of our unjust, ill-founded, and oppressive claims."

Against the might of Great Britain was opposed a poor country, with no manufactures of iron or cloth, unable to make a musket or cast a cannon. Yet America was a land of comfort and prosperity. Lafayette wrote of it, "Sim- Contemporaplicity of manners, kindness, love of country and of lib- ries, II. 486 erty, and a delightful equality everywhere prevails. . . All the citizens are brethren. In America there are no poor, or even what we call peasantry." Even during the war the colonists made. money from privateering and West Indian and European trade, and bought the necessary materials of war with their exports. 
The serious weakness of the Americans was that they were divided; John Adams later estimated that fully a third of

129. The

American

loyalists

the people were opposed to war, and still more strongly opposed to independence. The years 1775 and 1776 were full of commotion, tumult, and violence against the loyalists. Those Americans who still maintained that the British government was not tyrannical were intimidated, arrested, imprisoned, tarred and feathered, and in some cases executed. As the struggle grew fiercer, the colonists passed laws banishing the loyalists or confiscating their property. In many districts the struggle was a civil war in which hun. dreds of the Tories, as the loyalists were called, were kept down by force. The Tories included in the New England and mid. dle commonwealths most of the well-to-do classes, the former colonial officials and their friends, old officers of the British army, many of the clergy and of the graduates of colleges. In some states nearly half the people were loyalists. Thou. sands of them entered the British army and fought against their brethren; and thousands of families removed to Nova Scotia, Quebec, and other British colonies.

The British were overwhelmingly superior in the size of their military and naval forces, although much hampered by 130. The the necessity of transporting men and materials across rival forces a stormy sea. In 1776 they had 200 ships of war, and for men they drew on 11,000,000 people in Great Britain and Ireland, besides the loyalists. Yet Lord North committed the stupid blunder of hiring 30,000 Hessians, who had no personal interest in the struggle, and were leased by their princes like so many cattle. "Were I an American," said Chatham, "as I am an Englishman, while a foreign troop was landed in my country, I never would lay down my arms never - never - never"; and Franklin wrote grimly, "The German auxiliaries are certainly coming; it is our bușiness to prevent their returning." 
Out of the $3,000,000$ people in the colonies, the Tories and negroes numbered at least $1,200,000$. There were from 300,000 to 400,000 able-bodied patriots, of whom perhaps 150,000 served in the army at one time or another; but they probably never numbered more than 40,000 men under arms at one time, and sometimes the total force available for striking a blow was not above 5000. Besides troops of English descent, there were many Germans, Irish, and Scotch, some Dutch, Jews, French, and Welsh, and several thousand negroes, especially from Rhode Island. Both sides made the moral and military mistake of enlisting Indian allies; the Americans were first to seek this dubious aid; the British used it most effectively.

The main difficulty with the army was that the states insisted on furnishing militia on short terms of service, instead of allowing Congress to form a sufficient regular force with national officers, enlisted for the war. Washington said of the militia, "The system appears to have been pernicious beyond description. ... It may be easily shown, that all the misfortunes we have met with in the military line are to be attributed to this cause."

Many soldiers of fortune drifted over from Europe to seek employment, besides Lafayette, a French nobleman, who brought his own enthusiasm and the silent support of the French government; the German Baron von Steuben, an excellent soldier, skillfully drilled the troops and introduced improved tactics; the Poles Kosciusko and Pulaski and the French general De Kalb were gallant soldiers.

After a year of preparation, the British dispatched a fleet to take Charleston, but it was beaten off ( $J$ une 28, 1776) by the gallantry of Colonel Moultrie, in a fight signalized by the heroism of Sergeant Jasper. The main attack was on New York, near which Sir William Howe landed (1776-1777) with 20,000 men on Long Island (August 22). Washington 


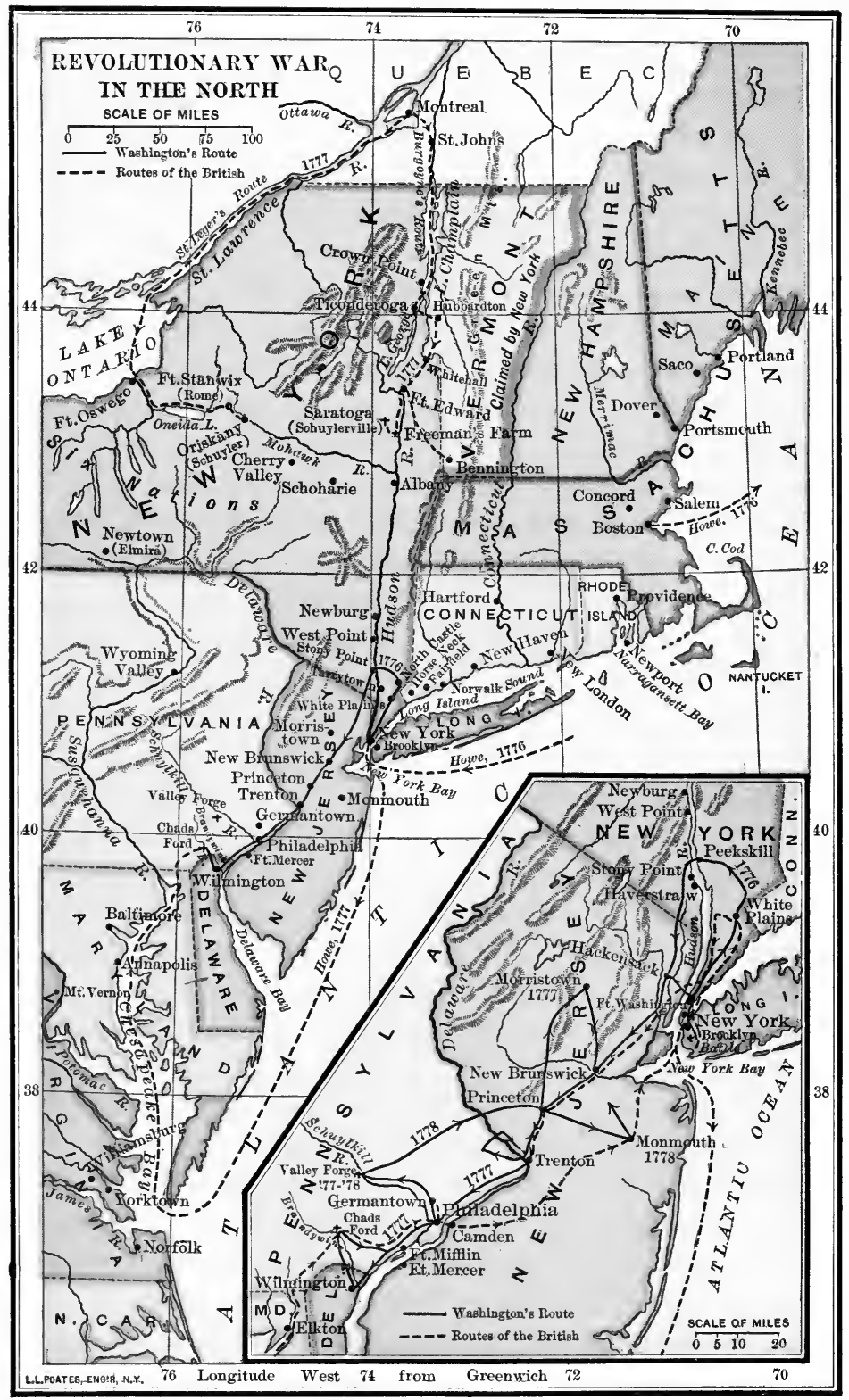


had never before maneuvered an army in the field or defended a country; his force of 18,000 men was badly defeated (August 27 ), and only Howe's slowness enabled

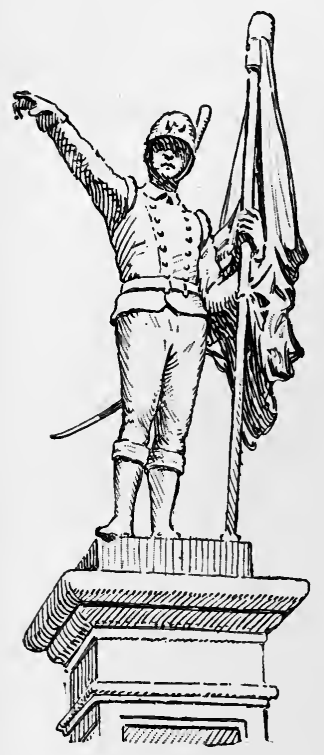

Statue of Sergeant JASPER in Charleston. him to escape across the East River to New York. The British maneuvered him out of the city, fought a successful battle at White Plains (October 28), and soon after captured Fort Washington on the north end of Manhattan Island, with 3000 prisoners.

Washington was forced back across New Jersey and the Delaware, his army sometimes falling below 3000 troops; for Charles Lee, a former British officer, in command of 7000 men, for a time disobeyed orders to come to his aid. $\mathrm{Al}$ most in despair Washington wrote, "If every nerve is not strained to re- Washingcruit the new army with all possi- ton, Works, ble expedition, I think the game 473 is pretty nearly up." But for the heroic efforts of Robert Morris, a wealthy merchant of Philadelphia, who raised money on his personal credit to keep the army together, the Revolution might have failed then and there.

Washington's indomitable spirit suddenly turned the scale. To prevent the British following him to Philadelphia he recrossed the Delaware in boats (December 26, 1776), struck the British post at Trenton, and captured 1000 Hessians. A few days later he successfully attacked the British at Princeton (January 3,1777 ), so that they withdrew to the neighborhood of New York, and Washington fortified himself at Morristown, where at one time he had only 1500 men. A compensating British victory was the capture of Newport. 
In the spring of 1777 the British planned three lines of attack, intended to cut New England off from the middle 132. Bur- colonies: (1) from Lake Champlain to the Hudson under goyne's campaign (1777)

General John Burgoyne; (2) from Lake Ontario to the Mohawk under Colonel St. Leger; (3) from New York up the river under Sir William Howe to join the northern forces. In June, 1777, Burgoyne started southward from Montreal with an army of about 8000 men, including HesMoore, sians; and he put forth a bombastic proclamation, in Diary of which he said, "I have but to give stretch to the In-
Am. Rev. I. 454 dian forces under my direction, . . . and the messengers of justice and wrath await them in the field; and devastation, famine, and every concomitant horror."

Washington was unable to leave Howe's front, and Schuyler was put in command to oppose Burgoyne, who nevertheless easily got as far as Fort Edward. Here he found a hornet's nest. Men poured in from near-by New England until Schuyler had nearly twice as many troops as Burgoyne, and General Stark of New Hampshire beat part of the British forces at Bennington (August 16). Meanwhile the British expedition to the Mohawk valley under Colonel St. Leger got no farther than the vicinity of Fort Stanwix, because of the skillful preparations of Schuyler and Benedict Arnold and the bravery of General Herkimer at the battle of Oriskany. General Horatio Gates was now put in command of the American northern army, though against Washington's judgment. The expected British army did not appear from the lower Hudson. Most of Burgoyne's Indians deserted, and the British lost men steadily in battle and by capture. Burgoyne was at last confronted by Arnold and others, active subordinates of the apathetic Gates, and, after two hard fights at Freeman's Farm, was obliged to surrender his whole remaining army at Saratoga, October 17, 1777 ; the prisoners were 3500 British and Hessian troops, with 2300 volunteers and camp followers. The defeat was the turn- 
ing point of the war, for the overthrow of the boastful proclamation-maker gave the patriot cause new life. In the words of a popular squib,

"Burgoyne, alas! unknowing future fates,

Could force his way through woods, but not through Gates."

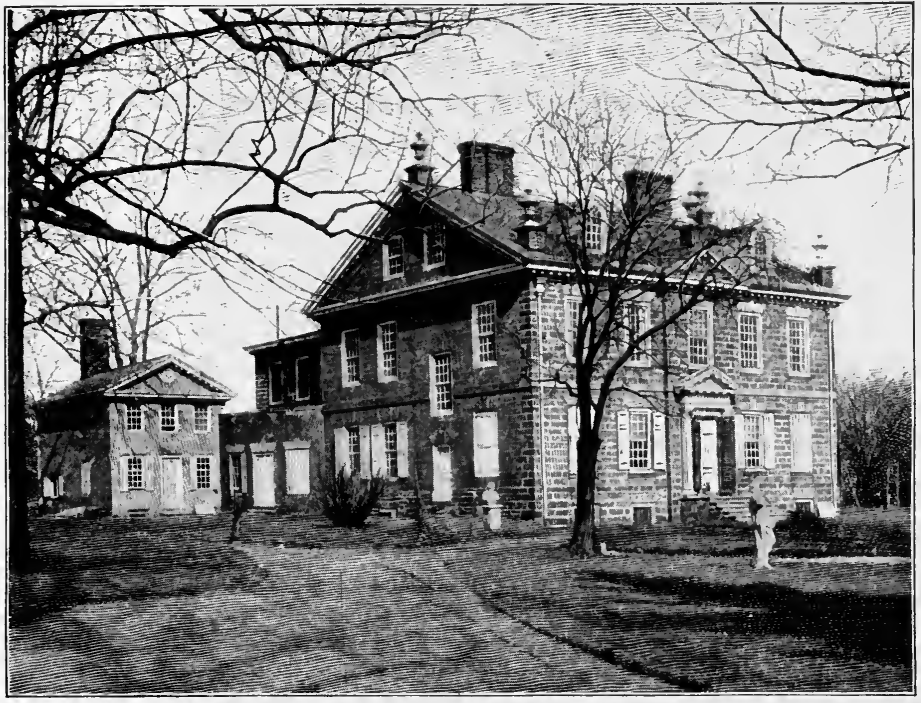

Chew House, Germantown.

Injured by cannon balls in battle of Germantown, $\mathbf{1 7 7 7}$; still standing.

Probably Howe might have prevented Burgoyne's capture by advancing up the Hudson; but he was induced to plan a separate campaign for the occupation of Philadelphia. In August he landed with 18,000 men at the head of 133. The British in Philadelthe Chesapeake; Washington with his 11,000 men was phia (1777) unable to stop him, and was defeated in a pitched battle at the river Brandywine (September 11, 1777). Two weeks later the British occupied Philadelphia, and Washington's bold attempt to dislodge them by a surprise at Germantown (October 4) was a failure. 
Disregarding the military maxim that the object of campaigns is to destroy the enemy's army, Howe was content to capture the lower forts and thus to clear the Delaware of foes, and he then sat down for a comfortable winter in Philadelphia. Thousands of Jerseymen and Pennsylvanians thought the war was over and gave in their allegiance; but Washington did not know when he was beaten, and took up winter quarters at Valley Forge, above the city, on the Schuylkill River.

Newport, New York, and Philadelphia were all held by the British, and reënforcements and supplies came to them steadily 134. Valley from over the sea, while Washington's army at Valley Forge (1777-1778)

Forge was living miserably in a camp village of log huts. Fuel was plentiful, but food and clothing were scanty, not because there was any scarcity in the country, but because so many of the neighboring people were disaffected, and the roads were so bad that it was almost impossible to bring supplies which were stored only a few miles away. At one time, out of a force of at most 11,000 men, 2898 were reported unable to go on duty for want of clothing. Yet the spirit of the Contempora- troops was excellent, as one of the officers wrote: "See ries, II.561 the poor Soldier . . . if barefoot he labours thro' the Mud \& Cold with a Song in his Mouth extolling War \& Washington - if his food be bad - he eats it notwithstanding with seeming content."

One cause of the suffering of the soldiers was the bad management of the commissary officers ; back of that was the weakness of Congress, of which Alexander Hamilton said, "Their conduct, with respect to the army especially, is feeble, indecisive and improvident." It was a time of great losses ; nine hundred American merchant vessels had already been taken; thousands of men had lost their lives or were prisoners in barbarous prison ships, or had returned home wounded or diseased. The states hung back, each hoping that other states would furnish the necessary men, and therefore Congress lost spirit and influence. 
The one beacon light which shone steadily was General George Washington. Every other Revolutionary hero and patriot could have been replaced; Washington alone was the indispensable man. He was a Virginian, and his appointment gave confidence to the southern states; he 135. George Washington the was a soldier who outranked in service and experience essential man nearly all the other officers in the army; he was careful of his men; he was a man of extraordinary industry and mastery of details, keeping up correspondence all over the country. As a general Washington showed a splendid pertinacity: he learned by his own defeats; if beaten in one place, he would reappear in another. He was extraordinarily long-suffering and patient, and he had a magnificent temper; that is, though naturally hot and impetuous, he kept himself under rigid control, except when a crisis came, and on such occasions, a contemporary records, "Washington swore like an angel from heaven."

Ford, True George Washington, 271

Washington bore personal slights with wonderful dignity. $\mathrm{He}$ wrote to Congress of "the wounds which my feelings as an officer have constantly received from a thousand things, that have happened contrary to my expectation and wishes." Especially did he shine out in the so-called Conway Cabal of 1778 , the purpose of which was to put Gates, "the hero of Saratoga," over his head The cabal fell to pieces when a letter from Conway was made public, in which he said, "Heaven has been determined to save your country, or a weak General and bad counsellors would have ruined it." Gates shortly after withdrew from command in the field.

After all, the greatest of Washington's qualities was a rugged manliness which gave him the respect and confidence even of his enemies. Though he was at the head of a military force, nobody ever for a moment believed that he would use it to secure power for himself. Wisdom, patience, and personal influence over men were wonderfully united in Washington- 
the greatest man in the Revolution, and, with the exception of Lincoln, the greatest of all Americans.

The capture of Burgoyne saved the republic, because it made a profound impression upon the French government, which for 136. The three years had been damaging its enemy, Great Britain, French alliance by secret aid in arms and money to the revolted colonies. (1775-1778) In 1775 Silas Deane was sent over to France; he was followed by Benjamin Franklin, who, as the principal one of three commissioners, brought about two treaties, signed February 6,1778 , with the following principal provisions: (1) these treaties recognized the "United States of North America" as an independent power; (2) the treaty of amity and commerce gave to the vessels of each power large privileges in the ports of the other; (3) the treaty of alliance (the only one in the history of the United States) provided that the two powers should make common cause against Great Britain till the independence of the United States should be secured.

England tried to head off these treaties with France by Lord North's third plan of conciliation, by which Parliament repealed the tea duty and the act suspending the Massachusetts charter, and promised not to lay any tax or send any troops without the consent of America. In June, 1778, British commissioners came over to treat for peace on these terms; but Congress replied that "they claim a right to alter our charters and establish laws, and leave us without any security for our lives or liberties." The real reason for refusal was that the treaty with France seemed to insure independence.

The news that a French fleet was coming to America obliged Sir Henry Clinton (who had superseded General Howe) to evacuate Philadelphia. He retired through New Jersey; but with his usual vigilance Washington followed and attacked at Monmouth (June 28, 1778). The treasonable disobedience of General Charles Lee brought about a drawn battle; but the British retired to New York, and they made no more general 
campaigns and fought no more pitched battles in the North, except forays on the coast.

Notwithstanding the immense naval strength of England, the Americans fought well and successfully at sea. In 1775 Congress organized the first naval force out of merchant vessels; and in 1776 Esek Hopkins was put in command of a national squadron of small ships, which raided the

137. The navy and the privateers town of New Providence in the Bahamas. Several of (1775-1780) the states also commissioned ships of war of their own; but during the whole war the Americans never built a single ship which could fight the ordinary three-decker ship of the line, of which Great Britain had about 120. The greater part of our naval warfare was carried on by privateers. From 1776 to 1778 the Americans took British merchantmen to the value of nearly ten million dollars; in 1777 alone 320 British merchantmen were taken; on the other hand, the little American navy was driven off the sea, and the British and loyalist privateers captured hundreds of American vessels.

After the French alliance, naval conditions were changed. In August, 1778, the French fleet appeared, blockaded New York, and then took part in an unsuccessful attack on Newport. The treaty also opened the way for the most dashing of all the American naval commanders of the time, John Paul Jones, for whom the French government fitted out a little fleet, including an old merchantman, the Bon Homme Richard. With this craft Jones cruised in the North Sea, and attacked and took the Serapis, a forty-four-gun ship of the British navy (September, 1779), the first instance of a square fight between American and British cruisers, and a glorious victory for the Americans. In American waters, however, the United States could do little but look on while the French and British fleets fought each other in the West Indies, or off the American coast. The Spaniards joined in the war in 1779, and the Dutch in 1780, and did their best to keep the British navy busy. 


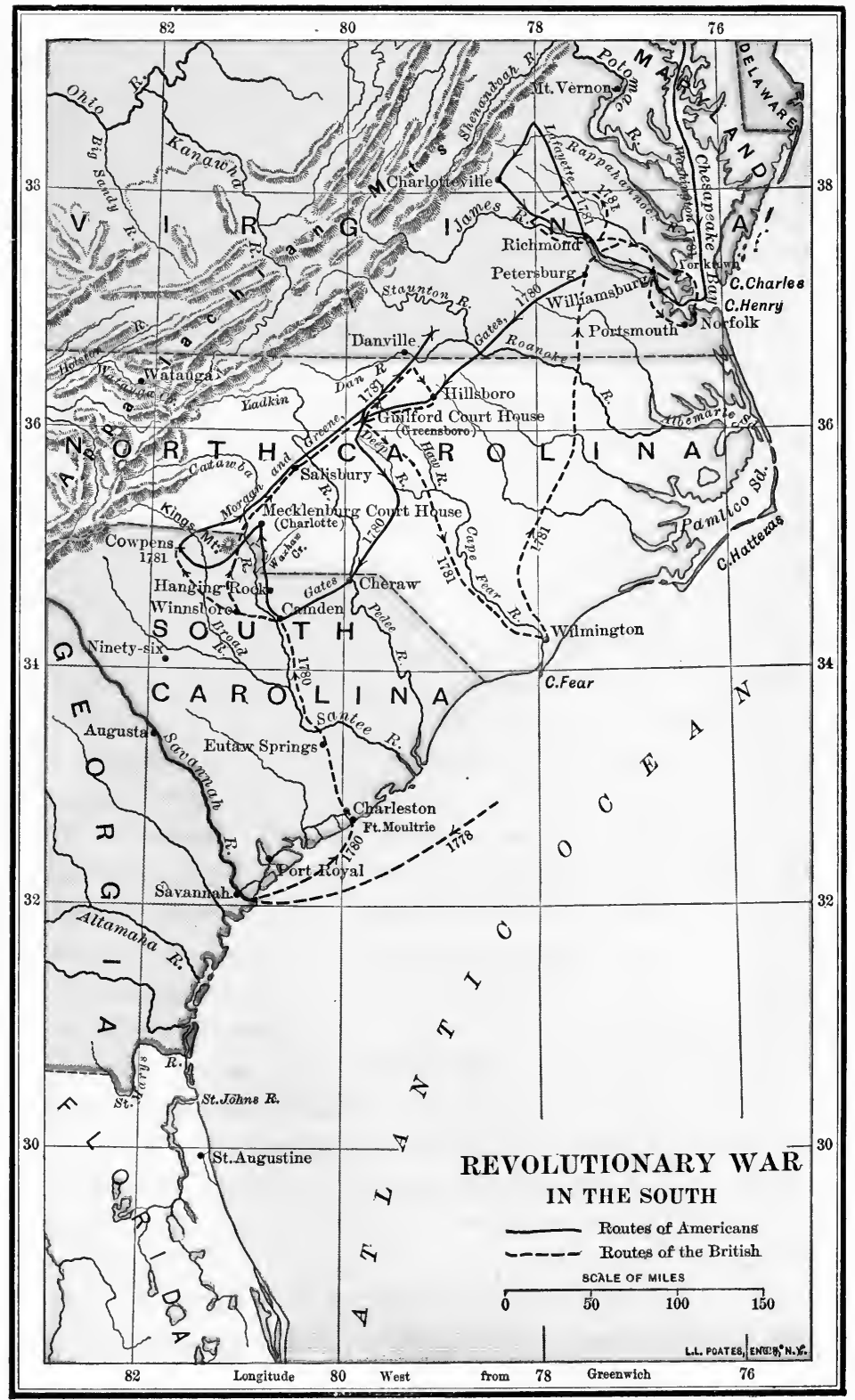


During 1779 there was a lull in the Revolutionary War; but by a gallant surprise "Mad Anthony Wayne" (July 16) overpowered the British post of Stony Point, on the Hudson.

138.

A year later the patriot cause almost perished through the treason of Benedict Arnold, a brave officer, veteran of many battles, who thought he had been slighted. He asked the command of the important post of West Point, in order to betray it for $\$ 30,000$ and a major general's commission. Fortunately the British agent, Major John André, was taken at the critical moment (September 23, 1780); West Point was saved, and with it the line of communication with New England. Since André was traveling through the American lines in disguise, he was a spy, and was justly executed as a spy, though his captors bore tribute to his brave and manly character. Arnold received the promised reward from the British.

In 1780 the British changed their plan of warfare by attacking the southern states. Savannah had already been taken (December, 1778), and a royal government set up in Georgia. An expedition under the French admiral D'Estaing, in 139. CamAn expecition under coöperation with a land force under General Lincoln, in (1778-1780) 1779 was unable to recover Savannah. With troops set free by the evacuation of Newport, Charleston was besieged by Sir Henry Clinton and Lord Charles Cornwallis, with about 13,000 men, and by the renowned loyalist cavalry commander, Tarleton. On May 12, 1780, Lincoln was compelled to surrender the city, with its whole garrison of about 3000 .

The British command in the Carolinas was now intrusted to Lord Cornwallis, an experienced officer who had strongly advised a southern campaign. He began to push into the interior, and Tarleton broke up the remnant of the American southern army at Waxhaw Creek; but Marion and Sumter, with militia, irregular troops, and guerrillas, somehow kept the field. The effort of Cornwallis to establish a loyal government, and to enroll loyalist troops, led to a fearful condition 
of partisan warfare, marked by excesses on both sides. To stem this invasion, Washington sent De Kalb from the North to Hillsboro, North Carolina; but Congress called Horatio Gates from his inactivity to take command. Gates formed the project of seizing Camden, occupied by the British as an important strategic point. With 1400 regular troops and 1600 militia, he moved on Cornwallis's force of 2000 men August 16,1780 ; the American army was routed with a loss of 2000 men. De Kalb was killed, and the "hero of Saratoga" ran away like any poltroon.

Cornwallis now set about the systematic conquest of North Carolina, but a force of 1200 loyalist troops under Ferguson was trapped by the militia and destroyed or taken at Kings Mountain (October 17). This important battle was won by western settlers, under John Sevier, and was the chief blow struck by the West in the Revolution.

The winter of 1780-1781 was again very hard for the American army, and bodies of the Pennsylvania and New 140. From Jersey "line" mutinied for lack of pay. Washington Charleston realized that his objective was the British army wherever to Yorktown it was to be found, and sent General Nathanael Greene to (1780-1781) take command in the South, the principal seat of hostilities. Cornwallis still held the advanced positions of Augusta and Ninety-six, but was harassed by the regulars under Marion, Henry Lee, and Morgan. Greene sent Morgan to attack a column of Cornwallis's army under Tarleton, who was com. pletely beaten at the battle of the Cowpens (January 17, 1781). The two armies then maneuvered northward. Cornwallis suffered severely at Guilford (March 15), was unable to maintain his communications, and fell back to the coast at Wilmington.

Most of North Carolina was thus lost to the British; and Greene soon made himself master of inland South Carolina. Cornwallis made up his mind to invade Virginia, where there was already a British force under Benedict Arnold and Phillips. 
Washington aided his friends in the South by holding the British forces in New York, and he sent Lafayette to confront the enemy in Virginia; but Lafayette could not prevent the junction of Cornwallis's and Arnold's troops, and the British army fortified itself at Yorktown to await reënforcements from New York. At this critical moment a French fleet under De Grasse blockaded the Chesapeake, repulsed a British fleet bearing reënforcements from New York, and landed 3000 French troops; while Washington at the right moment made a brilliant dash southward from the Hudson with 2000 Americans and 4000 Frenchmen under Rochambeau, to close in the net on the land side.

October 19,1781, after a spirited siege, Cornwallis surrendered his whole army of 7000 men. Nine months later the British gave up Savannah; and soon after evacuated Charleston. After seven campaigns the British held no territory of the original thirteen United States except New York city.

From the beginning of the war, Congress gave to the neighboring Indian tribes the paternal supervision which they had been accustomed to receive from the British. Congress appropriated money for presents, appointed superintendents of Indian affairs, and made some feeble attempts to 141. The western Indians civilize the tribes. But the principal relation with the Indians was to repel border warfare in three different regions.

(1) The southwestern Indians attacked the Watauga settle. ment in 1776, and harried the frontier, till the South Carolina legislature offered $£ 75$ for every Indian scalp. The Cherokees were beaten for the time, and made treaties with the states concerned.

(2) The northern states felt the horrors of Indian warfare when the loyalist leader Butler, with a force of Tories and Indians, descended on Wyoming Valley, Pennsylvania (July, 1778), and ravaged it with fire and sword. Later, he and Joseph Brant, a Mohawk chief, led a force of Iroquois to raid HART'S AMER. HIST. -11 
Cherry Valley, New York (November, 1778). As a punishment and an example, Congress dispatched an expedition under General Sullivan, who marched up into the territory of the Six Nations in 1779, defeated the Indians and their white allies, and laid waste their whole country. The Iroquois were so reduced in numbers and prestige by the war that they never again became a force in American affairs.

(3) The middle frontier was harassed by a mixed force of loyalists, Indians, and renegade whites, including the notorious Simon Girty, under direction of Henry Hamilton, commander of the British posts in the. Northwest.

Could not the tables be turned by attacking

112. Conq'est of $i$ e Northwest 1778-1779) the little British posts in the Northwest, - in which

there were few Eng-

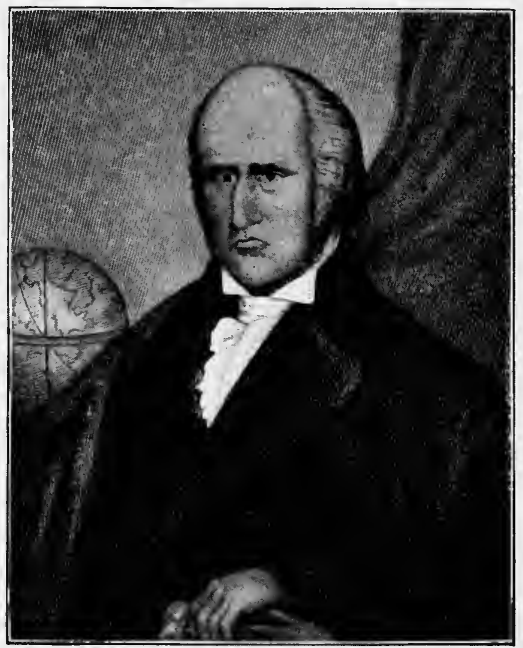

George Rogers Clark, abott 1790. From a contemporary portrait.

lish and only six thousand French and French half-breeds, thus to stop the Indian raids, and give a blow to British prestige? Among the settlers in Kentucky associated with Boone was George Rogers Clark, an excellent backwoodsman and experienced in Indian fighting. He was but twenty-five years old, and had neither money nor men; and no story of the Arabian Nights is more romantic or improbable than his conception of such an invasion and his success in carrying it out. Governor Patrick Henry of Virginia authorized him to attack the British post at Kaskaskia, not far from St. Louis. With 
about 100 men, he floated down the Ohio River, and then marched 100 miles across the country, surprised and took Kaskaskia (July 4, 1778), and, a few days later, Cahokia - in both cases without taking or losing a life.

The larger post of St. Vincent, or Vincennes, on the Wabash, was also ready to yield, when the British commander Hamilton returned from an absence and made preparations to teach

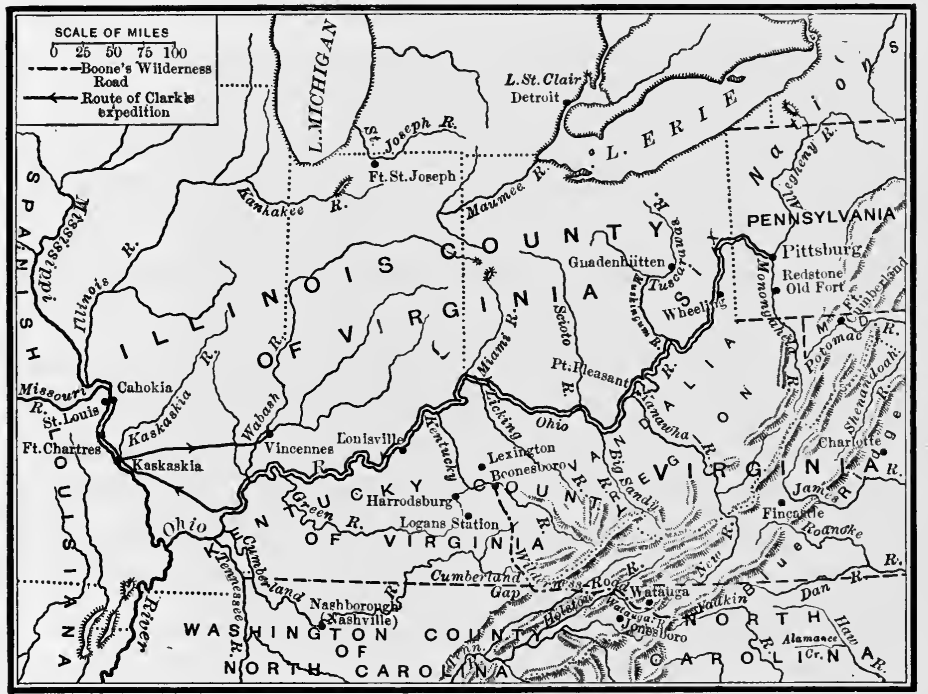

Clark's Expedition, and Early Settlements in the West.

the Kentuckians a lesson. Clark was too quick for him. As he had not Kentuckians enough for further operations, he enlisted and trained the French residents, whom he won over by giving them religious and civil liberty. These forces he used in an incredible march across a country drowned by a flood, and an attack on Vincennes (February, 1779), which surrendered without a fight. The Spaniards, after retaking the small Gulf posts which dominated the Floridas, attempted to share in the Northwest, and sent an expedition from St. 
Louis to raid the British fort of St. Joseph, in what is now northern Indiana.

Since Clark carried a commission from Virginia, and took possession of the country in her name, the whole area north 143. Claims of the Ohio was made into the county of Illinois by the to the West Virginia government (October, 1778), and a "county (1778-1781) lieutenant" was sent out to govern it. The Virginia claim rested partly on an attempt to recur to the charter of 1609 (annulled in 1624), with its uncertain phrase, "up into the land throughout from sea to sea, west and northwest." If that charter still had force, the Massachusetts grant of 1629 (annulled in 1684) and the Connecticut charter of 1662 must also be valid; and they covered part of the territory within the Virginia claim. The Carolinas had as good a charter claim as Virginia, through their grants of 1663 and 1665 (though surrendered in 1729); and Georgia in its charter of 1732 (surrendered in 1752). New York, not to be outdone, came in with a claim for indefinite territory between the Kentucky River and Lake Erie, on the ground that it was part of the territory of the Six Nations, who were under the jurisdiction of New York.

Contrary to these conflicting claims under old charters was a common-sense argument of national rights. The conquest of the West was possible, and could be permanent, only through keeping the British busy on the coast. Hence several of the states which had no western claims refused to ratify the Articles of Confederation till Virginia should yield. Even after New Jersey and Delaware ratified, Maryland stood out for the great national principle that the wild land taken as a result of the war belonged to no state, but to the United States as a whole.

As a pledge that the lands should be used for all the states, Congress passed a momentous vote (October 10, 1780) that Journals of "The unappropriated lands which may be ceded to . . . Congress the United States shall be disposed of for the common benefit of the United States, and be settled and formed into 
distinct republican states, which shall become members of the federal union." New York and Virginia promised to cede at least a part of their claims, and without waiting for the matter to be settled, Maryland ratified the Articles of Confederation (March 1, 1781).

During this dispute, the Northwest fell into confusion. The Virginian local authorities made extravagant land grants, and the French were much discontented. Irregular fighting 144. Govwent on with the Indians, and in 1782 the Christian In- ernment of dians at Gnadenhütten, on the Tuscarawas River, were (1778-1783) massacred in cold blood by militia from Pennsylvania. South of the Ohio River conditions were better. A new center of settlement was planted in 1779, at Nashborough (Nashville); and the next year a permanent settlement was made at the falls of the Ohio, and named Louisville for Louis XVI., king of France. Emigration flowed across the mountains from North Carolina and Virginia till the western population was nearly forty thousand; and some of the inhabitants petitioned Congress to make Kentucky and Illinois a state.

When Lord North heard of the Yorktown surrender (p. 179) he cried out, "Oh, God, it is all over." The merchants in England had suffered enormous losses by captures of their shipping, and therefore strongly urged a peace; and the king wrote to Lord North (March 27, 1782), "At last the fatal day has come which the misfortunes of the times and the sudden change of sentiments of the House of ries, II. 620 Commons have drove me to." He was obliged to accept a Whig ministry, which was determined to end the war on such conditions as would prevent its breaking out again.

A strong commission-Franklin, John Adams, John Jay, and Henry Laurens - was sent to represent their country at Paris, where the general peace was to be made. Though their instructions provided that the envoys should take no steps without the approval of the French government, they 
became satisfied that the French did not desire to give a good boundary west of the Appalachians. In consultation in their rooms one day, Franklin said to Jay, "Would you break your instructions?" "Yes, as I break this pipe." The pipe went into the fire, and the instructions were ignored; an unexpectedly favorable treaty with Great Britain was secured without the aid of France, under date of November 30, 1782. The same treaty was made "definitive" in September, 1783.

The main provisions of the treaty were as follows: (1) the northern boundary was in great part the St. Lawrence and the Lakes; (2) the Mississippi was made the western boundary, thus including not only Clark's conquest, but the remaining British posts in the Northwest, and the whole Southwest; (3) the southern boundary was the 31st parallel; south of that line Spain received back the Floridas; (4) "the right to take fish of every kind on the Grand Banks of Newfoundland" was acknowledged, together with the "liberty" to land . and cure fish on the neighboring coast of Canada; (5) debts due to British merchants from American corresponclents at the beginning of the war were to be valid; (6) Congress was to recommend the states to receive and treat well the loyalists who had not taken arms in the British service; (7) the British agreed not to take away " negroes or other property."

After the capture of Cornwallis, the American army had to be kept together until peace was assured. While the troops lay at Newburg, New York, some officers who were dissatisfied with the delay of Congress to vote them a cash bonus, issued the so-called Newburg Addresses, urging their comrades to refuse to disband. A few words from Washington calmed the difficulty, and Congress voted to the officers full pay for five years, and afterwards made large land grants to the common soldiers. In the spring of 1783 the troops were disbanded; New York was evacuated by the British, November 25, 1783, and the Revolutionary War was happily over. 
Though crops were good and business fairly prosperous throughout the war, both the states and Congress had a hard time to raise money. The states laid taxes which were 146. Revocollected with difficulty; they issued $\$ 210,000,000$ of lutionary paper money, which was mostly never redeemed; they (1776-1780) fixed prices in paper money and punished those who refused to receive it; they confiscated the estates of the loyalists; they borrowed money, and could not pay the interest.

National finances under Congress were rather worse than those of the states. (1) Congress borrowed money in several ways: in interest-bearing bonds; in loans from foreign governments ; in cer-

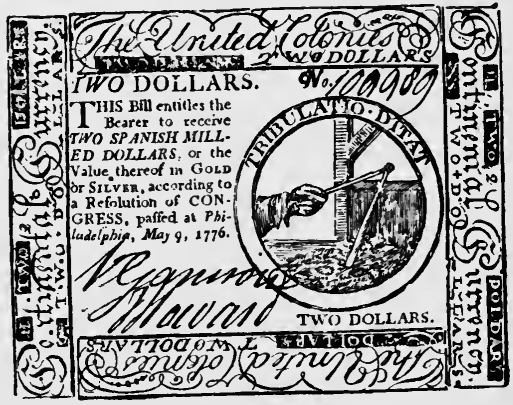

Continental Paper Money, 1776. tificates of debt issued to officers and other public creditors. At the end of the war the debt thus accumulated amounted to about $\$ 36,000,000$. (2) Congress raised about $\$ 6,000,000$ by "requisitions" on the states, which were virtually taxes; part of this was paid, not in cash, but in "indents," a kind of coupons for interest on the national debt. (3) France freely gave to Congress about $\$ 2,000,000$ to enable it to keep up the war, besides lending large sums later, under Franklin's influence. (4) A few hundred thousand dollars were raised by lotteries carried on for the profit of the United States. (5) The main resource of Congress was paper money, of which the first issue was made in June, 1775; then every few months thereafter till the total was $\$ 242,000,000$. In 1776 it began to depreciate; in 1778 it went down to about twelve cents on the dollar, rallied a little after the French treaty, and then went on down, down, till half a yard of broadcloth 
cost $\$ 200$. In 1780 Congress redeemed about half the issue at two and a half cents on the dollar and issued new notes, which went on the same downward way, till in 1781 a specie dollar would buy a thousand dollars in continental currency, and

Holmes,

Parson Tirrell's Legacy
"6 Paper money became so cheap,

Folks wouldn't count it, but said, 'a heap." "'

The paper money, both state and national, was really a kind of taxation. Congress got about forty million dollars' worth of supplies and of soldiers' services for paper notes which were never redeemed, and therefore caused that amount of loss to the people through whose hands they passed.

In the hostilities which lasted from 1775 to 1781 the British had the most ships, yet they could not break up the American 147. Sum- privateering. They had the most men, yet never routed mary

an American army except at Camden, and never captured a large force except at Fort Washington in 1776 and Charleston in 1780. On the other hand the Americans took the whole army of Burgoyne in 1777 and of Cornwallis in 1781. The British expected the loyalists to make their task easy, but although about twenty thousand entered the British service, the only loyalist insurrection which seriously hampered the patriots was in the Carolinas. The British occupied and had to give up Boston, Philadelphia, Newport, and Savannah. The Americans failed in Canada, but seized a large part of the northwestern country, a prize worth ten Canadas.

The British were marvelously weak in generals, while Washington, Greene, Lafayette, Marion, and Sumter are enrolled among the world's great soldiers. The British were divided in Parliament, but English public opinion supported the king, while America was split by the loyalists. Great Britain had a strong, long-established government, but the United States had to form its confederation under fire; and till March 1, 
1781, Congress acted without a constitution, and depended on the good will of the states.

The most definite reasons for American success were the timely and essential aid of France and the character of Washington, who had the courage and skill to command his troops, the patience to lead Congress and the states, and the heroism to stand to his guns till the very last. His leadership was a proof that the American Revolution was a righteous cause.

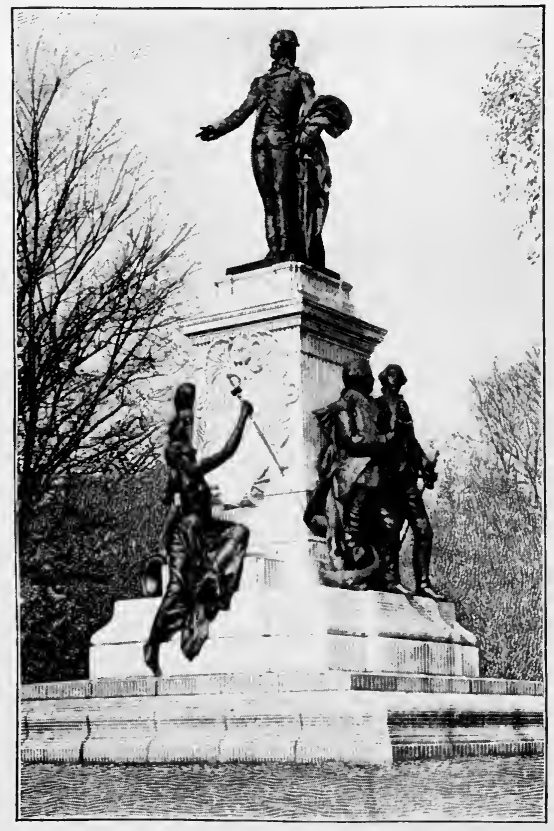

Lafayette Statue in Washington.

Designed by Falguière and Mercié, 1890.

\section{TOPICS}

(1) What was Pitt's attitude on the American Revolution? (2) What were the services of Baron von Steuben? (3) ServSuggestive ices of Lafayette? (4) Why did the British attack New York? (5) Why did not Howe help Burgoyne? (6) Was Gates the hero of Saratoga? (7) Why could not Washington hold Philadelphia? (8) Why did the French make a treaty with the United States? (9) Why did the Indians attack the frontiers, 1775-1778? (10) How could George Rogers Clark make such vast conquests with so few men? (11) How was Charleston taken by the British? (12) Private life of George III. (13) Sergeant Jasper's heroism. (14) Capture and trial of John André.

(15) Banishment of Tories. (16) Patriot songs. (17) Tory songs. (18) Confiscation of Tory property. (19) Negro troops Search topics in the Revolution. (20) The Hessians in America. (21) Work of 
women in the Revolution. (22) Spies in the Revolution. (23) Life at Valley Forge. (24) Treason of General Charles Lee. (25) Capture of the Serapis. (26) Curiosities of continental paper money.

\section{REFERENCES}

Geography Secondary authorities

Sources

Illustrative works

Pictures
See maps, pp. 168, 176, 181; Winsor, America.

Hart, Formation of the Union, \$§ 40-47; Sloane, French War and Revolution, 238-378; Channing, United States, 87-106 ; Van Tyne, American Revolution; Fiske, American Revolution, I. 147343, II., - Critical Period, 1-49; Lecky, England, IV. 1-289 ; Trevelyan, American Revolution, pt. ii. I. 172-349, II. ; Gay, Bryant's History, III. 451-469, 490-623, IV. 1-90; Wilson, American People, II. 242-330, III. 1-24 ; Lodge, American Revolution; McCrady, South Carolina, III. 186-858, IV. ; Foster, Century of Diplomacy, 1-88; Greene, Revolution, 137-443, - General Greene, 34-320 ; Dewey, Financial History, §§ 14-20; Roosevelt, Winning of the West, I. 272-327, II. ; Hinsdale, Old Northwest, 147-191; Winsor, Westward Movement, 81-100, 106-224 ; Tyler, Revalution (literary), II. ; Maclay, United States Navy, I. 34-151 ; Johnson, General Washington. 134-281, 325-330 ; Morse, John Adams, 144-223 ; Hapgood, Paul Jones; Thwaites, Daniel Boone, 129-191. See also references to chapter $\mathbf{x}$.

Hart, Source Book, §§ 59-63, - Contemporaries, II. §§ 159-183, 193-208, 211-220, - Source Readers, II. §§ 63-76, 79-91, III. §70; MacDonald, Select Documents, no. 3 ; American History Leaflets, no. 5 ; Old South Leaflets, nos. 43, 97, 98; Caldwell, Territorial Development, 26-48; Moore, Diary of the American Revolution; Riedesel, Letters and Memoirs. See N. Eng. Hist. Teachers' Ass'n, Syllabus, 326-330, - Historical Sources, § 77.

Moore, Songs and Ballads of the American Revolution, 130-138, 150-386 ; Matthews, Poems of American Patriotism, 46-82; Eggleston, American War Ballads, 40-101 ; Philip Freneau, Poems; Trumbull, $M$ 'Fingal ; Campbell, Gertrude of Wyoming; Cooper, The Spy,- The Pilot; Hawthorne, Old News, pt. iii.; S. W. Mitchell, Hugh Wynne; P. L. Ford, Janice Meredith; Henry Morford, Spur of Monmouth; Harold Frederic, In the Valley (Mohawk) ; Simms, Partisan, - Mellichampe, - Scout, - Katherine Walton, - Forayers, - Eutaw (S.C.); J. P. Kennedy, Horseshoe Robinson (Southern Tory); Thompson, Alice of Old Vincennes; Winston Churchill, Richard Carvel (Paul Jones).

Winsor, America, VI. VII. ; Wilson, American People, II. III. ; Lossing, Field Book of American Revolution. 


\section{CHAPTER XII.}

\section{THE CONEEDERATION (1781-1789)}

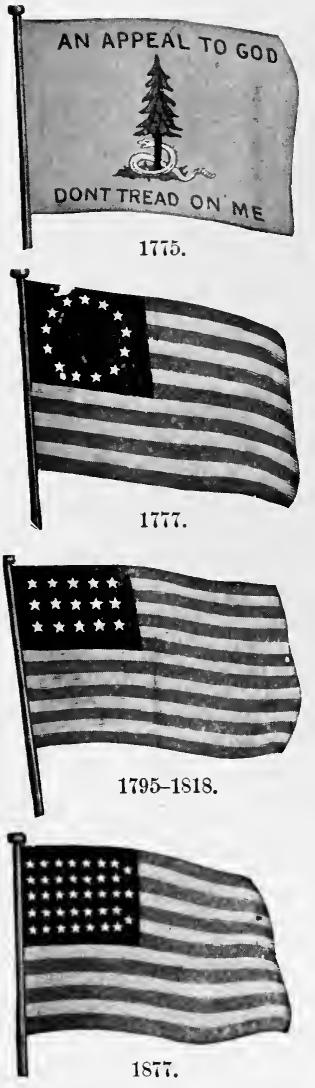

Growth of the Flag.
Many writers have laid stress on July 4, 1776, the date of the Declaration of Independence, as the great turning point of American history; but the date when the Articles of Confederation for148. The Confederation established (1781) mally went into effect-March 1, 1781 — is equally important, for it marks the beginning of a constitutional union. The government was crudely organized into three departments.

(1) Everything was centered in a Congress of delegates appointed by, and responsible to, the state legislatures, each delegation casting one vote. Congress sat always in secret session. Seven state delegations concurring could pass resolutions and ordinances, but on all vital questions nine states had to vote in the affirmative to make a constitutional majority.

(2) The supremacy of Congress made it something like the present British Parliament, for it created all the executive offices, and commissioned all officials, civil and military. Of these the 


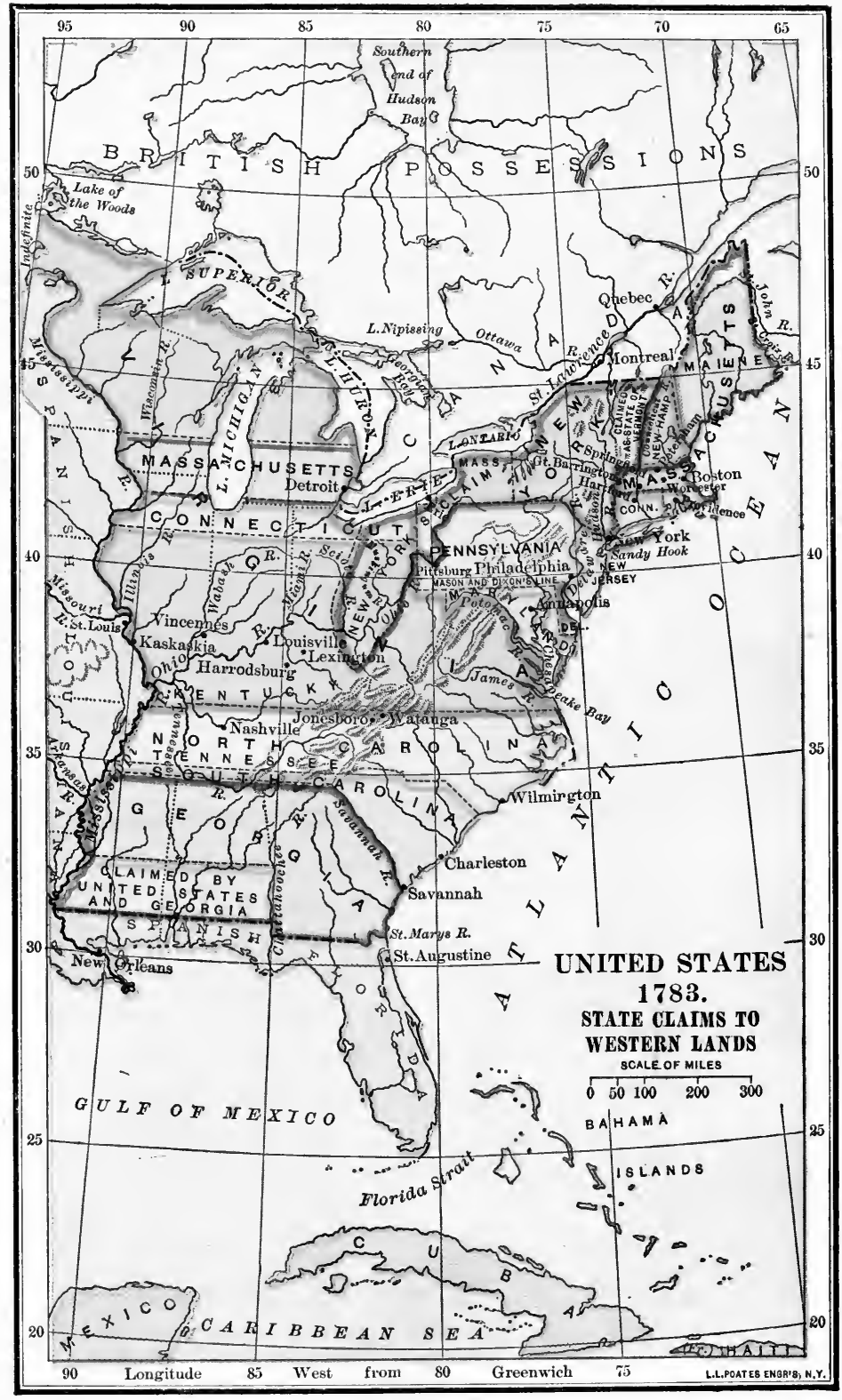


Secretary at War, Superintendent of Finance, Secretary for Foreign Affairs, and Postmaster General were the most important.

(3) In addition, Congress set up what is called the Old Court of Appeals in Prize Cases, which, by the consent of such states as chose to pass the necessary laws, decided cases involving captures of British merchant vessels on appeal from state courts.

In many respects the new Congress much resembled its predecessor, the Continental Congress; but it was much superior in effectiveness: (1) it had a definite constitutional basis in black and white; (2) it had a constitutional right to levy taxes on the state governments in the so-called requisitions, and could borrow money on the credit of the United States; (3) it had a definite status as one of the world's national governments ; (4) it assumed authority in matters of national concern, even though, like the public lands, they were not provided for by the Articles of Confederation.

One of the duties of Congress was to adjust the disputes with the states over the western lands, involving the three questions of state claims, administration of the public 149. Westlands, and organization of new western communities. In the whole process one of the most effective arguments (1781-1784) was put forward by Thomas Paine, in a pamphlet called Public Good, in which he insisted on the right of the whole Union, as the successor of the British government, to control lands hitherto ungranted.

Influenced by such arguments and by the protests of Maryland, the four states which claimed lands north of the Ohio River gracefully yielded. (1) New York ceded all claims west of the present western boundary of that state (1781). (2) Virginia gave up all claims to territory north of the Ohio River, except ownership in the Virginia Reserve Military Bounty Lands (1784). (3) Massachusetts yielded all claims west of New York (1785), and in 1786 gave up to that 
state her claim to govern western New York, retaining ownership of the land. (4) Connecticut, during the Revolution, claimed northern Pennsylvania and the region west of it, under the charter of 1662 , but a decision of a commission appointed by Congress went against her. In 1786 Connecticut ceded her claims to Congress, reserving, however, a strip 120 miles long on the south shore of Lake Erie west of Pennsylvania, as an outlying district of the state, a strip known as the Connecticut Reserve, or the Western Reserve ( $\$ 199$ ).

The claims south of the Ohio River were harder to adjust. (1) To Virginia was left the District of Kentucky, which remained a part of Virginia until admitted as a state in 1792. (2) North Carolina claimed Tennessee, including the Watauga and other settlements, and issued land grants covering the whole tract, but in 1790 she ceded to Congress the right to govern the region. (3) South Carolina, in 1787, gave up her claim to a narrow strip lying between western North Carolina and Georgia. (4) Georgia claimed everything between the present state and the Mississippi River, and did not consent to accept her present state boundaries till 1802.

Long before any part of the disputed lands came under exclusive control of Congress, that body decided to sell them 150. Basis and devote the proceeds to paying the national debt.

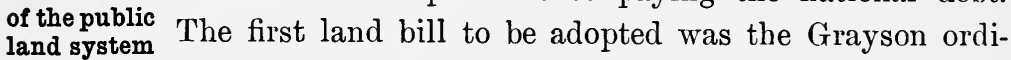
(1785-1788) nance (May 20, 1785), following a suggestion of Jefferson: the western country was to be divided into townships, six miles square, by lines running due north and south, and others crossing at right angles; each township to be subdivided by lines a mile apart into thirty-six sections, one of which was reserved for schools. The price of land was to be a dollar an acre.

To get the land into shape to be transferred, the government sometimes had to drive squatters off with troops; then the states and the holders of bounty land warrants had such quantities to 
sell below the government price that sales could not be made for cash. The government debt was at a distressing discount, and shrewd men hit on the idea of buying land with certificates of debt. The new Ohio Company (p. 195) contracted to buy about $1,500,000$ acres, and took about 900,000. The Symmes Company wanted a million acres, and finally got a quarter of a million, including the site of Cincinnati. The Scioto Company, managed by speculators, undertook to buy three and a half million acres, but never took any. In the year 1788 the state of Pennsylvania bought 200,000 acres - the tri-

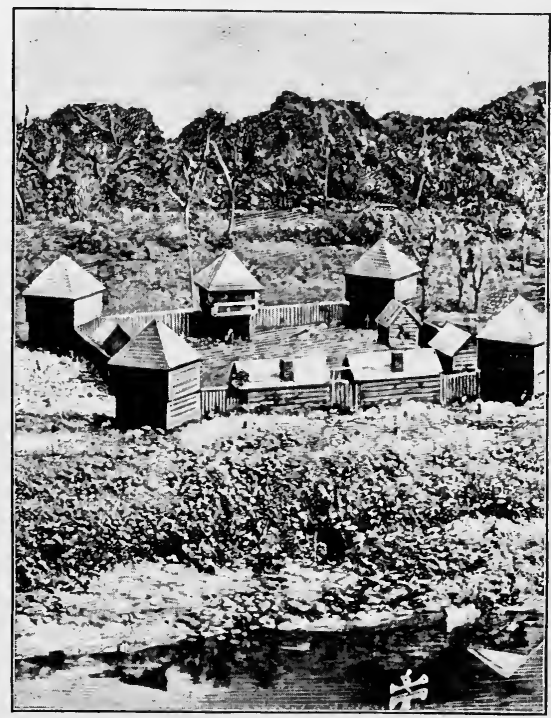

A Frontier Post, 1787. angle of land west of the New York line, which gave a lake front, including the site of the city of Erie.

To settle the new southwestern frontier, a body of hardy people called "backwoodsmen" were pressing on; they were Scotch-Irish, Germans, and people of English descent, but 151. Westthus thrown together they speedily became one people. They took up farms on land patents, or by "toma- (1783-1789) hawk right," blazing trees where they meant to settle. In a few days of hard labor they could build a log house; in a few days more a fort. Their large families grew up and settled more land about them, or they left their farms and again plunged into the far backwoods. Their ordinary dress 
was the fringed hunting shirt and leggings, and their flintlock rifles brought down game or Indians, as it might happen. During nearly thirty years prior to 1800 , the Kentuckians and Tennesseeans were disputing their territory with bold, savage enemies, the Indians, who called their white adversaries "Big Knife" or "Long Knives," and understood forest warfare better than they.

After the Revolution the Southwest filled up rapidly. The Kentuckians in 1784 took steps toward the immediate establishment of a state government, but desisted on Virginia's tacit agreement that she would soon give her consent to the separation. In 1785 a body of settlers in southwestern Pennsylvania and the adjacent part of Virginia asked Congress to adinit them as a state. In the settlements on the upper Tennessee the movement went even further. In 1784 a convention at Jonesboro formally voted to establish a state of Franklin, elected John Sevier governor, chose a legislature, made laws, and defied the jurisdiction of North Carolina. Again a policy of conciliation was followed; and the people returned to their allegiance under the promise that North Carolina would transfer the territory to the United States.

Although Congress had no constitutional authority to make or to grant territories, yet in order to provide a proper govern152. Jeffer- ment for the settlers both south and north of the Ohio, son's ordi- Jefferson drafted a general ordinance, which was adopted
nance (1784)

by Congress in 1784, except (1) that a clause forbidding slavery (after 1800) in all the territories was lost by a single vote, and (2) that Congress did not accept Jefferson's ponderous names for the new states - Pelisipia, Chersonesus, Metropotamia, Polypotamia, and so on.

The ordinance provided for a temporary territorial government, for a representative in Congress (without a vote), and eventually for a legislature, and promised speedy admission as states. Within a few months it looked as though this 
ordinance might be applied to a new colony north of the Ohio. Several Revolutionary officers from Massachusetts, including Timothy Pickering and Rufus l'utnam, organized the Ohio Company of Associates, and applied to Congress for a contract for lands west of the upper Ohio River.

In 1787 Manasseh Cutler, agent of the company, appeared in New York, where Congress was sitting, and obtained, with only one dissenting voice, an ordinance 153. Northbased on the ordinance of 1784 . Cutler wrote, however, "The amendments I proposed have all been accepted except one." The principal points in this great territorial charter, dated July 13, 1787, were as follows: (1) It specifically applied to the Northwest Territory, lying between the Ohio, the Mississippi, and the Great Lakes. (2) The first government of the territory was to be under a governor and three judges, all appointed by Congress; they were to act as a board to select laws for the territory, and the governor was to appoint all local officers; Congress also appointed a secretary. (3) Provision was made for a later representative assembly, with power to choose a non-voting delegate to Congress, and to make laws subject to the governor's veto. (4) Six "articles of compact" were formulated, which were to be forever binding on the new communities. These provided for personal liberty, for religious freedom, for "schools and the means of education," for federal supremacy over the territory, and for the creation of three to five states out of the territory; and added the momentous provision that "there shall be neither Slavery nor involuntary Servitude in the said Territory, otherwise than in the punishment of Crimes, whereof the Party shall have been duly Convicted."

Three months later the first territorial government was established for the Northwest Territory, under the governorship of General St. Clair. Two bodies of colonists sent by the Ohio Company, under the leadership of Rufus Putnam, traveled 
from Ipswich, Massachusetts, passed the river Hudson and crossed P'ennsylvania southwest and then west to Pittsburg;

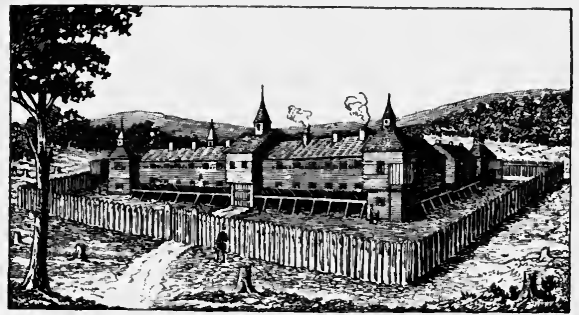

Campus Martius, Marietta.

From the American Pioneer, 1842. and on April 7, 1788, founded the town of Marietta, at the junction of the Muskingum and Ohio rivers (p. 244). A county government and courts were set up, and the Ordinance of 1787 was completely in force.

The western lands, however, brought Congress little money ( $\$ 150$ ), and the finances of the federal government had to be 154. $\mathrm{Fi}$ nances of the Confederation (1781-1784) cared for every year. The only taxes that the Confederation could lay were requisitions on the states, which from 1781 to 1788 yielded about $\$ 3,500,000$ in specie and about $\$ 2,500,000$ in "indents." The half million of specie a year about paid the barest expenses of the government, leaving nothing for interest on the debt. Congress made an effort in February, 1781, to put the finances of the country on a new footing, by appointing as Superintendent of Finance Robert Morris of Philadelphia, a merchant, shipowner, exporter, importer, and banker all in one, who lived in great style, and was then considered the richest man in America.

Morris at once set to work on the accounts and eventually figured out that on January 1, 1784, the United States owed about $\$ 8,000,000$ to foreign countries and $\$ 31,500,000$ to its own people. When, in 1783, the government could not raise enough specie for the accumulated pay of the troops, by using his own credit Morris at last paid the common soldiers; and he issued interest-bearing certificates for the claims of the officers. As a financial aid to the government, Morris persuaded Congress to charter the Bank of North America in 
Philadelphia (December, 1781) - the first joint stock bank in America. Notwithstanding his abilities and his honest purpose, Morris found the task too much for him, and, after less than four years' service, resigned his office.

Congress was troubled also by a controversy over the use of the Mississippi River. After the Revolution Congress made a series of commercial treaties with European powers: 155. Eurowith Holland, with Sweden, and with Prussia. In 1785 pean trade Spain sent over a minister who offered to make a treaty (1782-1788) which was very acceptable to the northern and middle shipowning communities. The United States, however, pressed for the right to navigate the river Mississippi to its mouth without paying duties to the Spanish colony of Louisiana, which stretched across its lower course. This concession Spain absolutely refused, and Congress seemed inclined to accept the Spanish terms; but the people of Kentucky and 'Tennessee protested against barriers to their valuable downriver trade. At this moment the cargo of a North Carolina trader was confiscated at New Orleans, whereupon the property of Spanish traders was seized by Kentuckians. Some of the southwestern people roundly threatened to leave the Union if cut off from the sea, and Washington wrote: "The western states (I speak now from my own obser- ton, Works, vation) stand as it were upon a pirot. The touch of a IV. 63 feather would turn them any way." 'The whole matter was postponed for the time.

Another commercial question was that of trade with England and the British colonies. American merchants were ready to buy almost exclusively in England, as they did before the Revolution. Nevertheless, the British government closed the West India trade to all vessels except British owned and British built (July, 1783); that is,

156. Relations with Great Britain (17831788) Great Britain applied, against the United States, as a foreign country, the same principles of exclusion from her colonial 


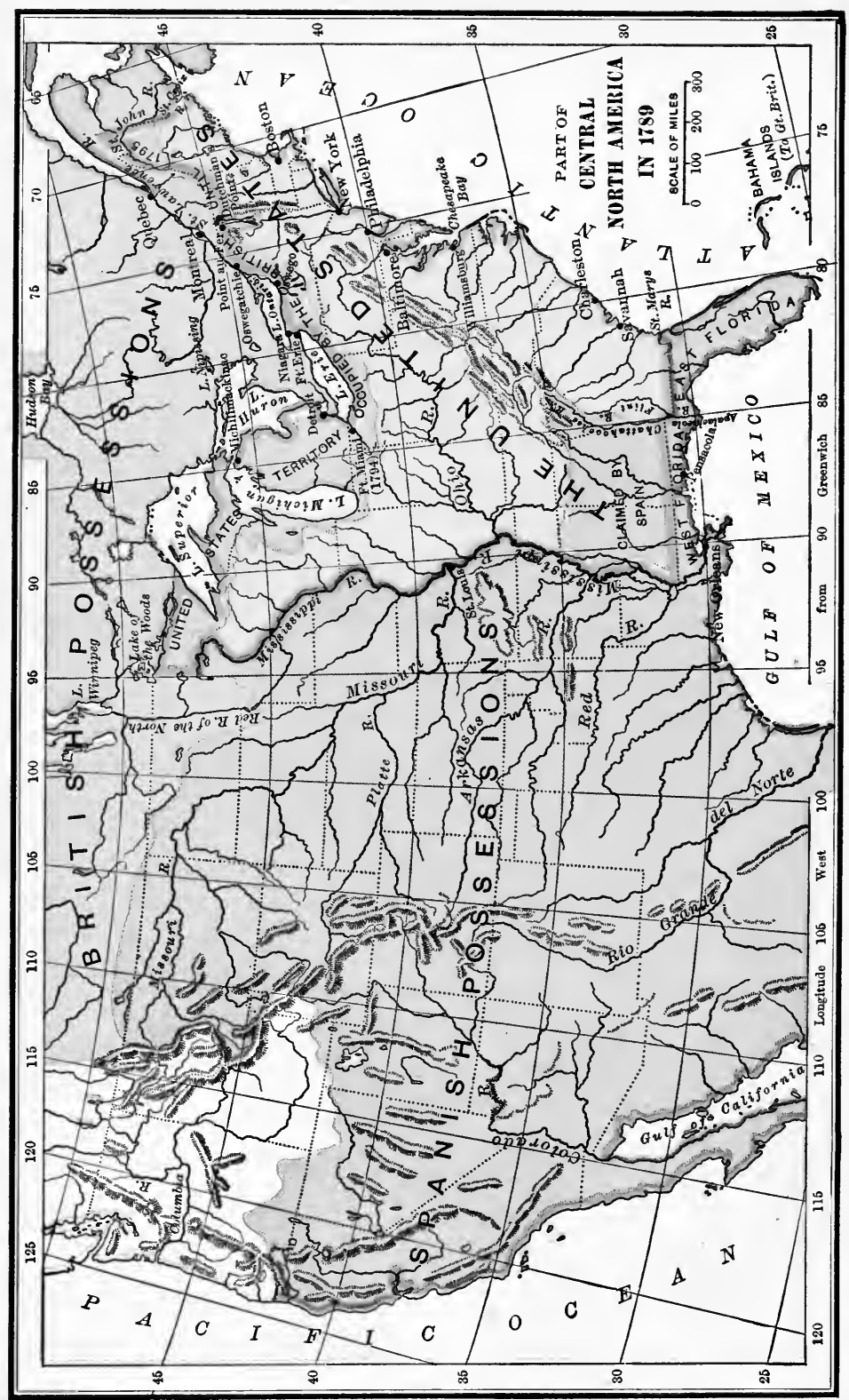


trade which she had for a century applied against France and Spain and other powers. Still, direct trade between Great Britain and the United States went on freely in the vessels of both nations, and the British merchants got most of the American orders; hence Great Britain steadily refused to make a commercial treaty.

Another set of difficulties between Great Britain and the United States arose because each nation charged the other with not carrying out the treaty of peace: (1) several states interfered with suits brought to collect the debts due to British merchants when the Revolution began; (2) the British government was offended because the states refused to receive back loyalists who were eager to accept the new order of things, although this hard and mistaken policy was not forbidden by the treaty; (3) negro slaves were carried away by. the British fleets; (4) the British held on to a line of posts through northern New York and the Northwest in American territory.

In neither foreign relations nor finances could the Confederation compel the states to do their constitutional duty: for instance, Georgia never paid a penny of her quota of requisitions ( $\$ 154$ ) in the whole period from 1781 to 1788 , 157. The states and and Jefferson wrote, "There never will be money in the (1781-1789) Treasury until the Confederacy shows its teeth." One of the serious difficulties in trying to get a commercial treaty with Great Britain lay in the fact that the states had the right each for itself to regulate foreign and interstate commerce. Some of them laid discriminating duties on British ships; others took off discriminations so as to induce British ships to come to their ports. Three states - Massachusetts, New York, and Pennsylvania - adopted protective tariff duties which were applied against their neighbors; and New Jersey retaliated with an act taxing the New York lighthouse on Sandy Hook.

The state acts which most affected neighboring states were HART'S AMER. HIST. -12 
the "Stay and Tender" laws, suspending all suits for debt for six months or a year, or permitting the debtor to offer goods, cattle, or even land in payment of his debts. Ignoring their experience in the Revolution, seven of the states put out issues of paper money, of which a great part was again repudiated; and this bore hard on merchants who had sold goods on credit for specie prices.

For many other reasons people were disturbed and discontented after the war: (1) they bought too much from England

158. Disturbances in the states and found it a long task to pay the bills; (2) taxes were high, or seemed high; (3) there was little specie in the country, and that was a miscellaneous lot of gold and silver coins of all countries; (4) the laws of the time were very severe on poor debtors, and from one end of the country to the other there was a chorus of complaint-much of it justified - that court fees and lawsuits and imprisonment for debt were intolerable hardships.

In many states riots broke out and rose almost to revolutions. Pennsylvania whisky distillers violently opposed an excise on their product. In New York city John Jay was nearly killed while opposing a riot. In New Hampshire an incipient insurrection had to be broken up by troops. The people of Maine, Vermont, Kentucky, and Tennessee all demanded separate statehood. The climax was reached in Shays's Rebellion of 1786-1787 in Massachusetts, which made a great impression on the country. As a protest against numerous suits for debt against the farmers, rioters in Great Barrington, Worcester, and other places prevented the judges from holding court; and then the movement grew rapidly. Early in 1787 Captain Daniel Shays got together about 1800 men and even attacked the United States arsenal at Springfield. State militia was sent to break up the insurrection; when the two forces actually met each other at Petersham, the rebels gave way in confusion, and order was shortly restored. 
Another disturbing element in the American Union was the existence of human slavery. Against this contrast to the principles of political equality and Christian brotherhood, 159. Quesmany voices were raised before the Revolution. Thus tions of John Woolman, a Quaker lay preacher, wrote: “These (1774-1785) are the people who have made no agreement to serve us, Woolman, and who have never forfeited their liberty that we know Journal, 110 of. These are the souls for whom Christ died." In 1775 the first antislavery society was formed in Philadelphia.

So long as all the communities had slaves, the system made no trouble among neighbors: runaway slaves were returned, if they got into another colony or state, exactly like stray horses; and in the Ordinance of 1787 there was a special agreement that fugitive slaves should be returned. During the Revolution the first legal steps were taken against slavery. The slave trade was prolibited by ordinances of the Continental Congress, and by statutes of almost all the individual states, and most of the 3000 negroes who served in the army during the Revolution were set free, with their families.

In several debates in the Continental Congress, however, the North and the South began to show a difference of spirit toward slavery, and this difference came out with great distinctness when five states and one independent community laid the ban of their laws on slavery. (1) Vermont in its constitution of 1777 prohibited the slavery of grown men and women. (2) Pennsylvania in 1780 passed an act providing that all persons born within the commonwealth after the date of the act should be born free. (3) The Massachusetts constitution of 1780 declared that "All men are born free and equal," which the courts afterward held to be a prohibition of slavery. (4) The similar revised constitution of New Hampshire in 1783 had the same effect in that state. (5) In Connecticut and (6) Rhode Island, emancipation acts, similar to that of Pennsylvania, were passed in 1784. 
By the Northwest Ordinance of 1787, freedom was guaranteed in the whole territory north of the Ohio River. In 1799 New York passed a gradual emancipation act; and in 1804 New Jersey followed. Thus was created a solid block of territory from the Atlantic to the Mississippi, north of Mason and Dixon's Line (the southern boundary of Pennsylvania) and north of the Ohio River, in which slavery was dead or dying. From that time on the Union was divided into two sections, having hostile labor systems.

The Confederation was a great advance on any form of 160. De- federal government that the world had ever known; but fects of the Confederation

it was an experiment, and in practice showed several kinds of defects.

(1) Congress was ill organized for its work; often less than the necessary seven states were represented, and for months together the delegations of nine states could not be assembled even for the most important business; and a clause against serving more than three years out of six turned men like Madison and Jefferson and Hamilton out of Congress when they had learned to be useful.

(2) The powers of the Confederation were too weak. It had not full authority to make commercial treaties; it had no power over interstate commerce and therefore could not prevent the states from injuring one another. It had no power to compel the payment of taxes and could raise revenue only by feeble requisitions on the states.

(3) Congress had no means of carrying out its powers. It could not compel individuals to obey; it could not collect its revenue, except through the states; it had no system of criminal law, and no permanent courts to apply its civil laws.

The best men of the time were perfectly aware of the defects 161. Sug- of the confederacy. Three different times did Congress submit to the states constitutional amendments, which (1781-1786) would at least have tided over the trouble. 
(1) In 1781 it asked authority, by the "Five per cent Scheme," to lay a duty of five per cent on imports, the proceeds to go toward paying the principal and interest of the public debt. Twelve legislatures voted for this constitutional ainendment, but since unanimous consent was necessary, the obstinacy of Rhode Island defeated the plan.

(2) In 1783 Congress proposed a "Revenue Plan" by which it might lay specific duties on a very low scale for twenty-five years, the states to appoint the collectors. Again twelve states accepted, but this time New York refused to ratify, and the amendment was lost.

(3) A "commerce amendment," submitted in 1784, was intended to give power to Congress to pass navigation acts against such countries as refused to make commercial treaties. This amendment was ratified by only seven out of thirteen states, and was a hopeless failure.

The most persistent and the most effectual critic of the Articles of Confederation was George Washington, then in retirement.

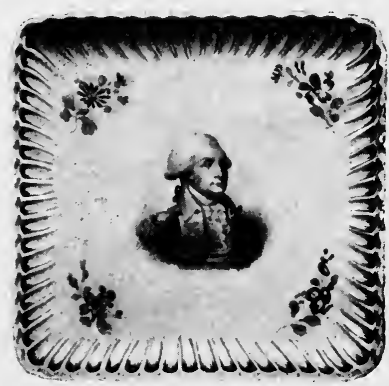
In 1783 he wrote a famous letter to the governors of the states, urging a stronger union. Later he complained that "Thirteen sovereignties pulling against each other, and all tugging at the federal head, will soon bring ruin on the whole." When asked to use his influence for reform, he replied: "Influence is no government. Let us have one by which our lives, liber- 
ties, and properties will be secured, or let us know the worst at once."

After five years of peace, the Union was still in confusion and uncertainty. Congress lost the popular respect and interest 162. sum- and was too clumsy for its own tasks. Almost the only mary thing that it did thoroughly was to organize the western territory, and for that it had no constitutional authority. The British treaties still remained unfulfilled, and Congress could get no commercial agreements with either Spain or Great Britain. Finances went from bad to worse ; Morris, an intelligent and conscientious minister of finance, resigned in disgust, and the creditors of the government at home saw little prospect of payment of their principal. The state governments were weak, disturbed by riots, - some of them by insurrection, and the southwestern frontier settlements threatened to secede from the Union altogether. All attempts to meet these difficulties by constitutional anendments failed, because of the rule of unanimous consent.

Nevertheless, under the Confederation, the country was prosperous: trade increased, towns were built, education advanced. There was plenty of raw strength suitable for a nation, and the very defects of the Confederation proved a lesson of the highest importance, because they taught people what to avoid. We honor the men who made and carried on the Confederation, because they had the good sense to correct their faults in the next attempt to make a national government_- in the Constitutional Convention of 1787.

\section{TOPICS}

Suggestive topics
(1) Basis of New York claims to western lands. (2) Basis of Massachusetts claims. (3) Basis of Connecticut claims. (4) Basis of Virginia claims. (5) Basis of North Carolina claims. (6) Basis of Georgia claims. (7) What were the advantages of the rectan- 
gular survey? The disadvantages? (8) Later territorial subdivisions of the Northwest Territory. (9) First antislavery society. (10) Why was the state of Franklin forned? Why discontinued?

(11) Effect of the nine states rule. (12) Account of the Federal Prize Court. (13) Paine's argument on the public lands. (14) How was the Northwest Ordinance obtained? (15) Was the Ohio Company a paying investment? (16) Jefferson's opinions on slavery. (17) Life of John Woolman. (18) Anthony Benezet's criticisms of slavery. (19) Washington's objections to slavery. (20) Was there danger of the secession of the West in 1786 ? (21) Treatment of returned loyalists by the states. (22) Was there danger of the success of Shays's Rebellion?

\section{REFERENCES}

See maps, pp. 190, 198; Mclaughlin, Confederation and Consti- Geography tution.

Hart, Formation of the Union, §§ 49-54, 56-58; Walker, Making of the Nation, 1-20 ; Channing, United States, 107-122 ; McLaughSecondary authoritics lin, Confederation and Constitution; Fiske, Critical Period, 90216 ; Schouler, United States, I. 12-35 ; McMaster, United States, I. 103-416, 503-524, III. 89-116 ; Wilson, American People, III. 24-60 ; Cambridge Modern History, VII. 305-314; Larned, History for Ready Reference, IV. 2377, 2920, V. 3252, 3280, 3289; Gordy, Political Parties, I. 9-63 ; Curtis, Constitutional History, I. 98-220 ; Winsor, Westward Movement, 22.j-374; Roosevelt, Winning of the West, III. ; Hinsdale, Old Northwest, 192-296, 345350 ; Sparks, Expansion, 81-87, 100-134 ; Dewes, Financial History, §§ 21-25; Locke, Antislavery, 46-87, 112-131, 157-159 ; Morse, Thomas Jefferson, 64-86, - Alexander Hamilton, I. 64154 ; Schouler, Thomas Jefferson, 122-152 ; Gay, James Madison, 1-83 ; Sumner, Robert Morris, 53-138 ; Brown, Andrew Jackson, $1-23$.

Hart, Source Book, §§ 64-67, - Contemporaries, II. §§ 209, Sources 210, III. \$§ 37-5!), - Source Readers, II. \$§ 35,36 , III. §§ 1-3; MacDonald, Select Documents, no. 4 ; American History Leaflets, nos. 22, 28, 32 ; Old South Leaftets, nos. 13, 15, 16, 40, 42, 127; Hill, Liberty Documents, ch. xvi. ; Caldwell, Territorial Development, 53-73. See N. Eng. Hist. 'Teachers' Ass'n, Syllabus, 330-332, Historical Sources, § 78.

E. Bellamy, Dulie of Stockbridge (Shays's Rebellion); R. M. Bird, Nick of the Woods (Ky.).

Wilson, American People, III. ; Sparks, Expansion.

Inlustrative works

Pictures 


\section{CHAPTER XIII.}

\section{MAKING THE FEDERAL CONSTITUTION (1787-1789)}

Tre right way to get a new start was pointed out by Henry Laurens in $\mathbf{1 7 7 9}$ when he asked, "Shall we call forth a grand

163. Preliminaries of the Federal Convention (1779-1787) convention in aid of the great council?" This suggestion of a special constitutional convention was repeated by state legislatures and individuals. Yet the first actual step toward a complete revision of the Articles of Confederation was a convention on interstate trade at Annapolis (September, 1786). So few states sent delegates that the only action was a report, drawn by Alexander Hamilton, proposing that a general convention meet in Philadelphia in May, 1787, to prepare amendments to the Articles of Confederation.

Under this unofficial call some of the states began to elect delegates, and Congress reluctantly issued a formal call for a convention "for the sole and express purpose of revising the Journal of articles of confederation, and reporting to Congress and Congress, the several legislatures, such alterations and provisions Feb. 21, 1787

therein as shall, when agreed to in Congress, and confirmed by the states, render the federal constitution adequate to the exigencies of government, and the preservation of the Union."

When the members of the Convention met and exchanged views, they saw that they must go outside the call of Congress

164. Members of the Convention and frame a new constitution altogether. For such a purpose the Convention was rather clumsy, inasmuch as each delegation cast one vote for its state. This arrangement gave as much voting power to a combination 206 
of five states - Connecticut, New Jersey, Maryland, South Carolina, and Delaware - as to the representatives of twice as many people living in the five states of Massachusetts, New York, Pennsylvania, Virginia, and North Carolina. Rhode Island sent no delegates, the New Hampshire delegation came in late, and Georgia, with a large and fertile territory, commonly voted with the large states, which thus had a majority of one vote on critical questions.

Fortunately the fifty-five gentlemen who at one time or another were members of the Convention included some of the greatest names in American history, among them eight signers of the Declaration of Independence. The heaviest work fell on a few leaders. Benjamin Franklin was old, but as canny as ever. Alexander Hamilton, one of the most impetuous members of the Convention, took too extreme ground and lost influence. William Paterson of New Jersey was the spokesman of the small states, and was ably seconded by John Dickinson, the Revolutionary statesman. The galaxy of the Convention was to be found in the Virginia delegation, which included George Washington; he gave it prestige throughout the country.

The man who did most to harmonize the sharp differences in the Convention was James Madison of Virginia. In 1787 Madison was only thirty-six years old. A graduate of Princeton College, he had seen service in the Virginia legislature and in Congress, where he learned to know the difficulties of the Confederation. He was a studious

165. James Madison, a father of the Constitution man, and before the Convention began sent for all the books that he could find on the history of earlier confederations, and prepared a sort of digest of those books, which he sent to Washington. He also consulted with his friends in Virginia and elsewhere, and drew up the strongly federal "Virginia Plan" as a basis of argument.

At the beginning of the Convention it occurred to Madison that posterity would be interested in the debates; and as 


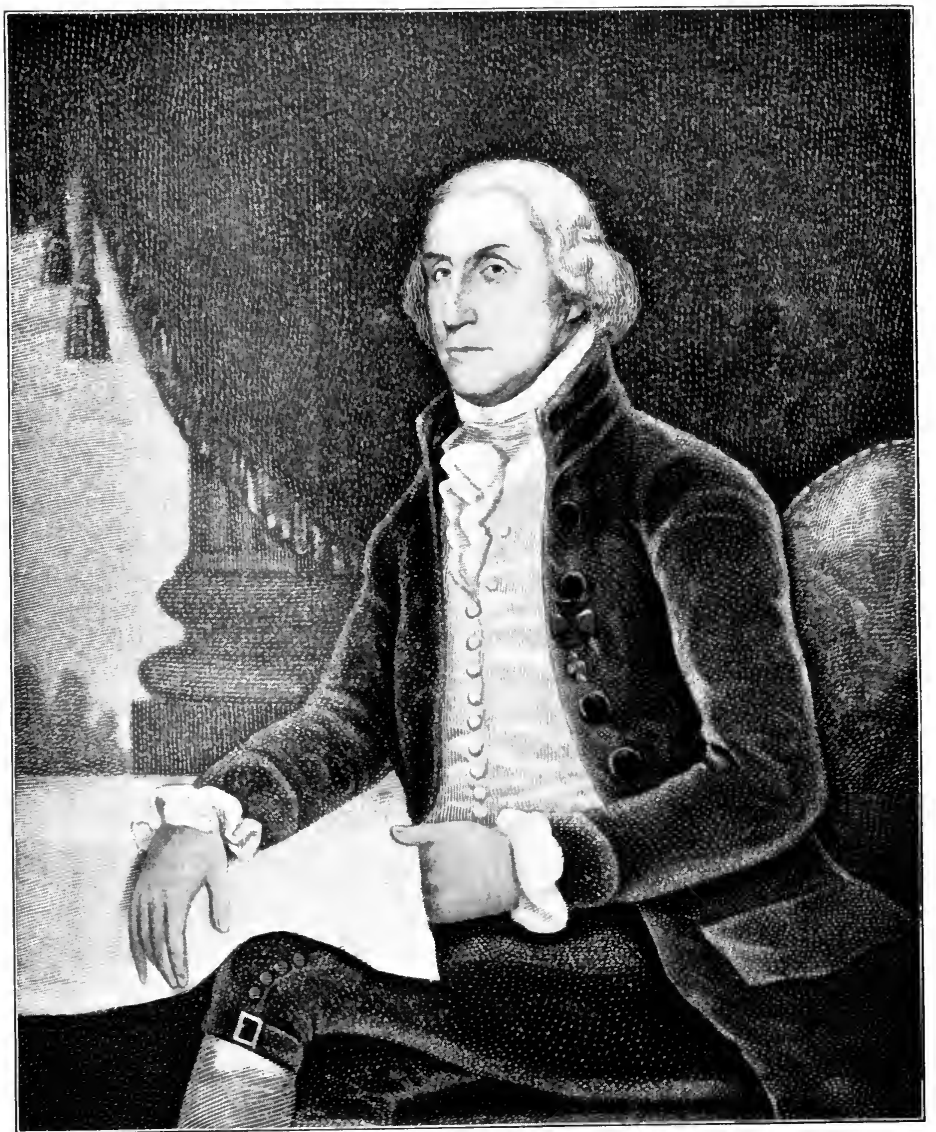

George Washington in 1784.

From Wright's portrait.

there were no reporters, he took down in shorthand an abbreviated or concentrated statement of the debates, which he wrote ont in the evenings and submitted to the speakers. In these discussions Madison himself took part more than fifty times, and throughout he advocated a national government, well knit, strong, and empowered to carry out its own 
just authority. As a representative of the largest and most populous state in the Union, the members from the small states sometimes thought him unfair; but in a quiet and sagacious way he often suggested a middle course, and few things against which he argued were adopted.

For materials with which to put together a new constitution, the delegates simply took the experience of mankind, so far as they knew it. Therefore they based their constitution on the principles of free government as developed in England; yet in its form the new federal government 166. Sources of the Constitution owed little to Parliament, or to the crown, or to the English judiciary; for the Convention took English institutions as they had been modified and expanded in the colonial governments, in the states, in the Continental Congress, and in the Congress of the Confederation. For instance, the two houses of Congress were suggested by the two houses of the colonial legislatures, and also by experience of the clumsy working of a single house in the Confederation. The great merit of the members of the Federal Convention was that they had the sanctified common sense to discard old forms of government that worked ill, and to substitute forms which from their experience they thought would work well.

The Convention was slow in starting, but chose Washington to be its president and settled down to work May 29, when Edmund Randolph, in behalf of the Virginia delegation, submitted a set of resolutions, commonly known as the Virginia Plan. This plan in broad outlines provided for a government of three departments; and next day in its 167. Blocking out the document (May-June, 1787) first formal resolution the Convention agreed "That a national government ought to be established, consisting of a supreme legislature, executive, and judiciary."

To avoid the radical step proposed in the resolution, two other plans were suggested in the course of the Convention: (1) the Connecticut Plan, which proposed to enlarge the powers of 
Congress under the Confederation, but to leave the execution of the national laws to state govermments ; (2) the New Jersey Plan, which stood for the views of the small states; it included three departments, but preserved the equal representation of the states in Congress. Hamilton's Plan, a highly centralized scheme, included a life senate and life president; the state governors to be appointed by the general government. The so-called Pinckney Plan, of which we have no contemporary copy, was much like the constitution as finally adopted. After about two weeks' debate, however, the Convention adopted a set of provisional votes, embodying most of the features of the Virginia Plan, as the foundation of the new constitution. The most serious question at this stage was how to divide members of Congress among the states. The South wanted an assignment in proportion to population, including slaves; the North wanted to leave the slaves out of account. As a midway course, it was provisionally voted to count slaves, but only at three fifths of their actual numbers.

A second debate, from June 19 to July 26, brought out the

168. The great constitutional compromises (June-July, 1787) most serious differences of opinion on four subjects, and set in motion forces which eventually brought about four compromises, the adoption of which made something like agreement possible.

(1) The so-called "Connecticut Compromise" settled the question of representation in Congress. The small states insisted on one house with equal vote of the states; the large states stood out for the Virginia Plan of two houses, with proportional representation in both. So obstinate and bitter were both sides that Franklin feared lest "our projects will be confounded, and we ourselves shail become a reproach and by-word down to future ages." He therefore moved that the Convention be opened every day with prayer. A Connecticut member threw out the suggestion that in one branch the 
people ought to be represented, in the other the states; and this idea was carried out by the first compromise (July 5), providing that there should be an equal vote of states in the Senate and a proportional representation in the House.

(2) A few days later came up the question of assessing federal direct taxes corresponding to the old requisitions : the North proposed that in fixing the proportion of each state, negroes should be counted at their full numbers, whereupon a North Carolina member declared that his state would not go into a union on that basis. The matter was compromised (July 12) by a vote that representatives and direct taxes should both be apportioned according to the three-fifths rule.

(3) It had been agreed that Congress should regulate foreign commerce, but the southern members feared that this power would lead to navigation acts for the protection of American shipping, which might raise the freights on southern exports. Hence Madison introduced a motion to require a two-thirds vote for such an act. On the other hand, the northern states, as well as Maryland and Virginia, were in general strongly opposed to reopening the slave trade. A compromise was arranged (August 25) under which Congress was left free to pass acts in aid of American shipping by the usual majority, but was not to prohibit the slave trade for twenty years. The slaveholding states also secured a clause against export taxes.

(4) A fourth compromise, not so distinctly expressed, fixed the relation of the states to the federal government. The Convention at first voted that Congress should have the right to veto state laws. Later it adopted a substitute clause (July 17) providing for appeals to the Supreme Court of the United States, in case a state infringed on the national Constitution.

A third stage of the Convention began July 26, when the work done by the Convention to that point was summed up in a series of resolutions, which were sent to a Committee of 
Detail. The report of that committee grouped the principles adopted into articles and sections, made many verbal changes, 169. Perfec- and included a few new features, such as the choice of tion of de- President by electors. After debating this report from tails (Aug.- August 7 to September 8, the Convention sent it to a Sept., 1787) Committee of Style, which reported September 13. Gouverneur Morris was the leading spirit in this revision, and to him are due the lucidity of phrase and clearness and exactness of language which distinguish the Constitution.

On September 17 the engrossed draft was presented for signature. Some delegates had gone home in disgust, and three members present - George Mason and Edmund Randolph of Virginia and Elbridge Gerry of Massachusetts - refused absolutely to sign the completed work because it seemed too strong. Thirty-nine of the original fifty-five members, however, representing twelve states, affixed their signatures to the Constitution. Madison records that, at this solemn moment, Franklin called the attention of the members to the sun painted behind the president's chair: "I have," said he, "often and often, in the course of the session and the vicissitudes of my hopes and fears as to its issue, looked at that behind the president, without being able to tell whether it was rising or setting; but, now at length, I have the happiness to know that it is a rising and not a setting sun."

The completed Constitution was founded on a different 170. Analy- set of principles from those of the old Confederation in sis of the form, in powers, in enforcement, and in the status of the
Constitution states.

(1) In its form, the Constitution broke up the old concentrated power of Congress, and created three equal and coördinate departments: Congress, the President and his subordinates, and the federal courts.

(2) The powers of the federal government included all those given to the Confederation, and many others, such as the 
full power to tax individuals, to borrow money, and to expend money. Control over territories was at last expressly given, as well as complete power over foreign and interstate commerce, including expressly weights and measures, coinage, post offices, copyrights, and patents. To the federal government was given unlimited powers to make war on land and sea, by regular forces or militia, to make peace, and to make treaties on all subjects.

(3) Proper means of enforcing these powers were given to the federal government: it makes laws for individuals and can punish them through the courts if they are disobedient; while the Supreme Court has jurisdiction in cases where states are parties, and can hear appeals from the state courts on cases involving the federal Constitution.

(4) The relations between the states and the Union were made much more definite than under the Confederation; and the states deliberately gave up to Congress, the President, and the federal courts, great fields of power - such as foreign commerce and unrestricted taxation. To be sure, several large areas of important powers were not distinctly conferred on Congress : there was no clause authorizing, in so many words, the annexation of territory, or the chartering of corporations, or the creation of a cabinet for the President, or federal control of slavery in the territories, or opposition to secession of a state. Many such unenumerated powers have since been assumed by the federal government because "implied" in the specific articles of the Constitution ( $\$ 197$ ).

To avoid the requirement of unanimous consent for alterations of the constitution, which wrecked the Confederation, the Constitution was to go into effect, as to the states ratifying, when nine state conventions should have ratified it. Though the Convention, as a matter of form, sent the document to the Congress of the Confederation, that body

171. The Constitution before the people (1787-1788) simply transmitted the instrument to the states. The friends 
of the new Coustitution, including many strong members of the Convention, at once began to discuss and to organize. Since the opposition accused them of aiming at consolidation and the destruction of the states, they gave themselves the naine of "Federals," or "Federalists," to show that they favored the proper rights of the states. Their opponents had no better party title than "Anti-Federalists."

Both sides at once betook themselves to the methods of that time for affecting public sentiment on great questions. They wrote elaborate series of letters, published from week to week in the local newspapers over such names as "A Land Holder," "A Countryman," "Cato," and "Cassius." Perhaps the best two series are the letters of "Agrippa" against the Constitution, and a series of essays skillfully defending the Constitution, written by Alexander Hamilton, James Madison, and John Jay, which appeared for many weeks in succession in New York newspapers over the name Federalist, and to this day make up one of the wisest and best discussions of the Constitution.

The fight raged over the Constitution from end to end; in general, in particular, and in detail, it was hotly assailed and strongly defended. The Anti-Federalists predicted that Congress would overawe the states, that the President would prove a despot, and that the courts would destroy liberty, while the Senate would be a stronghold of aristocracy. In one state convention a nember even objected that "if there be no religious test required, pagans, deists, and Mahometans might obtain offices among us, and that the senators and representatives might all be pagans." The point most criticised was the lack of a bill of rights. The Convention had assumed that individual rights were fundamental and could not be taken away by a federation; but the state constitutions all had such bills of rights, and it was a mistake not to include one in the new instrument of government. 
All the states except Rhode Island called the necessary state conventions; and the first contest was in the popular elections for delegates. 'Then came the conventions, which in five 172. Ratifstates had an easy task: though the Pennsylvania con- cation by vention assembled first, Delaware had the honor of $\begin{array}{r}\text { six states } \\ (\mathbf{1 7 8 7}-\mathbf{1 7 8 8})\end{array}$ being first to ratify (December 7,1787 ), and that by a unanimous vote; the great influence of Pennsylvania was thrown into the same scale (December 12 ), by a vote of 46 to 23 ; next came unanimous ratification by New Jersey (December 18),

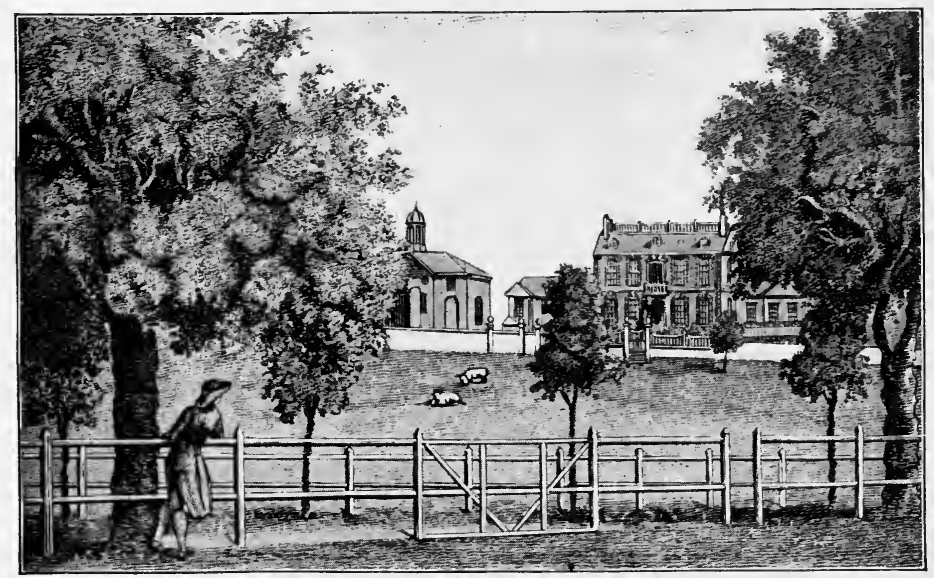

The Hancock House in 1789.

From the Massachusetts Magazine.

and by Georgia (January 2, 1788); Connecticut followed, after a hot discussion, by a vote of 128 to 40 (January 9).

The first dangerous contest was in Massachusetts; for when the convention assembled and elected John Hancock as its president, it was clear that the majority was against the Constitution, for reasons well stated by a country member: "These lawyers, and men of learning, and moneyed men," said he, "that talk so finely, and gloss over matters so smoothly, and make us poor illiterate people swallow down HART'S AMER. HIST. -13 
the pill, expect to get into Congress themselves; they ex. pect to be the managers of this Constitution, and get all the power and all the money into their own hands, and then they will swallow up all us little folks, like the great Leviathan, Mr. President - yes, just as the whale swallowed up Jonah. That is what I am afraid of." The balance of power in the convention was held by its president, John Hancock, who was kept away at first by a convenient attack of the celebrated "Hancock gout." He had to be secured by promising him the governorship and hinting at the presidency of the United States. Yet still there was no clear majority, for the opposition insisted that ratification should include a long list of amendments. As a last resort, the friends of the Constitution agreed that amendments be added, not as a condition, but as a strong suggestion. With all these influences, on the test vote (February $6,1788)$, Massachusetts ratified by only 187 votes to 168 .

The fight in Massachusetts was the crisis of the constitution, for the result had great influence on other states. Maryland 173. Ratifi- ratified by a vote of 63 to 11 (April 28); and South cation by Carolina ratified by a vote of 149 to 73 (May 23); and thirteen states New Hampshire by a vote of 57 to 46 made herself the (1787-1790) ninth state and completed "the federal arch" (June 21).

The Virginia convention supposed that their state would be necessary to make nine. Madison and Edmund Randolph, who had a second time changed his mind, were for the Constitution; and Washington, though not a member of the state convention, threw all his mighty influence in its favor. The strongest opponent was Patrick Henry, who did not shine as a logician. When taxes came to be discussed, he exclaimed: "I never will give up that darling word 'requisition': my country may give it up; a majority may wrest it from me, but I will never give it up till my grave." After the greatest exertions, Madison succeeded in having the long list of proposed amendments made a "recommendation" and not a con. 
dition of ratification; and the Constitution was ratified by the narrow vote of 89 to 79 (June 25,1788 ).

\section{The Ninth PILLAR erected !}

"The Ratification of the Conventions of nine States, thall be fufficient for the eltablifh. ment of this Conftitution, between the States fo ratifying the fame." Art. vil.

INCIPIENT MAGNI PROCEDERE MENSES.

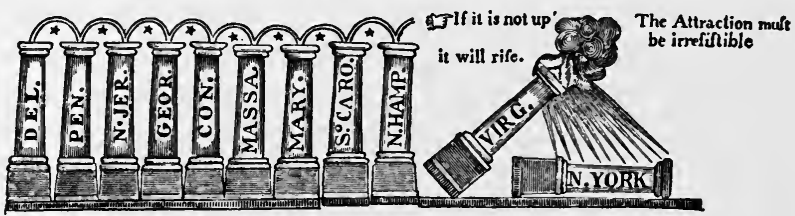

Adoption of the Constitution, 1788.

From the Independent Chronicle.

The New York convention was at first hostile to the Constitution, and Governor George Clinton, the political boss of the state, appeared in the convention to oppose it. Its successful champion was Alexander Hamilton. Again the plan of a conditional ratification was proposed, but finally by the close rote of 30 to 27 New York ratified (July 26, 1788), " in full confidence" that the proposed changes would be made after the new government should be organized.

For some time two states still held off. The North Carolina convention adjourned without taking a vote, but a second convention was called which duly ratified the Constitution (November 21, 1789). Rhode Island at this time called no convention, but was brought to terms later, when Congress proposed to treat it as a foreign nation; and she completed the roll of thirteen ratifying states (May 29, 1790).

The Federal Convention was simply the practical result of the preparation, from 1774 to 1787 , for a strong national government. In the fourteen months from May, 1787, 174. Summary to July, 1788, the nation reaped the fruits of fourteen years of experience of an inadequate government. 
After long discussions the Philadelphia Convention drew up a careful and well-arranged constitution which had to run the gantlet of the state conventions. In three-Delaware, New Jersey, and Georgia - there was no opposition; in fivePennsylvania, Connecticut, New Hampshire, Maryland, and South Carolina - the opposition was easily overcome; in three - Massachusetts, Virginia, and New York - ratification was obtained with the greatest difficulty. Two states, Rhode Island and North Carolina, did not ratify till after the government was in working order.

The acceptance of the Constitution was due to the thinking men, public leaders and business men, of the country, who could not stand the disorder and uncertainty of the Confederation. The creditors of the national and state governments wanted some assurance that they would be paid; the shipowner wanted rights in the ports of other countries; the trader wanted to be able to collect his debts in other states; and far-sighted public men like Washington and Hamilton were tired of the waste of time and effort necessary to make the government go at all. Rightly did John Adams say, "The Constitution was extorted by grinding necessity from a reluctant people."

\section{TOPICS}

Suggestive topics

Search topics
(1) Why did not Congress undertake a revision of the constitution? (2) Why did Rhode Island send no delegates to the Convention? (3) How was the Virginia Plan drawn up? (4) Why did so many members of the Convention withdraw ? (5) Main arguments in favor of the ratification of the Constitution. (6) Main arguments against ratification. (7) Why did the friends of the Constitution resist amendments in the state conventions? (8) What methods brought about ratification of the Constitution? (9) Did the states think that ratification was final, or repealable?

(10) Suggestions of a national constitutional convention, 17811785. (11) Paterson's Plan. (12) A debate in the Federal Convention. (13) Sources of our knowledge of the Convention. (14) History of the Connecticut Compromise. (15) History of the 
slave-trade compromise. (16) Threats of withdrawal, by members of the Convention from small states. (17) Franklin in the Convention. (18) James Wilson in the Convention. (19) The Pennsylvania convention. (20) The Massachusetts convention. (21) The Virginia convention. (22) The New York convention. (23) Patrick Henry's objections to the Constitution.

\section{REFERENCES}

McLaughlin, Confederation and Constitution.

Hart, Formation of the Union, \$§ 60-68, - Actual Government, \$ 24; Walker, Making of the Nation, 21-63; Channing, United Geography States, 122-133; McLaughlin, Confederation and Constitution; Fiske, Critical Period, 216-350; Landon, Constitutional History, 77-124, 211-218; Gordy, Political Parties, I. 64-102 ; Schouler, United States, I. 36-70 ; McMaster, United States, I. 277-281, 389-391, 416-423, 436-503 ; Cambridge Modern IIistory, VII. 243-304; Wilson, American People, III. 60-98; Larned, History for Ready Reference, IV. 2644, V. 3296 ; Curtis, Constitutional History, I. 221-647; Dewey, Financial History, §\$2732 ; Sparks, Men who made the Nation, 153-180; Hunt, James Madison, 87-166 ; Lodge, Alexander Hamilton, 49-82,-George Washington, II. 29-41 ; Pellew, John Jay, 222-234 ; Tyler, Patrick Henry, 298-356 ; Roosevelt, Gouverneur Morris, 108-145.

Hart, Source Book, §\$ 68-70, - Contemporaries, III. §§ 60-75 ; MacDonald, Select Documents, no. 5 ; American History Leaflets, no. 8 ; Old South Leaflets, nos. 1, 12, 70, 99 ; Hill, Liberty Documents, ch. xvii.; Caldwell, Survey, 74-96 ; Johnston, American Orations, I. 39-71. See N. Eng. Hist. Teachers' Ass'n, Syllabus, 332-334; Historical Sources, § 79.

G. F. Atherton, The Conqueror (Hamilton); Francis Hopkinson, Essays and Occasional Writings.

Wilson, American People, III.

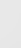




\section{CHAPTER XIV.}

THE AMERICAN PEOPLE FROM 1780 TO 1800

Wнат were the numbers, characteristics, and capacities of the people who made the federal Constitution? The census 175. Popu- of 1790 showed a population of 4,000,000, of whom lation and 80,000 were Indians, 60,000 free negroes, and 700,000 distribution slaves. In the remaining 3,160,000 the English race was predominant in all of the states; there were, perhaps,

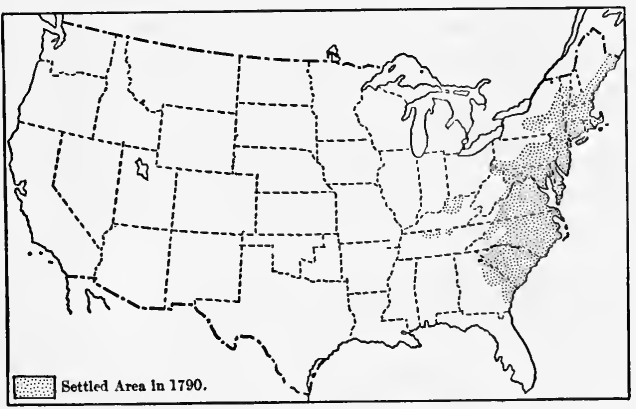

Settled Area in 1790. 200,000 ScotchIrish, chiefly along the frontier, a small but persistent Dutch element in New York, perhaps 100,000 Germans in Pennsylvania and the West, and a small Huguenot element in South Carolina. Over nine tenths of the people lived in the country: in 1790 the only places having a population greater than 8000 were Philadelphia, with about 42,000 people (including suburbs); New York city, with 33,000; Boston, with 18,000; Charleston, with 16,000; and Baltimore, with 14,000. Only about one twentieth of the whole population lived west of the crest of the Appalachians; and Louisville was the farthest town on the Ohio River.

Nearly all the white men in America worked on farms at 
least part of the year, and most of them on their own farms. Northern farmers raised vegetables for their own use, hay for their stock, corn and other grain, in some places hemp and flax, and salted down pork and beef. The most valuable

176. The farmer crop was wheat, cultivated from New England to Virginia, and the basis of a large export of grain and flour. In Maryland and Virginia tobacco was still abundant, while South Carolina raised rice and still a little indigo.

For an example of prosperity, take a French traveler's account of a Quaker family living near Philadelphia. The three daughters, beautiful, easy in their manners, and decent in their deportment, helped the mother in the household. The father was constantly in the fields, where he grew wheat and other crops. He had an excellent garden and orchard, ten horses, a big corn house, a barn full of wheat, oats, and other grain, a dairy, in which the family made excellent cheese. "Their sheep give them wool of which the cloth is made Brissot de Warville, I. 153,155 that covers the father and the children. This cloth is spun in the house, wove and fulled in the neighborhood. All the linen is made in the house."

The farmers for the most part had large families, and hence did not have to hire much labor. There was a good demand for handicraftsmen, shoemakers, harness makers, tailors, and the like. Their wages were in purchasing value only about half what wages are to-day, but every wage earner who had the ambition and enterprise and industry could strike out for himself, by taking up land and starting a farm.

Much of the hard labor was done by slaves. From Pennsylvania to North Carolina they were commonly treated with kindness. In Georgia and in South Carolina, where in 1790, out of 330,000 people, 136,000 were negro slaves, the labor was hard, and there were cases of cruel treatment. The cotton crop was small and of little value, because it took so much time to clear the seed out of the fiber, till in 1794 Eli Whitney, a Yankee 
schoolmaster living in Georgia, patented the cotton gin, a simple machine which could do the work of scores of men. His machine caused the production of cotton to rise from a few hundred bales in 1790 to 600,000 in 1820 . About 1795, sugar was successfully made in New Orleans.

Manufactures, except shipbuilding, were not much developed in America in 1800. A little iron and some steel were made in the middle states, all of it with charcoal. Carpet weaving and broom making had sprung up, and Philadelphia exported from 200,000 to 350,000 barrels of flour every year; this industry was aided by Oliver Evans's recent invention of the endless band elevator.

The shipping trade again became very prosperous after the war, and new avenues of commerce were opened. In 1784 the 178. Trade ship Empress of China made the first voyage to China and industry and brought home the impressive freight of 300,000 solid silver dollars. A profitable direct trade ensued with China, India, and the east coast of Africa. About 7000 men were engaged in the cod fishery, and several thousand in the whale fishery. The fur trade fell off as civilized settlers pushed westward, but John Jacob Astor, a New York merchant, made what was then considered the enormous fortune of over a million dollars, by developing the business in the far Northwest.

As an example of the rich and influential class of American merchants, let us take John Hancock of Boston. He bought ships, sold ships, and chartered ships to carry his cargoes. He bought and sold country produce, and exported fish, whale oil and whalebone, pot and pearl ashes, naval stores (pitch, tar, and turpentine), lumber, masts, and ship timber. He imported dress goods for men and women, manufactures of all kinds, and coal. The Hancock firm also did a banking business, lent money, held mortgages, and placed them for friends, and issued drafts upon their London correspondents. John Hancock had a stately house in Boston (p. 215), built of stone, 
including a ballroom sixty feet in length, with furniture, wall paper, and hangings imported from England. He drove a handsome "chariot," or family carriage. His table on state occasions bore quantities of silver; and he liked to wear crimson velvet suits with white silk embroidered waistcoats.

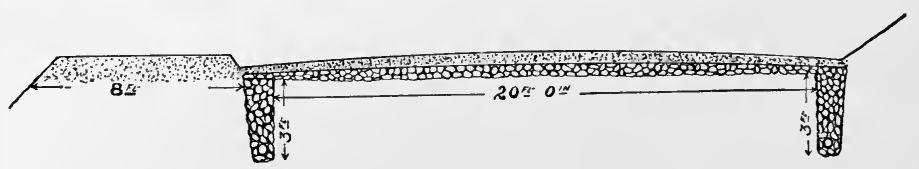

Cross Section of a Turnpike on a Side Hill.

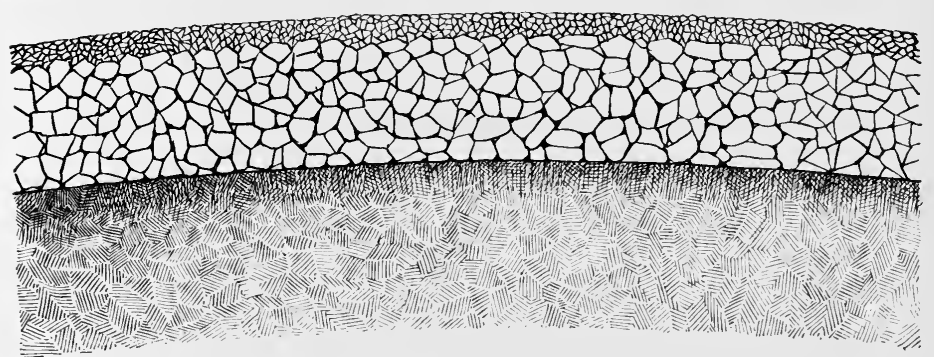

Cross Section of a Turnpike.

Showing arrangement of layers of stone.

Interior commerce was hampered by the lack of roads and interior waterways. About this time there was introduced into England a new method of roadmaking, by which the highway was prepared with a layer of large stones, a foot or more in depth, on which was laid a crowning

179. Means of communication of small, angular stones. Under travel these sharp fragments consolidated, making a smooth, hard surface. Many such roads, often called turnpikes or stone pikes, were built in America by individuals or corporations, beginning with the stretch from Philadelphia to Lancaster (1792; map, p. 291); and large streams were bridged. On such roads and bridges the owners were allowed to charge toll. 
The second half of the eighteenth century was a period of canal building in England, aud the furor spread to America. After the Revolution Washington visited the upper Potomac and Mohawk valleys, and suggested canals by both routes. The governments of Maryland and Virginia thereupon united in a plan for improving the navigation of the Potomac. A little later a traveler named Elkanah Watson formed "the subContempora- lime plan of opening an uninterrupted water communiries, III. 62 cation from the Hudson to Lake Ontario." A few canals were actually built, or begun, from 1793 to 1803 , notably the Santee in South Carolina, the Dismal Swamp in Virginia and North Carolina, and the Middlesex from Boston to Lowell.

Tolerable wagon roads were built about 1790 from Philadelphia, through Bedford in southern Pennsylvania, to Pittsburg; and later from Cumberland on the upper Potomac to the Monongahela River. The so-called Wilderness Road, marked out by Daniel Boone, the only direct overland route into Kentucky, was widened into a wagon track (1795).

To carry on the new enterprises, there was a rapid develop ment of joint stock companies, insurance, bridge, and turnpike

180. New economic factors companies, manufacturing concerns, and especially banks. All these companies had special charters, and the legislatures were beset by demands to grant privileges to new corporations. For manufactures on a large scale, steam power and machinery have long since taken the place of much of the hand labor. It is hard to realize now that, at the beginning of the nineteenth century, for erecting buildings, for making iron or cloth, for all the farm work and transportation, the only motive force was the muscles of men and animals, except a few mills rum by wind, water power, or the tide. In 1800 there was hardly a steam engine in America, and not a power loom.

The making of woolen and cotton cloth was revolutionized about the time of the Revolution by four English inventions: Hargreaves's "spinning jenny" (1767); Arkwright's spinning 
frame (1769); Crompton's mule spinner (1779); and Cartwright's power loom (1785). 'The spinning machinery was introduced into the United States by Samuel Slater of Pawtucket, Rhode Island, in 1790, and thence grew up, the woolen, cotton, and hemp mills of the United States. The power loom was first introduced into the United States by F. C. Lowell at Waltham, Massachusetts, in 1813.

Several other important inventions can be traced back to this period, such as Oliver Evans's power dredge, and Jacob Perkins's nail-making machine. The renowned Yankee industry of clock making was also begun by Eli Terry at Plymouth, Connecticut. The use of steam for propelling ships was suggested by two American inventors. In 1786 John Fitch put a boat on the Delaware propelled by a steam engine at a speed of seven miles an hour ; and in 1787 James Rumsey ran a steam craft of another type on the Potomac River; and Washington predicted that Rumsey's invention would solve the problem of water transportation.

Another proof that America was changing, was a new spirit of humanity and sympathy. Throughout the world in the eighteenth century, social life and the criminal law were saturated with cruelty; the constable beat the vagrant, the master workman beat the apprentice; the farmer beat the indentured servant or maid; the planter beat the slave. The insane man or woman was treated literally as a beast-chained, starved, and flogged. The criminal or the man charged with crime was brutalized in a poisonous and stifling jail, a school of criminals. Americans who won the battles of the Revolution, and the sailors in John Paul Jones's ships, were often half starved and were beaten by their own officers. Debtors might in any state in the Union be lodged in jail and kept there a lifetime for a petty debt.

Such oppression and disregard of one's neighbor were not only contrary to Christianity, but were also opposed to the 
great Revolutionary doctrine of the equality of man, set forth in the bill of rights of every state constitution. Equality was so well carried out that foreign travelers were amazed to see innkeepers sit down with their guests, and military officers chosen by their men. Gradually, for the weak and helpless, benevolent societies began to spring up, and a new sense arose of the duty of the community to all its people. Moreover, this feeling of sympathy and responsibility began to extend to the slaves. Hence 'Thomas Jefferson, born and bred a slaveholder, wrote in 1781: "Can the liberties of a nation be thought secure Jefferson, Notes on Virginia, 237

when we have removed their only firm basis, a conviction in the minds of the people that these liberties are of the gift of God? That they are not to be violated but with his wrath? Indeed I tremble for my country when I reflect that God is just: that his justice cannot sleep forever."

With all the assertions of the right of the many to govern, the United States in $\mathbf{1 7 8 0}$ was far from being a thoroughyoing 182. Amer- democracy. In the New England states, the ministers ican democracy and the merchants were still practically an aristocracy, holding, as John Adams put it, that "the rich and the well born and the able must be separated from the mass and placed by themselves." Even the little New England town meetings were not free from the mastery of the local squire; according to a satirist -

Trumbull, M'Fingal

\section{"Yet at town meetings ev'ry chief}

Pinn'd faith on great M'Fingal's sleeve,

And as he motion'd, all by rote

Rais'd sympathetic hands to vote."

Pennsylvania, New Jersey, and New York farmers were not influenced so much by great family names as by political organizations. The first state nominating convention was held in Pennsylvania in 1788. Two years later Senator Maclay obMaclay, served that in New York "The Sons of St. Tammany had Journal, 260

a grand parade through the town in Indian dresses. ... 
There seems to be some kind of scheme laid of erecting some kind of order or society under this denomination." The Tammany Society did develop within ten years as a political force; but the organization of the New York democracy was in the hands of two rival clans, the Livingstons and the Clintons, who early developed the practice, whenever they got into power, of turning their political opponents out of office.

Alongside the northern, middle, and southern states, grew up a fourth section of the country - the West, which in many ways was different from the older communities. (1) It was the only part of the country in which democracy was real. Out there the only wealth was land, which could

183. Influence of the West be had almost for the asking. Most adult men could vote; and it was hard for them to believe that an experienced statesman could be of greater public service than anybody else who could command a majority. (2) Two systems of navigable waterways intersected the West - the Great Lakes on the north, and farther south the eastern branches of the Mississippi. (3) The West was settled with great rapidity. Its population increased from 110,000 in 1790 to 386,000 in 1800 ; and before 1804 three western states were added to the Union (§199), while only one eastern state was admitted - Vermont (1791).

After the Revolution the opportunities for education rapidly increased in the United States. New England kept up rural schools in hundreds of "district schoolhouses," which took both boys and girls as young as two years old. The teachers were slenderly paid, and were "boarded round"

184. Schools and education from family to family in the district. Most of the towns in the Union had schools, usually supported by fees. In Philadelphia, where such a school was attended by Alexander Graydon, he read Latin fables, learned Roman history, fought the other boys, was flogged by his teacher, and when fourteen years old had read Ovid, Virgil, Cæsar, and Sallust, and was 
reading Horace and Cicero. The formal education of girls stopped in what we should call the grammar grade; but the

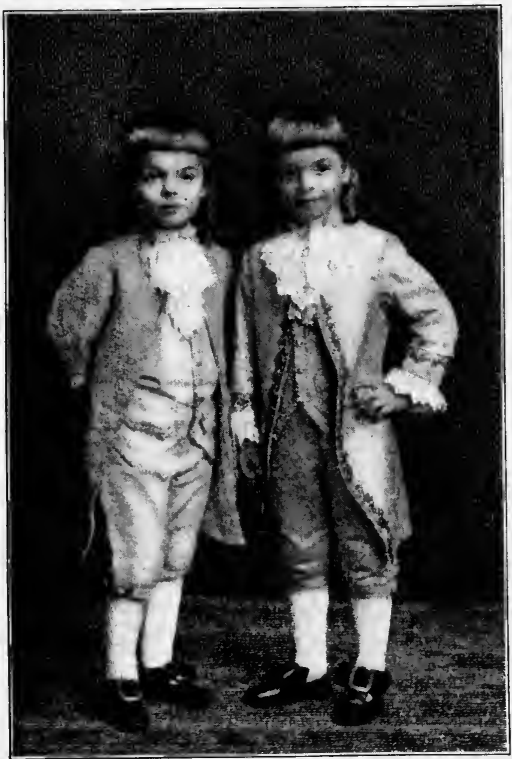

Children's Costume of about 1776.

Worn by the author's children. daughters of cultivated families embroidered, tapped the harpsichord, and read good books, and there were some girls' boarding schools.

For secondary education New England developed a system of endowed academies which spread into the middle states and West. Among them were the two Phillips Academies of Andover and Exeter, and the Lexington (Kentucky) Grammar School. Such a thing as a public high school existed only in a few favored New England towns; but wealthy families throughout the Union often had private tutors for their children. Several new colleges also were founded between 1775 and 1800 ; the University of Pennsylvania was reorganized and put on a collegiate basis (1779); and in 1795 was established the University of North Carolina, the first state institution of the kind. The first professional schools in the United States were two medical schools founded in Philadelphia and Boston.

The United States still had no genuinely national literature, 185. Litera- for most of the authors followed English models and ture and art were very dull. The most admired American poets were Philip Freneau, who wrote stirring patriotic songs during the 
Revolution, and Joel Barlow, whose epic, The Vision of Columbus, is a kind of washed-out Pope's Homer's Iliad. 'The only satirist and essayist of the time who is now much read was Benjamin Franklin, decidedly the most distinguished American author of the eighteenth century. The field of literature in which America excelled was the writings of public men, who furnished a new stock of political ideas to the world. Some of these books are descriptive, like Jefferson's famous Notes on Virginia; others are discussions of public questions, like the Federalist, and Alexander Hamilton's financial reports. George Washington, though he assumed to be only a man of affairs, wrote admirable letters on public questions.

The fondness of Americans for newspapers and periodicals showed itself in the first daily newspaper, the Pennsylvania Packet, founded in 1784. The newspapers were dull; they had no editori-
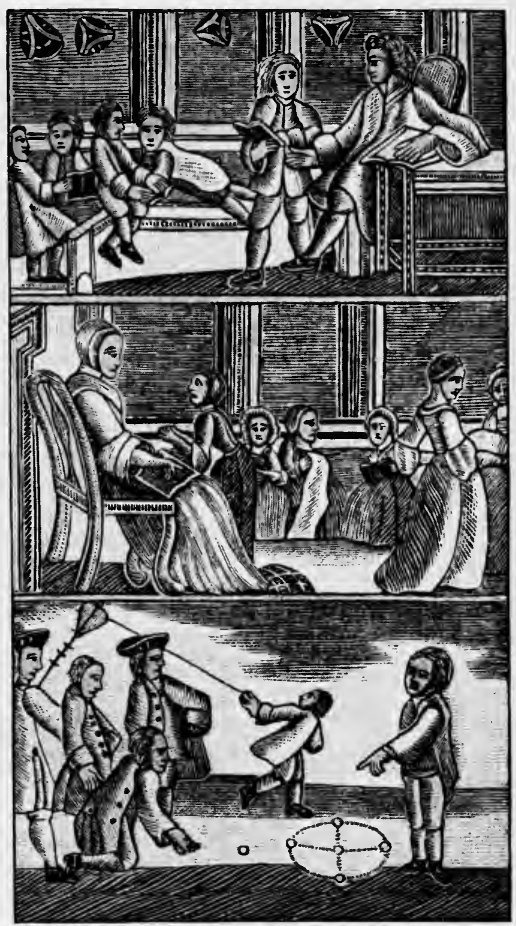

School AND Sport.

From a schoolbook of 1796. als, few advertisements, and filled many columns with reprints from foreign newspapers, and with long-winded essays on politics. Two literary magazines were founded about this time: the Universal Asylum and Columbian Magazine, of Philadelphia, and the Boston Magazine. 
The most notable American art was the architecture of the best houses and public buildings. Residences like the Chew House in Germantown (p. 171), and the Harrison House in Virginia, are still unsurpassed in American domestic architecture; and all over the eastern states are scattered good courthouses and other public buildings, and a few good church buildings of the time: for example, the old South Church in Boston, Trinity Church and St. Paul's in New York, and St. Michael's in Charleston.

Soon after the Revolution most of the great 186. Church churches in Amerorganiza- ica sought national

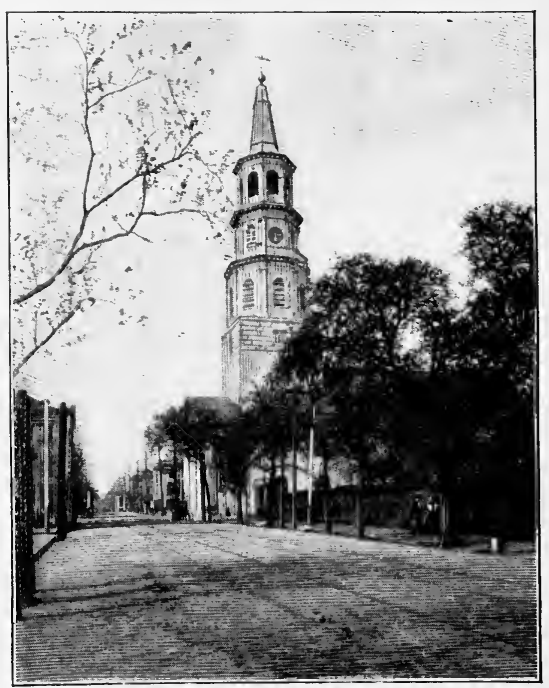

St. Michael's Church, Charleston, BUILT IN 1761.

Type of massive stone church. tion

organization. As a logical result of their theories of republican government, the southern states withdrew their public support of the Episcopal Church. In 1784 James Seabury was consecrated as Bishop of Connecticut at Aberdeen, Scotland; he came over, and in the next year was held the first general convention of the Protestant Episcopal Church in the United States. The Methodist Church, founded by Wesley and Whitefield, began its formal American organization in 1784, when the Methodists summoned a national conference, which adopted the title of Methodist Episcopal and gave to Francis Asbury and Thomas Coke the title of Bishop. The long prejudice against the Catholics softened, and several 
states put them on an equal footing with the Protestants. In 1789 a (atholic bishop was sent over to Baltimore, and thus that church was formally organized in the United States.

Another type of church government was established when in 1789 the Presbyterian local synods united in "the General Assembly of the Presbyterian Church in the United States of America," which has ever since been the supreme governing body of that church. The Dutch Reformed Church of New York and New Jersey, though closely akin to the Presbyterian in doctrine, had a separate synod.

The thousand Congregational churches in New England were nearly all supported by taxation, and each was its own highest tribunal ; for, as in the Baptist Church, no general convention had authority among them. The Quakers also practiced local selfgovernment; and both Quakers and Methodists freely admitted women to take part in their service.

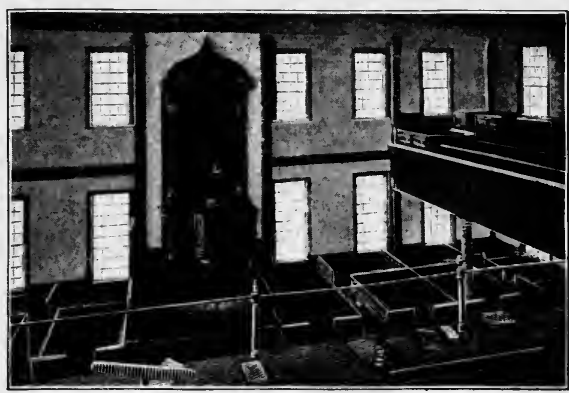

Square-PeWed Church, Salisbury, Mass., BUILT IN 1791.

Type of eighteenth-century meetinghouse.

Among the many other Protestant denominations were the German Lutherans, Moravians, and Dunkards; and the Mennonites, none of whom would take an oath, or fight, or accept office, or go to law. Universalists and United Brethren had a few congregations. The curious communities known as the Shakers were founded during the Revolution by Annah Lee, whom her followers called the Elect Lady, or Mother Ann. The Jews had synagogues in all the large places, but no central organization.

On the frontier, religion was emotional. There was a great HART'S AMER. HIST. - 14 
revival of religion in 1800, and the "camp meeting" was invented in Kentucky.

All the churches enjoyed the greatest religious freedom that had ever been known in the history of mankind. Each denomination chose and ordained its ministers, laid down its doctrine, and disciplined its members in its own way. For the individual there was equal freedom. The federal Con-

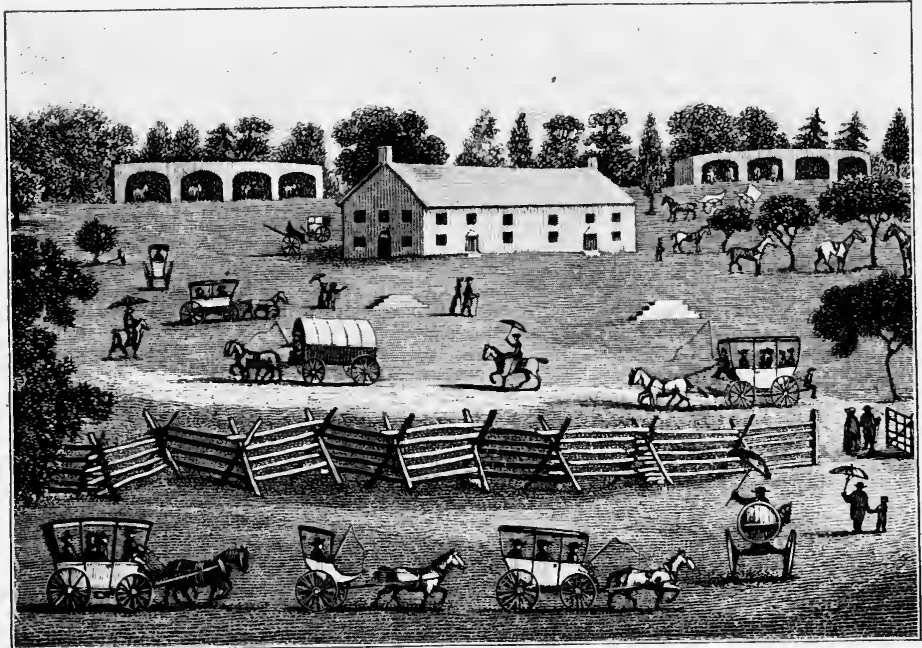

Quaker Meeting, 1809. (From Kendall's Travels.)

stitution of 1787 prohibited any religious test for federal office, and the states in course of time removed most of the religious qualifications both for voters and for public officers.

To describe the American people just after the Revolution is a hard task, because there was no single kind of American 187. Sum- people. The New Englanders were traders, fishermen, mary and independent farmers. The middle states were still half frontier, and the farmers predominated. In the South existed four elements of society : the great planters; the small 
planters, with whom were associated a large number of nonslaveholding farmers; the poor whites; and the negroes.

Yet there was a thorough community of interest among the American people. Almost everybody spoke English; almost everybody was a Protestant; people passed freely from state to state, and easily acquired citizenship. The many callings and occupations depended closely upon one another; the fur trader got the raw skins from the frontier Indians, and the country merchant bought the produce of the neighboring farmers; the city merchant and shipowner carried the goods abroad, and brought back return cargoes of manufactures, which were distributed through the states. The corporations built necessary roads and canals, and provided banks and conveniences for trade. The United States was a country of wonderful opportunities, so that a man might expect to get away from poverty and ignorance if he chose.

The. great characteristic of the American people was their power of organization. They were organizing business, and preparing to make use of coming conveniences of intercourse; they were building highways, accumulating capital, and opening up the unrivaled treasure-house of the West. Above all they were organizing towns, counties, and states - if they could also organize a strong national government, nothing could stay their progress as a nation. As an observer St. John Crèvecceur, Letters of $\boldsymbol{a}$ said, "The American is a new man who acts upon new Furmer, 53 principles; he must, therefore, entertain new ideas, and form new opinions."

\section{TOPICS} (1) What caused the rapid growth of colonial and state popula- Suggestive tion? (2) What did the United States export, 1780-1800? (3) Effects of the cotton gin. (4) What had the United States to sell in China? (5) Why was the Erie Canal suggested? (6) Why did not Fitch's or Rumsey's steamboat succeed? (7) Why was America slow in beginning manufactures? (8) Why were there no Episcopal bishops in America before 1784 ? 
Search topics

Secondary authorities

Sources

Illustrative works

Pictures
(9) Germans in North America up to 1800. (10) French Huguenots in North America. (11) Scotch-Irish in North America up to 1800. (12) Slavery in New Hampshire. (13) Slavery in Massachusetts. (14) Slavery in Connecticut. (15) Slavery in Rhode Island. (16) Slavery in New York. (17) Slavery in New Jersey. (18) Slavery in Penusylvania. (19) Travel on the Wilderness Road. (20) Debtors' prisons. (21) District schools after 1800. (22) College life in 1800. (23) American poetry in 1800. (24) Francis Asbury. (25) Eli Whitney. (26) John Jacob Astor. (27) Samuel Slater. (28) Do you think the Frenchman's experience of a farmer's family ( $\$ 176)$ is typical? (29) Other rich merchants in the United States besides Hancock. (30) The Tammany Society from 1790 to 1820 . (31) A journey about the year 1800. (32) The Wilderness Road. (33) Life on American ships of war.

\section{REFERENCES}

Hart, Formation of the Union, $\S 55,70-72,79$; Sloane, French War and Revolution, 378-388; Walker, Making of the Nation, 64-72 ; Fiske, Critical Period, 50-89; Rhodes, United States, I. 3-27 ; Sparks, Expansiın, 135-187 ; Schouler, United States, I. 112, 221-241 ; Adams, United States, I. 1-184; McMaster, United States, I. 1-102, 423-436, II. 1-24, 57-66, 158-165, 538-582, III. 514-516, V. 268-284 ; Weeden, New England, II. 816-875 ; Locke, Antislavery, 88-111, 166-197 ; Curtis, Constitutional History, II. 231-244 ; Morse, Thomas .Jefferson, 36-50 ; Merwin, Thomas Jefferson, 45-58; Hunt, James Madison, 67-86 ; Ward, Bishop White, 1-89. See also references to chapter vi.

Hart, Source Book, §§ 88, 89,-Contemporaries, III. §§ 10-36, - Source Render's, II. \$\$ 59-62, III. \$§ 4-8, 14-25, 29-33, 72, 100104, 116, 117 ; Old South Leaflets, nos. 65, 126 ; Caldwell, Survey, 132-142; Scudder, Men and Manners in America; Bowne, Girl's Life Eighty Years Ago ; Grant, Memoirs of an American Lady; Graydon, Memoirs.

A. M. Earle, Stage-Coach and Tavern Dreys, - Two Centuries of Costume; J. de F. Shelton, Salt-Brx House, 168-237 ; H. B. Stowe, Minister's Wooing, - Oldtown Folks (N.E.) ; Sophie May, In Old Quinnebasset (N.E.) ; A. E. Barr, Maid of Maiden Lane, - Trinity Bells (N.Y.) ; C. B. Brown, Arthur Mervyn (Philadelphia) ; J. P. Kennedy, Swallow Barn (Va.).

Mrs. Earle's books mentioned above; Sparks, Expansion; Wilson, American People, III. 


\section{CHAPTER XV.}

\section{ORGANIZING THE GOVERNMENT (1789-1793)}

THE federal Constitution laid down the general principles of the government; but the details had to be settled by new laws and customs, so that the work of Congress from 1789 to 1793 was hardly less important than that of the Philadelphia Convention. By vote of the old Congress of the Confederation, a date was set for the first presidential election, and the new Congress was to meet in New York the first Wednesday in March, 1789, which happened to be March 4. For the presidency there was no contest; everybody knew that George Washington would have the first vote of every elector. More of their second votes were cast for Joln Adams than for any one else, and he was thus elected Vice President.

The members of Congress drifted into New York slowly, so that the House was not organized till April 1, 1789, and the Senate not till April 6. Frederick Muhlenberg of 189. ConPennsylvania was elected Speaker of the House, and gressorgan(1789) presiding officer of the Senate. Then the two houses laid down rules for their procedure, and thus made precedents which now have almost the weight of law. The House from the beginning, and the Senate from 1793, have usually sat in open session. Congress voted its members a salary of $\$ 6$, later $\$ 8$, a day while in session, for which a fixed salary was substituted after 1854. All committees at first were chosen by ballot in both houses, but after 1790 the House authorized the Speaker to appoint the committees, a great power which he has enjoyed ever since. Within a few years began to grow 
up a system of standing committees appointed at the beginning of each session.

Meanwhile, the electoral vote having been counted, Washington was notified of his election, and on his arrival from 190. Inau- Mount Vernon was received in New York by thousands guration of of enthusiastic people. On April 30, 1789, he was soldent (1789) emnly inaugurated at Federal Hall on Wall Street, where he took the oath of office, and made a simple and earnest

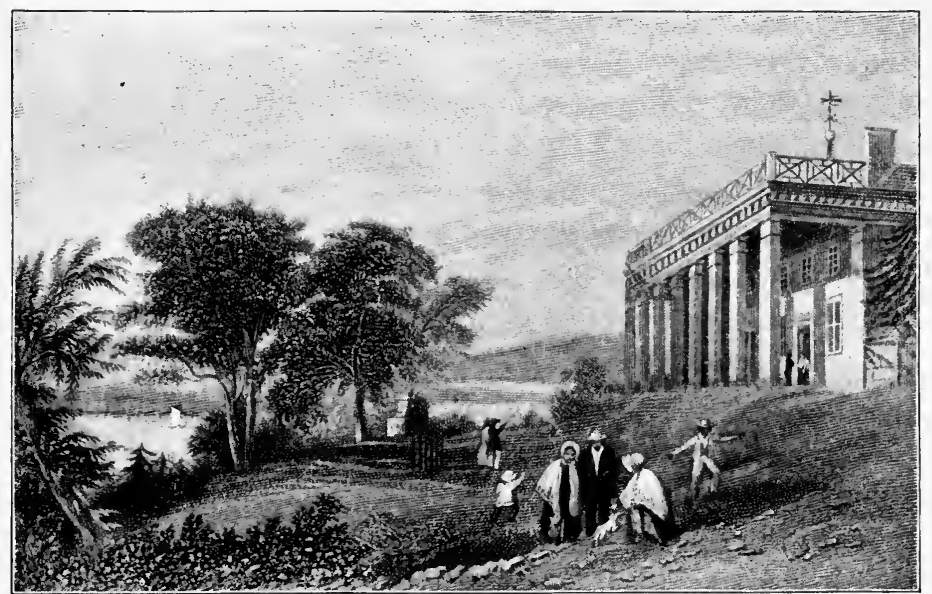

Mount Vernon about 1830.

From an engraving by Stuart.

speech. Congress voted the President $\$ 25,000$ a year, the largest salary then received by any man in the United States. Washington liked becoming ceremony, and it was understood that he approved the proposed title of "His Highness, the President of the United States of America and Protector of their Liberties," though Patrick Henry said of the title that "it squinted toward monarchy." Eventually no title was given by law; so that the official form of address to the President is simply, "Mr. President." 
One of the earliest tasks of Congress was to organize the executive departments, and in its first session it created four. (1) First was the Department of Foreign Affairs, soon changed to Department of State. Thomas Jefferson became the first regular Secretary of State. (2) The War Department was next organized, and Henry Knox

191. Executive departments organized (1789) (Secretary at War under the Confederation) was reappointed Secretary of War. (3) The Treasury was organized in great detail, and the first Secretary of the Treasury was Alexander Hamilton. (4) The former Post Office was continued, and Samuel Osgood was appointed Postmaster-General. All these officers were appointed by the President subject to the confirmation of the Senate. By the casting vote of John Adams in the Senate, Congress established the wholesome principle that the President, who by the Constitution is obliged to see that the laws are faithfully executed, should have the unrestricted power of removing heads of departments and other officers, without the consent of the Senate.

The President at once began to use his constitutional right to call on the heads of departments for written opinions; and he went further by asking the three Secretaries and the Attorney-General (who for many years had no regular department under him) to meet him from time to time and discuss public business. This is the beginning of the unofficial Cabinet, to which the Secretary of the Navy, Postmaster-General, Secretary of the Interior, Secretary of Agriculture, and Secretary of Commerce and Labor have since been added.

Under the wise provision of the Constitution that amendments may be proposed by Congress, about four hundred resolutions of amendment, suggested by states in their ratifications, or later by members of Congress, were boiled down by Congress to twelve amendments, which got the requisite two-thirds vote in both houses and were

192. Amendments to the Constitution (17891791) sent out to the states for ratification. These amendments 
formed a little bill of rights, assuring jury trial, freedom of speech and of the press, etc., against any enactment by the federal government, and including in the Tenth Article the important clause that "The powers not delegated to the United States by the Constitution, nor prohibited by it to the States, are reserved to the States respectively, or to the people." Ten only of the twelve propositions secured the necessary ratification by three fourths of the states and became part of the Constitution (1791).

The Constitution provides that there shall be a Supreme Court and inferior courts, leaving it to Congress to settle the 193. Courts details. By an act (September 24,1789), most of which organized is still in force, Congress created three kinds of courts (1789-1793)

- district, circuit, and supreme - and two kinds of judges - district and supreme. Ordinary cases, involving federal law, could be brought in the District Courts, appealed to the Circuit Courts, and thence to the Supreme Court. Appeals could be taken from the highest state courts to the federal Supreme Court in cases involving federal law. Thus all suits turning on federal law might finally be brought before the Supreme Court of the United States, so that there might be one highest authority on federal law throughout the country.

The President at once appointed John Jay of New York to be Chief Justice. The first Supreme Court case which attracted much notice was Chisholm vs. Georgia in 1793, in which the court gave a judgment against the state. To prevent such suits against a state by citizens of another state or of a foreign country, the Eleventh Amendment was at once proposed, and speedily added to the Constitution.

The center of American social and political life was Phila-

194. Seat of government (1789-1790) delphia, seat of Congress during most of the Revolution. While the British were in Philadelphia Congress sat in York, Lancaster, and Baltimore; and after Congress was insulted in its own hall by mutinous soldiers in 1783, it 
sat in Princeton, Trenton, Annapolis, and New York, but did not select any of them as the permanent seat of government. The location of a capital therefore came up again in 1789. A Pennsylvania member spoke for Wright's Ferry (Columbia, Pa.), and praised the fish of the Susquehanna; but a Georgia member, who did not like to travel so far, Annals of retorted, "This . . . will blow the coals of sedition and Congress, $\boldsymbol{I}$. endanger the Union. . . . This looks like aristocracy." And a New England member said "he did not dare to go to the Potomac. He feared that the whole of New England would consider the Union as destroyed."

When the matter came up again in 1790 , it was tangled with a proposal that the federal government assume the outstanding state debts, which all the southern members opposed and all the New England members favored. Hamilton, as a northern man, appealed to Jefferson, over whose dining table an agreement was reached that the Virginia members would vote for assumption, if Hamilton would find the votes necessary to fix the capital on the Potomac; and by this compromise (it would be called a "deal" nowadays) both measures were passed. Eighteen million dollars was distributed impartially among the states; and the capital was fixed for ten years at Philadelphia, and then in a district ten miles square to be selected by the President on the Potomac River. This was the origin of the District of Columbia.

To Alexander Hamilton the present government of the United States owes almost as much as to Madison or to Washington; for he had the genius to think out methods of organizing the new national government. Hamilton was born in the island of Nevis in the West Indies (1757), and was educated at King's College, now Columbia University. When the Revolution broke out, he be-

195. Alexander Hamilton, the federal financier (1789-1793) gan to write patriotic pamphlets, then joined the army, and attracted the notice of Washington, who never ceased to love 
and admire him. He sat in the Congress of the Confederation for a time (1782-1783), but a friend said of him that he was not Hamilton, "adapted to a council composed of discordant materials. Hamilton, or to a people which have thirteen heads." He was a II. 241

famous lawyer, but his genius was especially fitted to finance, and it was a national blessing when, in September, 1789, at thirty-two years of age, he was appointed Secretary

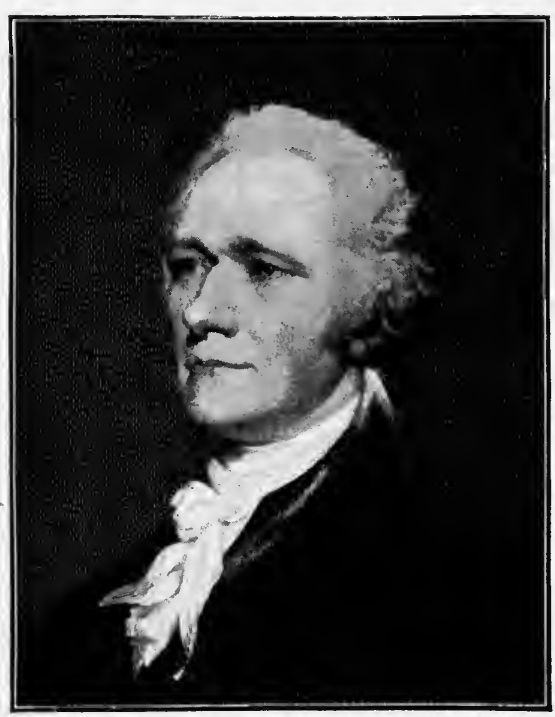

Alexander Hamilton.

From the portrait by Weimar. of the Treasury.

It was a discouraging post. Hamilton found a debt of $\$ 52,000,000$ and no money in the treasury; the accounts were in confusion; the old paper-money notes were repudiated; and few seemed to expect that the federal government would ever pay its bonded debt. Between January, 1790, and January, 1792, Hamilton issued a series of five reports on the finances of the country: on Public Credit, on Manufactures, on a Bank, on Currency, a second Report on Public Credit. In these reports he developed a system of national finance, which he pushed with such force and statesmanship that he induced Congress to accept every one of the following plans:-

(1) Import duties were to provide for the interest on the public debt. (2) An excise on the manufacture of whisky would raise additional money and would make the western 
people understand that they had a government. (3) The debt of the United States was to be funded in one kind of obligations, and the government was to assume the state debts, so as to interest the capitalists in the success of the govermment and raise the credit of the United States for future needs. (4) A national bank was to perform the government business and furnish a safe currency. (5) Protective import duties were to encourage and build up home manufactures.

The first tariff act became a law before Hamilton came into office; and the debate on it contained nearly all the arguments of the twenty and more tariff debates that have followed. 196. NaManufacturers petitioned Congress for protection; Penn- tional sylvania wanted to protect "our infant manufactures"; $\begin{array}{r}\text { commerce } \\ \text { come and }\end{array}$ South Carolinians thought protection "big with oppression"; midway men were willing to lay duties to encourage young industries, and manufactures of military material. The result of these discussions was the first tariff act (July 4, 1789), which was then thought to be protective; specific duties were laid on about thirty articles, and on other articles ad valorem duties ranging from $7 \frac{1}{2}$ per cent to 15 per cent. The average rate of duty was only about $8 \frac{1}{2}$ per cent - the lowest in our federal history. Later, at Hamilton's suggestion, the import duties were raised a little, and an excise was laid on whisky (March 3, 1791), amounting to 7 or 8 cents a gallon.

The question of the national debt was settled just as Hamilton wished. Some people wanted to take account of the fact that many owners of certificates of domestic debt had bought them at a depreciation; but Hamilton carried his point of paying them in full to the actual holders, on the ground that if the government ever wanted to borrow money, it must issue securities that would easily pass from hand to hand. In a few months the surprised holders of government bonds began for tine first time to receive regular interest on their holdings, and the securities of the United States rose to par. 
Hardly less important than the financial improvement of the country was the reorganization of business. Under its power to regulate coinage, Congress passed an act (April 2, 1792) establishing a United States mint, at which any possessor of gold or silver could have it coined into gold or silver pieces without charge for the stamping. The act also established the ratio of fifteen to one between gold and silver; that is, $\$ 15$ in gold weighed as much as $\$ 1$ in silver. As neither gold nor silver was then produced in the United States in any quantity, the actual coinage was very small for many years.

Under the new power over foreign commerce, Congress passed a navigation act (July 20, 1789), laying a discriminating tonnage duty in favor of American-built and Americanowned shipping; and provided for the national registration of vessels and for public lighthouses. A little later, all foreign vessels were excluded from the coasting trade.

The most far-reaching commercial act was the charter of the United States Bank (February 25, 1791), which Hamilton con197. The sidered the crowning part of his whole system. It had United States Bank

(1791) a capital of $\$ 10,000,000$, of which the United States government owned a fifth. In the conditions of that time, this was as remarkable as a bank with a capital of a thousand millions would be to-day. The bank was expected to receive deposits; to hold most of the government balances; to make loans to business men; to put out paper notes and hold "reserves" of gold and silver in its vaults; to pay its notes on demand; and to act as the agent of the government. The real object of the bank was much deeper; Hamilton wanted to teach the business men of the country that their welfare and prosperity would be aided by a great federal corporation.

Hamilton found the constitutional authority in the clause of the Constitution which gives Congress power to pass acts that are " necessary and proper for carrying into execution the ... powers vested by this constitution in the goverument of 
the United States." Jefferson sent a written opinion to the President, in which he argued that the bank would not be constitutional, because Congress had no express power to charter a corporation; and that the bank was not "necessary and proper," since all its services to the government could be performed in some other way. Hamilton's answer was that Congress had the "implied power" to carry out its express powers through a corporation, if that would do the work better; and that "necessary and proper" did not mean "indispensable," but "suitable." All the northern votes except one were in favor of the act. Washington signed it, and twentyeight years later the Supreme Court adopted Hamilton's doctrine of implied powers, and it is now constantly used in the legislation of Congress. The bank was at once organized, with head office in Philadelphia and eight branches in other cities, and proved a safe and prosperous concern.

Congress early began to use its new powers over the territories. To prevent the settlers from pressing upon the Indians, Congress passed acts shutting out from trade or sojourn in the Indian lands everybody who had not a license from the President. On the other hand, a series of new Indian

198. Western Indians (1789-1795) treaties were negotiated and ratified by the Senate, for the cession of lands to accommodate white settlers. Nevertheless, Indian war burst out in the Northwest Territory in 1789, and the next year forces under General Harmer were twice defeated. General St. Clair, governor of the Northwest Territory, set out to build a chain of forts from the Ohio to Lake Erie; and in a pitched battle with the Indians at the site of Fort Recovery (November 4, 1791) he lost a thousand out of his fifteen hundred men. Washington's private secretary records the President's emotion when the news came: "And yet to suffer that army to be cut to pieces, hacked, butchered, tomahawked by a surprise - the very thing I guarded him against! O God, O God, he is worse than a murderer!" 
"But," he added, recovering himself, "General St. Clair shall have justice!"

Anthony Wayne, who was now put in command, built frontier posts, and thoroughly thrashed the Indians at the Falls of the Maumee, and made possible the treaty of Greenville (1795), by which the Indians gave up the territory now composing southern and eastern Ohio. In Georgia Indian wars broke out in 1793; but the United States stood by its right to control and negotiate with the tribes, and make treaties for land cessions.

Meanwhile settlers began to pour into the Northwest. Virginia opened up her reserve of Military Bounty Lands 199. Settle- north of the Ohio. Then followed new communities ment of the near Chillicothe on the Scioto, and at Losantiville, now (1789-1800) called Cinciunati. Along Lake Erie settlement began about 1795, when Connecticut sold the greater part of the Western Reserve to the Connecticut Land Company. General

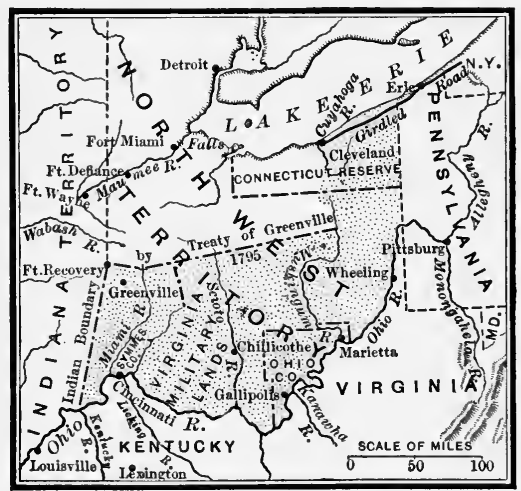

The Northwest in 1800.

Showing territory ceded by treaty of Greenville. Moses Cleaveland, agent of the company, in $\mathbf{1 7 9 6}$ founded at the mouth of the Cuyahoga, on Lake Erie, the city now called for the founder, Cleveland. Next year the "Girdled Road" was made from the Pennsylvania line along the lake to Cleveland. In 1800 the state of Connecticut ceded to the United States all jurisdiction over the Reserve, so that the lake and river settlements might be united into a new state. Indiana Territory was immediately set off, and in 1802 the 


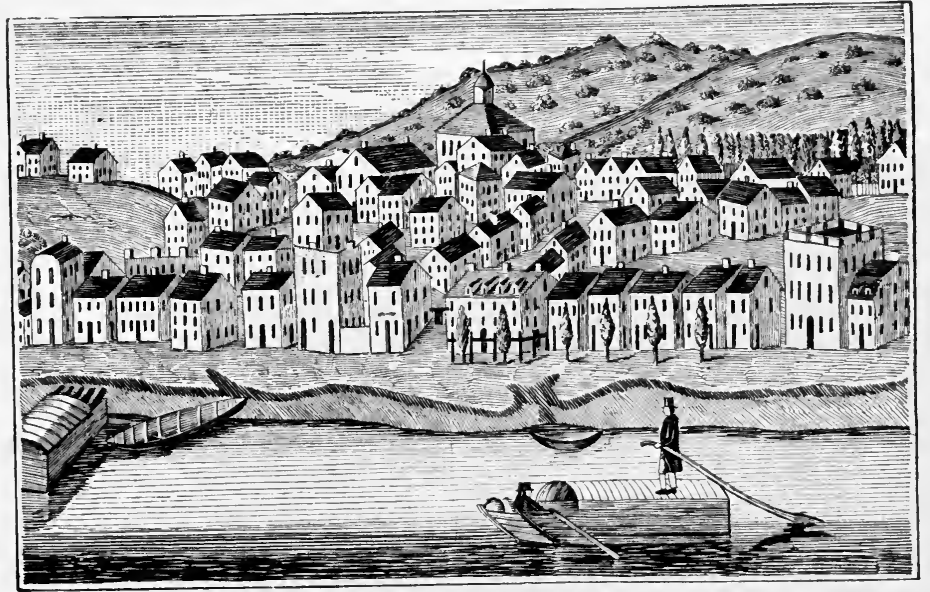

Cincinnati in 1810.

From Howe's Historical Collections.

people of Ohio were authorized to form a state government, and were duly admitted to the Union the next year.

Congress provided for the southern region by an act (1790) organizing the "Territory South of the Ohio River," which six years later was admitted into the Union as the state of Tennessee; it was preceded by the admission of Kentucky in 1792. Still farther south the boundary controversy with Georgia continued (pp. 190, 192); but Congress created the Mississippi Territory out of a part of the disputed land (1798), and four years later Georgia ceded everything west of her present boundary, and the long controversy as to western lands was ended.

Till about 1793 there were no national political parties, for the Anti-Federalists disappeared soon after the Constitution was adopted, and hardly a man in the country any longer criticised the Constitution. The first division on living issues came about in Washington's Cabinet, 200. Germs of political parties where Jefferson says that he and Hamilton from day to day 
attacked each other "like cocks in a pit." The two men and their followers absolutely disagreed on the cardinal questions of the nature of government. Hamilton and his friends believed that the opinion of the educated and property-holding classes must always be the best for the ignorant and the poor. He is said to have remarked once at a dinner: "Your people, your people, sir, is a great beast." The other side was represented by Jefferson, who counted himself among "those who identify themselves with the people, have confidence in them, cherish and consider them as the most honest and safe, although not the most wise depository of the public interest."

Hamilton and his friends believed further that it was the duty of government to encourage private enterprise, and to that end laid down the principle of "loose construction," or "implied powers." Jefferson's theory of "strict construction" of the Constitution was that government ought to do as little as possible, that it ought to lay taxes only for absolutely necessary expenses, and that the development of the country ought to be left to individuals. On almost the same day (in May, 1792) Hamilton wrote that Madison and Jefferson were at the head of a "faction decidedly hostile to me, ... and dangerous to the Union, peace and prosperity of the country"; and Jefferson described Hamilton and his friends as "Monarchical federalists." In the election of 1792, though there was not a vote against Washington, there was a strong and almost successful attempt to displace Adams as Vice President; and thenceforth one body of men throughout the country took on the party name of Federalist, and the Jeffersonians called themselves Democrats.

For about three years, from 1789 to 1792 , the friends of 201. sum- the Constitution had the opportunity of showing how it mary would work; they got a large majority in Congress, elected Washington to be President, and framed organizing 
legislation which was in harmony with the work of the Convention. The reorganization of finance and commerce was the next great national task. The genius of Alexander Hamilton rendered an inestimable service to the country, for he could look forward into the future and see the probable outcome of his plans; and such was the confidence of the business interests of the country in him that he carried all his measures through.

Against the doctrine that it was the duty of the national government to make the country prosperous, Jefferson and his friends fought vigorously; and before the end of Washington's first administration appeared the elements of two political parties, which were bound to oppose each other on all grave questions, and which intended to fight each other in the national elections. The reëlection of Washington in 1792 postponed, but could not prevent, the coming of strict party government.

\section{TOPICS}

(1) Why did the first Congress meet in New York? (2) Are secret sessions of the Senate desirable? (3) Who have been Suggestive topics the great Speakers of the House? (4) Why are there standing committees in Congress? (5) Who have been the great Secretaries of State? (6) Who have been the great Secretaries of the Treasury? (7) Who have been the great judges of the Supreme Court? (8) Why should the President remove officers without the consent of the Senate? (9) Why were the first ten amendments to the Constitution necessary? (10) Jefferson's political principles from 1781 to 1791 . (11) Was Hamilton a monarchist?

(12) John Adams as Vice President. (13) Life in the first Congress. (14) History of the Eleventh Amendment. (15) HamSearch topics ilton's share in fixing the place of the national capital. (16) Opposition to Hamilton in Congress. (17) Debate on the first national tariff. (18) Objections to the first United States Bank. (19) Later discussions of "implied powers." (20) Jefferson's opinions of Hamilton. (21) Hamilton's opinions of Jefferson. (22) Foundation of Cincinnati. (23) Foundation of Cleveland. (24) Foundation of Buffalo. (25) The Yazoo land dispute. 


\section{REFERENCES}

Geography

Secondary authorities

Sources

Illustrative works

Pictures
See maps, pp. 11, 198; Semple, Geographic Conditions, 75-92 ; Bassett, Federalist System.

Hart, Formation of the Union, §§ 73-82; Walker, Making of the Nation, 73-114 ; Channing, United States, 133-147 ; Johnston, Politics, 19-29 ; Stanwood, Presidency, 20-41 ; Bassett, Federalist System; Wilson, American People, III. 98-128; Gordy, Political Parties, I. 103-158; Schouler, United States, I. 70-220 ; McMaster, United States, I. 525-604, II. 24-57, 67-89, 144-154, III. 116-123 ; Dewey, Financial History, §§ 34-52 ; McDougall, Fugitive Slaves, \$§ 16-19 ; Hinsdale, Old Northwest, 296-313, 368-388 ; Roosevelt, Winning of the West, IV. 1-100; Winsor, Westward Movement, 375-574 ; Foster, Century of Diplomacy, 103-135 ; Lodge, George Washington, II. 41-123, 218-237, 304-395, - Alexander Hamilton, 83-150 ; Ford, True George Washington; Morse, Thomas Jefferson, 87-129 ; Schouler, Thomas Jefferson, 153-169; Hunt, James Madison, 167-212.

Hart, Source Book, §§ 71-73, - Contemporaries, III. \$§ 76-89, - Source Readers, III. \$§ 57-61 ; MacDonald, Select Documents, nos. 6-12 ; Old South Leaflets, nos. 10, 74; Ames, State Documents on Federal Relations, no. 1, pp. 1-15; Maclay, Journal. See N. Eng. Hist. 'Teachers' Ass'n, Syllabus, 334-336, - Historical Sources, § 80 .

Cooper, Pioneers ; J. I. Allen, Choir Invisible (Kу.); E. E. Hale, East and West (Northwest Territory); J. K. Paulding, Westuard Ho! (Ky.).

Wilson, American People, III. 


\section{CHAPTER XVI.}

\section{FEDERALIST POLICY (1793-1801)}

HARDLY was the new federal government in operation when it was drawn into the confusion resulting from the revolution in France which began in 1789. In September, 202. The 1792, France was declared a republic ; soon after, King French revLouis XVI. was executed by his people (January 21, (1789-1793) 1793); ten days later the French republic declared war against Great Britain and Spain. The national sympathy of America went out to France as a friend, ally, and sister republic, apparently struggling against tyranny. Furthermore, by the treaty of 1778 the United States was bound to defend the French West Indies in case of "defensive war." Since the British had recently been enemies, and were still on bad terms with the United States, the French government expected that the United States would directly, or by connivance, join in the war against Great Britain and Spain; and they sent over a new ambassador, Edmond Genêt, to carry out that policy.

When the news of the outbreak of war was received in America, Congress was not in session, and President Washington decided quickly that the country was in no condition for war. Even Jefferson, whom Hamilton accused of "a womanish attachment for France, and a womanish resentment against England," reluctantly admitted that the treaty of 1778 had no just reference to the changed conditions of the time. The President accordingly, on April 22, 1793, issued what is usually called the Proclamation of Neutrality, a declaration that the United States would "pursue a conduct friendly and impartial towards the belligerent powers."

Genêt landed in Charleston (April 8, 1793), and began to 
issue privateering commissions to Americans and to enlist them for the French service. He was received in Philadelphia with enthusiasm, and Democratic clubs were formed on the model of the French revolutionary clubs. Genet at first accepted the proclamation of neutrality, but he did not scruple to enlist men in the West for an expedition to capture New Orleans from the Spanish, a plan which pleased the Kentuckians. Then he lost his judgment and in his violence and fury overreached himself : he fitted out a cruiser, the Petit Democrat, in Philadelphia, and, in defiance of Jefferson's protest, sent her to sea. He lost standing further by trying to force Washington to call an extra session of Congress; and in December, 1793, his own government was weary of him, and sent a recall.

The naval war involved all the principal European maritime nations: Dutch, Spanish, French, and British merchantmen 204. Eng- were chased on every sea. The United States was the land and neutral commerce principal neutral, and on the rights of neutrals England (1793-1794) and the United States quickly found that they had different views : -

(1) The United States admitted that neutral ships could be captured anywhere on the sea if bound to a port actually blockaded by a squadron; but the British claimed the same right on a "paper blockade," that is, a mere notice, not backed up by a blockading fleet.

(2) The United States admitted the right to capture ships having on board " contraband," meaning military stores destined for an enemy; but the British claimed that provisions were also contraband, and seized American food ships bound to French ports.

(3) The United States insisted that "free ships make free goods"; that is, that an American ship was not subject to capture simply because it had the property of Frenchmen on board. The British took such ships wherever they could find them. 
(4) Great Britain, under what was called the "Rule of 1756," proceeded to capture American vessels bound from French colonies to American ports, because such trade had not been allowed by France in time of peace.

Forthwith scores of American ships were taken as prizes by British cruisers and privateers. So far as they had opportunity, the French were as violent as the English; they seized provision ships and British goods in American ships. If there had been a commercial treaty with Great Britain, much of the trouble with that country would have been prevented.

The trouble was aggravated by the method of recruiting for British ships of war by "impressing " (seizing) sailors on shore, or from British merchant ships. Under the theory that a man born in England remained an Englishman as long as he lived, the British extended their impressment to 205. Impressment and the war fever English sailors employed in American ships, and to (1793-1794) Englishmen born and recently naturalized in the United States; often, also, they impressed Englishmen born who were American citizens at the time of the treaty of peace, and even American sailors born in America, and no more subject to Great Britain than to the emperor of China. Congress in April, 1794, was on the point of declaring war against Great Britain, but once more Washington's calm good sense saved the country from a great danger. He nominated John Jay, then Chief Justice of the United States, as special envoy to make a last remonstrance to Great Britain.

After nearly four months' negotiation, Jay signed a treaty in London (November 19, 1794) which was intended to settle all but one of the four controversies then outstanding: (1) To carry out the treaty of 1783 , the British agreed to evacuate the undisputed American territory (p. 199); but then and thereafter would make no compensation for slaves

206. Peace with Great Britain and Spain (1794-1795) carried away in 1783. On the other hand, the United States undertook to make compensation to British merchants who 
had not been able to collect debts due in 1775; and the loyalist question was dropped. (2) For the capture of American vessels the British government agreed to make a compensation, if a commission of arbitration so found; and eventually paid $\$ 1,000,000$. Jay gave up the principle that "free ships make free goods," and agreed that provisions under some circumstances might be held contraband. (3) A commercial treaty to last a term of years was negotiated, but the British would not open trade to the West Indies on terms that the United States would accept. (4) On impressment, Jay could get no agreement.

In general the Jay treaty did not satisfy the shipowners and commercial people, and all the weight of Washington's influence was necessary to induce the Senate to ratify it by the bare constitutional majority of 20 to 10 . The House at first showed a strong inclination to refuse the appropriation necessary to carry out the treaty, but voted the money at last; and war with Great Britain was thus averted.

Meanwhile a very favorable settlement was made with Spain by a treaty of 1795, which gave us the desired commercial arrangements, the still more desired navigation of the Mississippi, and an acknowledgment of the southern boundary as laid down by the British treaty of 1783 .

While Jay was negotiating his treaty, trouble broke out in western Pennsylvania, where the low national excise duties 207. Whis- were especially felt by the many small distillers. Sev$\mathrm{ky}$ insurrection (1794) eral hundred armed men attacked the house of InspectorGeneral Neville, and it was plundered and burned (1794). The mail from Pittsburg eastward was robbed, and about seven thousand men assembled at Braddock's Field and marched to Pittsburg to intimidate the town.

Since Governor Mifflin of Pennsylvania would not act, Washington disregarded him and called out thirteen thousand militia from New Jersey, Pennsylvania, Maryland, and Vir- 
ginia. In October the little army crossed the mountains and came down into the western counties, but found not an insurrectionist in arms, for most of the people who were wanted had decamped. For their share in the rising, two men were found guilty of treason and sentenced to death, but pardoned by the President. In his messages to Congress Washington connected the rebellion with "certain combinations of men," or, as the Senate put it, "self-created societies," that is, with the Democratic clubs founded in 1793. The shot went home, and Jefferson and his friends - though they had no part in instigating the rebellion - soon thought it desirable to find a party name which had not such associations with France, and began to call themselves Republicans.

Throughout this difficult period, George Washington was the most clear-headed and unyielding friend of good national government. As President he showed one of the great- 208. Retireest qualities of an adininistrator ; namely, the power to $\begin{array}{r}\text { ment of } \\ \text { washington }\end{array}$ judge and select men. He gave a never-failing support (1796-1797) to Hamilton, and did his best to keep on good terms with Jefferson. It was a great trial to Washington that after 1792 the newspapers began to abuse him, and even his friend Jefferson wrote a letter criticising him, to a correspondent named Mazzei, which found its way into print. Jefferson tells us that one day at a cabinet meeting the President vehemently declared "that he had never repented but once the having slipped the moment of resigning his office, and that was every moment since, that . . he had rather be on his farm than to be made emperor of the world, and yet that they were charging him with wanting to be a king!"

In his celebrated farewell address of September 17, 1796 (composed in part by Hamilton, but full of Washington's principles), Washington rose to the highest patriotism and statesmanship. His theme was Union; union of the North and South, union of the East and West, a union which would 
be in danger if the United States took sides with either party in the European wars. Hence he advised his countrymen to keep out of "permanent alliances with any portion of the foreign world."

As Washington announced that he intended to retire to private life, the two political parties each tried to elect his successor in the presidential election of 1796; and by the close electoral vote of 71 to 68 Vice-President Adams was elected President. The Federalists did not unite on any one candidate for Vice President; and by a defect in the Constitution as it then read, the rival candidate for President, Thomas Jefferson, was thus elected to the lower office.

John Adams of Massachusetts was one of the two or three men most responsible for the Revolution. He served in the 209. Ad- two Continental Conministration of John gresses, then was Adams (1797-1801) minister to France and to Holland, and was one of the commissioners of the peace of Paris. In 1785 he was sent as first minister to Great Britain, and when the king laughingly hinted that Adams was no friend to France, he replied aptly, Adams, Works, VIII. 258 "That opinion, sir, is not mistaken; I must avow to your Majesty, I have no attachment but to my own country."

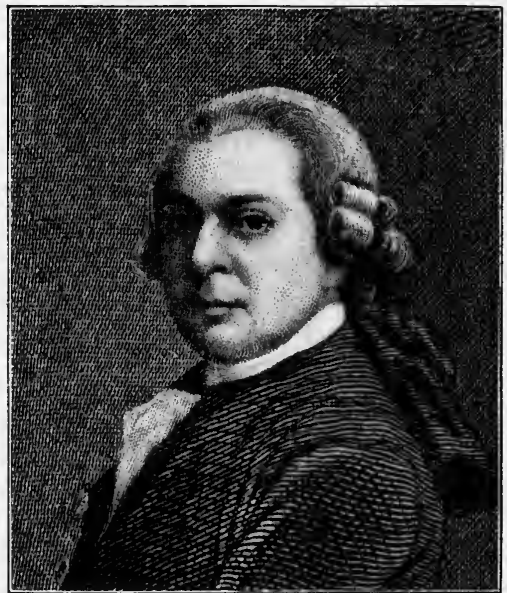

JoHN ADAMs, 1783.

In court dress; from the portrait by Copley.

After eight years' service as Vice President, Adams became President in 1797, and he made the fundamental mistake of adopting his predecessor's Cabinet, which felt itself superior to 
its chief and which took counsel with his personal enemy, Hamilton. Adams finally dismissed Timothy Pickering, Secretary of State, and forced another Cabinet officer to resign, after which he had some peace and comfort in Cabinet meetings.

In getting out of trouble with Great Britain, the United States was plunged a second time into difficulty with the French, who felt the bitterest resentment over the Jay treaty, because it gave to Great Britain privileges denied to

210. X. Y. versy France. In retaliation, the French in 1796 again began (1796-1798) to seize American vessels; and when Charles C. Pinckney arrived in Paris with a commission as minister, he was not

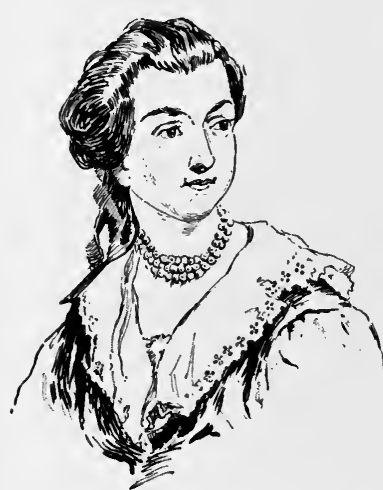

Abigail adams, about 1790.

Wife of John Adams; from Copley's portrait. received by the Directory which. was then the French government, and later he was warned to leave France. In a message on this insult (May 16, 1797) Adams said, "Such attempts ought to be repelled with a decision which shall convince France and the world that we are not a degraded people, humiliated under a colonial spirit of fear and sense of inferiority."

Still Adams could not bear to see his country drawn into war if he could help it, and he therefore commissioned Pinckney, John Marshall of Virginia (two Federalists), and Elbridge Gerry of Massachusetts (a Democratic Republican) to make a last effort to come to an understanding with France. After some months, dispatches arrived, stating that the French government, incensed at Adams's message, refused officially to receive the commissioners; and that three men, called in the dispatches "X., Y., and Z.," came unofficially to inform them that if they wanted a treaty, they must furnish a quarter of a million dollars "for the pocket of the Directory 
and ministers." When Mr. X. said plainly to the envoys, Am. State Papers, Foreign, II. 157 "Gentlemen, you do not speak to the point; it is money: it is expected that you will offer money," they responded firmly, "No, no, no; not a sixpence." And the President thereupon notified Congress (June 27, 1798), "I will never send another minister to France without assurances that he will be received, respected, and honored as becomes the representative of a great, free, powerful, and independent nation."

Adams's protest at the shameful attempt to exact bribes from American ministers raised him to the highest popularity of 211. Alien his whole life. Songs were written in his honor, among and Sedition Acts (1798)

them Hopkinson's Hail Columbia. The Republicans were so stunned by the behavior of France that they could not stop four sweeping pieces of anti-French legislation by Congress in 1798: (1) a Naturalization Act raising the required term of residence to fourteen years; (2) the Alien Friends' Act, authorizing the President to expel aliens in time of peace; (3) the Alien Enemies' Act, for the expulsion of aliens (by which was meant Frenchmen) in time of war; (4) the Sedition Act, making it a crime to publish libels against the government, or Congress, or the President. The Sedition Act was passed because the Republican pro-French newspaper press Annals of was violent and abusive; as an example the Federalists Congress, 1797-1799, p. 2097 quoted from the Aurora, a Jeffersonian newspaper, which called Adams "a person without patriotism, without philosophy, without a taste for the fine arts - a mock monarch."

Late in 1798 the legislatures of Kentucky and Virginia each passed a series of resolutions, drawn up by Jefferson and Madi-

212. Virginia and Kentucky resolutions (1798-1800)

son respectively, in which they attacked the Alien and Sedition Acts, declared that they were contrary to the Constitution and hence were "not law, but utterly void, and of no force," and called upon the other states to join them in remonstrance. A second and stronger series of Kentucky resolutions was passed in 1799 , containing the dangerous 
declaration that "nullification by the states of all acts of Congress that are unauthorized by the Constitution, is the rightful remedy." 'These resolutions, which were really a kind of political platform, attracted great attention throughout the country, and the Alien and Sedition Acts in the end caused the down. fall of the Federalist party.

After the X. Y. Z. affair, there seemed nothing for it but war with France. In 1798 Congress declared the treaties of 1778 at an end, and began to build a fleet; and the Navy Department was organized, with a Secretary. Congress could not quite bring itself to declare war; but (1798-1800) it did authorize the capture of French cruisers and, under some circumstances, of merchantmen, by warships and by American privateers, of which 365 were commissioned in a single year. The American frigate Constellation captured the French frigate Vengeance; and the federal ship Boston took the French corvette Berceau.

Just at this time, Napoleon Bonaparte rose to supreme power in France; and he saw no object in fighting America. Indirectly he sent word that he was willing to make peace, and Adams, against the advice of his party friends and his Cabinet, in 1799 directed negotiations resulting in a treaty of peace (September 30, 1800), which for a time safeguarded American neutral trade.

The death of Washington, in 1799, took away the balance wheel of American politics, for Adams offended his party associates and never had any hold on the Republicans. Though Adams would not apply the Alien Act, several 214. Election of Jeffersor. prosecutions of Republican journalists under the Sedi- (1800-1801) tion Act were unfairly pressed; and such a protest was made that the Federalists were startled at their own work. Meanwhile the Federalist journals were allowed to indulge in publications which were at least as scurrilous as those of their opponents. 
As the time drew on for the presidential election of 1800 , a long-standing feud between Hamilton and Adams came to the surface. Hamilton had twice already tried by some trick to set $A$ dams off the track that led to the presidency; but he could not prevent his rival from again receiving the party nomination. Jefferson, the candidate of the Republicans, was supported by Aaron Burr, of New York, who was nominated for Vice President; and that state changed over from the Federalist column. The result was that the Republican candidates got 73 electoral votes and Adams got only 65 . John Adams and his party were defeated.

Every Republican elector voted both for Jefferson and for Burr, so that there was a technical tie. As the Constitution

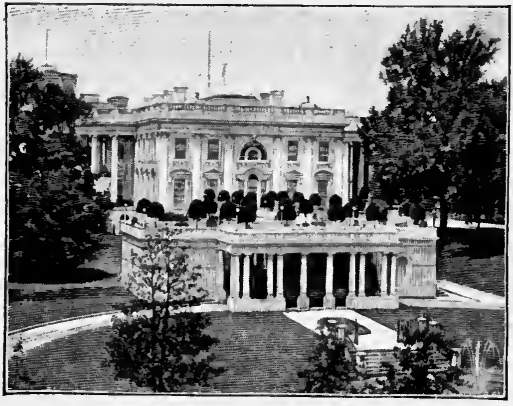

White House, Washington.

Built in 1800; additions in 1902. then stood, the House had the power to select between these two men, each state delegation casting one vote. The Federalists had the majority by states, and, in the face of the intention of the Republican voters to make Jefferson President, many of the Federalists voted for Burr, and came near electing him. Jefferson and his friends were furious, and even Hamilton advised his friends to vote for Jefferson, who in the end was chosen (February 17, 1801) by 10 states to 4 . The Federalists looked on the success of Jefferson as the undoing of the work of twenty years of effort to establish a firm government; and their conduct left in Jefferson's mind a strong feeling of injury and distrust. This dangerous crisis, in which the will of the people was almost set aside through an imperfection in the Constitution, led to the proposal of the 
Twelfth Amendment (ratified September, 1804) under which the President and Vice President are voted for separately.

The Federalist party remained in power from 1793 to 1801 . In his second administration, Washington was obliged to accept the fact that there were two parties, and he remained a Federalist to the end of his days. His party was weak in

215. Summary Congress, and nothing but Washington's great personal popularity carried the country through the four crises of his second administration - neutrality, the Whisky Insurrection, danger of war with Great Britain, and the Jay treaty.

When Washington retired, party spirit grew more violent; Adams was neither tactful nor discreet, but he stood for the rights of his country, and his bold messages made him for the time a truly national President.

In the Alien and Sedition Acts, Congress stretched its constitutional powers to their utmost and stirred up the fiercest feelings of resentment. The Virginia and Kentucky resolutions were a protest against the Federalist policy, and also the first clear statement of the principle of state sovereignty, which in its completest form led to the secession of 18601861.

The country was divided on the question of going to war with France, and the Federalist party was divided on the question of making peace. In 1800 the Republicans succeeded in electing Jefferson as President.

\section{TOPICS}

(1) What were the main causes of the French revolution? (2) Why should the United States have been expected to defend Suggestive French territory in America? (3) What is "contraband of war"? (4) Why did New England object to the Jay treaty? (5) Why should Washington wish to be on his farm? (6) Who were responsible for the insult to our ministers in the X. Y. Z. affair?

(7) What were the objections to the Alien Friends' Act? 
Search topics

Geography Secondary authorities

Sources

Ilustrative works

Pictures
(8) What were the objections to the Sedition Act? (9) Why would not Congress formally declare war on France in 1798-1799? (10) Why did Hamilton dislike Jonn Adams? (11) Why did Hamilton advise his friends in Congress to vote for Jefferson?

(12) Cabinet discussion on the proclamation of neutrality. (13) Reception of Genêt in Philadelphia. (14) Genêt's complaints against Washington. (15) Instances of impressment of American seamen. (16) Incidents of the Whisky Insurrection. (17) John Marshall as one of the three commissioners to Paris. (18) Addresses to John Adams. (19) Did Virginia and Kentucky mean to resist the United States in 1798-1799? (20) Capture of the Insurgente. (21) Cooper case of trial for sedition. (22) Callender sedition case. (23) Were the "Democratic clubs" responsible for the Whisky Insurrection?

\section{REFERENCES}

See map, p. 198 ; Bassett, Federalist System.

Hart, Formation of the Union, §§ 83-92; Walker, Maling of the Nation, 115-167 ; Channing, United States, 147-159 ; Johnston, Politics, 30-54 ; Stanwood, Presidency, 42-73 ; Bassett, Federalist System ; Schouler, United States, I. 238-514; McMaster, United States, II. 89-144, 165-537; Wilson, American People, III. 128-163 ; Gordy, Political Parties, I. 159-382 ; Foster, Century of Diplomacy, 136-181; Maclay, United States Navy, I. 155-213; Roosevelt, Winning of the West, IV. 101-257; Lodge, George Washington, II. 123-219, 237-298, - Alexander Hamilton, 151233 ; Morse, Thomas Jefferson, 130-185, - John Adams, 251-318; Merwin, Aaron Burr, 71-90 ; Conant, Alexander Hamilton, 100135; Hunt, James Madison, 213-270 ; Stevens, Albert Gallatin, 1-169.

Hart, Source Book, §§ 74-77, - Contemporaries, III. §§ 90-105, - Source Readers, III. $\S$ 74, 87, 88, 99; MacDonald, Select Documents, nos. 13-23; American History Leaflets, no. 15; Ames, State Documents on Federal Relations, no. 1, pp. 15-26 ; University of Pennsylvania, Translations and Reprints, VI. no. 2 ; Old South Leaflets, nos. 4, 38, 78, 103 ; Hill, Liberty Documents, ch. xviii. ; Johnston, American Orations, I. 84-143. See N. Eng. Hist. Teachers' Ass'n, Syllabus, 336, 337, - Historical Sources, § 80.

Eggleston, American War Ballads, I. 102-112 ; M. E. Scannell, Little Jarvis (French War); Cooper, Miles Wallingford; H. H. Brackenridge, Modern Chivalry (Whisky Rebellion); Carter Goodloe, Calvert of Strathore (France).

Wilson, American People, III. 


\section{CHAPTER XVII.}

\section{EXPANSION OF THE REPUBLIC (1801-1809)}

THe history of the United States from 1801 to 1809 is almost a biography of the President, Thomas Jefferson; the people

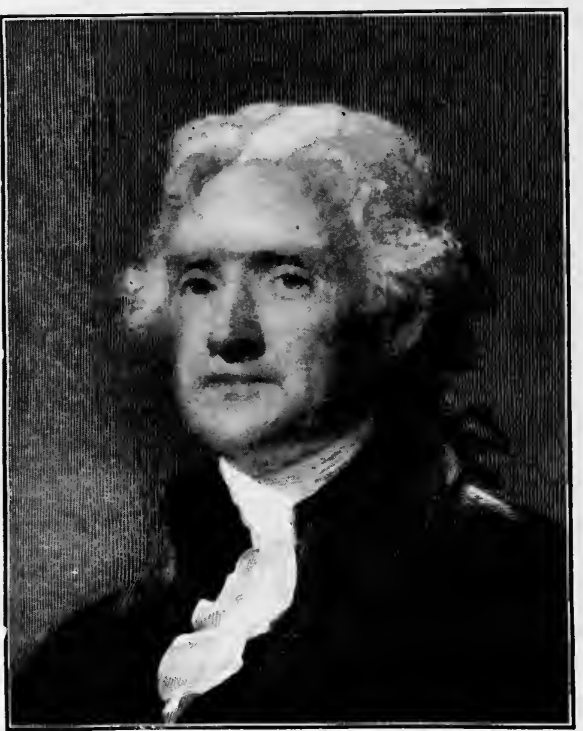

Thomas Jefferson, about 1800.

From the portrait by Stuart. liked him and Congress fol- Thomas Jefferson, lowed him. exponent of Born in 1743, democracy the son of a Virginia planter, owner of land and slaves, a student of William and Mary College, Jefferson nevertheless had a Yankee love of novelty, an interest in all sorts of farm machinery, sciences, and discoveries. A visitor said of him that he was " at once a musician, skilled in drawing, a geometrician, an astronomer, a natural philosopher, and statesman." In public service he had a career hardly paralleled in versatility by that of any other American. He was a member of the Virginia Assembly at twenty-six years of age, in the Continental Congress, governor of Virginia in 1781, then two years a member 
of the Congress of the Confederation, then ambassador to France for five years, and Secretary of State (1790-1793).

This highly aristocratic and intellectual gentleman preached extreme doctrines of political equality and popular government. As President he insisted on what he called "republican simplicity" in the White House and in public intercourse. Hence he began the present practice of making all presidential communications to Congress in written messages (his predecessors had delivered formal addresses to Congress in person). $\mathrm{He}$ was a strong advocate of local government on the New England town-meeting plan, and of public education. The foundation of his theories of government was confidence in the average man; he opposed the use of force even to keep public order. Jefferson was never a good speaker and disliked appearing in public; yet no man of his time had such influence over the people. His principle of political equality he found in the minds of his countrymen; he stated it and made it familiar, and in the end it led to the giving up of the requirement of ownership of property, payment of taxes, or religious belief, as qualifications for voters or for officeholders.

One of Jefferson's favorite beliefs was that governments ought to do as little as possible. Hence, as soon as he became

217. Republican policy (1801-1805)

President, he began to cut down the small army and navy, and to reduce the national debt. In this policy he had of Pennsylvania, a Genevan by birth, a member of Congress from 1795 to 1801, where he was the Democratic critic of Hamilton's finance, and an able and honest statesman. Gallatin at Jefferson, once set to work to extinguish the debt, a task which JefWorks (Ford), ferson said was "vital to the destinies of our governIX. 264

ment." Under the Federalists the debt had increased a little, and in 1801 stood at $\$ 83,000,000$; but from 1801 to 1812 , by prudent reduction of expenses and increase of revenues, it was brought down to $\$ 45,000,000$ 
It was easier for Jefferson to pay off the national debt than to settle what his party friends thought their reasonable claims to office. Great pressure was put on him to follow the practice usual in the state polities of New York, Pennsylvania, and other states, by turning out the officeholders, nearly all of whom were Federalists. In his inaugural address, March 4, 1801, Jefferson disclaimed any intention to ignore his political opponents. "We have called by different names brethren Contemporaof the same principle," said he; "we are all republi- ries, $I V .345$ cans, we are all federalists." Later he announced that he should appoint none but Republicans, until the Republicans and Federalists in office were about equal; after which, said he, "I . . . shall return with joy to that state of things when the only questions concerning a candidate shall be, Is he honest? Is he capable? Is he faithful to the Constitution?" Before he could reach that millennium, he removed or replaced 109 civil officials, or about one third of all the officeholders in important posts.

In the last days of Adams's term twenty-three new judicial officers were created - often called "midnight judges." Jefferson was furious at what he called Adams's indecent conduct " in crowding of appointments . . . after he knew he was making them ... not for himself, even to nine

Jefferson,

Works

(Ford),

VIII. 45 o'elock of the night at twelve o'clock of which he was to go out of office." Therefore, in the first session of the Republican Congress, the new judgeships were abolished (1802), and Adams's appointees lost their places. When the Supreme Court tried to protect some minor officers, whom Jefferson had refused to recognize, in the case of Marbury vs. Madison (1803), Jefferson's friends retorted by an unsuccessful attempt to impeach and remove Samuel Chase, one of the Supreme Court justices.

Jefferson's love of peace was sorely tried by the Mohammedan pirates of Moroceo, Alopiers, Tripoli, and Tunis, who cap- 


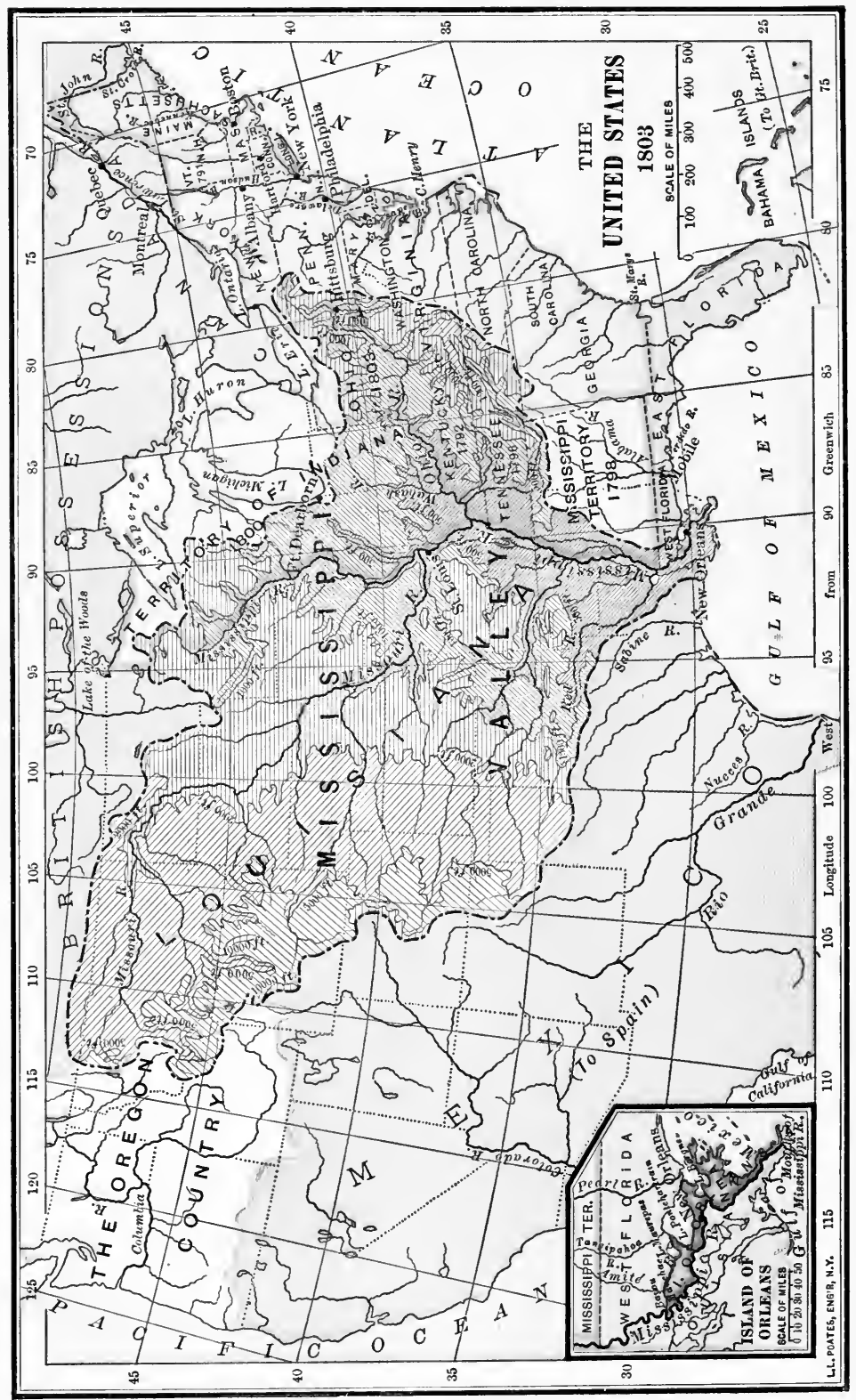


tured vessels and enslaved the crews. Like most nations, the United States paid an annual tribute to these ruffians; but the more they got, the more dissatisfied they were. The pasha of Tripoli said, "We are all hungry and if we are not provided for, we soon get sick and peevish." Although Jefferson had expressed a wish to coop up the navy under his own eye, in the East Branch of the

218. Barbary wars (1802-1806) Potomac, he had to use it when Tripoli declared war on the United States. From 1801 to 1805 American squadrons fought the Tripolitan pirates till the pasha gave in. Tunis, Algiers, and Morocco yielded without serious fighting.

Jefferson was a man who felt strongly the duty of looking out for the nation's interest; and he was greatly aroused by a change in the ownership of Louisiana. Napoleon Bonaparte was just then at peace with Great Britain, and 219. Question of New Orleans formed a scheme of colonial empire, for which he wanted (1800-1802) Louisiana. What was Louisiana? To answer this question we must keep in mind that the regions east and west of the Mississippi River had not the same territorial history. Both sides were clained by France under La Salle's discoveries and the settlement of 1699 ( $\S 49,94$ ). In 1763 the whole eastern half, except the Island of Orleans (the triangle between the Mississippi, the Bayou Manchac, and the Gulf, including New Orleans), was ceded to Great Britain, including the strip along the Gulf coast from the Island of Orleans to the river Perdido, to which the British gave the name of West Florida. The whole western half, together with the Island of Orleans, went to Spain (\$ 101). In the Revolution, Spain conquered from Great Britain the strip from the Island of Orleans to the Perdido, and called it West Florida. In 1800, by the treaty of San Ildefonso, Napoleon received back "the colony or province of Louisiana, with the same extent that it now has in the hands of Spain, and that it had when France possessed it." The greatest military power in the world thus HART'S AMER. HIST. - 16 
became the possessor of both banks of the lower Mississippi and a near neighbor to the United States.

The natural uneasiness of the Americans, when in 1802 they heard of this change, was heightened when the Spanish governor withdrew the privilege of sending goods through New Orleans free of duty, which had been secured by the treaty of 1795. Plainly, he meant to turn over the province to France with the river blocked to American trade. Hence it was that Jefferson wrote to Robert R. Livingston, our minister in France: Contempora- "There is on the globe one single spot, the possessor of ries, $11 I .363$ which is our natural and habitual enemy. It is New Orleans. The day that France takes possession of New Orleans ... . from that moment, we must marry ourselves to the British fleet and nation."

A party in Congress wanted to take New Orleans by military force; and an act passed authorizing 80,000 volunteers. 220. Pur- Jefferson was cooler. He instructed Livingston to chase of Louisiana (1803) attempt the purchase of the Island of Orleans and the strip to the eastward between the southern boundary of the United States and the Gulf. In January, 1803, he designated his friend James Monroe as a special envoy to France to aid Livingston. Fortunately for America, Napoleon was already tired of his own plan, for war with Great Britain was about to break out again, and it would be impossible for him to protect the sea route to Louisiana. Meanwhile he failed to reconquer the necessary halfway station of Haiti, where Toussaint L'Ouverture, a negro general, aided by fever, had the impertinence to destroy 10,000 of his best troops. Therefore, while Livingston was trying to buy West Florida and New Orleans, suddenly the French foreign office asked him what he would give for the whole of Louisiana.

One day later Monroe arrived, and the two ministers did not hesitate to go beyond their instructions by accepting the offer, but for some weeks haggled over the price. The treaty 
was completed April 30, 1803 ; the United States was to pay $\$ 11,250,000$ in cash and $\$ 3,750,000$ to American claimants against the French government, a total of $\$ 15,000,000$; in return Napoleon ceded the Island of Orleans and the whole western half of the valley of the Mississippi, with an area of 900,000 square miles ( $\$ 223$ ). Livingston, Monroe, and Jefferson each thought that he was responsible for this splendid addition to the territory of the United States. Lonisiana came like a plum dropping from the tree; but Jefferson is fairly entiiled to the credit of seeing more clearly than any other man of his time the danger of having France as a neighbor, and the possibilities of the West.

Since there was nothing in the Constitution on the question of annexing territory, Jefferson asked for a constitutional amendment; but his friends found authority in the old Federalist doctrine of implied powers, and the treaty was promptly ratified. Notwithstanding factious protests by

221. Incorporation of Louisiana (1803-1812) some of the New England Federalists, the next step was to take possession of the new country; New Orleans was turned

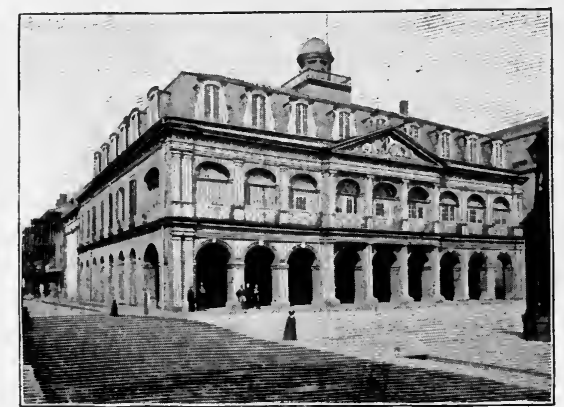

Copyright, 1900, by Detroit Photographic Co.

Cabildo, New Orleans, built in 1794.

The Spanish government building. over by the Spanish commander to a French officer (November 30, 1803), and twenty days thereafter by the Frenchman to the United States; though the distant Spanish post of St. Louis was not transferred till March, 1804.

The population of the new acquisition was about 40,000, almost entirely settled along the water front of the Mississippi and Red rivers. Congress speedily passed an 
act organizing the lower part of Louisiana as the Territory of Orleans, with an appointed legislature. The people of New Orleans were in an uproar. They did not like the new laws, the new language, or the new governor, and Congress goodnaturedly gave them a territorial government with an elective legislature (March, 1805). Seven years later an act was passed for the admission of this small part of the old province of Louisiana as "Louisiana," an equal state in the Union.

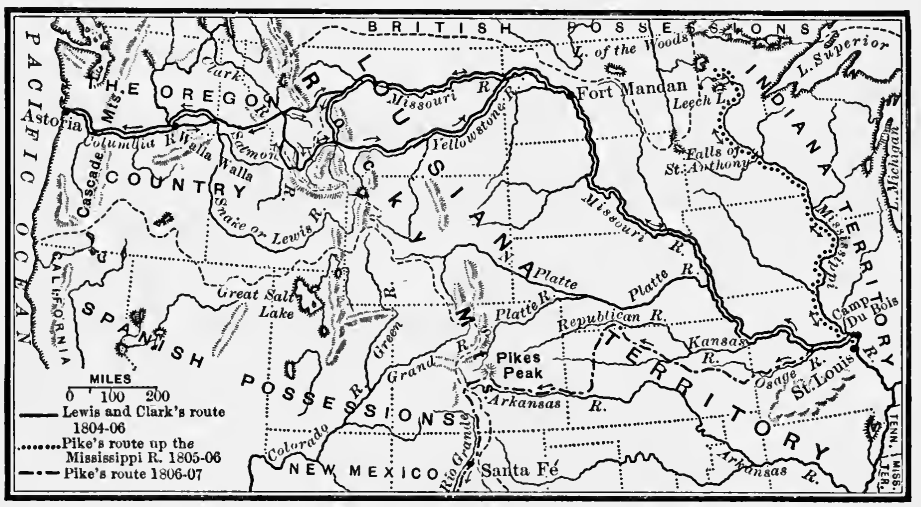

Explorations of Lewis and Clark, and Pike.

Jefferson's far sight early penetrated into the northwestern Pacific coast, where in 1792 Captain Gray, in the ship Colum222. Reach- bia of Boston, had found the mouth of a great river, ing out for and named it for his ship. As soon as Jefferson became (1792-1811) President, he induced Congress to provide for an overland expedition to the Oregon country, under the command of William Clark and Meriwether Lewis, Jefferson's private secretary. The whole Missouri valley had become part of the United States by the annexation of Louisiana when this expedition left St. Louis with forty-five men (May 14, 1804). In the course of six months they ascended the Missouri 1600 miles; they camped all winter, and in the spring of 1805 started 
northwest, under the guidance of the Indian "Bird Woman," who carried her child on her back. In August, 1805, they reached a point on the Missouri River where a man could bestride it; and then they struck across the mountains on horseback and found a westward-flowing river; following down, they reached the mouth of the Columbia River (November 15, 1805), 4000 miles from St. Louis.

This expedition through a country absolutely unknown to white men opened up half a continent; and it was the second link (next to Gray's discovery) in the chain which bound Oregon to the United States. Eventually it gave the United States a Pacific sea front, and opened a broad window toward the Pacific islands and Asia. In 1811 John Jacob Astor forged the third. link of our possession, by establishing a fur-trading post at Astoria, on the south side of the Columbia.

Meanwhile, in 1806, Lieutenant Zebulon Pike, with a command of United States troops, reached the northern boundary of Louisiana in an exploration up the Mississippi River to find its source. He then made his way overland, discovered Pikes Peak, and came out beyond our boundaries in New Mexico.

'The annexation of Louisiana soon led to serious boundary controversies with Spain. The treaty of 1803 contained no description of Louisiana except the phrase of the treaty of San Ildefonso: "with the same extent that it now has in the hands of Spain, and that it had when France pos- (1803-1813) sessed it"; but "in the hands of Spain" Louisiana did not include West Florida; while "as France possessed it" Louisiana extended to the Perdido. The Spanish government insisted that their cession of Louisiana in 1800 was not intended to include West Florida, and Talleyrand supported that contention. Yet Livingston, who had started out to purchase West Florida, could not give up the idea that he had secured it as part of Lonisiana, and Jefferson soon took up that belief.

Spain was in possession of the disputed strip, and refused to 
give it up. In 1810 the United States annexed part of the region, and in 1811 Congress passed a secret act authorizing the President to take East Florida also, but it was not till 1814 that the whole even of West Florida was occupied. In the latest official map of the United States, West Florida does not appear as part of Louisiana.

Our relations with Spain in 1806 were further disturbed by difficulties along the southwest boundary of Louisiana. 224. Burr Aaron Burr's willingness to accept the presidency in insurrec- 1801 was never forgiven by Jefferson, and in the presidention (1804-1807) tial election of 1804 George Clinton of New York was put in his place for Vice President. Jefferson and Clinton swept the country; the Federalist candidates got only 14 electoral votes. Meanwhile Burr was defeated as independent candidate for governor of New York, and laid this defeat to Alexander Hamilton, who had warned his friends that Burr was dangerous and untrustworthy. Burr therefore forced a duel on Hamilton and killed him (July 11, 1804).

When his term as Vice President expired in 1805, Burr was a desperate man. Being indicted for the murder of Hamilton, he thought it prudent to go west for a time, and returned with vague schemes for settling or conquering a region in the Southwest on, or more probably beyond, the Spanish boundary. In 1806 he raised a few score men, who in his absence were drawn up in a kind of warlike array on Blennerhasset Island, in the Ohio River. He joined this force and floated down the river (December, 1806), and turned into the Mississippi. His friend, and, as he hoped, his partner, James Wilkinson, general of the United States army, played him false. Hastily making an agreement that the Sabine River should be the temporary boundary of Louisiana, Wilkinson hurried to New Orleans, arrested some of Burr's followers, and forwarded to Jefferson a letter in which Burr proposed to seize New Orleans, where "there would be some confiscation." Jefferson had been wait- 
ing to see how far Burr would go; he now issued a proclamation against him, and had him arrested and sent east to stand trial for treason. Chief-Justice Marshall ruled that there was no evidence of treason, and, to the wrath of the President, Burr went free; but he never had the public confidence again.

After a renewal of the European war in 1803, interference with neutral trade began again. The British justified harsh measures on the ground that the Americans indulged in three forms of sharp practice: (1) Deserters from British ships of war were welcomed to employment on Yankee merchantmen. (2) American ships frequently

225. Impressments and captures (1803-1807) carried two or three different sets of ship's papers, to make themselves out something different from what they were, so as to avoid capture. (3) The Americans carried on, through American ports, trade from French colonial ports to France.

To meet these real or fancied difficulties, the British began to capture or search American vessels, often for reasons not urged earlier: (1) By the new doctrine of "continuous voyages," their courts held that the profitable trade in West India sugar brought to the United States, unloaded, and then reshipped to Spain or France, was subject to capture. (2) Vessels which had carried a doubtful cargo out, were captured on their way home with innocent cargoes. In order to enforce these new principles, British men-of-war cruised up and down the American coast, and captured American vessels outside the ports to which they belonged. Impressments began again on a large scale, for the hard, underpaid, and often cruel naval service of Great Britain caused hundreds of sailors to desert.

Against all these outrages the United States government remonstrated; but Jefferson wanted to keep the peace, and instead of building war ships he induced Congress to spend $\$ 1,600,000$ in building and maintaining, for coast

226. Internationa] crisis defense, a flotilla of small gunboats. In 1804 our rela- (1806-1807) tions with Great Britain became worse : the commercial clauses 
of the Jay treaty of 1794 by agreement were allowed to expire, and Great Britain would not grant as good terms again; therefore, we had no commercial treaty at all. To compel Great Britain to come to terms, Congress enacted a nonimportation act, - practically the old Association of 1774 over again, which never took effect.

By combining the fleets of France and Spain, Napoleon still hoped to check the British sea power; but in 1805 the splendid genius of Admiral Nelson at the battle of Trafalgar destroyed the allied fleet, and left Great Britain supreme at sea. The resourceful emperor of the French then set up what was called the "Continental System," by which all the numerous allies of France agreed not to purchase any British goods. Great Britain retaliated in 1806 and 1807 with Orders in Council, setting up "paper blockades" on the French coast. Napoleon replied by the Berlin and Milan Decrees (November, 1806, December, 1807), forbidding all trade to the British islands or in British goods. The real sufferers from this furious war of documents were the American shipowners, yet they were the people who least wanted war. Although, between 1803 and 1811, the British took 917 American vessels, and the French took 558, the profits of the neutral trade were so great that the American tonnage engaged in foreign trade almost doubled.

The difficulty reached its crisis in June, 1807, when the United States ship Chesapeake was stopped on the high seas off Cape Henry by the British frigate Leopard, so that some deserter's from the British navy who had enlisted on board the American ship might be taken off. The Chesapeake, though in international usage a part of the territory of the United States, was fired upon and disabled, and two or three American-born sailors were then seized, besides one English deserter.

The accumulation of injuries called for action of some kind. Negotiation had failed: Great Britain would neither make a 
treaty nor give any satisfaction for the Leopard outrage. The United States might fight, but war would cut off American trade almost altogether. To yield and say nothing meant to give up abjectly the rights of an independent nation. Jefferson's ingenious mind found a way out of this apparently impassable bog, by the Embargo Act (December 22, 1807), prohibiting the sailing of ships from the United States to foreign ports. Jefferson was sure that both France and Great Britain would have to come to terms if the American food products and other exports were cut off. On the contrary, Napoleon simply confiscated American vessels in French ports, because, he argued, they must have violated the American embargo; and the British, though they felt the loss of American exports, held out stubbornly.

The people who suffered most and who made the most ado were the Americans. The New England, middle, and southern states were all heavy exporters, and as the year 1808 wore on, thousands of people found their livelihood taken away. Ships moldered at the wharves, wheat rotted in the warehouses; the peace-loving Jefferson found his temper rising, as the people, especially the New Englanders, slipped out of port or defiantly carried their goods over the Canadian boundary. At the end of fourteen months, the country, especially New England, would bear no more; and against Jefferson's private remonstrance, Congress repealed the Embargo Act (March 1, 1809).

During this storm and stress of international affairs, Congress was from time to time taking action on slavery. In 1793 Congress passed an act by which the federal 228. Slavgovernment took the responsibility for the pursuit and ery and the slave trade return of fugitive slaves. In the organization of Mis- (1801-1807) sissippi Territory in 1798, and of the Territory of Orleans in 1804, slavery was allowed to remain in those regions. North of the Ohio a controversy arose, from 1802 to 1816, because many of the people in the new 'Territory of Indiana, who came 
from Kentucky and other southern states, petitioned over and over again to be allowed to hold slaves; but Congress refused.

On another slavery question the South was itself divided. Maryland and Virginia did not import slaves, but had surplus slaves to sell to their southern neighbors. They joined with the northern states at the earliest possible moment to prohibit the foreign slave trade absolutely. By act of Congress (1807) it was made a crime to import any slaves after January 1, 1808 , into any port of the United States. The act was openly violated: even had it been enforced, the natural increase of the slaves was raising their numbers to the millions.

Another very important event of the year 1807 was the first successful voyage by steam power. Robert Fulton in New 229. Begin- York set himself to the problem, raised with difficulty ning of steam transporta- engine from England, and (August, 1807) set in motion, tion (1807) on the Hudson River, the clumsy-looking Clermont, which could steam against wind and tide, and on her trial

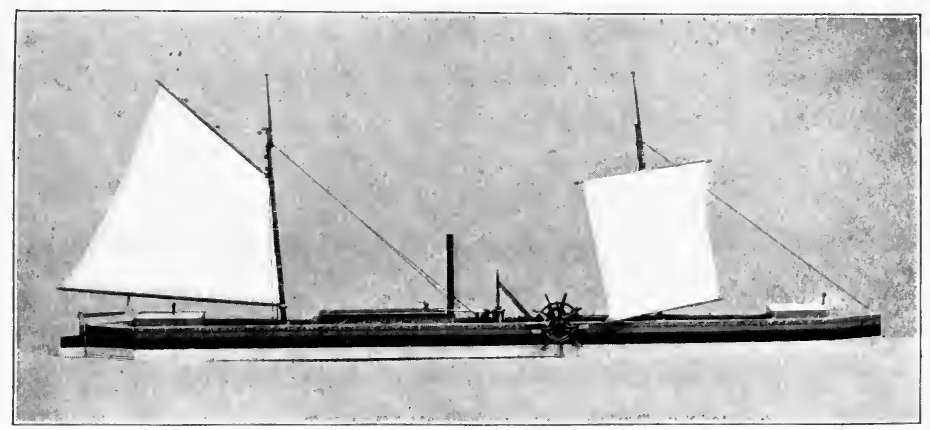

The CLekMovt. (From a model in the National Museum, Washington.)

trip reached Albany in less than a day and a half. 'The use of steamers spread rapidly. A regular line to Albany was established in 1808; within five years a line was rumning on the Delaware, a steamboat was built at Pittsburg, and steam 
ferryboats were introduced in New York and Philadelphia; and in 1816 steamers were introduced on Long Island Sound.

Jefferson came into office in 1801, amidst excitement and the hatred of the Federalists, and showed himself a moderate and prudent statesman, though he could not quite deny himself the removal of some of the Federalist office-

230. Summary holders. Everything he touched seemed to prosper; revenues increased, expense and debt decreased, the Barbary pirates were handsomely punished, Louisiana was annexed to the United States, and Jefferson prepared the way for a Pacific frontage in Oregon. He controlled his friends and crushed his most persistent enemy, Burr.

Jefferson's second administration (1805-1809) was full of humiliations and disappointments, brought about in great part by the fierceness of the war between France and Great Britain. Each power looked on American neutral trade simply as something that helped the other side. Hence the embargo was a failure from the first; for it did just what the Orders and Decrees were trying to do, by cutting off American trade; while the capture of American vessels affected thousands of people at home, and the impressment of American seamen caused intense bitterness. The trouble was that Jefferson and all the rest of the United States together could not bring to reason two such powerful and infuriated enemies as Great Britain and France, or prevent such burning indignities as the capture of the Chesapeake.

\section{TOPICS}

(1) Why did Jefferson object to the "midnight judges"? Suggestive (2) How was the national debt reduced from 1801 to 1811 ? topics (3) Why did Jefferson remove officials ? (4) What naval officers of later fame saw service in the Barbary wars? (5) What did the name "Louisiana" mean in 1803 ? (6) Did Jefferson have constitutional authority to negotiate a treaty for the purchase of Louisiana? 
Search topics

Geography Secondary authorities

Sources

nlustrative works

Pictures
(7) Why did the Federalists object to the annexation of Lonisiana?

(8) Why did Jefferson wish to send an expedition to Oregon? (9) Was Aaron Burr a traitor? (10) Why did the people of Indiana Territory want slaves? (11) Why did France and Great Britain refuse to repeal their Decrees and Orders? (12) Why did Hamilton accept Burr's challenge ?

(13) Jefferson's home at Monticello. (14) " Republican simplicity" at the White House under Jefferson. (15) The BishopGoodrich case of removal from office. (16) Toussaint L'Ouverture's relations with Napoleon. (17) Adventures of Lewis and Clark. (18) Discovery of Pikes Peak. (19) Duel between Burr and Hamilton. (20) Fulton's first voyage by steamer. (21) The British cruisers on the American coast, 1804-1811. (22) Battle of 'Trafalgar. (23) Berlin Decree. (24) Complaints of the embargo. (25) Character of Jefferson.

\section{REFERENCES}

See maps, pp. 264, 268; Semple, Geographic Conditions, 93-113. Hart, Formation of the Union, \$§ 94-105; Walker, Making of the Nation, 168-213; Channing, Jeffersonian System; Stanwood, Presidency, 74-96 ; Schouler, United States, II. 1-229 ; McMaster, United States, II. 583-635, III. 1-88, 142-338, 516-528, V. 373-380, 418-432 ; Adams, United States, I. 195-446, II.-IV.; Wilson, American People, III. 153-204; Dewey, Financial History, §§ 54-58; Locke, Antislavery, 131-165 ; Roosevelt, Winning of the West, IV. 258-343 ; Hosmer, Louisiana Purchase, 21-178; Sparks, Expansion, 188-215 ; Cable, Creoles of Louisiana, 1-160 ; Foster, Century of Diplomacy, 185-232 ; Morse, Thomas Jefferson, 186-307 ; Merwin, Thomas Jefferson, 119-164, - Aaron Burr, 57-147 ; Stevens, Albert Gallatin, 170-300 ; Adams, John Randolph, 1-233 ; Brady, Stephen Decatur, 1-61 ; Thurston, Robert Fulton ; Lighton, Lewis and Clark.

Hart, Source Book, §§ 78-81, - Contemporaries, III. \$§ 106122, - Source Readers, III. § 73 ; Ames, State Documents on Federal Relations, no. 1, pp. 26-44 ; Old South Leaflets, nos. 44, 104, 105, 128, 131 ; MacDonald, Select Docnments, nos. 24-27 ; Caldwell, Territorial Development, 77-108. See N. Eng. Hist. Teachers' Ass'n, Syllabus, 338-340,-Historical Sources, § 81.

Scenes at Washington; G. W. Cable, The Grandissimes,Strange True Storics of Louisiana; E. E. Hale, Man without a Country, - Philip Nolan's Friends ; E. L. Bynner, Zachary Phips (Burr); M. E. Seawell, Decatur and Somers.

Wilson, American People, III.; Sparks, Expansion. 


\section{CHAPTER XVIII.}

\section{WAR WITH GREAT BRITAIN (1809-1815)}

JefFerson was glad to follow Washington's example in retiring from the presidency at the end of his second term, and practically transferred the office to his Secretary of 231. Madi-

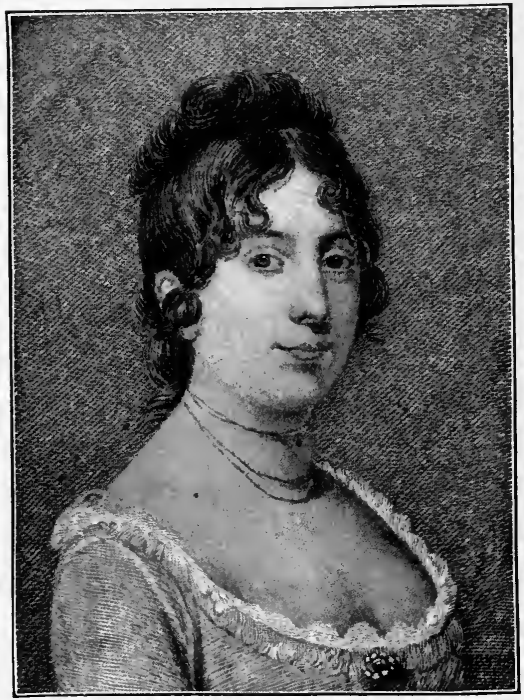

Dolly Madison, about 1810.

Mrs. James Madison, a famous social leader. From the portrait by Stuart.
State, James Madison, who was (1809-1811) elected President in 1808 over the Federalist C. C. Pinckney by 122 electoral votes to 47 . Madison had lost his earlier aggressiveness and spirit, was not a good party leader, and with the exception of Gallatin assembled a weak Cabinet.

The efforts of President Madison to adjust the troubles with Great Britain by negotiation failed; a fair treaty was signed by the British minister Erskine in 1809, but Great Britain refused to ratify his work. His successor, James Jackson, accused the President and Secretary of State of lying, and noted in his private correspondence that "a more despicable set I never met with before," which was his way of comBook, 213 
plaining because the United States government absolutely refused to have any more dealings with him; but he was received and welcomed by New England Federalists.

Congress had no better success. In 1809 (March 1) it had passed a law prohibiting commerce with France and Great Britain, but the commerce went on indirectly. In 1810 , by the "Macon Bill No. 2," Congress attempted to play off one enemy against another, and produced no real effect on either. Napoleon in August, 1810, publicly announced, "His Majesty loves the Americans; their prosperity and their commerce are within the scope of his policy"; on the same day he showed his affection by a secret decree ordering the confiscation of all American ships in his ports.

To the troubles on the seaboard were added dangers on 232. Indian the western frontier, where wars (1811-1814) two Indian leaders had

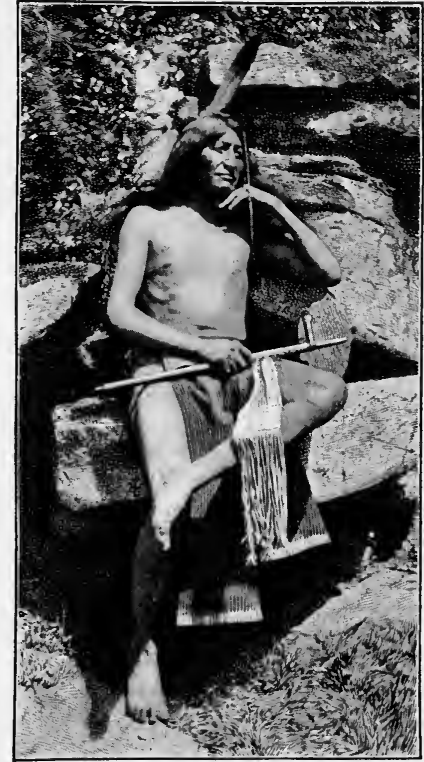

A Modern Indian.

arisen - the twin brothers Tecumthe and the Prophet. Tecumthe was perhaps the greatest Indian in American history, because the only one who grasped the idea of throwing the whites back by forming a confederation of all the frontier tribes from north to south. Though he could not raise the southern tribes in 1810, he had under his control 5000 warriors, a force which, if it would only act together, could defeat any army that the United States was able on short notice to bring into the field. 
In 1811, while Tecumthe was absent, William Henry Harrison, governor of Indiana Territory, forced the fight by marching against the Indian town of Tippecanoe, on the Wabash River, with 1000 men. The Indians boldly came out to attack him, and inflicted a loss of about 200, but were seized with panic and abandoned the town, which Harrison then entered and burned. Both sides considered it a victory for the whites. A few months later war broke out on the southern frontier, where Fort Mimms, near the Alabama River, was captured by the Creeks and about 500 people were killed. General Andrew Jackson was put in command of the troops, and in several campaigns during 1813 and 1814 nearly crushed out the opposing Indians.

Meanwhile the public feeling of wrath and indignation steadily rose toward France, and still more toward England. In the new Congress, which met in December, 1811, Henry Clay of Kentucky was chosen Speaker of the House; he organized it with a view to war, and made young John C. Calhoun of South Carolina chairman of the Committee on Military Affairs. The West had no

233. Outbreak of war with

Great

Britain

(1811-1812) patience with the timidity of the shipowners, for to the frontiersmen nothing seemed easier than to conquer Canada, and, as Clay said, "negotiate the terms of a peace at Quebec Contemporaor Halifax." The country was then prosperous; manu- ries, III. 420 factures were springing up, and nearly $\$ 200,000,000$ worth of goods were made in the country in a single year. But Congress did not consider that the national revenues were falling off ; that the army numbered only $7000 \mathrm{men}$; and that there were no good roads to the Canadian frontier.

Even President Madison could not stand the pressure for war, and war was formally declared against Great Britain June 18, 1812, though it was pointed out in Congress that we ought to fight France also. The official reasons for the war were as follows: (1) the insolence of the British cruisers on 
the coast; (2) the capture of over 900 American vessels since 1803 ; (3) blockades and other unrighteous practices moler the British Orders in Council; (4) the stirring up of Indian hostilities; (5) impressment. An apology had been made for the Chesapeake affair; at the last moment the British partly withdrew the offensive Orders; and we now know that it was an error to suppose that the British instigated the Indian wars. Nevertheless, two substantial grievances remained: the capture of our merchantmen; and the impressment of about 4000 seamen, of whom many were still prisoners on British cruisers.

It was supposed that a single campaign would probably decide the war, and as soon as possible troops were sent forward under General Hull to seize Canada. But the tables were unexpectedly turned when the British captured Detroit (August, 1812); and two attempts of the Americans to cross at the Niagara River were total failures, because the men had neither discipline nor confidence in their officers.

Joy came from an unexpected quarter when

234. Victories at sea (1812)

the news of naval victories began to pour in. At the outbreak of the war the United States navy consisted of eighteen vessels, of which the largest was a handy 44gun frigate. President

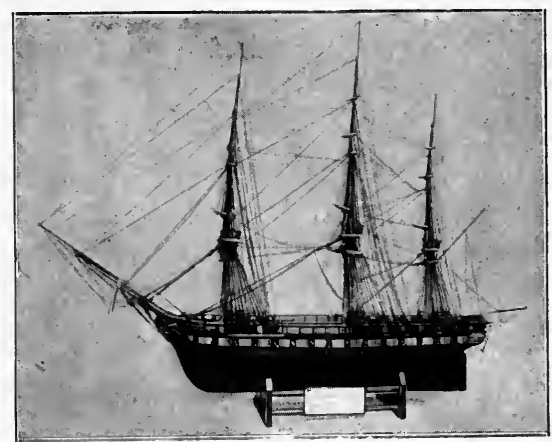

Copyright, 1897, by Martha H. Harvey.

The Constitution, or "Old Ironsides."

From a model in the Peabody Museum, Salem, Mass., given by Com. Isaac Hull in 1813. Madison expected that our little fleet would surely be captured; nevertheless, our frigate Constitution fell in with the Guerriere, a ship of about her tonnage, and in thirty minutes the Guerriere lay a helpless wreck (August 19, 1812). Two months later the 
little Wasp took the British brig Frolic; and the frigate United States captured, and subsequently brought into port, the British frigate Macedonian. Then the Constitution made another splendid capture, the frigate Java. During the year the only loss of the Americans was the Wasp, taken by a British threedecker battle ship. In all, thirteen British ships of war were lost besides those on the lakes. In vain did the British attempt to show that the American ships in every case had more tonnage, or more men, or more weight of broadside. The British navy had not been accustomed to calculate odds so closely; really every capture was due to the superior guns and marksmanship of the Americans.

The tide of naval victory changed in 1813, notwithstanding several other gallant captures of British cruisers. The American frigate Chesapeake was taken by the Shannon (May 30); and by the end of 1813 most of the American cruisers were driven into port and there blockaded. Then

235. The indecisive year (1813) the President was captured; but the frigate Essex, Captain Porter, got into the Pacific and made havoc of the English whalers, till captured in Chilean waters in 1814.

The boundary lakes, Ontario and Erie, were also scenes of naval operations during the years 1812 and 1813. On Lake Ontario there was no pitched battle; but after the defeat of a body of Kentuckians at the river Raisin, near Detroit (Jan. uary, 1813), Lieutenant Oliver H. Perry was sent to Lake Erie to prepare the way for a recapture of Detroit. With wonderful energy he constructed a fleet of five vessels, trained his crews, and on September 10, 1813, accepted from the enemy the battle of Lake Erie, off Put-in-Bay. He reported his victory in the laconic letter, "We have met the enemy and they are ours: two ships, two brigs, one schooner, and one sloop."

Perry's victory cleared the way for a successful campaign in western Canada. His navy carried General Harrison's comHART'S AMER. HIST. -17 


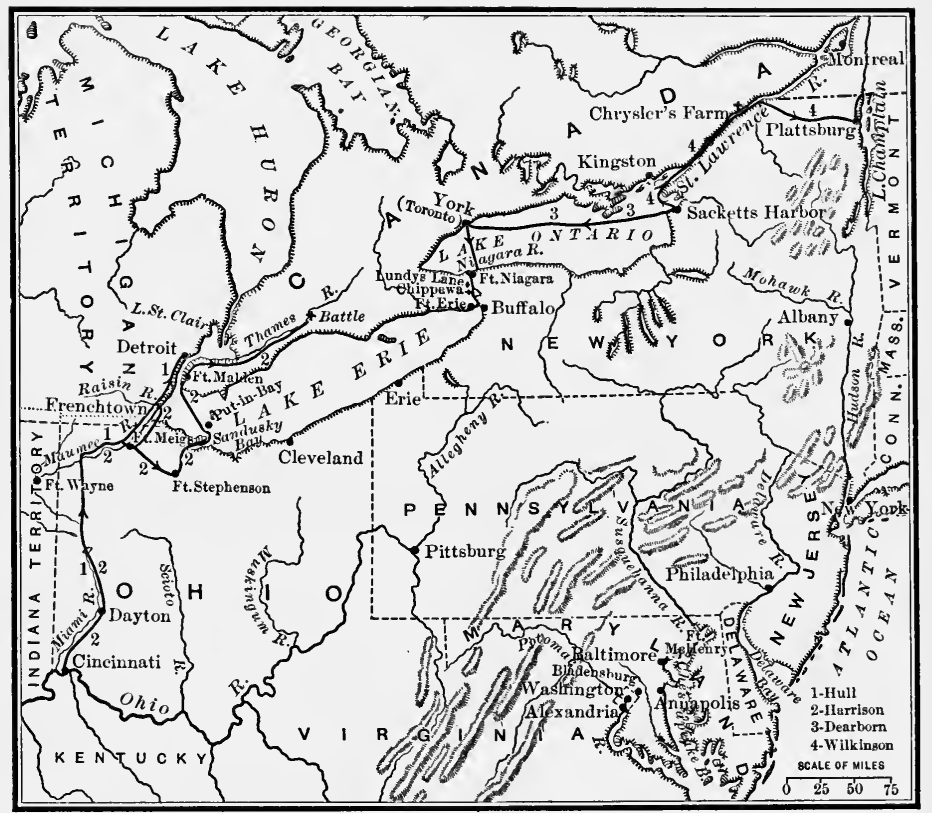

THE WAR OF 1812.

mand across the lake; and Harrison defeated the Canadians and their Indian allies at the battle of the Thames in Canadian territory (October 5, 1813), where Tecumthe was killed. Detroit soon after surrendered to Harrison. Renewed attempts to invade eastern Canada, under General Wilkinson, were again a failure; and the year 1813 left the war a sort of drawn game - each side occupying substantially the territory which it held at the beginning of the war.

In 1812 Napoleon made his disastrous retreat from Russia; and after two years of steady fighting was overwhelmed and 236. The compelled to abdicate. Large British forces by land and United States on the defensea were thus set free for a series of determined invasive (1814) sions of the United States in 1814. (1) The British occupied the coast of Maine as far as the Kennebec River, and 
blockaded most of the American coast. (2) A small British force was sent to seize Astoria, Oregon. (3) In August a British force of only 5000 troops landed about fifty miles from Washington on Chesapeake Bay, marched up into a country inhabited by at least 50,000 able-bodied men, beat off (at Bladensburg) an ill-commanded force hastily summoned to repel them, and took and burned the capital of the United States - as an alleged retaliation for destruction in York (now Toronto) by American forces. (4) A similar attack on Baltimore in September, which suggested Key's patriotic poem, The Star-Spangled Banner, was beaten off by the militia. (5) A British force attempting to advance southward up Lake Champlain was stopped (Sep. tember 11, 1814), partly by a fleet under Commander MacDonough, partly by the presence of militia intrenched at Plattsburg, under Macomb.

In a last attempt to invade Canada, under General Jacob Brown, aided by Lieutenant Winfield Scott, the Americans crossed the Niagara River and fought two battles, at Chippawa and at Lundys Lane (July 15, 1814); but though the Americans claimed the victory, they again retreated to their own territory. The closing incident of the war was an attack on the Gulf coast by General Pakenham. General Andrew Jackson fortified himself at Chalmette, just below New Orleans, where, January 8,1815 , the British column of 5300 troops assaulted his works, defended by about 4000 troops, of whom only a third were actually engaged. Again the raw American militia, properly commanded and intrenched, beat off the British army, inflicting a loss of 2000. A few days later, however, the British took the forts below Mobile, and remained in a threatening attitude.

Though for a time there was not an American commissioned ship of war on the ocean, the naval war was continued with brilliancy and success by a swarm of American privateers. American shipowners, whose vessels could no

237. The privateers (1812-1814) 
longer with safety carry a cargo, turned them into private fighting ships, which often richly paid for themselves out of their prizes. In three years about 1700 American merchant ships were taken by the British; on the other hand, 2300 British merchantmen were taken by privateers, besides 200 by cruisers, though 750 were retaken by the British; and the insurance on a voyage from England to Ireland rose to 14 per cent. Dismay spread through the maritime interest of England. As the London Times said of the American ships, "If they fight, they are sure to conquer; if they fly, they are sure to escape."

One reason for the failure of the Canadian land campaigns was the political opposition to the war. In 1811 a New Eng238. Inter- land member of Congress, Josiah Quincy, roundly threatnal opposi- ened that New England would secede if Louisiana were tion to the war made a state, thus increasing the power of the South. As (1812-1814) a protest against the war, part of the Republicans under De Witt Clinton made common cause with the Federalist opposition in the election of 1812 , and the coalition got 89 electoral votes to 128 for Madison. This personal and party opposition was carried into official form. When the President of the United States called upon all the states for a certain number of militia, New Hampshire, Massachusetts, Rhode Island, Connecticut, and New Jersey refused to send them.

There was some reason for protest and indignation. Congress neglected to provide either men or money enough to keep the war going. No proper tax laws were passed till 1813, when the hated Federalist excise and direct taxes were revived. The government borrowed $\$ 98,000,000$ during the war, but the bonds had to be sold at a depreciation of from 5 per cent to 30 per cent; large amounts of "treasury notes" - promises to pay in the future - had to be issued for supplies; and legal tender paper money was openly suggested. The worst weakness of the war was the dependence on militia 
regiments, for Congress was never willing to authorize a large federal army. When volunteering fell off, plans were laid for a draft, which happily was not necessary.

The critical time came in 1814, when New England began to feel the blockade and the war taxes. In December, 1814, a convention of official delegates from several New England states met at Hartford. We know little of the secret debates of the convention, but its official report proposed that Congress should give up its power to prohibit foreign commerce, and should leave the proceeds of federal taxes to the states in which they were paid. Such demands could not be granted without giving up the federal Constitution; and they amounted to saying that unless the war were speedily stopped, the New England states would withdraw from the Union.

Peace was made before the Hartford convention reported, and in fact before the battle of New Orleans. In January, 1814, the United States sent commissioners to negotiate a peace. The year was opportune, for the great Duke of Wellington gave his opinion against trying to assault (1814) American militia in their trenches; the British shipmasters were crying for relief from the American privateers; and the European war seemed over. Hence the British were inclined to make favorable terms, and the treaty of Ghent, December 24,1814 , was a diplomatic triumph for the United States.

The only subject on which satisfaction could not be had was impressments - the main cause of the war; but as soon as the European war was over, impressments dropped away of themselves; and, as a matter of fact, never began again. On all other points the treaty was highly favorable to the United States: (1) although at the end of the war the British were in possession of eastern Maine, Oregon, and the coast near Mobile, they agreed to surrender all territorial conquests; (2) the British again promised not to take away slaves or other private property; (3) since war puts an end to all 
preëxisting treaties, the questions of the fisheries and of commercial relations were for a short time left at loose ends; but after a few months they were settled by separate treaties.

From one point of view the War of 1812 is a painful subject. The United States went into it hastily, without prepara240. Sum- tion either of men or of money. The land war against mary

Canada was badly bungled; troops did not come forward, supplies could not be hauled, whole armies were stuck in the mud for weeks because of bad roads. The only creditable op-

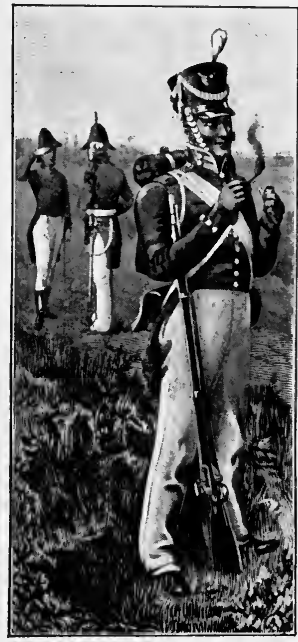

SOLDIERS OF 1812.

From official publications. erations on the northern frontier were the battles of Lake Erie, the Thames, Lundys Lane, and Plattsburg. The seaboard was blockaded and harassed; our merchant marine almost exterminated; our vessels of war sunk, taken, or cooped up in port; the national capital captured ingloriously and burned, almost under the nose of the President of the United States.

This is less than half the story. The war developed three good generals, William H. Harrison, Jacob Brown, and Andrew Jackson, - men who knew how to fight, even with untrained volunteers, and who showed that on the defensive the militiamen were, man for man, stronger than the best British regulars. And the laurels of the War of 1812 were won on the sea, where in thirteen duels between ships of about equal strength the Americans won eleven. The Englishman admires the man who can beat him at his own game, and respect for American seamanship and for American pluck has been a tradition in England ever since. 
Still, the capture of a few British warships did not weaken the British navy. The two influences which led Great Britain to make a favorable peace were the courage of the militia, which made invasion a difficult task, and the courage of the privateersmen, which devastated the British merchant marine. The United States was like a turtle which draws its feet and tail beneath a protecting shell, yet reaches out its hooked jaws to catch its adversary in the most vulnerable part.

\section{TOPICS}

(1) Why was Jefferson glad to retire from the presidency? (2) Why did the British government refuse to ratify Erskine's treaty? (3) Why did Indian wars break out in 1811 ? (4) Why did Indian wars break out in the Southwest? (5) How was Detroit captured by the British? (6) Why did the Americans defeat the British in ship duels? (7) Why was Commodore Perry successful ? (8) Why were the British able to capture Washington? (9) Why did all the American attacks on the Niagara frontier fail ? (10) Why were the British beaten at New Orleans? (11) Why was Josiah Quincy opposed to the admission of Louisiana?

(12) Tecumthe's career. (13) Settlement of the LeopardChesapeake difficulty. (14) Defeat of the Guerrière. (15) CapSearch topics ture of the Java. (16) Capture of the Macedonian. (17) Capture of the Chesapeake. (18) Porter's cruise in the Pacific. (19) Capture of Astoria. (20) Story of the origin of Key's Star-Spangled Banner. (21) Incidents of privateering in the War of 1812. (22) Inner history of the Hartford convention. (23) Attempts to make peace in $1812-1813$.

\section{REFERENCES}

See map, p. 282; Babcock, Rise of American Nationality; Geography Semple, Geographic Conditions, 134-149.

Hart, Formation of the Union, §§ 107-117 ; Stanwood, Presidency, 97-105; Babcock, Rise of American Nationality ; McMaster, Secondary United States, III. 339-458, 528-560, IV. 1-279 ; Adams, United States, V.-VIII. IX. 1-103; Wilson, American People, III. 204234 ; Cambridge Modern History, VII. 331-348 ; Gordy, Political Parties, II. 9-333; Mahan, War of 1812 ; Roosevelt, Naval War of 1812 ; Maclay, United States Navy, I. 305-658, II. 3-22 ; Hollis,

Suggestive topics 
Frigate Constitution; Hosmer, Mississippi Valley, 146-191 ; Cable, Creoles of Louisiana, 161-209 ; Dewey, Financial History, §§ 5964 ; Gay, Schurz, Henry Clay, I. 67-125; Brown, Andrew Jackson, 24-86 ; Parton, General Jackson, 25-248; Brady, Stephen Decatur, 62-137 ; Eggleston and Seeley, Tecumseh and the Shawnee Prophet.

Sources

Hart, Source Book, §§ 82-87, — Contemporaries, III. §§ 123--129, - Source Readers, III. \$\$ 62-65, 76-81, 85, 89-98; MacDonald, Select Documents, nos. 28-32 ; Ames, State Documents on Federal Relations, no. 2; Caldwell, Studies, I. 204-208; Johnston, American Orations, I. 164-215. See N. Eng. Hist. Teachers' Ass'n, Syllabus, 340, - Historical Sources, § 82.

Mlustrative works

Pictures

Matthews, Poems of American Patriotism, 83-107; Eggleston, American War Ballads, 113-145; Irving Bacheller, D'ri and I; G. C. Eggleston, Big Brother,-Captain Sam,-Signal Boys; Edward Eggleston, Roxy (Tippecanoe); J. A. Altsheler, Herald of the West (Washington and New Orleans); M. E. Scannell, Midshipman Paulding; Kirk Munroe, Midshipman Stuart; W.K. Post, Smith Brunt; Howard Pyle, Within the Capes.

Wilson, American People, III. 


\section{CHAPTER XIX.}

\section{SET'TLING THE WEST (1800-1820)}

IN 1802 Jefferson predicted that the Mississippi valley "will ere long yield more than half of our whole produce and contain more than half of our inhabitants." Two Contemporadecades later the West contained one fourth of the in- ries III. 363 habitants of the Union, and had revealed many elements of its own natural wealth: (1) The soil was deep and

241. Resources of the West fertile; the bottom lands of Kentucky and Tennessee, the wooded areas of Ohio, and the prairies farther west all bore surprising crops. (2) Most of the settled area abounded in superb timber - the best trees ran to 150 or even 200 feet in height and 30 to 40 feet in girth, furnishing abundant building material. (3) The country was well watered and fitted for grazing, so that about 1820 the westerners began to drive herds of cattle over the mountains to market. (4) The abundant waterways and the ease of making roads quickly opened the country to settlement. (5) Coal mining began in Pittsburg in 1784, and the black diamonds cropped out in many places. (6) Iron ore was abundant, and charcoal iron furnaces were started, while lead was discovered in Illinois and Wisconsin.

A stream of immigrants sought this promised land, with an effect seen in the census returns of some of the states: Tennessee had 36,000 people in 1790 and 262,000 in 1810 ; Ohio rose from 45,000 in 1800 to 581,000 in 1820. New settlements sprang up. Fort Dearborn, on the movement Chicago River, first built in 1803, was destroyed by Indians in 1812 , was rebuilt in 1816 , and became the nucleus of 
Chicago. Terre Haute, Fort Wayne, and South Bend were settled about 1817. St. Louis had been founded by the French in 1764. Although the eastern states were all growing rapidly,

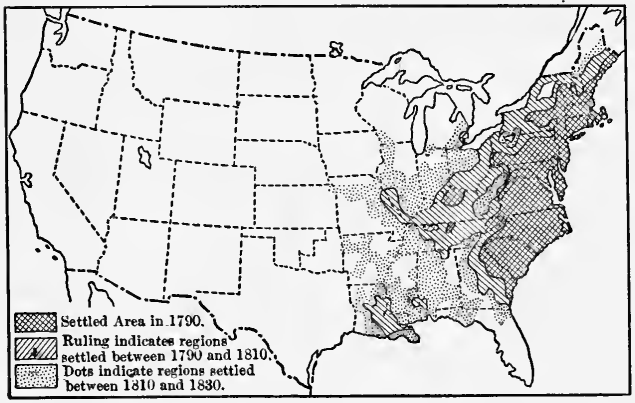

Settled Area in 1830. they were able to send off swarms of emigrants, because large families were common throughout the country. Every son could make a livelihood, and almost every daughter was wanted as a farmer's wife.

To accommodate this stream of land-hungry people, the United States, in 1800, adopted a new public land system: land was divided into small parcels and sold at land offices on the frontier at a minimum price of $\$ 2$ an acre, one fourth of the purchase money down and four years' time for the balance. Many followed the principle of the old woman in Eggleston's novel, who, when her husband was buying, said, "git plenty while you're a gittin'."

To reach the western lands several main highways from east to west were marked out by nature. (1) A route led from 243. Roads Albany through the valley of the Mohawk, and thence to the West via Geneva to Buffalo. (2) In 1812 Rochester was founded, the plain to the west of it was quickly occupied, and a new main road was laid out directly west to Lake Erie. (3) From Philadelphia a good road ran through Bedford in southern Pennsylvania to Pittsburg, 350 miles. (4) From Alexandria (opposite Washington) a road led about 300 miles to Pittsburg, by Braddock's old route up the Potomac to Cumberland, and across the Laurel Mountains to the Monongahela 


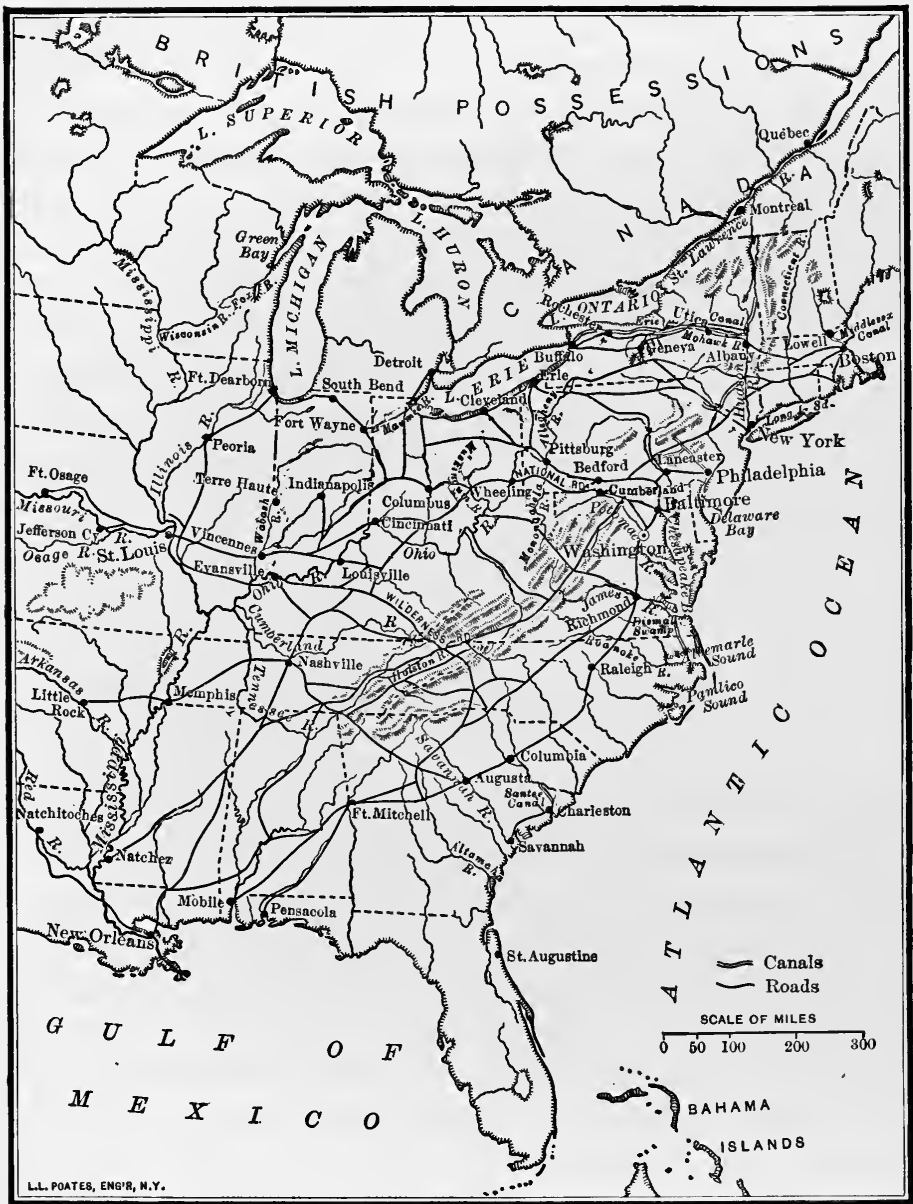

ROADS AND Waterways to the West IN 1825.

River. (5) From Alexandria or Richmond people followed the long-traveled easy pass from the upper Roanoke southwest to the Holston River, and thence down the Tennessee, or northwestward through the Cumberland Gap to Kentucky. (6) From 
Georgia westward there was easy travel to Mississippi Territory and New Orleans.

Most of the wheel roads crossed many swamps and unbridged streams, and were without good inns. In regions where there was very little stone, pikes were out of the question. As a substitute, companies built "plank roads" of thick boards laid side by side, and charged toll. The greater part of the highways west of the mountains were simple rough tracks, winding in and out among stumps and trees, pleasant in dry weather, and a slough when it rained. Hence the journey from the eastern states to the West was a serious business. The ordinary vehicle was the Conestoga wagon of wood, with an arched canvas top. The emigrants sold most of their furniture and other heavy movables, took food with them, and cooked as they went along. Breakdowns were frequent in the terrible roads, and an average of twenty miles a day was quick travel.

When once the tributaries of the Mississippi were reached, movement became easier; even on small rivers like the upper

244. River and lake travel

Wabash and the Muskingum flatboats were used. The simplest craft in the lively river traffic was the birchbark canoe, which would hold one or two persons, or the dugout, often larger. More elaborate was the raft - sometimes as much as a hundred feet long, floating all day on the current, and tied up at night; some of the rafts carried houses, open fires, and cattle. More comfortable was the flatboat, with its crew of unkempt and brawny polemen, the terror of frontier towns; or the flat-bottomed ark, sometimes as much as sixty feet long. A step higher was the keel boat, a more carefully built and ambitious structure, housed over with a deck, and provided with two "broadhorns," or steering oars.

On some such craft the settler floated lazily down the rivers and met the dangers of the voyage - the river pirates, who often attacked even armed boats; and Indians, who poured in 
a volley from the shore. Much of the immigration intended for central Ohio, Kentucky, and Tennessee took advantage of the water highways by following down the Ohio and then poling up a tributary to the place of destination.

After 1812 steamers multiplied on the western rivers. The hulls could be built anywhere out of timber on the spot; the fuel was wood from the river banks; engines and boilers at first had to be brought over the mountains. The river life is best described in the recollections of his boyhood which Mark Twain has preserved for us in his books on the West. In 1820 it took thirty-five days to go up from New Orleans to Pittsburg by steam, and about ten days to go

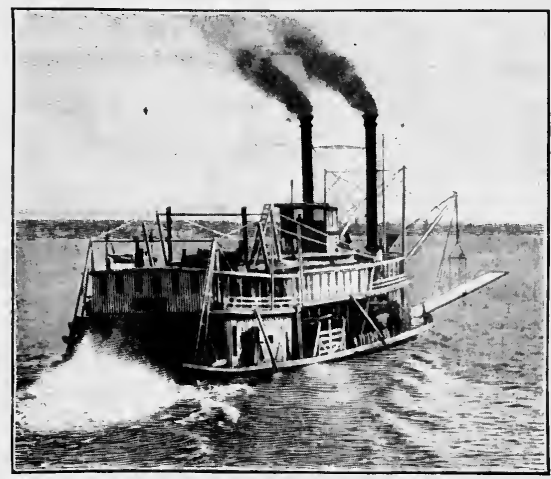

A Mississippi River Steamer. down. The Great Lakes were not safe or convenient for sail craft or for rowboats; and were not much used as a highway for emigration till steamers were introduced. The first Lake Erie steamer was the Walk-in-the-Water, built in 1818; in 1832 a steamer reached Chicago from the East; after that time hundreds of thousands of emigrants passed through the Lakes.

Difficulties in traveling westward, and the poverty of the frontier communities, suggested that the federal government build highways. The first act on the subject (in 1802) 245. Interwas that for the admission of Ohio, which provided that 5 per cent of the proceeds of the public lands sold in that $\begin{gathered}\text { provements } \\ (1802-1820)\end{gathered}$ state should be applied to roads to reach those lands. This idea took definite form in an act of 1806 for the survey of a road from Cumberland, Maryland, to the Ohio River. 
Construction of this National Road, or Cumberland Road, began speedily; in 1820 it was opened to Wheeling, and was then continued westward to Columbus, thence to Indianapolis, and southwestward toward St. Louis. As soon as it was

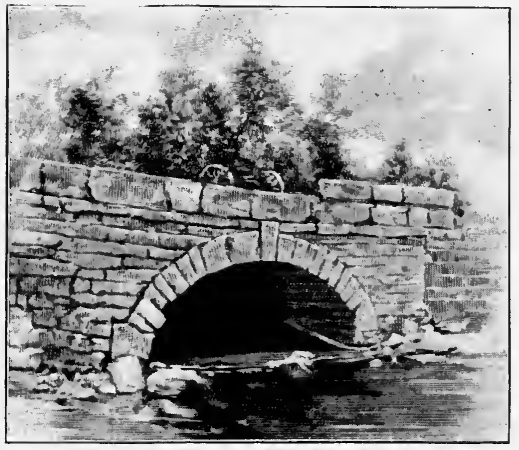

Bridge on the Cumberland Road. Built about 1825, in Ohio. opened, it became the great artery of western travel, for it was direct, had easy grades, and was macadamized. Congress in the course of thirty years spent upon it $\$ 6,800,000$; but it was at last superseded by railroads, and about 1850 Congress transferred it to the states in which it lies.

The most obvious line of western transit by water was from the Hudson up the Mohawk and across to Lake Ontario. The 246. Erie first statesman to take up the building of a canal on this Canal (1817-1830) route was De Witt Clinton of New York, who saw the many advantages to the state and city of New York from a waterway which would make New York Harbor the commercial mouth of the Great Lakes, thus diverting traffic from New Orleans. The War of 1812 gave impetus to this idea, because it showed how hard it was to transport men and supplies from the coast and the interior to the Lakes.

In 1817, under the energetic leadership of John C. Calhoun, who said that "he was no advocate for refined arguments on Contempora- the Constitution," Congress passed the so-called Bonus ries, III. 439 Bill, appropriating $\$ 1,500,000$ to be distributed among the states for internal improvements. It was expected that New York would have a big slice to spend on the proposed Erie Canal, but President Madison stepped in, and on the last 
day of his term vetoed the bill, for the strict constitutional reason that he could find no clause of the Constitution which distinctly authorized such expenditure.

The state of New York at once set to work to build its own canal, and in 1823 the Erie Canal was finished from the Hudson near Albany to the Genesee River ; in 1825 the direct line was completed to Black Rock, near Buffalo, 350 miles from Albany. The original canal cost $\$ 7,000,000$; but over $\$ 100,000,000$ more has been spent on extensions and repairs. Yet the whole expenditure was more than repaid by tolls.

The effects of the Erie Canal were marvelous. Lands all along the line at once trebled in value, and the freight rate from tide water to Lake Erie dropped from $\$ 120$ a ton to $\$ 19$. New York city increased from 124,000 people in 1820 to 203,000 in 1830 , and has ever since remained the most populous city in the Union. After 1825 a large part of the overland emigration passed through the Erie Canal. The passage from Schenectady to Utica (about two hours by rail nowadays) was twenty-two hours by canal boat; the passengers were crowded, and half stifled at night, and the frequent cry of "low bridge" disturbed the journey by day.

When the settler reached the golden West, he found substantially the old colonial life over again - land to clear, log houses to build, towns to found, schools to start. An 247. Fronobserver said of the westerners, "They are in a low contemporastate of civilization, about half Indian in their modes of ries, III. 463 life." Abraham Lincoln, born in Kentucky in 1809, lived as a boy in an Indiana hovel called a "half-faced camp." Better abodes were built of logs, with log chimneys and puncheon (split log) floors, and might cost twenty or twenty-five days' labor.

Yet in the midst of much that was rough, men like Philander Chase, Episcopal Bishop of Ohio, struggled on, founding schools, building new churches, educating the ministers, and elevating 
the community. The Methodist or Baptist frontier minister had perhaps half a dozen little churches on his hands, and "rode circuit" from hamlet to hamlet, preaching, baptizing, burying, organizing churches, and, if necessary, threatening rowdies who undertook to disturb the meeting. One of the favorite occupations of the time was to go to camp meeting, which was a combination of picnic, summer resort, and religious exercise, where people took household furniture, children, dogs, and psalm books. If the ministers roared and the converts shrieked, foamed at the mouth, and fell in convulsions, we must remember that such exaggerated experience often aroused and turned to better ways rough but powerful natures that could not be reached by milder means.

For education in the Northwest early provision was made. Each settlement soon had its common school, and out of land reserved by the Northwest Ordinance, and private contributions, arose in a few years half a dozen little colleges. In 1830 two western magazines were started: Hall's Illinois Magazine and Flint's Western Monthly Review.

Next to religion, politics was the most interesting topic in the West. Local parties very quickly were merged in the gen-

248. New communities eral national parties; elections were lively, and about 1800 was introduced the practice of "stump speaking," or open-air addresses to a series of popular meetings. The western states led in a movement for the suffrage of all adult white men and for elective judges. In politics and in social life the most influential man in a village was the storekeeper, who was often also distiller, country banker, real estate dealer, and justice of the peace, and hence called "Squire."

Local government in the West was imported from eastern communities. The northwestern states set up a system of school districts on the New England model. In Ohio, where the New England element was strongest, the people adopted a kind of modified town meeting. In Indiana and Illinois, where 
there were many southern people, and also in the southwestern states, the county of the southern type became more important.

No man more distinctly represents the West than Henry Clay. Born a poor boy in Virginia, he emigrated to Kentucky, and at twenty-nine he sat as Senator from Kentucky in 249. Henry Washington (1806). From that time to his death in 1852 Clay was most of the time in the service of the federal government as senator, representative, or Secretary of State. In four terms he showed himself the greatest Speaker in the history of Congress, managing the House of Representatives as a skillful coachman handles a four-horse teain.

What made Clay so distinctively a western man was his political optimism. $\mathrm{He}$ believed in all good things, in the future of his country, the growth of the West, the good judgment of the average voter. $\mathrm{He}$ was the inventor and the strongest advocate of what he called "the American System,"

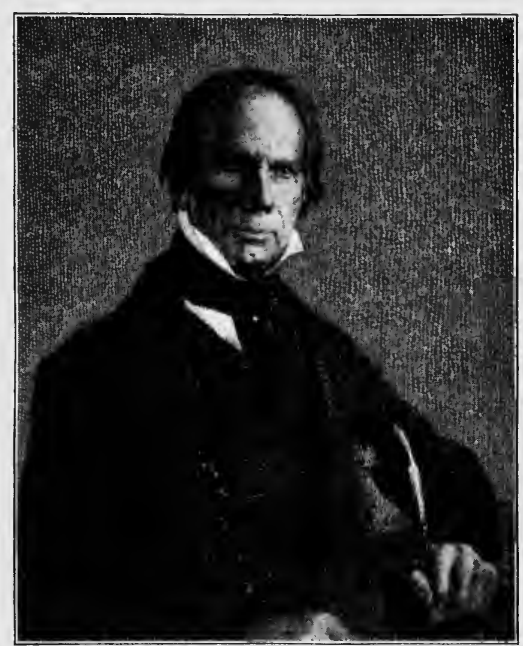

Henry Clay, about 1848.

From a daguerreotype. by which he meant the commercial development of the country by protective tariffs and other public aids. Above all, throughout his life he worked steadily and wisely for the establishment of better means of transit. His personal qualities gave strength to his political views; he was courteous, quick, had a natural power of attracting friends to him, and was ingenious in devising compromises when party spirit ran high.

For some time after the Slave Trade Act of 1807, slavery HART'S AMER. HIST. -18 
seemed hardly to be a sectional question; antislavery societies 250. Slav- were active in the border slave states and in the neighborery questions (1808-1819) Anerican Convention for promoting the Abolition of Slavery and improving the Condition of the African Race." This convention and the local societies discussed political questions affecting slavery, petitioned the state legislatures and Congress, and tried to stir people up to form abolition societies. One western man, Benjamin Lundy of Kentucky, was a kind of antislavery apostle, and in 1821 established an abolition paper, the Genius of Universal Emancipation.

These efforts were rather checked than aided by the National Colonization Society (founded in 1816), which aimed (1) to encourage emancipation by carrying the free negroes to Africa; and (2) to relieve slaveholders by taking away the free negroes who made their slave brethren discontented. In 1819 Congress appropriated $\$ 100,000$ to carry back slaves that might be captured on the high seas; a negro colony was founded in Liberia, on the west coast of Africa (1821), and first and last several thousand negroes were sent out.

Gradually the West came into the slavery discussion, at first because used as a kind of balance between North and South. From the admission of Louisiana (1812) the number of slave states was kept equal to that of free states, so that neither section might have a majority in the Senate; Indiana in 1816 was balanced by Mississippi in 1817 ; Illinois in 1818 was followed by Alabama in 1819 . The North, including the Northwest, grew so much faster than the South, that in 1820 (under the application of the three-fifths rule) there were 105 freestate members in the House to 81 slave-state members.

In 1818 the people of Missouri petitioned for admission into 251. Mis- the Union. Though in situation, population, and prodsouri Compromise ucts a western rather than a southern community, they (1819-1821) had slaves and wanted to keep them. When in February, 
1819, a bill for admission came up, an antislavery amendment, introduced by James Tallmadge of New York, passed the House by the close vote of 87 to 86 ; but the Senate refused to accept it, and the bill went over.

During 1819 many northern legislatures and public meetings declared that Missouri must never be a slave state. When Congress reassembled in December, 1819, a bill passed the House to admit Maine (at that time a "district" of Massachusetts) as a new state; and another bill for the admission of Missouri. To the latter the House, by a test vote of 94 to 86, added an amendment prohibiting slavery in Missouri. The Senate united the two measures into one bill, but instead of the House prohibition accepted the amendment of Senator Thomas of Illinois, forever prohibiting slavery in the Louisiana Purchase north of $36^{\circ} 30^{\prime}$ north latitude, except in Missouri. After a few days of great excitement, the House accepted the Thomas amendment as a compromise; Maine was admitted at once, and the people of Missouri were allowed to form a slaveholding constitution.

The Missouri constitution was found to make it the duty of the legislature to prevent the coming in of free negroes. This provision produced a second uproar and led to a second compromise, engineered by Henry Clay in 1821, by which the legislature of Missouri agreed to make no law infringing on the rights of citizens of other states; and Missouri was at last admitted to the Union.

The essence of the Missouri Compromise was the drawing of a geographical line across the Louisiana Purchase, north of which there were to be no slaveholding territories, and no slaveholding states except Missouri; that is, the act continued as far as the western boundary, the old geographical separation of slaveholding and free territory along Mason and Dixon's line and the line of the Ohio River. The compromise thus excluded slavery from the larger part of the Louisiana 


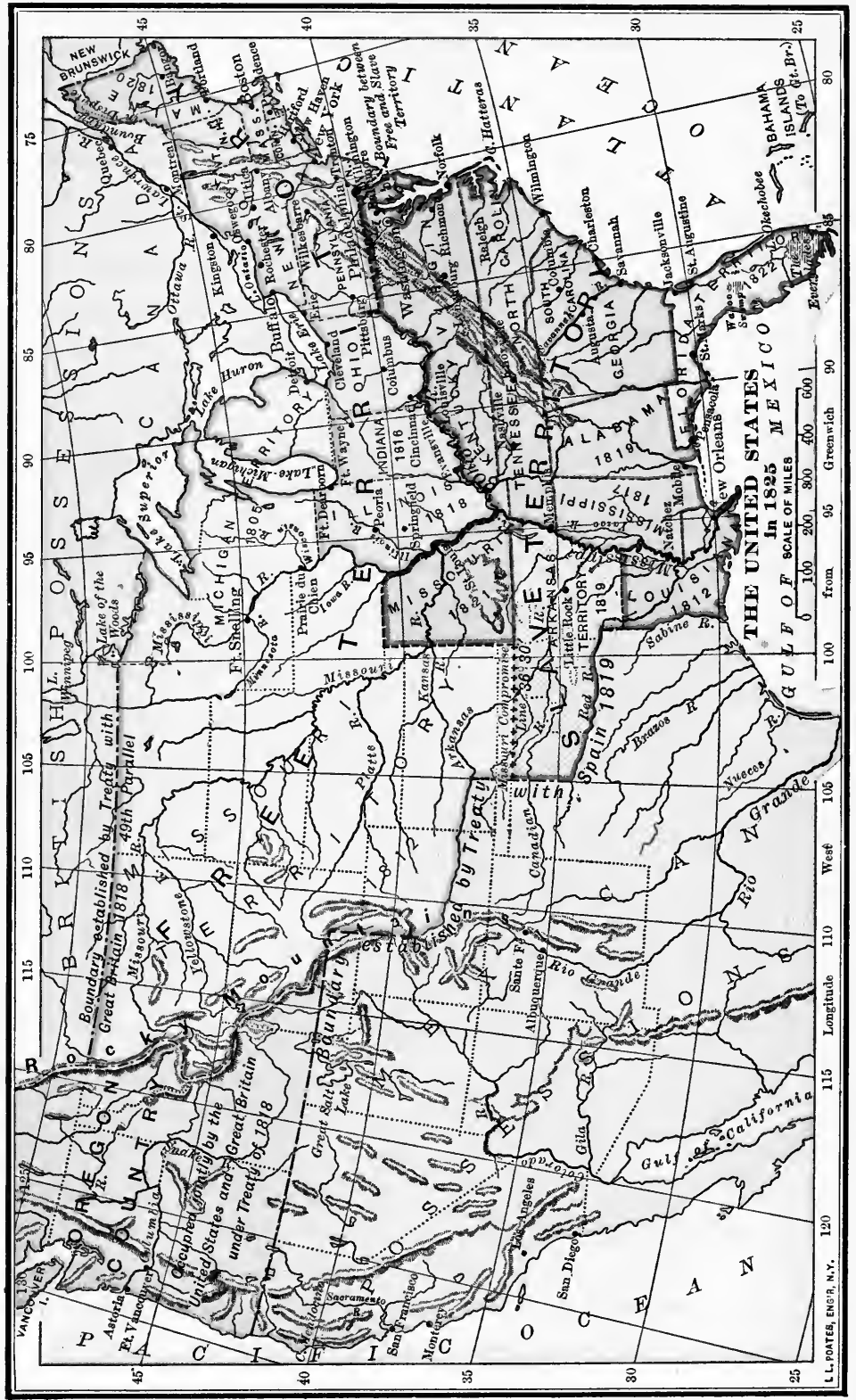

300 
Purchase, and also recognized the right of Congress to deal with slavery in the territories.

The compromise had plenty of enemies on both sides. John Randolph of Virginia politely called it "a dirty bargain." John Quincy Adams, when his friend Calhoun threatened secession, made perhaps the first prophecy of a civil war when he asked whether in such a case "the population of the North... would fall back upon its rocks bound hand and foot to starve, or whether it would not retain its powers of locomotion to move southward by land."

The West began to come forward about the year 1815 as a vital part of the nation and as a great political force in the national government. It was settled rapidly and tumul252. Sumtuously, so that in 1820 there were $2,600,000$ people west of the mountains. They came from the East in four main streams of settlement: (1) from New England and the mid. dle states to the belt of country between the Lakes and the Ohio; (2) across the mountains from Virginia, North Carolina, and western Pennsylvania, to build up Kentucky and Tennessee; (3) from the South to southern Ohio, Indiana, and Illinois; (4) from the Carolinas and Georgia westward to build up the communities of Alabama, Mississippi, and Louisiana.

At first the West was all frontier and had many of the disadvantages of frontier life, - poverty, ignorance, and popular excitement, - but there was a sound and strong fiber in the people. Congress began to recognize the importance of the West by building the National Road and choosing Henry Clay to be Speaker ; and the Erie Canal gave an ontlet to the sea. As a result of slavery, the western communities began to be divided, and took part in the great contest of 1820 over the admission of Missouri, by which all the region west of the Mississippi, like that east of it, was divided into a free and a slaveholding section. 


\section{TOPICS}

Suggestive topics

Search topics

\section{Geography}

Secondary authorities

Sources

Illustrative works

Pictures
(1) What part of the country east of the Mississippi is prairie ? (2) What became of the big trees in the West? (3) Why was there no early road from Philadelphia directly west to Pittsburg ? (4) Why did the western states soon elect their judges ? (5) Why was Henry Clay a great Speaker? (6) How did slaves come to be in Missouri?

(7) Chicago up to 1829.

(8) St. Louis up to 1829.

(9) The road from Rochester to Buffalo. (10) Plank roads. (11) Flatboats on the Ohio and Mississippi. (12) Indian attacks on river travelers. (13) Traveling on the Cumberland Road. (14) Traveling on the Erie Canal. (15) Early western schools. (16) Campmeeting scenes. (17) Early life of IIenry Clay. (18) Arguments for the Compromise of 1820. (19) Objections to the Compromise. (20) Why did the colonization of negroes in Africa fail ?

\section{REFERENCES}

See maps, pp. 291, 300 ; Semple, Geographic Conditions, 150168, 246-277; Turner, New West.

Hart, Formation of the Union, §§ 119-127, 136 ; Turner, New West ; Schouler, United States, II. 205-278, III. 96-109, 134-173 ; McMaster, United States, III. 123-142, 459-495, IV. 381-429, 570601, V. 13-18, 170-175; Adams, United States, IX. 148-174; Lanned, History for Ready Reference, IIl. 2341, 2925, V. 3359 ; Higginson, Larger History, 390-393, 404-422 ; Wilson, American People, III. 234-255 ; Hinsdale, Old Northwest, 313-328, 351367, 380-392 ; Hosmer, Mississippi Valley, 153-167 ; Sparks, Expansion, 220-274 ; Schurz, Henry Clay, I. 1-47, 137-146, 172202 ; Roosevelt, T. H. Benton, 1-20, 32-40; McLaughlin, Lewis Cass, 1-33, 95-132 ; Gilman, James Monroe, 128-143, 147-158, 191-202.

Hart, Source Book, §§ 90-93, - Contemporaries, III. §§ 135-141, - Source Readers, III. \$§ 11, 34-39, 42-53; MacDonald, Select Documents, nos. 35-42 ; Old South Leaflets, no. 108; Caldwell, Survey, 142-144, 233-245; Johnston, American Orations, II. 33-101. See N. Eng. Hist. Teachers' Ass'n, Syllabus, 342-343, Historical Sources, §83.

Bryant, Hunter of the Prairies; Cooper, The Prairie; J. E. Cooke, Leather Stocking and Silk; Edward Eggleston, Circuit Rider; A. G. Riddle, Ansel's Cave.

Wilson, American People, III.; Sparks, Expansion. 


\section{CHAPTER XX.}

\section{THE NEW NATIONAL SPIRIT (1815-1829)}

AfTER the War of 1812 the population, wealth, and national feeling of the United States advanced with leaps and bounds. An immense export and import trade sprang up again; 253. Manuand the war taxes brought in so much revenue that they could safely be given up soon after the peace. A commercial treaty with Great Britain (1815) removed some of the impediments to trade with that country. In 1818 the question of the northern fisheries was adjusted by a treaty with Great Britain (still in force) which allows American fishermen three privileges: (1) to take fish inshore (that is, inside a line parallel with the coast and three miles from shore) on parts of the coast of Newfoundland and Labrador; (2) to dry and cure fish on unsettled parts of those coasts; (3) to enter harbors of settled coasts for shelter, wood, and water. The treaty also provided for a boundary on the 49th parallel, from the Lake of the Woods to the Rocky Mountains ; and for the joint occupation of Oregon, which then meant the disputed region between the Rocky Mountains and the Pacific.

The rush of importations was disturbing to the new American manufactures. During the embargo times some of the capital which could not be used in shipping, went into little mills for weaving coarse cottons and woolens. At the outbreak of war in 1812 import duties were doubled, and the home manufacturers had almost a monopoly of the market; if foreign importations were to be admitted at the old rate of duty after the war ended, it seemed more than the home manufacturers could stand. 
The result was the tariff of April 27, 1816, passed by test votes of 25 to 7 in the Senate, and 88 to 54 in the House - a 254. Pro- tariff which now seems very low, but at the time was tective tariff of 1816 thought highly protective. It was supported by a new combination: (1) New England and middle state manufacturers; (2) western farmers under the leadership of Henry Clay; (3) South Carolina planters under John C. Calhoun, who interested his constituents by the hope of building up cotton manufactures in South Carolina. The strongest opponent was John Randolph of Virginia, who said the only question was, Contempora- "Whether you, as a planter, will consent to be taxed, ries, III. 435 in order to hire another man . . . to set up a spinning jenny." The average rate of duties on dutiable goods in 1811 was about 15 per cent; by the tariff of 1816 it was raised to 20 per cent.

Another evidence of national feeling was the charter of the second United States Bank in 1816. The bank founded by 255. Second Hamilton had expired in 1811, and its place had been national bank taken by numerous state banks. After the capture of (1816-1819) Washington all the banks, except those of New England, suspended specie payments, so that bank notes were the only currency. By an act of April 10,1816, a second United States Bank was chartered by Congress, with what was then thought the enormous eapital of $\$ 35,000,000$, of which the United States was to own one fifth. The main public services of the bank were: (1) to furnish sound paper currency, and to influence the state banks to pay their notes in specie; (2) to act as financial agent of the government in receiving and paying money ; (3) to hold on deposit the government balance, which ranged from $\$ 3,000,000$ to $\$ 10,000,000$. After one false start and danger of failing, the bank established branches far and wide, and did a large and profitable business.

Another significant evidence of national spirit was the attitude of the Supreme Court from 1801 to 1825, under the 
guidance of Chief-Justice John Marshall of Virginia. Marshall was born in 1755, served as a captain in the Revolutionary War, studied law, and sat in the state legislature and in the Virginia ratifying convention of 1788. In 1797 he became a Federalist member of the House, then Secretary of State, and near the end of

256. John

Marshall and the

Supreme

Court

(1801-1819)

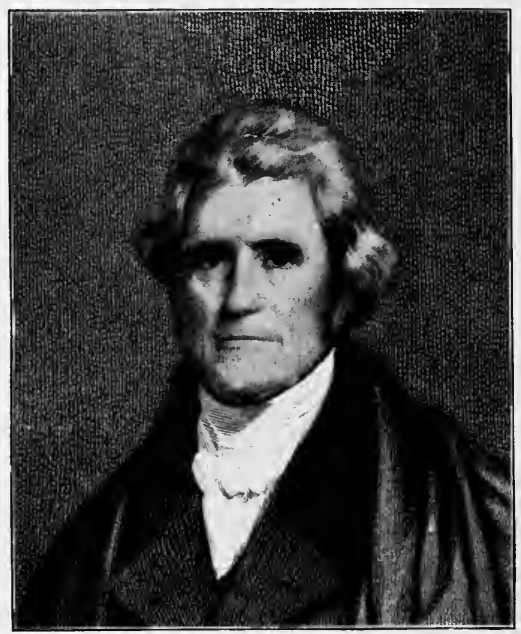

John Marshall in 1830.

From the portrait by Harding.

Adanıs's term was appointed Chief Justice, and held that high office until 1835.

Marshall is one of the most interesting of Americans. He was a simple householder, who often carried home his own turkey from the market, a renowned expert in the game of quoits, an upright Christian gentleman. His colleague, Story, said of him: "I love his Story, Stolaugh, ... it is too $r y, I .167$ hearty for an intriguer, and his good temper and unwearied patience are equally agreeable on the bench and in the study." Yet he was the greatest of American jurists, and his main service was to take advantage of cases which happened to come before the Supreme Court to set forth clearly, logically, and irresistibly the true principles of the federal Constitution; and he so influenced five judges appointed by Jefferson and Madison that they agreed with him.

(1) The court defined its own jurisdiction by compelling the state courts to permit appeals, even in cases where states were parties (case of Cohens vs. Virginia, 1821). 
(2) The court asserted the constitutionality of the bank and the doctrine of implied powers (case of McCulloch vs. Maryland, 1819). " "Let the end be legitimate," said Marshall, "let it be within the scope of the Constitution, and all means which are appropriate, which are plainly adapted to that end, which are not prohibited, but consist with the letter and spirit of the Constitution, are constitutional."

(3) The court kept the states to their orbit. It declared certain state statutes void, because contrary to the federal Constitution (case of Fletcher vs. Peck, 1810); and it reached its furthest point by declaring that a charter to a private corporation is a "contract" which, under the federal Constitution, can not be repealed or altered by the state government (Dartmouth College case, 1819).

Most of the great decisions came during the administration of Madison's successor, James Monroe, who was chosen Presi257. Era dent in 1816 over the Federalist Rufus King, by 183 elecof Good Feeling toral votes to 34 . Monroe was overshadowed by four (1817-1825) young Republican statesmen, each of whom had a just ambition to be President; Henry Clay, Speaker of the House and always a critic of the President's policy; John Quincy Adams, Secretary of State, the strongest spirit in the administration; John C. Calhoun, Secretary of War, then an ardent nationalist or supporter of strong federal government; and William H. Crawford of Georgia, Secretary of the Treasury, a keen politician. Though Monroe and his rivals all called themselves Republicans, they accepted most of the old Federalist doctrines. The Federalists put up no candidate in 1820 , so that Monroe was reëlected without opposition, and by 1822 the Federalist party had died out. Hence the period got the name of the Era of Good Feeling, though in reality it was a time of intensely bad feeling, of jealousy, of bitterness, intrigue, and sharp disagreement.

Monroe's chief interest was in our foreign relations. After 
the overthrow of Napoleon in 1815, some of the sovereigns of Europe entered into an agreement, commonly called "The Holy Alliance." They agreed that they would "on all occasions and in all places lend each other aid and assistance"; and they put the Bourbons back on the (1815-1821) throne of the Spanish empire. Really the plan was for a kind of mutual resistance against revolutions.

While Spain was occupied by the French, the American Spanish colonies became virtually independent, but all except La Plata (Argentina) accepted the restored Bourbon king in 1815. From the Plata in 1817 the flame of revolution swept across the continent to Chile, under the leadership of General San Martin; thence northward to Peru and Colombia, then called New Granada, where General Simon Bolivar was the patriot leader; and in 1821 it reached Mexico. Except a few fortified seaports and the islands of Cuba and Porto Rico, all the vast possessions of Spain in the new world were turned into a group of Spanish-American republics.

Indirectly the United States helped in the process of extinguishing the Spanish power in America. Besides seizing the disputed territory of West Florida (1810-1814), the gov- 259. New ernment tried to negotiate a treaty for the annexation of American East Florida. Andrew Jackson nearly upset the proceed- (1809-1825) ings in 1818, by pursuing the Seminole Indians across the border, and then attacking the Spanish posts of St. Marks and Pensacola; nevertheless, under John Quincy Adams's skillful management, a treaty was negotiated in 1819, under which: (1) Spain for a payment of $\$ 5,000,000$ ceded both East Florida and all claims on West Florida; (2) the southwestern boundary was settled by running an irregular line from the mouth of the Sabine River to the source of the Arkansas and thence due north to latitude $42^{\circ}$; (3) the Spaniards surrendered all claims on the Pacific coast north of the 42d parallel. 
As soon as the treaty was ratified by Spain in 1821, Monroe recognized the independence of six Spanish-American powers - La Plata, Chile, Peru, Colombia, Mexico, and a Central American group. Brazil, till then a Portuguese colony, in 1825 made itself an independent American empire.

This change in the conditions of South and Central America was very welcome to the United States. Our people had a natural sympathy with neighboring peoples fighting for their liberty, and besides, for the first time in history, American shipowners and American merchants were allowed to trade freely with Spanish-American ports.

The benevolence of the Holy Alliance was tested in 1823, when the European powers by force put an end to a revolu260. The tion which had broken out in Spain against the arbitrary Monroe Doctrine (1823)

Bourbons. The restored Spanish government then requested that the European powers help to recover the Spanish colonies in America. At about the same time (1821) the Russian government laid claim to the exclusive trade and nccupation of the northwest coast, including part of Oregon; and both these acts of interference in America aroused the United States.

At this opportune moment George Canning, British foreign minister, made the friendly suggestion (August, 1823) to Richard Rush, our minister in England, to join with him in a declaration against the transfer of any Latin-American (Spanish or Portuguese) state to another European power. Monroe was inclined to accept Canning's invitation, but John Quincy Adams was determined that the United States should make a separate and independent announcement. Monroe yielded to the stronger mind of his secretary, and allowed him to draft that part of the message of December 2, 1823, which has been commonly called the Monroe Doctrine. It contains three main statements on the American question :(1) On colonization: while speaking of the northwest coast, 
Monroe said that "the American continents, by the free and independent condition which they have assumed and maintain, are henceforth not to be considered as subjects for future colonization by any European powers."

(2) On interposition : in discussing the proposed intervention by European powers against the Latin-American states, the message says that "interposition for the purpose of oppressing them, or controlling in any other manner their destiny, by any European power" would be considered unfriendly to the United States.

(3) On the European political system: the doctrine runs, "We should consider any attempt on their part to extend their system to any portion of this hemisphere as dangerous to our peace and safety."

Monroe meant his doctrine to be peaceful and harmonizing. His argument was, in substance: (1) since the United States does not interfere in European controversies, we should not permit third parties to interfere in the new world in quarrels not their own; (2) we are not hostile to existing colonies of European powers, but it is contrary to our interest that LatinAmerican territory be conquered and occupied by foreign powers. The Monroe Doctrine accomplished its purpose: all schemes of European intervention were given up; and Russia forthwith made treaties with the United States and Great Britain, accepting as the southern boundary of Russian America the parallel of $54^{\circ} 40^{\prime}$ north latitude.

The next exciting event in the United States was the presidential election of 1824, in which the alleged "Era of Good Feeling" disappeared. Crawford got the coveted nomi- 261. Elec. nation by a caucus of Republican members of Congress tion of 1824 in 1824 ; but that way of making nominations had grown unpopular. Other candidates were put forward by the new method of nomination by state legislatures - John Quincy Adams in New England, Henry Clay in Kentucky and several other 
western states, and Andrew Jackson in Tennessee. Calhoun accepted the almost unopposed nomination for Vice President.

Of all these nominations the most unexpected was that of Andrew Jackson. Jackson was of Scotch-Irish descent, born in 1767 among the poor whites of North Carolina. He studied law and went out to Tennessee in 1788, and was successively public prosecutor, member of Congress (1796), and federal senator (1797), then judge of the supreme court of Tennessee. Always a testy man, he lived in a part of the country where private warfare was thought a fine thing; he fought several duels and killed one man. He commanded at New Orleans in 1815, and in Indian campaigns in 1817 to 1819.

It was a hot and bitter campaign, full of personalities. The electoral votes turned out to be 99 for Jackson, 84 for Adams, 41 for Crawford, and 37 for Henry Clay. There being no majority of electoral votes, the choice went to the House of Representatives, where Adams was elected by the vote of 13 states to 7 for Jackson and 4 for Crawford (February 9, 1825). The Jackson men insisted that inasmuch as their candidate had more electoral votes than Adams the "will of the people" was defeated; and a friend of Jackson also brought forward the totally unfounded charge that Adams had bought his election by promising to make Clay Secretary of State. Jackson seems never to have doubted the truth of this slander.

No man of his time was better qualified than John Quincy Adams, by character and training, for his great office. As 262. Presi- Federalist senator from Massachusetts in 1807, he voted dent John for Jefferson's embargo, and was thereupon dropped by his Adams (1825-1829)

own party. He became a Republican, minister to Russia, one of the peace commissioners at Ghent, minister to England, and from 1817 to 1825 Secretary of State. Adams was by nature an expansionist. He would have liked to annex Canada; he was especially interested in Cuba; he wanted to buy Texas; he got rid of both Spanish and Russian claims 
to the Oregon region; and he went farther than Monroe in his interest in our Spanish-American neighbors.

A methodical, able, and hard-working President, just and honorable in all his public and private relations, Adams was still cold in manner, and had few close and warm friends till he retired from the presidency. He was then elected to the House (1830) and spent seventeen years there, in which he revealed magnificent power as a debater and became the champion of the North.

Hardly had Adams become President when the United States was invited to send delegates to a

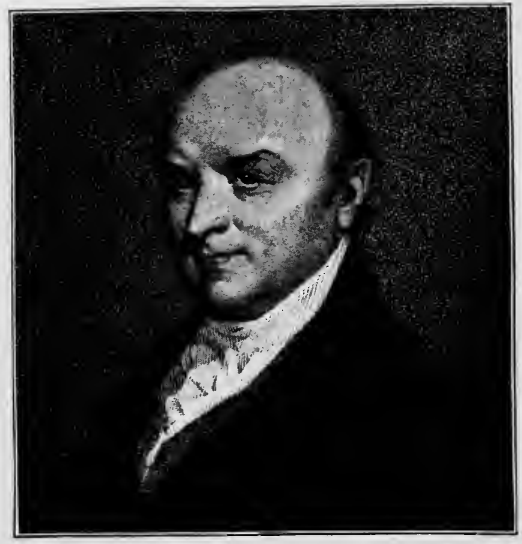

John QUincy Adams, ABout 1825. From the portrait by Stuart. congress at Panama, in 1826, to consult on the common affairs of America. The Senate hung back, and the President and his Secretary of State, Clay, were obliged to cut down the powers of the commissioners. The congress was a failure, and our delegates arrived too late for the meeting. During much of his term as President, Adams found himself checked and humiliated at every turn by partisan opposition in Congress, and could carry through none of his plans.

The tariff of 1816 did not bring prosperity to the country. Overtrading and speculation continued; the duties did not shut out foreign goods, and hence did not suit the manu- 263. The facturers. In 1819 there was a commercial panic. A tariffs of new tariff, drawn up in 1820, was defeated in the Senate $\mathbf{1 8 2 8}$ by one vote. In 1824 a tariff was passed by narrow majorities in both Houses (May 22), which raised duties somewhat, 
and for the first time taxed certain raw materials of $\mathrm{New}$ England manufactures, including raw wool. The strongest northern opponent of the tariff in 1824 was Daniel Webster, member from a shipowning district, who declared that "the Webster, general sense of this age sets, with a strong current, in Works, III. 132 favor of freedom of commercial intercourse, and unrestrained individual action." The great champion of the tariff was Henry Clay, who argued for his "American System."

A strong and persistent objection to protective tariffs, whether high or low, made itself felt in the South, where the hopes of establishing manufactures with slave labor had come to nothing. In 1828 a new tariff bill was introduced into Congress, and was now supported by Webster on the ground that his constituents had in good faith changed their investments over to manufactures. Opponents of the bill introduced amendments raising the duties on raw materials, in the expectation that the friends of the bill would vote against it in its amended form, and it therefore became known as "The 'Tariff of Abominations." Nevertheless, it became a law (May 19, 1828). The average rate of duty paid on dutiable goods rose from 36 per cent in 1826 to 49 per cent in 1830 - the highest tariff in the United States up to the Civil War.

Protests rained upon Congress. The Boston moneyed men protested; four southern legislatures protested; most impor264. Dis- tant of all, South Carolina and John C. Calhoun procontent over the tariff

tested. At first a strong advocate of a national bank, a tariff, and internal improvements, in the confidence that the federal government would help develop his own state of South Carolina, Calhoun gradually came to see that Congress could do little for a state which had no manufactures, and which depended on slave labor.

In 1828 Calhoun wrote a long argument, called The Exposition (published without his name), in which he argued not only that a protective tariff was unconstitutional, but that any 
state had a right to nullify a federal law which it thought unconstitutional, by forbidding it to be executed within the state limits; if other states disagreed, they might call a convention, and unless three fourths of the states in that convention approved the law, it would have to be abandoned (see § 273).

People began to tire of personal rivalries in politics, and to look for questions which really divided the nation. After the disappearance and supposed murder of one Morgan, 265. Elecwho had revealed secrets of the fraternity of Free tion of $\mathbf{1 8 2 8}$ Masons, an attempt was made to found an Anti-masonic Party in 1827; but opposition to free masonry was not a national or a permanent issue.

In the election of 1828 the only candidates for the presidency were Adams and Jackson; and the only vital issue was the personal one, whether Adams was a good man who deserved reëlection, or Jackson was a representative of the people who ought to supplant him. Adams was the subject of scurrilous campaign literature; it was charged "that he was rich; that he was in debt; that he had long enjoyed public office." On the other side an Adams man printed a "coffin handbill," charging Jackson with the illegal execution of six men thirteen years before on a technical charge of desertion.

Jackson's election was almost assured in advance by a combination of the West and South with Pennsylvania and New York, a majority of the electoral votes of which was turned over to Jackson by Martin Van Buren, head of the so-called Albany Regency. Jackson got 178 electoral votes to 83; and his popular vote was about 650,000 to 500,000 for Adams. As an enthusiastic friend and admirer of Jackson says, "General Jackson was therefore triumphantly elected President of the United States in the name of reform and as the standard bearer of the people." 
During the fifteen years from the close of the War of 1812 to the end of Joln Quincy Adams's administration, all sections 266. Sum- called upon the federal government to make a new finanmary cial and economic system. Congress responded by creat. ing the second United States Bank (1816), which became a sound and useful institution, affording a good currency and exercising a healthful influence on the state banks. Except the Cumberland Road, national internal improvements failed for the time because of Madison's and Monroe's vetoes of 1817 and 1822. The protective tariff of 1816 satisfied nobody, and every four years thereafter new bills were introduced, two of which were passed in 1824 and 1828. Each raised the rate of duties over the previous ones; duties on raw materials were added, and the "Tariff of Abominations" caused widespread protest, and in South Carolina led to threats of "nullification."

The revolt of the Spanish-American colonies gave new neighbors and new anxieties to the United States, which soon recognized the independence of the new states. When a European alliance attempted to interfere in the new world, the United States gave a warning in the Monroe Doctrine.

In politics the Federalist party died out, partly because of its unpopular course during the War of 1812, in spite of the fact that its chief principles had been accepted by the other party, and were applied by the Supreme Court. When the Republicans had no other enemies, they fell into personal factions; and the elections of 1824 and 1828 turned not on national issues, but on personal preferences.

\section{TOPICS}

Suggestive topics
(1) Why did Great Britain give a privilege of fishing inside the three-mile limit? (2) Why was a joint occupation agreed on for Oregon? (3) Why did Calhoun favor a tariff in 1816 ? (4) Why did John Randolph oppose a tariff ? (5) Why did the Republicans take over the Federalist principles? (6) On what ground did Jackson invade Florida? (7) On what grounds did Russia claim 
the northwest coast? (8) Why was the caucus system of nomination unpopular in 1824 ? (9) Why was Jackson's nomination unexpected in $18 \%+$ ?

(10) Disputes on the tariff of 1816 ; of 1820 ; of 1824 ; of 1828. (11) John Marshall's character and private life. (12) William H. Crawford's public life. (13) Revolutions in Spanish America from 1800 to 1820 . (14) Debates in the Cabinet in 1823 on the Monroe Doctrine. (15) Andrew Jackson as a judge. (16) Charge of a corrupt bargain between Clay and Adams. (17) Protests against the tariff of 1824. (18) John C. Calhoun as a nationalist. (19) Calhoun's doctrine of nullification as set forth in the Exposition of 1828 .

\section{REFERENCES}

See map, p. 300 ; Turner, New West.

Hart, Formation of the Union, §§ 120-125, 128-140; Wilson, Division and Reunion, \$§ 8-10, 25-27 ; Stanwood, Presidency, 106Secondary authorities 150 ; 'Turner, New West; Schouler, United States, II. 446-463, III. 1-96, 109-133, 173-178, 189-150; McMaster, United States, III. 496-514, IV. 280-380, 430-521, V. ; Adams, United States, IX. 106148, 187-197 ; Gay, Bryunt's History, IV. 244-259, 276-296 ; Gordy, Political Parties, II. 333-389, 445-581; Peck, Jacksonian Epoch, 1-122 ; Dewey, Financial History, \$§ 66-80 ; Stanwood, American Tariff Controversies, I. 111-348; Hart, Foundations of American Foreign Policy, 211-218; Latané, United States and Spanish America, 9-105; Sato, Land Question, 53-60 ; Gilman, James Munroe, 143-147, 159-179 ; Morse, J. Q. Adams, 107-118, 122-219 ; Schurz, Henry Clay, I. 126-171, 203-311 ; Sumner, Andrew Jackson, 60150 ; Brown, Andrew Jackson, 87-117 ; Thayer, John Marshall ; Lodge, Daniel Webster, 60-166; Shepard, Martin Van Buren, 88-176.

Hart, Source Readers, III. § 10, - Contemporaries, III. $\$ \S 130$, 132-134, 142-150 ; MacDonald, Select Documents, nos. 33, 34, 43-45 ; American History Leaflets, nos. 4, 24 ; Old South Leaflets, nos. 56, 129 ; Ames, State Documents on Federal Relations, nos. 3, 4, pp. 1-31 ; Hill, Liberty Documents, chs. xix. xx. ; Caldwell, Survey, 208-214, 227-233, - Territorial Development, 105-126. See N. Eng. Hist. Teachers' Ass'n, Syllabus, 341, 344,-Historical Sources, § 83.

Gustave Aimard, Queen of the Savannah (Spanish-American independence).

Wilson, American People, III.

Illustrative works

Pictures 


\section{CHAPTER XXI.}

\section{NEW POLITICAL ISSUES (1829-1841)}

When Jackson became President in 1829, the principles of American democratic government had in many ways advanced 267. Amer- much farther than in 1789: (1) many of the states had ican democ- rid themselves of the old property and tax qualifications racy

for voters; (2) nearly all the state officers, including judges, were elected by popular vote instead of being chosen by the legislature or governor, as formerly; (3) the property qualifications for officers were diminished or had disappeared; (4) by the system of "rotation in office" state and local officers were chosen for short terms, and rarely reëlected more than once or twice; (5) minor officers in most states and municipalities were likely to be removed when the opposition party got into power; (6) the cities were growing rapidly and demanded new forms of government.

Politics, too, had lost its old simplicity. The party newspapers were still unscrupulous and abusive, and there were some leaders of the type now called party bosses. The party in power in a state tried to keep in power by distributing offices as rewards to its followers. Parties often tried to perpetuate their power by the "gerrymander" - that is, by so arranging the boundaries of electoral districts that their friends should carry some districts by small majorities and their opponents should carry fewer districts by large majorities, so that the minority might rule. Violence at the polls was frequent, and fraud was not unknown.

The most noted representative of the new democratic prin- 
ciples was President Andrew Jackson; and, except Clay, no man in all the West was so widely known, so experienced in public affairs, and so capable of making quick decisions. In personal appearance Jackson was tall and spare, with a high forehead and a great mane of hair, which silvered while he was President. A lion to his enemies, Jackson 268. Andrew Jackson, the man of responsibility was the soul of courtesy, and to ladies almost a Don Quixote.

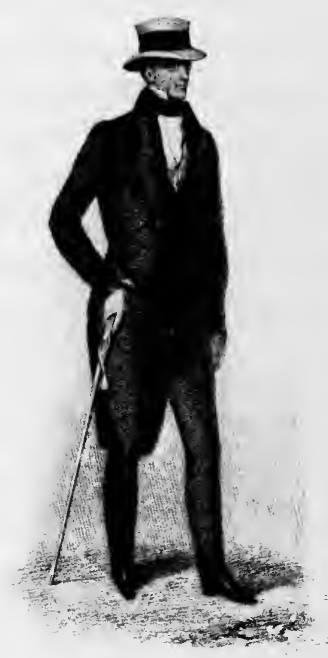

ANDREW JACKSON, ABOUT 1830.

From an old print of Earle's portrait. All his life long he was accustomed to lead in the community and in the army; hence he was over quick to make up his mind, and when he had once come to a conclusion, could not be moved from it. A political humorist of the time makes him say, "It has always bin my way, when I git a notion, to stick to it till it dies a natural death;

Letters of Jack

Downing and the more folks talk agin my notions, the more I stick to 'em."

On the whole Jackson's instincts were right; he hated monopoly and corporate greed and private advantage from public office. $\mathrm{He}$ saw much better than most men of his time the dangers likely to result from the national government's trying to help the states and the business men. His fault was that he looked upon the government as a kind of military organization in which it was treason to the country to interfere with the orders of the commanding general. If he had a prejudice against a man, he thought that man his enemy, and because Jackson's enemy, of course an enemy to his country. Yet it is true that Jackson was a living representative of the opinions of a majority of the voters in the United States. 
Jackson's military principles were carried into his appointments. His Cabinet had no eminent member except Martin 269. Ap- Van Buren, the Secretary of State, "The Little Magician,"

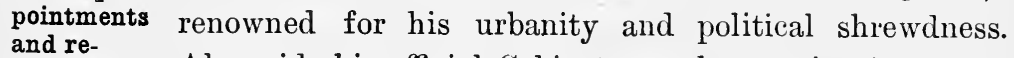
movals (1829-1837) Alongside his official Cabinet was the coterie of personal contained the real advisers of the President, including Van Buren; Major Eaton, Secretary of War; Amos Kendall, later brought into the post office to dismiss the local postmasters; and Duff Green, editor of the Telegraph, the Jackson organ. It was a mistake to appoint other men to the Cabinet whom he did not care to consult.

Never before that time had a President been so beset with office seekers; and the principal way in which vacancies could be found was by ejecting those who already held office. To the day of his death Jackson declared that no man was removed without a reason; but he was easily persuaded that hundreds of important officers were lazy, or corrupt, or political partisans. Hence in his eight years he removed 252 of the 610 officers appointed by the President; and nobody knows how many clerks and subordinates went with their chiefs. The vacancies thus made were filled without much discrimination, and the Senate threw out many of his nominations. Yet it is an injustice to Jackson to hold him responsible for bringing the system of partisan politics to Washington. He really meant to carry out what he called "the task of reform," but he demoralized the public service, because he took the advice of people intent chiefly on their own political fortunes.

Jackson's character was clearly brought out in his quarrel

270. Jackson's war on the United States Bank created when Biddle, president of the bank, refused to (1829-1832)

with the United States Bank. That bank had powerful rivals in the western state banks, of which, in 1829, there were about three hundred. Another set of enemies was remove some branch bank officers and to substitute Jack- 
son men (1829). Its most dangerous enemy was Jackson, because he represented an enormous constituency of farmers and small traders who were convinced that the eastern capitalists were getting more than their share of the annual products of the country. Jackson believed also, and with reason, that the bank sooner or later would become a political force.

Accordingly, beginning in his message of 1829, year after year Jackson repeated a warning that the bank was dangerous, unsound, and unconstitutional ; till, in 1832, as the presidential election was approaching, the friends of the bank, under Clay's leadership, made up their minds to force the issue into the campaign. They therefore passed a recharter bill in both houses, four years before the charter of 1816 was to expire; and Jackson, as was expected, vetoed it (July 10, 1832).

The bank question was for a time pushed aside by the threats of South Carolina to nullify the offensive tariff acts. The temper of the states was shown in a debate in the Senate 271. Nulliin 1830, in which Senator Hayne stood up for the right of a state to declare a federal statute void (\$ 273). (1828-1832) Webster of Massachusetts seized the opportunity in his "Second Reply to Hayne," to protest, with all his matchless eloquence and national spirit, against the doctrines of the South Carolina Exposition of 1828, written by VicePresident Calhoun ( $\$ 274)$. Jackson's position on nullification was not clearly made known till April, 1830, when, at a dinner on Jefferson's birthday, he was called on for a toast and gave "Our Federal Union: it must be preserved." A few weeks later Jackson quarreled with Calhoun on private grounds, and broke off relations with the Vice President.

A last effort was made to get Congress to reduce the offensive tariff, and a new tariff was passed (July 14, 1832); but Clay saw to it that the protective duties of 1824 were left in, and some of them raised; though the average rate of duty was reduced to about 34 per cent. 
In the presidential campaign of 1832 , the direct issue was the bank. For the first time delegates gathered in general party 272. Poli- conventions. The anti-Jackson men met in a "National tics and nullification Republican Convention," made the first national party (1832-1833) platform, and nominated Henry Clay. Jackson had already been nominated by members of several state legislatures, and his nomination was confirmed by a "Democratic National Convention," which also adopted the two-thirds rule for making nominations, and proposed Van Buren for Vice President. The election showed part of New England, with Maryland, Delaware, and Kentucky, for Clay, and the rest of the South (except South Carolina) and the West, with Pennsylvania and New York, for Jackson, who had 219 electoral votes to 49 for Clay, and 690,000 popular votes to 530,000 .

Jackson accepted the election of 1832 as an approval of his past course, and also of all the things that he meant to do in the future; and something had to be done very soon in South Carolina. A convention of that state, elected for the purpose, passed an ordinance, November 24, 1832, declaring the tariff acts of 1828 and 1832 to be "null, void, and no law, nor binding upon this State, its officers or citizens." This action Jackson treated as a personal affront. He sent General Scott to Charleston to arrange for defending the customhouse, and he issued a proclamation(December 11), warning the people of South Carolina against "the illegal and disorganizing action of the convention." At Jackson's request, an act, popularly called the "Force Bill" or "Bloody Bill," was passed by Congress (March 2,1833), giving the President more power to raise forces to meet such a crisis.

South Carolina began to raise troops, and the country was full of excitement. Calhoun resigned the vice presidency and came back to the Senate in 1833, in order to defend his doctrines in debates with Webster. In the end South Carolina really carried her point, for the majority of Congress believed 
that the South was wronged by the tariff, and under Clay's leadership, by the Compromise Tariff of 1833 (March 2), provided that the rates should be reduced at intervals till 1842, when they were all to come down to 20 per cent. The object of nullification having been accomplished without applying it, all plans of resistance were dropped by South Carolina.

For the ideas and arguments behind the nullification movement, we look to the addresses and speeches of John C. Calhoun. Calhoun came of the vigorous Scotch-Irish race, was born in 1782 in South Carolina, and entered Congress in 1811. As Monroe's Secretary of War (1817-1825) he was very

273. State rights theories of Calhoun efficient, and as Vice President (1825-1832) he was long looked upon as the probable successor to Jackson. In 1828 he made a square turn against national powers and worked out his doctrine of nullification a claim which was a magazine of argument for the secessionists at the time of the Civil IVar. It may be divided into three parts - the grievance, the nature of the federal government, and the remedy:-

(1) Calhoun's grievance was that without any constitutional warrant, by the "tyranny of the majority," the tariff took a tax out of

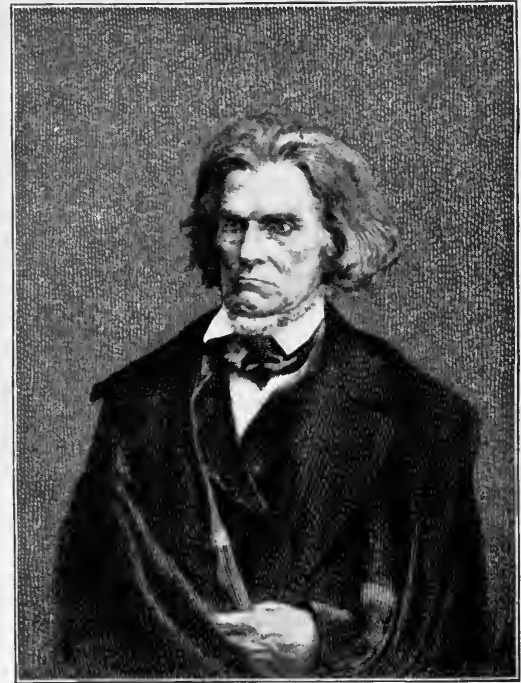

John C. Calhoun, about 1850.

From a daguerreotype. the pocket of the planters, and brought them no advantage. (2) His theory of the government was that "the Union is 
a union of states and not of individuals"; that the Constitution is a "compact" made by the states, and as in any other contract, if the states on one side failed to observe the limitations of the Constitution, the other states were freed from their obligation; that the federal government had no independent existence, but was only an "agency."

(3) Calhoun shrank from the logical remedy, secession; and proposed, instead, the remedy of "nullification," by which the people of South Carolina were simply to refuse to obey the tariff acts. For the federal government to bring suits to enforce the acts, or to use force, seemed to Calhoun's mind an act of war, which would dissolve the Union; and he had no doubt that other states would come to the rescue.

The spokesman of the national theory of the government was 274. Nation- Daniel Webster, born in al theories of Daniel Webster 1782, in New Hampshire, a graduate of Dartmouth College. In 1813 he was sent to Congress from New Hampshire; then in 1823 from Massachusetts, and in 1828 to a senator's seat from Massachusetts, which he occupied most of his life thenceforth, with two intervals of service as Secretary of State. Webster's theory of the government was substantially as follows:-

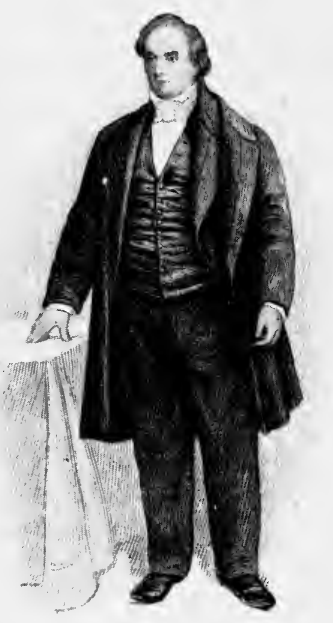

Daniel Webster, about 1840.

From the portrait by Harding.

(1) He scouted the idea that the Constitution is a compact, and called it an "instrument of government" for a nation. "It is, Sir, the people's Constitution, . . . made by the people, and answerable to the people. . . . We are all agents of the same supreme power, the people." 
(2) In language which rang throughout the Union, he denied the right of nullification and declared the great principle that the states could no more destroy the Union than the Union could destroy the states; for both were founded on the consent of the American people, taken as a whole.

(3) On the question who should decide in disputes as to federal powers, he held that the Constitution provided a mode " for bringing all questions of constitutional power to the final decision of the Supreme Court."

Webster's speeches were widely read and became the familiar doctrine in the North, especially in the crisis of the Civil War. One of the phrases just quoted appears in a little different form in Lincoln's Gettysburg Address of 1863.

The rivalry of South and North in part grew out of changes in the industrial conditions of the country. There was an immense development in raw materials, especially coal ; and 275. Changes the manufacture of pig iron was much cheapened when it was found that instead of charcoal or coke, anthracite in industrial conditions coal could be used (1838); and then that bituminous coal would answer (1846). Illuminating gas, first made in America in 1816 , gave another new use for coal.

In the twenty years from 1820 to 1840 more labor-saving inventions were brought forward than in the whole history of mankind before. The American manufacture of edge tools began; the invention of planing machines revolutionized woodworking; platform scales were introduced; the Nasmyth steam hammer was patented in 1842 ; the iron cook stove was put on the market about 1840; friction matches (invented in England in 1827) slowly began to take the place of the old flint and steel; the first crude Colt's revolver was patented in 1835. To furnish power for cotton and woolen mills, paper mills, and other industries, dams were built on the falls of the rivers in the eastern, middle, and southern states; and presently the manufacturing towns of Manchester, Nashua, Lowell, Lawrence, 


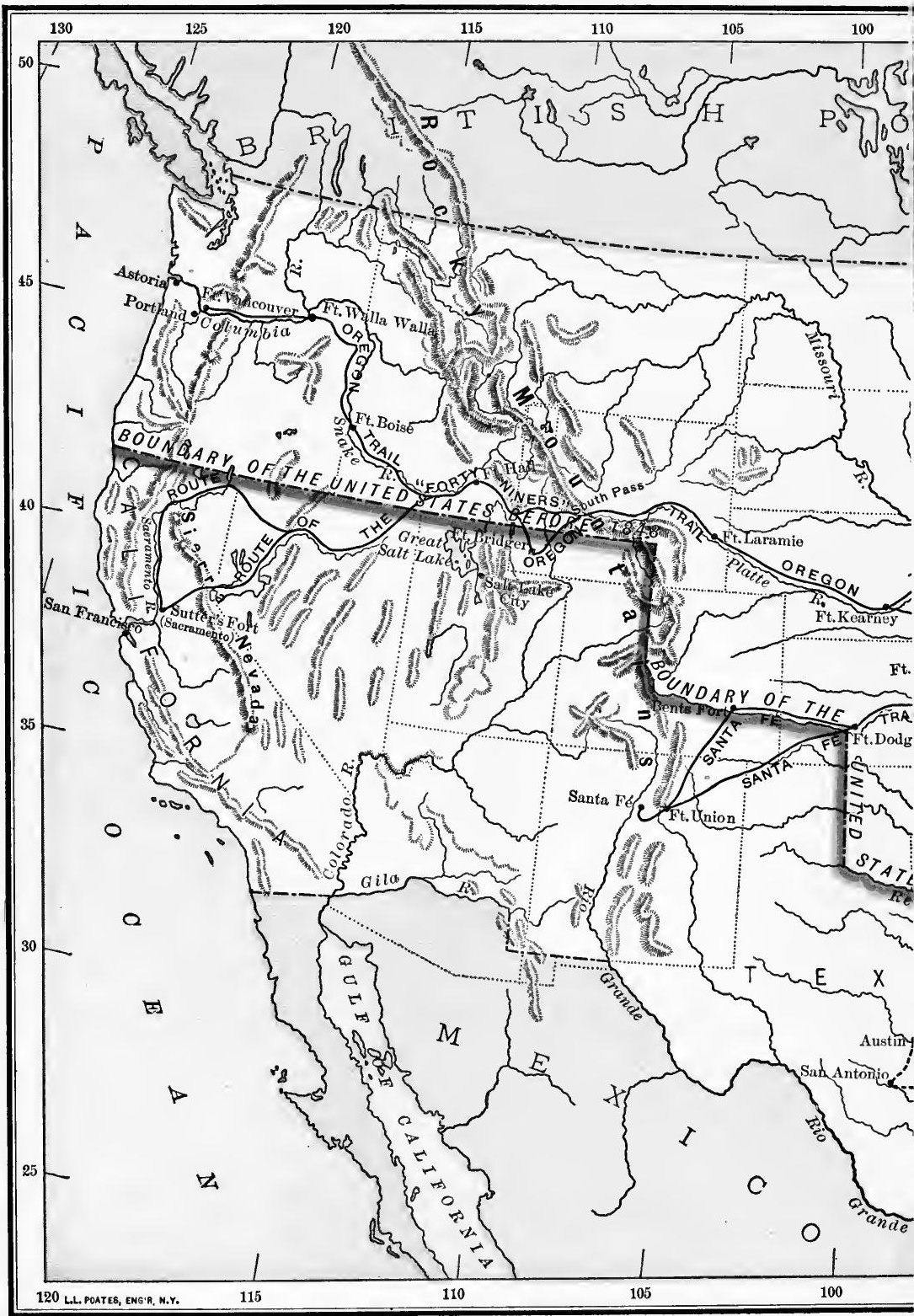


Holyoke, Cohoes, Trenton, and others, grew up. The methods of farming were changed by farm machinery. In 1834 McCormick patented the first horse reaper, the basis of the present elaborate mower's and reapers. About 1840 improved thrashing machines began to be used.

The ocean shipping interest was less affected, although steam coasters began to come in; and in 1819 the ship Savan. nah, with auxiliary steam power, voyaged from New York to Savannah and thence to Liverpool. The steamers Sirius and Great Western crossed the ocean from England, in 1838, practically under steam alone; and two years later a regular steamship line was established from Boston to Liverpool. Nevertheless, the bulk of ocean freight was still carried in wooden sailing ships, and the American clipper ship was considered the best in the world.

For internal commerce the success of the Erie Canal led to great undertakings by other states. Pennsylvania began a 276. Inter- canal system across the Alleghanies in 1826, and six nal improvements years later had a railroad from Philadelphia to Columbia, (1825-1841) a canal thence to the base of the mountains, an inclined road for hauling the boats in sections over the mountains, and a canal from the other side to Pittsburg. Several side canals were also constructed by Pennsylvania, including one from the Ohio River to Lake Erie (finished 1844). Ohio in 1825 entered upon the construction of canals from several places on the Ohio River to Lake Erie. Indiana spent $\$ 8,000,000$, and the 476,000 people of Illinois ran into debt $\$ 14,000,000$, or $\$ 30$ a head. In 1837 Congress began to make large gifts of public land in aid of state and private canals. A few important canals were built by private corporations, especially the Delaware and Hudson (1820), and the Schuylkill Navigation (18181825) for carrying coal. Eventually about six thousand miles of canals were constructed in the United States, of which less than one thousand miles are now in use. 
The growth in the average size of seagoing vessels called attention to the need of deepening and otherwise improving the harbors. In 1824 Congress began to make small appropriations for such purposes. Jackson was much opposed to spending government money for what seemed to him only private or local advantage, and therefore he vetoed a bill for a goverument road from Maysville on the Ohio toward Tennessee (1830); and he refused to sign several harbor bills. Still, many such improvements were made by Congress, among them the beginning of the Delaware breakwater in 1829 .

All other forms of internal improvement were soon cast into the shade by railroads, which suddenly cheapened transportation, stimulated travel, and built up new states and cities. Tramways for carrying heavy loads were built in 1807 near Boston, and in 1810 near Philadelphia. Railroads were soon begun westward from Albany, Philadelphia, Baltimore, and Charleston; but in 1830 only 122 miles had been built by the various companies, all for cars to be drawn by horses.

Soon after 1830 several great changes came about in railroads. An imported steam locomotive was introduced in 1829 for the Delaware and Hudson Canal Company; in 1830 Peter Cooper built an American locomotive for the Baltimore and Ohio, whereby horses were displaced. The inclined planes with stationary engines, which were introduced on many railroads, were replaced by continuous tracks; and on some roads coal was used as a fuel instead of wood. In 1834 the first long railroad in the world was completed-136 miles from Charleston, South Carolina, to Hamburg, opposite Augusta.

The first railroads had stone sleepers, or were built on piles driven along the line of the road. At right angles to the sleepers were laid the rails, wooden stringers about six inches square; to these were spiked short lengths of wrought iron 


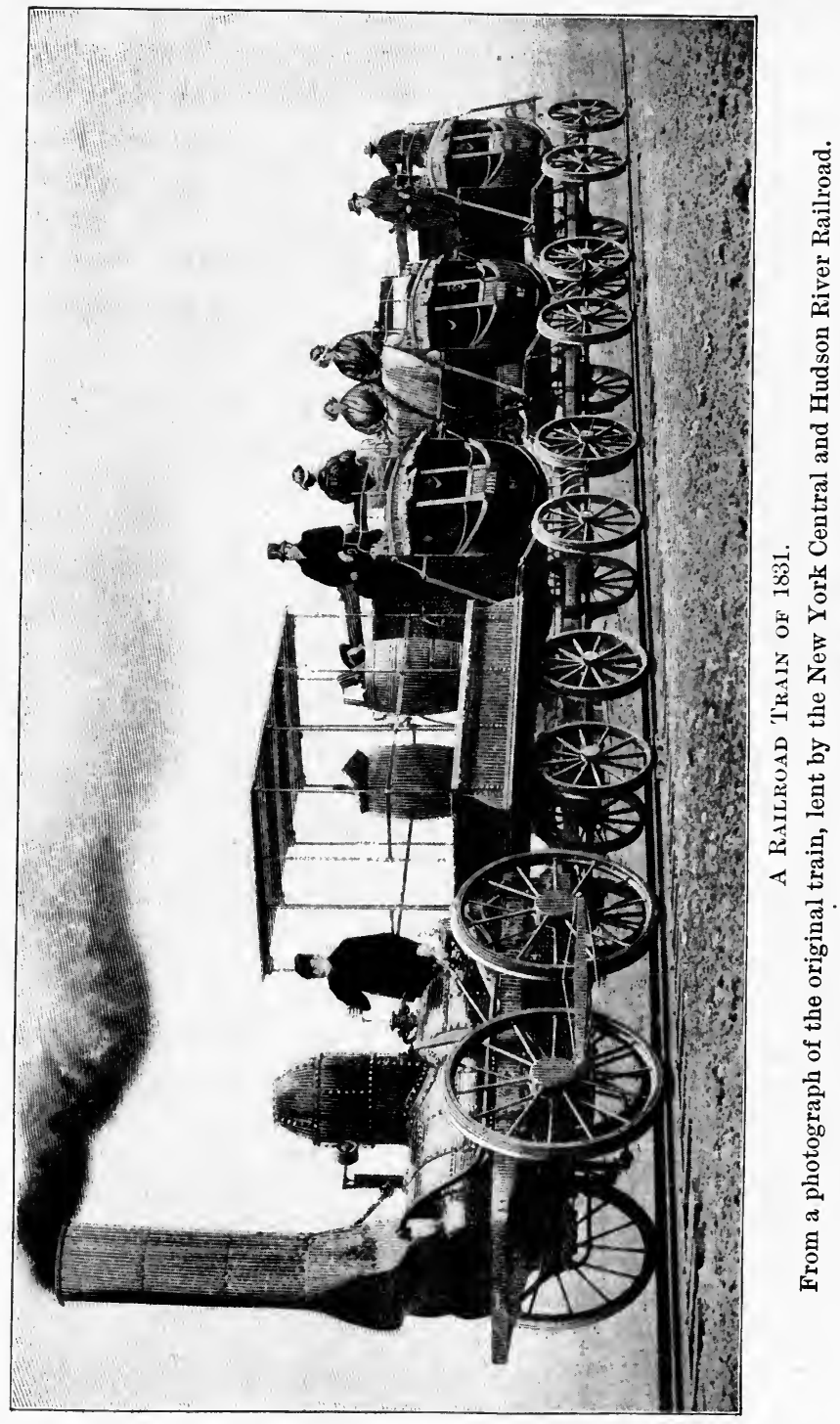


strips perhaps half an inch thick, and the curling up of the loosely attached irous was a common source of accident. The cars were at first modeled on the old stagecoaches, but the roads soon began to build the long car with a platform at each end and an aisle through the middle. Trains ran about fifteen miles an hour, and the early fares were three or four cents a mile. As there was no system of train dispatching, accidents were frequent.

At first anybody who could pay the tolls was allowed to run his cars on the tracks; but after locomotives came in, it was seen that both the roadbed and the motive power must be managed together. Several states looked on railroads as only a new type of public highway; and Massachusetts, Pennsylvania, Georgia, North Carolina, Michigan, and other states built lines of state railroad; others aided new roads with grants of money. Since many roads ran from one state into another, state ownership was difficult; and state management was expensive and clumsy; hence eventually most of the states sold or leased their lines to private companies.

The commercial question that most interested Jackson related to the United States Bank, which he attacked unrelentingly because be thought it secretly bankrupt. In September, 1833, he ordered his Secretary of the Treasury, Duane, to stop depositing in the bank. When (1832-1835) Duane refused, Jackson removed him and appointed Roger B. Taney, who gave the necessary orders. Though it is the right of the President to perform even ill-judged actions within his constitutional powers, subject only to public opinion, the Senate passed a resolution of censure on the President; but the country showed its approval in 1834 by electing majorities of Jackson men to both House and Senate. The deposits were never restored, and when the national charter expired in 1836, the bank could go on only under a Pennsylvania state charter. Jackson's foreign policy was fiery, but on the whole suc- 
cessful. He got from Great Britain the long-desired privilege of carrying on West India trade in American ships (1830). And by rather undignified threats, he compelled (1836) a settlement of the "French Spoliation Claims" for captures of American merchantmen, claims which had been running thirty years.

The most serious foreign question of Jackson's time was the attitude of the United States toward the new independent 279. Re- nation of Texas. The name "Texas" was applied by the public of Spaniards and Mexicans to the region lying along the (1819-1836) Gulf coast, beyond the western boundary of the United States. Into northern and central Texas Americans began to go in 1819, under the leadership of Moses Austin and Stephen F.

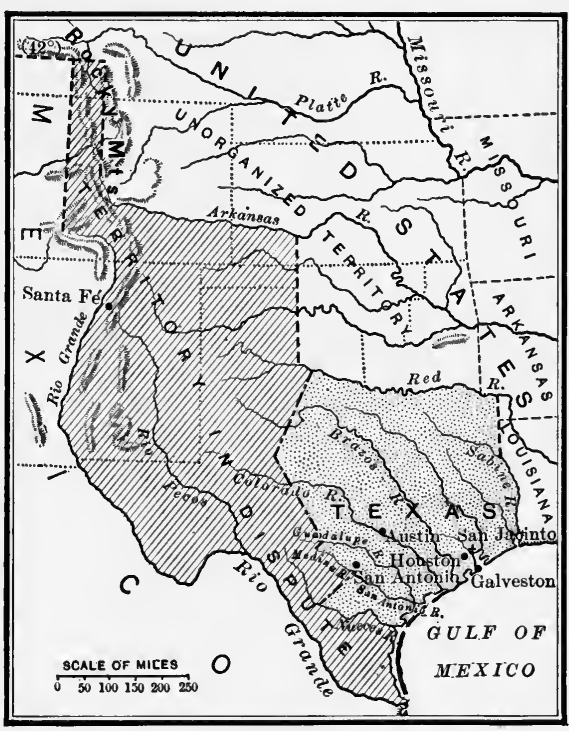

Texas Boundary Controversy.

Austin, who got large land grants. The Americans accepted the government of Mexico when that power became independent (1821), but in 1829, when the Mexican government abolished slavery, the Texans continued to hold their slaves, and to encourage other Americans to come in. In the hope of bringing the wandering children again under the home roof, both John Quincy Adams and Andrew Jackson made several vain attempts to buy Texas.

By 1835 the spirit of independence was so strong that the Texans resisted a Mexican force under General Santa Anna, 
the Mexican dictator. In March, 1836, under Sam Houston, a friend of Jackson, they declared their independence, drew up a national constitution, and made slavery a fundamental part of the government. Four days later a fortified convent, the Alamo in San Antonio, was taken by a Mexican army after a brave defense, and every man within it was killed. This massacre sowed undying hatred, and the Texans were too well organized and too good fighters ever to be conquered by Mexico. They desired to be annexed by the United States; and it might have been brought about had not the North protested against an annexation which would strengthen the slave power. In October, 1836, the Texan congress claimed a boundary "to the mouth of the Rio Grande, thence up the principal stream of the said river to its source."

The Texans fought not only the Mexicans but also the Indians upon their borders. Their neighbors east of the Missis-

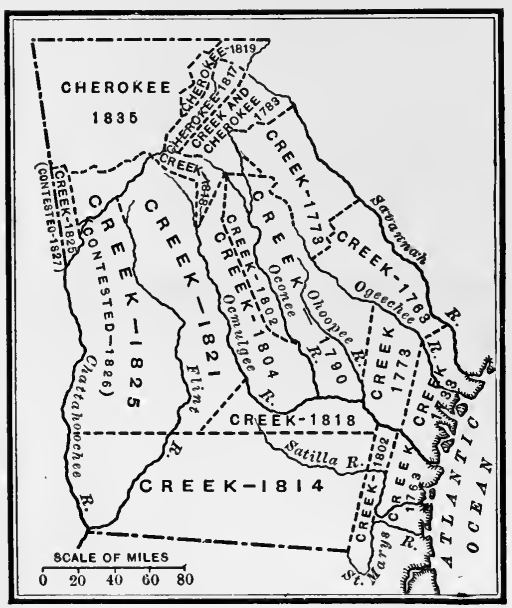

Indian Cessions in Georgia. sippi found the Indian problem less simple, as was shown

280. Indian difficulties (1824-1837) in a long-standing controversy between the Cherokees and Georgia.

Within the boundaries of Georgia in 1824 were about fifty thousand Creeks, Cherokees, and Indians of other tribes, who occupied reservations of eleven million acres, not subject to the laws of Georgia. A few Creek chiefs in 1825 signed a treaty for the cession of the Creek lands. The Indians tried to nullify the treaty by killing those who signed it; but the state 
of Georgia insisted on its right to survey the land, and, when President Adams interfered, threatened to fight. Thereupon the Cherokees, a rich people settled on farms, made a new tribal constitution (1827), which showed that they meant to remain indefinitely as a separate community within the boundaries of Georgia. That state, without waiting for a treaty or for the consent of the federal government, extended her authority over the Cherokee territory, shut the Indians out of the state courts, and made it a crime for white missionaries, or any other white people, to remain within the Cherokee country except on a license from the state of Georgia. President Adams was helpless, and the controversy went over to the next administration.

Jackson had never loved the Indians; and when he became President, he quickly solved the difficulty with the Cherokees by ruling that Georgia "possessed a right to extend her municipal jurisdiction over them." When the Cherokees made up a test case, and the Supreme Court decided that Georgia had no jurisdiction over the Indian country (1832), Jackson said, "John Marshall has made his decision, now let him enforce it." The Cherokees yielded to their fate. In 1834 Congress set apart the Indian Territory west of the Mississippi River, to which the Cherokees were transferred, together with the Creeks, Choctaws, Chickasaws, and Seminoles. The same policy of removal was applied to the tribes of the Northwest, causing in 1832 a brief Indian war - the Black Hawk War - in Illinois. Part of the Seminoles came back to Florida and for ten years about fifty warriors defied the United States army, and cost the federal government $\$ 20,000,000$. These wars practically ended the long friction between the two races, east of the Mississippi.

The purpose of removing the Indians was to open up land for 281. Immi- white settlers. In 1820 the United States ceased selling gration and publiclands (1820-1840) chaser could buy any quantity of land at a maximum 
price of $\$ 1.25$ an acre, or $\$ 200$ a quarter section. The demand for laborers brought a strong current of immigration from abroad. Between 1820 and 1829 about 110,000 people came; in the next decade, over 500,000 people, many of whom went straight out to make homes on the frontier. From 1820 to 1840 the population of the West increased from 2,600,000 to 7,000,000. Chicago in 1833 had 150 Contemporawooden houses, and a visitor said of it, "Almost every per- ries, III. 47i son I met regarded Chicago as the germ of an immense city."

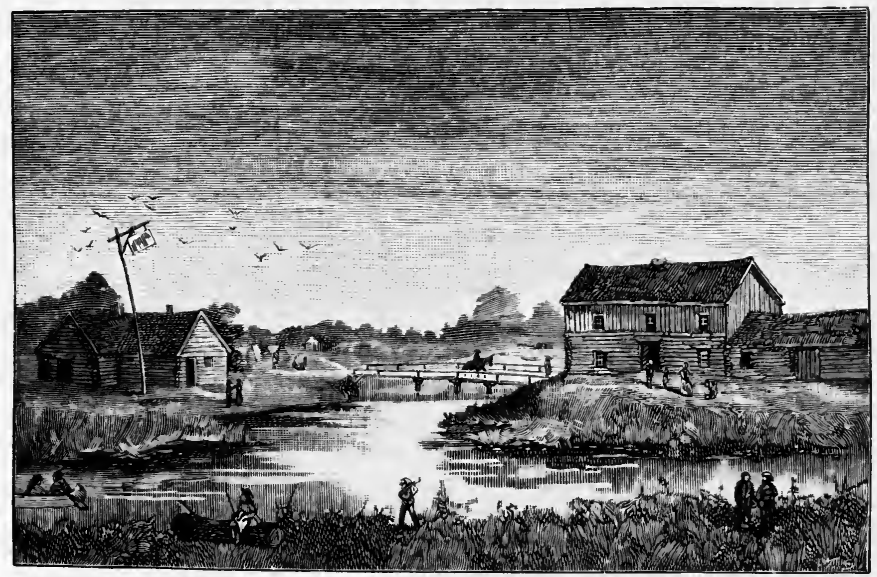

Chicago in 1832. (From an old print.)

The result of immigration and speculation was an unexampled demand for public lands; in the two years 1835 and 1836 the United States received $\$ 40,000,000$ from this source alone. To prevent the accumulation in the treasury of a surplus from the lands, various plans were suggested: (1) to give the lands to the states; (2) to reserve the lands in small tracts for actual settlers; (3) to distribute among the states the surplus from the sales of land. Clay favored the third plan, but Jackson in 1833 prevented it by a veto of a distribution bill. 
The election of 1836 was practically settled beforehand by Jackson, who selected Van Buren, required the Democratic

282. The panic of 1837 convention to nominate him, and by his own popularity pulled his candidate through. The opposition was too discouraged to make a party nomination, and Van Buren got 170 electoral votes to 124 scattered votes. No sooner had Van Buren taken office in March, 1837, than a financial panic was ready to break upon the country - the worst that the United States has ever seen. The principal causes of this calamity are the following:-

(1) Much banking business was carried on imprudently; partly because of the accumulation of government balances in the "pet banks" which were selected in 1833 to receive the public deposits. Depreciated state bank notes crowded specie out of use, and an act was passed (June 28, 1834) changing the ratio between gold and silver ( $\$ 196)$ to 16 to 1 , so as to encourage the use of gold.

(2) Lively speculation caused prices of cotton and other exports to rise, so that everybody seemed to be growing rich. The states found that they could borrow abroad, and ran up debts amounting to about $\$ 170,000,000$.

(3) Lively speculation in western land was backed up by the "pet banks" and their neighbors. Jackson became alarmed, and suddenly issued the Specie Circular (July 11, 1836), an order directing that nothing but gold and silver should be received for the public lands.

(4) In 1835 the national debt was extinguished, and a surplus began to run up. To get rid of it, in June, 1836, Congress passed a statute - the so-called "Deposit Act" - for depositing with the states (really for giving away) about $\$ 36,000,000$.

The call on the banks for the government deposits precipitated a crash. In May, 1837, all the banks of the country suspended specie payments; and nine tenths of the men in 
business in 1836 were bankrupt in 1837 . Many of the states, for the time being, defaulted on the interest on their bonds; three states repudiated principal and interest, and the money loss to their creditors was about $\$ 20,000,000$.

The "pet banks" eventually turned over to the government $\$ 28,000,000$ of public funds under the Deposit Act, and it was duly transferred to the states. Some of the states spent the money on canals, some to pay old debts, some for education, and a few states simply divided it among the voters. Slowly the country struggled up again; though in a second and lighter crash (1839) the old United States

283. Van Buren's quiet administration (1837-1841) Bank went completely to ruin. Some of the states, especially New York, took the lesson to heart, and passed new banking laws, under which the state banks were required to protect their notes.

A notable act of Congress during Van Buren's administration was a statute of 1840 for an independent treasury, or subtreasury, as it was often called, requiring the Treasury Department to keep its balances in its own vaults. Another important measure was the Preëmption Act of 1841, by which any citizen of the United States was to be allowed once in his life to buy 160 acres of arable government land.

The twelve years of Jackson's influence (for Van Buren's administration is only a kind of extension of Jackson's) were marked by great activity in public life. President Jackson sincerely believed that the federal government had

284. Summary given as much aid to individuals and states as was safe, and that it would be better to let the states develop themselves. Hence he never showed any enthusiasm over the tariff; he vetoed internal improvement bills right and left; and he attacked the United States Bank just as he used to assault an Indian fort; he vetoed the Land Distribution Bill, and reluctantly approved the Deposit Act.

HART'S AMER. HIST. -20 
The most serious discussions of this period were on sectional questions. The tariff was upheld by eastern, middle, and western states, and condemned by the South. Internal improvements most interested the western states, because they needed highways to reach their market. The bank question was at bottom an issue between the eastern believers in incorporated capital and the western advocates of individual action. Public land questions usually aroused West against East. The South usually held together on sectional questions, although in the nullification issue the other southern states refused to back up South Carolina.

The real force and public spirit of Andrew Jackson was shown by the final results of his eight years in office. He revived Jefferson's principles of strict construction and of as little government as possible; he hammered out in conflict with Congress a set of new principles, - low tariff, no United States Bank, no federal internal improvements, - which served the Democratic party for more than fifty years thereafter; and he caused his opponents definitely to take up the old Federalist principles of loose construction.

\section{TOPICS}

Suggestive topics

Search topics
(1) Why were some qualifications of voters and office holders removed? (2) Why was it difficult to frame good city governments? (3) Was the United States Bank dangerous to the country? (4) How came Webster to attack Hayne in the Senate? (5) Why did Jackson oppose nullification? (6). Why did Clay favor the Compromise of 1833 ? (7) Why did Calhoun change his mind on national powers? (8) Why have most of the canals been given up? (9) Why did Jackson oppose internal improvements ? (10) Why did Jackson wish to annex Texas? (11) Did Jackson introduce the Spoils system? (12) Had Georgia a right to the Creek and Cherokee lands ?

(13) Removals of federal officers for political reasons before 1830. (14) Removals for political reasons in New York before 1830. (15) Major Jack Downing's opinions of Jackson. (16) Jackson's intimate friends. (17) Jackson's enemies. (18) Popular 
opinion of the Kitchen Cabinet. (19) Some of Jackson's removals from office. (20) Calhoun's doctrine of the compact. (21) Webster's theory of the origin of the Constitution. (22) First anthracite and bituminous coal furnaces. (23) Ride on an early railroad. (24) Reasons for the Independent 'Treasury plan. (25) City popu. lation in 1790 compared with that in 1840. (26) State railroads in Massachusetts, or Pennsylvania, or Georgia, or Michigan.

\section{REFERENCES}

See maps, pp: 324, 325, 330, 331; Semple, Geographic Condi- Geography tions, 168-176; MacDonald, Jacksonian Democracy.

Wilson,.Division and Reunion, §§ 7, 12-24, 28-52, 57, 58, 71; Channing, United States, 212-224 ; Johnston, Politics, 109-139 ; Stanwood, Presidency, 151-205 ; MacDonald, Jacksonian Democracy ; Schouler, United States, III. 451-506, IV. 31-199, 229296, 316-352 ; McMaster, United States, V. 2-13, 121-168, 380394, 519-556 ; Peck, Jacksonian Epoch, 128-472 ; Dewey, Financial History, §§ 81-101; Houston, Nullification in South Carolina ; Sato, Land Question, 151-168 ; Sparks, Expansion, 274-289, 310319, - Men who made the Nation, 273-281, 294-334; Sumner, Andrew Jackson, 176-460 ; Brown, Andrew Jackson, 118-156 ; Parton, General Jackson, 281-326 ; Shepard, Martin Van Buren, 176-397, 449-467 ; Schurz, Henry Clay, I.312-384, II. 1-69, 129-152, 172-198 ; Lodge, Daniel Webster, 166-234 ; Holst, J. C. Calhoun, 83-120, 183-220 ; Roosevelt, T. H. Benton, 63-139, 151-209 ; Bruce, General Houston, 1-136 ; Trowbridge, S. F. B. Morse ; Raymond, Peter Cooper, 1-51.

Hart, Source Book, §102, - Contemporaries, III. §§ 158-168, 185 ; MacDonald, Select Documents, nos. 46-68, American History Leaflets, nos. 24, 30 ; Old South Leaflets, nos. 106, 130 ; Ames, State Documents on Federal Relations, no. 4, pp. 32-60 ; Johnston, American Orations, I. 233-334, IV. 202-237. See N. Eng. Hist. Teachers' Ass'n, Syllabus, 345-348, - Historical Sources, §84.

A. E. Barr, Remember the Alamo; Kirk Munroe, With Crockett and Bowie; C. A. Davis, Letters of J. Downing, Major (satire on Jackson); Simms, Richard Hurdis, - Border Beagles (interior). Wilson, American People, IV.; Sparks, Expansion. Illustrative works

Secondary authorities

Sources

Pictures 


\section{CHAPTER XXII.}

\section{SOCIAL AND SECTIONAL CONDITIONS (1831-1841)}

Side by side with the growth of democracy went a stronger feeling of public responsibility toward the poor, the weak, the 285. Hu- friendless, and even the criminal. People began to see manitarian that brutality to prisoners begets brutality to free men, reform

and that an object of punishment is to reform. The first modern prison was the Eastern Penitentiary at Philadelphia (finished just before 1830), where, in order to prevent one criminal from contaminating another, the prisoners were shut

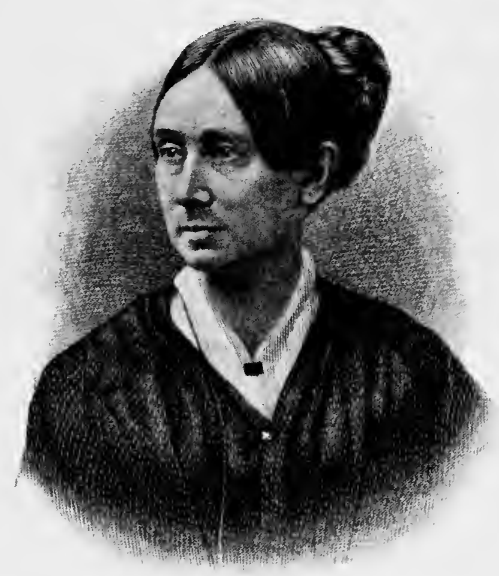

Dorothea Dix in 1850.

From an engraving. up in separate cells. The poor debtor also enlisted the sympathy of the community, especially when an old Revolutionary soldier was found who had been in jail for seven years on a debt of less than five dollars. In the course of the twenties and thirties all the states and the federal government passed laws releasing debtors who had nothing with which to pay.

Hospitals, clean and well-kept poorhouses, orphan asylums, and institutions for the deaf, dumb, and blind, also began to spring up; and in 1841 came forward a great woman, Dorothea Dix, who made it the 
object of her life to persuade people that it was the duty of the state governments to provide public asylums for the care of the insane. Interest sprang up in other neglected classes - first in the poor children, for whom the Sunday school had originally been founded. In 1807 some Williams College students became interested in the heathen of other lands, and stirred up the country to form mission societies. For that service each of the great denominations eventually created its own boards, and home missionary societies were formed for work on the frontier.

In the thirties and forties came also a new movement for public education. Massachusetts, under the guidance of Horace Mann, woke up in 1837 to the fact that she had wretched schoolhouses, dull text-books, untrained teachers, and ill-disciplined pupils. Public sentiment

286. Edu

cationa] reform was aroused in the state, the school system was improved, the people began to tax themselves more freely, and a state Board of Education was formed. The first normal school for the training of teachers was established in 1839. These ideas spread from state to state; and New York and Pennsylvania for the first time established thoroughgoing systems of rural schools.

The system of state universities was developed in 1825 by the founding of the University of Virginia (in which Jefferson was specially interested), the first American institution on the German model, offering a variety of elective studies. In the thirties Michigan established the so-called "Epistemiad," which developed into a state university. In 1837 there were over seventy-five endowed colleges in the country, besides twelve state universities and various kinds of special and technical schools. West Point Military Academy was founded in 1802, the Naval Academy in 1846, and law and medical schools by 1840 were numerous.

This was also a period of the foundation or enlargement of 
libraries - the Astor in New York, the Mercantile in Philadelphia, the Athenæum in Boston, and many others. Museums of art and science were opened in many cities, and the lyceum system of public lectures brought into towns and villages the most eminent men of the time.

Within the churches new duties were assumed, new socie. ties were founded, and several denominations were divided. 287. The From 1800 to about 1830 the Unitarian movement in churches and moral reform New England separated the Congregational Church into two ecclesiastical bodies. The Presbyterian Church, in 1837, split on doctrinal questions into "New School" and "Old School." The Methodist Church, in 1844, divided into a northern and a southern church, and the Baptist Church also showed a disposition to divide. The Catholic Church was much increased by steady immigration, especially from Ireland and Germany.

Up to about 1840 spirituous liquor was used freely by all classes : harvest hands received it; it was a part of the regular ration at sea; and it was freely served even at funerals. The Washingtonian societies, founded in 1840, agreed to use liquor in moderation, and from that it was a short step to total abstinence, and in 1846 to the "Maine Law," the first of the state prohibition laws.

A strong movement began about 1830 for "Woman's Rights," in which Frances Wright, and later Lucy Stone, Susan B. Anthony, and others were leaders. Their demand for good schools for girls was heard; girls were admitted to the public schools, then into high schools; academies were founded for them; and in 1833 Oberlin College was opened to women. The movement soon spread to a demand for woman suffrage, which, however, was nowhere granted till more than a generation later.

"Not a leading man but has a draft of a new community in his waistcoat pocket," said Emerson. From 1820 to 1840 scores of societies undertook to end sin and poverty by some 
new form of what was really monastic life. For instance, Robert Owen, an English enthusiast, came over and founded "The New Harmony Community of Equality" in Indiana (1824), in which the men and women wore a

288. Epoch of communities uniform, and the community undertook to bring up the children. The older Shaker societies by 1826 numbered 5000 souls.

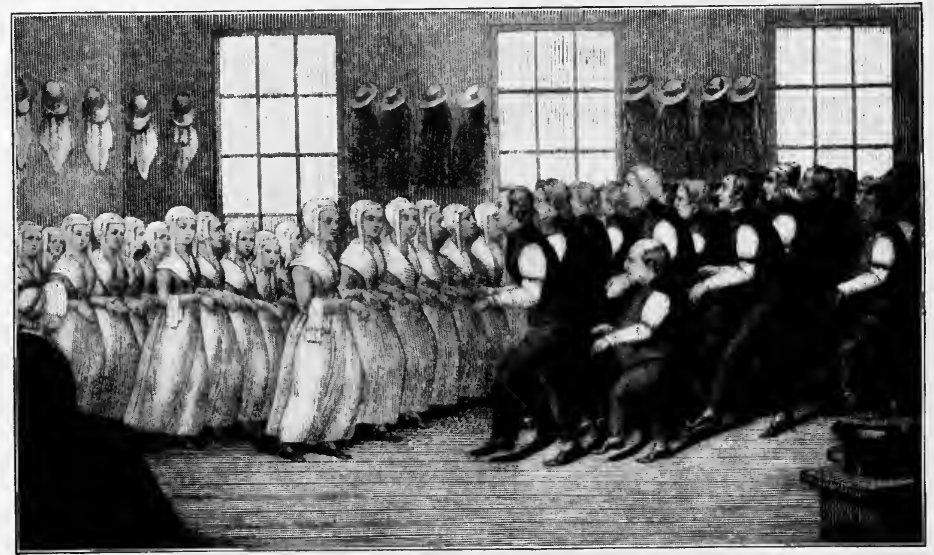

Shaker Dance, about 1830. (From a contemporary print.)

The most remarkable communal society was the Mormon Church, founded by Joseph Smith of Palmyra, New York, in 1829. In 1830 he published what he called the Book of Mormon, which he alleged to be a miraculously preserved account of the settlement of America by the lost tribes of Israel. $\mathrm{He}$ and his followers built a temple at Kirtland, Ohio ; in 1837 moved to Missouri; and soon after to Nauvoo, Illinois, where they built up a city of ten thousand adherents. The neighborhood disliked the Mormons, and Smith was killed by a mob in 1844. Two years later most of the Mormons moved to Utah.

A memorable example of the new community spirit was a little gathering of men and women at Brook Farm in Massachusetts, from 1841 to 1847 . They agreed to perform the work 
of the household and the farm, and to spend their leisure hours in the training of their minds. Among the members or visitors of this group were James Russell Lowell, Ralph Waldo Emerson, Charles A. Dana, and Nathaniel Hawthorne. The community dissolved, for it could not support itself by such labor; but its intellectual stimulus was felt in the whole country.

Until about 1830 most of the American essays, poems, novels, and criticisms were simply imitations of English writers. 289. Ameri- Even Washington Irving was intellectually an Englishcan litera- man of the school of Addison and Goldsmith, but he ture

found American subjects, and his Knickerbocker's History of New York (published 1809) is one of the most delightful of American satires. Of novelists the only widely known

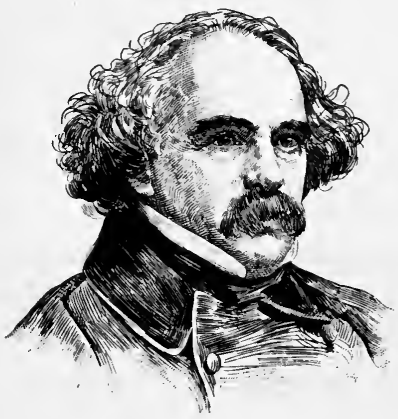

Nathaniel Hawthorne, ABOUT 1860. American at that time was James Fenimore Cooper, who began in 1821 to publish his entrancing novels of Indian life and character. In 1833 Edgar Allan Poe began his wonderful tales. William Cullen Byrant in 1811, when seventeen years old, touched the height of his genius in his poem of Thanatopsis. Other great writers, such as Hawthorne and Lowell, though they began to publish at this time, reached their zenith later. A school of American historians arose with the bold undertaking of George Bancroft to write the history of America from the beginnings, of which the first volumes came out in 1834; and a little later (1837) appeared William H. Prescott's Ferdinand and Isabella. Another important book was the first edition of Noah Webster's American Dictionary of the English Language, published in 1828.

Educated Americans were great readers of the English quarterly reviews; and in 1815 was established the North 


\section{SOCIAL AND SECTIONAL CONDITIONS (1831-1841) 343}

American Review, for many year's an intellectual force. Newspapers began to improve, and between 1833 and 1841 were founded the New York Daily Sun, the first one-cent newspaper; the New York Herald, which set a standard of the search for news; and Horace Greeley's New York Tribune, an example of breezy personal journalism. They were reënforced in 1849 by the Associated Press, which furnished information to a great number of papers.

The era of social reform extended very slowly to the South, which was not willing to harbor new ideas that might upset its rigid class system. The $3,700,000$ whites of 290. Souththe South in 1830 were divided into three social strata.

ern society

(1) At the summit stood from 25,000 to 30,000 members of the families of large slaveholders; in a few cases one master owned as many as a thousand slaves. These people were the social and political aristocracy; they furnished the governors, the judges, the representatives in Congress, and the senators. (2) About 630,000 people belonged to families each holding from one to four slaves: together with perhaps 500,000 prosperous nonslaveholding white farmers, they made up the ordinary community. (3) The poor whites, numbering about $2,500,000$, had neither slaves nor property, except rough land and miserable buildings, and except in some mountain communities never dreamed of using their votes against the slaveholding aristocracy.

Below all the whites were 180,000 free negroes, a despised and unhappy class, without political rights, held responsible for most of the petty crimes. and not allowed to move about freely. At the bottom of society were 2,000,000 291. Slave life African slaves, the people from whose physical toil came most of the wealth and consequence of their masters.

On the conditions of slave life there is an immense mass of conflicting testimony. Fanny Kemble, English wife of a Georgia planter, complained of sick slave women in hospital 
"prostrate on the earth, without bedstead, bed mattress or pillow." She saw her husband's slaves, including sick women, Kemble, Journal, armed with a whip. 102, 316 going to the field in gangs, each with a slave driver She saw a perfectly faithful slave given over to a new master who, in a few hours, was to carry him away forever from his father, mother, and wife. At the other extreme is the picture of slavery in Virginia drawn by Pollard - the white and the black boys growing up together, friends and playmates; the master listening to the complaints of lins slaves; and

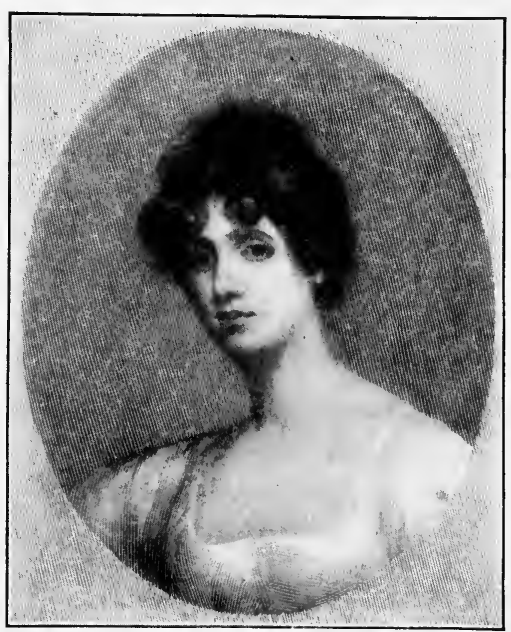

Fanny Kemble, about 1830.

the white mistress, sweet and stately, counseling the young and Pollard, protecting the aged. "I love the simple and unadulterated Black Dia- slave, with his geniality, his mirth, his swagger, and his monds nonsense; I love to look upon his countenance, shining with content and grease; I love to study his affectionate heart."

These views conflict, but are not contradictory, for there were many gradations of slavery. On some plantations the slaves were felt to be members of the family; on other plantations the life of the slaves was a round of dull misery, interspersed with thoughtless gayety. The house slaves were well fed, had light tasks, and were often petted by their masters; the field slaves were often overworked and abused. The right to own a slave included the absolute right to sell him, and there was no legal obligation to sell families as a whole; hence, heartbreaking scenes of separation at the 
auction block; yet the next day the slave, torn from his family, might be cheerfully fiddling on his way to the dreaded far South.

About 1800 the value of slave labor was small, but by 1830 cotton made it profitable. The prices of slaves rose, and border states like Maryland, Virginia, and Kentucky found ready sale for their surplus slaves in the cotton states. Hence, from the earlier idea that slavery was an evil to

292. Arguments for slavery be got rid of, the southern people came to believe that it was an evil which could not be shaken off; then, that it was a good thing which ought to be extended; and gradually a line of justification of slavery was worked out, which may be analyzed as follows:-

(1) That the negro was physically and mentally inferior to the white man, so that the theory of the equality of mankind did not apply; and that the only way to keep southern society together was to hold the negro a slave under such incitements as seemed necessary to keep him at work.

(2) That the slave was happiest and best off when somebody else fed him, clothed him, and cared for him in old age.

(3) That the good of the whites required slavery, for it would be impossible to clear the land without forced labor; and slavery gave to the white race a sense of responsibility and mistery.

(4) That the Scriptures authorized slavery: Noah said, "Cursed be Canaan; a servant of servants shall he be unto his brethren;" Abraham held slaves bought with Genesis ix. 25 money; St. Paul sent a fugitive slave, Onesimus, home to his master; Christ "taught many slaves, but never attempted to free any slaves."

(5) That slavery was necessary for democratic government, because it set the master free to attend to his political duties. As Calhoun put it, "Slavery forms the most solid and durable foundation on which to erect free institutions." 
Some of the most frequent objections to slavery were as follows : -

293. Antislavery arguments

(1) That the effect on the whites was to cultivate a fierce and passionate temper: no man could be safely trusted with such power of life and death, and of torture hardly less than death.

(2) That slavery was a denial to the negro of the opportunity to assert the manhood that was in him: southern laws, forbidding people to teach negroes to read and write, were a standing proof that their minds were so far as possible kept debased and ignorant.

(3) That the oft-reported horrors of the system were proofs of its natural tendency to cruelty. For example, the breaking up of families by sale was an inseparable part of the system, so that true marriage and the care of a family were impossible.

(4) That slavery had many economic disadvantages: it was expensive; it was wasteful; it used up the land; it could not be applied to any kind of machinery; it was not advantageous even to the masters, as was shown by the poverty of the South.

(5) That slavery was contrary to humanity, to the principles of Christianity and the practice of the church throughout the ages, and also to the whole theory of natural rights and democratic government. As Lincoln put it, "No man is good enough to govern another without the other's consent."

(6) That the alleged content and well-being of the slave did not lessen his inborn desire for freedom, as was shown by the runaway negro, who admitted that he had been well fed, well clothed, kindly treated, and trusted by his master. When he was asked why on earth he ran away, he replied quietly, "The situation am vacant!" It was a fair question why, if slavery was such a good thing, no free men, white or black, wanted to accept it. 
Various causes combined to bring the question of slavery to public attention about 1830 :-

(1) The discontent of the slaves, as shown by three risings: the Gabriel insurrection in Virginia in 1800; a plan to destroy Charleston, formed in 1820 by Denmark 294. The rise of the abolitionVesey, a free negro; a bloody insurrection in Southists ampton, Virginia (1831), under Nat Turner, a slave.

(2) The disposition of the South to enlarge the boundaries and the influence of slavery, and the consequent appearance of men like John Quincy Adams, who worked to prevent the extension of slavery.

(3) The question of the relative strength of the free and slaveholding sections of the country in the Senate, as affected by the admission of new states.

(4) The spread of humanitarian reform through societies, which at last reached the slavery question. Though the southern abolition movement suddenly collapsed about the year 1830 , within ten years one thousand northern abolition societies were formed with about forty thousand members; and they demanded the immediate and absolute emancipation of all the slaves.

Two kinds of people, often not clearly distinguished, took ground against slavery: the antislavery men, who wished at least to prevent its extension; and the abolitionists, who wanted to destroy it where it already existed. Among the abolitionists there were three groups: western, middle state, and New England:(1) The western abolition societies were started chiefly by former slaveholders, who crossed the Ohio River to get away from the system. Such were Rev. John Rankin and James G. Birney. (2) The middle state abolitionists were strong in Philadelphia, New York city, and central New York, and included men like Arthur and Louis Tappan and Gerrit Smith, who had money and freely gave it for the cause. (3) The New England group included Wendell 
Phillips, the abolition orator; John Greenleaf Whittier, the abolition poet; Theodore Parker, the abolition parson; and later James Russell Lowell, the abolition satirist.

Among the hundreds of northern agitators, William Lloyd Garrison, by his intense devotion to the cause, has somehow 295. Wil- come to be accepted as the typical abolitionist, although liam Lloyd he differed with everybody else, and always represented Garrison, the extreme the extremest principles. Garrison was born at Newabolitionist buryport, Massachusetts (1805), became a printer, and wandered about the country. In 1830 he went to jail in Baltimore for too freely criticising a slave trader. In January, 1831, Garrison founded in Boston a little paper which he called the Liberator, and which speedily became one of the best-known and worst-hated papers in the country. From the platform of principles which he published in the first number, he never swerved throughout his life. He "determined, at every hazard, to lift up the standard of emancipation in the eyes of the nation."

Garrison was a one-sided and prejudiced man, who never could see that the slaveholder was anything but a robber and murderer; but he compelled people to listen to him, even when he refused to have anything to do with the federal government, because it protected slavery; and he publicly burned the Constitution of the United States, calling it - in scriptural language - " a covenant with death and an agreement with hell."

The abolitionists had a very effective method of agitation. Local societies were federated in a state society, which held 296. The abolition movement an annual meeting; and into an annual national conven(1830-1840) time to time to arouse public sentiment, and women and negroes sat on the stage and took part in the exercises. The societies prepared petitions to the state legislatures, and to Congress, and did everything they could to interest people 
and to make them abolitionists. Newspapers were founded, tracts, books, and almanacs were prepared, and freely illustrated with pictures of the horrors of slavery; and one college, Oberlin, admitted negro students and became the western center of the abolition sentiment.

Meetings, societies, and publications all caused an astonishing uproar. In the South, practically nobody was allowed to advocate abolition; in the North the sensitive population expressed its horror of the abolitionists by riots. In 1835 an antislavery meeting in Boston was broken up by a mob, which laid hold of Garrison, tied a rope about his body, dragged him through the streets, and tried to kill him. In 1837 another persistent agitator and editor, Elijah Lovejoy, was murdered by a mob in Alton, Illinois, because he persisted in publishing an antislavery paper even in a free state. Colored schools were broken up, and in New York and Philadelphia colored settlements were attacked. Nobody was more hated and despised than the abolitionist.

The abolition societies adopted the practice of sending petitions asking Congress to prohibit slavery in the District of Columbia, and in 1835 William Slade of Vermont made the first abolition speech in Congress. This led to a series of so-called gag resolutions (1836-1844) by which the House (1835-1844) forbade any debate on antislavery petitions. The attempt to stop discussion aroused John Quincy Adams, who believed that his constituents and their representatives on the floors of Congress, had the right to argue in the public press on any subject. In 1837, and again in 1842, attempts were made to pass a vote of censure on him in the House; but Adams warned Congress that if they attempted to stop petitions by censuring the member who presented them, "they would have the people coming besieging, not beseeching." The first western abolitionist member of Congress, Joshua R. Giddings of Ohio, appeared in 1838, and he made it the main purpose 
of his life to bring about slavery debates on all sorts of side questions, in spite of an attempt (1842) to close his lips by a vote of censure.

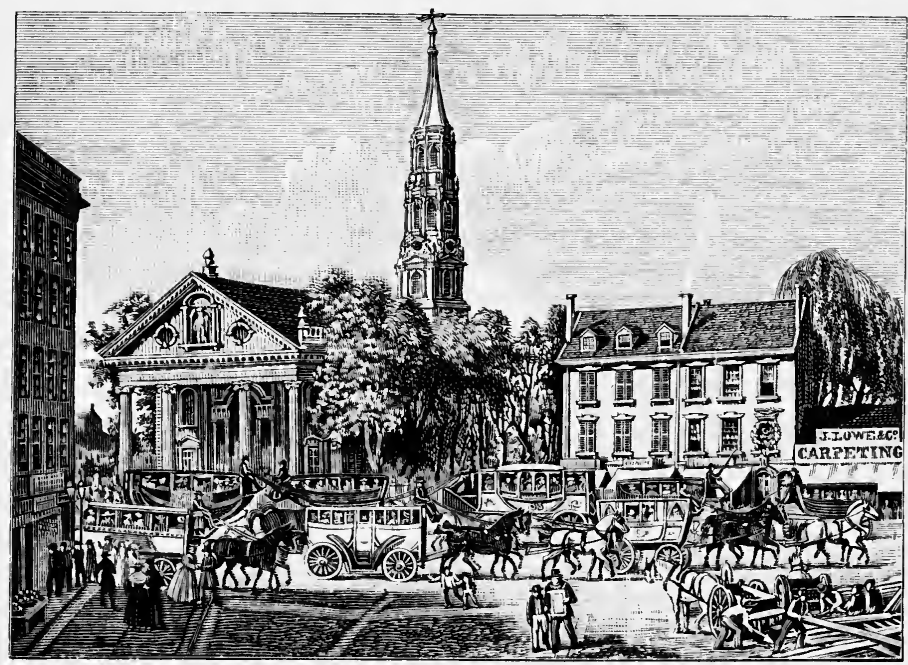

Broadway, New YoRK, in 1830. (From a contemporary print.)

Side by side with the political development of Jackson's administration went a great movement of humanitarian and 298. sum- religious reform. People at last had grown sympathetic mary

with the poor, the ignorant, the defective, the criminal, and the slave; they were trying all kinds of experiments; and they invented new sorts of societies and "causes."

The most important of the humanitarian movements was that of the abolitionists; and it was fiercely sectional, because the northern states were just getting rid of the last vestiges of slavery, and the South was on the whole well contented to have slavery. Since the agitators were all north of Mason and Dixon's line, and the thing to be reformed was all south of it, the Southerners looked on abolition as a wicked method of making them trouble. The abolitionists took the 
ground that slavery was a national evil, so long as the federal government recognized it and protected it; and therefore that it was a concern of the northern people as well as of the southern. Then they discovered that the place to preach the evils of slavery was in Congress. There was no stopping them, without giving up the right of free discussion; but from the time the abolitionists were fairly at work, the North and the South were estranged.

\section{TOPICS}

(1) Why should not people be imprisoned for debt? (2) Why should libraries be established out of public funds ? (3) Influence of Suggestive Brook Farm. (4) Washington Irving as a literary man. (5) James Fenimore Cooper as a literary man. (6) Edgar Allan Poe as a literary man. (7) Why did the poor whites vote with the great slaveholders? (8) Why did abolitionists cease agitation in the South about 1830 ? (9) Why did the attacks on the abolitionists swell their numbers?

(10) John Quincy Adams's objections to slavery. (11) Public services of Dorothea Dix. (12) ()rigin of normal schools in America. (13) Education at West Point. (14) The lyceum system. (15) Split in the Methodist Church in 1844. (16) Movement for foreign missions. (17) Washingtonian societies. (18) Joseph Smith's character. (19) Life in a wealthy slaveholding household. (20) Bright side of slavery. (21) Dark side of slavery. (22) Scriptural argument in favor of slavery. (23) Argument that slavery was good for the negro. (24) Stories told by fugitive slaves. (25) Prosecution for teaching negroes to read.

\section{REFERENCES}

Hart, Slavery and Abolition.

Wilson, Division and Reunion, §§ 53-57, 60-66; Hart, Slavery and Abolition; Sparks, Expansion, 290-296, 376-418; Rhodes, Geography Secondary authorities United States, I. 40-75, 303-383 ; Schouler, United States, III. 507-531, IV. 1-31, 199-229 ; McMaster, United States, IV. 522569, V. 82-108, 184-226, 284-3i2 ; Adams, United States, IX. 175187, 198-242 ; Larned, History for Ready Reference, IV. 2927, 2935, 2943, V. 3369, 33733, 3375 ; Page, Old South, 57-92, 143-185; Brown, Lover South, 16-49; Smith, Liberty and Free-soil Parties, IIAR'T'S AMER. HIST. - 21 
1-47; Wendell, Literary History of America, 157-435; Morse, $J$. Q. Adams, 242-308; Holst, J. C. Calhoun, 121-199; Roosevelt, T. H. Benton, 140-151 ; Hart, S. P. Chase, 28-91 ; Schurz, Henry Clay, II. 71-87, 153-171; Chesnutt, Frederick Douglass, 1-74, 107-118; Birney, James G. Birney; Sanborn, R. W. Emerson; Burton, J. G. Whittier. See also references to chapter xiv.

Sources

Hart, Source Book, §§ 94-101, - Contemporaries, III. §§ 151157, 169-184, - Source Readers, III. §§ 12, 13, 26, 28, 105-115, IV. \$§ 1-11; MacDonald, Select Documents, no. 69 ; American History Leaflets, no. 10 ; Old South Leaflets, nos. 78, 79, 81, 109 ; Caldwell, Survey, 148-156 ; Johnston, American Orations, II. 102122 ; Douglass, Life and Times; May, Antislavery Confict; Olmsted, Seaboard Slave States; Quincy, Figures of the Past ; Smedes, Southern Planter, 17-189. See N. Eng. Hist. Teachers' Ass'n, Syllabus, 348, - Historical Sources, § 85.

Illustrative works

Longfellow, Poems on Slavery; Whittier, Antislavery Poems, 9-94, - Snow Bound ; Lowell, Wendell Phillips, - W. L. Garrison, - On the Capture of Fugitive Slaves near Washington; Morgan Bates, Martin Brook (abolition); H. P. Belt, Mirage of Promise (abolition) ; Holmes, Elsie Venner (N.E.) ; Lucy Larcom, New England Girlhood; E. E. Hale, New England Boyhood; Hawthorne, Blithedale Romance; T. B. Aldrich, Story of a Bad Boy (N.E.) ; I). G. Mitchell, Doctor Johns (Conn.); Lily Dougall, Mormon Prophet; A. W. Tourgée, Button's Inn (Mormons); M. S. Tiernan, Suzette (Va.) ; A. B. Longstreet, Georgia Scenes; R. M. Johnston, Old Times in Middle Georgia; J. C. Harris, Uncle Remus; H. B. Stowe, Uncle Tom's Cabin; Edward Eggleston, Hoosier Schoolmaster, - The Graysons (West) ; Joseph Kirkland, Zury, - The Mc Veys (West).

Pictures Sparks, Expansion; Wilson, American People, IV. 


\section{CHAPTER XXIII.}

\section{RENEWED EXPANSION (1841-1847)}

The abolition controversy did not yet disturb the course of party politics. In the campaign of 1840 the Democrats nominated Van Buren for a second term. The anti-Jackson men, who had now formally taken the name of the Whig 299. The Whigs and Tyler party, nominated William Henry Harrison of Ohio for (1840-1842) President, and John Tyler of Virginia, a discontented Democrat, for Vice President. The Whigs expected to reëstablish the national bank, appropriate money for internal improvements, and, if possible, revive a protective tariff.

It was a boisterous campaign, full of great mass meetings. Somebody said that Harrison was fit only to sit in his log cabin and drink hard cider; the Whigs took up the slur; and $\log$ cabins on wheels, amply provided with barrels of hard cider, were used as a popular argument to voters. The Democrats were really beaten by the panic of 1837 , for hard times still continued. Harrison was chosen by 234 electoral votes to 60 for Van Buren, on a popular majority of about 140,000; and the Whigs secured both houses of the next Congress.

A month after his inauguration Harrison died, and John Tyler succeeded to the presidency. Though elected by the Whigs he did not accept their principles, and vetoed (August and September, 1841) two successive bills intended to restore the main features of the old United States Bank; whereupon every member of his Cabinet, except Webster, resigned. Tyler also came into collision with the party Whigs over the tariff. Though the Compromise of 1833 was to have taken full effect in 1842 , they were determined to substitute 
a high protective measure. Tyler vetoed two bills, but finally signed the tariff of 1842 , which went back substantially to the scale of the tariff of 1832, raised the average duties from about 24 per cent to 35 per cent, and completely upset the Compromise of 1833. Throughout the remainder of his administration Tyler quarreled with Congress.

About this time the progress of popular government led to two serious disturbances in the states. The holders of land 300. Dis- in the old Dutch patroonates in New York paid to the in the states descendants of the patroons an annual ground rent, or (1839-1844) "quitrent," of from $\$ 7$ to $\$ 18$ a year for each hundred acres. In 1839 these tenants began to refuse payment, to hold "Anti-Rent" meetings, to parade the country in masks and disguises, and to attack and kill sheriffs and rent payers. After several years of agitation the landlords agreed to accept lump money payments from the former tenants.

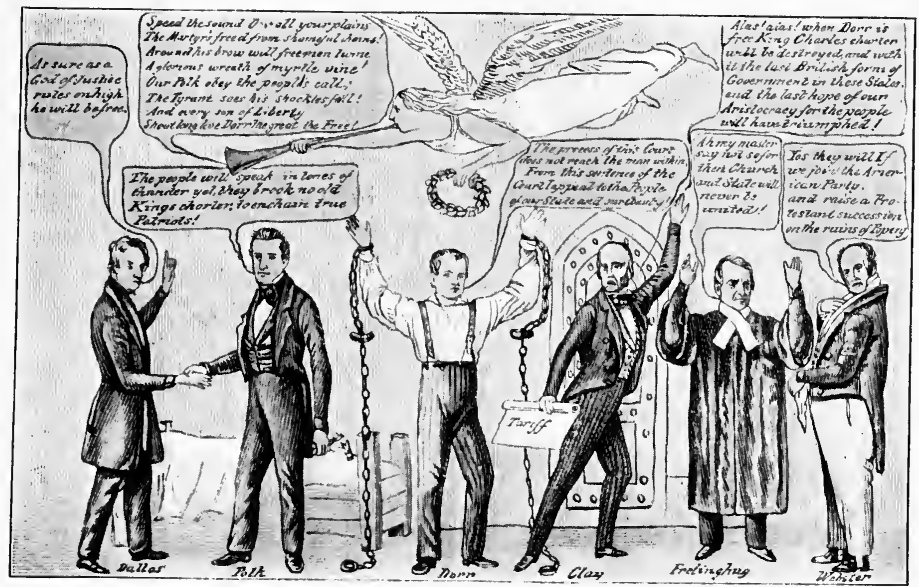

A Contemporary Cartoon of the Dorr Rebellion, 1812.

A more alarming popular movement arose in Rhode Island because no one could vote there except a "frøeman," - that is, a man holding real estate worth $\$ 134$, or renting for $\$ 7$ a 
year, - or the eldest son of such a man. A "People's Party," including both freemen and non-voters, held a convention in 1841 to adopt a more liberal state constitution, took a popular vote on it, declared it adopted, and elected 'Thomas IV. Dorr as governor. Dorr attempted by force to take possession of the state property (1842), but his men would not stand. The

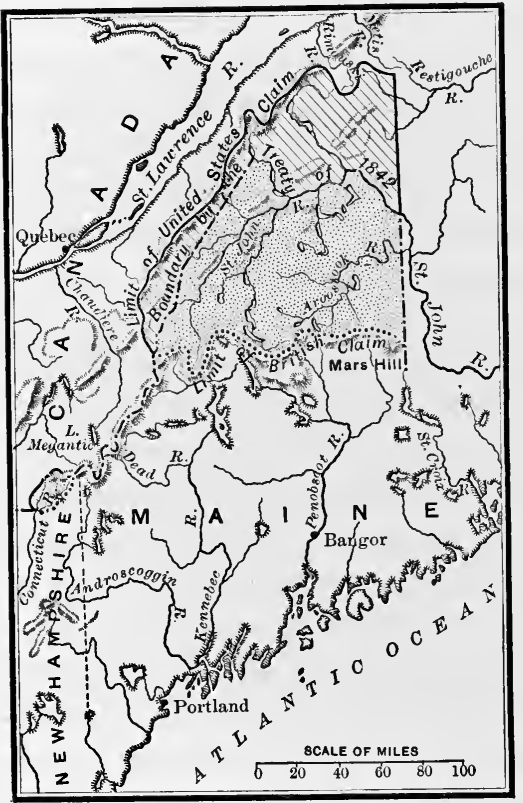

Northeast Boundary Controversy. governor under the old charter vainly called on President Tyler to send United States troops to help him; but Dorr was tried for treason and sentenced to imprisonment. Practically he accomplished his work, for the suffrage was at once enlarged by the regular goverument.

Other sorts of land questions and territorial questions made the years 301. North1841 to $1845 \mathrm{mo}-$ roundary mentous. One of (1783-1842) them was a renewed controversy with Great Britain over the Maine boundary. By the treaty of 1783 the line was to run "from the northwest angle of Nova Scotia, viz. that angle which is formed by a line drawn due north from the source of Saint Croix River to the Highlands; along the said Highlands which divide those rivers that empty themselves into the river St. Lawrence, from those which fall into the Atlantic Ocean, to the northwesternmost head of Connecticut River." It was soon found that the two governments did not agree as to 
what stream was the St. Croix, nor where to locate the northwest angle, nor where the Highlands were, nor even what was meant by "Atlantic Ocean."

In 1821 the line was run from the Atlantic to a point called Mars Hill; the British insisted that the "Highlands" lay there, and the Americans insisted that they were beyond the St. John River. After a vain attempt at arbitration (1827-1831), the state of Maine in the "Aroostook War" (1838) attempted to seize part of the disputed territory. Webster remained in Tyler's Cabinet long enough to settle this question: in 1842 he negotiated the Webster-Ashburton treaty, by which the disputed territory was divided, and each party got about half. The settlement was creditable and satisfactory to both sides, and ended a controversy which threatened to bring on war.

Until about 1820, the interior of North America was still little known; but in that year Major Long explored part of the Rocky Mountain chain, and from that time trade developed on what was called the Santa Fé trail, a road leading southwestward from the Missouri River to the Rio Grande (p. 324). In 1832 Bonneville's party went as far west as Great Salt Lake, crossing the Rockies with a wagon train, and some of them reached the Pacific.

Farther north the American Fur Trading Company in the twenties opened up a route to Oregon; and in 1834 Nathaniel

302. Explorations of the interior (1820-1845)
J. Wyeth of Massachusetts guided a party of settlers to Fort Hall, north of Great Salt Lake, and thence to Oregon. In 1836 Dr. Marcus Whitman and other missionaries to the northern Indians went out along this route. In the winter of $1842-1843$ Dr. Whitman came east from Oregon by a dangerous, roundabout route, partly on business of the mission, partly because he supposed that Webster was willing to give up all claims to Oregon. There was no such danger; the country was awake to the importance of a 
Pacific outlet; and there is no contemporary evidence to show that Whitman saw Webster or influenced the President. In 1843 he joined an expedition formed by other people and with it returned to Oregon.

A young army officer named John C. Frémont, aided by good guides, in the forties made three long explorations westward. In the first (1842) he went up the Platte River to its head waters, and crossed over the Rocky Mountain divide by the South Pass to the head waters of the Colorado. In 1843 he went through the mountains via Great Salt Lake to Oregon, and then across the Sierra Nevada to California. In 1845 he was sent off with an armed party and again reached California. He was a poor explorer, and made no proper surveys; but he was a son-in-law of Senator Benton of Missouri, young, dashing, and good-looking, and got the name of "Pathfinder" for his exploits.

One of Tyler's lines of policy was to annex Texas; and he made John C. Calhoun Secretary of State for that express purpose. Calhoun negotiated a treaty of annexation (April 12, 1844), which was rejected in the Senate by a vote of 35 to 16 ; and the scheme went over. The arguments in favor of annexation were: (1) that the Texans were simply Americans across the border; (2) that Texas was a rich and fertile country which would add wealth to the Union; (3) that annexation was a natural form of expansion; (4) that it was simply a "reannexation" of territory rightly a part of the Union from 1803 to 1819 ; (5) that it would retain for the slaveholders a needed control of the Senate.

Both the antislavery people and the abolitionists violently opposed annexation: (1) because it would bring into the Union more territory to be a field of slavery; (2) because it would give to the slaveholding influence perpetual control of the national government; (3) because it would probably bring on war with Mexico. 
The question of Texas came up again in the campaign of 1844. The natural candidates were Clay and Van Buren, both 304. An- of whom publicly declaimed against annexation. Clay nexation of was unanimously nominated by the Whigs. In the
Texas (1844-1845) Democratic convention Van Buren had at first a majority of the delegates, but was deprived of his nomination by the unexpected readoption of the two-thirds rule; and James K. Polk of Tennessee was nominated because he was known to favor annexation. The Democratic platform declared for "the reoccupation of Oregon and the reannexation of Texas at the Niles, earliest practicable period." Clay then felt compelled Register, to change his ground by saying that he would be glad LXVI. 429

to see Texas annexed, "without dishonor, without war, with the common consent of the Union, and upon just and fair terms."

The Liberty or Abolition party nominated James G. Birney, but in the election of 1844 got only 62,000 popular votes against 1,299,000 for Clay and 1,337,000 for Polk; yet it decided the national election by deliberately drawing off enough Clay votes in New York to throw that close state for Polk, whose electoral vote was 170 to 105 for Clay. The Liberty men hoped thus to compel the Whigs to take antislavery ground.

Congress and President Tyler did not wait for the new administration: since annexation seemed to have the approval of the majority of the people, a joint resolution passed the House by a vote of 120 to 98 , and the Senate by 27 to 25 (March 1, 1845), permitting the admission of Texas as a state on very favorable terms. No territory had ever before been annexed by this method; but Texas accepted and came into the Union as a full-fledged state in December, 1845. Under the terms of the joint resolution, she retained all her public lands, and might later, with her own consent, be subdivided into five states, all presumably slave states, except that slavery 
was to be prohibited in the new state or states north of the line of $36^{\circ} 30^{\prime}$. As to the Mexican boundary, the joint resolution took no ground; but President Polk's theory was that Texas included everything that Texas claimed; that is, all the territory as far as the Rio Grande.

Few Presidents have been so successful in carrying out what they undertook as James K. Polk, Tyler's successor. He was born in 1795 , was a graduate of the University of North Carolina, was fourteen years a member of the House of James Representatives (four years Speaker), and then for one (1845-1849) term governor of Tennessee. He had large public experience, and an imperious and far-reaching mind. The defect of Polk's character was his lack of moral principle as to the property of our neighbor, Mexico. His diary shows clearly that his real intentions and purposes were very different from those which he put forward in public. From the first he meant not only to annex Texas, but to add to the Union the enormous belt of territory stretching from the Gulf to the Pacific, to gain the port of San Francisco for Pacific trade, and to turn over the greater part of the new territories to slavery.

A strong Democratic majority appeared in both houses of Congress in 1845-1846, and speedily repealed the recent Whig financial legislation. The Independent Treasury system, which had been repealed by the Whigs in 1841, was restored; and the treasury has ever since remained the principal custodian of public funds. Robert J. Walker, Secretary of the Treasury, drafted and presented to Congress a measure which became law as the tariff of July 30, 1846. The duties on luxuries were very high, reaching 100 per cent on brandy and spirits; on ordinary manufactures they were only about 30 per cent; the average on dutiable goods was about 25 per cent; and the annual proceeds in a few years were twice as great as those of the tariff of 1842 .

For Polk's designs on California it was highly desirable to 
settle the long-standing controversy with Great Britain over Oregon, a name then applied to the whole Pacific slope from 307. The California to the Russian possessions. By extinguishOregon boundary ing the Spanish claims (1819) and the Russian (1824), (1818-1846) the United States and Great Britain were left the sole competitors for this fine country. The claims of the United States rested on: (1) discovery by Captain Gray (1792); (2) first.

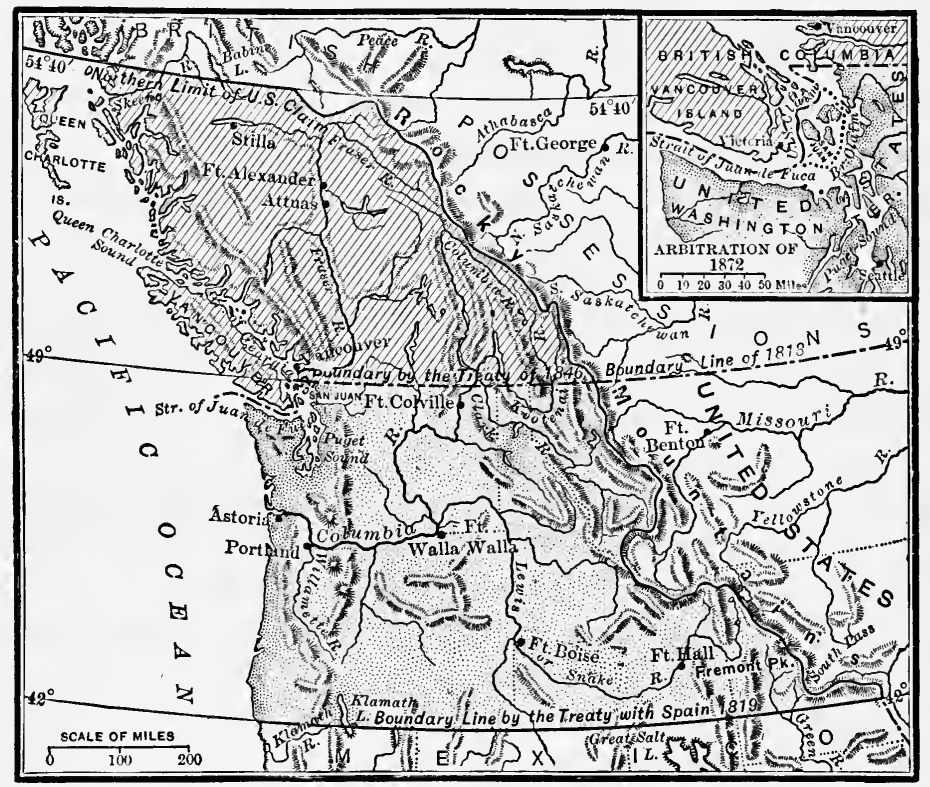

NORTHWEST BOUNDARY CONTROVERSY.

exploration by Lewis and Clark (1805); (3) first settlement by Astor (1811); (4) first permanent settlement, in the Willamette valley (1832). The British claim was based chiefly on the establishment of posts by the Hudson's Bay Company, but that company persistently kept out permanent settlers.

In 1826 Great Britain offered to divide the Oregon country on the line of the Columbia and Kootenai rivers; and between 
1818 and 1846 the United States repeatedly offered to extend to the Pacific the 49th parallel, which was already the boundary as far west as the Rocky Mountains; nevertheless a Democratic campaign cry in 1844 was "Fifty-four Forty, or Fight"; that is, a claim to the whole coast as far north as Russian America. It was therefore a surprise to the country when (June, 1846) Polk made a treaty accepting the compromise line of the 49th parallel, from the Rocky Mountains to the coast of Puget Sound; and the northwestern controversy was thus settled after fifty-four years of dispute.

The understanding with Great Britain came because President Polk had no mind to fight two wars at once, and for many reasons he expected a war with Mexico: (1) The annexation of Texas in 1845 caused the Mexican government to make boisterous threats, on the ground that Texas was 308. Outbreak of the Mexican

War still Mexican territory, threats that could easily have been (1845-1846) settled by a little diplomacy. (2) Mexico had been exasperatingly slow in settling claims for outrages against the persons and property of Americans; and those claims were now hard pressed by Polk. (3) Mexico absolutely rejected the boundary claimed by the Texan constitution of 1836 ; in fact, this included part of the old province of New Mexico and the town of Santa Fé, which was no more Texan than St. Louis (4) Polk was determined to annex California, by any means; and he secretly instructed our consul at Monterey, near San Francisco, to do all in his power to induce the native Californians to revolt, just as the Texans had done.

Polk was willing to get what he wanted without fighting, and in 1845 he sent John Slidell to Mexico to buy California if possible. The Mexicans would not even receive him, and made preparations for war. Without waiting to hear from Slidell, Polk ordered General Zachary Taylor, who was stationed at Corpus Christi on the Nueces River, to advance with his troops to the Rio Grande, where he closed the trade of the river with 
his guns. The inevitable collision came April 24, 1846, when the Mexicans attacked a body of American eavalrymen on the northern or eastern side of the Rio Grande.

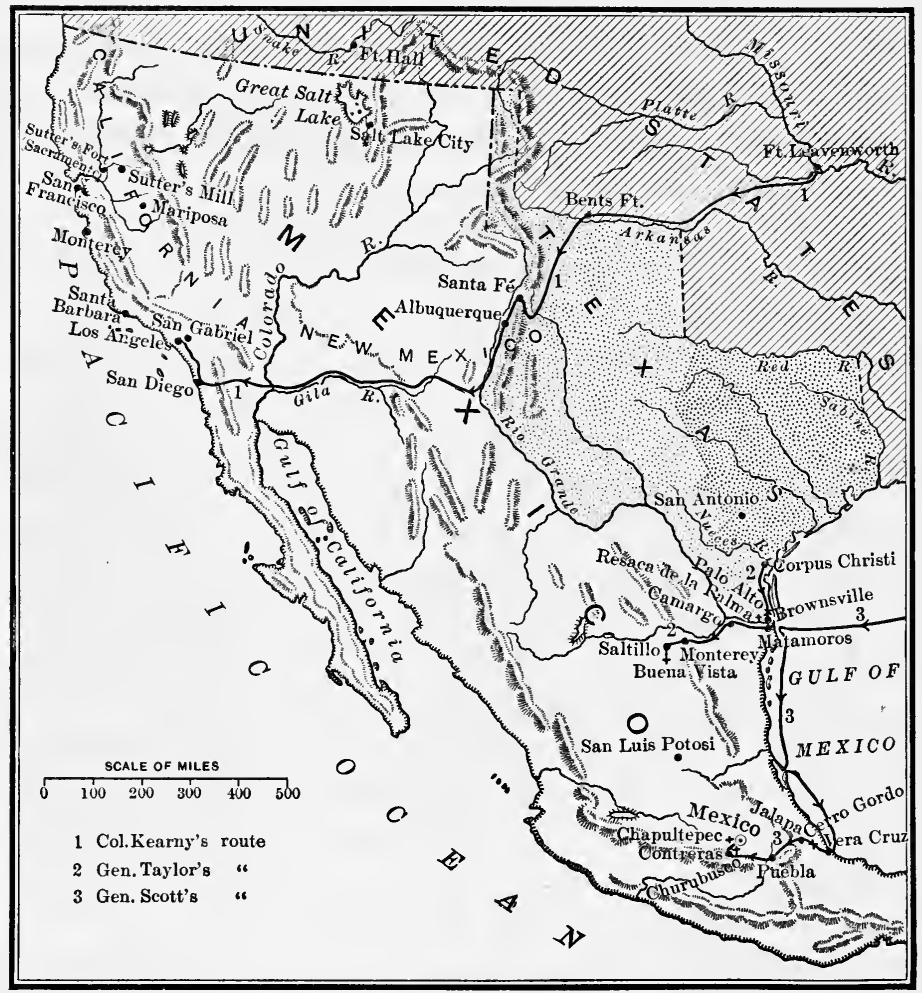

Mexican War.

Polk prepared a message to Congress, demanding war, on the ground that the claims were not settled, and that Slidell had been rejected. Before it was sent in, dispatches from Taylor announced the Mexican attack, and in a special message of May 11, 1846, Polk did not scruple to declare that "War exists, and, notwithstanding all our efforts to avoid it, exists 
by the act of Mexico herself." Two days later Congress passed an act "for the prosecution of the existing war," because "by the act of the Republic of Mexico a state of war exists." The wrath of the antislavery men over the purpose of enlarging the slave power was expressed by James Russell Lowell in the fiercest satire of his Biglow Papers :-

“'They may talk o' Freedom's airy

Till they're pupple in the face,

It's a grand gret cemetary

Fer the barthrights of our race,

They jest want this Californy

So's to lug new slavestates in

To abuse ye, an' to scorn ye,

An' to plunder ye like $\sin ! "$

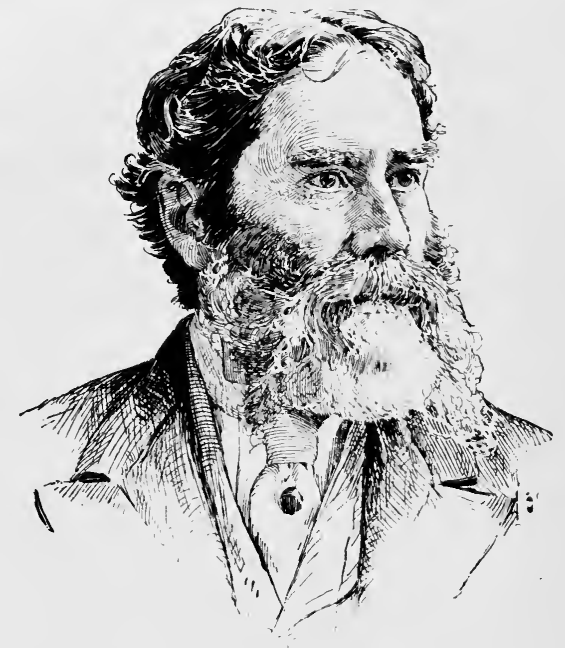

James Russell Lowell, about 1880.

The war was not fairly begun before President Polk tried to purchase a peace through General Santa Anna, formerly dictator of the Mexican republic; and he asked Congress for $\$ 2,000,000$ to be used for "negotiations" motProviso (August 4, 1846). The absolute determination of the (1846-1849) North not to take in more slave territory was expressed by an amendment of David Wilmot of Pennsylvania, which was added by the House to the "Two Million Bill." This "Wilmot Proviso" declared that, "As an express and fundamental Congrescondition to the acquisition of any territory . . . neither sional Globe, slavery nor involuntary servitude shall ever exist in any p. 273 part of the said territory." The bill failed through a technicality; but the South was aroused. Abraham Lincoln, in 
1847-1849, voted in Congress forty-two times for the principle of the Wilmot Proviso; but he voted in vain, for the Senate always showed an adverse majority.

Though the Mexican War was begun on false pretexts, and for the unrighteous purpose of the conquest of California, it 310. Prog- was carried on brilliantly by land and sea. General Tayress of the lor pressed steadily forward; beat the Mexicans in the
Mexican

War (1846-1847) (May 9), on the north side of the Rio Grande; then crossed the river, and again defeated the Mexicans at Monterey (September 21-23). Santa Anna, on returning to Mexico, took the patriot side, and organized a new army, with which he vainly attacked Taylor at Buena Vista (February 22, 23,1847 ).

In 1846 the administration began to be nervous about Taylor's popularity, and ordered General Winfield Scott, commander in chief of the army, to make a direct attack on the heart of Mexico. Scott landed and took Vera Cruz (March, 1847); and then fought his way steadily up into the mountains, pushed the Mexicans back at Cerro Gordo (April 18), and marched down into the valley of Mexico (August). In a succession of hard fights Scott beat the enemy back and advanced toward the city of Mexico, which he attacked with about 6000 disposable troops and finally captured, September 14, 1847. The Mexican government was broken up, and thereafter was unable to put in the field anything more than bands of guerrillas.

The belt of territory from Texas to the Pacific Ocean was occupied almost without resistance. In June, 1846, General 311. Annex- Stephen W. Kearny marched by the Santa Fé trail from ation of New the Missouri River, with about 1600 men; and on August Mexico and California (1846-1848) 18 entered Santa Fé without firing a shot. He set up a civil government, and then with a small number of troops started on westward to take possession of California. But 
California was already conquered. In June, 1846, the three hundred American settlers in California revolted and founded the Bear Flag Republic; and Frémont, in defiance of orders to let the native Californians set up their own government, brought his little force of troops to aid the Americans (July 5). Then a naval force under Commodore Sloat reached California (July 7, 1846). There was a brief war with the native Californians, ending with two battles near San Gabriel (January 8, 9, 1847);

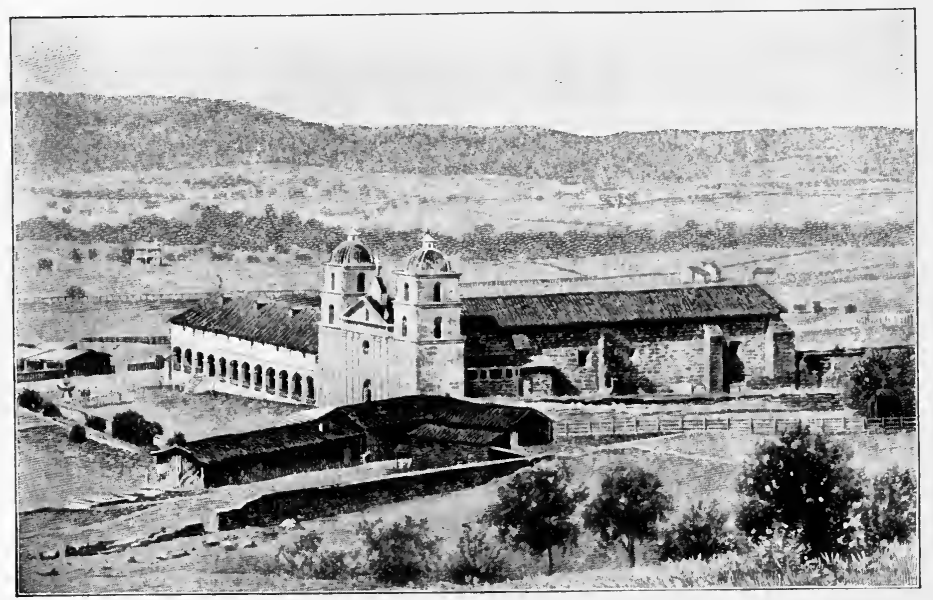

Santa Barbara Mission, California, FuUnded in 1786.

after which time there was no disputing the physical fact that the Americans were in possession of the country.

After the Santa Anna plan failed, Polk commissioned N. P. Trist, a clerk in the State Department, to make terms with Mexico. Trist proved inexperienced, quarrelsome, and insubordinate. He renewed the attempt to buy a peace from Santa Anna, but no body of reputable Mexi312. Peace with Mexico cans would take the responsibility of dismembering their country; and Trist was recalled (October, 1847).

It was a dangerous crisis, for the two strongest members of 
the President's Cabinet wanted him to take the whole of Contempora- Mexico. Polk's diary says, "I replied that I was not ries, IV. 34 prepared to go to that extent, . . . that I had in my last message declared that I did not contemplate the conquest of Mexico." The recall of Trist startled the Mexicans, who persuaded him to make a treaty, on the basis of agreeing to pay to the Mexican leaders (nominally to the Mexican treasury) $\$ 15,000,000$; Mexico gave up all claim to Texas as far as the Rio Grande, and ceded the whole of New Mexico and California. This treaty was accepted by Polk and approved by the Senate. Thus the Mexican War resulted in a great increase of territory, gained by bullying and fighting a weak neighbor. The war cost about $\$ 100,000,000$ and the lives of 13,000 of the 100,000 soldiers engaged.

The annexation of California at once brought up the question of the control of the routes across Central America (map, p. 313. Isth- 581). When the war broke out, the overland route to mus diplo- California took from three to eight months' time; and the (1846-1849) voyage around the Horn lasted from three to four months. People began to use the various short cuts across the narrow lands; and at once revived the idea of an isthmian canal. Therefore, in 1846, a treaty proposed by New Granada (now the United States of Colombia) was accepted by the United States, which guaranteed the Isthmus of Panama against seizure or interference, while New Granada guaranteed to the United States equality of use of any canal or roadway across the isthmus.

The only other practicable canal route across Central America was through the Lake of Nicaragua; and Great Britain claimed a "protectorate" over the neighboring Mosquito Indians. This pretension caused a crisis in our relations with Great Britain, leading to the Clayton-Bulwer treaty (April $19,1850)$, which was a fair compromise under the conditions of the time, and favorable to both parties. It secured common 
use and neutral control of the Nicaragua route, and the British agreed not to make any settlements in Central America. The principle of neutral and common use of a canal was also to be extended to the Isthmus of Panama.

The principal question during the years 1841-1847 was the annexation of territory. The Whig administration was wrecked by 'Tyler's coming to power; and the Democratic princi- 314. Sumple of strict construction prevailed in domestic matters.

Between 1842 and 1846 the Maine and Oregon boundary questions were settled, and Texas was annexed. That state with its actual boundaries might have been peacefully incorporated into the Union, but the claim to the Rio Grande seemed to the Mexicans robbery. President Polk, a masterful man, seized the opportunity to force the issue of war, in order to annex New Mexico and California. He got more than he bargained for, when he found our army in possession of a country too disrupted even to ask for terms of peace; but almost by accident, a treaty of peace was reached in 1848 .

Polk's designs on California, and above all the discussion of the Wilmot Proviso, aroused the North to the new and frightful crisis which had arisen over slavery in the new territories.

\section{TOPICS}

(1) Why was John Tyler nominated for Vice President? (2) Why did Tyler veto the bank bills in 1841 ? (3) Why did Tyler veto the tariff bills in 1842 ? (4) What was the boundary line fixed by the treaty of 1842 ? (5) Frémont's third expedition, 1845. (6) Why was not Van Buren nominated in 1844 ? (7) Why did the Liberty men refuse to vote for Clay? (8) Arguments for and against the tariff of 1846 . (9) Conflict between Taylor and the Mexicans, April 24, 1846. (10) What was the object of the Wilmot Proviso? (11) The battle of Monterey. (12) Capture of the city of Mexico. (13) Need of the Clayton-Bulwer treaty.

(14) Campaign meetings in 1840. (15) What were the "Highlands" mentioned in the treaty of 1783 ? (16) What was the

Suggestive topics

Search topics

HART'S AMER. HIST. -22 
" northwest angle of Nova Scotia"? (17) The Aroostook War, 1838. (18) Examples of quitrents in the American colonies. (19) An account of the Biglow Papers. (20) Examples of protest against the annexation of Texas. (21) Contemporary arguments for the annexation of Texas. (22) Travel on the Santa Fé trail. (23) Did Marcus Whitman confer with Daniel Webster? (24) Tom Corwin's argument against the Mexican War. (25) U. S. Grant in the Mexican War. (26) The Bear Flag Republic. (27) Adventures on the isthmian route to California.

\section{REFERENCES}

Geography

Secondary authorities

Sources

nlustrative works

Pictures
See maps, pp. 324, 355, 360, 362; Semple, Geographic Conditions, 178-224; Garrison, Westward Extension.

Wilson, People, IV. 88-128 ; Channing, United States, 224-234; Stanwood, Presidency, 206-225; Garrison, Westward Extension; Schouler, United States, IV. 359-550, V. 1-100; Rhodes, United States, I. 75-98 ; Larned, History for Ready Reference, I. 318, III. 2030, IV. 2646, V. 3377 ; Smith, Liberty and Free-Soil Parties, 48-120 ; Dewey, Financial History, \$\$ 102-109; Sato, Land Question, 60-69 ; Sparks, Expansion, 296-309,319-335 ; Foster, Century of Diplomacy, 281-325 ; Callahan, Cuba, 195-220 ; Schurz, Henry Clay, II. 199-315 ; Holst, J. C. Calhoun, 221-306 ; McLaughlin, Lewis Cass, 175-235; Roosevelt, T. H. Benton, 210-289 ; Morse, Abraham Lincoln, I. 1-86 ; Bancroft, W. H. Seward, I. 1-156 ; Elliott, Sam Houston, 122-133 ; Howard, General Taylor, 76-294; Wright, General Scott, 149-288; Wilson, General Grant, 1-73; Garrison, Texas; Winn, Mormons; Royce, California.

Hart, Source Book, §§ 103, 104, - Contemporaries, III. §§ 186189, IV. \$§ 8-16, - Source Readers, III. \$§ 40, 54-56, IV. §§ 47, 48; MacDonald, Select Documents, nos. 70-76 ; Old South Leaflets, nos. 45-132; Caldwell, Territorial Government, 131-199; U. S. Grant, Memoirs, I. 61-174; Dana, Two Years before the Mast. See N. Eng. Hist. Teachers' Ass'n, Syllabus, 349, - Historical Sources, § 86 .

Matthews, Poems of American Patriotism, 108-115; Whittier, Antislavery Poemis, 94-146, - Angels of Buena Vista; Lowell, Biglow Papers (first series), - Present Crisis ; Ruth Hall, Downrenter's Son (antirent); Charles Morris, Historical Tales, 255-269 (telegraph); Dana, Two Years before the Mast (Cal.); G. F. Atherton, Splendid Idle Forties (Cal.).

Wilson, American People, IV.; Sparks, Expansion. 


\section{CHAPTER XXIV.}

\section{RESULTS OF THE MEXICAN WAR (1848-1853)}

Polk's astute plans for making California a slaveholding region were brought to naught by a few grains of yellow metal. On January 24, 1848, about a week before the. 315. Gold treaty of peace was signed, James W. Marshall of in CaliNew Jersey picked up some flakes of gold in the race (1848-1853) of a new sawmill about sixty miles from Sutter's Fort, now called Sacramento. The news spread like the cry of fire; within six months the coast settlements of California were

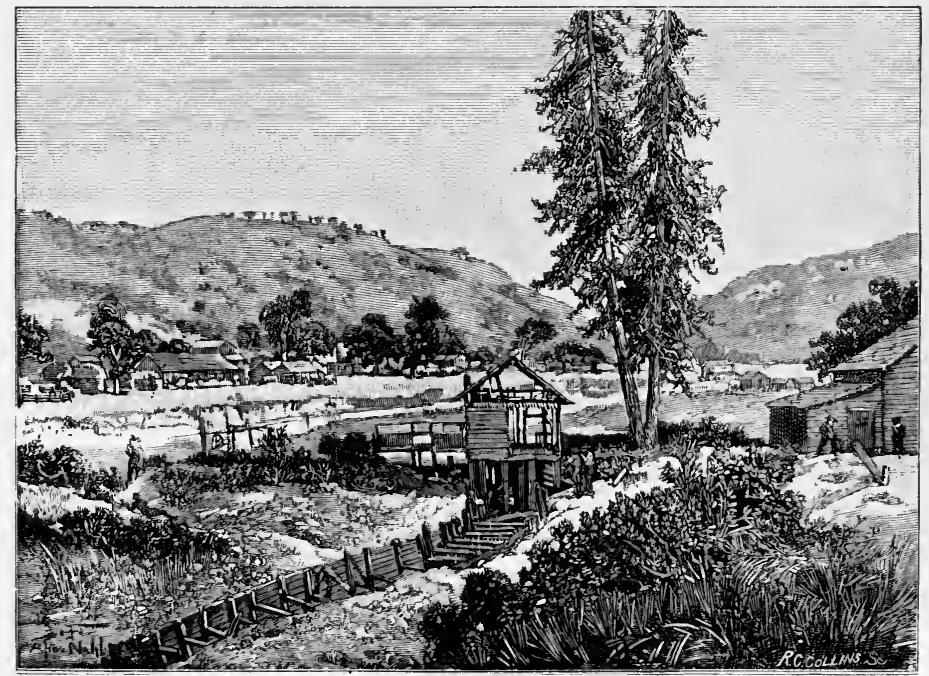

Sutter's Mill and Race.

From a painting in the Ferry House, San Francisco. 
almost deserted; the inhabitants hurried to the gold diggings, which were "placers" (gravel reaches or terraces) yielding gold in dust, coarser particles, and nuggets. Soon all sorts of merchandise rose in price three times over; and some miners by their individual labor were taking from $\$ 3000$ to $\$ 5000$ a month at the diggings.

The next year thousands of "Forty-niners" made their way to California, some around Cape Horn, some across the Isthmus of Panama or Nicaragua, some in wagon trains straight west across the plains (p. 324). Between fifty thousand and one hundred thousand people poured into California, and in two seasons more than $\$ 30,000,000$ of gold was taken out. If somebody "struck it rich," "in half an hour a motley multiColton, tude, covered with crowbars, pickaxes, spades, rifles, Three Years and wash bowls, went streaming over the hills in the nia, 293 direction of the new deposits." The old Spanish mining laws were inadequate, and the criminal laws did not apply to the circumstances; and there was no government to pass new statutes. The miners therefore organized, made their own mining rules, and set up so-called "vigilance committees" for offhand punishment of crime.

Gold mining was not all success. Probably every dollar of placer gold ever found in California cost on the average at least a dollar and a quarter in human toil, besides the waste of human life. After 1853 the yield of exposed placer gold declined, and mining in California gradually became a regular industry backed up by capital. Large streams were turned out of their beds in order to find the placer gold at the bottom of their courses; then the gold was traced back to the quartz ledges, and stamp mills were set up.

One object of the annexation of California was to secure 316. Trade ports for direct trade with the Pacific islands, China, in the $\mathrm{Pa}$ cific and Japan. The halfway station of the Sandwich or (1844-1854) Hawaiian Islands had for twenty years been under 
the influence of American missionaries, and the native dynasty recognized that the interests of the United States were greater than those of any other power. Chinese trade, however, was very much hampered by restrictions in Chinese ports. In 1844 Caleb Cushing, sent out by the United States, was able to secure a very desirable commercial treaty by which five Chinese "treaty ports" were designated for American trade; American consuls were allowed to hold courts for cases involving their countrymen; and American merchants and other people got the right to buy pieces of ground for their own occupancy, "and also for hospitals, churches, and cemeteries."

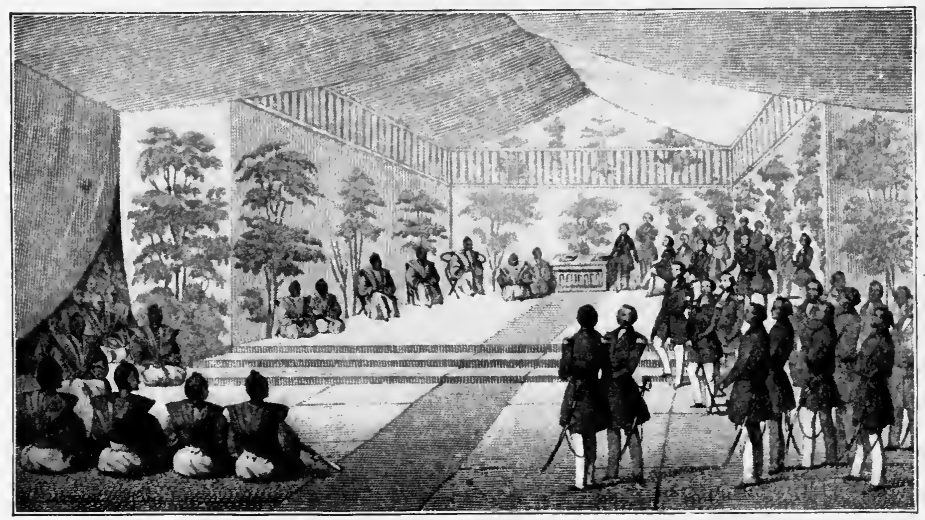

Perry in Japan, 1854. (From Perry's Narrative.)

Japan refused to admit any traders or foreign merchantmen on any terms, till the United States sent Commodore Matthew C. Perry to open up relations. He entered ports where no European vessel had ever been seen; he succeeded in breaking in the shell of the old empire; and he secured a favorable commercial treaty in 1854 .

The principal issue in the presidential election of 1848 was the future of New Mexico and California. The Whigs nominated General Zachary Taylor. Van Buren's friends soon 
after 1844 formed what was called the "Barnburner" faction of Democrats in New York; and when the Democratic con317. Crisis vention of May, 1848, refused their delegates full recogon territo- nition, and then nominated for President a "dough-face," rial slavery (1846-1849) or northern proslavery man, Lewis Cass of Michigan, on a noncommittal platform, the Barnburners bolted. They combined with the Free-soilers (who included the former Liberty men) in nominating Van Buren for President, on the platform of "Free Soil, Free Speech, Free Labor, and Free Men." This combination polled nearly 300,000 votes and threw New York over from the Democratic to the Whig side, thus allowing Zachary Taylor, a slaveholder, to be elected by 163 electoral votes to 127 for Cass.

From 1846 to 1849 several different propositions were made for settling the question whether slavery was to be legal in California and New Mexico: (1) the Wilmot Proviso, excluding slavery by act of Congress; (2) establishment of slavery by act of Congress; (3) continuation of the $36^{\circ} 30^{\prime}$ compromise line from Texas to the Pacific; (4) "popular sovereignty," which was a suggestion by Cass that the question be left to the people of the respective territories; (5) "executive regulations," through the Walker Bill, which would have given to the President authority to form a government. None of the five propositions could get a majority in both houses of Congress, and the only action bearing on the question was an act organizing the Territory of Oregon (August 14, 1848) with a prohibition of slavery.

As soon as Taylor became President (March 4, 1849), he used his influence and authority to bring about a state consti318. Slav- tutional convention in California. That convention drew ery questions up a state constitution (September, 1849) which definitely (1849-1850) prevented either a compromise line or local slavery on the Pacific coast; for it declared that California extended all the way along the coast from Mexico to Oregon, and it abso- 
lutely forbade slavery. Free miners, working with their own hands, would not permit slaveholders to come out with their slaves and compete in the placers. A state government was immediately organized without waiting for any act of Congress.

The air was full of slavery questions. Antislavery men felt that the time had come for some action which would put a stop to the domestic slave trade almost under the shadow of the Capitol; and Abraham Lincoln introduced a bill (January, 1849) for gradual emancipation of the slaves in the District of Columbia. The fugitive slave act of 1793 had never worked well, and a de-

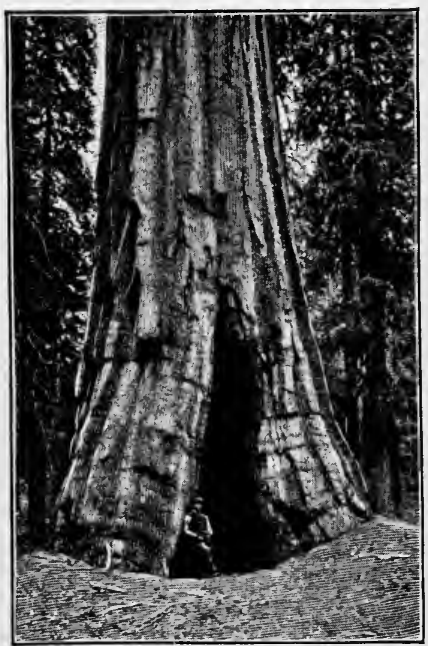

A California Big 'Tree.

"Grizzly Giant," in the Mariposa Grove.

cision of the Supreme Court (Prigg vs. Pennsylvania, 1842) took away much of its force. Besides, there was a regular system for aiding fugitives to escape, popularly known as the "Underground Railroad," in which more than 3000 people are known to have taken part; and through which, from 1830 to 1860 , upward of 60,000 slaves escaped. Fugitives were kept in the houses of abolitionists, forwarded from place to place at night, or hidden in out-of-the-way places; and if the pursuers came, were finally shipped across the Lakes to free Canada. The South demanded that a more effective fugitive slave law be provided, and bills for that purpose were introduced.

Behind all these questions was the larger issue of the relative power of free and slave states. Up to 1849 the principle 
of balancing states continued; Arkansas (slave) was admitted in 1836, and Michigan (free) in 1837, Florida and Texas (slave) in 1845, and Iowa and Wisconsin (free) in 1846 and 1848. To admit California as a free state meant permanent superiority of the North in the Senate, for there was nowhere a southern territory ready to enter the Union.

To settle all these complicated questions once for all, Henry Clay, "The Great Pacificator," came forward in January, 1850,

319. Compromise de- energies, and which was carried into effect seven months bate (1850) later. He declared, "No earthly power could induce me Congres-
sional Globe, to vote for a specific measure for the introduction of 1849-1850, slavery where it had not before existed"; but he bep. 279

lieved that New Mexico and California were already free by Mexican law; and therefore that the North might safely accept his plan.

The Compromise of 1850 was really made possible by Daniel Webster, as leader of the "Cotton," or commercial, Whigs of the North. In his famous "Seventh of March Speech," he argued that the North had not done its duty to the South, and was putting the Union in danger by refusing Contemporaries, $I V$. 53

a fair compromise. As for slavery in New Mexico, he was sure that it could never be profitable there, and he summed up his principles in the striking phrase, "I would not take pains to reaffirm an ordinance of nature nor to reënact the will of God."

Perhaps there was some danger to the Union: the Virginia legislature voted for "determined resistance at all hazards"; and a convention was called to meet at Nashville to disCongres- cuss the question of separation. Robert Toombs of sional Globe, Georgia declared in open Congress, "I do not hesitate p. 28 to avow ... in the presence of the living God, that if ... you seek to drive us from ... California . . . I am for disunion." In milder terms John C. Calhoun, in the last 
speech of his life, argued against a compromise, because the only thing that could pacify the South was for the North to stop the agitation of the slavery question, and to promise that nothing should be done by Congress contrary to the interests of slavery: as he said, "If you, who represent the stronger portion, can not agree to settle ... on the broad

Johnston, American Orutions, II. 159 principle of justice and duty, say so; and let the states we both represent agree to separate."

Northern senators like Salmon P. Chase of Ohio scouted the idea that the Union was in danger, and denounced any compromise as a yielding of principle to empty threats. They looked on Webster as a man who had always been opposed to slavery but was now betraying his own section, in the hope of getting southern support for the presidency.

President Taylor, who was under the influence of Senator William H. Seward of New York, leader of the "Conscience Whigs," refused to favor Clay's compromise; but he died suddenly in July, 1850, and Vice-President Millard Fillmore of New York became President, and signed in 320. The compromise adopted (1850) succession the five bills into which the Clay Compromise had been divided. (1) By the first bill New Mexico was organized as a territory comprising lands on both sides of the Rio Grande, but Texas received $\$ 10,000,000$ as indemnity for accepting her present limits; the real issue was carefully avoided by providing (a) that "the Constitution and all laws which are not locally inapplicable" should apply to New Mexico; (b) that no citizen of the United States should be deprived of his "life, liberty, or property except by the judgment of his peers and the law of the land"; (c) that when admitted as a state "the said Territory . . . shall be admitted into the Union, with or without slavery, as their constitution may prescribe at the time of admission." This was a tacit permission to hold slaves while it remained a territory. (2) The next bill admitted California as a free state. (3) The 


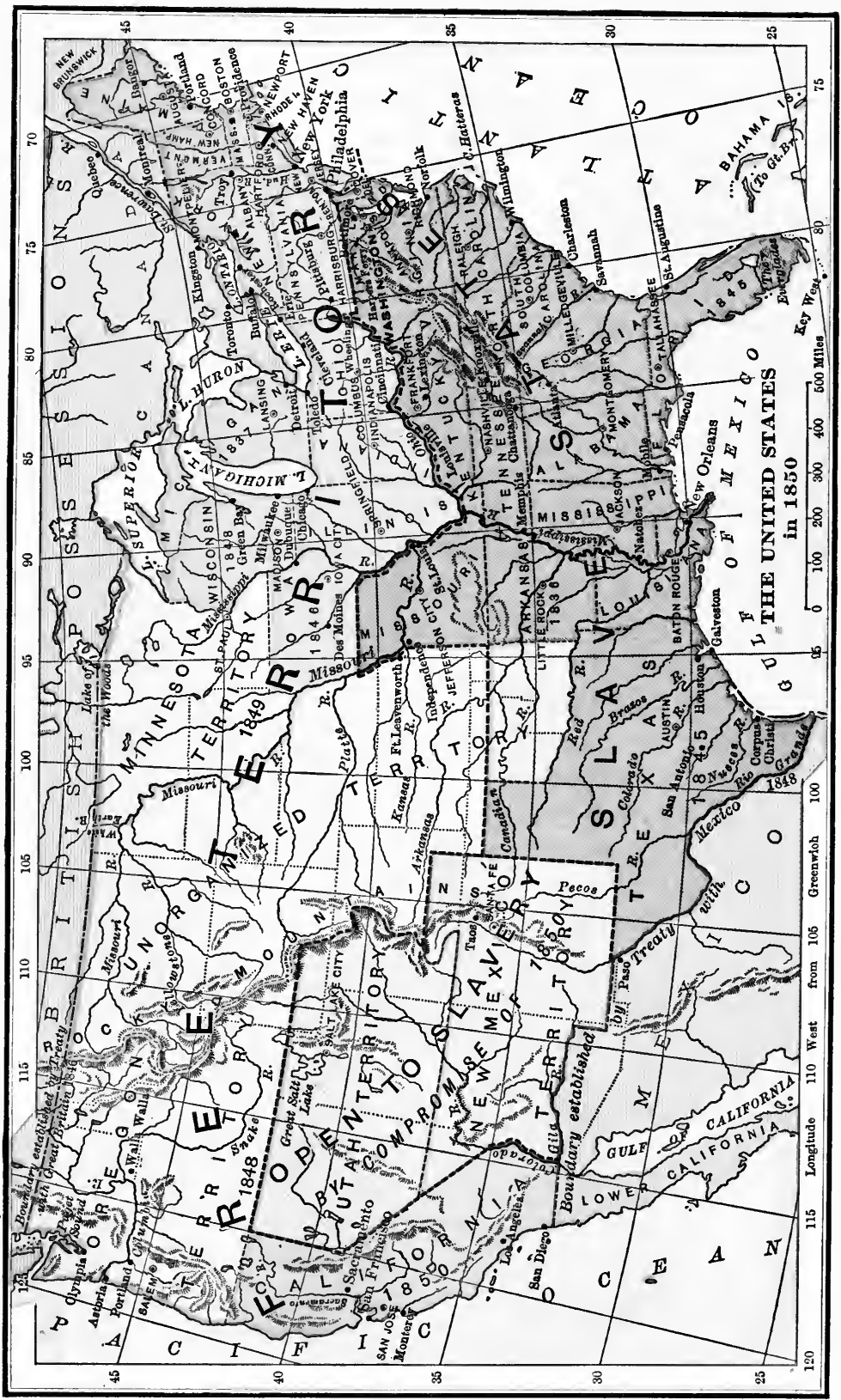


Utah Bill, with provisions like those of the New Mexico Bill, organized a territory north of New Mexico, apparently intended to be free. (4) A new fugitive slave act provided for a system of United States Commissioners to try cases in a "summary manner." (5) Another act prohibited the slave trade in the District of Columbia.

Among the new senators in 1849 was William H. Seward of New York, who at once came forward as a leading antislavery man in Congress. Born in 1801, Seward went to Union College and was for a short time tutor in a slaveholding family in the South. He went into politics in New York state and was twice Whig governor of New York (1839321. Seward and the higher law (1840-1850) 1843). His intimate friend and political manager was Thurlow Weed, one of the most adroit, long-headed, and unscrupulous politicians in the history of the country.

In the debate of 1850 Seward was the recognized spokesman of the antislavery opponents of the compromise. His argument was that compromises settled nothing, and that it was useless to try to provide for questions before they came up. In his speech Seward let fall a phrase which stamped him in the minds of the South as an implacable enemy: "The Constitution devotes the domain to union, to justice, to de- Contemporafense, to welfare, and to liberty. But there is a higher ries, IV.58 law than the Constitution, which regulates our authority over the domain, and devotes it to the same noble purpose." What he meant to say was that the law of God agreed with the Constitution; what he was understood to say was that the higher law nullified the Constitution, which undoubtedly recognized slavery as existing in some states and territories.

Balked of the expected slaveholding state in California, the extreme southerners now turned to Cuba, so rich, so near to the United States, so abounding in slaves. Polk

322. Attempts on Cuba had even offered a hundred million dollars for the is- (1849-1851) land in 1848. Several expeditions of "filibusters," that is, 
of volunteer adventurers, were fitted out in New Orleans; and one of them, under one Lopez, landed in Cuba (August, 1851) with nearly 500 men. The expedition was captured by the Spaniards, and Lopez with about fifty of his followers was executed. On hearing the news, the populace of New Orleans attacked the Spanish consulate. President Fillmore, while strongly censuring the expedition, did what he could to save the remaining prisoners, and a proper apology was made to Spain for the New Orleans incident.

The radical antislavery people showed their discontent with the compromise by violent resistance to the fugitive slave law, 323. Fugi- of which several instances should be mentioned. In tive slave February, 1851, an undoubted fugitive named Shadrach cases (1851-1858)

Hart, Source Book, 243 was arrested in Boston and brought before the United States Commissioner. An eyewitness said, "We heard a shout from the courthouse continued into a yell of triumph, and in an instant after down the steps came two huge negroes bearing the prisoner between them with his clothes half torn off, .... and they went off toward Cambridge, like a black squall, the crowd driving along with them and cheering as they went." In September, 1851, a man named Gorsuch, who had pursued runaways to Christiana, Pennsylvania, was killed by his own slaves. An attempt was made to frighten the abolitionists by trying for treason a Quaker named Castner Hanway, who was present and refused to aid Gorsuch. The prosecution, however, broke down, and the slayers of Gorsuch were not found. In 1854, while a fugitive named Burns was confined in the United States courthouse in Boston, a mob of abolitionists, in an attempt to rescue him, broke in the door and killed one of the deputy marshals.

The breakdown of prosecutions against the rescuers, in these and other like instances, showed that northern public sentiment was so strong against slavery that it was not worth while to appeal to the fugitive slave law. The spectacle of a 
hunted fugitive, sent back to lifelong captivity for no crime except that of being a black slave, brought home the conditions

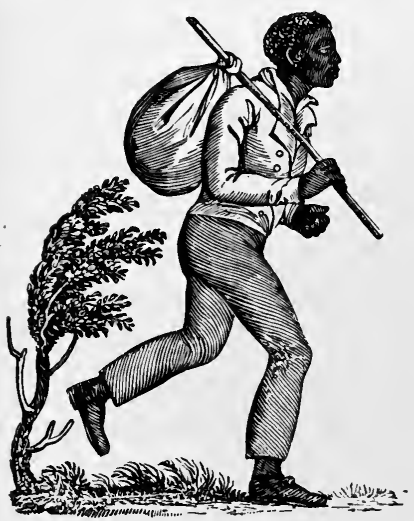

Runaway Slave.

Cut used in newspaper advertisements. of slavery to thousands of northern people.

The hostility to slavery was voiced by the legislatures of most of the northern states in the "Personal Liberty Bills." 324. PerUnder the fugitive slave laws sonal libof 1793 and 1850 , a free negro who was suspected of being a fugitive could be arrested and his status determined without any opportunity for the cross-examination of witnesses; and in several instances free men were thus kidnaped and sent into slavery. To meet this danger, about 1840 the northern states began to pass acts to compel a jury trial for alleged fugitives, and to forbid their officials to take any part in the proceedings against such persons. So far the states were acting within their rights; but after the Act of 1850 , new statutes were passed in all the northern states except two, interfering in various ways with the operation of the national fugitive slave statute and Constitution. All these acts showed that the free states, Constitution or no Constitution, would not recognize any responsibility for slavery.

In this time of storm and stress, the person who perhaps did most to affect the history of the country was Harriet Beecher Stowe, through her story Uncle Tom's Cabin, Tom's Cabin published first as a serial in 1851, and afterward in many (1852) editions in book form. The book was not primarily intended to be a political weapon; but it expressed a bitter sense of injustice at the system of man owning man, and it made the whole world see the human side of negro character, the kin- 
ship of men of every race. It was the only antislavery book widely read and discussed in the South.

How far Uncle Tom's Cabin is a truthful picture of slavery has been much disputed. Mrs. Stowe had indeed seen something of slave life in Kentucky ; and some of the incidents, such as Eliza's escape on the ice, were actual events. The purpose of the book was to call attention to the inevitable cruelty of human bondage and its degrading effect on the master, and to that end the author made use of harrowing scenes, all of which were possible under slavery, and many of which could be paralleled by extracts from the southern newspapers of the time.

Uncle Tom's Cabin recalled men to the real question of the day, away from artificial politics. No serious issue existed 326. Politi- between the two political parties: the Whigs no longer cal break- wanted a bank, or national internal improvements, or a up (1852) protective tariff; but there was a strong and fierce division of opinion inside each party on the slavery question. Nevertheless, in the political campaign of 1852 both Whigs and Democrats insisted that the compromise was a "finality," and that the antislavery people were making all the trouble because they would keep on discussing it. The Whigs nominated Winfield Scott of Virginia, a good soldier, but a weak candidate. For the Democratic nomination there was a fierce competition between Cass, Douglas of Illinois, Buchanan of Pennsylvania, and Marcy of New York; but the place went to an inconspicuous man, Franklin Pierce of New Hampshire, who had been for two terms a member of Congress, and for one term a senator, and had served creditably in the Mexican War. The former Free-soil party reorganized as the Free Democracy. Pierce received 254 electoral votes to 42 for Scott. Though the Whigs polled nearly $1,400,000$ popular votes against 1,600,000 for the Democratic ticket, and 155,000 for the Free Democrats, they carried only four states. 
The five years from 1848 to 1853 were full of excitement and danger. At the beginning of the period Congress had to face three hotly disputed questions: (1) the boundaries of Texas; (2) the future of New Mexico; (3) the future

327. Sumof California. The South insisted that the recently annexed territory should be divided by the compromise line of $36^{\circ} 30^{\prime}$ extended to the Pacific; the North insisted that both California and New Mexico should remain free. At the same time the questions of slavery in the District of Columbia, and of fugitive slaves, came in to confuse the issue.

After four years of exhausting discussion, all these issues were apparently adjusted by the Compromise of 1850 . The people of California secured a free-state government, and Congress cut down the Texan territorial claim; a new and more severe fugitive slave law was passed; and the slave trade in the District of Columbia was prohibited. New Mexico was divided into the two territories of Utah and New Mexico, in each of which slaveholders were allowed to settle with their slaves if they chose, the expectation being that New Mexico would become a slave state.

Yet as soon as the compromise had been passed, four new issues arose out of slavery: (1) the annexation of Cuba; (2) the nullification of the fugitive slave law by violence and by "personal liberty laws"; (3) the revival of the abolition spirit under the stimulus of Uncle Tom's Cabin; (4) the defeat of the Whigs, which showed that slavery had caused fatal internal divisions in that party as a national organization.

\section{TOPICS}

(1) Why did the Free-soilers object to Lewis Cass? (2) Why did Taylor wish to form a state government in California? Suggestive (3) Why did Clay think that slavery did not exist in New Mexico ? (4) What was the need of a new fugitive slave act in 1850 ? (5) Was Daniel Webster's Seventh of March Speech a bid for the presidency? (6) What did Calhoun think would save the 
Search topics

Geography Secondary authorities

Sources

Inlustrative works

Pictures
Union? (7) Why did not Taylor favor the Compromise of 1850 ? (8) Why was Franklin Pierce nominated for the presidency? (9) A brief account of the Whig party.

(10) At the silver mines in California. (11) Hydraulic mining in California. (12) The Walker Bill of 1849. (13) Caleb Cushing in China. (14) The Underground Railroad. (15) Robert Toombs's opinions on slavery. (16) Discovery of gold in California. (17) The Barnburners in New York. (18) The Buffalo Free-soil convention. (19) Commodore Perry in Japan. (20) The California constitutional convention, 1849. (21) William H. Seward's opinions on slavery. (22) The New Orleans riot of 1851. (23) The Shadrach fugitive slave case. (24) The Gorsuch fugitive slave case. (25) Examples of personal liberty bills. (26) Contemporary opinions of Uncle Tom's Cabin. (27) Return of Anthony Burns.

\section{REFERENCES}

See maps, pp. 324, 362, 376 ; Garrison, Westward Extension.

Wilson, Division and Reunion, §§ 83-89; Stanwood, Presidency, 226-257 ; Garrison, Westward Extension ; Schouler, United States, V. 100-260 ; Rhodes, United States, I. 99-302 ; Larned, History for Ready Reference, I. 350, IV. 2929, V. 3382 ; Macy, Political Parties, 102-161 ; Smith, Liberty and Free-Soil Parties, 121-260 ; McDougall, Fugitive Slaves, \$\$ 19-83 ; Siebert, Underground Railroad; Latané, United States and Spanish America, 105-116, 176-194, - American Relations in the Pacific, 72-123; Schurz, Henry Clay, II. 316-415 ; Lodge, Daniel Webster, 265333 ; Hapgood, Daniel Webster, 102-114 ; Holst, J. C. Calhoun, 306-350 ; McLaughlin, Lewis Cass, 235-292 ; Bancroft, W. H. Seward, I. 156-332 ; Hart, S. P. Chase, 95-132; Brown, S. A. Douglas, 1-81 ; Morse, Abraham Lincoln, I. 87-93.

Hart, Source Book, §§ 105-107, - Contenporaries, IV. §§ 7, 17-33, - Source Readers, III. §86, IV. \$§ 12-16; MacDonald, Select Documents, nos. 77--82 ; Old South Leaflets, no. 82; Johnston, American Orations, II. 123-340. See N. Eng. Hist. Teachers' Ass'n, Syllabus, 360,-Historical Sources, $\$ 86$.

Lowell, Biglow Papers (first series); Whittier, Antislavery Poems, 146-155, 159-173, - Ichabod; Kirk Munroe, Golden Days of ' 49 ; Bret Harte, Luck of Roaring Camp, - Tales of the Argonauts; J. T. Trowbridge, Neighbor Jackwood (fugitives); C. R. Sherlock, Red Anvil (fugitives).

Wilson, American People, IV. passim. 


\section{CHAPTER XXV.}

\section{FORESHADOWING OF CIVIL WAR (1853-1859)}

Slavery was primarily a matter for state legislation, like the question of title to land; but it became a national question because the federal government had to take cognizance of slavery in four ways :-

(1) Congress had power to legislate for the District of

328. Politics and slavery Columbia in all cases whatsoever. The question of slavery in the district, which came up about 1827, was pressed by the abolition politicians after 1835 , and accented by the discussion in 1850 , as to the sale of slaves in the district.

(2) Congress had complete power over the foreign and interstate slave trade: the foreign slave trade was prohibited by acts of 1807 and later amendments, but a movement began in the far South in 1859-1860 to reopen the African slave trade; the domestic trade was never restricted, except in the District of Columbia.

(3) Congress had power over the recovery of fugitive slaves, and exercised it by the two acts of 1793 and 1850 .

(4) Congress had power to regulate the territories, and exercised it by four successive acts prohibiting slavery in definite areas: ( $a$ ) the Ordinance of 1787 , for the Northwest Territory, reaffirmed by an act of Congress of 1789 ; $(b)$ the Missouri Compromise of 1820 , covering the Louisiana cession north of $36^{\circ} 30^{\prime}$; (c) the Texas resolution of 1845 , prohibiting slavery in any states which might be created out of any part of Texas north of $36^{\circ} 30^{\prime}$; (d) the Oregon Act of 1848, prohibiting slavery in that territory. In New Mexico and Utah, by the Compromise of 1850, Congress evaded its responsibility, leaving 
the question to be settled by the people who might be on the ground when the time came to organize states. It was clear that any future annexation of territory would lead to a fierce contest to decide which section should control it.

Nevertheless, in his inaugural address (March 4, 1853), President Pierce hinted that he favored the annexation of 329. At Cuba. His Secretary of State, William L. Marcy, and tempt to an- his Secretary of War, Jefferson Davis, disagreed on that
nex Cuba (1854) question; and Pierce vacillated, according as one or the other of these two men had influence over him. As minister to Spain he appointed Pierre Soulé, of Louisiana, an ardent "fire eater," as extreme advocates of slavery were called, and an annexationist, who bent all his energies to acquire Cuba. When the steamer Black Warrior was seized in Havana for a technical violation of the customs regulations (March, 1854), the President threatened war.

While this question was pending, Soulë, Buchanan, minister to England, and Mason, minister to France, were ordered to confer in Belgium, and they drew up the "Ostend Manifesto" (October 18, 1854), which is an open and unblushing avowal of the doctrine that might makes right, and that Cuba must be annexed in order to protect slavery. This remarkable document says that if Spain refuses to sell Cuba for a fair price, "then by every law, human and divine, we shall be justified in wresting it from Spain if we possess the power" lest "we permit Cuba to be Africanized." Marcy's influence at last prevailed, and the United States accepted a settlement of the Black Warrior difficulty (February, 1855), so that no excuse for war remained.

Perhaps the main reason for holding back from Cuba was

330. Stephen $\mathbf{A}$. Douglas, the far westerner the storm that burst on the administration because of its action on the Nebraska question. After 1820 the region west of the Missouri River remained without a territorial government, for it had no white population till the over- 


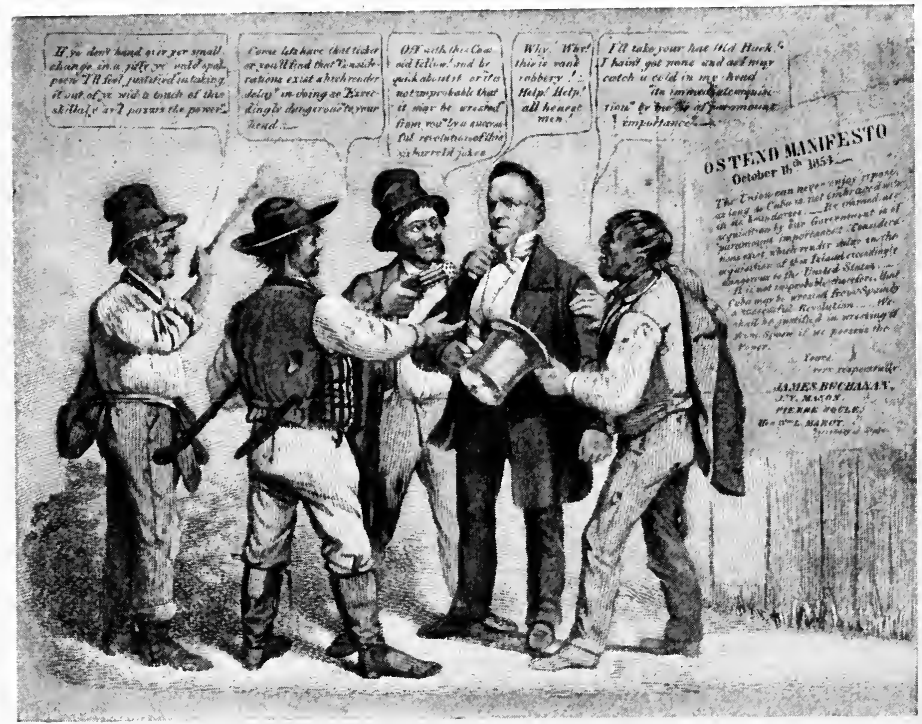

Cartoon on the Ostend Manifesto.

Published as a broadside, 1856.

land travel to California began in 1849. Senator Stephen A. Douglas of Illinois, chairman of the committee on territories, introduced a bill for the organization of Nebraska Territory (January 4, 1854), accompanied with a long argument to show that slavery would be legal there, because the Compromise of 1820 , applying to that region, had been set aside by the Compromise of 1850 . After various twists and turns Douglas incorporated into his bill the clear statement that the clause of the Missouri Act of 1820, which forbade slavery in certain territory, "is hereby declared inoperative and void." To support this disturbing principle, Douglas reinvented the doctrine of "popular sovereignty," or "squatter sovereignty," namely, that the people of a territory had the same right to legislate' on local affairs, including slavery, as the people of the states.

HART'S AMER. HIST. -23 
In this controversy Douglas represented a strong influence which eastern men did not understand. Born in Vermont in 1813, he early went to Illinois, where he held various state offices, including that of judge of the supreme court. In 1847 he was sent from Illinois to the Senate, and there represented those crude, boisterous, but determined political forces which had earlier made Jackson President. He came from a constitu-

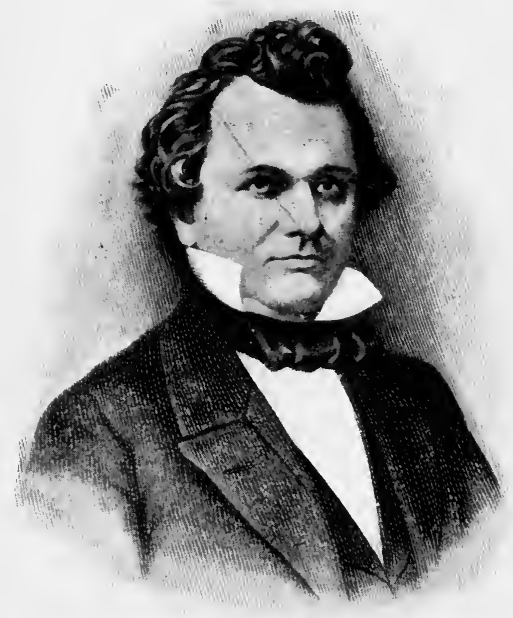

Stephen A. Douglas, about 1850. ency which was accustomed to care for itself, and which therefore thought it as reasonable that the people of a territory should settle the question of slavery as that they should settle the question of schools. Later in life he made the significant admission that he "did not care whether slavery was voted down or voted up"; but he was intensely ambitious, and there is no doubt that he looked forward to the next presidential election, and hoped to convince the southern Democrats that he was at the same time safe and powerful.

Of all American public men, Douglas was the fiercest debater. Though a short man, he had a big voice which poured forth anything that came into his mind, especially a coarse and effective personal abuse of those who opposed him. He was quick, forcible, and undaunted, and never much concerned himself about accuracy or consistency. His main defect was 
that he could not understand or measure the moral opposition to slavery.

The Nebraska Bill infuriated a great part of the northern people, for no public man had suggested in the discussion of 1850 that the compromise then passed applied anywhere outside of New Mexico and Utah, or that the Act of 331. Kansas-No1820 ceased to apply to the Louisiana Purchase. The protest was expressed in a paper called the Appeal of the Independent Democrats (January 16, 1854), drawn up by Salmon P. Chase, abolition senator from Ohio, which declared the bill to be "part and parcel of an atrocious plot to exclude from a vast unoccupied region immigrants from the old world and free laborers from our own states."

In the course of the discussion the new territory was divided into two territories, Kansas and Nebraska, showing a plain expectation that Kansas, which lay immediately west of Missouri, would become a slaveholding community to balance California. In spite of the bitterest opposition, ably led by Chase, Douglas got 37 votes in the Senate against 14, and then forced the bill through the House by 108 to 100, and arranged with Pierce, who signed the bill, May 30, 1854. Perhaps Douglas began to see his error when, on the test vote on the Nebraska Bill in the House, half the northern Democrats refused to go with him; and when in the congressional election in the fall of 1854, most of the other half lost their seats.

The inevitable effect of the Kansas-Nebraska Act was quickly revealed when hundreds of Missourians crossed over into Kansas and entered up land for farms, which most of them did not mean to occupy. The challenge 332. Civil war in Kansas was accepted by several emigrant aid companies, (1854-1856) founded in New England, which within about three years sent out six thousand free-state men, as permanent settlers, many of them armed with a new weapon of precision, the Sharp's rifle. The purpose of the Missourian neighbors (commonly 
called "Border Ruffians") was shown in the election of March, 1855, for members of the first territorial legislature; 2905 legal voters somehow were credited with 6307 votes. Hundreds of armed Missourians came over into Kansas to set up or drive away election officers at their will, and thus elected a large majority of the legislature. It met (July, 1855) and passed a code of laws which established slavery, and made it a crime even to assert that "persons had not the right to hold slaves in this territory."

To protect themselves against this minority rule, the antislavery people framed a state constitution at Topeka (November, 1855) and attempted to set up a government. The rival settlers and neighbors in the spring of 1856 came to civil war in which about two hundred lives were sacrificed and the free-state town of Lawrence was sacked. Among the most reckless of the free-state people was a man named John Brown, who turned out whenever there was a fight; and in May, 1856, he directed his men to seize and kill some proslavery neighbor's at Osawatomie. President Pierce could not keep order, but under his direction the antislavery Topeka legislature was dispersed by United States troops, July 4, 1856.

Both the Whig party and the Democratic were rent in twain by the Kansas-Nebraska Bill, and a great political upheaval 333. New came in 1854. An attempt was made to form an Republican American Party on the principles of dislike of Catho(1854-1856) lics and distrust of foreigners. It was backed by a powerful secret society, the "Supreme Order of the StarSpangled Banner"; the members of which, because they always replied to any question about their society, "I know nothing about it," were commonly called "Know-nothings." The Know-nothings secured the state government of Massachusetts, and extended even into the southern states, and they soon claimed more than a million votes, but broke into factions over the slavery question in 1856. 
A stronger political combination was found in a union of the Free Democrats with "anti-Nebraska" Whigs and Democrats. To this new party in various conventions the name "Republican" was given, perhaps for the first time at Jackson, Michigan, in July, 1854. By all sorts of fusions and coalitions of Know-nothings, Republicans, Whigs, and Democrats, the Anti-Nebraska people carried fifteen of the thirty-one states in 1854, and elected eleven senators and a small majority of the House of Representatives.

In 1856 the Republicans, called by their opponents "Black Republicans," girded themselves up for the presidential election. Instead of nominating Seward, their ablest man, they put up John C. Frémont, who was popularly supposed to have conquered California. To the grief of Stephen A. Douglas, the Democrats passed him over precisely because he had roused such opposition by helping the South in his KansasNebraska Bill; they nominated for the presidency James Buchanan of Pennsylvania.

An incident of the presidential year was a speech made by Senator Charles Sumner of Massachusetts, entitled "The Crime against Kansas," which in coarse and violent language assailed Senator Butler of South Carolina. Preston Brooks, representative from South Carolina and a kinsman of Butler, assaulted Sumner in the Senate Chamber and beat him insensible. Brooks was censured by the House, resigned, and was triumphantly reëlected by his constituents; but his brutal violence seemed to the North an evidence of a purpose to silence antislavery men in Congress.

In the election of 1856 Buchanan got 174 electoral votes to 114 for Frémont; and the Republicans failed to secure the House for 1857-1859. Yet Frémont had 1,300,000 votes against 1,800,000 for Buchanan; and carried every northern state except New Jersey, Penusylvania, Indiana, and Illinois. Ex-President Fillmore, candidate of the Know-nothings and 


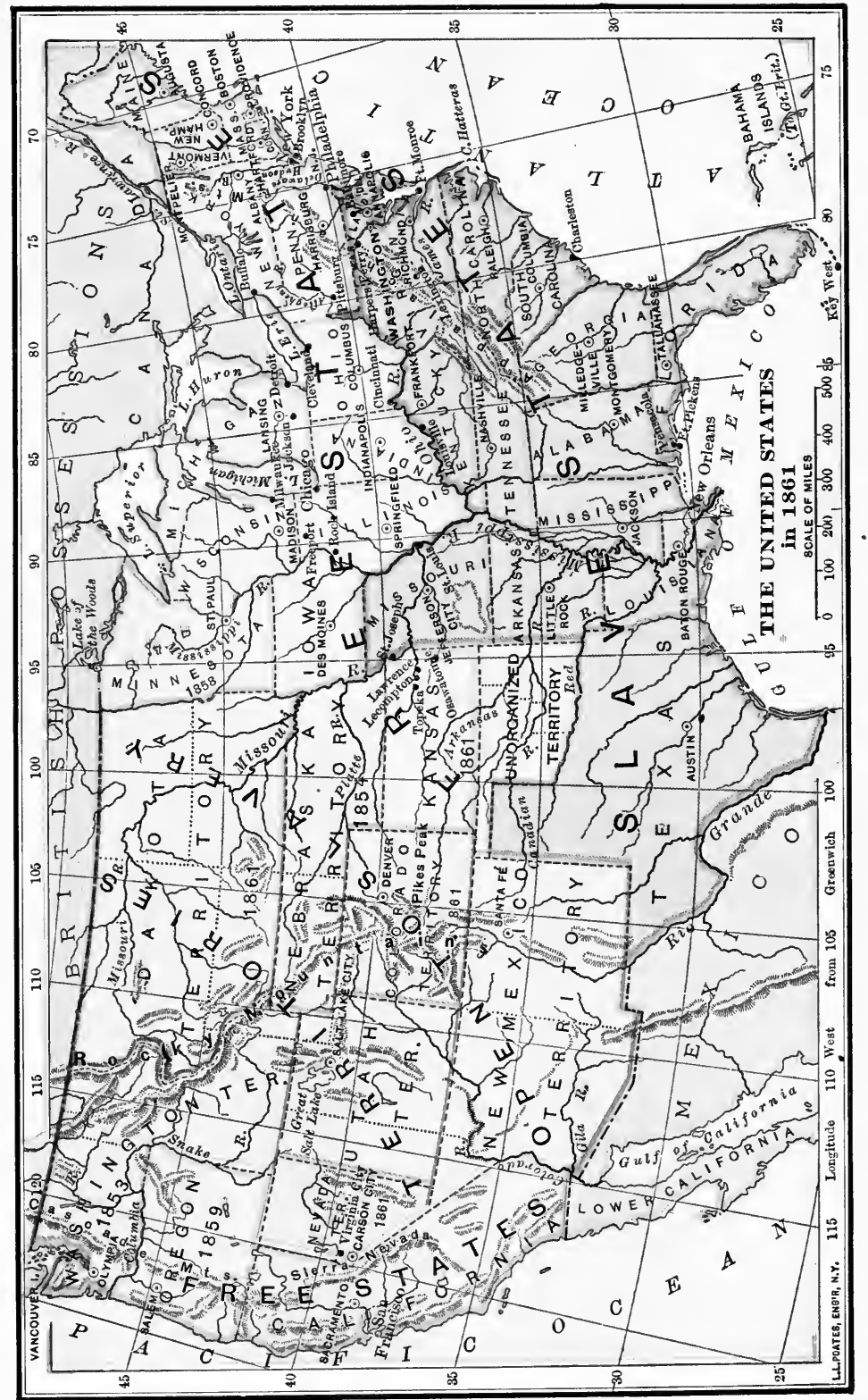


the remnant of the Whigs, had 875,000 votes, but carried only one state, Maryland.

Since neither Congress nor the squatters proved capable of settling the question of territorial slavery, the Supreme Court of the United States tried its hand, in the case of Dred Scott $v s$. Sandford. Dred Scott, the slave of a Dr. Emerson, was taken by his owner in 1834 to Rock Island, Illi334. Dred Scott decision nois (within the bounds of the old Northwest Territory), in 1836 to Fort Snelling (in the Louisiana Purchase, north of Missouri), and then brought back to Missouri (a slave state). Some years afterward Dred Scott sued for his freedom, on the plea that his master had taken him to free regions.

After four preliminary suits, the case was finally decided by the federal Supreme Court in March, 1857, eight judges out of nine drawing up separate opinions. Six judges united in the decree of the court to the effect that the Missouri Act of 1820 was unconstitutional from the first, because Congress had no power to regulate slavery in the territories. So far the court went along with Douglas; then four judges, and perhaps a fifth, turned squarely against Donglas's doctrine of popular sovereignty, by holding that nobody could prohibit slavery in a territory, because the right of property in a slave was distinctly affirmed in the Constitution. That is, the court, so far as it could, hold slavery to be a national institution, the normal thing in every territory, and beyond the reach of any power except a state legislature.

The Chief Justice also laid down the doctrine, with which the majority of the court appeared to concur, that free negroes could not become citizens of the United States, that they had never been included in the political community, and that in the minds of the Revolutionary fathers they "had no rights which the white man was bound to respect." This and all the other proslavery opinions were bitterly contester by Justices McLean of Ohio and Curtis of Massachusetts, who 
further insisted that technically there was no ground for any decision whatever. Dred Scott was left a slave, but was immediately manumitted by his master; and the decision was so forced and so contrary to historical facts that the Republican leaders declared that they were not bound by it.

Notwithstanding the excitement over the slavery question, the questions which seemed at the time most vital were those 335. Growth of daily business, and the United States had never been of commerce so prosperous as from 1845 to 1857 . California gold fur(1845-1857) nished a new export of specie, and breadstuffs were in great demand abroad. Exports in 1856 were nearly three times as great as in 1846. To carry this trade and that of other countries, American shipping reached the highest point in our history - 3,300,000 tons in 1860. These were the days of the magnificent clipper ships, wooden sailing craft of unexcelled speed and handiness, making voyages from England to New York sometimes in less than fourteen days, and from China to New York in about eighty days.

Screw steamers as yet were mostly ships of war, but the ocean paddle steamers grew in size and speed till they could cross the ocean in twelve days. In 1847 Congress granted a subsidy to two lines of steamers: $\$ 850,000$ a year to the Collins American line, New York to Liverpool; and \$200,000 a year to a line from New York to Bremen. The Collins line was extravagantly managed, lost several ships, and broke down in 1858.

Internal communication advanced with equal strides. The railroad mileage in 1840 was under 3000 ; in 1850,9000 ; in 1860, 30,000. Till 1850 there was hardly such a thing as a through railroad line, but in 1851 the New York and Erie Railroad was finished from New York to Lake Erie, and in 1853 a continuous chain of separate lines of railroad reached Chicago from the east. In 1859 railroads from the north and east reached New Orleans. Railroads now began to be con- 
solidated into systems by uniting them end to end; for example, the ten short connecting lines from Albany to Buffalo, in 1853, were united under the New York Central.

Beginning with a grant to the Illinois Central in 1850, the United States aided western railroads by immense grants of public lands. It was a natural suggestion that a road might be built to the Pacific in the same way, and Congress went so far as to send out several exploring expeditions, especially one of 1853, which surveyed various practicable routes. Though a railroad was built by American capital across the Panama Isthmus and opened for business in 1858, the plans for an isthmian canal still hung fire; the task was too great for private capital ; and there was a violent dispute over the meaning of the Clayton-Bulwer treaty, till (1860) Great Britain gave up all claim to a protectorate over territory near the Nicaragua route.

The revenues of the government rose so fast that a new tariff was passed by a non-partisan vote (March 3, 1857). Every member from Massachusetts and every member from South Carolina voted for the bill, which decreased the existing low duties of 1846 by about a fifth; and the average rate of duties was brought down to about 20 per cent. Before the new tariff could have any effect, a commercial panic came upon the country, caused principally by the expenditure of about $\$ 70,000,000$ on railroads in ten years. The panic began in August, 1857, and in October all the banks in the country suspended specie payment; many railroads failed; and first and last more than five thousand business houses broke, with losses of more than $\$ 150,000,000$. The federal government saw its annual revenue reduced from $\$ 76,000,000$ to $\$ 46,000,000$; and it was obliged to issue treasury notes for its expenses. Still there was no such widespread suffering and no such check to business as after the panic of 1837, and by 1860 business was again normal. 
Till the Pacific railroad was built, much of the traffic overland to California went by wagon roads which passed through 337. MorUtah Territory, near Great Salt Lake. This region had mon rising been settled by the Mormons, who were forced to aban(1857-1858)

don Nauroo in 1846. Under their new prophet, Brigham Young, they reached Great Salt Lake the next year, and set up what they called the independent State of Deseret. Polygamy was announced to be a part of the religious and political system of the community, and to be based on a direct revelation from the Almighty. To their great disappointment, the Mormons found themselves in the United States by the Mexican cession of 1848; but when Utah Territory was created in 1850 it was thought expedient to make Brigham Young governor.

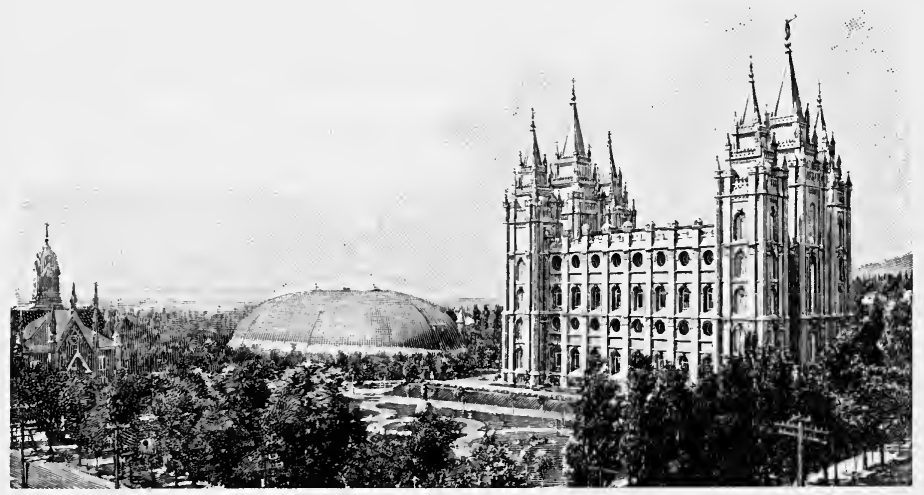

Mormon Church Buildings, Salt Lake City.

Tabernacle, built 1870; Temple, built 1893.

The overland traffic to California disturbed the Mormons, who wanted to be let alone, and always made trouble for their federal officials. In 1857 Buchanan appointed a new territorial governor, but Brigham Young refused to give up his office, called out armed men, and when 1500 troops were sent, forbade them to come into the territory. During the follow- 
-ing winter the Mormons captured the supply trains of the troops and tried to starve them out. When the government proposed to send out a large force the Mormons yielded sullenly; but they kept up their religious organization, like an independent state, and it was more than thirty years before the laws of Congress against polygamy were executed among them.

The danger point in American politics was still in Kansas, where a proslavery convention at Lecompton prepared a constitution (November, 1857). President Buchanan promised that the work of the convention should be submitted 338. Lecompton constituto popular vote; but the convention provided that the tion (1858) voters might cast their ballots for "Constitution with Slavery" (i.e. with a separate article distinctly establishing slavery), or for "Constitution with no Slavery," which left in bondage slaves then in the territory, and forbade free negroes to live in the state.

At an election under proslavery authority, 6063 votes were counted for "Constitution with Slavery" and 576 for "Constitution with no Slavery." But the free-state men now secured control of the legislature, which ordered a second election, at which the vote was, for "Constitution with Slavery," 138; for "Constitution with no Slavery," 24; against the Constitution altogether, 10,226. A plan to admit the state under the discredited Lecompton constitution, against the will of the majority, was warmly supported by Buchanan, but was frustrated by Douglas, who could not abjure his own doctrine of squatter sovereignty, that the people of a territory ought to govern themselves. Under a compromise act called the English Bill (May 14, 1858), the Iecompton constitution was sent back to the people of Kansas, with a splendid offer of public lands if they would vote to accept statehood under it. On the final test vote the people of Kansas by a decisive majority of 9500 rejected the attempt to make them a slave state against their will, and remained a territory till 1861. 
In opposing the Lecompton constitution, Douglas undoubtedly remembered that his term in the Senate was about to 339. Rise of expire, and that the legislature chosen in Illinois in Abraham Lincoln 1858 would elect to the vacancy. As a rival claimant to (1809-1858) the seat, came forward Abraham Lincoln, who wrote up his autobiography as follows:-

“Born, February 12, 1809, in Hardin County, Kentucky;

"Education defective;

"Profession a lawyer;

"Have been a eaptain of volunteers in the Black Hawk War;

"Postmaster at a very small office;

"Four times a member of Illinois Legislature;

"And was a member of the lower house of Congress."

Lincoln rose steadily from the squalor of a poor white family living in Kentucky, Indiana, and Illinois. After trying surveying and storekeeping, in which he made a flat failure, he studied law, went to the legislature, was an early Whig, and became known throughout the state for his good stories, homely sayings, and honest attention to the cases intrusted to him. In 1841 he had his first sight of slaves, and he called slavery "a thing which has, and continually exercises, the power of making me miserable." From 1847 to 1849 he sat in Congress.

When the Kansas-Nebraska question arose, Lincoln came out firmly for the anti-Nebraska cause. In 1855 he was all but elected Republican senator from Illinois; in 1858 he was designated by the Illinois Republican convention as their candidate for the senatorship, and accepted in a magnificent speech, of which the text was: "A house divided against itself can not stand. I believe this government can not endure permanently half slave and half free."

He next took the bold step of challenging Douglas, the most effective stump orator in the country, to a series of joint 
debates. Before tremendous audiences his eloquence and power caused people to forget his personal awkwardness. Douglas tried to turn the question into a personal controversy, and he accused Lincoln of seeking the social equality of the negro, to which Lincoln memorably replied: "In the

340. Lincoln-Douglas debate (1858) right to eat the bread without the leave of anybody else, which his own hand earns, he is my equal, and the equal of Judge Douglas, and the equal of every living man."

The culmination of the debate was reached at Freeport. When Lincoln put the question whether the people of a territory (i.e. Kansas) in any lawful way could prohibit slavery, Douglas's reply, commonly called the "Freeport Doctrine," was that the people of a territory could prevent slavery by "unfriendly legislation"; that is, Lincoln compelled him to stand by his squatter sovereignty, and to ignore the Dred Scott decision. The answer so far satisfied Douglas's constituents that he secured a small majority of the Illinois legislature and was reëlected to the Senate; but when he went back to Washington, he found that his party colleagues were against him. Lincoln had practically obliged Douglas to break with the southern Democrats, who controlled the party organization.

The most striking event of the year 1859 was the attempt of John Brown, already known in Kansas, to arouse a slave insurrection. His plan was to establish a camp for runaway negroes in the sonthern mountains. He secured Brown raid money and counsel from some New England friends, (1859) recruited twenty-two men, and hired a farm in the Maryland mountains near the town of Harpers Ferry. He descended upon that place October 16, and seized the United States arsenal, which had no guard, sent out parties to capture some of the white planters, and tried to rouse the neighboring slaves, who were expected to carry off a quantity of the arms. The next day the whole countryside was in an uproar; the negroes did not rise, and Brown hesitated until too late to 
escape; the engine house in which he had fortified himself was finally taken by United States marines, under Colonel Robert E. Lee; Brown was wounded and captured, and ten of his men (including a son) were killed, and five of his assailants.

It is greatly to the credit of Virginia that this intractable man had a fair and open trial. He was duly convicted of

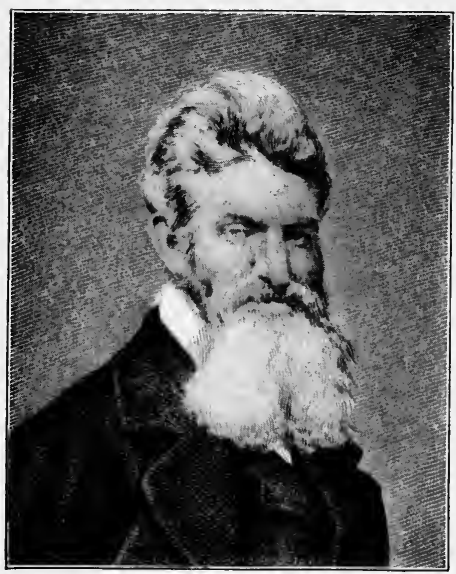

JoHN BRown IN 1859. murder and treason against the Commonwealth of Virginia. He met his death like a hero, and won the respect of his jailers and southern visitors; he never had the slightest feeling of remorse or guilt. In his last letter to his family he solemnly said, "John Brown writes to his children to abhor, with undying hatred also, that sum of all villanies, slavery." Moderate northern people expressed their condemnation of Brown's methods, but could not help admiring his heroic spirit; and John Brown probably did more than any other man to convince the South that slavery was no longer safe within the federal Union; for he showed that there were abolitionists who were perfectly willing to sacrifice their own lives to free other people's slaves.

The six years from 1853 to 1859 showed that slavery was a disturbing influence which could not be quieted or removed. 342. sum- For the sake of slavery, attempts were made to annex mary

Cuba, the Kansas-Nebraska Bill was passed, rival parties were allowed to wage civil war in Kansas, the Supreme Court tried to establish a new principle in the territories, and $\mathrm{Bu}$ - 
chanan and his friends attempted to force a proslavery constitution upon the people of Kansas.

From 1853 to 1859 the antislavery people took the offensive in politics. Their national antislavery ticket almost won the election of 1856 ; they attacked Douglas through a new champion, Abraham Lincoln, and compelled him in 1858 to break with many of his party associates. Then a few of the most extreme abolitionists tried to show how vulnerable slavery was by encouraging the John Brown raid.

After six years of struggle nothing was decided: Cuba was not annexed; Kansas was not a slave state; the Dred Scott decision was openly defied by the Republicans. The only thing clear was that this fierce controversy was driving the two sections further and further apart, that they distrusted each other more and more; and that neither President nor Congress nor Supreme Court could suggest any middle view on the subject of slavery which would satisfy both North and South.

\section{TOPICS}

(1) What was the objection to abolishing slavery in the District of Columbia? (2) Why did President Pierce want to annex Cuba? (3) Why did the Mormons go out to Utah? (4) Did the Compromise of 1850 set aside the Missouri Act of 1820 ? (5) The Know-nothing party. (6) Why was not Seward nominated by the Republicans in 1856 ? (7) Why did the Mormons give way in 1858 ? (8) Evidence that Buchanan promised that the Lecompton constitution should be submitted to a popular vote. (9) Why did Lincoln compel Douglas to announce his Freeport Doctrine? (10) How did the Freeport Doctrine conflict with the Dred Scott decision? (11) Was John Brown justified in inciting a slave insurrection?

(12) Propositions to reopen the slave trade in the fifties. (13) The Ostend Manifesto of 1854. (14) Who first put forth the Suggestive topics principle of popular sovereignty? (15) Appeal of the Independent Democrats. (16) Why did the Kansas-Nebraska Bill pass the Senate? (17) Origin of the emigrant aid companies. (18) The Border Ruffians. (19) Was John Brown justified in killing the 
Shermans and Doyles? (20) Origin of the name, "Republican Party." (21) Why was Buchanan nominated by the Democrats in 1856 ? (22) Why was a new tariff act passed in 1857 ? (23) Had negroes in 1776 " no rights which the white man was bound to respect"? (24) A railroad journey in the fifties. (25) The Panama railroad. (26) Was the Lecompton constitution in itself a bad constitution? (27) Lincoln's early life. (28) Lincoln's early opinions on slavery. (29) Interesting things in the LincolnDouglas debate. (30) John Brown's trial.

\section{REFERENCES}

Geography

Secondary authorities

Sources

Illustrative works

Pictures

See maps, pp. 390, 324, 325; Sinith, Slavery and Political Parties.

Wilson, Division and Reunion, §§ 90-100 ; Johnston, Politics, 167-189 ; Stanwood, Presidency, 258-278; Smith, Slavery and Political Parties; Schouler, United States, V. 270-454; Rhodes, United States, I. 384-506, II. 1-416 ; Macy, Political Parties, 183282 ; Smith, Liberty and Free-soil Parties, 261-307 ; Curtis, Constitutional History, II. 259-285, 295-299 ; Spring, Kansas ; Brown, Lower South, 50-82, - S. A. Douglas, 82-128 ; Dewey, Financial History, §§ 110-115 ; Taussig, Tariff History, 115-154 ; Hart, Foundations of American Foreign Policy, 108-127 ; Foster, Century of Diplomacy, 335-356; Latané, United States and Spanish America, 116-136, 194-198 ; Morse, Abraham Lincoln, I. 93-160 ; Bancroft, W. H. Seward, I. 333-519; Hart, S. P. Chase, 132-177; Storey, Charles Sumner, 101-164; Chamberlin, John Brown.

Hart, Source Book, §§ 108-112, - Contemporaries, IV. §§ 3448, - Source Readers, IV. § 17 ; MacDonald, Select Documents, nos. 85-92 ; American History Leaflets, nos. 2, 17, 23 ; Old South Leaflets, nos. 80, 83-85 ; Hill, Liberty Documents, ch. xxi. ; Johnston, American Orations, III. 3-207; Samborn, John Brown; Helper, Impending Crisis. See N. Eng. Hist. Teachers' Ass'n, Syllabus, 350-353, - Historical Sources, § 86.

Whittier, Antislavery Poems, 176-213, - Brown of Ossawatomie ; Stedman, How Old Brown took Harper's Ferry; A. W. Tourgée, Hot Plowshares (antislavery); Theodore Winthrop, John Brent (Far West, Mormons) ; Arthur Paterson, For Freedom's Sake (Kan.) ; A. E. Orpen, Jay-Hawkers ; Noah Brooks, Boy Settlers (Kan.) ; G. H. Derby ("John Phœnix"), Phœnixiana (Cal.).

\footnotetext{
Wilson, American People, IV.; Sparks, Expansion.
} 


\section{CHAPTER XXVI.}

\section{THE CRISIS (1859-1861)}

The Republicans had a small majority in the House of Representatives from 1859 to 1861 ; and would have elected John Sherman of Ohio to be Speaker, but that he had signed a circular approving a book called The Impending Crisis, which was written by a poor white named Helper,

343. Issue

between

North and

South to show that slavery was contrary to the interests of (1859-1860) whites in the South who owned no slaves; hence Sherman was thought radical.

The Senate was strongly proslavery; and Jefferson Davis of Mississippi, leader of the extremists, introduced a series of resolutions (February 2, 1860), which were intended to formulate the position of the South: (1) that Douglas's Freeport Doctrine was unsound; (2) that Congress should interfere, if necessary, to protect slavery, thus going beyond the Dred Scott decision; (3) that the northern states should stop public agitation by the abolitionists; (4) that the states were sovereign. In effect, these resolutions, which passed the Senate by 35 to 21 votes, gave notice that the election of a President who opposed those principles might be made an excuse for breaking up the Union.

The whole country watched with anxiety the regular Democratic convention which met at Charleston in April, 1860. Douglas had a majority of the delegates, but the southerners insisted that he should accept a platform which 344. Election of 1860 was substantially the Davis resolutions. Douglas was willing to pledge himself to "abide by the decisions of the Su- 
preme Court"; but he could not promise to vote for forcing slavery into an unwilling territory. On that small difference the convention split; the delegates of most of the southern states withdrew, and the convention adjourned after fiftyseven ineffectual ballots. It reconvened at Baltimore in June, and, after another split, Douglas was there nominated, on the platform proposed by his friends at Charleston. The southern bolters met separately and nominated John C. Breckinridge, then Vice President of the United States.

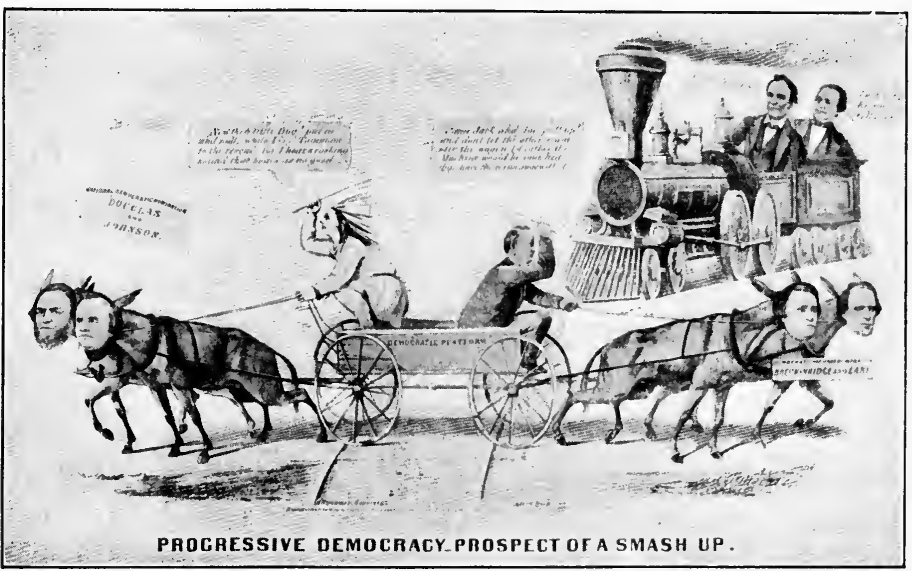

Election Cartoon of 1860.

Many of the old southern Whigs, and the northern Whigs who had not become Republicans, united in what they called the Constitutional Union party, and nominated John Bell of Tennessee, on the brief platform, "The Constitution of the country, the union of the States, and the enforcement of the laws."

The Republican convention met in Chicago (May 16, 1860), in an immense hall, with thousands of spectators. It was generally expected that Seward would be nominated, for he had 
shown his artislavery spirit by declaring that slavery caused an "irrepressible conflict," and he had an enthusiastic delegation from New York, and scores of other supporters. But Seward was thought too radical: what was wanted, was a moderate western man who could carry the doubtful states of Pennsylvania, Ohio, Indiana, and Illinois. Abraham Lincoln was the most available among such men; and on the third ballot he was nominated.

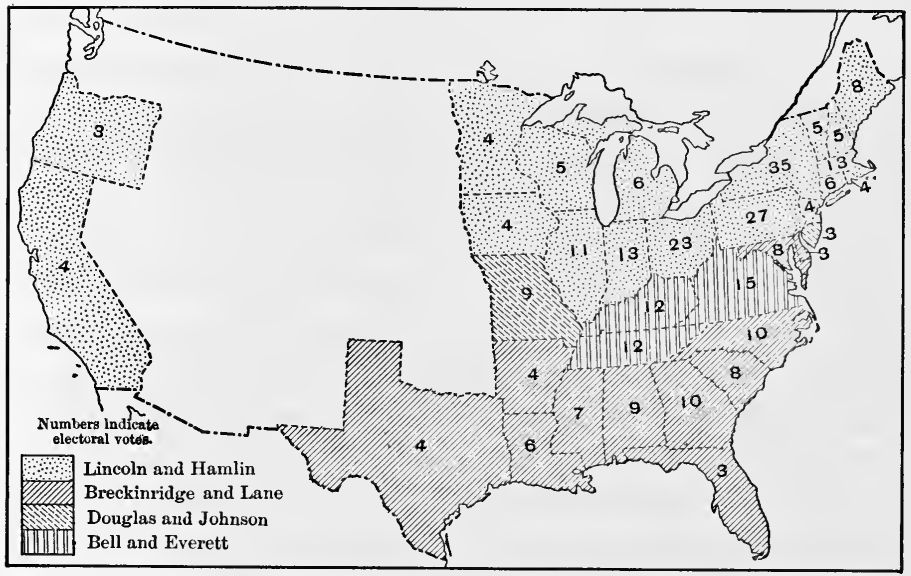

The Election of 1860.

The campaign was fierce and exciting. For the first time semimilitary companies were organized to parade and carry torches. On election day (November 6), 180 Lincoln electors were chosen against 72 for Breckinridge, 39 for Bell, and 12 (Missouri and a part of New Jersey) for Douglas. Out of the popular vote, Lincoln had about 1,900,000 against 1,400,000 for Donglas, 850,000 for Breckinridge, and 600,000 for Bell. Yet if his opponents had concentrated on any two, or any one, of the other candidates, the result would have been the same; for the Republicans had a majority in every northern state except New Jersey, California, and Oregon. 
During the campaign of 1860 it was freely predicted that the election of Lincoln would lead to secession. To most 345. Seces- northern men the threat seemed preposterous, for the elecsion of South Carotion of Lincoln did not carry with it directly the Supreme lina (1860) Court, or the Senate, or even the House which was chosen to sit from 1861 to 1863 . Nevertheless, on the day after the national election, the South Carolina legislature took steps toward calling a secession convention; and within a few days the principal federal officers in South Carolina, including the two United States senators, resigned their offices. Hardly a Union man could be found in the whole state; not one was elected to the convention.

During the next seven weeks South Carolina was in turmoil; federal buildings and supplies were seized; companies of men were drilled; eager conferences were held with people from the neighboring states; and the excitement culminated when the secession convention assembled at Columbia, adjoumed to Charleston, and on December 20,1860, by a unanimous vote, passed an ordinance declaring that South Carolina was no longer a part of the Union. A member of the convention said, "We have carried the body of this Union to its last resting place, and now we will drop the flag over its grave."

In this awful crisis of secession, the country hardly had a President. Buchanan had long stood on the same political 346. Presi- ground as the radical southerners who were seceding, dent Bu- and he called in Jefferson Davis to advise him. The chanan's policy (1860-1861) President's message to Congress, December 3, 1860, "the incessant and violent agitation of the slavery question throughout the North for the last quarter of a century." As for secession, Seward neatly summed up the message as Nicolay follows: "The President has conclusively proved two and Hay, Lincoln, II. things: (1) that no state has a right to secede unless 371 it wishes to; and (2) that it is the President's duty to 
enforce the laws unless somebody opposes him." A few days later Lewis Cass, Secretary of State, resigned because he thought the President was not doing his duty.

After secession, the South Carolina government immediately demanded the surrender of the forts within its borders; and while the question was pending, Major Anderson, in command of the scanty force in Charleston harbor, moved his troops (December 26) from the exposed Fort Moultrie into the strong, isolated Fort Sumter. Floyd, Secretary of War, and Ánderson's immediate superior, insisted that he should give up Fort Sumter. Jeremiah

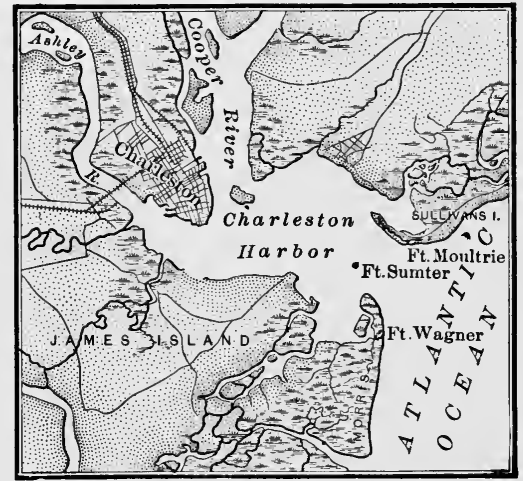

Charleston Harbor. Black, Secretary of State, and Edwin M. Stanton, who had just entered the Cabinet, declared that in that case they would resign. "You don't give me any time to say my prayers," said Buchanan; "I always say my prayers when required to act upon any great state affairs." In the end he

Crawford, Fort Sumter, 198 yielded to his northern advisers, and Anderson was left in Fort Sumter. From that time to the end of his administration, Buchanan had no longer any will or force of his own.

As had been planned beforehand, conventions specially chosen for that purpose by six other states, between January 9 and February 1, followed the example set by South Carolina. In most of them, before secession, all the United States mints, posts, arsenals, forts, public buildings, and public 347. Secession of the Gulf states (1861) property were seized, except Fort Pickens, below Pensacola, Key West and the Dry Tortugas on detached islands, and Fort Sumter in the harbor of Charleston. (1) Mississippi 
seceded by a vote of 84 to 15 . (2) Florida seceded by a vote of 62 to 7. (3) In Alabama the "submissionists" and "coöperationists" both opposed immediate secession, but it was voted by 61 to 39 . (4) In Georgia alone was there a powerful open opposition, but it seceded by a test vote of 165 to 130 . (5) Louisiana was enriched by the down-river trade of the Northwest, and long hesitated; but seceded by a vote of 113 to 17 . (6) In Texas, Governor Sam Houston set himself strongly against secession, but a convention was unofficially called, and the state seceded by 166 to 7 .

The next step was to combine the seceded states into a union. In February, 1861, a convention of delegates from six states met at Montgomery, drew up a "provisional constitution" for "The Confederate States of America," and elected Jefferson Davis of Mississippi President of the new Confederacy, and Alexander H. Stephens of Georgia Vice President. A Cabinet was duly appointed by President Davis, and a provisional Congress was shortly elected and sat for a year.

Secession was defended by southern conventions and public men substantially on the following grounds :-

348. Southern grievances
(1) That the North was bent on making money for itself, and was no longer interested in the general welfare of the Union. The charge was later made that the tariff discriminated against the South ; but in the discussions of 1860 the South made no complaint of the existing tariff of 1857 .

(2) That the North misinterpreted the Constitution, and would not admit the doctrine of state rights and secession; that the Republicans were even opposed to the Dred Scott decision, and meant to overturn it; and that by the personal liberty laws the northern states defied their constitutional obligations.

(3) That the North hated slavery, insisted on discussing it, and allowed abolition meetings and newspapers publicly to speak abusively of the slaveholders; and that the northern 
people approved of John Brown's attempt to cause a slave insurrection.

(4) That the growth of slavery was checked, because the North was determined not to admit any more slave states, nor to annex any more slaveholding territory, and was trying to draw a "cordon of free states" around the South, and thus slowly to strangle slavery.

(5) That the election of Lincoln was an act of hostility, a sectional victory, which meant an attack on slavery in the states.

In this list the main and the deciding grievance is in essence that the North disliked slavery, wanted to check it, and allowed people to discuss it. As Robert Toombs of Georgia put it, "What is wanted, is that the North shall call slavery right." It is also true that by the admission of Minnesota in 1858 , Oregon in 1859, and Kansas in 1861, the number of free states was raised to 19 , as against 15 slaveholding states.

A feeling of injury and wrath was also widespread in the North, for grievances expressed substantially as follows:-

(1) That the Southerners had for years been forcing the annexation of territory, in order to strengthen slavery.

(2) That the South had arrogantly attempted to sup-

349. Grievances of the North press free speech in the northern states; and even in Congress had attempted to intimidate John Quincy Adams, Joshua R. Giddings, and Charles Sumner.

(3) That by the South Carolina negro seamen act of 1820 and other statutes against the movement of free negroes, the southern states violated rights of northern negro citizens which were guaranteed by the Constitution.

(4) That the Kansas episode showed a determination by fraud and violence to foist a slavery constitution on the people of a practically free territory.

(5) That the slave power had ever since 1829 practically controlled the Supreme Court, the Senate, the presidency, and 
the House (except for two Congresses), and now wanted to leave the Union when the other people began to get control.

(6) That the South entertained doctrines of secession which were contrary to the Constitution and destructive to the Union.

The southern theory of secession was that it was not war, but a constitutional, expedient, and practical method of set-

350. The argument for secession tling the controversy between the sections :-

(1) The constitutionality of secession was accepted by most southern public men, and by some in the North. Once admit that the states were sovereign and the Constitution only a compact among them, and any state was undoubtedly entitled to leave the Union when it felt disaffected.

(2) The expediency of secession depended on the ultimate purpose of the secessionists. A few of them wanted to go out of the Union, so as to put a pressure on the North to readmit them on such terms as they might dictate; but Davis and other leaders from the first intended to form a permanent southern government; and they confidently expected all the slave states to join them.

(3) Secession as a constitutional or a peaceful remedy was "practicable" only if it did not lead to war. Most southern leaders thought the North would not fight; others foresaw a long war, but were sure that the South would be successful in the end.

Were there no Union men in the South? There were thousands. A few were permanent Union men, such as Sam 351. South- Houston, or James L. Petigru, who marched out of St. ern Union Michael's Church, in Charleston, when prayers were first (1860-1861) offered for the President of the Confederacy; but most of them, like Alexander H. Stephens, yielded when their states seceded. Stephens, born in 1812, educated in North Carolina, entered Congress as a Whig in 1843. Though little, and boyish in appearance, he was soon recognized as one of the strongest men in Congress. When the crisis of 
1861 came, Stephens headed the opposition to the secession of his state, Georgia. He urged that the southern people had not been entirely blameless, and that the only real ground for secession was the personal liberty laws, which would probably be withdrawn if a proper effort were made. When the Georgia convention declared for secession, Stephens announced that he would go with his state; and later made a famous speech in which he said of the Confederate constitution: "Its Hart, Source foundations are laid, its corner-stone rests upon the great Book, 297 truth, that the negro is not equal to the white man; that slavery ... is his natural and normal condition."

As soon as the temper of the South was understood, three desperate efforts were made to stop secession by a compromise, such as had settled the dangerous crises of 1820, 1833, 352. Plans and 1850.

(1) In December, 1860, two "grand committees" were (1860-1861) appointed, one of thirteen members from the Senate, and one of thirty-three from the House. In the Senate committee Seward, as spokesman for the Republican party, offered a proposition (which was privately drafted by Lincoln) to the effect (a) that Congress should not interfere with slavery in the states; (b) that the personal liberty laws be withdrawn; (c) that the federal government should punish such movements as the John Brown raid; $(d)$ that fugitives should have a jury trial. Jefferson Davis offered as the southern ultimatum that the free states should be compelled to protect slave property in transit or temporary sojourn. Plainly neither side was really desirous of compromise. The House committee eventually submitted "the Corwin Amendment," prohibiting interference by Congress with slaves in the states, and both houses voted it; but it was clearly insufficient for the crisis.

(2) The slave states were divided among themselves. Neither the five "border states," - Delaware, Maryland, Virginia, Kentucky, and Missouri, - nor the next tier of states, - 
North Carolina, Tennessee, and Arkansas, - as yet saw sufficient reason for secession. Senator Crittenden of Kentucky, therefore, prepared a series of constitutional amendments, intended to keep the border states in the Union, and providing that: $(a)$ the territories were to be divided between freedom and slavery ; $(b)$ the District of Columbia was to remain slaveholding; $(c)$ interstate slave trade was to stop; $(d)$ the personal liberty laws were to be withdrawn. Against this plan Lincoln, as President-elect, used all his personal influence over the Republicans in Congress; for he felt that any compromise which recognized, extended, and perpetuated territorial slavery was an admission that the Republican party had no reason for existence.

(3) A third attempt at compromise was a "Peace Congress," called by the border states at Washington in February, 1861; twenty-one states were represented. This body sat for a month and made a report, which was substantially the Crittenden compromise; but neither Senate nor House would recommend its adoption.

If the North would neither consent to secession nor make a compromise, what was left but to keep the seceding states

353. Plans

of coercion (1861) in the Union by force? To this remedy there were many objections. Thousands of people in the North, especially the abolitionists, thought the country would be better off without the slaveholding states; the army and navy were small and scattered; and President Buchanan argued that there was no way of "coercing a state" - that is, of constitutionally compelling the obedience of people organized in what they called a "Sovereign State." Yet some action had to be taken, because the sites of the few forts still in possession of the United States had been formally ceded by the states to the Union; hence, to give them up would be an acknowledgment of the right of secession, while to hold them was to throttle the southern ports of Pensacola and Charleston. 
Fort Sumter, which lay in the channel of Charleston, became the storm center. Black and Stanton advised sending two hundred men with ammunition; and on January 9, 1861, the merchant ship Star of the West, carrying the stars and stripes, appeared for this purpose off the fort, but was fired upon by a South Carolina battery, and compelled to turn back. Anderson stationed his men at the guns, and was about to return the fire; but on reflection he wisely referred the whole matter to the government in Washington; and the South waited for the new administration to declare its position.

For three months Presidentelect Lincoln remained quietly at his home in Springfield, arranging his Cabinet, receiving delegations, listening to office seekers, and keeping his eye on Congress. He early selected Seward to be his Secretary of State, and thereby put that impulsive statesman under bonds not to do anything to embar- Inauguration of Lincoln, 1861. rass his future chief. He also sent word to General Scott (December 21, 1860), asking him to be prepared "to either 
Lincoln, hold or retake the forts, as the case may require, at and Works, I. 66 after the inauguration."

In February, 1861, Lincoln started eastward, and made a series of speeches, in which he foreshadowed his future Ibid. 674 policy. "On what rightful principle," said he at Indianapolis, "may a State, being not more than one fiftieth part of the nation in soil and population, break up the nation?" March 4, 1861, Lincoln appeared at the Capitol, took the oath of office, and in his inaugural address sounded the keynote of his administration. "I hold that in contemplation of universal law and of the Constitution, the Union of these States is perpetual . . . and to the extent of my ability I shall take care Ibid. II. 3,6 . . that the laws of the Union be faithfully executed in all the States.... Physically speaking, we can not separate. We can not remove our respective sections from each other, nor build an impassable wall between them."

Mr. Lincoln's first official act was to select his Cabinet, and he showed his political wisdom by choosing about equally 355. Period among former Whigs and former Democrats. To Chase of uncertainty (1861) of Ohio, the ablest of the political abolitionists, he assigned the treasury. Simon Cameron of Pennsylvania, against Lincoln's first judgment, was made Secretary of War. Edward Bates of Missouri, Attorney-General, was a southern Republican; Gideon Welles of Connecticut, Secretary of the Navy, was a former New England Democrat. Caleb B. Smith of Indiana was Secretary of the Interior, and Montgomery Blair of Maryland was Postmaster-General.

For some weeks, the time of the President was absorbed by a terrible scramble for minor offices of every kind, in the nearest approach to a "clean sweep" of officeholders that the country has ever seen. The question of Fort Sumter could not be long postponed, however, because commissioners of the Confederate government appeared and demanded an interview on that subject, which the President declined. The President 
next asked for written opinions from the members of his Cabinet, on provisioning Fort Sumter. Seward replied that he was for conciliation and would not provoke war, and Montgomery Blair was the only member of the Cabinet who advised using force. Seward unwisely assumed that he was to be the real head of the administration, and took it upon himself to say through third parties to the southern commissioners that he was sure that the fort would be given up. A few days later (April 1) Seward sent to the President a remarkable letter, in which he proposed to take charge of the government, and make war on Spain, France, and England, so as to bring back the seceders to defend the United States. Lincoln replied with dignity but firmness that the President must do whatever was done, and after this little contest Seward cheerfully accepted the fact that the President was his chieftain.

Lincoln was convinced from the outset that even if he gave up the forts, it could only postpone war; that the old questions of fugitive slaves, of boundaries, of the border states, especially the division of the territories and of the Pacific 356. Fort Sumter coast, would instantly come up again; and that a sepa1861) rate confederacy would demand more than was demanded by southern states before secession.

Batteries were by this time constructed around Charleston Harbor, commanding Fort Sumter. When on April 8, 1861, Lincoln sent a notice that he purposed to forward a supply of provisions to Sumter, he threw on Jefferson Davis and his Cabinet at Montgomery the responsibility of firing the first gun. Even the Confederate Secretary of State, the "fire eater" Robert Toombs, objected to armed resistance, and said: "Mr. President, at this time it is suicide, murder, and will lose us every friend at the North. ... It is unnecessary; it puts us in the wrong; it is fatal."

$\mathrm{He}$ was overruled, and instructions were given to General Beauregard, in command of the Charleston distriet, to reduce 
Fort Sumter. At 4.30 A.m. of April 12, 1861, a shell, fired from Crawford, Fort Johnson by Captain George S. James, "rose high F'ort Sum- in air, and curving in its course, burst almost directly
ter, 427

over the fort." With his sixty men and a few laborers, Anderson defended himself against forts manned by seven thousand men. After thirty hours of bombardment, Fort Sumter was knocked about his ears, while the relief expedition

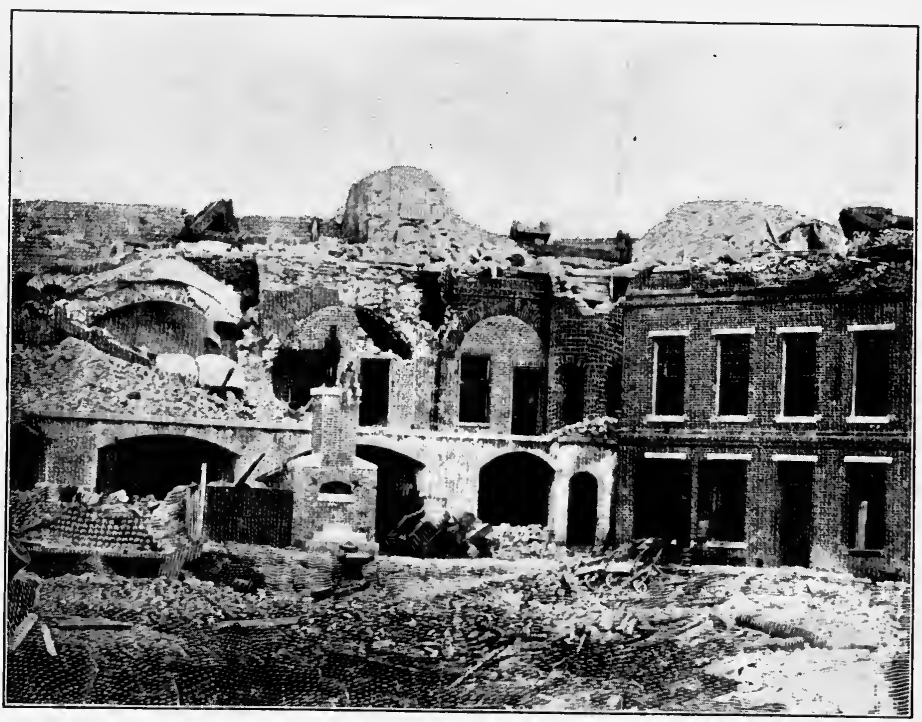

Interior of Fort Sumter after Bombardment, April, 1861.

lay helpless outside the bar. Anderson therefore surrendered the fort, April 14, 1861, marching out with colors flying and drums beating, and saluting his flag with fifty guns.

April 15, 1861, President Lincoln issued a proclamation call357. Seces- ing on the state governors to send 75,000 state militia, sion of the and this action compelled the border states to take sides
border states with either South or North. So far they had been (1861) quiet: in Virginia, Arkansas, and Missouri conventions had assembled, but refused to secede; in North Carolina and 
Tennessee no conventions had been called. The Kentucky legislature voted that "Kentucky should maintain a strict neutrality during the present contest." Now, to the President's request for men, the governor of Missouri replied, "The requisition is illegal, unconstitutional and revolutionary in its object, inhuman and diabolical, and can not be complied with"; and every other border-state government refused.

Virginia at once seceded; but Fort Monroe was held by the Union; Arkansas and 'Tennessee followed; North Carolina then seceded; and all four states immediately joined the southern Confederacy. Delaware remained quiet. Maryland for a time seemed likely to secede; and on April 19 the Sixth Massachusetts Regiment, while passing through the city of Baltimore, was attacked by a mob and several men were killed - the first blood of northern troops shed in the Civil War. In Kentucky, there was a secession convention and a nominal secession legislature, but the regular government of the state remained loyal throughout the war, and furnished seventy-six thousand troops to the Union army. In Missouri a camp of secessionists was formed in St. Louis, but the Germans in the city remained loyal, were drilled and organized, and under Captain Lyon broke up the camp (May 10); and there was no formal secession.

Who shall describe the excitement, wrath, and grief in the North while Fort Sumter was under bombardment? On Sunday, the day of surrender, hundreds of northern ministers called on their congregations to support the government. The members of the militia companies hurried to their armories; the states opened their arsenals for arms and military supplies; banks offered millions of dollars in loans to the state governments ; the legislatures appropriated unheard-of sums for military supplies; the women joined with the men in fitting out the soldier and bidding him Godspeed. As the need grew more urgent, the flower of American youth volunteered, and some colleges were almost broken up by loss of 
students. Even the President's old enemy, Stephen A. Douglas, with characteristic impetuosity came to him, and offered any service that he could give for the preservation of the Union.

The first full regiment to report was the Sixth Massachusetts, raised among the farmers and townspeople around Lexington and Concord. Within forty-eight hours from the President's call, it was on its way to Washington. As it marched through Boston the people rose almost with one accord to do it honor, and its reception in New York is typical

Hart, Source Book, 305 of the popular feeling all over the Union. "We saw the heads of armed men, the gleam of their weapons, the regimental colors, all moving on, pageant-like; but naught could we hear save that hoarse, heavy surge - one general acclaim, one wild shout of joy and hope, one endless cheer, rolling up and down, from side to side, above, below, to right, to left."

In the twelve months from April, 1860, to April, 1861, the country went through as much history as in the ten years 359. sum- previous. - In the election of 1860 the country was mary divided between the Republicans, strong only in the northern states; and the Douglas or moderate Democrats, the Breckenridge or extreme proslavery Democrats, and the Conservatives, mostly old Whigs, all three distributed through the Union. Lincoln's election precipitated a crisis which had long been approaching, and the secession of South Carolina started off the other cotton states like bricks in a row. Three months after the election, and a month before Lincoln's inauguration, the southern Confederacy was formed.

President Buchanan was helpless because he had yielded so much to his extreme proslavery friends and allies that he had lost the right to protest at anything they might do. Lincoln could not accept secession, even of the Gulf states, because 
convinced it would leave controversies which must speedily bring back the necessity of war. Efforts to hold intact the border states failed, because Lincoln saw that nothing could satisfy them except the further extension of slavery, which the Republican party was formed to resist.

Yet Lincoln could not bear to begin civil war, and in his inaugural address he affirmed his solemn purpose to preserve, protect, and defend the Union. Though he never intended for a moment to give way to secession, and was ready to accept a contest for Charleston harbor, he made the other side take the responsibility of firing the first gun, and thereby of arousing the spirit of the North.

\section{TOPICS}

(1) Why was John Sherman's approval of The Impending Crisis so obnoxious to the southern members? (2) What was there that was new in the Davis resolutions of 1860 ? (3) Why did the southern delegates oppose the nomination of Douglas in 1860 ? (4) Why was Seward set aside at Chicago in 1860 ? (5) Admission of Kansas, 1861. (6) Why did Buchanan consult Jefferson Davis on his message? (7) Why did Anderson move from Fort Moultrie to Fort Sumter? (8) Why was not Fort Pickens seized by Florida? (9) What was the ground of the opposition to secession in Georgia? (10) What men were responsible for the secession of the southern states? (11) Why was Alexander H. Stephens opposed to secession? (12) Why did compromise fail in Congress? (13) Why did not Lincoln receive the commissioners of the Confederate government? (14) Was Lincoln's attempt to provision Fort Sumter an act of war? (15) Why did Toombs object to firing on Fort Sumter? (16) Was the firing on Fort Sumter an act of war? (17) How was Maryland saved to the Union?

(18) Contested elections of Speaker of the House. (19) The Chicago Republican convention, 1860. (20) The South Carolina Suggestive topics secession convention, 1860. (21) Northern approval of John Brown. (22) Controversy between South Carolina and Massachusetts over the negro seamen act. (23) Seizure of United States public property in the South. (24) Northern advocates of secession. (25) James L. Petigru as a Union man. (26) The Peace Congress of 1861. (27) Lincoln on his way to Washington. (28) Lincoln's choice of a Cabinet. 


\section{REFERENCES}

Geography

Secondary authorities
Illustrative works

Pictures
See maps, pp. 390, 434, 435.

Wilson, Division and Reunion, §§ 101-106, 117 ; Channing. United States, 254-265 ; Johnston, Politics, 189-198; Stanwood, Presidency, 279-297; Iodge, Civil War, 1-8; Hart, Causes of Civil War; Rhodes, United States, II. 416-502, III. 115-415; Schouler, United States, V. 454-512, VI. 1-50; Wilson, American People, IV. 186-208; Cambridge Modern History, VII. 439-450; Gay, Bryant's History, IV. 432-447 ; Larned, History for Ready Reference, V. 3405 ; Ropes, Civil War, I. 1-97 ; Curtis, Constitutional History, II. 285-295, 300-338 ; Macy, Political Parties, 283317 ; Nicolay, Outbreak of Rebellion, 1-81; Hinsdale, How to study and teach History, 297-311 ; Brown, Lower South, 83-152, - S. A. Douglas, 129-141 ; Morse, Abraham Lincoln, I. 161-272 ; Hapgood, Abraham Lincoln, 151-208; Bancroft, W. H. Seward, I. 520-553, II. 1-45, 91-163; Hart, S. P. Chase, 178-211; Lee, General Lee, 52-98; Trent, R. E. Lee, 31-48; Shaler, Kentucky; Du Bois, William Lowndes Yancey.

Hart, Source Book, §§ 113-115, - Contemporaries, IV. \$§ 4974, 76, 77, 96, 97, - Source Readers, IV. § 29 ; MacDonald, Select Documents, nos. 93-96, - Select Statutes, no. 1 ; American History Leaflets, nos. 12, 18; Old South Leaflets, nos. 11, 107 ; Caldwell, Survey, 108-117 ; Johnston, American Orations, III. 230329, IV. 16-81; Century Company, Battles and Leaders, I. 7-98. See N. Eng. Hist. Teachers' Ass'n, Syllabus, 353,-Historical Sources, § 87.

Whittier, Antislavery Poems, 213-215; Winston Churchill, The Crisis (Lincoln) ; M. D. Conway, Pine and Palm; John Fox, Little Shepherd of Kingdom Come; W. A. Barton, Pine Knot (mountains of Kentucky and Tennessee).

Wilson, American People, IV. ; Harper's Weekly. 


\section{CHAPTER XXVII.}

\section{NORTH AND SOUTH IN 1861}

THE result of the Civil War depended on the relative strength of the contestants, measured in men, resources, business organization, and moral force. In population, 360. Poputhe North, which included the West and Northwest, far lation of the surpassed its rival: in 1790 the North and the South sections had each 2,000,000 people; but in 1860 the free states and territories counted $19,000,000$, and the slaveholding states and territories $12,000,000$. The difference was due to a more rapid growth of population and to the $3,500,000$ foreigners in the North, while there were but 300,000 foreigners in the part

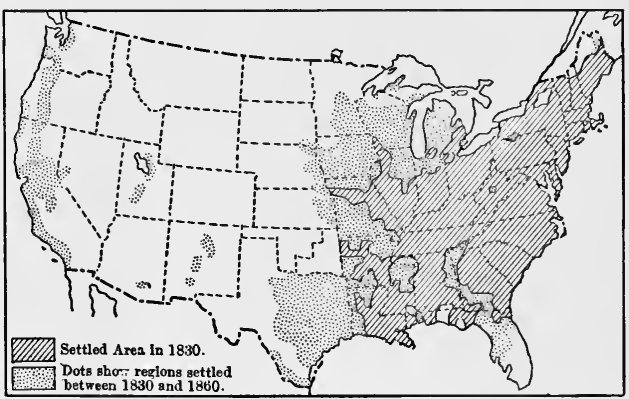

Settled ARea in 1860. of the South which seceded; for immigrants disliked going where there were few cities and few manufactures, and where manual labor was despised.

When the crisis came, to the nineteen free states were added four of the slaveholding states, Maryland, Delaware, Kentucky, and Missouri, with a total population of 3,100,000. Of those people probably 500,000 adhered to the South; but HART'S AMER. HIST. $-25 \quad 419$ 
West Virginia and East Tennessee stood by the Union, and nearly made good that loss. The total population of the region controlled by secession was therefore about 8,900,000 as against $22,100,000$ for the area supporting the Union. Out of the $8,900,000,3,500,000$ were slaves, and 140,000 free negroes, leaving a white population of $5,300,000$, of whom about $1,400,000$ were white men between eighteen and sixty years old, presumably capable of military service. The free states and four loyal slave states contained about 5,000,000 men from eighteen to sixty years old.

For the-support of an army, the

361. The North had farmer and many advanthe planter tages. About twice as much land was under cultivation as in the South; and

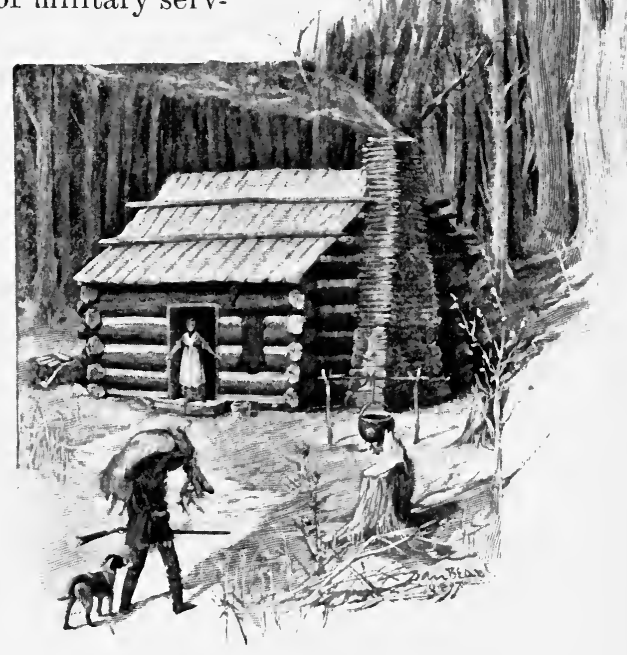

A Log House in the Backwoods.

far'm machinery, fertilizers, and improved methods made farm. ing more productive. On the western border lived several million frontiersmen, in rude houses of $\operatorname{logs}$ or rough lumber or even of prairie sod; but these men of the West and Northwest were getting on, saving money, making improvements; and, as far west as Wisconsin, much of the country was as thickly settled and prosperous as the rural parts of New York state. In the South plantations of hundreds and even thousands of acres were common, but the staple crop was cotton, of which 
the South exported a value of $\$ 191,000,000$ in 1860 . It did not raise all its own food, and was buying corn and hog prod. ucts in large quantities from the Northwest. Most of the profits of farming went to the great slaveholding planters.

The rise of city and factory populations developed in the eastern states a democracy very like that of the West. The manufacturers and heads of corporations, many of whom had risen from the ranks of labor, were now leaders in American industry. The South supposed that this was a

362. DQmocracy and aristocracj timid class, which would never permit a war for fear of losing its profits, and that workmen and clerks were "mudsills," who would not and could not fight. Yet from such men came a great part of the victorious northern armies. In the West there was a genuine and wideawake democracy, which knew no such thing as family prestige, and was not controlled by the commercial class.

In the South slaves were almost the only form of great wealth, and the 300,000 slaveholding families were as much a governing class as in colonial times. Out of

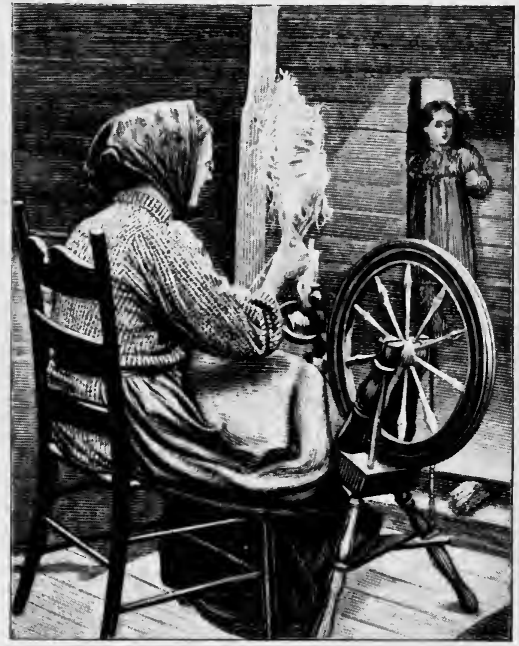

A Poor White, spinning.

From a Kentucky photograph. those families came also nearly all the doctors, lawyers, and ministers in the South. The most numerous type of the southern white was that of the "crackers," or "poor whites," illiterate and unprogressive, but born fighting men. Most of them believed that the interest of slavery was their interest 
also, and therefore supported the planter at the polls and in the trenches. Nevertheless, the mountain whites along the west slope of the Appalachians had no slaves, hated the slaveholders, and constantly opposed them in the state governments.

During the period from 1840 to 1860 the state constitutions, both North and South, grew more and more democratic. 363. Ideals The most striking novelty in government was jealousy of state government

of the legislatures, which were tied down by amendments of the state constitutions; and there was much new legislation to provide for new problems of business and social life. In the South the states legislated less for social welfare than in the North; partly from long habit, partly because there was no class of free mechanics to demand legislation.

Party management grew more and more elaborate, especially in the populous northern states, and in a few states the power of the political boss was highly developed; yet candidates for state offices were nominated in conventions where the result was not arranged beforehand, and there was plenty of discussion in state legislatures. In purity of politics the South was better off than any other part of the country, for the use of money at elections was there uncommon. The one question which could not be discussed there, and on which nobody was allowed to disagree with his neighbor, was slavery.

The census of 1860 showed 158 cities of 8000 or more people, containing about a sixth of the total population. Of these, 137

364. Ameri- were in the states which adhered to the Union, and 21 can cities within the later southern Confederacy. New Orleans, with a population of 168,000, lived, largely, from down-river western trade, and the largest southern city supported wholly by southern commerce was Charleston, with 41,000 people.

In the North, as the old towns expanded, they turned into crude, irregularly built, and ugly cities, and nobody seemed to foresee how fast they would increase. Washington was an unpaved bog in time of rain, and its scavengers were half-wild 
hogs. Most of the cities had public water supplies: Philadelphia began a system of city waterworks in 1801, New York built its Croton aqueduct in 1835-1842, and Boston got Cochituate water in 1845. The cities were poorly policed and riots were frequent. In 1834 the colored quarter in Philadelphia was attacked, and a Boston mob burned a Catholic convent in a suburb. In the large cities politics were very unsavory: New York and San Francisco were renowned for their corrupt and disorderly governments and for fraud and violence at elections.

About 1860 people began to wake up to the possibilities of improving their own cities. In 1857 the city of New York organized a "metropolitan police" of uniformed and disciplined men, and laid out Central Park, the first great municipal pleasure ground in the country. Horse cars began to be widely used about 1845. The western cities were now growing fast: Cincinnati, St. Louis, and Chicago were still rude and dirty, but had populations of $161,000,161,000$, and 109,000. Next to them in importance were Louisville $(68,000)$, Pittsburg $(49,000)$, Detroit, Milwaukee, and Cleveland (each about 45,000).

For public education, the cities developed a system of free graded schools, in which pupils of about the same age and experience could be gathered into one room; and about 1850 they began to appoint trained superintendents to direct their schools. The country district schools were

365. American education still taught by farmers' sons and daughters, who often had no other education than that of the district school itself. Still, even the remote prairie farmer had a schoolhouse near by to start his boys and girls in education. Some of the northern cities had public high schools, for boys and girls; in a few places there were separate girls' high schools; in the North were many "female seminaries," and other large boarding schools for girls.

Colleges were still small; none of them had over 530 undergraduate students in 1860 . College athletics made a begin- 
ning at this time, with the rowing in some eastern colleges, but the aninal spirits of the students still found vent in all sorts of boisterous horseplay. True universities were at last beginning to develop. The older colleges added departments : a theological school here, a law school there, a school of mines in another place; and the new western state universities included from their beginning a system of special and technical schools. In 1862 Congress made a large gift of land to found agricultural colleges in the states. The University of Iowa took the bold step of admitting women to the various parts of the university (1856), an example later followed by all the western state universities.

Southern education was on a different footing. Only about a fifth as many children were at school as in the North. The slaves and free negroes had no form of education, and the

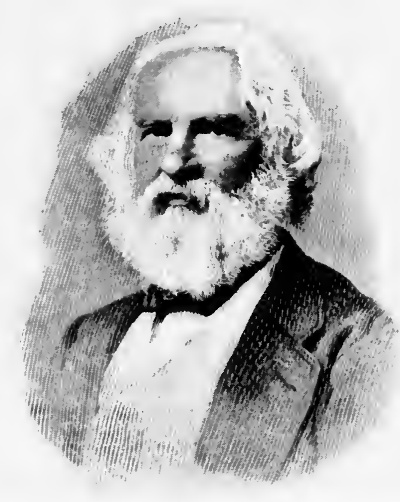

Henry W. LongFellow, AвоUT 1870. country poor whites had little or none. In the towns the public schools had small funds and few trained teachers. The South had many military academies, the best known of which were the famous "Citadel" in Charleston and the Virginia Military Institute at Lexington, Virginia. Some of the wellto-do families sent their sons to southern state or denominational colleges, or abroad, or to northern colleges, and the ruling class was highly From a photograph lent by the family. educated and intellectual.

The year 1860 falls about in the middle of the golden age of American literature, in which flourished Whittier, the pathetic poet of slavery and suffering; Longfellow, the sunny-minded 
and graceful; Oliver Wendell Holmes, the wit of his time; and Ralph Waldo Emerson, whose essays, full of virile thought and masterful English, had been published al-

366. American literature most twenty years earlier. Nathaniel Hawthorne ( $\$ 289$ ), perhaps the greatest of all American writers, died in 1864.

In addition to the North American Review and De Bow's Review, an excellent southern review of economic and political questions, two other magazines were founded in lighter vein: Harper's Monthly, started in 1850 , and soon after made an illustrated magazine; and the Atlantic Monthly, founded in November,

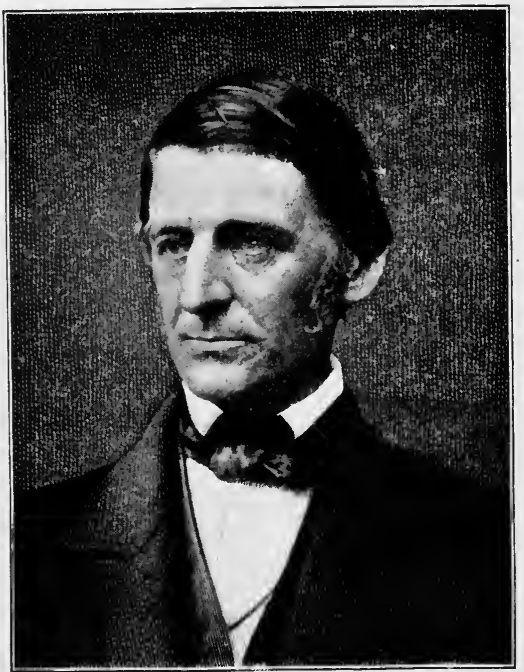

Ralph Waldo Emerson in 1856. 1857, under the editorship of James Russell Lowell. Lowell excelled as a poet, essayist, and critic; but he will always be best remembered for his Biglow Papers, the keenest of satires on slavery.

The new school of American historians was at the height of its activity in 1860; to George Bancroft and William $\mathrm{H}$. Prescott were added John Lothrop Motley with his Rise of the Dutch Republic (1856); and Francis Parkman, greatest of all American historians, who about 1850 began his life work of describing the relations of the Indians, the French, and the English in the new world, "the romance of the woods."

'The fierce contest of the Civil War developed many political humorists. Among the more genial was Artemus Ward, whose 
quaint phraseology and ingenious misspelling can not hide the vigor and incisiveness of his thought. It was he who was willing "to send all his wife's male relatives to the war."

In this active intellectual life the South had little part. Aside from its able political writers, it had no body of defender's of slavery equal to opponents like Mrs. Stowe, Whittier, and Lowell; and no essayists, poets, satirists, or historians who were read in the North or affected northern public opinion.

With the passing of the years, the great national churches had grown larger, stronger, and wealthier. Though the Pres367. Reli- byterians, Baptists, and Methodists were split by the gion and churches

slavery question, the segments flourished. The Congregationalists, Unitarians, Episcopalians, and Catholics were not formally divided by slavery. The Catholic Church was steadily enlarged by the immigration of Irish and German Catholics, and kept out of the discussion of slavery. Theology was in general milder than in 1830 , and there was less preaching on future punishment, and more on present duty. Benevolent organizations were now very active: Bible societies, tract societies, foreign missionary societies, education societies, helped to raise the moral standards of the people.

The South, more than the North, made its churches intellectual and social centers. It had many good church buildings, large congregations, and eloquent ministers, perhaps the most renowned of whom was Bishop William Meade of Virginia. In both city and country the negroes had separate churches, usually with a minister of their own color; and there is a tradition that one such church bought and owned its minister.

People were learning what immense resources the country 368. Natu- possessed in other products than those of the farm. Lumral resources ber was still very cheap, and a great business was developed in supplying the white pine of Michigan and Wisconsin to the treeless prairie states. Oil always floated on 
the surface of Oil Creek, a tributary of the Allegheny River, and in 1859 it was discovered that, by putting down drill holes along this creek, porous rock containing this valuable illuminant could be tapped; and new methods of refining oil made the product marketable.

Mining grew to be a great industry, and many states provided geological surveys of their territory. Hard coal abounded in northeastern Pennsylvania, soft coal in western Pennsylvania, Ohio, and western Virginia; lead mines were worked near the upper Mississippi; iron mines in New England, Pennsylvania, Virginia, and the upper peninsula of Michigan ; rich copper deposits were found south of Lake Superior, and gold in California. In 1858 gold was found near Pikes Peak, and the city of Denver quickly

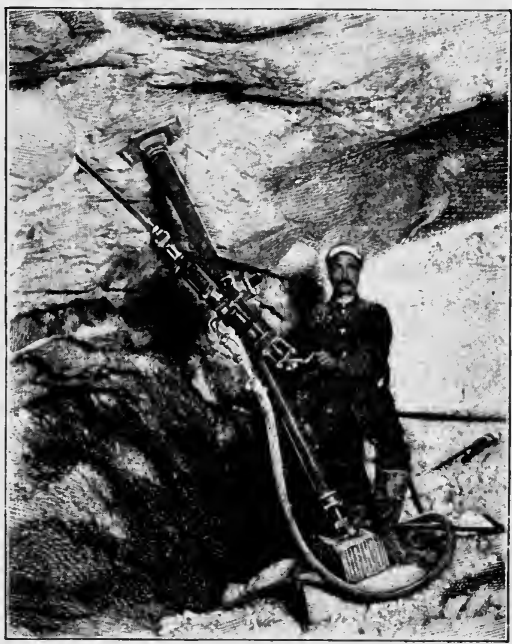

Rock Drill in a California Gold Mine. sprang up. In 1859 silver was discovered in great abundance at Virginia City, Nevada ; and in 1861 gold in Montana. The South was equally rich in stores of timber, in coal, iron, oil, and the natural wealth of the soil; but the profits of industry went into buying slaves and raising cotton, and there was no labor adapted to manufacturing. Hence, in the whole seceding South the only coal mines worked on a large scale were those on the upper James in Virginia.

During the thirty years preceding 1860, great progress was made in commercial organization. Corporations of every kind 
rapidly increased. Banks abounded, and in 1853 a clearing house was organized in New York to simplify the banking 369. Organ- business. Labor also began to organize into trades unions, ization of which demanded a shorter day; in 1840 the United industry

States made ten hours the legal day for its employees.

Manufactures developed rapidly because of cheap fuel, brought down from the Pennsylvania mines to the Hudson and the Delaware, so that it could be distributed all along the seaboard, for use in factories and houses. In the West the fuel was bituminous coal, in which there was a great trade down the Ohio from Pittsburg to Cincinnati, Louisville, St. Louis, and many other places. Soon after 1860 Lake Superior iron ore began to come down the Lakes; and before long places convenient to both coal and iron, especially Cleveland and Pittsburg, became great iron-manufacturing cen-

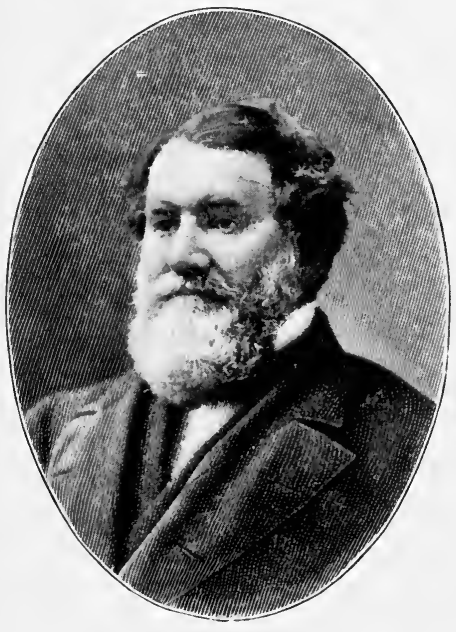

Cyrus H. MCCormick, About 1875. ters. In this commercial development also the South had but a small share. The only considerable iron works in the South was the Tredegar at Richmond; there was only one other large southern rail mill; and the southern water powers were not developed. A large amount of southern capital, however, was invested in banks, which gave credit to the small planter and the farmer. Of the foreign imports one tenth came to the South in 1860, and nine tenths to the North.

From 1840 to 1860 was a period of rapid progress in inventions. McCormick's mowing machine, invented in 1834 
and put on the market in practicable form in 1845, was steadily improved, and was soon followed by grain reapers on the same principle. The manufacture of cloth was im- 370. Groat proved, all the way from the farm to the wearer's back, inventions in carding, spinning, weaving, dyeing. In 1846 Elias Howe made his first practicable sewing machine, clumsy enough, but provided with a needle with the eye near the point, a device which has revolutionized sewing. In 1844 Goodyear discovered a means of "vulcanizing" rubber, so as to make it up into shoes, garments, and hard articles.

The French inventor Daguerre in 1839 announced a method of taking self-recording sun pictures called daguerreotypes. They required an exposure of about twenty minutes, and the result was a single picture on a silver plate. An American, Dr. Draper, at once discovered that the process could be applied to portraits; a few years later an Englishman named Archer found that a negative developed from a collodion film could be fixed on a glass plate, from which any number of prints could be made: thus photography sprang into being. In 1841 two men, Dr. Morton and Dr. Jackson, working separately, discovered that by inhaling the vapor of ether, a person could be made completely insensible to pain, and then could return to consciousness without permanent ill effects.

The greatest new discovery in methods of communication of intelligence was the electric telegraph, first discovered in 1835, and worked out and applied by Samuel F. B. Morse and Alfred Vail in 1844. It carried the news of the nomination of James K. Polk from Baltimore to Washington. 'Telegraph lines rapidly spread through the country, and in 1851 an electric fire-alarm telegraph was set up. Machinery began to be applied to many new purposes. The first steam fire engine was constructed about 1853. In 1847 Richard Hoe invented a rotary printing press, run at great speed and delivering a continuous stream of newspapers. 
The South had little use for these inventions: factories and workshops were few; most manufactures were imported. Mowers and reapers were of no use, as there was little hay or grain. The only widely distributed labor-saving machine was the cotton gin, and of the southern cotton not a fortieth part was manufactured in the South.

Railroads as yet gained little from the inventions of the period. Nearly the whole of the railroad system was single 371. Trans- track, the trains slow, the stations (as many are to-day) portation small and dirty. From New York to Chicago the fastest schedule time in 1860 was thirty-eight hours - nearly twice the time now required. The cars were small and comfortless, but sleeping cars had been introduced for the long routes. Railroad accidents were frequent and destructive: the iron rails broke, the wooden bridges and trestles failed, and there was no system of running trains by telegraph. The South fell behind the North in transportation; the railroads were lighter in construction, ran less regularly, and charged higher fares. The tributaries of the Mississippi were provided with lightdraft steamers, but the South built very few vessels, and the seagoing coasters were mostly northern property.

The railroad and steamboat quickened the carrying of the mails; and other reforms were made in the postal service. Official adhesive stamps were introduced.(1847); the postage was reduced to five cents (1845), and then to three cents (1851). Unfortunately neither the post office nor the railroad undertook the plain duty of carrying parcels. In 1839 a young man named Harnden conceived the idea of carrying packages back and forth between Boston and New York, and he thus began the express business in the United States. The Adams Express Company was formed in 1854. In the fifties Wells, Fargo and Company organized an express system on the Pacific coast; and Butterfield and Company introduced a "pony express" for letters and valuables, which covered the 
nineteen hundred miles from St. Joseph on the Missouri to Sacramento in ten days (map, p. 516).

Rich, busy, populous, energetic, and advancing was the United States of America in 1861; the 27,000,000 white people were fairly employed and content; their government was the most democratic in the world, and, with many defects, yet answered their wants. They began to understand the natural wealth of their country, in timber, oil, metals, and coal; they had an excellent and constantly improving commercial organization; and their inventive minds were pushing forward new labor-saving discoveries and inventions. Foreign and interior transportation were developing, so that the United States already had more railroads in proportion to the population than any other country. A national literature expressed the national character and pride.

The natural advantages of the country were as great in the South as in the North; the southerners had great seaports, rivers, forests, and mines ; the people came of about the same stock : yet in most of the marks of civilization the South was far behind the North; it had fewer and poorer cities, factories, railroads, schools, magazines, writers, and readers. For this disparity, which told heavily against the South during the Civil War, the main cause would seem to be slavery, a system under which a great laboring class - nearly one third of the southern population - was systematically cut off from knowledge, education, and the opportunity to rise.

\section{TOPICS}

(1) Why did so few immigrants go to the South? West Virginia and East Tennessee stand by the Union? made northern farmers more prosperous than southern? the cultivation of cotton a good thing for the South ?

(2) Why did

(3) What (4) Was (5) Was slavery a good thing for the poor whites? (6) How far were the southern slaves useful to the South in carrying on the Civil War? 
Search topics

Geography Secondary authorities

\section{Sources}

nlustrative works
(7) Why did not the South allow discussion on the slavery ques. tion? (8) Why were the colored people so frequently attacked by mobs in the North? (9) Why did not the southern educated class make the South prosperous? (10) Why is Ralph Waldo Emerson famous? (11) What makes Nathaniel Hawthorne the greatest of all American writers?

(12) The city of Washington before the Civil War. (13) The building of the Croton waterworks for New York. (14) Antinegro mobs in Philadelphia. (15) Burning of the Catholic convent in Charlestown, 1838. (16) District schools before the war. (17) College life before the war. (18) James Russell Lowell's antislavery utterances. (19) Funny things from Artemus Ward. (20) A trip from New York to Chicago before 1860. (21) Whittier's antislavery poems. (22) Longfellow's home life. (23) Jokes of Oliver Wendell Holmes. (24) Henry Ward Beecher as a pulpit orator. (25) Bishop Meade as a churchman. (26) Discovery of oil in Pennsylvania. (27) Discovery of gold in the Rocky Mountains. (28) McCormick's inventions.

\section{REFERENCES}

See map, p. 390.

Wilson, Division and Reunion, \$119; Schouler, United Siates, V. 260-269, VI. 318-341; Cambridge Modern History, VII. 692, 696, 744-747 ; Rhodes, United States, III. 1-114; Chadwick, Causes of the Civil War; Hart, Practical Essays, 258-298; Cable, Creoles of Louisiana, 232-260; Hale, J. R. Lowell; Carpenter, H. W. Longfellow; Linn, Horace Greeley, 56-109; Raymond, Peter Cooper, 52-95; Gould, Louis Agassiz. See also references to chapter xxii.

Cairnes, Slave Power; Olmsted, Cotton Kingdom ; S. D. Smedes, Southern Planter; Helper, Impending Crisis. See also references to chapters xvi. xxvi. xxviii.

H. W. Beecher, Norwood (N.E.); F. H. Smith, Fortunes of Oliver Horn (Md. and N.Y.); A. W. Tourgée, Royal Gentleman (slavery); T. N. Page, In Ole Virginia; L. G. Moore, Rachel Stanwood (South); G. W. Cable, Dr. Sevier (New Orleans); Epes Sargent, Peculiar (slavery, Missouri); Alice Cary, The Great Doctor (Middle West); Edward Eggleston, Mystery of Metropolisville (Minn.); C. H. Roberts, Down the O-hi-o; Mark Twain, Life on the Mississippi, - Huckleberry Finn; "Edmund Kirke" (J. R. Gilmore), Among the Pines; W. M. Baker, The New Timothy. See also references to chapter xxii. 


\section{CHAPTER XXVIII.}

PERIOD OF UNCERTAINTIES (APRIL, 1861-DECEMBER, 1862)

The Civil War practically began April 12, 1861, when the Confederates fired on Fort Sumter, although the official Confederate point of view was that the attempt to relieve Fort Sumter was an act of "war between the states"; an unrighteous attempt by a "foreign government" to

373. The purpose of the war conquer independent and sovereign communities. The northern point of view was at first that the war was only a big riot of individuals; that although the southerners might try to excuse themselves because they were following the orders of "sovereign states" and a "Confederacy," really the states were still in the Union; and that every individual still owed "paramount allegiance" to the United States, and was liable to execution for treason if he made armed resistance to the authority of the federal government.

In practice it was impossible to treat southerners in uniform, acting under orders of their superiors, as anything but soldiers, and, if captured, as prisoners of war; and by a proclamation of April 19, 1861, for the blockade of the southern ports, President Lincoln virtually admitted that there was a government on the other side, carrying on civilized war. White flags were recognized, and, after a year, the exchange of prisoners began.

To emphasize the issue of preserving the Union, and to make it clear that the war was not inaugurated to free the slaves, the national House of Representatives, with only two negative votes, voted, July 22, 1861, "That this war is not 


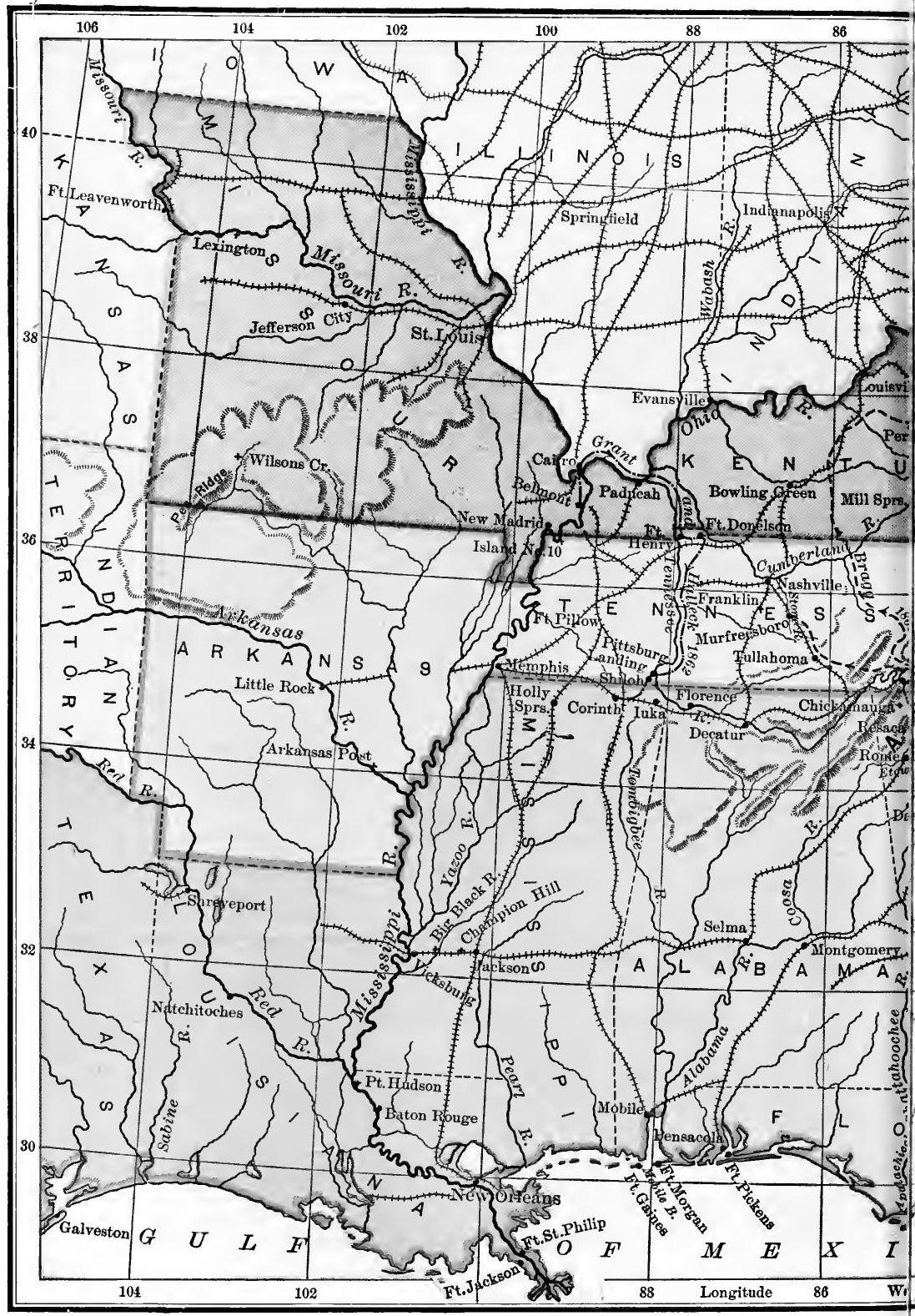


Congressional Globe, $1861, p .223$

waged upon our part in any spirit of oppression, or for any purpose of conquest or subjection, or purpose of overthrowing or interfering with the rights or established institutions of those States, but to defend and maintain the supremacy of the Constitution and to preserve the Union with all the dignity, equality, and rights of the several States unimpaired."

The only way to break up the Confederacy, and to bring the states back into the Union, was to invade the South, a 374. Prob- region naturally very strong. The eastern and southern lem of invading the South boundáry was the Atlantic and Gulf coast, most of the harbors of which were quickly fortified. The western boundary of the Confederacy was a wilderness. Now an invading army is like a serpent which can strike only with its head, and as it moves forward leaves the length of its body exposed. Such an army must follow some kind of highway over which supplies and reënforcements may be sent up to the front; hence the rough and impassable Appalachians and heavily wooded country east and west of them covered the middle of the Confederate northern boundary, and seemed a sure protection.

The Confederate military frontier early in 1861 left to the Union Fort Monroe, the opposite "eastern shore" of Virginia, and the country just across the Potomac from Washington; the line then followed a little to the south of the Potomac River, and through the mountains of West Virginia and Kentucky; then ran to the two Confederate forts of Donelson and Henry, on the Cumberland and Tennessee rivers; touched the Ohio at Paducah, crossed the Mississippi at Belmont, and then passed about midway through Missouri.

Nevertheless that strong line of defense was weakened by four routes into the interior of the Confederacy, and along them were fought most of the campaigns of the Civil War: (1) the lower Mississippi River, deep enough to admit ships 
from the sea; (2) the upper Mississippi, a great national highway, abounding in steamers; (3) the line of railroad from Louisville to Nashville, and thence across the mountains to Chattanooga and Atlanta; (4) a strip of territory lying east of the mountains in Virginia, which was crossed by three railroads leading south from Washington to the Shenandoah valley, Lynchburg, and Richmond.

To fight its battles, the South had a population accustomed to outdoor life, to the use of firearms, and to the management of horses; and it had also commanders trained in the national military school of West Point and in the wars of the Union. Since the negroes did the hard work at home, nearly all the able-bodied white men could be enlisted. According to Colonel Livermore, the authority on this question, over $1,230,000$ different men were enlisted in the Confederate army, and served long enough to be equivalent to $1,080,000$ men under arms an average term of three years.

Though the North was not considered to be a military people, the first call for 75,000 militia for three months brought out 92,000 "citizen soldiers"; and during 1861660,000 men were enlisted for three years. Of each call for troops during the war a proportion was assigned to each state. At first volunteers poured in, but in 1863 this impulse lost strength and a draft was ordered, which, however, produced only 36,000 men. In the course of the whole war about 2,500,000 adult men were in the military service of the Union, of whom about 400,000 reënlisted at least once. The total service was equivalent to $1,560,000$ serving for three years. To raise, organize, and supply such enormous forces required a great man as Secretary of War. In January, 1862, Lincoln practically removed Simon Cameron from that Department, and appointed Edwin M. Stanton, chosen for his loyalty to the Union, his rugged honesty, and his great ability, although he had the worst of tempers, and would occasionally defy the President. 
The regular navy was at first disorganized, because more than a third of the officers resigned to join the Confederacy,

376. The navy and the blockade and all the navy yards in the southern states were seized by the Confederacy, with the vessels that happened to be in port. Of the ninety vessels nominally in the Union navy, only seven steamers and five wooden cruisers were in home ports and available when the war began. The President's proclamation of blockade, April 19, 1861, was a notice to foreign ships that he purposed to put squadrons outside all the southern ports, to capture vessels going in or running out. Thus began the celebrated "anaconda policy" of pressing on the Confederacy from all sides at once. To form the necessary blockading squadrons, merchant vessels, both sail and steam, were hastily bought and equipped, naval volunteers were enrolled, and in a few months squadrons were actually blockading the coast and making frequent captures.

To evade the blockade, small and very swift steam "blockade runners" were built abroad, to run from the near-by Bahama and Bermuda islands to Confederate ports, carrying in military stores and miscellaneous cargoes, and carrying out cotton, compressed into small bulk. Many of these vessels were captured, but their profits were so great that two successful trips would pay for a vessel. As the war advanced, the blockade grew more and more effective; in all about 1500 captures were made by the Union fleet, and the trade of the South with the rest of the world was nearly throttled.

Energetic efforts were made by the Confederate authorities to build a navy. They did construct several fleets for harbor 37\%. Con- defense, but their only seagoing ships were the "comfederate navy and merce destroyers." The South at once began to issue privateers "letters of marque" (commissions to private ships to capture Union merchantmen) and also to send out cruisers, or public armed ships. At first the United States tried to make out that the crews of such vessels were pirates, and several of 
these men were convicted and sentenced to death; but President Davis threatened to execute an equal number of Union soldiers held as prisoners, and the United States finally decided to treat them as prisoners of war.

Several vessels were also fitted out as Confederate ships of war in British ports; of these the principal ones were: (1) the Florida (formerly the Oreto), purchased and allowed to go to sea from a British port in March, 1862, contrary to the protest of our minister; (2) the Alabama, which was built at Liverpool for the Confederacy, and although Minister Adams steadily protested, slipped away to sea (July, 1862), her crew and guns coming out to her on another ship; (3) the Shenandoah (formerly the Sea King), which put to sea in October, 1864 . These three vessels, with a few others, following the American precedent of the Revolution and War of 1812, found a rich prey in the American merchant ships, of which the total number captured was 260 , valued at $\$ 20,000,000$. Such was the dread of capture that many American ships were sold to foreign firms so as to be safe under neutral flags. Gradually the United States navy hunted out and blockaded, took, or sank all these vessels except the Shenandoah, which was still at work when the war ended.

The Confederate government moved from Montgomery to Richmond after Virginia seceded. The "permanent constitution," which went into effect February 18, 1862, was nearly the old federal Constitution over again, with the significant change that the word "slave" was freely used; but in practice many parts of this Constitution never went into effect; for instance, the Supreme Court

378. The southern Confederacy and Jefferson Davis was never formed, the executive overshadowed the rest of the government, and state rights were often disregarded.

The head and type of the Confederacy, President Jefferson Davis, born in Kentucky (1808), was educated at West Point and served seven years as lieutenant in the army. From 1845

HART'S AMER. HIST. -26 
to 1851 he was in Congress, and a soldier in the Mexican War, where he served with distinction. From 1853 to 1857 he was Pierce's Secretary of IVar, and then as senator from Mississippi came forward as the leader of the ultra proslavery men in Congress. After the election of Lincoln, Davis used his

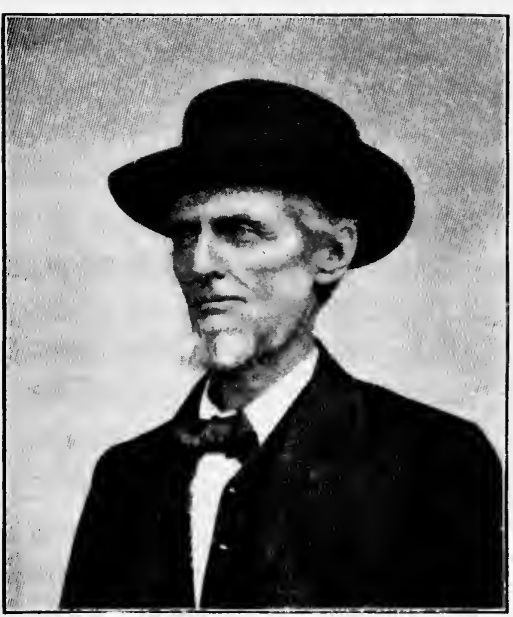

Copyright, 1867, by Anderson.

JefFerson Davis, about 1870. place and influence, before resigning from the Senate of the United States, to bring about the dissolution of the Union. During the war he was almost a civil dictator, acting through his influence on the Confederate Congress; his veto was overridden but once in four years.

In the speeches and public papers of Davis he simply accepted as a matter of course, not subject to argument, that negroes were no part of the political community; he also tacitly assumed that the ruling class, of which he was a member, were entitled to govern their fellow white men. In both respects he satisfied the public sentiment of the South, which, on the whole, loyally supported him to the end. He was a type of the resolute, masterful, slaveholder statesman.

The United States was slow in sending out a new min379. Bel- ister to Great Britain, and on the day before Charles ligerency; the Trent (1861) Francis Adams reached London; the British government Am. Ann. Cyclopædia, issued (May 13, 1861) a proclamation of neutrality in 1861, p. 624 the contest between "The United States of America, and certain states styling themselves the Confederate 
States of America." Other European governments followed. This was a formal recognition that there was a belligerent - power in the southern states, a government that had armies in the field, and war ships on the sea which were entitled to the same treatment in foreign ports as the public ships of the Union. Although President Lincoln's proclamation of blockade practically recognized this "belligerency," the North long cherished wrath against Great Britain for thus treating the Civil War as a war instead of as a domestic rebellion.

To the Confederacy the action of England seemed far too weak; and in 1861 commissioners were sent to Europe to ask for full recognition as an independent nation. The commissioners, Mason and Slidell, while on their way from Havana to St. Thomas in the British merchant steamer Trent, were forcibly taken off by Captain Wilkes in the United States ship of war San Jacinto (November 8, 1861). The country and Congress were delighted at the capture ; but Lincoln pointed out that the search of neutral ships was just what drove the United States to war in 1812. Lord Palmerston, British prime minister, prepared a dispatch which might have led to immediate war; but Queen Victoria insisted that a more peaceful tone should be taken. On the other side, Lincoln and the Cabinet saw that to stand out meant war with Great Britain and the success of the Confederacy, and they prudently decided that it was very doubtful whether, under the principles of international law, Mason and Slidell were rightfully taken, and the two men were finally given up.

Congress met in special session, July 4, 1861, to provide for the war. The "Morrill Tariff" had already passed in March after many southern members had withdrawn from Congress ; it restored the rates of the tariff of 1846, but added some high protective duties. At various times through- (1861-1864) out the war the tariff was raised and raised again, and Congress soon began to lay new taxes of many kinds: the old- 
fashioned excise; duties on incomes (bringing in $\$ 347,000,000$ in all); duties on manufacturing; direct taxes on the states; licenses for professions; stamp duties in many ingenious forms; taxes on everything that could be reached. The taxes rose from $\$ 40,000,000$ in 1860 to $\$ 490,000,000$ in 1865 ; but they did not keep pace with the expenditures, which were $\$ 66,000,000$ in 1860 , and $\$ 1,290,000,000$ in 1864 . To meet the deficits, heavy loans were secured; and the government debt grew from $\$ 90,000,000$ in 1861 to nearly $\$ 3,000,000,000$ in 1866, bearing an interest of $\$ 133,000,000$ a year.

Another great change was a complete revolution in currency and banking. In 1862 Congress authorized the issue of "legal tender notes," that is, paper money which must be accepted if offered by debtors to creditors. These "greenbacks" gradually grew to over $\$ 450,000,000$. Congress in 1863 chartered a system of national banks, and soon after laid a tax of 10 per cent on the notes of the state banks, which drove those notes out of circulation, and caused many of the banks to accept national bank charters.

It is time to take up the thread of narrative history. For a few weeks after the fall of Fort Sumter, Washington was in 381. The danger; but the militia and volunteer regiments pushed war in the forward and saved it; and it was then strongly fortiEast (1861) fied. A Confederate force of about 23,000 men under Beauregard was lying at Manassas Junction, thirty miles from Washington (map, p. 449); and the country loudly called for somebody to break up that army. Against the judgnent of the military men, a force of 30,000 Union troops, under General McDowell, attacked at Bull Run (July 21, 1861), not knowing that Joseph E. Johnston had brought 6000 more men from the Shenandoah.

When the federal onset was checked by a Virginia brigade Pollard, Lost Cause, 146 under command of Thomas J. Jackson, a bystander cried, "There are Jackson and his Virginians standing like a 
stone wall!" and as "Stonewall Jackson" he has gone down in history. Nevertheless the Confederate army was weakening, when 3000 fresh troops arrived on the field by railroad, and the Union lines broke. Says an eyewitness, ". For three miles hosts of federal troops, all detached from their regiments, all mingled in one disorderly rout, were fleeing along the road." The Union loss was 2700 men, killed, wounded, and missing, besides twentyeight guns.

The North profited by Bull Run more than the South, for it came to realize the task before it. President Lincoln held his courage, and within three days was making preparation for new campaigns in both East and West. George B. McClel-

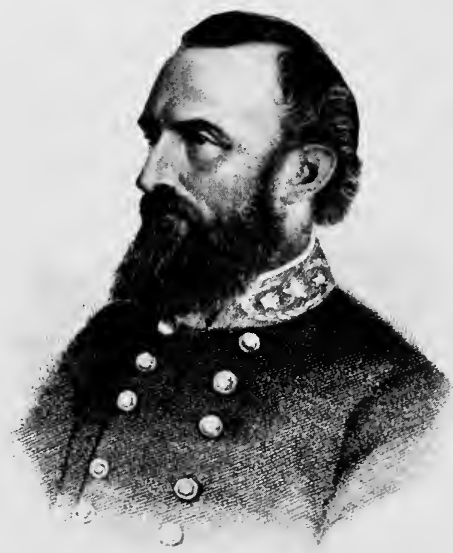

"Stonewall" JaCkson, in 1862. lan, who had shown military genius in West Virginia, was at once put in command of the army in front of Washington, and in November became commander of all the armies of the United States. During the next nine months he devoted himself to organizing an "Army of the Potomac." Day after day, week after week, the only news from that part of the front was the stereotyped telegram, "All quiet on the Potomac."

Besides the blockading service, the Union navy in 1861 began a series of brilliant expeditions. Fort Hatteras on the coast of North Carolina was captured (August, 1861); then Hilton Head, near Port Royal, South Carolina, was taken by Admiral Dupont (November, 1861) with a fleet of 17 vessels. His success against heavy earthworks gave much encourage- 
ment to the navy; and a permanent post was established at Hilton Head, only sixty miles from Charleston. Several islands at the mouth of the Savannah River were occupied a few months later.

In the West armies were quickly formed and began a campaign. During 1861 Kentucky was prevented from seceding; 382. Fight- and the federal troops under Lyon held a part of Missouri. ing in the In January, 1862, General George H. Thomas beat the April, 1862) Confederate Zollicoffer near Mill Springs on the upper Cumberland River. General Ulysses S. Grant, who had shown his ability in a little expedition down the Mississippi to Belmont, now moved forward. Flag-Officer Foote with steam gunboats easily took Fort Henry

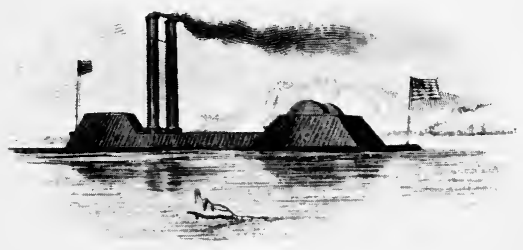

A Mississippi Ironclad, 1863.

From a contemporary print. (February 6, 1862). Grant then besieged and, after three days' fight, captured Fort Donelson, with its garrison of 14,500 men (February 16 ; map, p. 434). This was the first large success of the Union army, and it compelled the Confederates to abandon Kentucky. Nashville was at once occupied without a blow by General Don Carlos Buell; and a provisional state government was set up for Tennessee with Andrew Johnson as governor.

Farther west the Confederates retreated down the Mississippi to a strong position called Island No. 10, which, however, was captured by General Pope and Flag-Officer Foote in April. In March the Confederate army west of the Mississippi was broken up at the battle of Pea Ridge. The result of three months' campaigning was therefore the gain by the Federals of a strip of territory a hundred miles wide and more than five hundred miles long, and it made a military reputation for Grant, Buell, Thomas, and Pope, all of whom later commanded 
large armies, as well as for General Halleck, who had exercised general command as head of the Military Department of Missouri.

After the capture of Fort Donelson, Halleck sent Grant's army to Pittsburg Landing, on the Tennessee River. Halleck's department having been enlarged (March, 1862), he ordered Buell to march from Nashville and unite his forces with Grant's. Before Buell could get up, however, Albert Sidney Johnston, with 40,000 Confederates, suddenly attacked Grant's army of 43,000, April 6, 1862,

383. The

western campaign (April-December, 1862) at Shiloh, near Pittsburg Landing on the T'ennessee River. Surprised, and as yet little experienced in fighting in line, the Union troops were driven back almost to the river. General W. T. Sherman, one of the division commanders, fought gallantly; General Johnston was killed on the field, and Beauregard succeeded him. Next morning · Buell's army of 20,000 had arrived to reënforce, the tables were turned, and the Confederates were driven from the field. The total Union loss was 13,000 ; the Confederate, 11,000 .

Halleck, taking immediate command, moved southward, and captured the town of Corinth, Mississippi (May 30), which commanded the railroads east from Memphis. The river fleet pushed down immediately and took Memphis, and the Union troops controlled the Mississippi River, south to the strongly fortified town of Vicksburg.

The career of victory was interrupted by a Confederate invasion of Kentucky. Under General Bragg, successor to Beauregard, 35,000 men advanced to Chattanooga (July 31) and then started straight for Louisville, which they almost reached before General Buell could occupy the city. The Union army struck Bragg at Perryville (October 8), and after a hot fight he withdrew to Chattanooga (p. 434). Buell was removed from command, and General Rosecrans was appointed in his place (October 24, 1862). Rosecrans attacked Bragg in the bloody 
battle of Stone River or Murfreesboro (December 31, January 2), and compelled him to retire. At the other end of the western line, during November and December, Grant and Sherman pushed southward down the Mississippi, alongside a fleet of gunboats commanded by Porter; but failed to take Vicksburg.

Meanwhile, in the spring of 1862, Flag-Officer David G. Farragut was sent out with a fleet to force the lower Missis-

384. Farragut and New Orleans (1862)

sippi. Farragut was born in Tennessee in 1801, of Scotch descent, and entered the navy when ten years old, and served as a midshipman in the War of 1812. Though he lived in Norfolk, Virginia, he stood by the old flag in 1861. The fleet with which he began to operate against New Orleans was made up of six steam frigates and forty-two smaller

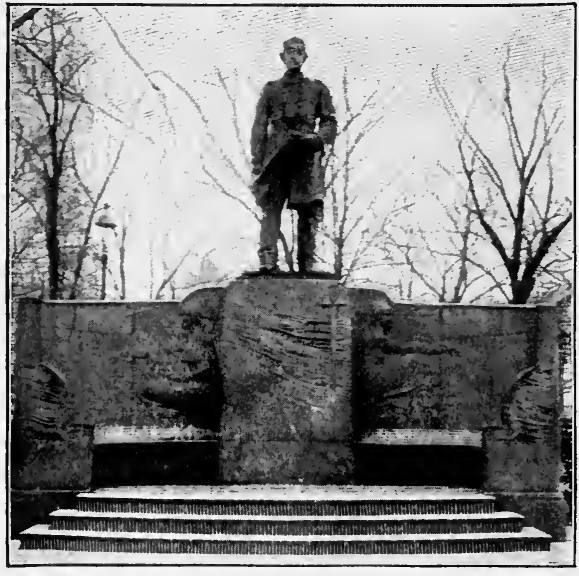

David G. Farragut.

Statue by St. Gaudens, in New York. vessels. Some time after entering the mouth of the Mississippi, he notified the fleet that as flag officer he would speedily make the signal for close action and abide the result, "conquer or be conquered." April 24, 1862, he boldly led his fleet up the river, which was defended by Forts Jackson and St. Philip, a strong boom, and some Confederate vessels; a fireship came down on his flagship Hartford, but the men of one battery kept up the fight, while the other half put out the fire. At the end of the fight the boom was destroyed, his vessels were beyond the forts, and there was nothing to stop the fleet, which shortly 
anchored in front of the city of New Orleans; and the forts soon surrendered. A large force of Union troops soon after took possession of New Orleans, under command of General Butler, who for a year ruled the city like a conquered province.

By March, 1862, the Army of the Potomac, stationed in the forts around Washington, had grown to 185,000 men, eager to show their quality and to move "on to Richmond." After many conferences and disagreements, McClellan decided 385. Merrito march up the peninsula between the James and York rivers, where his flank could be protected by the fleet mac and Monitor (1862) at Hampton Roads. It was known that the Confederates at Norfolk were rebuilding the former United States frigate Merrimac into a powerful ironclad; and to meet this danger

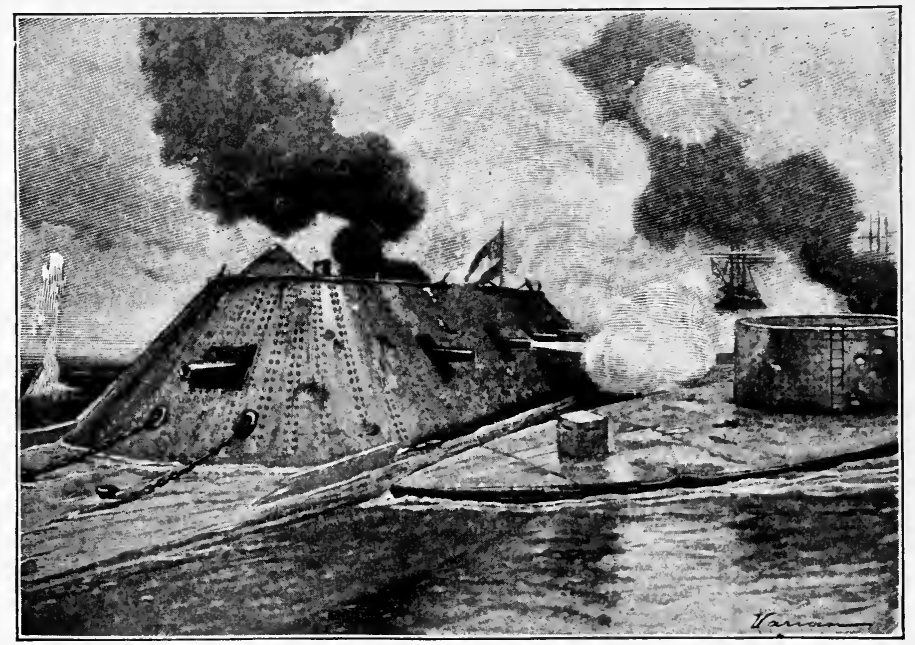

MERRIMAC AND MoNITOR, 1862.

John Ericsson, an inventor in New York, had prepared plans for an armored craft of totally different design, a little "cheesebox on a raft," with a revolving turret carrying two heavy guns, mounted on a deck almost flush with the water. This 
ship, named the Monitor, was built in one hundred days, and sent down from New York.

The Merrimac, which the Confederates had renamed the Virginia, unexpectedly came out March 8, 1862. She steamed slowly but steadily to the Union fleet in Hampton Roads, and attacked and destroyed the wooden sloop of war Cumberland and the frigate Congress. Next morning the Merrimac appeared again, but found, in front of the rest of her prey, the little Monitor; arrived during the night; and for five hours the two ships pounded each other. Neither could destroy her adversary, but the Merrimac finally retired, and one of the greatest dangers of the whole war was safely passed, for not another vessel in the world could have stopped the Confederate ship. She never made another attack, and in May, when Norfolk was captured, she was scuttled and burned by her own crew.

In April, 1862, McClellan was at last ready to attack, but, to his deep disappointment, the President detached General

386. The

Peninsular Campaign (April-July, 1862)

McDowell with 40,000 troops to cover Washington.

McClellan's army slowly made its way up the peninsula, spent about a month in the scientific siege of Yorktown, - a weak place, defended in part with "Quaker guns," made of painted logs of wood; fought a battle at Williamsburg; and then moved steadily forward to the neighborhood of Richmond. The official returns later showed that McClellan had about 115,000 present for duty against about 90,000 in the Confederate army, which was commanded by General Joseph E. Johnston.

In front of Richmond was the Chickahominy River, with broad, swampy bottoms. Through and around this barrier McClellan advanced till May 31, when he was checked at the battles of Seven Pines and Fair Oaks, only seven miles from Richmond. Johnston was wounded, and next day Robert F. Lee took command of the Confederate Army of Northern Vir- 
ginia. Meanwhile, McDowell had been ordered to join McClellan on the north ; but Stonewall Jackson, in a brilliant campaign in the Shenandoah valley, threatened Washington, and Lincoln a second time withheld McDowell's corps. Jackson thereupon suddenly joined Lee; so that instead of forcing the fight,

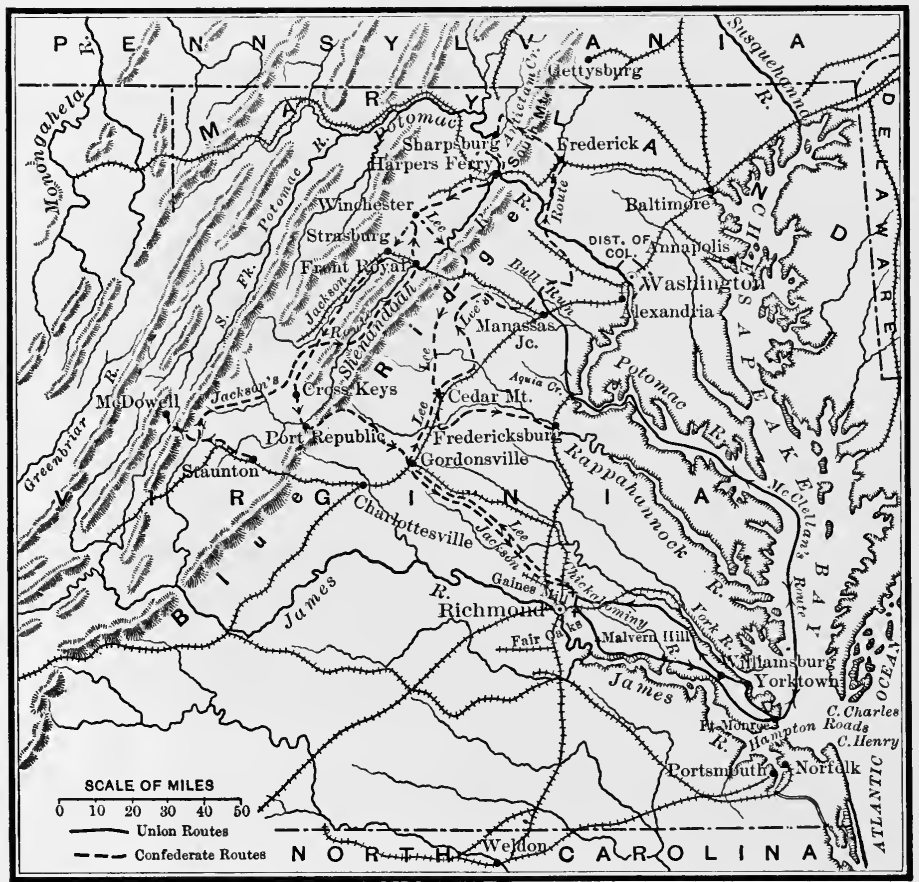

Virginia Campaigns of 1861-1862.

McClellan found himself attacked. Then followed the terrible "seven days' fighting," in which McClellan was forced to give way and retreat to the James River (June 26 to July 1), ending at Malvern Hill. This so-called "change of base" was a confession of defeat.

In thirty-one days McClellan had lost over 21,000 men and the enemy about 27,000 ; but they had saved their capital and 
the Confederacy for the time. In the sting of defeat McClellan telegraphed to Secretary Stanton: "I have lost this battle McClellan's because my force was too small.... If I save this army Own Story, now, I tell you plainly that I owe no thanks to you
June 24

or to any other persons in Washington. You have done your best to sacrifice this army." McClellan was a brave man and a natural leader, always heartily trusted and loyally obeyed by his subordinates, and he knew how to handle troops; but he was misled by his secret-service agents, who reported that the Confederate army was much larger than his own, he was never willing to attack unless he was sure that he would win, and he was exceedingly unjust to Stanton and Lincoln.

Undismayed by the fearful losses of the Peninsular Campaign, the President in July, 1862, called for 300,000 more 387. Bull men; and 420,000 soon responded. McClellan was Fun to ${ }_{\text {Fredericks- }}$ eager to advance again on Richmond, but he had lost burg (Aug.- the confidence of the administration; and General HalDec., 1862) leck was summoned to Washington (July 11) to be confidential military adviser to the President, under the title of general in chief.

General Pope, a western officer, received command of the new Army of Virginia, to which was gradually added most of the old Army of the Potomac, now withdrawn from the James. He was little known to his subordinates, few of whom liked or trusted him. Pope operated in the desolate and swampy country about fifty miles southwest of Washington, till outmarched and attacked by Stonewall Jackson's "foot cavalry." This led to a three days' contest near the old battlefield of Bull Run (August 28-30, 1862), and Pope was so badly defeated that the army was withdrawn to the neighborhood of Washington.

For the first time there was a chance to carry the war into the North. Lee's army crossed the Potomac and took Har- 
pers Ferry, with a garrison of 12,500 men (September 15). McClellan was again put in active command after the second Bull Run, and attacked Lee on the Antietam (near Sharpsburg) just north of the Potomac (September 17). This was the best opportunity in the whole war to end the contest by destroying Lee's army; but after a federal loss of over 12,000, and a Confederate loss of 14,000, Lee's army was allowed to withdraw across the Potomac intact.

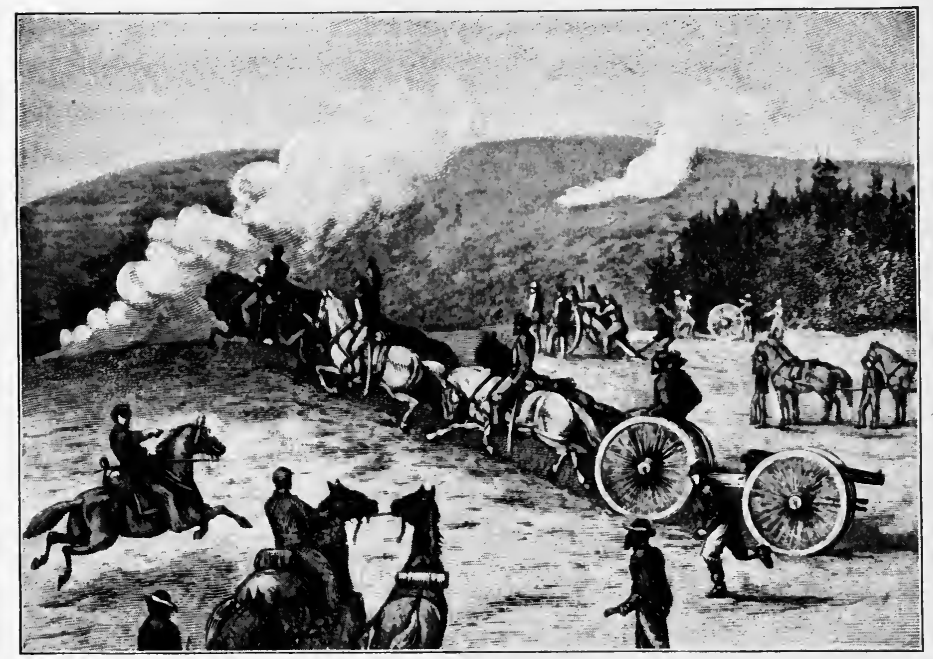

Field Gun going into Action.

From a war-time lithograph by Forbes.

A few weeks later (November 5, 1862) McClellan was removed, and General Burnside was appointed to succeed him. Burnside marched to the Rappahannock River, beyond which Lee with 80,000 men intrenched himself. On December 13, 1862 , the federal army of 113,000 men attacked in front near Fredericksburg and was defeated in one of the bloodiest battles of the war, with a loss of 11,000 killed and wounded, and without the slightest military advantage. 
At the end of 1862 the war had practically lasted a year and a half. In the East four successive attacks by large armies 388. Sum- failed: the first battle of Bull Run under McDowell; the mary

Peninsular Campaign; Pope's campaign; and the Fredericksburg fight. In spite of heavy losses and heroic fighting, the Army of the Potomac could not cross the 120 miles between Richmond and Washington. On the other hand, Lee could not invade the North beyond a few miles in Maryland, or capture Washington; and the Army of the Potomac was still intact and impatient for a new trial.

In the West the army pushed steadily southward, took Fort Henry, Fort Donelson, Island No. 10, Nashville, and Corinth, and was pushing down the Mississippi River. Bragg's Kentucky campaign was checked at Perryville. The western army was full of confidence, and began to know and appreciate its commanders, especially Grant, Sherman, Thomas, and Rosecrans, who, at the end of the year, began an advance against Bragg; the battle on the Stone River was the first step toward seizing the highway through Chattanooga to Atlanta.

At sea the blockade grew more and more effective, and several points on the Atlantic coast were taken. The capture of New Orleans was a great blow to the prestige of the South, and took away the control of the Mississippi River. After the success of the Monitor, other ships of the same type were speedily built, so that there was no longer danger from Confederate vessels of war.

\section{TOPICS}

Suggestive topics
(1) Was the war brought on chiefly over the question of state rights? (2) How could the South furnish 1,230,000 soldiers out of a white population of $5,300,000$ ? (3) Why were civilians appointed as generals in the northern army? (4) Was the British proclamation of neutrality unfriendly? (5) Was Captain Wilkes justified in seizing Mason and Slidell ? (6) Why were Mason and Slidell given up? (7) Where did the government borrow such 
immense sums? (8) Was it necessary to make the paper notes legal tender? (9) Why was Fort Donelson so quickly taken? (10) Why did McClellan choose the peninsular route to Richmond? (11) Why did the Monitor beat the Merrimac? (12) How did Farragut force the forts on the Mississippi River? (13) How did Bragg get so far north in Kentucky?

(14) Exchange of prisoners during the Civil War. (15) Destruction of the navy yard at Norfolk in 1861. (16) The southern mountains and mountaineers in the war. (17) Methods of raising troops in the North. (18) Methods of raising troops in the South. (19) Adventures of blockade runners. (20) Life in the blockading squadron. (21) The cruise of the Alabama. (22) The cruise of the Shenandoah. (23) Jefferson Davis as president of the Confederacy. (24) The income tax during the Civil War. (25) The military career of Stonewall Jackson. (26) McClellan as the organizer of the Army of the Potomac. (27) Butler's administration of New Orleans. (28) The withdrawal of McDowell's corps from McClellan's army. (29) Military services of a northern general, as, for example, Thomas, Sheridan, Rosecrans, Grant, Sherman, etc. (30) Services of a southern general, as Beauregard, A. S. Johnson, J. E. Johnston, Bragg, Lee, T. J. Jackson, etc. (31) Military services of a naval officer, as David D. Porter, Farragut, etc. (32) Controversy about Fitz-John Porter, August, 1862.

\section{REFERENCES}

See map, pp. 434, 435; special maps in Dodge, Ropes, Rhodes, Battles and Leaders; atlas of the Official Records of the Rebellion; Semple, Geographic Conditions, 280-308; Brigham, Geographic Influences, 200-229; Hosmer, Appeal to Arms.

Dodge, Civil War, 8-94, 102-126 ; Hosmer, Appeal to Arms; Ropes, Civil War, I. 98-274, II. ; Schouler, United States, VI. 50authorities 214, 232-260, 282-287, 290-316 ; Rhodes, United States, III. 415-630, IV. 1-57, 95-157, 173-199, 237-239, 427, 428; Wilson, American People, IV. 208-229, 237-240, 265-312 ; Cambridge Modern History, VII. 450-484, 491-501, 549-575, 603-621; Dewey, Financial History, §§ 117-140 ; Taussig, Tariff History, 155-170 ; Foster, Century of Diplomacy, 357-380 ; Nicolay, Outbreak of Rebellion, 82-221; Fiske, Mississippi Valley in the Civil War, 1-178; Maclay, United States Navy, II. 159-364, 508-548; Webb, The Peninsula; Ropes, Army under Pope; Palfrey, Antietam and Fredericksburg; Force, Fort Henry to Corinth; Cist, Army of the Cumberland, 1-135; Soley, Blockade and the Cruisers; Ammen, Atlantic Coast, 1-73, 
163-199 ; Mahan, Gulf and Inland Waters, 1-109; Morse, Abraham Lincoln, I. 273-387, II. 31-94, 134-139, 170, 171 ; Bancroft, W. H. Seward, II. 163-253 ; Hart, S. P. Chase, 211-252, 274-289; Adams, C. F. Adams, 147-239 ; Michie, General McClellan, 69442, 459-475 ; Wilson, General Grant, 74-159, 380-339; Lee, General Lee, 99-239) ; Hughes, General Johnston, 36-156 ; Hovey, Stonewall Jackson, 1-107.

Sources Hart, Source Book, §§ 116-119, - Contemporaries, IV. §§ 75, 80, 84-95, 98, 99, 102-116, - Source Readers, IV. \$§ 30-42, 49-71, 74-80, 90-109 ; MacDonald, Select Statutes, nos. 2-16, 19, 21-27, 30, 37 ; American History Leaflets, nos. 18, 26 ; Riddle, Recollections, 28-128, 168-198; Grant, Personal Memoirs, I. 229-421 ; Century Company, Battles and Leaders, I. 99-750, II. III. 1-147 ; American Annual Cyclopedia, 1861, 1862 ; Hosmer, Color Guard, - Thinking Bayonet; Goss, Recollections of a Private ; Higginson, Army Life in a Black Regiment; W. T. Sherman, Memoirs; South and West ; Manassas to Appomattox; E. Eggleston, Rebel's Recollections; Jones, Rebel War Clerk's Diary. See N. Eng. Hist. Teachers' Ass'n, Syllabus, 354-356, - Historical Sources, §88.

Illustrative

Matthews, Poems of American Patriotism, 127-214; Moore, works Lyrics of Loyalty, - Rehel Rhymes; Eggleston, American War Ballads, I. 167-226, II. 3-105 ; Lowell, Biglow Papers (second series), -Washers of the Shroud; C. F. Browne, Artemus Ward: His Book,-Artemus Ward: His Travels; R. H. Newell, Orpheus C. Kerr Papers ; R. G. White, New Gospel of Peace; J. T. Trowbridge, Drummer Boy,-Cudjo's Cave; B. K. Benson, Who Goes There? Charles Morris, Historical Tales, 270-291.

Pictures

Century Company, Battles and Leaders; Harper's Pictorial History of the Rebellion; Edwin Forbes, Artist's Story of the Great War; E. R. Johnson, Campfire and Battlefield; Harper's Weekly; Frank Leslie's Weekly. 


\section{CHAPTER XXIX.}

\section{EMANCIPATION AND MILITARY ADVANCE (1862-1863)}

As the war went on, it became evident that its purpose could not be linited, as proposed by the resolution of July, 1861, to restoring the Union as it was; for slavery could not be 389. The kept out of the contest. A recognized measure of war against a slaveholding country is for the invading com- (1861-1862) mander to declare the slaves of his enemy free; and Congress made an indirect use of this power in August, 1861, through a confiscation act providing that if slaves were used in promoting any insurrection, "the owners should 'forfeit' claim to such labor."

As soon as the armies began to move, hundreds of negroes took matters into their own hands by running away and

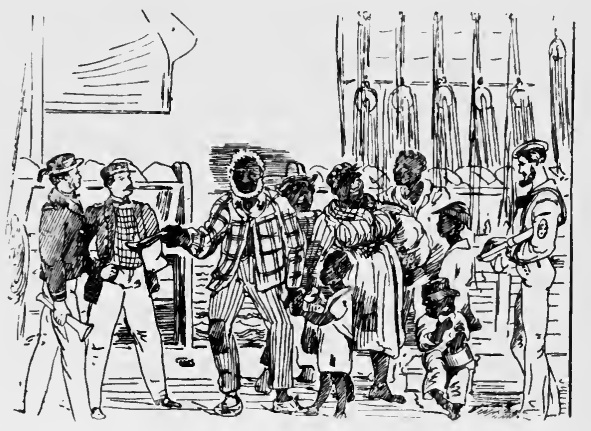

Arrival of Contrabands, 1862.

From war-time sketches. coming into the federal camps. General Benjamin F. Butler, in command at Fort Monroe, found more than a thousand-such refugees. When he was asked to surrender some fugitives to their masters, who came from within the Confederate lines to claim them, he replied, "I shall detain the negroes as contraband of war." The phrase struck the popular fancy, and from 
that time to the end of the war, "contraband" meant a southern slave, usually a refugee. Two Union generals tried to go farther. General Frémont (August, 1861) and General Hunter (May, 1862) issued proclamations freeing the slaves in their military districts, and even beyond; but President Lincoln disavowed both the proclamations, because slavery was too large a question to be settled by subordinates.

On slavery Congress at first outran the President, and in 1862 passed three sweeping emancipation acts :-

390. Emancipation by Congress (1862-1864)

(1) The 3000 slaves in the District of Columbia were set free (April 16, 1862), and their masters were given a 64) compensation of about $\$ 300$ for each one.

(2) In flat contradiction to the Dred Scott decision of 1857 , Congress passed a statute (June 19,1862) immediately abolishing slavery in every territory, without compensation.

(3) A strong feeling of personal wrath against the leaders on the other side caused Congress to provide, in a second confiscation act (July 17, 1862), for the seizure of all the property of people convicted of treason, or who "engaged in armed rebellion," including such slaves of rebel owners as might in any manner come inside the Union lines. Though Lincoln thought it "startling to say that Congress can free a slave within a State," he signed the bill; and as fast as the federal lines extended, thousands of slaves flocked to the federal camps, and thus became free.

By this time it became necessary to prove to foreign nations that the North was making war in behalf of freedom, and not 391. Danger simply for the sake of ruling the South, for the blockade of foreign cut off the raw material for the foreign cotton manuintervention (1862-1863) men were thrown out of work. Napoleon III., emperor of the French, was trying to conquer Mexico and had no liking for the North; and the ruling aristocracy of England made no secret of its hope that the South would succeed. That brilliant 
young statesman, William E. Gladstone, publicly said, "Jefferson Davis and other leaders of the South have made an army; they are making, it appears, a navy; and they have made, which is more important than either . . . a nation."

Rhodes,

United

States,

IV. 339

Southern agents in Europe strove hard to persuade foreign powers to recognize the independence of the South. After the defeats of McClellan and Pope in 1862, Lord Palmerston, the British prime minister, was on the point of offering a "mediation," which would have been partial recognition; but there was a strong Union sentiment in England, especially among the workmen in the cotton mills, who felt that the rights of free labor were involved, and they were represented in Parliament by the orator John Bright. The defeat of the ironclad Merrimac, the battle of Antietam, and still more the successes in the West during 1862, took away the pretexts for immediate recognition.

The man for this crisis was Abraham Lincoln, the one indispensable figure in the Civil War. 'Two characteristics made him the greatest man of his time: his practical common sense went straight home to the essential point in everything that he was considering; and a quick sensitive 392. Abraham Lincoln, President heart knew by instinct the beliefs and hopes of his fellowcountrymen. Toward the weak and needy, Lincoln had a tender feeling. He could not even bear to sign the death warrant of a deserter, for, he said, "I am trying to evade the butchering business." Thə same sympathy and sweetness of character were shown in a thousand ways to the people who beset the White House with their little personal errands the poor woman whose only son was sick in the hospital, or the boy who wanted a commission, or the stranger who came in from mere curiosity.

Although Lincoln always distrusted his own military judgment, he learned to understand the conditions of war better than most of his commanders; and his writings are full of 
quaint telegrams to his generals; for example: "Fight him, Lincoln, too, when opportunity offers. If he stays where he is, Works, II. fret him and fret him." On another side of his character, 345

Lincoln was the shrewdest politician of his time; he was very keen in judging election returns; he knew how to keep congressmen good-natured with offices. Yet he had unyielding tenacity when necessary. To General Grant he once telegraphed: "I have seen your dispatch expressing your unwillingness to break your hold where you are. Neither am I willing. Hold on with a bulldog grip, and chew and choke as much as possible."

During the first three years of the war, Lincoln was criticised or even deserted by many members of his own party, who thought him weak and indecisive because he held a temperate middle course, avoiding extremes. Only by degrees did people begin to understand that this plain, homely man in the White House had a spirit of surpassing wisdom, and an unselfish care for his country's welfare. Patient in defeat, calm in victory, Abraham Lincoln came to be recognized as a true father of his country.

Throughout 1862 President Lincoln was brooding over the question of his duty to his country, and his power as con393. Pre- stitutional commander in chief to declare free all the liminaries slaves in the Confederacy. Lincoln was born in a

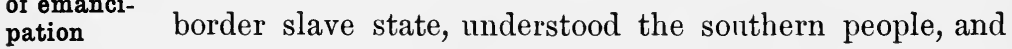
(1862) was anxious not to take any step which would drive Kentucky and Missouri out of the Union. Therefore, he sent to Congress a message (March, 1862) urging that the federal government coöperate with the states in setting the slaves free, with a money payment to the masters.

Lincoln said of himself: "I am naturally antislavery. If Morse, slavery is not wrong, nothing is wrong"; and at anLincoln, 105 other time, "You must not expect me to give up this government without playing my last card." In August, 1862, 
Horace Greeley came out in the Tribune with what he called the "Prayer of Twenty Millions," violently abusing the President for his "mistaken deference to rebel slavery." The President replied in a public letter, "My paramount object ... is to save the Union, it is not either to save or to destroy slavery."

At last Lincoln made up his mind that the best way to save the Union was to free the slaves. Calling his Cabinet together September 22, 1862, he read them the draft of a pre- 394. Procliminary Proclamation of Emancipation, which declared that "On the first day of January, in the year of our Lord one thousand eight hundred and sixty-three, all persons held as slaves within any State or designated part of a State, the people whereof shall then be in rebellion against the United States, shall be then, thenceforward, and forever free." As a military measure the proclamation had no immediate effect; it roused only defiance in the South and was at first coldly received in the North. In the elections of congressmen a few weeks later, the Republican party barely retained a majority of the House of Representatives. Nevertheless, on January 1, 1863, the President issued his second and final proclamation, which applied to all the seceded states except Tennessee and those parts of Louisiana and Virginia occupied by federal troops.

Then Lincoln set himself to the task of persuading the border-state members to free their slaves and take a compensation. They might have had about a hundred million dollars, but they refused to admit that slavery was wrong, even by giving it up. In all the border states thousands of slaves ran away. By act of Congress (in 1862) the troops were forbidden to return them; and in 1864 Congress repealed the Fugitive Slave Act. After that time the slave who stayed with his master in the border states did so only because he liked him.

The good effects of the proclamation were at once seen abroad, where the friends of the Union in England in 1863 
prevented a last effort to have Great Britain and France 395. Effects "mediate" in the struggle. When two ironclad ships of of emanci- war, the "Laird rams," were ordered for the Confederacy
pation (1863-1865) in England, our minister, Adams, protested, and used Diplomatic the grim phrase, "It would be superfluous in me to point Correspond- out to your Lordship that this is war." The British
ence, 1863, p. 367

government had already decided to hold the vessels, and they were never delivered to the Confederacy.

Three of the loyal border states, which were practically under military rule, settled the slavery question for themselves: (1) the new state of West Virginia ( $\$ 401$ ) in 1862 adopted an antislavery constitution; (2) a constitutional ordinance in Missouri provided for gradual emancipation (July 1, 1862); (3) a new Maryland constitution abolished slavery outright (October 13, 1861). Lincoln tried to help the process by finding some place in Central America where the former slaves could be colonized; but that remedy proved to be impracticable.

Both the confiscation act of 1862 and the final Emancipation Proclamation authorized the enlistment of negro troops. The first full negro regiment in service was the First South Carolina Volunteers, commanded by Colonel T. W. Higginson, a New England abolitionist. In the summer of 1863 the government ordered a draft, and states began to fill up their quotas by recruiting negroes in the federal camps on the coast. One of these regiments, the Fifty-fourth Massachusetts, took part in a bloody assault on Battery Wagner near Charleston (July 18, 1863). Its colonel, Robert G. Shaw, was killed; and the enemy "buried him with his niggers." The 179,000 negro troops eventually received the pay and treatment of white troops.

The year 1863 began with 918,000 men under arms on the

396. The Union side and 466,000 on the southern. The campaign Mississippi opened in the West, where General Grant tried to get River campaign (1863) beyond Vicksburg by digging a canal across the narrow neck of a great bend in the Mississippi River. This 
plan failed; but Grant tried various schemes of opening a communication, through shallow bayous, which would avoid Vicksburg. Finally he determined to march seventy miles through the back country on the west side of the river, and then to recross and strike Vicksburg from the east.

The first heavy fighting in this campaign was the capture of Port Gibson by McClernand (May 1, 1863), and the consequent fall of Grand Gulf, south of Vicksburg. Grant's next step was, with three days' rations, to leave the base at Grand Gulf and push northeast, living mainly on the country. He skillfully maneuvered against

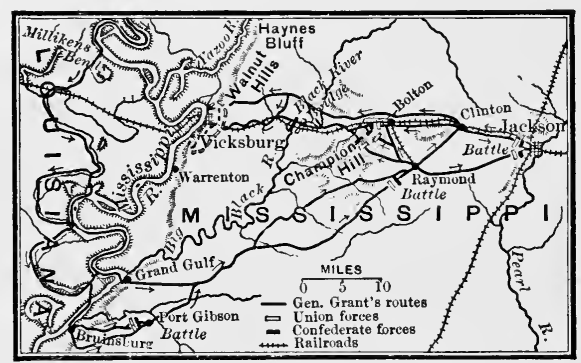

Vicksburg Campaign, 1863. Joseph E. Johnston on the east, defeated Pemberton at Champion Hill, and drove him back into Vicksburg. He then closed in along with Sherman, in command of the right of the army, who had accompanied Grant through the campaign, and thus by boxing the compass south, east, north, and west again, Grant cut Vicksburg off from all help.

After two attempts to take the place by assault, Grant regularly invested the city and bombarded it. As the seven weeks of siege progressed, people came down to pea meal mixed with corn meal, of which they made a sort of bread. The streets were full of débris, wounded men, and houseless people. The inhabitants moved to caves in the bluffs, dug out bomb-proofs, and lived there day and night. July 4, 1863, Vicksburg surrendered unconditionally with $29,000 \mathrm{men}$, the largest number of prisoners taken by either side during the entire war. General Banks, who had mean while pushed north from New Orleans, now took Port Hudson with its garrison 
of 6000 men (July 9). A week later a freight steamer from St. Louis arrived in New Orleans, and President Lincoln said, "The Father of Waters again goes unvexed to the sea."

The Army of the Potomac fought as bravely as the western armies, but it was glad to hold its own territory, and

397. The Gettysburg campaign (1863)

a second time to drive an invading enemy back from northern soil. General Joseph Hooker, a gallant officer, was put in command (January 25, 1863), and assembled his army at Chancellorsville, where it was confronted by Lee's army and suddenly attacked by Stonewall Jackson (May 2), and thrown back in confusion with great loss; but Jackson was accidentally shot by his own men - a terrible blow to the South. After five days' hard fighting, Hooker turned northward, having lost 17,000 men out of 97,000 .

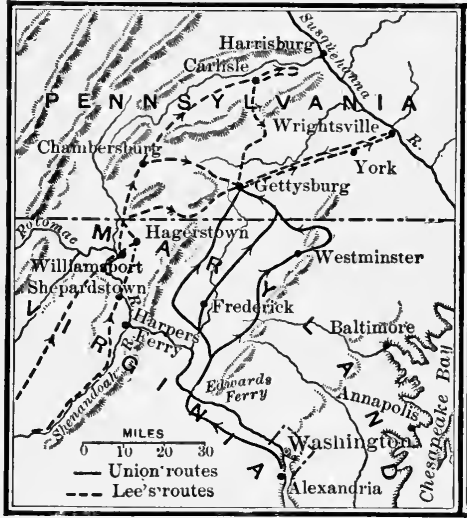

Gettysburg Campaign.

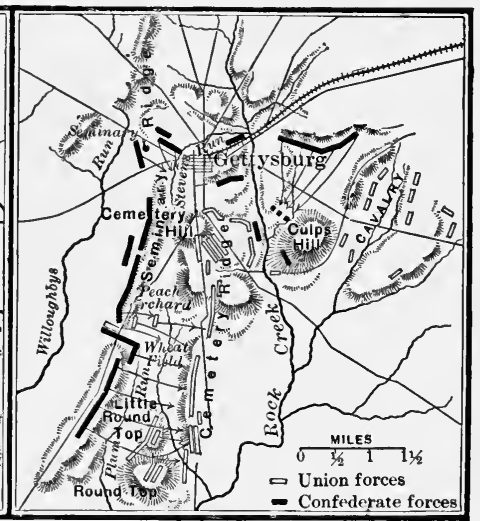

Battle of Gettysburg.

The check gave Lee his greatest opportunity during the whole war. He moved northward, crossed the Potomac, and reached southeastern Pennsylvania. At this critical moment Hooker asked to be relieved because of friction with Halleck, and was replaced by General Meade. The two armies came together near Gettysburg (July 1), and the next day the south- 
ern troops again attacked. July 3, 1863, came the "third day at Gettysburg," the greatest battle of the Civil War.

The Union army was fortified on a crescent-shaped range of hills, ending with the strong position of Round Top, and the whole defended by 80 guns. At one o'clock the Confederates opened against the ridge with 115 guns, and at the end of two hours of artillery fire, a division of 15,000 men, under command of Pickett, burst into the open and came surging up the slope into the Union lines on Cemetery Ridge.

It was the most critical moment of the war. A few of the assailants got over the breastworks; and could they have held their ground, the Union army must have broken in disorder, and Philadelphia, Baltimore, or Washington might have been the prize of Lee's army. But the Union lines held steady, the remnants of Pickett's division fell back, and Lee was defeated.

Of the 88,000 Union troops engaged, more than one man in four went down, killed or wounded. The Confederate army of 75,000 men lost 23,000, or almost a third of its number. On the night of the next day Lee slowly retreated, and the Union army let him cross the Potomac; but it was the last chance to invade the North in large force.

Two more terrible battles were fought in the West before the year 1863 ended. To Rosecrans, with the Army of the Cumberland, was assigned the task of advancing from Murfreesboro and maneuvering against Bragg, who was forced back first from Tullahoma and then into the strong position of Chattanooga; while Burnside moved up from

398. Chickamauga and George H. Thomas (1863) Kentucky to Knoxville, to give support to the large population of Union men in East Tennessee.

After crossing several ranges of mountains, Rosecrans took Chattanooga and came out on Chickamanga Creek, not far south of the city. Bragg was reënforced by Longstreet with 12,000 men from Lee's army, and attacked Rosecrans on the Chicka- 
mauga (September 19, 1863) with a heavy force. The next "day the attack was renewed, and the federal line broken, the right wing and part of the center being driven from the field; but General Thomas, in command of the left wing, stood his ground, and drew off the field at night in good order. Two days later the whole army returned to Chattanooga.

No soldier on either side was more passionately admired than General George H. Thomas. After graduation at West

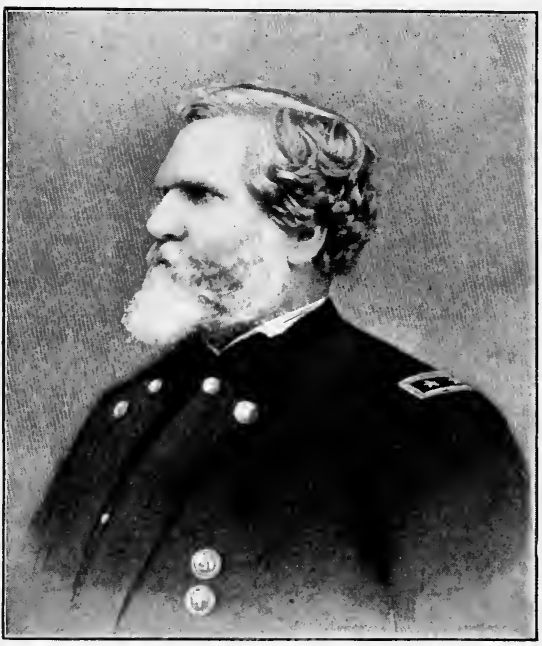

George H. Thomas, in 1864.

Point in 1840, he served in the Mexican War. In his first little fight in the Civil War he opposed Stonewall Jackson. He was sent to Kentucky, beat Zollicoffer in 1861, and served as an excellent subordinate to Buell and Rosecrans, Thomas was a quiet, reserved man, shy and proud; but he had a wonderful gift of inspiring his men with confidence and devotion, and he was commonly called "Pap Thomas" by his troops. Thomas's great national reputation was gained at Chickamauga. When Rosecrans hastened to Chattanooga, expecting his defeated army to pour in there, General Garfield asked leave to return to the field, and he said, "I shall never forget my amazement and admiration when I beheld that grand officer holding his own with utter defeat on each side, and such wild disorder in his rear." From that unflinching courage Thomas got the name which he carried the rest of his life, 
" the Rock of Chickamauga." Throughout the rest of the war after Chattanooga he accepted the position of lieutenant, confidant, and friend of General Sherman.

After Chickamauga, Rosecrans found the tables turned, for he was penned up in Chattanooga by Bragg, who occupied the neighboring heights of Missionary Ridge and Lookout Mountain. River communication by the Tennessee was closed by the enemy, though a difficult land route was 399. Fighting around Chattanooga (1863) kept open, and soon the army was almost starving. As Rosecrans seemed slow in helping himself, he was superseded by Thomas, and Grant was placed in command of the combined forces of Sherman and Thomas, and at once began to extricate the army. As a preliminary the enemy's post at Browns Ferry on the river was captured (October 27), so that steamers could come up, and the army was fed.

An additional force under Sherman was brought up, and Grant now turned to attack the enemy. In three successive days

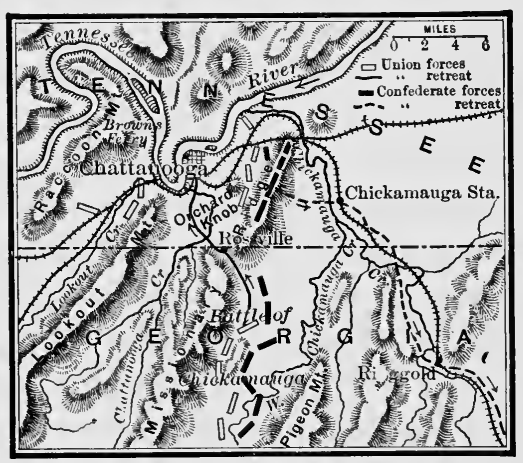

Chattanooga Campaign. (November 23 to 25,1863 ) the Confederate army was driven out of its strong position on the mountains above Chattanooga. First, Thomas took the works at the foot of Missionary Ridge. Next day Sherman attacked the north end of Missionary Ridge, and took position on the enemy's flank; and in the dramatic but not critical "Battle above the Clouds," Hooker drove Bragg's troops off Lookout Mountain. On the third day Thomas's army attacked Missionary Ridge, and without orders the troops climbed steadily up the hill, and in an hour cleared that mountain of enemies. There is no more stirring 
incident in the annals of war than the lines of bluecoats, in sight of thousands of their fellows, dashing up the slope, capturing batteries, guns, and men, and raising the stars and stripes on the summit. Bragg retreated in great confusion; and an expedition was immediately sent up the valley of the Tennessee to relieve Burnside, who was besieged in Knoxville.

The superior numbers of the Union forces enabled them to attack the South

400. Minor operations (1863)

in many detached movements.

After the Vicksburg campaign a Union army occupied central Arkansas. In the Shenandoah valley there was little fighting in 1863. A fleet of monitors and other ships made desperate attempts to take Charleston, but though Fort Sumter was reduced to a heap of ruins, it could not be captured; and the city was bombarded only by distant batteries. On the other side the cavalry of Stuart and Mosby in Virginia, and Forrest in the West, excelled in rapid forays, which cut the Union communications, destroyed supplies, and created alarm. Another dashing cavalryman was John Morgan, who crossed the Ohio River in July, 1863, and for about a month
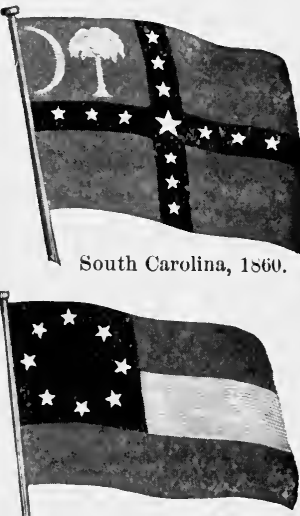

"Stars and Bars," 1861.
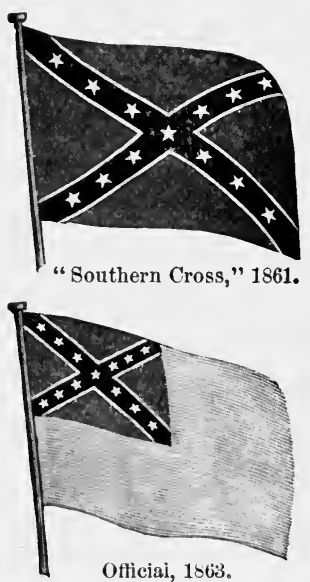

Confederate Flags. ranged through the rich country of southern Ohio. The Ohio militia, the so-called "Squirrel hunters," were called out; and Morgan was eventually cornered and captured.

Two years and a half of war showed the difficulty of proving 
that the seceding states were still in the Union. The forty mountain counties of western Virginia settled the problem for themselves by refusing to secede with Virginia. They held a constitutional convention, organized as the state of West Virginia, and (1861) asked to be admitted into the Union. As the Constitution provides that no state shall be divided "without the consent of the Legislatures 401. Beginnings of reconstruction of the South (1862-1863) of the states concerned," Congress accepted the fiction that the loyal legislature at Wheeling represented the whole state of Virginia; and in June, 1863, West Virginia became a separate state.

In 1861 to 1863 , under the direct and earnest insistence of President Lincoln, so-called state governments were formed in Virginia, Arkansas, Louisiana, and Tennessee; governors were elected by a handful of voters, legislatures were chosen, senators and members of the House appeared in Washington, and several were actually admitted to Congress, though at the same time these states were represented in the Confederate Congress at Richmond. By a formal proclamation (December 8, 1863) Lincoln offered to all persons who had "participated in the existing rebellion," except the leaders, pardon and Lincoln, Works, II. 344 amnesty "with restoration of all rights and property, except as to slaves"; and he promised to recognize new state governments in any of the seceded states, if formed by one tenth or more of the voters, provided they would take an oath of allegiance to the United States.

The most dramatic episode of this year was the Emancipation Proclamation, which was preceded by acts of Congress prohibiting slavery in the District of Columbia, and in the territories, and freeing refugee slaves belonging to " rebels

402. summary in arms." The proclamation did no immediate harm to the slaveholders, but the knowledge of it spread among the slaves; and wherever Union armies moved, great numbers of slaves 
left their plantations and never went back. In the border states, too, slavery was disturbed, and thousands of negroes ran away. By the end of 1863 it was plain that if the North won, nothing could save slavery, in either the seceding or the border states.

During 1863 military success turned to the side of the Union. In the East the Union troops lost the battle of Chancellorsville, but won at Gettysburg; and showed that the North could not be successfully invaded. In the West the line of the Mississippi was opened, by the taking of Vicksburg, though beyond that river there was some fighting, and till the end of the war many southern troops still found their way across to the main Confederate army. On the direct line into the South from the Ohio River to Atlanta, the Union troops got as far as Chattanooga, which they took and finally held, after two desperate battles.

\section{TOPICS}

Suggestive topics

Search topics
(1) Frémont's emancipation proclamation, 1861. (2) Hunter's emancipation proclamation, 1862. (3) Why did Emperor Napoleon III. favor the South? (4) Why did the English aristocracy favor the South? (5) What did the northern people think of Lincoln? (6) Why did Horace Greeley criticise the President? (7) Why did the British government hold the Laird rams in 1863 ? (8) Objections to the draft of troops in the North. (9) Surrender of Vicksburg, July, 1863. (10) Why did Congress admit West Virginia? (11) Why did Lincoln offer amnesty in December, 1863?

(12) John Quincy Adams's suggestions of destroying slavery by the war power. (13) Refugees at Fort Monroe. (14) Debate in Congress on emancipation in the District of Columbia, 1862. (15) Instances of the confiscation of the property of rebels. (16) John Bright as a friend of the North. (17) President Lincoln at the White House. (18) President Lincoln's opinions of the generals. (19) What did the southern people think of Lincoln? (20) Some of Lincoln's good stories. (21) Cabinet discussions of the Proclamation of Emancipation. (22) How did the negro troops fight? (23) Grant's plans for capturing Vicksburg. (24) Cave life in Vicksburg. (25) Thomas at the battle of Chickamauga. 
(26) "Jeb" Stuart as a cavalry leader. (27) How did Lee get across the Potomac in 1863? (28) The third day at Gettysburg, July 3, 1863.' (29) 'The battle of Missionary Ridge.

\section{REFERENCES}

As in chapter xxviii.

Dodge, Civil War, 94-101, 127-192 ; Hosmer, Appeal to Arms ; Rhodes, United States, III. 630-637, IV. 57-95, 157-172, 199-223, 256-407 ; Schouler, United States, VI. 214-232, 261-289, 341-400, 424-460; Wilson, American People, IV. 229-253 ; Cambridge Modern History, VII. 484-491, 501-513, 553-560, 580-602 ; Larned, History for Read! Reference, V. 3430, 3453, 3462, 3476, 3480, 3485, 3498 ; McDougall, Fugitive Slaves, §§ 85-105; McCarthy, Lincoln's Plan of Reconstruction; Fiske, Mississippi Valley in the Civil War, 179316 ; Doubleday, Chancellorsville and Gettysburg; Humphreys, From Gettysburg to the Rapidan; Greene, The Mississippi, 55237 ; Cist, Army of the Cumberland, 136-262 ; Mahan, Gulf and Inland Waters, 110-184; Ammen, Atlantic Coast, 74-110 ; Morse, Abraham Lincoln, II. ; Hapgood, Abraham Lincoln, 268-342 ; Ban'croft, W. H. Seward, II. 281-348, 374-399; Adams, C. F. Adams, 240-344; Wilson, General Grant, 160-213, 339-343; Wister, U. S. Grant, 72-98; Pennypacker, General Meade, 109-260 ; Force, General Sherman, 98-186 ; Coppée, General Thomas, 118-198 ; Davies, General Sheridan, 52-88; Walker, General Hancock, 73-157 ; Lee, General Lee, 240-325 ; Hughes, General Johnston, 156-221 ; Soley, Admiral Porter, 234-375.

Hart, Source Book, §§ 120-124, - Contemporaries, IV. §§ 100, 101, 117-131, 145, - Source Readers, IV. \$§ 19-23, 27, 28, 81-87; MacDonald, Select Statutes, nos. 17, 18, 20, 28, 29, 31, 33-36, 38, 42 ; American History Leaflets, no. 26 ; Old South Leaflets, no. 11 ; Hill, Liberty Documents, ch. xxii. ; Caldwell, Survey, 185-189 ; Johnston, American Orations, IV. 82-124; Carpenter, Six Months at the White House ; Dana, Recollections, 16-155, 168-185 ; Riddle, Recollections, 129-163, 199-255 ; Grant, Personal Memoirs, I. 422581, II. 1-123 ; Century Company, Battles and Leaders, III. 148752, IV. 1-96 ; American Annual Cyclopadia, 1862, 1863. See N. Eng. Hist. Teachers' Ass'n, Historical Sources in Schools, $\$ 88$.

Matthews, Poems of American Patriotism, 215-232 ; Eggleston, American War Ballads, II. 109-155; Lowell, Memorice Positum; Whittier, Antislavery Poems, 219-258; G. W. Cable, The Cavalier; J. W. de Forest, Miss Ravenel's Conversion.

As in chapter xxviii.

Geography

Secondary authorities

Sources

Illustrative

works

Pictures 


\section{CHAPTER XXX.}

\section{END OF THE WAR (186t-1865)}

Life was exciting in Civil War times. People opened the morning papers with dread, for after the battles there were 403. How long lists of killed and wounded, which carried woe to the North thousands of families. Then came a flood of wounded lived

and sick pouring back from the front; thousands of them died in the hospitals, other thousands went maimed about the streets.

Northern people were always doing things for the soldiers. In almost every village and city there was a ladies' aid society,

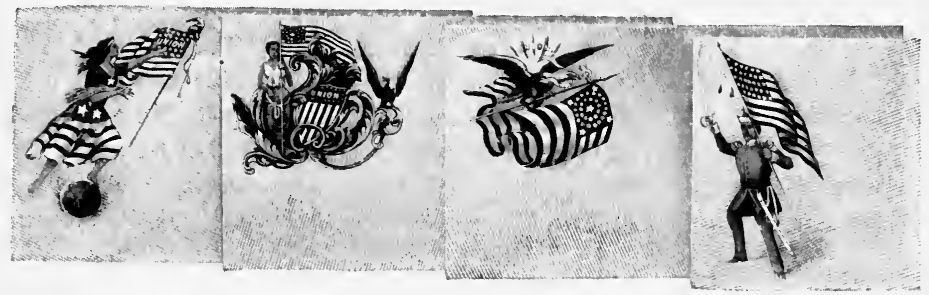

Designs on Envelopes used during the Civil War.

in which the women scraped lint for wounds, made bandages and comfortable clothing, haversacks, mittens, and articles for the sick, and collected provisions, clothing, and blankets for the soldiers. Two large charitable societies, the Sanitary Commission and the Christian Commission, took charge of these supplies, moved them to the front, and distributed them to the needy.

People had to get accustomed to several new kinds of money. After the banks suspended specie payments in December, 
1861, a gold coin was a curiosity; and presently the silver also went out of circulation. For months the only small change was sticky postage stamps, till Congress provided the little "shin plasters," or fractional currency. Early in 1862 appeared the crisp and beautiful new legal tender "greenbacks," and as they came pouring out they began to fall in value; and prices correspondingly rose to double, sometimes to triple, the old rates. Yet business was good in most parts of the country, crops were large, manufactures increased, the railroads were busy, and many business men were happy.

Though the war was fought to vindicate the Constitution, the country was subjected to many unpleasant methods of government, some of them plainly unconstitutional:-

(1) In the territory actually occupied by the army, including the city of Washington, martial law (that is,

404. Military government the will of the commander in chief) was openly declared; it superseded the ordinary law and courts, and civilians could be arrested simply by the order of the military commander.

(2) Under an order of the President (April 27, 1861) the writ of habeas corpus was suspended, so that suspected people could be put in prison without any specific charge or hope of trial. Many thousand people first and last were arrested in this haphazard manner, often without knowing what was the charge against them; and the only way to freedom was through the intervention of some man of influence.

(3) Provost marshals were appointed in all the northern cities, hundreds of miles away from hostilities; and they arrested thousands of people under military law.

(4) In 1864 a military commission tried and condemned to death Dr. Milligan of Indiana for taking part in a traitorous secret society.

(5) In the border states, and even in the North, military officers sometimes shut up churches, dissolved societies, or stopped the publication of newspapers. It is true that the HART'S AMER. HIST. -28 
papers abounded in war gossip, war news, and war stories, and the correspondents often revealed military secrets.

Notwithstanding abundant loyalty and heroism, the war was carried on in the face of strong opposition. The "Peace Demo405. Inter- crats" at the beginning favored letting the South secede, nal opposition to the war and later opposed the war. They accepted the name of "Copperhead," bestowed by their opponents, and wore as badges the heads cut out of copper cents, or butternuts cut in sections - because the butternut was the ordinary dye for the clothing worn by Confederate soldiers; and they created formidable secret societies, called Knights of the Golden Circle, with scores of thousands of members in Ohio and Indiana.

The leader of the Peace Democrats was Clement L. Vallandigham, member of Congress from Ohio, who boasted that he never voted a dollar or a man for the war. In May, 1863, he made a harsh and cutting speech against the system of military law for civilians. For this offense he was convicted by a military court-martial, and sentenced to imprisonment; but Lincoln sent him across the lines into the Confederacy a practical joke which seemed to many people impolitic.

An act of Congress for drawing soldiers by lot from among the able-bodied men led to terrible "draft riots" in New York city (July, 1863). The opposition turned into a savage mob which hunted down and stoned to death dozens of harmless negroes and then white people, and then burned colored orphan asylums. The next step was to attack buildings which represented any kind of government, especially police stations and armories. The police fought splendidly, but were too few to resist such a rising. Federal troops were hastily summoned, and after three days of riot the mob was put down by musket and bayonet. About a thousand people lost their lives as victims of the mob, or by the shots of the defenders of order, and the money damage was many millions.

Behind the Confederate lines life was just as exciting, and 
much less comfortable than in the North. Throughout the South there was the same passionate support of the soldier as in the North, the same fervent prayer to the Almighty to bless their cause. By severe conscription acts every able-bodied man between sixteen and seventy was called

406. How the South lived into the army, so that General Grant said, "They robbed the cradle and the grave." The negroes on the plantations raised the crops and took care of the women and children, and a slave insurrection would have dissolved the Confederate army ; but the negroes never rose.

The war brought dire poverty on the South. The blockade cut down the cotton export from $\$ 191,000,000$ in 1860 to $\$ 19,000,000$ in 1862 . Confederate paper notes were never legal tender, but they were put out by hundreds of millions, and their value fell to a cent and a half on the dollar: corn meal sold in Richmond for $\$ 80$ a bushel in paper; flour at $\$ 1000$ a barrel; a newspaper cost a dollar.

As the war progressed the South could no longer replace its men who fell or were made prisoners; and therefore the North refused to exchange, even though a hundred thousand northern soldiers remained in southern prisons. The commissary of the Confederate army was ill managed; and there were few supplies in the country. Libby Prison for officers in Richmond, and various prisons farther south, were all badly mismanaged. Andersonville was in the hands of a small garrison, officered by men of the overseer type, who were in constant fear lest the prisoners should break loose. Hence, in a country abounding in timber and with plenty of good water, the prisoners were confined in a treeless stockade on a foul stream, and were fearfully overcrowded, with no materials to build proper houses. They had the same kind of food that was provided for the jails and the negro quarters, and often for the Confederate troops at the front, - chiefly corn meal, sometimes ground cob and all. 
In March, 1864, President Lincoln selected the commander who had made the most brilliant record in the West, General 407. Grant's U. S. Grant, and made him lieutenant-general with the Virginia campaign (1864) authority of general in chief of all the armies in the country, and Halleck became practically the President's chief of staff. Grant selected the Army of the Potomac, under direct command of Meade, as his own fighting force, and on May 4, 1864, took the field with 102,000 effective men and 350 guns, against Lee's army of 61,000 men. The next day,

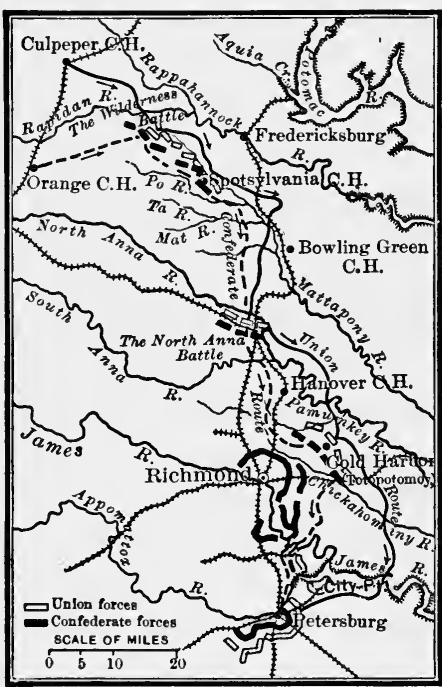

From the WiLderness to Petersburg as he was moving through the wooded region of northern Virginia known as the Wilderness, he was attacked by Lee, and drew out only after three days of blind and confused fighting.

Up to this time the Army of the Potomac had always retreated after such a check, but as brigade after brigade came to a crossroads and was directed to turn southward, the whole length of the column rang with cheers, for the men realized that they were to fight it through. In a series of assaults "all along the line" near Spottsylvania, May 10 to 21, Grant lost16,000 men, killed and wounded, or in sixteen days since May 4 over 30,000; and though he had also inflicted great losses on Lee, he could not break the Confederate lines.

Grant now moved southward parallel with Lee's army, both sides intrenching every night. At Cold Harbor, fifteen miles from Richmond, he found the enemy strongly intrenched in 
what was really a great fort. He attacked (June 3) with 80,000 men, and within an hour had lost 7000 . His purpose was to wear Lee out, and he could have afforded to give two men for one, to break up that opposing army then and there.

Once more Grant edged south ward, crossed the James River (June 15), and attempted to seize Petersburg, the key of eastern Virginia; but in several unsuccessful assaults he lost about 8000 men. A vain attempt to entice him from his grip on Petersburg was made by the Confederate general Early, who, in a sudden dash northward with 20,000 men, took and burned Chambersburg, Pennsylvania, and reached the edge of the city of Washington, which he could have taken, had he known how few its defenders were. In front of Grant's line at Petersburg a mine was dug to blow up an important Confederate defense at a spot now called the Crater (July 30, 1864); but after a loss of 2900 men the Union troops had to withdraw and continue the slow siege, which lasted nearly a year.

From this time the eyes of the whole country were on Grant before Petersburg. Ulysses S. Grant was a man of the plain people, a descendant of an early colonist of Massachusetts, probably of Scotch ancestry. The son of a tanner, he was born in Ohio (April 27, 1822), was brought up

408. Ulysses S. Grant as a general first to farm work, then graduated in 1843 at West Point. Two years later he was sent to Taylor's army and distinguished himself in the Mexican campaign. He resigned from the army in 1854, and then tried various kinds of business in St. Louis and Galena, Illinois, and fell into obscurity. On the day after the fall of Sumter, Grant made up his mind to return to the army ; and in August, 1861, became brigadier general. From 1861 to 1863 his name was connected with most of the successful operations in the West, till Lincoln said of him: "I can't spare this man; he fights."

Grant was a very taciturn man, slow to express an opinion; he disliked writing, and sometimes got into trouble because he 
would not report. Yet he coined some apt phrases, as in his Grant, demand for the surrender of Fort Donelson: "No terms Memoirs, I. 311,226 except an unconditional and immediate surrender can be accepted. I propose to move immediately upon your works"; and in 1864, "I propose to fight it out on this line if it takes all summer."

Grant's greatest characteristic was his indomitable grit. After the terrible discouragements of the campaign of 1864, he wrote, 一to Lincoln's great satisfaction, - "I want

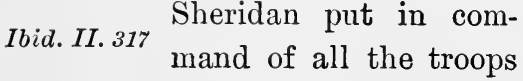
in the field [of the Shenandoah], with instructions to

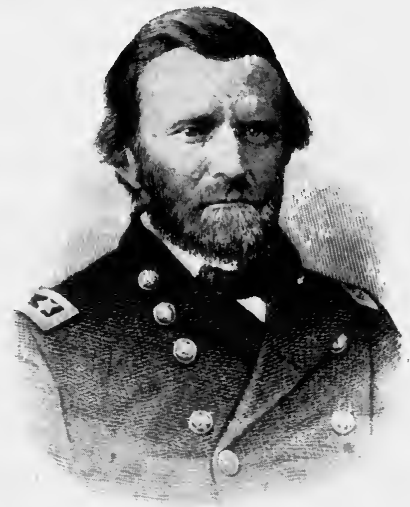

Ulysses S. Grant, in 1863. put himself south of the enemy and follow him to the death. Wherever the enemy goes let our troops go also." This intense determination kept in action the forces that brought the war to an end. Grant did not stake all on one battle; he was not daunted or discouraged by defeat; he simply kept at it till his enemy was vanquished.

Grant's most dangerous opponent was Robert E. Lee, who was born in 1807, of an old and aristocratic Virginia family; he 409. Robert graduated from West Point (1829), and spent thirty-two E. Lee as a years in the regular army; he distinguished himself in the general

Mexican War. Just before the Civil War broke out he wrote to a friend, "If the Union is dissolved and the government disrupted, I shall return to my native state and share the Trent, Lee, miseries of my people, and, save in defense, will draw my 38

sword on none." A few days after the fall of Fort Sumter he was offered the command of the United States army, 
and declined it. He resigned, and, after Virginia seceded, accepted a Confederate commission.

For a year Lee saw little active service; then he took command of the Army of Northern Virginia, June 1, 1862, and for nearly three years was the unquestioned leader of that army. His division and corps commanders, Stonewall Jackson, Gordon, Longstreet, A. P. Hill, D. H. Hill, Ewell, Early, J. E. B. Stuart, remained with him with few exceptions till the end of the struggle. What made Lee a great soldier were his skillful preparations, his watchfulness, and his ability to accomplish much with small resources.

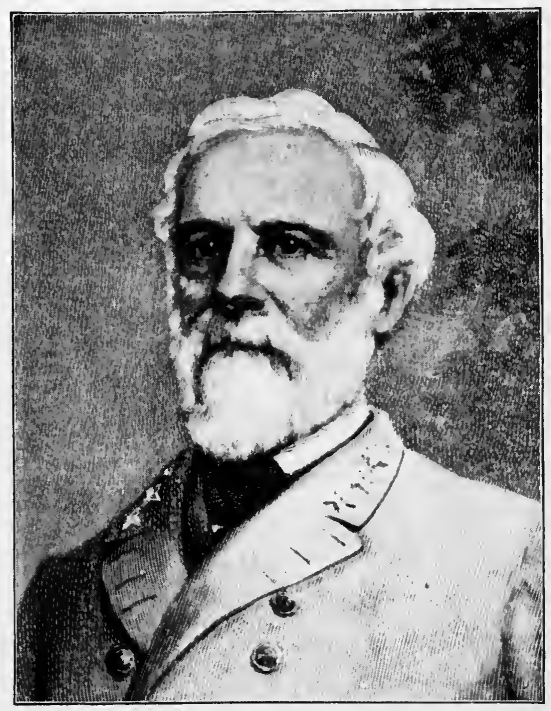

ROBert E. Lee, ABout 1870.

In this respect he greatly resembled Washington, with whom he has often been compared. He had great power over men, and his soldiers had perfect confidence in "Uncle Robert."

On the same day that Grant moved south (May 4, 1864), Sherman began his advance from Chattanooga to Atlanta, 135 miles through the mountains, against Joseph E. Johnston, who had superseded Bragg. During four months Sherman worked his way steadily along the line of the railroad (p. 434), skillfully flanking Johnston's smaller army from point to point. His one front attack, at Kene410. Joseph E. Johnston's defense of Georgia (1864) saw Mountain (June 27), caused a loss of 2000 men, with no 
military advantage. Johnston was superseded in July, 1864, by the more dashing Hood. Sherman circled about Atlanta, almost captured the opposing army, and at last was able to teleOfficial Records, $X X X V I I I$. graph (September 3), "Atlanta is ours, and fairly won." pt.v.p. 771 he was a classmate of Lee at West Point, and then served against the Indians and the Mexicans. In 1860 he was made quartermaster general of the United States army, but followed

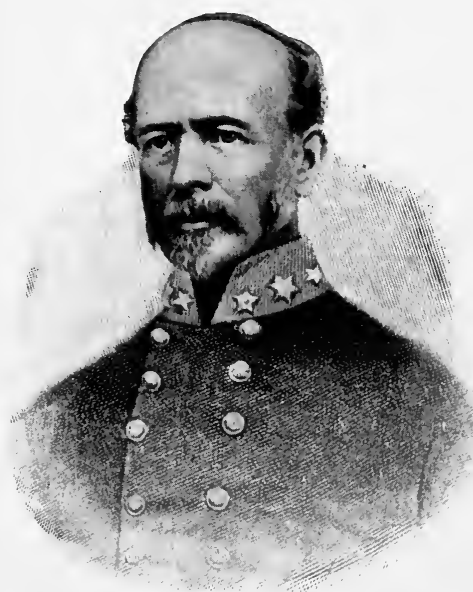

Joseph E. Johnston, in 1864. his state of Virginia when it seceded. He was one of the first generals appointed by the Confederacy, commanded in the Shenandoah valley, at Bull Run, in the Peninsular Campaign, and against Grant outside of Vicksburg. Johnston's most remarkable service was in 1864, when with about 70,000 men he tried to hold Sherman's army of 113,000. His policy was to avoid general engagements, but to wear the invaders out by a long campaign, and by attacking their ever lengthening line of communications.

The navy shared in the hard work of 1864, especially by Farragut's attack in August, with 18 vessels and a landing 411. The force of 5500 troops, on the powerful defenses of Mobile navy in 1864

Bay. Farragut lashed his ships in pairs ; and he fastened himself to the rigging of his flagship, the Hartford. As the fleet went in, the monitor Tecumseh was torpedoed, and instantly sank, but the admiral signaled "Go ahead!" All the rest of the fleet got through the channel into the bay, when a dangerous Confederate ram, the Tennessee, swept down upon 
them. One after another the Union vessels dashed at the big ironclad, firing their heavy guns, and they pounded her till one who was present said, "She lay like a bleeding stag at bay among the hounds." The Tennessee surrendered and the forts were taken, so that the port of Mobile was closed.

Farragut's determination never ceased throughout the war; he was one of the most careful commanders that ever lived; he made all his preparations beforehand, weighed the risks, and then nothing could stop him short of the sinking of his vessel; and his courage affected everybody in the fleet. So perfect were his discipline and his coolness, that in his great fights he always came out safe with a small loss of men.

The navy and the army also coöperated on the North Carolina coast. Fort Fisher was taken (January, 1865), and the port of Wilmington was closed. Thereafter there was no large port open to the blockade runners except Charleston.

Philip H. Sheridan, another great commander, came to the front in 1864. Born in New York of Irish parents, he was a graduate of West Point, and served on the western frontier. He was put in command of a brigade, and soon 412. Philip H. Sheridan after of a division in Buell's army (1862). He fought at in ley (1864) Perryville, Stone River, Chickamanga, and Chattanooga, and in 1864 was made chief of the cavalry corps of the Army of the Potomac.

After fighting through the terrible campaign of 1864 , he was sent into "the Valley" of the Shenandoah. There he undertook the task of pushing back General Early and of devastating the country so that it should no longer feed the Confederate army. After fights at Opequan Creek and Fishers Hill, the enemy rallied and attacked the army at Cedar Creek (October 19) and drove it out of its camp, while Sheridan was twenty miles to the north. He hurried to the sound of the guns and found a number of demoralized men on the road, but a large part of the troops were still in line. 
As he galloped along the line he shouted, "We are all right. Davies, . . Never mind, boys, we'll whip them yet, we'll Sheridan, whip them yet. We shall sleep in our quarters to185 night." He pushed the enemy back, and actually reoccupied his old camp at Cedar Creek that night.

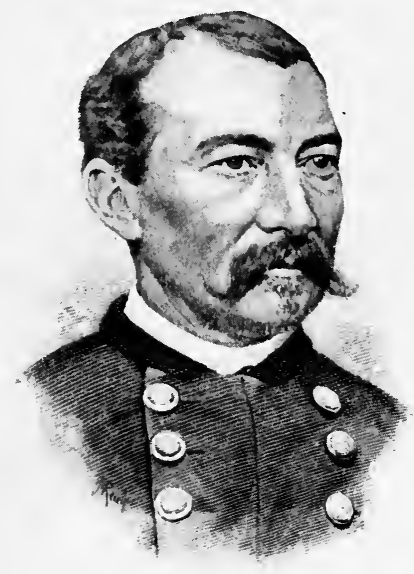

Philip H. Sheridan, about 1870.

Sheridan's characteristic as a soldier was his impetuous attack. He never waited to be perfectly ready, but struck before he was expected. $\mathrm{He}$ was bold and dashing, would lead into any kind of danger, and yet took no unreasonable chances, and was never defeated in an independent command. He was very careful to keep his men well fed and supplied, and was a master in the organization and use of cavalry.

The state elections of 1863 responded to the victories at Vicksburg and Gettysburg by giving good Republican majori413. Parties ties. Though Lincoln had the confidence of the people, and politics in 1864 a clique of disaffected Republican politicians, (1862-1864) including Secretary Chase, wanted to set him aside. Some of these malcontents got up a convention and nominated John C. Frémont for the presidency, a movement finally headed off. The regular Republican convention was practically unanimous for Lincoln, on a platform that slavery must be destroyed; Andrew Johnson of Tennessee was put on the tieket as Vice President, in order to strengthen it in the border states. The Democrats nominated for the presidency General George B. McClellan, as representative of the war Democrats and as a soldier candidate; but declared in their 
platform that there " had been four years of failure to restore the Union by the experiment of war."

The failure of Grant to break up Lee's army in June, 1864, had a damaging effect on the campaign, and Lincoln was deeply discouraged, for he miscalculated the people's affection for their President. To the eighteen free states in the Union in 1860 had been added Kansas, West Virginia, and Nevada (1864). Lincoln carried them all except New Jersey, and also two of the four border slave states, Maryland and Missouri. He had 212 electoral votes to 21 ; but only 2,200,000 popular votes against 1,800,000 for McClellan. The election of Lincoln made it certain that the war would be fought to a finish, and men were found to recruit Grant's army before Petersburg.

Sherinan's strong imagination suggested to him that the next step was to cut the Confederacy in two by marching eastward from Atlanta to Savannah through the heart 414. Marchof the country, and Grant, with much hesitation, gave his consent. After destroying the workshops and deing through fenses of Atlanta, Sherman marched eastward (November 15, 1864) with 62,000 men (p. 434). There was no army in front of him and no militia that could oppose him. The Confeder. ate authorities had begged the southern people to plant corn instead of cotton, and therefore he found plenty of food. The army lived on the country, and as Sherman passed through he left it devastated, so far as he could.

The army was followed by "Sherman's Bummers," several thousand stragglers who paid very little attention to the orders against looting private houses ; and thousands of contrabands joined in the procession on foot or in wagons. The railroads were destroyed for miles; even the rails were heated and twisted up. Sherman reached Savannah (December 10, 1864), and eleven days later the city surrendered; Lincoln wrote to Sherman, "The honor is all yours."

General William T. Sherman is in many ways the most in- 


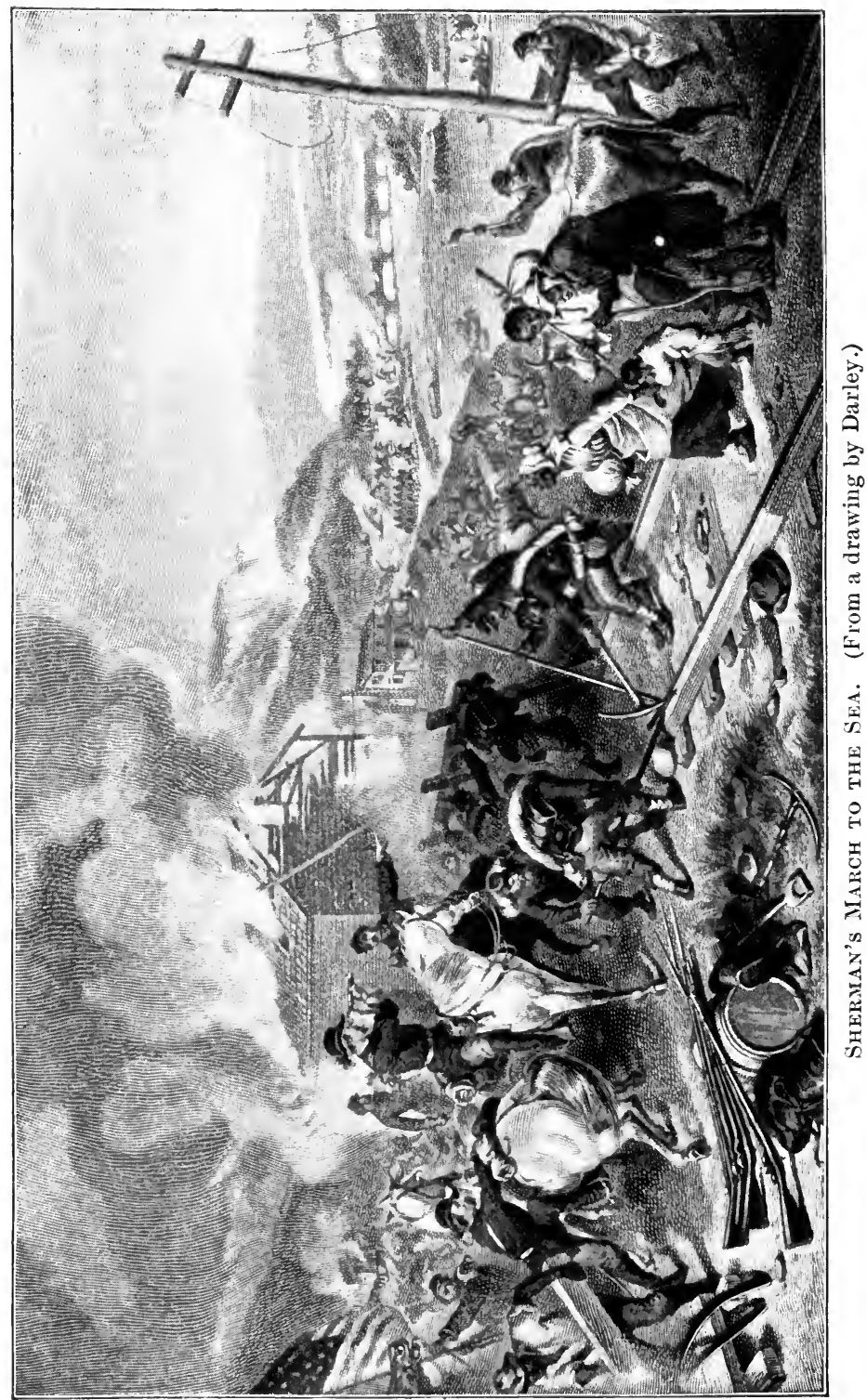


teresting of all the military commanders of the war. Born in Ohio in 1820, a member of a distinguished family, all his life long he was acquainted with public affairs. Sherman graduated at West Point (1840), and was sent out to California in 1846. In 1855 he resigned, and when

415. William $\mathbf{T}$.

Sherman as

a general the war broke out, was superintendent of a military school in Louisiana.

Sherman served at Bull Run, then in the West, and won his first renown at Shiloh. Then he commanded a corps under

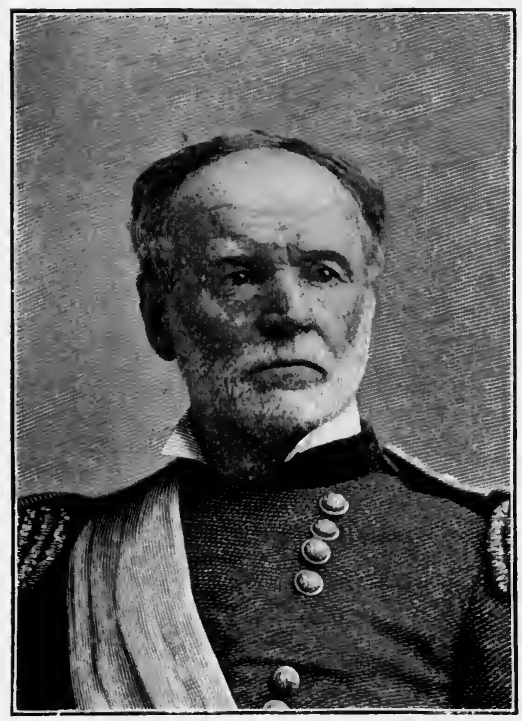

William T. Sherman, about 1880. Grant in the Vicksburg and Chattanooga campaigns. When Grant went east in 1864, Sherman was put in command of most of the western armies, and acted in perfect accord and harmony with his chieftain. He begged Grant to make the West the center of the final campaign: "Here lies the seat of the coming empire, and from the West, when our task Sherman, Memoirs, I. 400 is done, we will make short work of Charleston and Richmond." As a military man Sherman's characteristic was his skill in forecasting what the enemy was likely to do. He was a great strategist, and in his many fights and campaigns always tried to get a good position before he attacked. His men admired him and called him "Old Billy"; but he was too brusque and fiery for the warm personal love which they poured out on McClellan and Thomas. 
The force left by Sherman under command of Thomas, when Sherman started on his march to the sea, was strung all the 416. Hood way along from Nashville to Atlanta. Hood, instead of and Thomas following Sherman, struck northward with 41,000 men, 1864) but he lost 6000 in a vain attempt to capture Schofield's force of 29,000 at Franklin (November 30). Three days later Hood intrenched himself south of Nashville, where Thomas massed his previously scattered forces, fortified the city, and made ready for a great battle. Thomas had no horses for his cavalry; then he waited for reënforcements; then the ground was slippery with ice, so that cavalry could not maneuver. In vain did orders follow day after day from Grant, bidding him attack.

Fully prepared at last, Thomas moved out December 15, 1864, and in the hard-fought battle of Nashville drove Hood from his lines. The next day he attacked again, and Hood's army was routed and dispersed. Of 50,000 Union men Thomas lost 3000 ; of 23,000 Confederates engaged, 4500 were taken prisoners. This battle practically ended the war in the West, and vindicated Thomas's prudence and generalship.

From Savannah Sherman marched northward to Columbia, and the town was burned as he entered it (February 17, 1865) - almost the only case of the kind during the war. Neither Sherman nor any other federal officer gave orders to burn it, and the federal troops finally put out the fire. Sherman's presence in the interior of South Carolina made Charleston indefensible, and it was occupied by other Union forces (February 18, 1865). Sherman, for the first time since leaving Atlanta, was now opposed by a large force, and had to fight J. E. Johnston at Bentonville, North Carolina (March 19), with a loss of 1100. A month later he occupied Raleigh, North Carolina.

The Army of the Potomac, during these brilliant move417. Cap- ments, was lying patiently in the trenches before Peters(1865) . burg, losing thousands of men by disease and constant 
skirmishing, but slowly wearing down Lee, who could not replace his losses. He even proposed to President Davis to levy negro regiments; but the time was too short to carry out the plan.

The last great struggle of the war now came on before Petersburg, where Grant, with 113,000 effective troops, well fed, clothed, and supplied, kept Lee in the trenches, while

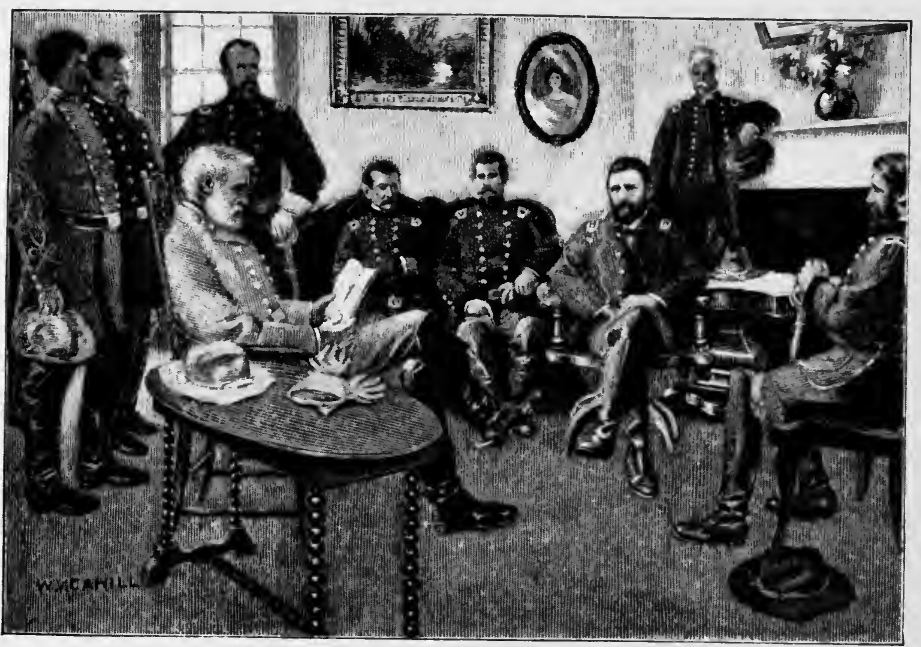

SuRRender of LeE.

Sheridan remorselessly raided the country to the north and west of Richmond. Lee forced a series of fights, beginning March 25, to cover his preparations for a retreat; he then abandoned Richmond and Petersburg (April 3), and struck westward along the Appomattox River, and next day Richmond was occupied by the Union troops. Grant followed close after Lee, and Sheridan dashingly closed in the net. A week after leaving his intrenchments, Lee was surrounded at Appomattox, and, April 9, 1865, he surrendered his command, which had now dwindled to 27,000 men. Lee's part- 
ing speech to his troops was simply, "Men, we have fought Lee, Lee, 496 through the war together; I have done my best for you." at Raleigh; and the Civil War was practically at an end, although a few distant places held out a few weeks longer. Two weeks later Jefferson Davis was captured while trying to escape.

Many suggestions had been made during the war, looking toward terms of peace. Foreign governments tried in vain to 418. Terms of peace (1864-1865) mediate in 1861, 1862, and 1863. In 1864 some overtures were made to President Davis, who replied, "You may 'emancipate' every negro in the Confederacy, but we will be free, we will govern ourselves." Just before the collapse Lincoln and Seward met Vice-President Stephens of the Confederacy on a steamer at Hampton Roads (February 3, 1865); but Lincoln was firm that the only conditions of 'peace were for the South to return to the Union and for slavery to cease, and on those issues the conference failed.

After Richmond fell, Lincoln took pains to notify General Grant that he was not to make any pledges for the future of the South. Accordingly, Grant insisted that Lee's troops should surrender unconditionally; but he then released Lee's men, "not to be disturbed by the United States authority so long as they observed their paroles and the laws in force where they reside"; and Grant won the respect and gratitude of the southern officers and soldiers by leaving them their horses. Sherman, in receiving Johnston's surrender, undertook to make pledges about the reorganization of the states; but these terins were disavowed by President Johnson in Washington.

The success of the Union arms raised Lincoln to the highest 419. Assassination of point in his whole life. He had the people behind him, and could have struck out a policy which Congress must have followed. He was himself a southern man by birth, understood the southern people, and in his great 
nature there was no room for enmity toward those who had fought bravely and were beaten. The difficult problem of reconstruction seemed ready for him to solve. Terrible, therefore, was the blow that fell upon the whole country when, just four years from the surrender of Fort Sumter, the President was shot in a box at Ford's Theater, during a play, by the organizer and head of a band of conspirators. The next morning the President's life ebbed away, and he died April 15, 1865, at the height of his service and power. The assassin was hunted down and shot while desperately defending himself from capture. Other members of the conspiracy, including one woman, were tried by military court-martial, and four of them were hanged.

The whole country felt that Lincoln had died for his country as truly as though he had been in the front line at Gettysburg. The work that he did will live imperishably, for he rescued the Union and he destroyed slavery. The principles of his life he summed up a few days before his death: "With malice toward none; with charity for all; with firmness in the right, as God gives us to see the right, let us strive on to finish the work we are in; to bind up the Lincoln, Works, II. 657 nation's wounds; to care for him who shall have borne the battle, and for his widow, and his orphan - to do all which may achieve and cherish a just and lasting peace among ourselves, and with all nations."

What was the cost of the Civil War? In men, 360,000 on the Union side, who were killed or died of disease, and a corresponding Confederate loss of about 258,000. In money, the United States paid out during the Civil War, for other purposes than its ordinary civil expenses, $\$ 3,660,000,000$; the Confederacy probably spent $\$ 1,500,000,000$ measured in gold.

As for property, no free territory was invaded, except Pennsylvania and Ohio for a few days; and the destruction of northern merchant vessels amounted to only $\$ 20,000,000$. The loyal 
border states, as well as the South, however, were invaded at many different points and devastated by marching armies, both Union and Confederate. Thousands of houses were burned, the business of cities was for months suspended, the cotton crop was nearly a dead loss. The whole South was commercially ruined, while the North, in spite of its immense expenses, had more men, more capital, and more money at the end of the war than at the beginning. The South felt also that it had lost four million slaves valued in 1860 at $\$ 2,000,000,000$. The slaveholding families did lose the opportunity of turning their human property into cash; but most of the negroes were still on the ground and ready to work the land; and the community was no poorer for the change.

Was this enormous expenditure of life, treasure, and national forces worth while? Yes, for it did six vital things: (1) it taught forever the lesson that there is no such thing as peaceable and constitutional secession; (2) it proved once for all that slavery is an institution which weakens the economic and social forces of a country; (3) it opened up to four million negro people the opportunity to make the best of themselves; (4) it showed the self-perpetuating power of republican government; (5) it put an end to the project of dividing the strength and influence of the United States between two separate nations; (6) it proved the courage and self-sacrifice of the people of the United States, both North and South - all the people, not soldiers merely, but men, women, and children.

From January, 1864, to May, 1865, the war went steadily against the South. Both sides felt the pinch of taxes, the bad 421. Sum- effects of too much paper money, the hardships and mary despotism of military government; and both sides made desperate attempts to fight it out.

In the East, by Grant's Virginia campaign, the field of operations was at last shifted to the neighborhood of Richmond. 
Sheridan, in the Valley, showed his brilliant qualities as a commander and a destroyer. In the West Sherman pushed steadily down the railroad to Atlanta; toward the end of the year he broke loose and crossed the country to Savannah; and Thomas, after careful preparation, defeated Hood's army, the last that could be raised by the Confederates in the West.

The end came in the spring of 1865, when first Lee and then Johnston surrendered; and there was no longer any center of resistance. The whole South was speedily garrisoned with Union troops.

\section{TOPICS}

(1) Why did the federal government issue paper money during the Civil War? (2) Why were people in the North arrested and Suggestive topics confined without warrant? (3) Was the punishment of Vallandigham judicious? (4) Why was Grant put in command of the eastern armies? (5) Why was Grant obliged to retreat at the Wilderness? (6) Why could not Grant break Lee's lines in 1864 ? (7) Why was the explosion of the Crater a failure? (8) Why did Robert E. Lee resign his commission in the United States army? (9) Why were there so few changes among the officers of the Confederate Army of Northern Virginia? (10) Lee's military career during the Civil War. (11) Was Joseph E. Johnston's military policy wise? (12) Why was McClellan nominated by the Democrats in 1864 ? (13) What were the objections to the raising of negro regiments by the South ? (14) Why was Sherman's convention with Johnston disavowed? (15) Was the South made poorer by the emancipation of the slaves ?

(16) The Sanitary Commission. (17) The Christian Commission. (18) Knights of the Golden Circle. (19) Why did the Peace Democrats oppose the war? (20) Draft riots in New York city. (21) Conscription in the South. (22) Life in Libby Prison. (23) Relations between Lincoln and Grant. (24) Lee's military services before the Civil War. (25) Nomination of Frémont for the presidency in 1864. (26) Sherman's march to the sea. (27) The battle of Franklin, Nashville, or Bentonville. (28) Capture of Lee at Appomattox. (29) Peace conference at Hampton Roads. (30) National grief at the death of Lincoln. (31) Work for the soldiers in your own town during the war. (32) Enlistment of soldiers in your own towñ during the war. 
Geography

Secondary authorities

Sources

Illustrative works

Pictures

\section{REFERENCES}

As in chapter xxviii.

Stanwood, Presidency, 298-312 ; Dodge, Civil War, 192-327; Hosmer, Outcome of the Civil War; Schouler, United States, VI. 400-424, 460-633 ; Rhodes, United States, IV. 223-255, 407-539, V. 1-518; Wilson, American People, IV. 253-262 ; Cambridge Modern History, VII. 514-558, 575-580, 696, 697 ; Gay, Bryant's History, V. 193-374; Dunning, Civil War and Reconstruction, 1-62 ; Schwab, Confederate States of America; Maclay, United States Navy, II. 397-456, 475-507, 549-559 ; Humphreys, Virginia Campaign of ' 64 and ' 65 ; Pond, Shenandoah Valley in 1864; Cox, Atlanta,-March to the Sea, Franklin and Nashville; Mahan, Gulf and Inland Waters, 185-249 ; Admiral Farragut, 237-326; Ammen, Atlantic Coast, 199-248; Morse, Abraham Lincoln, II. 175-198, 245-357 ; Hapgood, Abraham Lincoln, 343-419; Davies, General Sheridan, 89-251, 306-319; Walker, General Hancock, 158-294 ; Force, General Sherman, 187-310, 328-338; Coppée, General Thomas, 199-291, 310-324; Lee, General Lee, 325-399, 420-424; Hughes, General Johnston, 222-280, 290-308; Soley, Admiral Porter, 376-486.

Hart, Source Book, §§ 125, 126, - Contemporaries, IV. \$§ 77, 79, 81-83, 132-140, - Source Readers, IV. \$§ 18, 62, 72, 73, 88, 89, 93, 98 ; MacDonald, Select Statutes, nos. 32, 39-41, 43; American History Leaflets, no. 26 ; Old South Leaflets, no. 11; Dana, Recollections, 156-167, 186-291 ; Riddle, Recollections, 164-167, 256-343; Brooks, Washington in Lincoln's Time; Grant, Personal Memoirs, II. 124-554; Century Company, Battles and Leaders, IV. 97-768; American Annual Cyclopcedia, 1864, 1865. See N. Eng. Hist. Teachers' A's'n, Historical Sources, § 88.

Matthews, Poems of American Patriotism, 233-277; Eggleston, American War Ballads, II. 106, 156-278; Lowell, Commemoration Ode; Holmes, In War Time; M. A. De Wolfe Howe, Memory of Lincoln (poems); Charles Morris, Historical Tales, 292-319; G. C. Cary, Rebel's Recollections; B. K. Benson, Friend with the Countersign; 'T. N. Page, Among the Camps, - Two Little Confederates, - Burial of the Guns; Harold Frederic, The Copperhead; J. C. Harris, On the Plantation; M. L. Avary, Virginia Girl in the Civil War; L. M. Alcott, Höspital Sketches; K. P. Wormeley, Other Side of War ; A. E. Dickinson, What Answer? (draft riots); W. O. Stoddard, Battle of New York (draft riots). As in chapter xxviii. 


\section{CHAPTER XXXI.}

\section{RECONSTRUCTION OF THE UNION (1865-1875)}

What was to be done with the South when the war was over? This perplexing question involved three different subjects: the status of the individual whites, the future of the negroes, and the relations to the Union of the states which had attempted to secede.

422. The southern whites

So far as individuals were concerned, no federal law prevented former Confederates from continuing to take part in the state governments; but penalties for treason were hanging over them all. From that danger, however, the military men were practically free, under the terms of surrender of Lee's and Johnston's armies; and when warrants were issued for the arrest of Lee and many other military commanders, to be tried for treason, General Grant would not permit the arrests. No such protection extended to members of the civil governments of the Confederacy and of the seceded states; but the only man actually held for treason was Jefferson Davis ( $\$ 428$ ). Lincoln would probably have stood firmly against any kind of punishment for the common people of the South, whether soldiers or civilians; but Congress had already confiscated the property of some of the leaders; and the Fourteenth Amendment later punished many of those who had taken a leading part, either civil or military, by excluding them from office.

At the end of the war, the slaves had been declared free in the whole country except the states of Kentucky and Delaware: (1) Congress had prohibited slavery in the District of Columbia and the territories; (2) the Presi-

423. The southern negroes 
dent had emancipated the slaves in the seceded states, except Tennessee and certain counties of Louisiana and Virginia; (3) Maryland, West Virginia, and Missouri ( $\$ 395$ ) had passed immediate or gradual emancipation acts for themselves; $(4)$ the loyal governments of Louisiana and Virginia (\$401) had adopted constitutions that freed the slaves, and Tennessee in 1865 passed a special emancipation act, - which did away with the exceptions in the Proclamation of Emancipation.

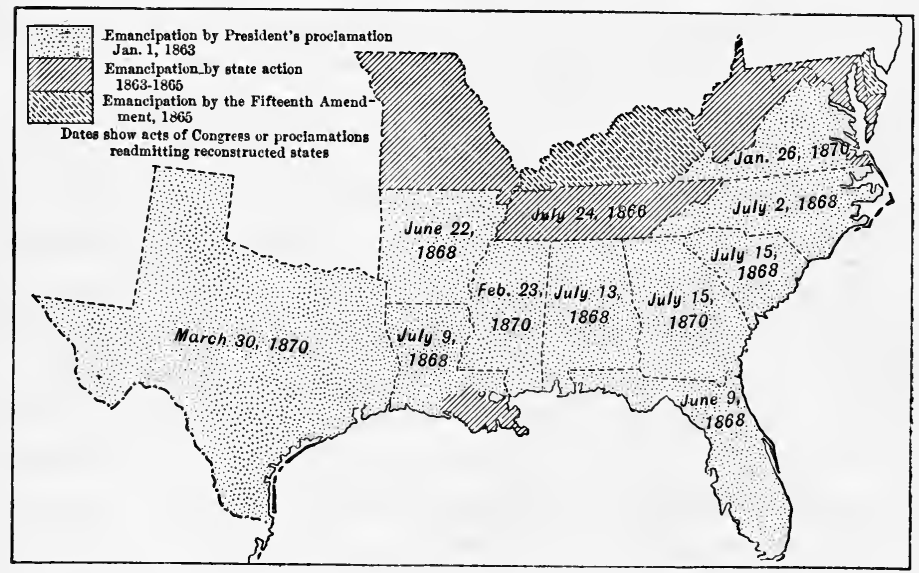

Emancipation and Reconstruction.

For the thousands of negroes who had left their old homes and flocked into the federal camps, Congress had already passed an act for a Freedman's Bureau (March 3, 1865), which was intended, through military officers, to protect the negroes from injustice, to find work for them, keep them from starving, and start schools for their education. This action, however, involved the assumption of a responsibility for individuals within states which the federal government had never before taken.

To prevent any question that the slaves were forever free, the Thirteenth Amendment to the Constitution was carried 
through both houses (January 31,1865 ) by the personal influence of President Lincoln, who said in a public speech, "It winds the whole thing up." Three fourths of all the states, through their legislatures, ratified this amend-

Lincoln, Works, ment, which in December, 1865, became a part of the Constitution. It provided that "Neither slavery nor involuntary servitude, except as a punishment for crime whereof the party shall lave been duly convicted, shall exist within the United States, or any place subject to their jurisdiction."

As for the eleven former seceded states, did they still have "all the dignity, equality, and rights of the states unimpaired," as set forth by the resolution of 1861 ? ( $\$ 373$.) If so, they must be permitted to come back into their former place; and through their senators and representatives

424. Theories of state reconstruction would help to settle their own future. The steady northern theory of the war was that the states were in the Union and could not get out of the Union; that the whole trouble was made by individuals who traitorously in arms resisted the United States. Yet, at the end of the war, the individuals went unpunished; and the seceded states were kept out of their constitutional relations to the Union. Even after fnrnishing eight ratifications needed to carry the Thirteenth Amendment, they were held not really to be in the Union.

To explain this singular state of things and to establish a basis of readjustment, four main theories were put forth: (1) The "presidential theory," held by Lincoln, was that the states were entitled to come back and send members to Congress, as soon as the President decided that they had repented. (2) The "state suicide theory," urged by Charles Sumner, was that by secession the states lost statehood and became territories. (3) The "conquered provinces theory," for which Thaddeus Stevens was responsible, looked on the South as a subjugated region, with which Congress could deal exactly as though it were a part of a conquered foreign country; it was actually 
suggested that South Carolina be divided between Georgia and North Carolina and thus obliterated from the map. (4) The "forfeited rights theory" was that the states still existed and were members of the Union, but through traitorous acts of the community as a whole had made themselves subject to some punishment which would reach them as states.

The first theory to be applied was the presidential (see $\$ 401$ ). On Lincoln's death, Andrew Johnson of Tennessee succeeded 425. Presi- to the presidency. Though a southern man, he was a dential reconstruction (1865) mountain white and hated the planters. By an amnesty proclamation (May 29, 1865), Johnson expressly shut out the old southern leaders, so as to leave the poor whites to form new state governments. Accordingly, during the year 1865, while Congress was not in session, under his military power he appointed civil governors for the southern states. These governors called constitutional conventions, which formed antislavery constitutions and provided for new elections of members of Congress, governors, and legislatures, which chose United States senators. In December, 1865, members-elect appeared from all the seceded states except Texas, and demanded seats in Congress.

Unfortunately for the South, some of the former seceded states enacted statutes on "vagrancy" and "labor contracts," 426. Con- which made the negroes practically subject to masters, gress assumes reconstruction (1866-1867) and caused the North to believe that if those southern states were left to themselves, they would after a few years reënslave the negro; and that if the new members were admitted to Congress, there was no guaranty that a large part of the work of the Civil War would not be undone. They were therefore kept out; and Congress soon took the question of reconstruction into its own hands by a joint resolution (March 2, 1866) that neither house would admit either senator or representative until Congress as a whole should decide that the state was again to be represented. 
Johnson saw his plan of reconstruction practically nullified. He was a coarse, blustering man, who did not know how to get on with other people, who had no powerful friends, and who was distrusted by the antislavery element. The Republican leaders were backed up by a two-thirds majority in both branches of Congress, and openly broke with the President by passing over his veto a Civil Rights Act (April 9, 1866), which put the negroes under the protection of the federal government. In three years Johnson vetoed twenty-one bills, of which fifteen were passed over his veto.

In order to put it out of the power of a later Congress to repeal the purposes of the Civil Rights Act, the two houses (June 16, 1866) submitted the Fourteenth Amendment, of which the main principles are four: (1) For the protection of the negro, all persons born or naturalized in the United States are declared to be citizens of the United States and also of the state in which they reside; and states are forbidden to "deprive any person of life, liberty, or property without due process of law," or to "abridge the privileges or immunities of citizens of the United States." Thus a great area of power was transferred from the states to Congress ( $\$ 437$ ). (2) In order to favor negro suffrage, states were to lose part of their representation in Congress if they cut off any adult male citizens from voting. (3) To punish the leaders in the Confederacy, many of them were excluded from office ( $\$ 437$ ). (4) To set a stigma forever on secession, the Confederate and state debts incurred " in aid of insurrection or rebellion against the United States" were declared void.

In a formal reconstruction act (March 2, 1867) Congress passed over the "state suicide theory," and accepted a compromise between the "conquered provinces" and "forfeited rights" theories, by providing that the seceded states before they could come back into the Union must frame new constitutions, must give the negro the suffrage, and must ratify the 
Fourteenth Amendment and thereby consent to punish their own leaders.

'The man most responsible for these severe conditions was Thaddeus Stevens of Pennsylvania. He was an excellent 427. Thad- lawyer with a good practice, who went into politics as a deus Stevens's Whig, and made his début in Congress in 1849 by leadership declaring that he was hostile to slavery "in every form and place." When the war broke out, Stevens was chairman of the Committee on Ways and Means, and legislative leader

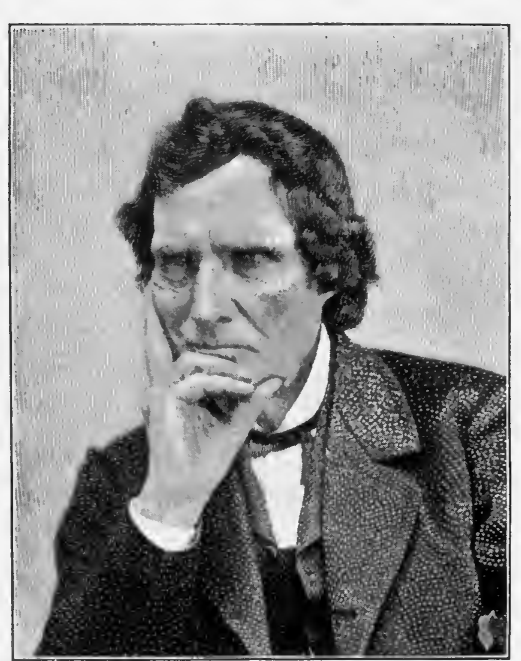

Copyright, 1901, by H. P. Rice.

'Thaddeus Stevens. of the House. He complained of the House resolution of July, 1861 ( $\$ 373$ ), because the only object of the war was to "subdue the rebels." When people talked about the Constitution, he said in the House, "I hold that none of the states now in rebellion are entitled to the protection of the Constitution." Stevens was one of the best debater's who ever sat in Congress, but he was absolutely one-sided in politics and thought everybody on the other side a scoundrel. He was strongly in favor of emancipation, not so much to help the slaves as to hurt the slaveholders; and he insisted on enlisting Congres- negroes in the army, for he said: "The only place where

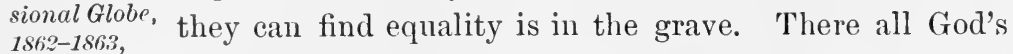
III.p. so children are equal"; and he favored negro suffrage explicitly on the ground that it would "continue the Republican ascendancy." 
The Supreme Court during the Civil War was much altered by President Lincoln's appointment of five new judges, including Chief-Justice Salmon P. Chase. Under Chase's leadership the court from 1866 to 1869 made a series of decisions on the questions of the war and reconstruction: (1) The right of the Union to make war on rebellious states was affirmed. (2) The right of Congress to recon428. The Supreme Court and reconstruction (1866-1869) struct such states after the war was supported. (3) The usual penalties for treason were held (by Chase in a circuit court) to be superseded by the Fourteenth Amendment, and Jefferson Davis was therefore set free after two years of imprisonment. (4) The military courts set up by Congress during the war were declared to be illegal if held away from the scene of hostilities. (5) In the famous Texas vs. White case (1869) the court dwelt on "an indestructible Union composed of indestructible States."

After the breach with Congress President Johnson tried to arouse public sentiment by coarse and abusive speeches, especially during the political campaign of 1866 , when he said, "We have seen hanging upon the verge of the Government, as it were, a body called, or which assumes to be, 429. Impeachment of President Johnson the Congress of the United States." $\mathrm{He}$ did himself more harm than good; for in 1866 a Republican and antiJohnson two-thirds majority was again elected in both houses of Congress.

In 1868 the House of Representatives went so far as to present articles of impeachment against President Johnson, and the trial before the Senate lasted over two months. Discarding many frivolous allegations, the managers selected for a test vote the charge that Johnson had tried to remove Secretary Stanton, contrary to a Tenure of Office Act which had been passed over the veto March 2, 1867. Thirtyfive Republican senators voted for conviction; twelve Democratic and seven Republican senators for acquittal; and the 
impeachment failed, though a change of one vote would have made the necessary two-thirds vote. All but one of the dissenting Republican senators lost their seats at the expiration of their terms; but there is now no doubt that they saved the country from the dangerous precedent of removing a President because he differed with and quarreled with Congress.

During the long discussion on reconstruction the government was making up its accounts. On June 30,1866 , the outstand430. Finan- ing debt was $\$ 2,773,000,000$. The government at once

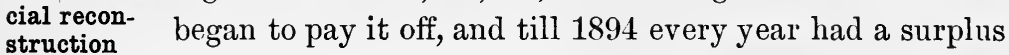
(1865-1 870) of receipts over expenses available for that purpose. The currency was made up of "greenbacks," national bank notes, and paper small change, for all of which the federal government took the responsibility. Greenbacks in 1865 were worth about seventy cents on the dollar, measured in gold; by 1871 they rose to ninety cents.

At first it was intended that the greenbacks should be paid off in hard money, but in 1866 there was a small commercial panic, and then an outcry was made that the bondholders had paid greenbacks for their bonds, and ought to be repaid in the same - that is, that the national debt should be paid in more promises to pay. A political movement began, called the "Ohio Idea," or by its enemies the "Rag Baby," which startled Congress into voting (February 4,1868 ) that the greenbacks should not be reduced below $\$ 350,000,000$. A year later, however, Congress voted that the bonds should be paid in "coin."

On the other side, in 1870 the Supreme Court held, by four judges to three, that the greenbacks were unconstitutional. In a few months there came two vacancies in the Supreme Court; two new judges were appointed; and by a majority of five to four the court held greenbacks justified under the war power, thus reversing the previous decision. Thirteen years later, the court ruled that legal tenders could be issued at any time. 
At the end of the war a large force of Union troops was sent to Texas, as a hint to an undesirable neighbor across the Mexican boundary. Napoleon III., emperor of the Hrench, had taken advantage of the embarrassment of the Union to 431. American foreign questions turn an expedition to collect damages (1861) into a war of (1856-1869) conquest against Mexico. A French army, amounting at one time to 60,000 men, set up what they called an empire, with Maximilian, an Austrian archduke, as emperor. This occupation of Mexico was very offensive to the United States; and Secretary Seward many times warned the French not to force a monarchical government on an American republic. His firmness compelled the French to withdraw in 1867. Within four months Maximilian was taken prisoner by his loving subjects, set up against a wall, and shot; and that was the end of the empire of Mexico.

Another group of foreign questions brought out by the Civil War related to the Isthmus route to California and to a naval station in the West Indies. Looking toward a canal, Secretary Seward made treaties with Honduras and Nicaragua, something like that of 1846 with Colombia. Then he turned to the West Indies, and pressed upon the Danish government a treaty of purchase for the little islands of St. Thomas and St. John (1867); but the Senate declined to ratify the treaty, in which there was little public interest.

Another of Seward's projects, however, was successful. Russia, during the Civil War, had been extremely friendly; and when that government intimated that it would like to dispose of Russian America, Seward surprised the country by arranging a treaty for the purchase of the whole region for $\$ 7,200,000$; it was ratified by the Senate, April 9, 1867. People knew very little about the region, which is now named Alaska; but in it the United States acquired half a million square miles of land, a valuable seal fishery, and what proved to be a rich gold-mining region. 
Immigration was resumed on a large scale as soon as the war ended. Many German immigrants went back to visit friends ; 432. Ameri- and if they had originally come away without having can citizen- served the term required of every young German in the ship and immigration. (1868) German armies, they were liable to arrest, even though naturalized citizens of the United States. To get rid of this trouble, a set of treaties was negotiated (beginning 1868) with the various German states, - and with Belgium, Austria, France, and Great Britain, - by which if a native of those countries comes to the United States and stays five years, he loses his native citizenship, whether naturalized here or not; but if he goes back to his mother country and lives there two years, he may lose his American citizenship.

The welcome to immigrants extended across the Pacific. Chinese laborers drifted to California and Oregon, and thousands of them were employed in the construction of the Pacific railroads (\$ 434). In 1868 the "Burlingame Treaty" specifically promised that our government would protect Chinese in this country in the enjoyment of the same rights as those enjoyed by citizens of other countries.

The immigrants were helping to develop the West, into which settlers were pouring by hundreds of thousands. 433. Devel- Many were attracted by the Homestead Act, passed in opment of 1862, under which any head of a family, native or the far West foreign born, might take up 160 acres of government (1861-1875) land, and at the end of five years' residence get a title to it free of cost. Within ten years $28,000,000$ acres of land were thus "homesteaded"; and 9,000,000 acres were given away under an act of 1873, granting "tree claims" to settlers who would plant and keep alive a certain number of trees.

Another cause for the rush to the West was the discovery of new mines - copper at Butte, Montana (1864), gold in the Black Hills of Dakota and Wyoming (1874), silver at Leadville, Colorado (1876). Between 1861 and 1876 it was found 
desirable to organize three new states: Nevada (1864), Nebraska (1867), and Colorado (1876), raising the total number to thirtyeight; and to set up the territories of Dakota, Idaho, Arizona, Montana, and Wyoming.

Much of the western country was still unknown to white men when, in 1869, Major Powell, with a dare-devil boat expedition, went down the Colorado River, and revealed the wonders of its Grand Canyon. In 1870 an exploring party reached the upper Yellowstone valley, and made known the canyons, hot springs, and spouting geysers, which are among the greatest wonders of our natural scenery.

The Indian reservations established in the Northwest in Jackson's time were hard pressed by the wave of white settle-

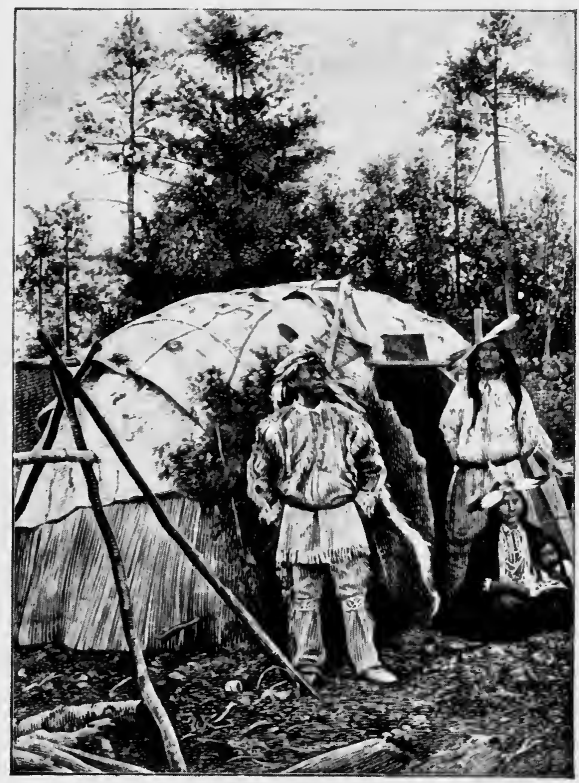

Modern Indians, With Wigwam. ment. President Grant set on foot a "peace policy" in 1869, and placed many reservations under agents nominated by religious societies; but he could not stop Indian wars. The little Modoc tribe in the lava beds of northern California for many months (1872-1873) defied the whole United States government; and the Sioux of the upper Missouri country, under the leadership of Chief Sitting Bull, in 1876 totally destroyed a force of about two hundred troops with their 
commander, General Custer; but this was the last dangerous contest with the Indians in the Northwest.

During the Civil War it became plain that a railroad to California was a commercial and political necessity. For this 434. The Pacific railroads purpose, beginning in 1862, Congress chartered the Union Pacific, Northern Pacific, Atlantic and Pacific, 'Texas Pa(1862-1875) cific, and Sioux City and Pacific railroad companies; and granted lands and privileges to these roads and to the Central Pacific, Kansas Pacific, Southern Pacific, Texas and Pacific, and Western Pacific roads. These companies eventually built four trunk lines (p. 516): one from Lake Superior to Puget Sound; one from Omaha and Kansas City to San Francisco; one from New Orleans to San Francisco via El Paso; and one from St. Louis and Chicago to San Francisco (Atchison route).

These roads had three great privileges: (1) several of them were chartered by the federal government; $(2)$ most of them had land grants - half the government land lying in a strip twenty miles wide along their whole length, amounting in all to one hundred million acres; (3) the government issued bonds to the Union, Central, Kansas, Western, and Sioux City Pacific roads to an amount finally of $\$ 64,000,000$. Construction was pushed rapidly on the most direct of the trunk lines, from Omaha via Great Salt Lake to California; and in 1869 the last spike was driven at Ogden, Utah, and a through rail connection was established 1917 miles long from Omaha to San Francisco.

For the presidential election of 1868 the Republicans nominated General Grant; the Democrats put up Horatio Seymour 435. Presi- of New York; the real issue was whether the congresdent Grant's sional plan of reconstruction should be carried out. Two administra- of the eight states just readmitted to the Union voted (1869-1877) for Seymour; but Grant got 214 electoral votes to 80 , and a popular majority of 300,000 .

President Grant came into office in March, 1869. Absolutely honest himself, and absolutely truthful, he had an un- 
wavering belief in those whom he selected as friends. He was impatient of contradiction, wanted to give orders himself, and his friends made him believe that he was essential to the salvation of the country. He was a sincerely patriotic man, and as President rendered many great services to the country. Like General Jackson, Grant made a vigorous fight for the rights of the President; and he used his veto power forty-three times, principally against extravagant special pension and relief bills. Grant was the first President after John Quincy Adams who was much interested in a non-partisan civil service. He was opposed to the practice of removing the civil officers of the government, down to floor scrubbers, every time a new President came in; and he induced Congress in 1871 to pass a civil service reform act. He tried to carry it out in good faith, till Congress three years later cut off the appropriations and the scheme collapsed.

While the late seceded states were reorganizing, they remained under the authority of military commanders, who vetoed laws, removed civil governors, dismissed legisla- 436. Proctures, issued orders where the legislatures did not pass ess of reconacts, made ordinances for the cities, and in general used (1867-1871) all the privileges of despotism. Yet, with few exceptions, they were moderate and just rulers. Reconstruction under the acts of Congress was a slow process. Members of Congress from Tennessee were readmitted in 1867, from six more states in 1868, from Virginia, Mississippi, and Texas in 1870; Georgia, after being twice set back, was allowed to reënter the Union in 1871. By the combined ratifications of twenty northern states, two border states, and eight states in process of reconstruction, the Fourteenth Amendment was declared July 28,1868 , to be a part of the Constitution.

The Freedman's Bureau was allowed to lapse in 1869; but, in order to put negro suffrage out of the control of the southern states, the Fifteenth Amendment was framed by Congress, forHART'S AMER. HIST. -30 
bidding any states to withhold the suffrage on account of "race, color, or previous condition of servitude." It was duly ratified, and was declared to be part of the Constitution on March 30, 1870.

When the southern states were fully restored, the adult negro men all had a vote. Every legislature had negro members, and some of them a negro majority. Most of these negroes were ignorant men who were controlled by two classes of whites, called "scalawags" (southern Republicans) and "carpetbaggers" (northern men who had gone down South to get into politics). Taxes were increased, debts ran up, and the extravagance and corruption of some of the legislatures surpass belief. The state debt of Alabama swelled from $\$ 8,000,000$ to $\$ 25,000,000$ in six years; the South Carolina legislature spent $\$ 350,000$ in one session for "supplies, sundries, and incidentals." These exactions came on states already impoverished by four years of war-states in which almost the whole community, white and black, was poor and struggling.

Five years of the reconstructed governments in the South brought about something very like a second rebellion, and 437. Fail- three of the main principles of reconstruction were pracure of recon- tically given up :-
struction

(1871-1875) (1) The special protection of the negro, supposed to be embedded in the Fourteenth Amendment, was weakened and almost destroyed by the decisions of the Supreme Court, which ruled in 1869 that the amendment was not "intended to bring within the power of Congress the entire domain of civil rights, heretofore belonging exclusively to the states." Congress passed a Civil Rights Act in 1875, to give the negroes the same privileges as white people in hotels, railroad cars, and so on ; but after eight years it was held unconstitutional by the Supreme Court.

(2) Congress used the power given to it by the Fourteenth Amendment to pass an amnesty act in 1872 , by which all but 
about three hundred former Confederate leaders were restored to their political rights.

(3) Negro suffrage was broken up in many states by violence, through the $\mathrm{Ku}$ Klux Klan movement, which began in 1868 . Young men, masked and disguised, rode about the country at night, threatening the negroes, and dragging out and whipping or even shooting their leaders. White men also, especially the "carpetbaggers," were terrorized and sometimes driven out. Congress in vain attempted to protect the negroes by the "Force Bills" of 1870 and 1871, under which the President could suspend the writ of habeas corpus, and could send troops to protect the polling places in the South.

The Ku Klux Klan gave the Republicans a new campaign issue for the presidential election of 1872. The Democrats combined with the Liberal Republicans (an anti-Grant organization) to nominate Horace Greeley, the old-time abolitionist and hater of the Democratic party. Grant was easily reëlected by 286 electoral votes to 63 ; and he had a popular majority of 700,000 .

In the South the effort of the Democrats to get the state governments out of the hands of the "carpetbaggers" brought about several little civi? wars, especially in Louisiana, where for weeks two legislatures, each supporting a governor, sat in halls a few squares from each other. The whole country was weary of the squabbles. In the "tidal wave" of congressional elections in 1874, a large number of Democratic members were elected to the House from the South; and from that time nearly all the negroes, by persuasion, or fraud, or force, or by new state constitutions, were prevented from influencing any southern election where their vote could affect the result.

One of Grant's best services to the country was the settlement of the "Alabama Claims," a term which was loosely used to include several kinds of damage, for which Great Britain was held responsible: (1) the recognition of the (1869-1875) 
belligerency of the Confederacy (May, 1861); (2) captures of American merchantmen by the Alabama and other cruisers built or fitted out in British ports ; (3) hospitality to the commerce destroyers in British ports, and allowing them to coal and refit; (4) "indirect damages," especially the supposed prolonging of the war through the effects of British sympathy.

A political change in England in 1867 gave the suffrage to workingmen who had sympathized with the North during the Civil War; and a new ministry was willing to admit the mistake made by its predecessors. A Joint High Commission drew up the treaty of Washington (May, 1871), including "three rules" of international law which in effect were an admission that Great Britain had failed to do her duty; and in the treaty the British government made a formal apology "for the escape, under whatever circumstances, of the Alabama and other vessels from British ports." The details were left to a commission of arbitration, composed of one British, one American, and three foreign representatives.

When the arbitrators met at Geneva, in 1872, the adjustment was almost wrecked by an unexpected claim for "indirect damages," to the amount of hundreds of millions, put in by the United States. This claim was eventually withdrawn, and the arbitrators examined the evidence and found that the direct damages to American commerce from the negligence of Great Britain amounted to $\$ 15,500,000$; and in due time that sum was paid over to the United States.

In 1872 a long-pending controversy over the San Juan group of islands in Puget Sound was also settled by arbitration between Great Britain and the United States (map, p. 360). There was also a question of certain privileges desired by American fishermen on the coasts of Canada. A third arbitration commission decided in 1877 that those privileges for a period of ten years were worth a lump sum of $\$ 5,500,000$, which was paid by the United States. 
For reasons which have never been made clear, President Grant took a passionate interest in an attempt to annex the negro republic of Santo Domingo, in the eastern part of 439. Santo the island of Haiti. A treaty of annexation was drawn $\begin{gathered}\text { Domingo } \\ \text { and Cuba }\end{gathered}$ up in 1869; but ('harles Sumner, chairman of the Senate (1868-1877) committee on foreign relations, used all his influence against the treaty and in general against the administration, and prevented its ratification.

Another West Indian question was raised in 1868 when the native Cubans rebelled against the Spanish rule. On both sides it was a war of atrccities: the insurgents burned the sugar plantations; the Spaniards shot the insurgents like wild beasts. Our government remained neutral and tried to prevent filibusters from slipping over to aid the Cubans. In 1873 the steamer Virginius, with a filibustering expedition on board, was captured on the high seas by a Spanish cruiser, the prisoners were taken into port, and fifty-three of them, including eight Americans, were shot in cold blood. There would have been war but that President Grant was determined to have peace. The Spanish government granted an indemnity to the families of the Americans who were killed, but proved that the steamer Virginius was not really an American vessel at all.

Just after the Civil War came a period of fierce speculation: 24,000 miles of new railroad were built in four years; great losses came in the Chicago fire (1871) and in the Boston fire (1872), and a commercial crisis in 1873 caused failures to the amount of about $\$ 225,000,000$. Three instances of (1871-1875) fraud seemed to show a lax morality in business and in the public service: (1) it was found (1872) that the Credit Mobilier, a corporation formed to build the Union Pacific Railroad, had offered bribes in the form of its stock to members of Congress; (2) a Whisky Ring was unearthed (1875), which was defrauding the government by false accounts; (3) Secretary Belknap, of the War Department, was detected in selling the privilege 
to tralle at army posts; an attempt was made to impeach him, but he resigned, and the impeachment broke down for lack of a two-thirds vote (1876).

The question of the currency came up again, and four sig. nificant statutes were passed by Congress:-

(1) In 1876 the old "shin plasters," or fractional currency, were withdrawn, and silver dimes, quarters, and half-dollars were again issued.

(2) In a long technical act on coinage (February 12, 1873) a clause was introduced - later dubbed the "Crime of 1873 " by which the coinage of the silver dollar was stopped. Inasmuch as silver was worth more than gold at the ratio of 16 to 1 then in force, no silver dollars were then in circulation; but since gold coin was thereafter the only full legal tender coin struck by the mint, it became by this act the only legal standard of values.

(3) Vigorous efforts were made to add to the paper currency. A bill passed both houses of Congress (April 14, 1874) for the issue of about fifty millions more of greenbacks ; but President Grant vetoed it because "inflation" of the currency by issue of more paper money was contrary to the policy and promises of the government.

(4) An act (January 14, 1875) made preparations for resuming specie payments, by accumulating a specie reserve.

Though the Civil War lasted only four years, it took about eight years longer to restore the Union on the old basis. The 441. Sum- main difficulties were two: (1) the war began on the mary assumption that the states were in the Union, but when it was over, they could not safely be reconstructed at once; (2) the North was afraid that the negroes would not receive their full rights unless they were protected by the national government.

Congress took the process of reconstruction ont of the hands 
of President Johnson, and tried to register the results of the war in three constitutional amendments. (1) The Thirteenth Amendment forbade the enslavement of the negroes; this was generally accepted. (2) The Fourteenth Amendment was intended to give the negroes protection in their personal rights of holding property, fair trial, travel in public conveyances, and so on. The pith was taken out of it by the interpretation of the Supreme Court, and the states were left nearly free to deal with those questions as they saw fit. (3) The Fifteenth Amendment was intended to assure the negroes the suffrage, but they were shortly deprived of it by intimidation and violence, and did not recover it.

Nevertheless the actual result of reconstruction has been to condemn secession, and to call attention to the right of every man, white or black, to make the best of himself, and to give his children the best chance possible. In its finances, its commerce, and its foreign relations, the United States got rid of the disturbances left by the Civil War with surprising quickness, and began a new period of advance.

\section{TOPICS}

(1) What was the purpose of the Thirteenth Amendment? (2) Why did the southern states ratify it? (3) What did Lincoln Suggestive think about reconstruction? (4) Why could not the Republicans hold their two-thirds majority in the impeachment of Johnson? (5) What was the argument of the Greenback party in 1868 ? (6) Why did the United States object to the presence of the French in Mexico? (7) Why did the United States purchase Alaska? (8) What were the arguments for the Pacific railroads? (9) Why was Georgia twice set back in reconstruction? (10) Why was the Civil Rights Act of 1875 held unconstitutional? (11) Why did Congress amnesty most of the Confederate leaders ? (12) Why did Great Britain apologize for the Alabama captures? (13) Jefferson Davis in Fort Monroe. (14) Vagrancy acts of 1865. (15) Management of the Freedmen's Bureau. (16) Search topics Public career of Andrew Johnson before 1865. (17) Thaddeus Stevens as a debater. (18) Secretary Seward's protests 
against the French occupation of Mexico. (19) Burlingame's mission and treaty with the United States in 1868. (20) Massacre of General Custer's command. (21) Early descriptions of a transcontinental rail journey. (22) The carpetbag legislatures. (23) Origin of the Ku Klux Klan. (24) The Credit Mobilier. (25) Amnesty Proclamation of May, 1865. (26) Why were not southern representatives and senators admitted in December, 1865 ? (27) Debates on the reconstruction acts of 1867. (28) Why did the Supreme Court reverse its own legal tender decision?

\section{REFERENCES}

Geography Secondary authorities

Sources

lilustrative works

Pictures
See maps, pp. 492, 10, 11, 516 ; Dunning, Reconstruction.

Wilson, Division and Reunion, §§ 125-139; Johnston, Politics, 207-242 ; Stanwood, Presidency, 313-355 ; Dunning, Reconstruction,-Civil War and Reconstruction, 63-303; Wilson, Anerican People, V. 1-104 ; Rhodes, United States, V. 516-626 ; Larned, History for Ready Reference, V. 3560, 3721, VI. 170; Curtis, Constitutional History, II. 349-396; Landon, Constitutional History, 250-265, 331-348; Brown, Lower South, 191-225; Dewey, Financial History, §§ 142-158, 163-170 ; Foster, Century of Diplomacy, 401-437; Latané, United States and Spanish America, 136-174, 221-265 ; McCall, Thaddeus Stevens, 239-348; Storey, Charles Suniner, 255-270, 282-432 ; Hart, S. P. Chase, 319-435; Bancroft, W. H. Seward, II. 419-500; Adams, C. F. Adams, 377397 ; Linn, Horace Greeley, 214-259.

Hart, Source Book, §§ 127-132, 134,-Contemporaries, IV. § 141-157, 162, 163, 173-176, - Source Readers, IV. \$§ 24-26 ; MacDonald, Select Statutes, nos. 44-95, 99 ; Hill, Liberty Documents, ch. xxiii.; Caldwell, Survey, I. 189-193; Territorial Development, 203-213; Johnston, American Orations, IV. 129-188 ; McCullough, Men and Measures; Botume, Amongst the Contrabands; American Annual Cyclopedia, 1865-1874; Smedes, Southern Planter, 231-341. See N. Eng. Hist. Teachers' Ass'n, Historical Sources, $§ 89$.

Lowell, Biglow Papers (second series); A. W. Tourgée, Fool's Errand,-Bricks without Straw; E. E. Hale, Mrs. Merriam's Scholars; Octave Thanet, Expiation; T. N. Page, Red Rock; G. W. Cable, John March, Southerner; D. R. Locke, Struggles of Petroleum V. Nasby; J. W. De Forest, Honest John Vane (Washington); S. E. White, The Westerners.

Wilson, American People, V.; Gay, Bryant's History, V.; Harper's Weekly; Harper's Monthly. 


\section{CHAPTER XXXII.}

\section{NEW FOUNDATIONS (1875-1885)}

When the questions arising out of the Civil War were adjusted, a great social and commercial advance began. In 1876 the Americans commemorated the hundredth anniversary 442. Elecof the nation by a Centennial Exposition held at Phila- tion of 1876 delphia, at which machines and products of every kind were shown; millions of people had their first opportunity to see spinning, weaving, printing, paper manufacture, and like processes, actually performed before their eyes.

For the presidential nomination of 1876 the Republican convention passed over both General Grant, who would probably have accepted a third term, and James G. Blaine, Speaker of the House from 1869 to 1875 , and finally settled on

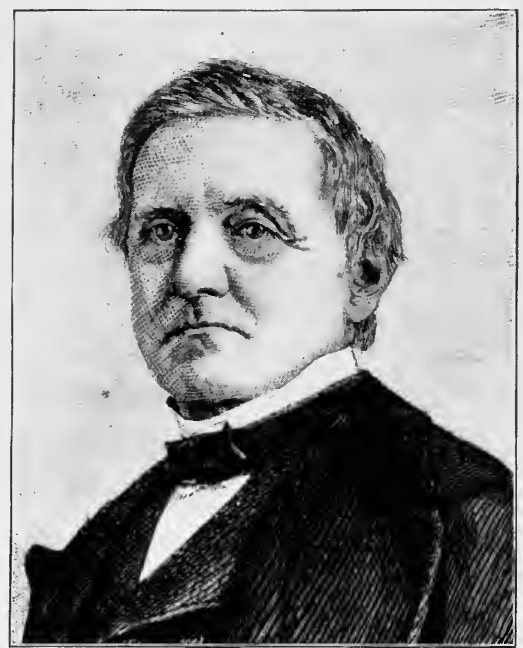

Samuel J. Tillden in 1876.

General Rutherford B. Hayes, governor of Ohio. The Democrats nominated Samuel J. Tilden of New York, a very honest and conservative man, the ablest in the party. An organization of the western farmers, under the name of Patrons of 
Husbandry, - oftener called "Grangers," - formed in 1867, now made itself felt in the nomination of a third party candidate by the "Greenback Party," which stood for the views of the Grangers.

The main issue in the campaign was "the Bloody Shirt" - that is, the question of the disloyalty of the South and its friends during the Civil War. On the morning after election day Tilden appeared to have 203 votes and Hayes 166 ; and on the popular vote Tilden had a plurality of 250,000. The Republicans, however, at once claimed that the legal votes in South Carolina, Florida, Louisiana, and Oregon were for their candidate, and that the Republican Senate was to make the count and decide the contest; the Democratic House insisted that the two houses must unite in counting the vote.

The question was complicated, because in the three disputed southern states many Democratic ballots were thrown out. On 443. Elec- the other hand, everybody knew that if the negro voters

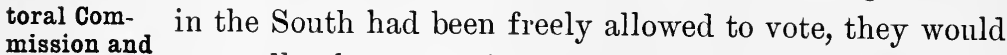
the South assuredly have carried those states for Hayes. As (1877-1881) March 4 approached without a settlement of the dispute, public excitement ran high. After fierce discussion, an act was passed (January 29, 1877) for a special Electoral Commission of fifteen members - seven Republicans, seven Democrats, and (it was expected) one Independent. Instead of the Independent a Republican was chosen; and on every one of the many disputed questions, by a majority of eight to seven, the commission decided for the Republican contention. The result was that on March 2, 1877, Hayes was declared elected by 185 electoral votes to 184 .

Before the commission finished its work Hayes had intimated that he did not mean to keep troops in the South any longer; and in a few weeks the soldiers were removed. The Democrats held their majority in the House from 1875 to 1881, and tried to force the President's hand by adding to the 
army appropriation act a "rider" (that is, a clause not necessary for the purpose of the act) against the use of federal election supervisors, authorized by the anti-Ku-Klux act of 1871. The President won by vetoing seven such bills in succession; and a few years later the rules of the House were so changed as to forbid the practice of attaching riders. In 1879 the Senate joined the House in an act forbidding the use of federal troops at the polls.

From 1875 to 1882 was in general a period of prosperity. The high war tariff stood after most of the other taxes were reduced; and the United States had a surplus every year, and was buying gold to get ready for a resumption of 444. Financial legislaspecie payments, which came about almost without inci- (1877-1879) dent January 1, 1879. John Sherman, Secretary of the Treasury, had accumulated $\$ 140,000,000$ in gold to protect the $\$ 350,000,000$ outstanding greenbacks, but such was the public confidence that hardly anybody demanded gold for notes.

Meanwhile an attempt was made to inflate the currency in a new way. Silver sold in London for sixty pence an ounce in 1872 , and for only fifty-three pence in 1878; and the silvermine owners of the far West felt sure that the act of 1873 demonetizing silver was causing the fall in the price of their product. The Greenback party polled less than 100,000 votes in 1876 , but the new Greenback Labor party cast $1,000,000$ in the state and congressional elections of 1878 ; and it demanded that the United States again coin silver dollars. Mr. Bland of Missouri introduced a bill which passed over Hayes's veto (February 28, 1878), providing that the United States should coin " not less than two million dollars' worth per month nor more than four million dollars' worth per month" into silver dollars at the old ratio of 16 to 1 ; and during the next twelve years the mint struck three hundred and seventy million of the dollars. The act, however, did not restore the old right which had existed from 1792 to 1873 , of "free coin- 
age," that is, of exchanging bullion at the treasury for its weight in silver dollars ( $\$ 196$ ), though free coinage of gold was continued. In effect, therefore, gold remained the standard, but the silver dollars circulated freely at their face value.

Soon after the Civil War people woke cp to the problems of their municipal government. The cities outgrew both their 445. Devel- physical surroundings and their forms of government. opment of Most of them were slovenly; old residential quarters American cities (1860-1880) were taken up for business, or went backward into teneat grade; pavements were poor; no city was thoroughly cleaned; few had proper sewers or water supply; even a rich

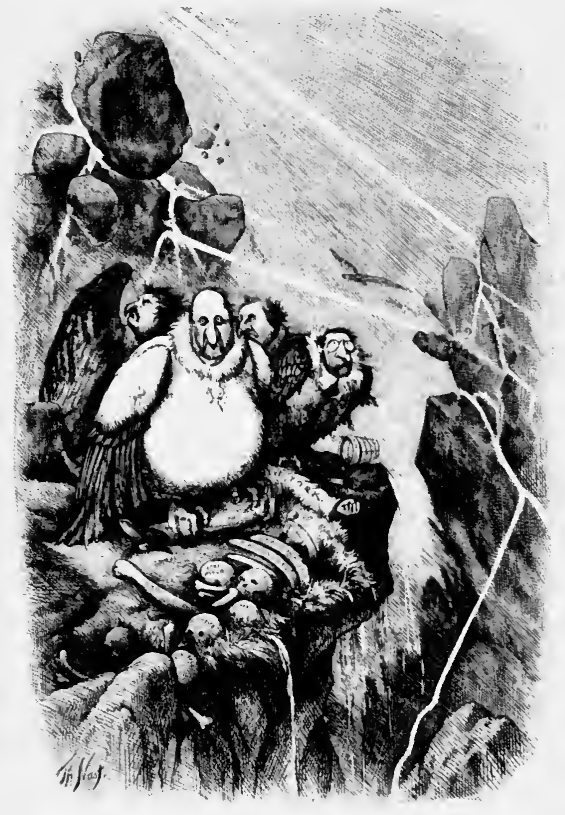

WAIting FOR THE Storm to BLOW OVER.

Cartoon by Thomas Nast; the largest vulture represents Boss Tweed. city like Philadelphia had surface drainage in many quarters. By 1870 most of the cities had mayors chosen by direct popular election, regular police departments, and many of them paid fire departments and good schools; but not one had a well-organized central government, controlling all parts of the city's functions.

Great defects in city governmentwereshown in the systematic plunder of New York eity by a gang known as the Tweed Ring (1869 to 1872). "Boss Tweed" 
worked through the government of the county of New York, and by fraudulent contracts stole about $\$ 100,000,000$. In exposing this nest of robbers Samuel J. Tilden rendered good service. The ring was broken up, the conspirators scattered, and Tweed was sent to the state prison. What the cities needed was system, economy, and forethought, such as was found among private stock companies.

Savings banks sprang up all over the North, and their deposits increased about sixfold from 1860 to 1880 . Life insurance was also developed as a means of saving and of providing for families, and in the same period policy holders and amounts invested increased nearly ten times over. (1865-1875) 446. Rise of great corThe insurance companies and savings banks were always ready to lend money on good real estate security, and that helped the building of towns and cities. Manufacturing corporations were growing in numbers and in power; and many private firms were changed into stock companies.

Another type of corporation was the great monopoly controlling some large line of business. In 1870 was chartered in Ohio a corporation called the Standard Oil Company, directed principally by John D. Rockefeller, for the purpose of manufacturing illuminating oil out of petroleum. In a few years it became one of the largest and most profitable corporations in the country. It consolidated with other companies; it had special contracts with the railroads, and was soon able to drive most of its rivals out of business; and its property, which in 1870 was about $\$ 1,000,000$, rose in 1900 to an amount estimated at $\$ 500,000,000$.

The richest and most important corporations were the railroads. All the eastern roads had state charters, which could give no rights outside the state limits. Hence "parent companies" were formed to lease or operate local lines. Foremost was the Pennsylvania Company, 447. Beorganization of transportation (1860-1880) which now holds at least thirty charters in twelve states. In 


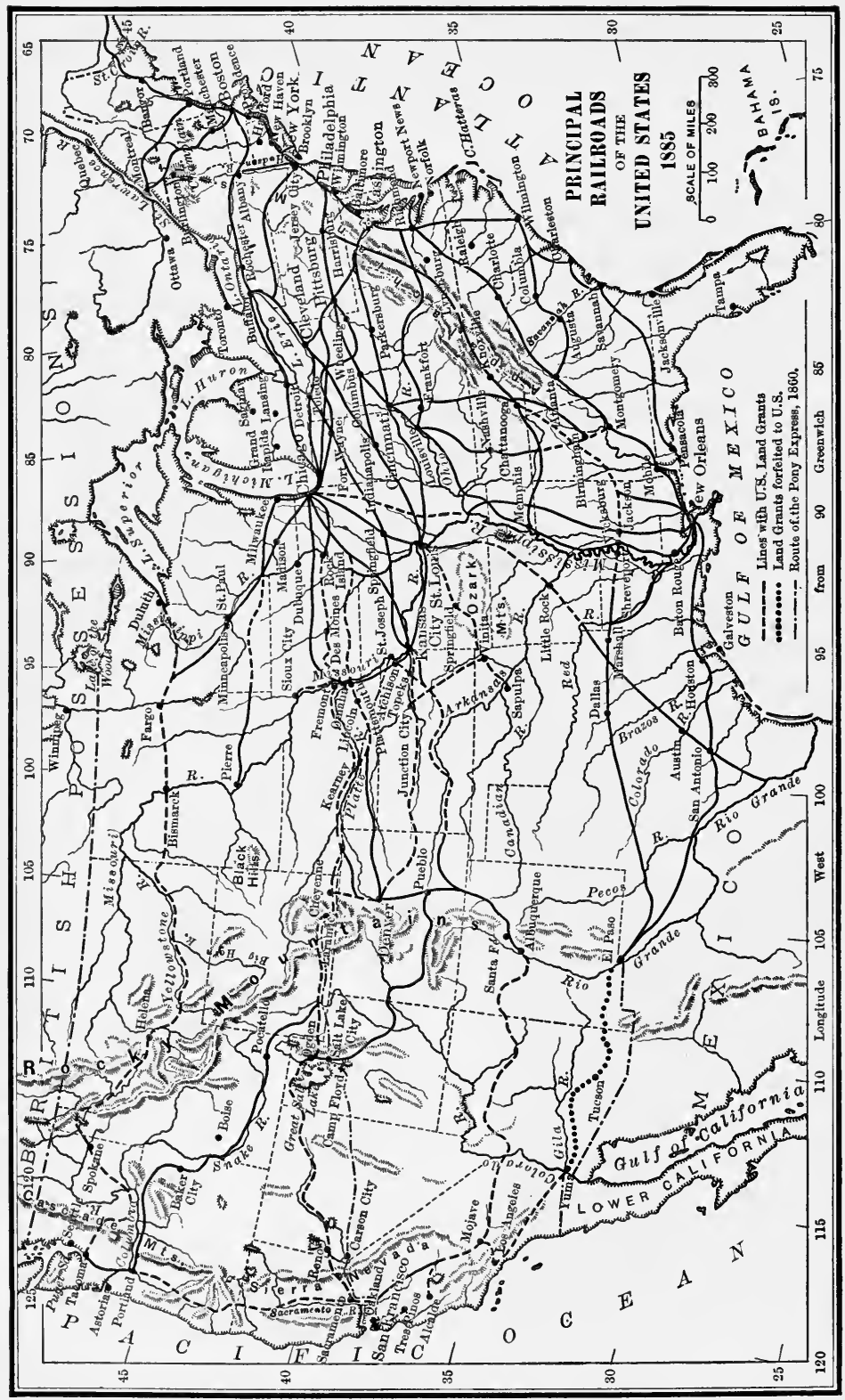


this process there was plenty of "stock watering" - that is, issuing of shares to an amount greater than the cost of the property, and then trying to earn dividends on the whole capital

Up to the Civil War most of the railroads were organized in lengths of a few hundred miles at most. Cornelius Vanderbilt, a steamboat king, bought an interest in several railroads branching out from New York, and in 1869 made a mion between the Hudson River Railroad and the New York Central, which gave an all-rail line, under one management, from the wharves of New York to the wharves of Buffalo. The Pennsylvania Railroad, till then running from Philadelphia to Pittsburg, absorbed the Fort Wayne route to Chicago (1869), and the Pan Handle route to Cincinnati and St. Louis; and in 1875 changed its eastern terminus to New York. It also founded an "American Line" of steamers (1873), sailing from Philadelphia to Liverpool.

The great delay and expense of ferry transfers led to the building of great railroad and highway bridges. The first

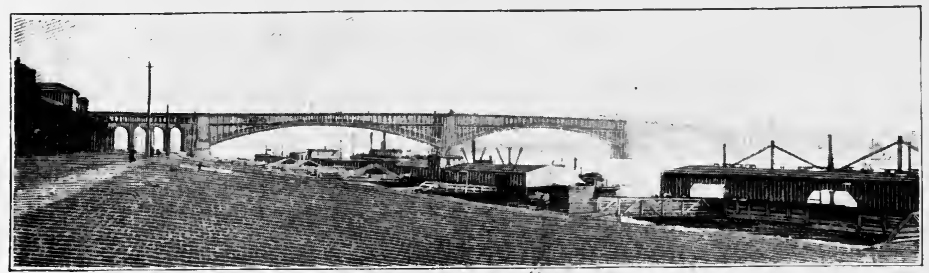

Eads Steel Bridge, St. Louis. (Spans, 520 feet.)

bridge across the middle Mississippi was built at Rock Island, Illinois, in 1856. Between 1865 and 1880 that river was bridged at a dozen other places, and in 1874 the Eads steel arch railway bridge was constructed at St. Louis. In 1867 a wagon suspension bridge was built across the Ohio from Cincinnati to Covington; and the river was bridged for a railroad at Parkersburg in 1871. The greatest work of this kind was 
the suspension bridge from New York to Brooklyn, begun in 1870 , and opened for travel in 1883.

Another great improvement was caused by the invention of the Bessemer process for making steel direct from pig iron;

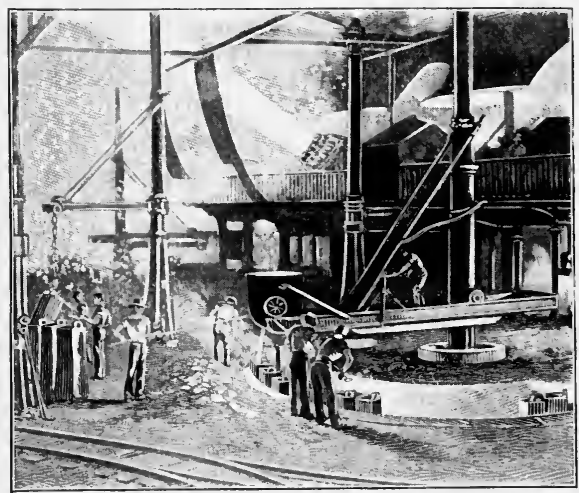

Making Bessemer Steel.

The stream of fire is from the "converter." the first American Bessemer works were put up at Cleveland, Ohio, and at Bethlehem, Pennsylvania. The Bessemer steel furnished cheap and substantial railroad rails; the stronger wheel base made it possible to run heavier cars, carrying loads still heavier, and thus transportation was cheapened. After 1880 the track gauges of almost all the railroads were made uniform, so that through freight and passenger cars could be more widely used.

New methods of sending intelligence came into use. The Western Union Telegraph Company absorbed a number of small companies, and spread a net of wires and offices over the Union; and in 1866 the first permanently successful Atlantic cable was laid. The mail system also underwent three improvements : delivery of mails by carriers (1863), postal money orders (1864), and mail cars in which clerks sort the mail while en route (1864).

Parallel with the concentration of capital went a combina448. Labor tion of labor. The first important political victory of and strikes labor was the exclusion of the Chinese, of whom the cen(1875-1882) sus of 1880 showed 105,000 in the United States. On the Pacific coast, where they were most numerous, a prejudice 
arose against them, and an agitator named Dennis Kearney, " the Sand Lots Orator," headed a movement expressed in the last words of his every speech, "The Chinese must go!" In 1879 Congress passed a bill to restrict the coming of the Chinese. President Hayes vetoed it, lest China retaliate, but in 1880 he negotiated a treaty by which the Chinese government agreed that Congress might regulate Chinese immigration. Congress thereupon "regulated" it by prohibiting it for twenty years (1882); and President Arthur vetoed this bill also. A modified bill was then passed under which the immigration of Chinese laborers was "suspended" for ten years; a principle to which the Chinese consented by treaty. Additional acts to prevent Chinese from coming in secretly were passed, and in 1892, and 1902, the entrance of Chinese laborers was again prohibited for ten years. The action of Congress prevented the coming of hundreds of thousands of men who would have brought about a race difficulty like the negro question in the South.

Trades unions were active long before the Civil War, and in 1869 the order of Knights of Labor was founded, as a general society open to workmen of all trades; but its power was little felt before 1883. Contests between employers and organizations of workmen led to a series of terrible strikes, the worst of which was the railroad strike of 1877 at Pittsburg and other places. The railroads were paralyzed, trains and stations were set on fire, and millions of dollars' worth of property destroyed. The state authorities could not stop this disorder, and United States troops were eventually called in, and put it down.

In the election of 1880 the Democrats, who had never ceased to call Hayes "the fraud President," hoped to be clearly successful. They found a soldier candidate in General Winfield S. Hancock, one of the bravest and soundest soldiers of the war. The friends of General Grant and (1881-1885) of Blaine again fought each other in the Republican conHART'S AMER. HIST. -31 
vention, and a compromise candidate was nominated, General James A. Garfield of Ohio, a good soldier and the Republican leader in the House. General Hancock seemed likely to be elected, till he wrote a letter in which he said that the tariff was "a local issue." He carried every southern state (the beginning of the so-called "Solid South"), and New Jersey, Nevada, and California. Though in the popular vote about even with Garfield, he received only 155 electoral votes to 214 .

President Garfield was shot by a half-crazed man, and died (September 19, 1881); he was succeeded by the Vice President, Chester A. Arthur of New York. Arthur proved a safe if not a brilliant President; and in his administration steps were taken to check the system of political removals introduced in Jackson's time, by which the smallest subordinate places were distributed by favor and generally as a reward for political service. Men were constantly removed to make room for new appointees; and it was a regular custom to assess government employees a certain proportion of their salaries for the national party campaign funds. By the Civil Service Act of January 16,1883, it was provided that: (1) appointments to certain clerkships and other subordinate places in the government, commonly called "the classified service," were to be made only on competitive examinations; (2) removals for political reasons were forbidden; (3) political assessments by a government official or in a government building were prohibited.

After 1879 money again piled up in the treasury and there was a popular demand, expressed by such men as James A. Garfield, for a reduction of the tariff. The discussicn came to a head in 1882, and Congress authorized a commission to draw up a bill - the only case of the kind in our history. But Congress discussed, revised, and essentially altered the draft, so that the final outcome, the tariff of March 3, 1883, reduced duties on some kinds of goods, but raised the average rate of duty from about 43 per cent to about 45 per cent. 
After the settlement of the Alabama claims ( $\$ 438$ ) several questions of foreign policy arose in Latin America. President Grant threatened in 1875 to call on the great European powers to unite with us in intervention in Cuba, and Spain made peace with the Cubans in 1878. Negro (1875-1881) slavery speedily died out in Cuba, and the trade of the island rapidly increased; but as a participant in the rebellion afterward said, "We went to work to save money for another revolution."

In 1878 the government of Colombia granted a "concession" to a French company to construct a canal across the Isthmus

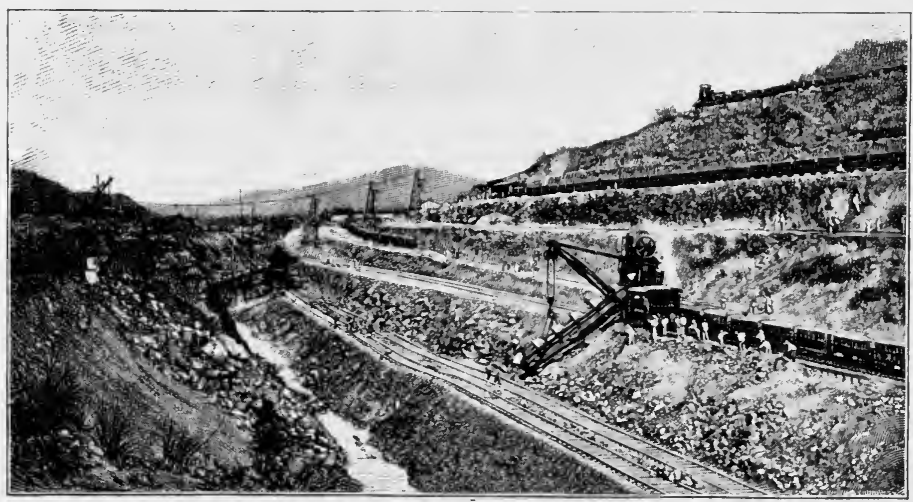

French Work on the Panama Canal.

Culebra cut, 300 feet above sea level.

of Panama. The leading spirit was Ferdinand de Lesseps, who had constructed the Suez Canal, and who had the confidence of the French investors. He designed a tide-level canal through a divide about 300 feet high; and the company at once began to raise money. Vainly did President Hayes try to arouse the people of the United States at the prospect of a canal to be controlled by Europeans, although in a message to Congress (1880) he said that a canal would be a great ocean 
thoroughfare between our Atlantic and our Pacific shores, and "virtually a part of the coast line of the United States."

From March to December, 1881, James G. Blaine was Secretary of State. In those few months he attempted to found an 451. Pan- American policy which should bring about three things: American leadership among the American states, reciprocity with (1881-1882) those states, and an isthmian canal under the control of the United States:-

(1) Blaine was struck by the losses and confusion caused by the wars among the Latin-American powers. In 1881, after an exhausting struggle, the Peruvians were at the mercy of Chile, and Blaine instructed our ministers to Peru and Chile to use their influence to soften the demands of the conquerors. The ininisters went beyond their instructions, and threatened Chile, which left on the minds of the Latin-American states the impression that Blaine meant to settle their affairs for them.

(2) Blaine strongly believed that it was for the interest both of the United States and of the countries south of us to build up mutual trade by special "reciprocity" treaties, by which the tariff duties should be reduced on both sides; but he could not persuade Congress of the need.

(3) Blaine was very anxious to make it clear that the Panama Canal was the special concern of the United States; and he tried to get rid of the troublesome Clayton-Bulwer treaty. Great Britain simply stood by the treaty.

A private company was formed in New York (1884) to build a rival canal by the Nicaragua route, and made some preliminary surveys. The French Panama Canal Company was at work from 1881 to 1889 ; but after spending $\$ 100,000,000$ on the canal and $\$ 160,000,000$ more on salaries, commissions, interest, and nobody knew what else, the company failed (December, 1888) and the work was suspended. 
From 1875 to 1883 the most striking thing in American history is the commercial development of the country. After the dangerous crisis of the disputed election of 1876-1877, the 452. Sumcountry was prosperous and put to use new methods of mary doing business. Never had there been such great undertakings; cities were rapidly built up, towns and villages increased. Though most of the old canals fell out of use, the railroads were lengthened, improved, and consolidated into long systems. Railroad and other corporations came into being with such capital and power as the country had never before dreamed of. The laborers also began to understand the power of combination; they forced legislation against the Chinese, and showed their power in several terrible strikes.

The finances of the United States so much improved that specie payments were resumed in 1879 , but at the same time the currency was expanded by the coinage of the Bland silver dollars. In the tariff discussion of 1883 an.unsuccessful effort was made to adapt the revenue system to the changed conditions of the country. There was a beginning of national civil service reform, and an attempt was made to found a new foreign policy by asserting a special interest in Latin America.

\section{TOPICS}

(1) Why were the soldiers removed from the South in 1877 ? Suggestive (2) What are the functions of a life insurance company? (3) What topics is the difference between savings banks and national banks? (4) What is the advantage of corporations over private firms? (5) Whict is stock watering? (6) Why did Kearney urge that "The Chinese must go"? (7) Why did President Hayes object to a French canal across the Isthmus of Panama? (8) Why was General Garfield nominated for the presidency in 1880 ? (9) What is "the classified service"? (10) Why did Blaine wish to abrogate the Clayton-Bulwer treaty?

(11) Political career of Samuel J. Tilden before 1876. (12) Debates on the Electoral Commission Act of 1877. (13) What caused Search ihe fall in silver from 1872 to 1878 ? (14) Debates on the Bland 
Bill, 1878. (15) Methods of the Tweed Ring. (16) Samuel J. 'Tilden's opposition to the 'Tweed Ring. (17) Early history of the Standard Oil Company. (18) Cornelius Vanderbilt as a railroad king. (19) History of the Eads steel bridge at St. Louis. (20) History of the suspension bridge at Cincinnati. (21) History of the Brooklyn bridge at New York. (22) Submarine telegraph cables. (23) Origin of the Knights of Labor. (24) Debates on the Civil Service Act of 1883. (25) Why was General Grant not nominated for the presidency in 1876 ? (26) Why was James G. Blaine not nominated for the presidency in 1876 ? (27) What were the principles of the Greenback Labor party? (28) What were the objections to the votes of South Carolina, Florida, and Louisiana in 1876 ?

\section{REFERENCES}

Geography

Secondary authorities

Sources

Illustrative works

Pictures
See maps, pp. 516, 581.

Wilson, Division and Reunion, §§ 140-142 ; Johnston, Potitics, 242-265; Stanwood, Presidency, 356-418; Wilson, American People, V. 104-169 ; Cambridge Modern History, VII. 644-654 ; Gay, Bryant's History, V. 447-485, 512-543 ; Larned, History for Ready Reference, V. 3577 ; Curtis, Constitutional History, II. 397-440 ; Dewey, Financial History, §§ 159-161, 171-180; Noyes, American Finance, 17-103; Taussig, Tariff History, 230-250; Stanwood, American Tariff Controversies, II. 192-219; Latané, United States and Spanish America, 198-214; Wilson, General Grant, 310-329, 350-364.

Hart, Source Book, §§ 133, 135-137, 140,-Contemporaries, IV. $\S \S 158-160,168,169,177$; MacDonald, Select Statutes, nos. 96-98, 100-108; Johnston, American Orations, IV. 296-328; Appleton's Annual Cyclopcedia, 1875-1884. See N. E. Hist. Teachers' Ass'n, Syllabus, 358, - Historical Sources, § 90.

Anonymous, Democracy; G. F. Atherton, Senator North; P. L. Ford, Honorable Peter Stirling; Gwendolen Overton, Heritage of Unrest (Indians); F. H. Burnett, Through One Administration. Harper's Weekly; Harper's Monthly; Scribner's Monthly. 


\section{CHAPTER XXXIII.}

\section{ECONOMIC AND SOCIAL ISSUES (1885-1897)}

The presidential election of 1884 marks the time when the two national parties gave up the outworn issues of the Civil War and reconstruction, and began to divide on the 453. Change pressing questions of revenue, expenditure, currency, of political trusts, and especially on the protective tariff. The Re- (1882-1889) publican candidate was at last James G. Blaine; the Democrats put up Grover Cleveland, who had been elected governor of New York in the year 1882 by the unprecedented plurality of 192,000 .

The campaign abounded in fierce personalities. Blaine's enemies secured and published certain "Mulligan Letters," which, they considered, showed that he had used his office of Speaker for the private advantage of himself and his friends. Cleveland was supported

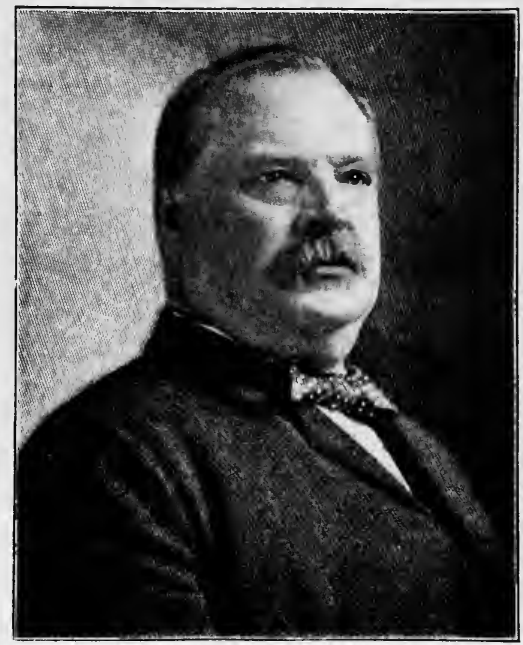

Grover Cleveland, about 1890. not only by his own party, but also by the "Mugwumps," or independent Republicans, who expected him to stand for purer politics. For several days after the election the result was in doubt - without New York Cleveland could not 
be elected, and in that state he had a plurality of only 1149 , in a total vote of 1,167,000. The "Solid South," with Indiana, New Jersey, New York, and Connecticut, gave Cleveland 219 electoral votes against 182 for Blaine from the other states.

As Cleveland was the first Democratic President since Buchanan, his election seemed to his opponents a revolution, and it was freely predicted that he would pay off the Confederate debt or even reduce the negroes again to slavery. $\mathrm{He}$ was a resolute President who vetoed 301 bills, and followed Grant in defeating many private pension and relief bills; but the Democrats never had a majority in the Senate during his first term, and the President could do little to secure legislation to carry out the purposes of his party.

Nevertheless during Cleveland's administration and that of his successors many important non-political acts were passed. 454. Filling The West at last saw the end of half a century of Indian up the West difficulties, when the Apaches, the most ferocious of the (1886-1903) hostile tribes, were subdued in 1886. The next year Congress passed the Severalty Act, under which the best Indians were encouraged to leave their tribes, take up separate farms, and become citizens. A part of the Indian Territory was set off as the Territory of Oklahoma (1890); and the opening of part of this new area of farm lands caused a frantic rush (April 22, 1889), from the border line to the interior, to stake out and take up farms and town lots.

The reason for this stampede was that good farm lands owned by the government were almost all taken; and the grazing lands were gone, or were controlled by ranchmen who had got possession of the river fronts, indispensable for watering cattle. In Colorado, Utah, California, and other states, water companies were formed to irrigate land. This gave rise to lawsuits over "water rights," especially when people lower down the rivers began to complain that the streams were diminishing. 
In 1902 the federal government stepped in and appropriated for large irrigation works the proceeds of the public lands in many western states. To protect government timber, and keep the streams from drying up, the federal government from 1891 to 1903 set off $47,000,000$ acres of public land for forest reserves; and it had also set apart, as national parks forever, the upper Yellowstone and Yosemite valleys, and several groves of big trees in California.

The West insisted on and secured six new states - namely, the agricultural states of North Dakota, South Dakota, and Washington (1889); and the mining and grazing states of Montana (1889) and Idaho and Wyoming (1890). Utah was not included, because the territorial government was not able to prevent the practice of polygamy, which was enjoined as a moral duty by the leaders of the Mormon Church. As several milder statutes failed, Congress passed the Edmunds-Tucker Act (1887), punishing polygamy with heavy penalties, and attempting to turn over to the public schools the property of the corporation called the Church of Jesus Christ of LatterDay Saints (i.e. the Mormon Church). The church then officially declared against polygamy, but it was not till January 4, 1896, that Utah was allowed to become a state, and then on the solemn pledge in the state constitution that polygamy should never be allowed.

The South, like the West, went through great social and economic changes. After the war it recovered its supremacy in the world's cotton market. The thin and worn-out soils were strengthened by the universal use of fertilizers; and the formerly valueless cotton seed became a valuable byproduct. Rice culture spread from South Carolina into Louisiana and Texas; and, under the tariff, sugar growing became profitable in Lonisiana. Many of the splendid forests of hard pine and other timber were reached, cut, and sold. Manufactures at last reached the South. The abundant 
coal of northern Alabama was so near good ore that at Birmingham and elsewhere pig iron could be made cheaper than anywhere else in America; and great rolling mills and rail mills grew up. In 1901 immense deposits of oil were discovered in Texas, furnishing a cheap fuel. Cotton mills were started on a great scale, but had to depend on the labor of the poor whites ; for few foreigners come into the southern states, and the negroes, though they perform most of the unskilled labor in the South, do not seem adapted to the factories.

The South also enjoyed a large intellectual growth; public

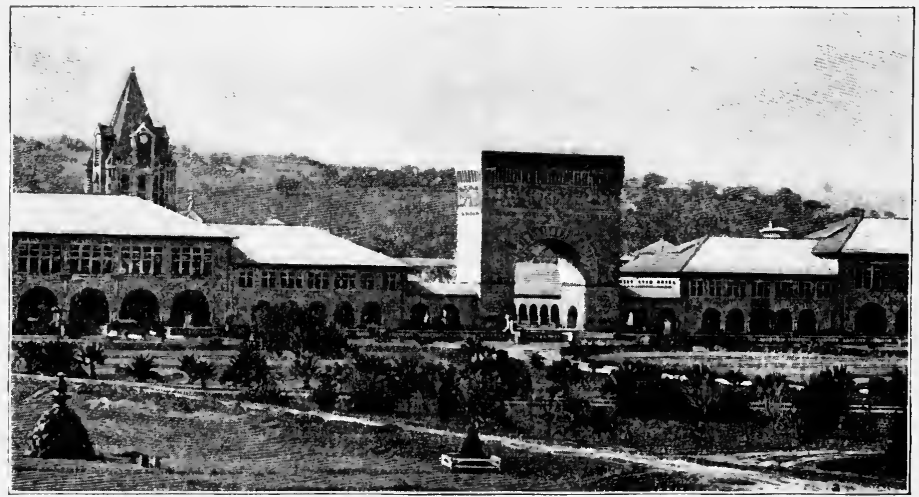

Stanford University, California. (Gateway and cloisters.)

schools were founded, including hundreds of high schools ; colleges increased in number; several states, notably Virginia, North Carolina, and Texas, fostered vigorous state universities. For the negroes there were founded separate public schools (mostly elementary); and good private institutions at Hampton, Atlanta, Tuskegee, and elsewhere, which prepared the most promising negroes to be teachers, ministers, doctors, lawyers, and also mechanics and farmers.

Education throughout the country made great advances after 456. Mod- 1865; and nearly twenty colleges were founded exclution sively for the education of women, while many of the old 
universities opened their doors to women. The founding of Johns Hopkins University in 1876, on the German model, stirred up all the older endowed and state universities, and was followed by Tulane in New Orleans (1884), Leland Stanford (1891), and Chicago (1892). 'The methods of college education altered; less classics and mathematics were required, and more sciences, modern languages, philosophy, economics, and English; there was less routine and more elective work; less rule and discipline, and more freedom; less horseplay, and more athletics. Public schools, both city and rural, improved by new subjects of study, new methods of teaching, and bettertrained teachers.

New libraries appeared in all parts of the Union, both in the great universities and in cities, espe-

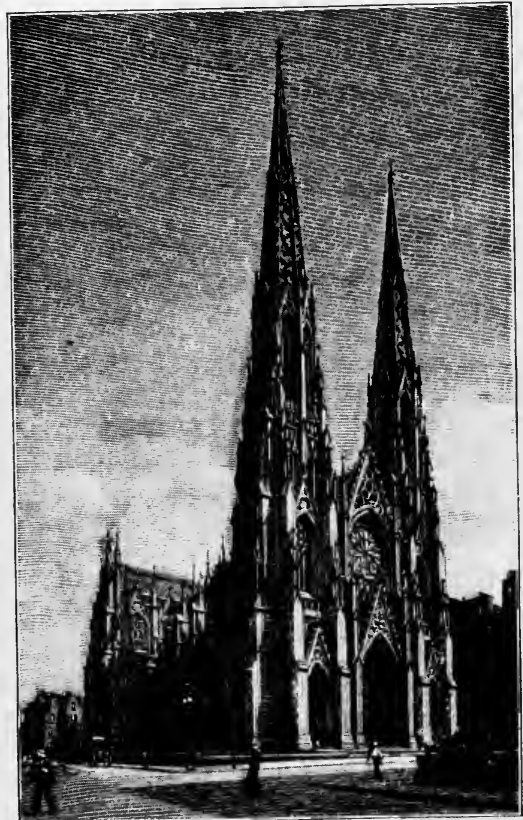

Copyright, 1902, by C. C. Langill.

St. Patrick's Cathedral, New York, OPENED IN 1879.

Designed by James Renwick. cially the Boston Public Library, the New York Public Library, the Newberry in Chicago; and a palatial building was erected for the enormous collection of the Library of Congress at Washington. Many small libraries were enlarged by gifts made by Andrew Carnegie, a man of large fortune, who also gave (1901) a great fund to endow scientific and historical research. 
American literature by 1890 had lost its great lights of the "golden age"; but a new school of writers arose-John 457. Litera- Fiske, Henry Adams, James Ford Rhodes, and Alfred 'T. ture and art Mahan among historians; Bret Harte, W. D. Howells, George W. Cable, and Winston Churchill among novelists; "Mark Twain" (S. L. Clemens) and "Mr. Dooley" (Finley Peter Dunne) among satirists; among essayists and depicters of

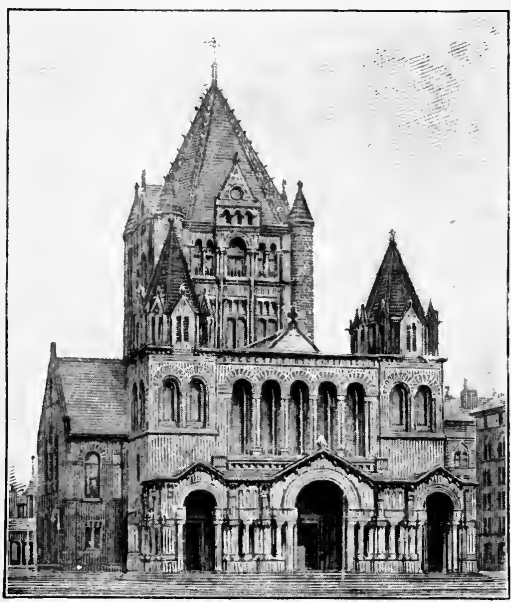

Trinity Church, Boston, completed IN 1877.

Designed by Richardson. character, Joel Chandler Harris and Thomas Nelson Page; and the best American illustrated monthly magazines are unrivaled in their kind.

For the first time in American history, a genuine native school of art developed, including Abbey, Sargent, and Chase, among the great artists of the world; McMonnies, St. Gaudens, and Daniel French, sculptors for the ages; Hunt and Richardson and McKim, worldrenowned architects. Americans, beginning with Frederick Law Olmsted, learned to make beautiful grounds, parks, and boulevards, and to adorn them .with such memorials as the Washington Monument in Washington, and such public buildings as the Museum of Fine Arts in Chicago.

Hundreds of new inventions, and improvements in old ones,

458. Progress of invention came into use after the Civil War: systems of heating buildings by hot air, steam, and hot water; artificial ice; barbed wire fencing and wire nails; house drainage; building paper; elevators for storing and loading grain; 
passenger elevators in high buildings; asphalt and wooden block pavement; plate glass windows of large dimensions; improved firearms, especially the automatic machine guns of Hiram Maxim and others; new explosives, especially dynamite; sulky plows and other farm machinery; compressed air drills for mining; steel safes and bank vaults; chemical dyestuffs; new metals and alloys. Many new safety appliances were adopted in the steam railroad service, especially the air brake, introduced by George Westinghouse in 1868, the automatic coupler, the continuous car platform and vestibule, telegraphic train dispatching, and automatic switches and signals.

The system of "assembling" machines out of parts, each of which is made by the thousand in standard dimensions, has wonderfully cheapened many lines of manufacturing : it is applied all the way from watch-making to locomotive building. It leads, however, to subdivision and specialization of labor, and tends to diminish all-round training of mechanics.

Three machines deserve special mention: (1) the low. bicycle appeared about 1876 , and has been followed by the

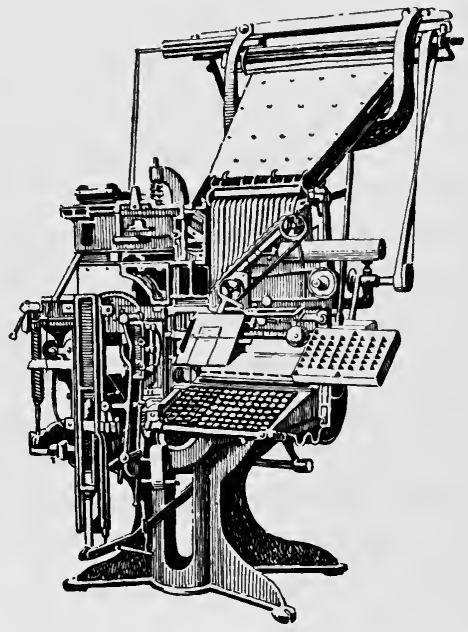

Linotype Machine.

Casts a line of type in one piece, from matrices "set" by use of a keyboard and afterward "distributed" automatically. automobile; (2) the typewriter, first put on the market in 1874, furnishes a new employment for thousands of men and women; (3) the type-setting and type-casting machines, perfected after 1890, have quickened and cheapened the process of making books and newspapers. 
The greatest inventive leap has been the use of electricity, especially in four forms: (1) electric lights, - first the arc, then the incandescent, - pushed into use by Charles F. Brush and Thomas A. Edison, who took out at Washington more than one thousand patents for various inventions; (2) the telephone, first exhibited by Professor Alexander Graham Bell in 1876; (3) electric trolley cars taking power from a wire, made practicable about 1880 ; (4) electric motors for fixed machinery and for wheeled vehicles.

Corresponding to the development of new mechanical processes was the growth of new forms of business organization. 459. The Corporations were so numerous and so useful that it was trusts

a great step when (about 1850) the states began to stop making special charters, and allowed people to incorporate themselves under general laws. Such corporations enjoy two special privileges: the right to hold corporate property and to sue; and the limited liability of stockholders, relieving them from responsibility in their private property for the debts of the company. In return, the states have a right to regulate corporations in ways not applied to private partnerships. Nevertheless many things make it hard to keep them in control: (1) The corporation may be so rich and powerful that it simply ignores the laws and government, as happened in the early days of the "Standard Oil Company"; (2) the corporation, though acting within the law, may have a monopoly of some line of business - such as sugar refining - and thus defy competition; (3) one corporation may own another corporation, and mix up the accounts of the concerns, often to the disadvantage of the small owners of the stock; (4) to float new enterprises, great bankers and capitalists sometimes get together in "syndicates" with secret and complicated interests and obligations ; (5) occasionally several corporations, instead of combining, make an agreement that the stock of all the corporations shall be held and voted by a body of trustees. 
The last case is, strictly speaking, the only real "trust"; but the name is loosely given to any large corporation or combination of corporations which is trying to control a large line of business - such as the meat trust and the tobacco trust. A very common form of "trust" is a company or group of companies which controls some public service, such as water, gas, or traction, and often holds a city at its mercy. The so-called trusts increased very fast after 1890, the most striking being the United States Steel Company, organized in 1901 with a capital of $\$ 1,100,000,000$.

The great corporations most in the public eye are the railroad companies. Railway kings like William H. Vanderbilt, Jay Gould, James J. Hill, and E. H. Harriman have consolidated small roads into systems thousands of miles in extent, especially the trunk lines from Chicago to 460. Control of transportation New York, and the transcontinental routes. Up to 1887 the only power which regulated the railroads was that of the state governments, sometimes working through railroad commissions, with power to investigate and supervise, or even to fix rates. The states, however, had no complete control over business passing from one state to another, for interstate commerce is subject to the federal government. The railroads, therefore, contrary to the established legal principle that a common carrier must take everybody's freight on equal terms, were in the habit of making discrimination between shippers: (1) they gave special rates to large shippers; (2) they charged higher freights for a shorter distance - say from Chicago to Syracuse - than for a longer distance on the same route - say from Chicago to New York; (3) they formed "pools," or agreements, by which all the freight offered was arbitrarily divided among competing roads.

The federal government for many years let the railroads alone, and gave its attention to water ways. Every year or two after 1870 a river and harbor bill passed Congress, and 
became law, unless, as several times happened, it was vetoed. In 1879 Captain Eads built a system of jetties at the mouth of the Mississippi, which made New Orleans a deep-sea harbor. For the enormous lake trade in iron ore, coal, grain, and lumber, the government built a ship canal between Lake Superior and Lake Huron, around the falls of Sault Ste. Marie; deepened the channels through St. Clair Lake and the Detroit River;

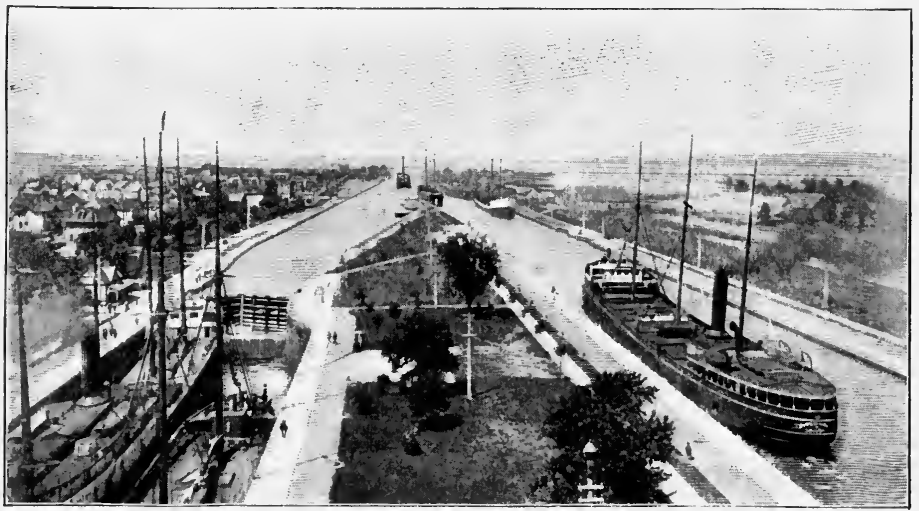

Locks of the Sault Canal, completed in 1896.

and made harbors at Chicago, Milwaukee, Cleveland, Buffalo, and many smaller lake ports.

Eventually public sentiment forced Congress to pass the "Cullom Act," or Interstate Commerce Act (February 4, 461. Na1887), to regulate commerce between the states, on the tional con- following principles: (1) the railroads were forbidden to trol of interstate commerce (1887-1903) make a higher charge to one customer than to another for the same service; (2) they were forbidden to form "pools"; (3) all freight rates were to be publicly posted and could neither be raised nor lowered without notice; (4) by the "short haul clause," no railroad could charge more for carrying freight a shorter distance than it charged for carrying freight over the same line to a greater distance; (5) the 
roads were to make sworn reports of their business to the government. To carry out this act, an Interstate Commerce Commission was provided with power to investigate and make decisions. Since 1887 Congress has passed other acts on interstate trade, increasing the power of the commission; prohibiting the roads from combining to restrain trade (1890); stopping the transportation of liquors into prohibition states (1890); compelling the roads to use a uniform car coupler (1893); and forbidding the circulation of mail or express matter intended for lotteries or gift concerns (1895).

The advances to the Pacific railroads ( $\S 434$ ) by 1899 amounted to $\$ 64,000,000$ of the original bonds, and $\$ 72,000,000$ of interest, paid by the United States. Under pressure from the government, the roads repaid nearly all of this money.

The regulation of railroads suggested that Congress might also regulate any corporation or trust which did a foreign or interstate business. Accordingly Congress passed the 462. ReguSherman Anti-Trust Law (July 2, 1890), which penalized illegal combinations of manufacturing and trading com:

lation of corporations panies, as well as of railroads. In some cases trusts used their monopoly to sell cheaper to foreigners than to home customers. The states also tried to regulate corporations in business done entirely within the limits of one state. Some states have gas, insurance, and other executive commissions; some rely on requiring corporation accounts to be filed; some tax the trusts; and New York state, in 1899, taxed the traction companies on the value of their privilege to use the streets.

The labor unions grew as fast as the trusts. The first large unions were made up of all the men in a particular trade that would join - for example, the Brotherhood of Locomotive Engineers. In 1886 the American Federation of Labor was formed, to unite so far as possible the special trades unions into a national body, which should have authority to order men in one trade to strike in order to help strikers in 
another trade; and the Federation through strikes pressed the issue whether employers would "recognize the union," - that is, would make agreements with their employees only through officers of the union, - and would establish the "closed shop" - that is, would employ only union hands.

The supply of labor was affected by a wave of immigration of races which, up to 1870, were not much known in America

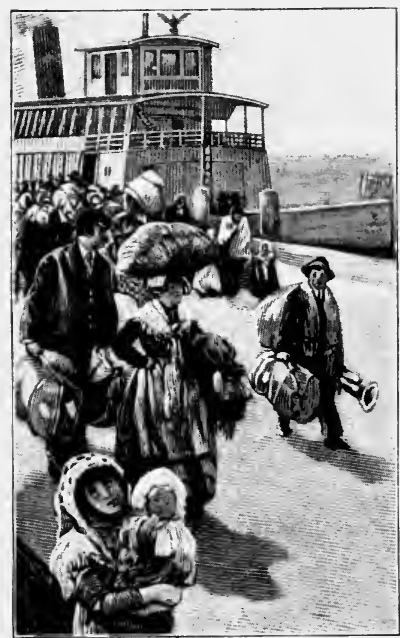

LANDING OF IMMigRANTS, 1900. - Italians, French Canadians, Poles, Bohemians, Hungarians, Russian Jews, Slovaks, Armenians, Greeks, and Syrians. The workingmen secured from Congress a series of acts somewhat restricting immigration. (1) Convicts, idiots, and like unfit persons were shut out, and a head tax of fifty cents was laid on all immigrants admitted (1882). (2) Congress excluded "contract laborers" who might come over under an agreement to take a specified job when they arrived (1885). (3) Polygamists, diseased persons, and persons unable to support themselves were shut out (1891). (4) The immigrant head tax was raised to two dollars (1903). That some foreigners were dangerous to society was shown by an anarchist outbreak in Chicago (May 4, 1886). After weeks of violent speeches, principally by foreigners, urging people to resist the government, a dynamite bomb was thrown in the Haymarket and killed seven policemen. The crime was supposed to result from the utterances of the anarchists; several of them were convicted, and four were executed. After the assassination of McKinley by an anarchist, the immigration of anarchists was prohibited (1903). 
A test of the power of the new labor unions was a series of great strikes. The first came in 1886 on the Gould system of railroads leading southwest from St. Louis. In 1892, in a fearful strike at the Homestead Iron Works near Pittsburg, a body of private guards, furnished by a de(1886-1902) tective agency, and sworn in as constables, were fired upon by the strikers, several of them killed, and wounded men were put to death by infuriated men and women. There were many strikes during 1893 and 1894, of which the worst began in a strike of the hands employed by the Pullman Car Works near Chicago. The American Railway Union, through their president, Eugene V. Debs, took up the dispute, and demanded that the company settle it with them, as representing organized labor. When the company refused, Debs called out the railroad men on a "sympathetic strike"; and the men on one road after another refused to handle first Pullman cars, then the cars of the "tied-up roads," till the whole railway business of Chicago, and indeed of the whole great country west of Chicago, was in confusion. Non-union men (called "scabs" by the strikers) who were employed by the railroads were beaten, and some of them killed. The unions disclaimed responsibility for these acts of violence.

As the government of Illinois did not keep order, President Cleveland made use of the only organized force adequate for such cases by calling out United States troops to prevent the obstruction of United States mails and of interstate commerce (July 8, 1894). This broke the.strike, and the Pullman Coinpany then came to an understanding with its employees. A federal court served an injunction on Debs, forbidding him to interfere with interstate commerce. As he ignored this injunction, Debs was imprisoned for contempt of court, and the Supreme Court of the United States held the sentence good.

Economic reforms can be carried out only by wise and impartial governments, and people awakened to the need of 
purifying national, state, and municipal politics. President

Cleveland made some progress in improving the civil service; 465. Politi- but outside the "classified service" he sanctioned thoucal reforms sands of removals, especially among the postmasters, in (1883-1895) order to make room for party friends. Under Cleveland's successor, Harrison, the chairman of the Civil Service Commission was Theodore Roosevelt, who gave the name of "Merit System" to the method of opening the public service to those who passed the best competitive examinations, and he followed up officials who violated the law; 44,000 offices were by 1893 placed in the classified service.

Several other defects in the workings of the federal government were corrected in this period. A Presidential Succession Act (January 19, 1886) provided that in case of the death or disability of the President and Vice President, the Secretary of State should fill the vacancy, and if he were disabled, some other member of the Cabinet in a specified succession. The danger felt in 1877 in the count of electoral votes for President was removed by an act (February 3,1887 ) for accepting as final the certificate of state electoral authorities. The Tenure of Office Act of 1867, which caused the impeachment of Johnson (\$ 429), was completely repealed (March 3, 1887). The House of Representatives found its business blocked by "filibustering" motions and amendments meant to kill time; and under the leadership of the Speaker, Thomas B. Reed, one of the ablest men of his time, adopted in 1890 a new code of rules giving the Speaker more power to stop such practices.

The states felt the reforming spirit, and two of them - New York (1883) and Massachusetts (1884) - passed statutes for the Merit System; and it was later introduced into Chicago (1895) and other cities. The cities tried to improve their governments by securing new charters from the legislatures. New York and Brooklyn and several smaller places united in 1897 in the city of "Greater New York," second in popu- 
lation and wealth only to London. To solve the difficulties of handling great numbers of people by private traction companies, independent subways were built by the cities of Boston (1898) and New York (1904); and Chicago, in 1903, took steps looking to public ownership of all the traction lines in the city. Several states made more stringent laws against fraud and

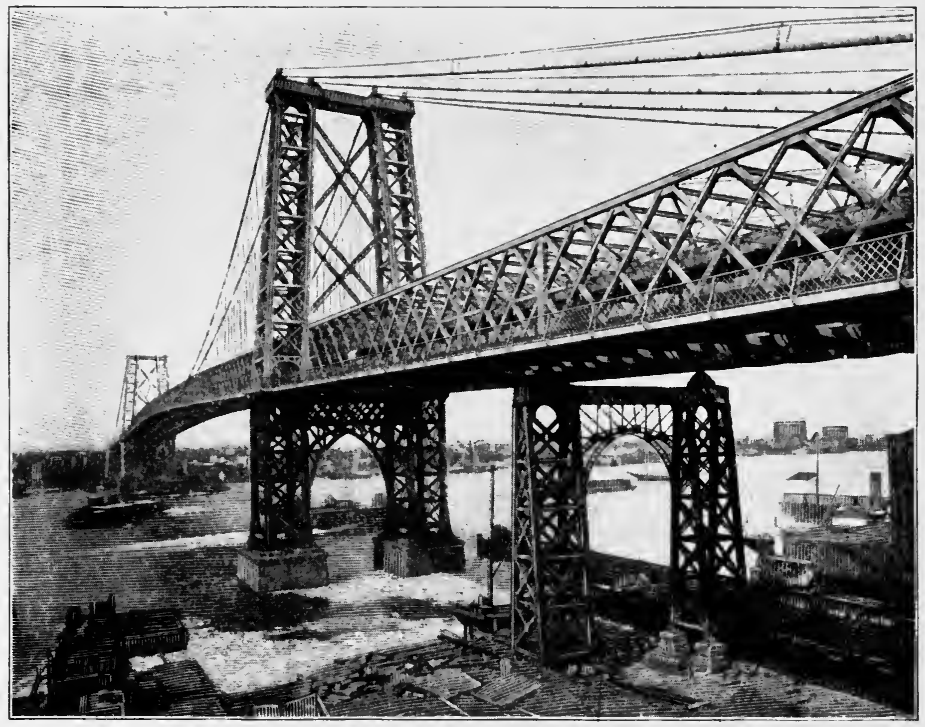

Williamsburg Bridge, New York.

(Completed in 1904 ; main span, 1600 feet.)

bribery in elections, and for preliminary registration of voters. To protect the voter in his right to cast a secret ballot, the states began, in 1888, to provide the "Australian ballot," an official list of all the accredited candidates, on which the voter in a booth by himself marks with a penciled cross the names or party tickets voted for. A majority of the states have adopted this ballot, and also laws against soliciting votes at or very near the polling place; the reform aids secrecy in vot- 
ing, and thus helps independent candidates. Many states have also passed laws to regulate the "caucus" or "primary meeting," so as to give all the voters of a party a chance to take part in nominating candidates.

For many years the suffrage tended constantly to expand, till in 1876 it was extended to women in Wyoming. Three other territories and states have since adopted the same rule. About 1890 began a reaction against a general suffrage in the southern states, marked by a series of new constitutions providing educational and tax qualifications, intended to exclude most of the negroes. Another development in the states was the provision in several western constitutions for the "initiative" and " referendum," - methods for proposing laws and for submitting them to acceptance or rejection by popular votes.

Side by side with the legislation by the nation and states on general economic and social problems went a long and fierce 466. Reve- struggle over national finance, especially the tariff and the nue and the tariff currency. President Cleveland set the political issue for (1887-1890) the campaign of 1888 in his annual message of 1887, Contempo- in which he discussed only the tariff: "It is a condiraries, $I V$. tion which confronts us - not a theory," said he. The "condition" was an annual surplus which, in 1887, reached $\$ 56,000,000$, and which was partly due to the high import duties. It locked up, in the treasury, currency needed for trade, and was a temptation to extravagant appropriations. The Democratic convention of 1888 unanimously renominated Cleveland; the Republicans settled on Benjamin Harrison, who had been senator from Indiana, and candidate for governor of that state. For the first time the Republican platform and party made high protection a party principle. By a plurality of 13,002 votes in New York, Harrison carried that state, and thus secured 233 electoral votes to 168 , and was elected; though the Cleveland men cast about 100,000 more popular votes than the supporters of Harrison. 
In the session of 1888-1889 a controversy arose about pensions. Congress had kept the promises made to the soldiers during the Civil War-that they and their families should not suffer want because of their service. Pensions were liberally voted to the widows and minor children of soldiers killed; and to the living veterans suffering from permanent wounds or disability contracted in the service, if they needed help; and in 1889 the pensioners numbered 490,000 and drew $\$ 89,000,000$ a year. A Dependent Pension Bill passed both houses (January 31,1887), granting a pension to every survivor of those who had served in the war if not able to support himself by physical labor. Cleveland vetoed it on the ground that there was no public need for pensioning men who had means or could be supported by their children.

The first Congress under Harrison had a Republican majority in both houses, and began in 1890 to vote money freely: $\$ 20,000,000$ of direct tax paid during the Civil War ( $\$ 380$ ) was refunded to the northern states; public buildings were provided for small cities; a ship subsidy act was passed, under which about $\$ 700,000$ a year has since been paid; the Dependent Pension Act was passed, and the outgo for pensions jumped up to an average of $\$ 140,000,000$ a year. A new navy had already been begun, and in 1893 the country possessed "the white squadron" of armed cruisers, besides gunboats and torpedo craft.

In accordance with the Republican platform of 1888, a new tariff was drawn up by the Committee of Ways and Means, of which William McKinley was chairman, and the bill took its name from him. The Republicans argued the necessity of protecting American manufacturers and laborers from foreign competition, and of reserving "the home market" for American producers; the Democrats contended that the tariff kept up the prices to the consumer of protected products, was class legislation, and brought in an unnecessary and dangerous sur- 
plus. The tariff of 1883 on dutiable goods averaged about 45 per cent; the McKinley tariff (passed October 1, 1890) raised it to about 49 per cent; but the "free list" of goods admitted without duty was larger in the McKinley bill than in the previous tariff.

The debates on the trusts and on the tariff brought out the fact that the South and West felt - with some reason - that 467. Free they got less than their share of the nation's pros-

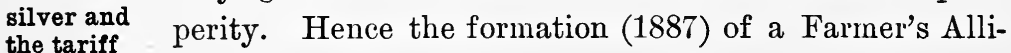
(1890-1895) ance, which carried the stanch Republican states of Kansas and Nebraska; and a National People's party was soon

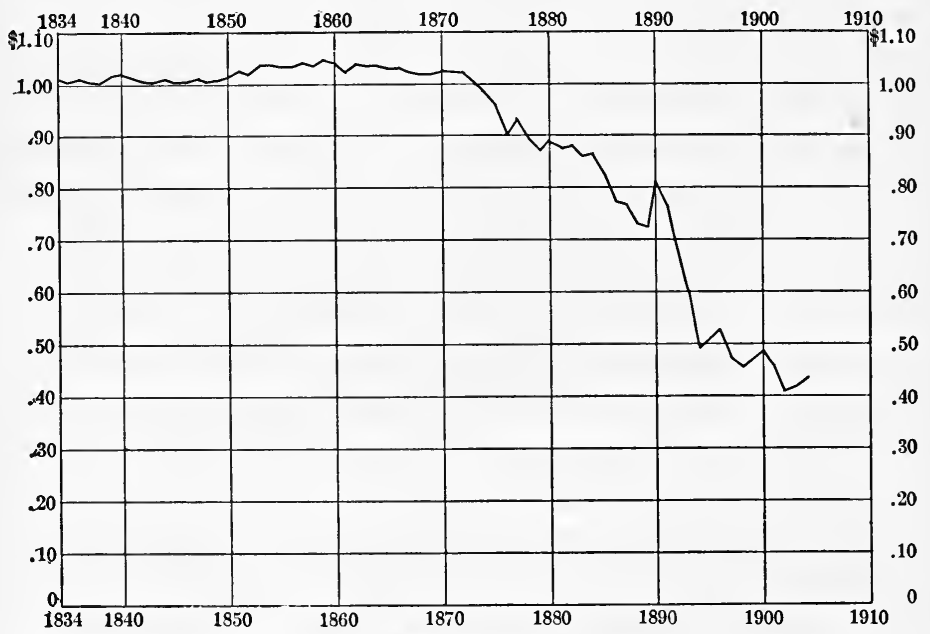

Change in the Market Price of Silver.

Distance from base line shows gold value of the silver in a silver dollar.

formed (May, 1891). The silver-producing states - Colorado, Montana, Wyoming, Idaho, and Nevada - joined the movement, because the price of their product went down from 89 cents in gold, for the weight of a standard silver dollar in 1878, to 73 cents in 1889 , and 67 cents in 1892 . The combination 
showed its strength in 1890 by introducing a bill for the free coinage of silver at the ratio of 16 to 1 ; which would have enabled owners of silver bullion to turn it into legal tender silver dollars. To head off this bill, Congress passed the Sherman Act (July 14, 1890), which provided that the Secretary of the Treasury should buy 4,500,000 ounces of silver bullion each month at the market price, paying for it in a new kind of paper notes. Thus a market was given to the silver producers, and the currency was increased to satisfy the West and South.

The McKinley tariff raised the prices on silk, woolen, and cotton goods of every kind, and thus brought its effect home to thousands of buyers. Hence the Democrats went hopefully into the campaign of 1892 , on the tariff issue, and again nominated Cleveland, who won a sweeping victory. He had 277 electoral votes to $\mathbf{1 4 5}$ for Harrison and 22 for a People's party candidate, and a popular plurality of 380,000 ; and his party elected a majority in the House and Senate for 1893-1895.

When Cleveland was a second time inaugurated (March 4, 1893), the treasury was in difficulties, which brought on the severest commercial crisis in twenty years. A panic was prevented only by the banks standing by one another, and calling on Congress for relief. As always happens in hard times, the tariff revenues fell off; the expenses of the government increased; and the gold in the treasury ran down till it looked as though the holders of the paper notes would make a run on the treasury. A special session of Congress reluctantly listened to the appeals of President Cleveland and the bankers, and stopped the silver purchases (November 1, 1893). After a few months business revived.

The Democrats kept their campaign promise of making a new tariff, which was framed in 1894 by William L. Wilson, chairman of the Ways and Means Committee; but the Senate, under the lead of Gorman of Maryland, put in so many protective duties that the President would not sign it, but let it 
become an act without his signature. The act included an income tax of 2 per cent on all incomes exceeding $\$ 4000$ a year, which of course bore hardest on the wealthy eastern and middle states. On a test case, the Supreme Court decided (May, 1895) that any income tax levied on income from real estate or personal property was unconstitutional unless distributed in proportion to the population of the states, although

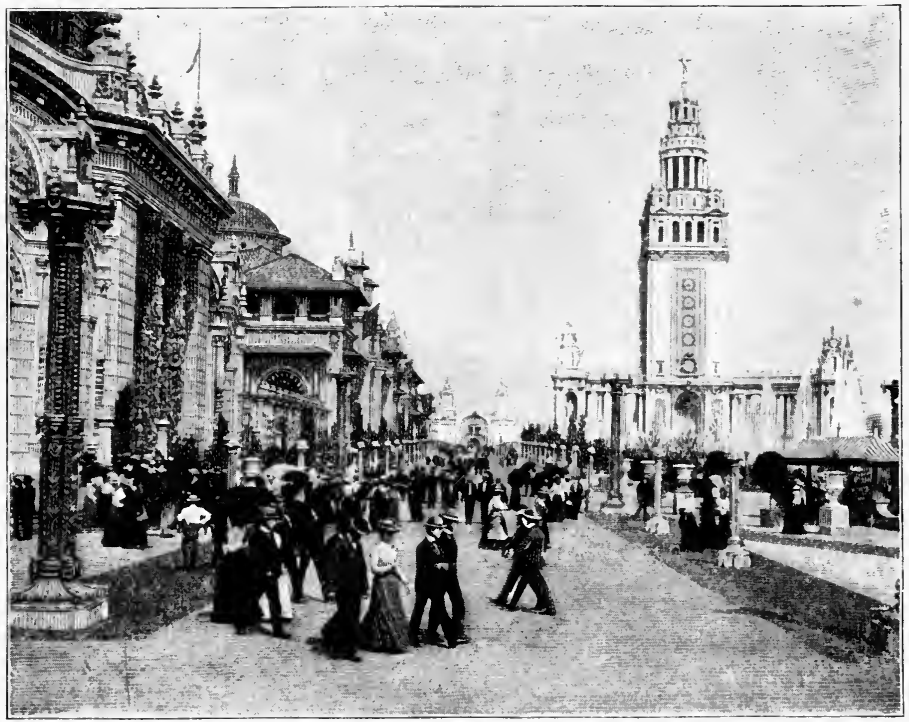

Electric 'Tower, in Exposition at Buffalo, 1901.

such a tax had been levied during the Civil War (\$ 380); and the treasury was obliged to give up a revenue estimated at $\$ 40,000,000$ a year. The customs dropped from $\$ 203,000,000$ in 1893 to $\$ 132,000,000$ in 1894 ; and for the first time since the Civil War there was a serious deficit, amounting to $\$ 70,000,000$; for several years this deficit was repeated, so that the public debt increased $\$ 250,000,000$ previous to the Spanish War of 1898. 
Notwithstanding the hard times of 1893 , a magnificent World's Columbian Exposition was held at Chicago during that year. The buildings were superb and the ex- $\begin{array}{r}\text { World's } \\ \text { Fairs }\end{array}$
hibits very striking, and 23,000,000 admissions were (1893-1904) 468. recorded. Similar exhibitions were held on a smaller scale at Buffalo (1901) and at Charleston (1902), and a still larger and more elaborate one at St. Louis in 1904.

Many new foreign questions arose after 1885 , in which James G. Blaine, as Harrison's Secretary of State from 1889 to 1892 , was a principal agent. Blaine was born in Pennsylvania in 1830, settled in Maine, went to Congress in 1863, was Speaker from 1869 to 1875 , and then Senator

469. Latin America (1889-1892) from Maine. He was always a strong partisan, believed in his own side and hated and attacked his political opponents. He was an effective debater, but made many enemies by saying bitter things - as when he called Senator Conkling of New York a "turkey cock." Blaine has often been compared with Henry Clay, whom he much resembled in his strong assertion of the rights of America, his power of making personal friends, and his long and unsuccessful ambition to be President; but he was too quick and aggressive to be a good diplomat. Blaine could not get on with President Harrison, resigned in 1892, and died not long after, a disappointed man.

The question of the Isthmus made no progress under Blaine's second secretaryship of state. In 1890 he called a Pan-American Congress at Washington, which recommended a Pan-American bank, a Pan-American railroad, and commercial reciprocity treaties. Some such treaties were negotiated but were never confirmed by the Senate, because reciprocity with our neighbors means that both sides shall reduce their tariffs.

The difficulty of keeping on good terms with our LatinAmerican neighbors was shown by a dispute with Chile. Some of the men of the United States ship Baltimore were attacked on the streets of Valparaiso (October, 1891); one was 
killed and several wounded. Three months passed without a suitable apology, and President Harrison (January 25, 1892) sent a message to Congress suggesting war; but on the same day the iong-delayed apology came, and hostilities were avoided.

Blaine inherited and aggravated another dispute which took several years to settle. The United States claimed that its 470. The possession of the seal fisheries in Alaska included the seals and whole Bering Sea; and Canadian vessels which took (1886-1893) seals in the open sea were seized by our revenue cutters (1886). Blaine defended the seizure, on the ground that Bering Sea belonged to the United States, although John Quincy Adams in 1823 absolutely denied that anybody could shut up any part of the north Pacific Ocean. Then Blaine argued that the seals really were a kind of tame "seal herds," the property of the United States wherever they went, even in the open sea. In 1893 the controversy was settled by a board of arbitration in Paris, which decided against the United States.

The people of the United States were suddenly aroused in December, 1895, by an unexpected message from President 471. Ven- Cleveland, describing a long-standing boundary controezuelan boundary (1895)

versy between Venezuela and the British colony of British Guiana, and stating that Great Britain had declined the mediation of the United States and refused to arbitrate the dispute. This action Cleveland and his Secretary of State, Richard Olney, construed to be an attempt by Great Britain to Contempo- control part of an American state, and hence contrary raries, $I V$. to the Monroe Doctrine. "To-day the United States," 830

said Olney, "is practically sovereign on this continent, and its fiat is law upon the subjects to which it confines its interposition." The President unmistakably threatened war

A commission was appointed by the President to find out the true Venezuelan boundary. Great Britain was taken aback at this unexpected feeling on a dispute which seemed 
far removed from any interest of the United States, but gracefully yielded and accepted arbitration; and the arbitrators decided (1899) that Great Britain was entitled to most of the territory claimed.

Low prices for silver, wheat, and cotton kept the West and South poor; the People's party controlled several states, and took up as its special grievance the repeal of the $\mathbf{4 7 2}$. Elec. silver purchase in 1893. On this question the Democrats tion of 1896 were divided. Their regular convention met at Chicago (July, 1896), protested against the income tax decision, declared for the free coinage of silver, and nominated William J. Bryan of Nebraska, a remarkable speaker and leader. The People's party, including many former Republicans, also nominated Bryan for President, but put up a separate "middle of the road" man for the vice presidency; the two parties, however, practically voted for the same electoral ticket. The "Sound Money Democrats" made a separate nomination.

The Republican nominating convention at St. Louis in 1896 declared again for protection and adopted a plank against free coinage of silver, unless the principal nations of the world would agree to it; they nominated their logical candidate, William McKinley of Ohio. In the lively campaign of 1896 both McKinley and Bryan spoke frequently to immense audi. ences. The result was for a long time in doubt; but wheat unexpectedly rose in price, and $\mathrm{Mr}$. McKinley gained in the farming states and was elected by 271 electoral votes to 176 , and a plurality of 600,000 . He received the votes of all the northeastern and central states, North Dakota, California, Oregon, and four southern states; and the Republicans got control of both houses of Congress.

Though the tariff played little part in the election, President McKinley summoned a special session of Congress, which passed the Dingley tariff (July 24, 1897), the third within seven years. This tariff restored and somewhat raised the 
scale of the McKinley duties. Its enemies in Congress maintained that it was passed in fulfillment of a promise to the protected industries that they should have some return for making large contributions to the campaign fund. A great increase in the world's production of gold put the currency question on a new basis so that it was not difficult to secure an act of Congress (March 14, 1900) establishing the single gold standard.

The period from 1884 to 1897 was one of great excitement. Four times there was a change of parties in the White House; 473. sum. and the country saw four successive tariff acts: (1) the mary

act of 1883 , which was rather more protective than the previous war tariff; (2) the act of 1890 , which was highly protective; (3) the act of 1894, which was still protective, although the duties were reduced; (4) the tariff of 1897, which was the highest of the series. The contest over the currency was marked by the Sherman silver purchase act (1890), the repeal of that act (1893), and the gold standard act (1900).

The organization of labor and of eapital came forward in a new shape, by the attempt to unite all the skilled labor of the country in a national labor union, and by the creation of corporations with immense capital, controlling whole lines of business. Congress passed several acts to control "trusts" doing an interstate business - the Interstate Commerce Act (1887), the Anti-Trust Act (1890), and the act for publicity of accounts (1903).

Controversies with foreign countries related almost wholly to American questions, especially reciprocity, the Bering Sea sealing question, the isthmian canal, and the Venezuela boundary. War was several times possible, but the spirit of peace prevailed. Throughout the country there was prosperity notwithstanding the crisis of 1893 ; inventions increased, the 
comforts of life were greater, education was better and more widely spread; it was a happy country.

\section{TOPICS}

(1) Why did new issues come up in the presidential election of 1884? (2) What does "mugwump" mean? (3) Why was the south "solid" in 1884? (4) Why has the United States so rapidly disposed of the arable public land? (5) Why have so many women's colleges been founded since 1865 ? (6) Why have there been so many inventions since 1865 ? (7) What is the advantage of general laws for corporations over special charters? (8) Why do so many river and harbor bills fail to get through Congress? (9) What is the advantage of publicity in corporation accounts? (10) Why are "contract laborers" forbidden to immigrate to this country? (11) Why was the Tenure of Office Act repealed in 1887 ? (12) What are the advantages of the Australian ballot? (13) What is the objection to a surplus? (14) Why was the French Panama Canal a failure?

(15) Political career of Blaine up to 1884 . (16) President Cleveland's vetoes. (17) Rush for land in Oklahoma in 1889; in Search topics 1891 ; in 1893. (18) Beauties of the Yosemite Park. (19) Beauties of the Yellowstone Park. (20) Description of the Library of Congress. (21) Mr. Dooley on American politics. (22) Winston Churchill's historical novels. (23) Debate on the Interstate Commerce Act of 1887. (24) Haymarket mob in Chicago in 1886. (25) Speaker Reed's "counting a quorum," January, 1890. (26) Financial crisis of 1893 . (27) Debates on the Wilson tariff of 1894. (28) Proceedings of the Pan-American Congress of 1890. (29) Nomination of Bryan in 1896. (30) Debate on the Dingley tariff of 1897. (31) Why did the Supreme Court disallow the income tax in 1895 ?

\section{REFERENCES}

See map, pp. 10, 11; Semple, Geographic Conditions, 310-396; Geography Ford, National Problems.

Wilson, Division and Reunion, §§ 142-148; Johnston, Politics, 265-279 ; Stanwood, Presudency, 419-569; Ford, National Problems; Wilson, American People, V. 169-269; Cambridge Modern History, VII. 655-674, 697-722 ; Gay, Bryant's History, V. 544-674; Larned, History for Ready Reference, V. 3581, VI. 145, 553, 684 ; Brown, Lower South, 247-271; Cable, Negro. Question; Dewey,

Suggestive topics 
Financial History, §§ 181-196; Noyes, American Finance, 104254 ; Taussig, Tariff History, 251-409 ; Stanwood, American Tariff Controversies, II. 219-394 ; Hart, Practical Essays, 98-132.

Sources

Hart, Source Book, § 138, - Contemporaries, IV. \$§ 161, 164167, 170-172, 178, 179, 197-209; Maclonald, Select Statutes, nos. 109-127 ; American History Leaftets, no. 6 ; Johnston, American Orations, IV. 238-269, 329-420 ; Appleton's Annual Cyclopadia, 1885-1897. See N. Eng. Hist. 'Teachers' Ass'n, Historical Sources, $\S \S 90,91$.

Illustrative

Frank Norris, The Octopus, - The Pit; Will Payne, Money works Captain; H. K. Webster, Banker and the Bear (corner); Merwin and Webster, Calumet "K," - Short Line War (labor, corporations); Anonymous, The Breadwinners; Octave Thanet, Heart of Toil ; J. A. Riis, How the Other Half Lives, - Children of the Poor; W. E. B. DuBois, Souls of Black Folk; P. L. Dunbar, Folks from Dixie; C. W. Chesnutt, Marrowo of Tradition (negroes); Emma Rayner, Handicapped among the Free (negroes) ; C. E. Craddock, Prophet of the Great Smoky Mountain; Owen Wister, The Virginian (Western); M. H. Foote, Cour d'Alene (mining), - Chosen Valley (irrigation); M. L. Iuther, The Henchman.

Pictures

Harper's Weekly; Harper's Monthly; Scribner's Monthly; Century. 


\section{CHAPTER XXXIV.}

\section{THE SPANISH WAR AND ITS RESULTS (1897-1903)}

A NEw era of national history began when our territory was extended by war with Spain in 1898. After the end of the Cuban insurrection in 1878, Cuba quickly recovered pros474. The perity, till the island had an export trade of $\$ 100,000,000$ Cuban ina year, most of it to the United States. Yet many of (1895-1898) the native-born Cubans were discontented, for in government and society they were considered inferiors by the "peninsulars," or native Spaniards ; taxes were high; and the trade of the island was, so far as possible, kept in the liands of Spanish merchants.

An insurrection broke out in Cuba in 1895, aided by a "Junta," a council of wealthy Cubans in the United States, who within three years sent from the United States more than twenty filibustering expeditions, with arms and men for the insurgents. The war was savage on both sides; the sugar plantations were devastated, and neither party could beat the other. The Spaniards held the western end of the island, and ordered the people outside the towns to come within the Spanish lines into reconcentrado camps, where many of them miserably perished. Property was destroyed, often that of American citizens; and some American residents, traders, and newspaper correspondents were arrested on proof or on suspicion that they were helping the insurgents.

A natural sympathy with a people struggling for independence led a Senate committee, in 1896, to investigate the conditions of Cuba. Public feeling was aroused in February, 1898, by the publication of a private letter of the (1895-1898) 
Spanish minister De Lome, which in translation seemed to speak slightingly of the President and the American government; and De Lome was obliged to resign his post.

Demonstrations against the Americans in Havana led our government to send the battleship Maine to that city. On the night of February 15, 1898, the Maine was blown up by an explosion, which killed 260 of the men; and an American naval board of inquiry later reported that the ship was destroyed by a submarine mine. Our consul-general, Fitzhugh Lee, said: "I do not think it was put there by the Spanish government. I think probably it was an act of four or five subordinate officers." Yet there was a widespread feeling in the United States that the Spanish government was responsible.

War was so likely that Congress placed at the disposal

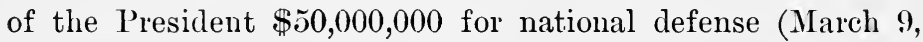
1898). President McKinley and Thomas B. Reed, Speaker of the House, were both anxious to prevent war; but there was a strong public feeling that Spain could not keep order in Cuba, could not subdue the insurgents, and could not protect American property or even the shipping in Cuban harbors. The time seemed to have come to end the Spanish government in the western world. Senator Proctor of Vermont added to the flame by a speech describing the horrors which he had seen in Cuba (March 17, 1898).

After some months of negotiation with Spain, in which guarantees of reform in Cuba were proposed by Spain, but 476. Out- thought insufficient, President McKinley sent a mesbreak of the sage to Congress (April 11, 1898), in which he described
Spanish War (1898). the loss of property and life, and said, "In the name Contempo- of humanity, in the name of civilization, in behalf of 576 endangered American interests, which give us the right and the duty to speak and act, the war in Cuba must stop." April 20, 1898, a joint resolution was passed directing the President to use the military and naval forces of the United 
States to compel Spain to leave Cuba. To this measure was added the Teller resolution: "That the United States hereby disclaims any disposition or intention to exercise sovereignty, jurisdiction, or control over said island except for the pacification thereof, and asserts its determiCongressional Record, 1897-98, nation, when that is accomplished, to leave the government and control of the island to its people."

On the outbreak of war, Cominodore Dewey, in command of the American vessels in the Pacific, was ordered to find and

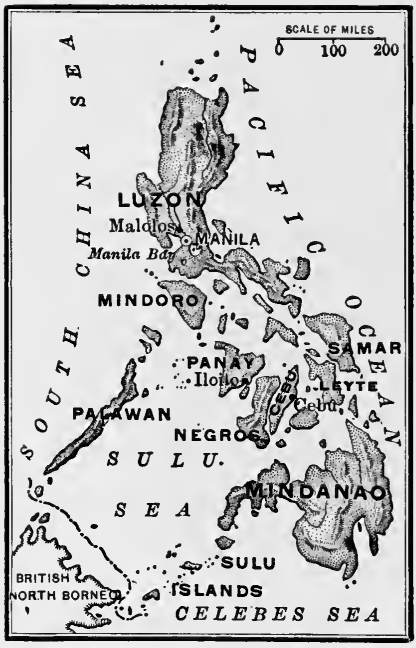

The Philippines.

fight the Spanish fleet sta- 477. Camtioned in the Philippine paign in the Islands. He had six ships

(1893)

(and a dispatch vessel), of which the largest was the cruiser Olympia, of 5870 tons. The Spanish fleet, consisting of four iron cruisers and one wooden one, besides auxiliary vessels, was found lying under the guns of the forts of Cavite, in Manila Bay. May 1, 1898, Dewey attacked : after four hours' spirited fight he set the Spanish fleet on fire; and that night he was able to send home a brief dispatch to the effect that he had destroyed eleven vessels and the fort; that his squadron was uninjured, and that a few men were slightly wounded.

Dewey anchored off the city of Manila, which for some time remained in the hands of the Spaniards. He brought with him to the island, Aguinaldo, a Philippine native of influence, who had been engaged in an insurrection against the Spanish power, and who raised a Philippine army to besiege the city on the land side. Manila was attacked by sea and land and 


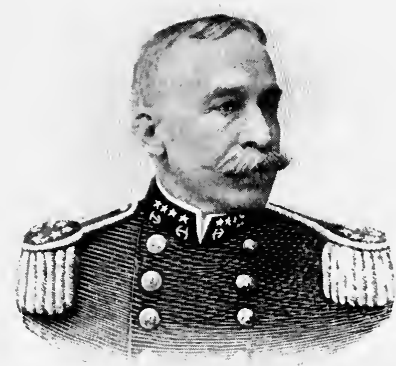

Admiral George Dewey

eventually taken (August 13, 1898) by a fleet under Dewey, and an American army under General Wesley A. Merritt. Although no promise was ever made to Aguinaldo by Dewey or any one else, he firmly expected that he would have the opportunity to found a Philippine state, and his troops remained in the trenches before Manila, side by side with the Americans.

Cuba was very soon blockaded by a fleet under the command of Admiral Sampson, but the Spaniards could be forced to 478. Cam- leave Cuba only by an army. As the United States had paign in only about 26,000 regular troops, the President called for Cuba (1898)

125,000 volunteers, and Congress authorized the increase of the regular army to 63,000 ; in a few weeks about 200,000 men were enlisted in the volunteers, consisting in good part of state militia regiments or smaller commands. The navy was well organized; but the army was mostly not trained for Alger, campaigning, and the War Department was not prepared SpanishAmerican to handle, clothe, or feed so many men. Secretary of War, 455 War Alger said, "It is doubtful if any nation rated as a first-class power ever entered upon a war of offense in a condition of less military preparation than was the United States in 1898."

Meanwhile a second Spanish fleet of four cruisers and three tor-

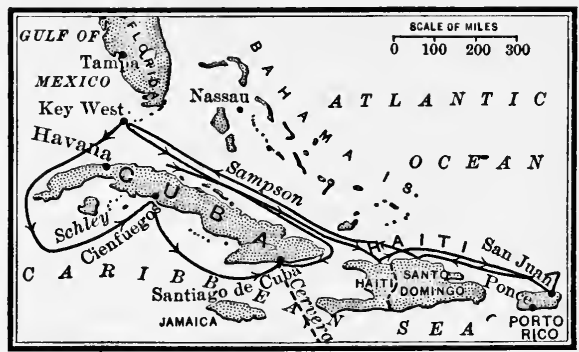

Routes of Fleets to Santiago de Cuba. 
pedo boats left Spain for Cuba. Admiral Schley with a flying squadron was sent out to look for the Spaniards, and with some difficulty ascertained that they had slipped into the harbor of Santiago de Cuba. Admiral Sampson then took command and blockaded the port. A few days later Lieutenant Hobson gallantly tried to block the harbor by sinking the collier Merrimac in the channel.

A small force of 17,000 men was brought together in Tampa Bay under General Shafter, and landed on the south coast of Cuba, a little east of Santiago (June 22), whence it marched up to capture that city from the Spaniards. The army had no proper transportation or medical supplies, and the food was poor and sometimes seanty. No Cuban army could be found. The principal fight was at San Juan Hill (July 1, 1898), in which good service was done by the "Rough Riders," part of Roosevelt's dismounted cavalry regiment.

On July 3, 1898, the Spanish fleet under Admiral Cervera made a dash out of Santiago. Admiral Sampson's flagship, New York, was out of range to the eastward, and Admiral Schley was next in command. In execution of Sampson's standing orders the American ships dashed at the enemy, and in a running fight

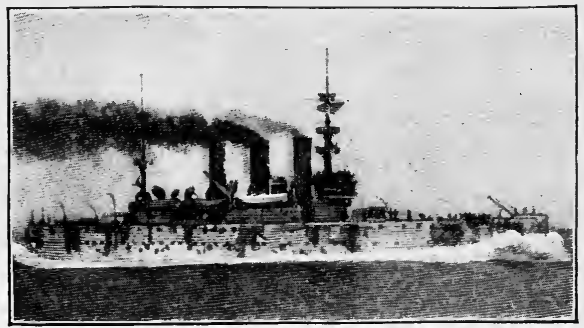

U. S. SHIP NEW YORK IN 1898. forced ashore and destroyed all four of the cruisers and two torpedo boats, with little damage to any of the American ships. The credit for this victory is due to the vim and dash of all the officers and men engaged, and also to the foresight of Admiral Sampson, who made preparations to receive just such an attack. The troops now pushed nearer to Santiago, and 
that city with its garrison surrendered July 17, 1898. The island of Porto Rico was taken by 17,000 men under command of General Miles, who landed July 25, on the southwest coast, moved eastward and took the city of Ponce, and then crossed the island to San Juan. There was little resistance, and the people welcomed the invaders.

The Spaniards still had a force of about 50,000 men at Havana, and the little American army at Santiago was 479. End of already seized with fever. It was not properly supthe war (August, 1898) Alger, SpanishAmerican plied with hospital tents and medicines, and ten of the general officers united in a so-called "round robin" addressed to General Shafter, to say, "This army must War, 265 be moved at once or it will perish." Accordingly it was transported from Cuba to Long Island (August 7). Spain was evidently incapable of further resistance, and in her behalf negotiations were opened at Washington and on August 12, 1898, a "protocol," or agreement, was signed, under which Spain was to evacuate Cuba, and to cede Porto Rico to the United States; the future of the Philippines to be settled by a later treaty of peace. The protocol came too late to stop hostilities at Manila, for the city surrendered August 13 , before the news of peace arrived.

For the definite treaty of peace President McKinley appointed a special commission. That commission found its 480. Treaty chief task the disposition of the Philippines, which were of peace very distant from the United States, and had a mixed (1898-1899) population ranging from head-hunting savages to highly civilized Spanish-speaking gentlemen. Several methods of settlement were suggested: (1) Should the United States leave the islands or a part of them to Spain? (2) Should an independent government of the natives receive control, as Aguinaldo's large following desired? (3) Should the islands be annexed outright to the United States?

The arguments for annexation were: (1) that they were a 
rich and fertile region which the United States would be glad to possess; (2) that the war with Spain had destroyed the government of the Philippines and made it the duty of the United States to give the people a just and orderly government; (3) that the Philippines were so near the coast of Asia that they would give the United States a commanding position and great influence in the opening up of trade with China and the interior of Asia.

For some time the President hesitated. Annexation of distant islands seemed a departure from all the previous policy of the government; but both McKinley and his new Secretary of State, John Hay, agreed that it was the course most likely to bring peace to the islands, and to give the United States a position in the Pacific. The treaty of peace, signed December 10, 1898, therefore provided that "Spain relinquishes all claim of sovereignty over and title to Cuba," and ceded outright Porto Rico, the island of Guam in the Ladrones, and all the Philippine Islands. The United States was to fay $\$ 20,000,000$ to Spain.

A treaty does not go into effect until ratified by two thirds of the Senate, and for some time it was doubtful whether such a majority could be obtained for the annexation of the Philippines. Bryan, as a Democratic leader, came to Washington and used his influence with Democratic senators to join in making the necessary two-thirds majority; the treaty was ratified by the Senate February 6,1899 , and approved by the President February 7, but was not ratified by Spain till March 19, and was not proclaimed by the President till April 14, 1899 .

After the capture of Manila, Aguinaldo still hoped for independence, and kept up his forces outside the city of Manila. American troops were sent to Iloilo, on the island of Panay (December 24, 1898), showing an intention to hold the r ippine

481. Philislands permanently. The Philippine leaders grew dis- (1899-1902) contented, and their soldiers brought on a fight (February 4 , 
1899); hence, on the date of the ratification of the treaty by the Senate (February 6), an insurrection was going on against the United States. For two years Aguinaldo kept together an organized force, until he was made a prisoner; and the insurrection continued in various parts of the islands until 1902.

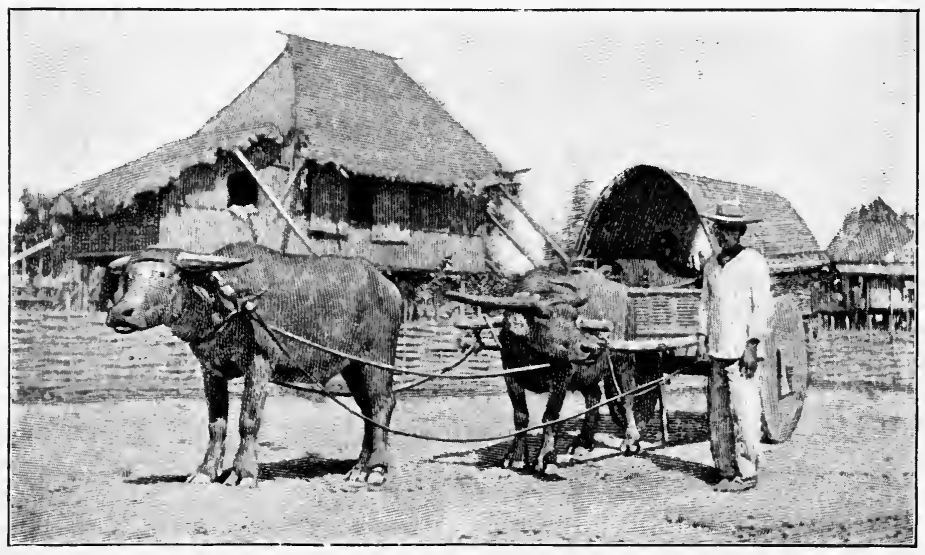

Street Scene in Manila, 1900.

The treaty of 1899 declared that "the civil rights and political status of the native inhabitants of the territories hereby ceded to the United States shall be determined by the Congress." Accordingly a modified form of territorial government was created for Porto Rico (April, 1900), in which the majority of the upper house of the legislature is appointed by the President; but the act did not make Porto Rico part of the United States, like Hawaii ( $\$ 483$ ). For the temporary government of the Philippines the President, on his own responsibility, appointed two successive commissions of civilians, and Congress later authorized him to establish a government at his discretion (March 2, 1901). He continued the former commission under Judge Taft, and it organized a government for the islands, and local governments wherever it was safe. 
Troubles at once arose over the tariff in the dependencies. The question, so far as it concerned Porto Rico, was settled by the act of April 12, 1900, providing a special tariff for that island, but allowing it speedily to come into the regular tariff system of the United States - that is, to be free from all duties on trade with the states. In 1901 the Supreme Court supported this legislation by decisions in the "Insular Cases" in which the majority of the court ( 5 to 4 ) agreed: (1) that Congress could make a separate tariff for the dependencies; (2) that Porto Rico and the Philippines were not foreign countries; (3) that they were also not complete parts of the United States, unless Congress should choose to incorporate them.

Acting on those principles, Congress made a special tariff of import duties in the Philippines (March 8, 1902), and fixed the duties on imports from the Philippines into the United States at three fourths the rates on similar imports from other countries. By another act (July 1, 1902) a bill of rights was adopted which contained substantially the guarantees of personal liberty set forth in the federal Constitution, except the clauses for jury trials and for keeping and bearing arms; and a permanent form of government - substantially that previously framed by the Commission - was created by Congress. Judge Taft was appointed civil governor under this statute, which also made provision for a future Philippine assembly.

As Cuba was completely disorganized by the war, United States troops remained in the island. General Leonard Wood was appointed military governor, and within a few months the island was restored to order; roads and telegraphs were built, hundreds of schools were opened, and

482. Relations with Cuba

(1898-1903) prosperity slowly returned. What were to be the future relations of the United States to Cuba? Annexation was out of the question, in view of the Teller resolution of 1898. By the "Platt Amendment" (March 2, 1901), Congress laid down as 
bases for the future government of Cuba the following principles: (1) Cuba must make no foreign agreements contrary to the interests of the United States; (2) Cuba must not incur a debt that she could not pay; (3) sites were to be ceded on the Cuban coast for United States naval stations; (4) Cuban ports must not be allowed to be breeding places of disease.

A Cuban constitutional convention agreed to these conditions (June 12, 1901), and formed a republic of which General Palma was elected first president. The control of the island was formally given up to the new government (May 20, 1902), and the United States troops were withdrawn. Next came the question of the commercial relations of the two countries. The Cubans had lost their former market in Spain, and expected that the United States would make a reduction on the regular tariff duties on imports from Cuba. As the House paid no attention to urgent messages from both President McKinley and his successor, President Roosevelt, a treaty was negotiated (1903) for a 20 per cent reduction on regular import duties, and was ratified by the Senate with a proviso that it be subject to the approval of the House of Representatives, a very unusual method of securing a treaty.

The interest of the United States in the Pacific led to several other annexations of territory. The Hawaiian Islands since

483. Annexations in the Pacific 1876 had enjoyed a favorable commercial treaty with us; (1898-1899) from a United States ship, a party which included most of the people of American descent in the islands revolted from the native monarchy and set up a republic. President Cleveland would not agree to annexation, but a joint resolution of Congress (July 7, 1898) soon brought the Hawaiian Islands into the United States, and in 1900 they were organized as a territory.

The United States, Great Britain, and Germany all had interests in the Samoa Islands; hence a tripartite treaty had been agreed on (June 14, 1889), by which the three powers admin- 
istered the islands together. The natives tried to fight out their own quarrels, and this led to such confusion that in 1899 the three powers made a division treaty, by which the United States took the island of Tutuila with the harbor of PangoPango, the best in the group. Various small islands, Christmas, Baker, Midway, Wake, Howland, and others, which lay in the mid-Pacific and had never been claimed by any other power, were annexed by the United States, as landing or telegraph stations.

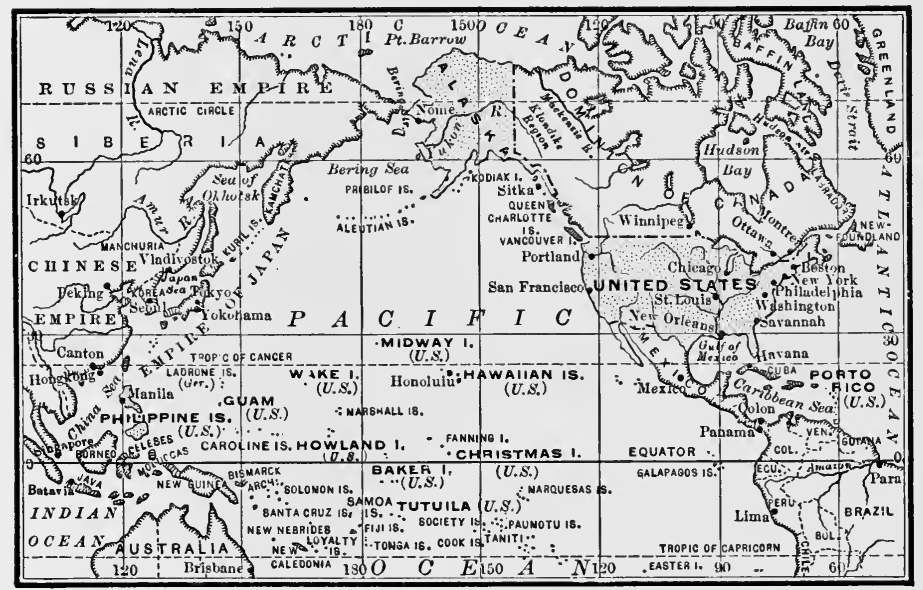

The United States and its Possessions.

The results of the war of 1898 gave the United States a new place in the world's councils. In a conference held at the Hague, in Holland, to discuss means of preventing wars, the influence of the United States was high among the 484. China and the twenty-seven nations represented, and helped to bring (1898-1903) about a general treaty providing courts of arbitration (1899).

That influence was also strong in China, where France, Great Britain, Germany, Japan, and Russia were all trying to take and keep Chinese territory. The Chinese grew alarmed, and in 1900 a revolution of the so-called Boxers broke out, which 
swept over the northeast part of China, cost the lives of several hundred Europeans, and ended in a relief expedition made up of detachments sent by Great Britain, France, Germany, Japan, Russia, Italy, and the United States, which marched up into the country and rescued the ambassadors and others who had been

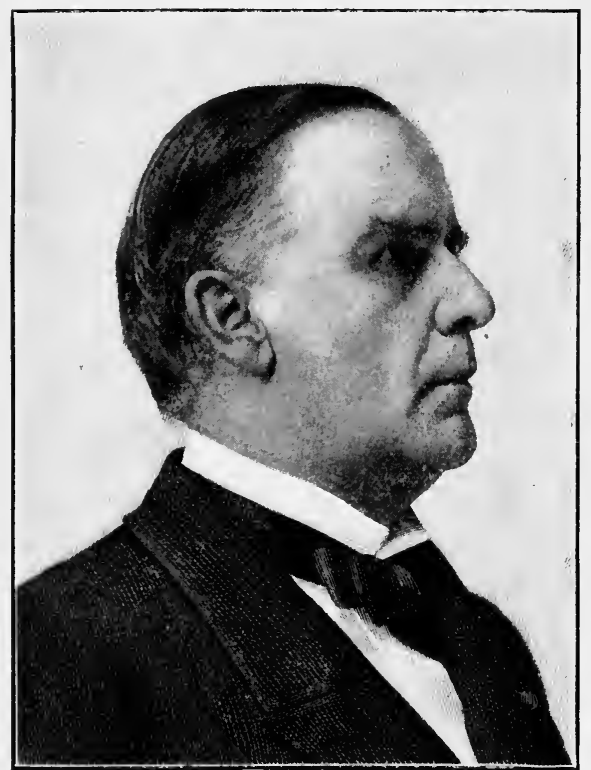

WiLliam MCKinley, in 1894. besieged in Peking (August 14, 1900).

The European powers wanted to take territory from China, but Secretary Hay, for the United States, insisted that they should accept the "Open Door" policy - that is, that no part of China be cut off from the general commerce of the world. By consummate American diplomacy the other powers were brought to accept the plan of the United States.

During this period, President McKinley came more and more to the front as a man of power. He was born in Niles, 485. Wil- Ohio, in 1843, served with gallantry in the Civil War, liam McKin- and rose from a private to a major. In 1877 he was dent sent to Congress, where he grew in reputation, and in 1889 was made chairman of the Ways and Means Committee; that is, leader of his party on the floor of the House; and to him was committed the task of drafting the new tariff in 1890. By a "gerrymander" he lost his seat in Congress, but in 1891 
he was elected governor of Ohio, and he was the logical candidate of his party for the presidency in 1896. His intimate friend, Marcus A. Hanna, came into the Senate from Ohio, and was the President's right-hand man. McKinley was one of the most gracious and genial men who ever sat in the White House, and charmed almost everybody who met him.

Cuba had been misgoverned for nearly four centuries, and when the people revolted and there seemed no end to a cruel contest, the United States restored peace by a short war, in which the losses of killed and wounded on both sides

486. Sum. were less than 6000 , though the war cost the United States about $\$ 100,000,000$ in taxes and $\$ 200,000,000$ in increase of debt.

In the process the United States acquired the island of Porto Rico, and thus became for the first time a West Indian power. It also took in the group of the Philippine Islands with 120,000 square miles and $7,000,000$ inhabitants. The native Filipinos disliked the Spanish rule, and were no better pleased with. American control. They revolted, and order was restored slowly and at great cost of life.

The war left many troublesome questions, such as the tariffs between the new dependencies and the main country, and local government for the native peoples. On both these matters the United States adopted rules for the Porto Ricans and Filipinos which did not apply to the states of the Union or to the territories.

As a result of the enlarged interest in the Pacific, Hawaii and several small islands were annexed; and the United States for the first time took a leading part in an Asiatic question by insisting on a proper settlement of the Chinese difficulty. Changes in territory, and increase of area and population, were less significant than the springing up of the feeling that the United States was concerned in all that affected the future of the world. 


\section{TOPICS}

Suggestive topics

Search topics

Geography

Secondary authorities

Sources

Illustrative works

Pictures
(1) Why were the Cubans dissatisfied with the Spanish government? (2) What was the objection to the reconcentrado camps? (3) Why was the Teller resolution of April, 1898, passed? (4) Why was Aguinaldo brought to the Philippines? (5) Why was not the United States better prepared for war? (6) Why was the army in Cuba defective in transportation and medical supplies? (7) Why did Santiago surrender so quickly? (8) Why did the United States pay $\$ 20,000,000$ to Spain?

(9) Report of the Senate committee on Cuba in 1896. (10) Destruction of the battleship Maine. (11) Native government of Cuba during the insurrection. (12) The siege of Manila, 1898. (13) Hobson's sinking of the Merrimac. (14) The fight at San Juan Hill. (15) The Rough Riders. (16) Naval battle of Santiago. (17) The Schurman Commission on the Philippines. (18) The present government of the Philippine Islands. (19) The present government of Cuba. (20) Public services of William McKinley previous to 1896. (21) Why did President Cleveland oppose the annexation of Hawaii? (22) What right had the United States to reform the government of Cuba?

\section{REFERENCES}

See maps, pp. 553, 554, 561 ; Semple, Geographic Conditions, 397-435.

Latané, America the World Power, -United States and Spanish America, 174, 175, 214-220 ; Wilson, American People, V. 269300 ; Cambridge Modern History, VII. 674-686 ; Larned, History for Ready Reference, VI. 65, 171, 225, 258, 367, 583 ; Elson, Side Lights, II. 352-401 ; Dewey, Financial History, \$§ 197-202 ; Carpenter, American Advance, 288-331 ; Callahan, Cuba, 453-497; Maclay, United States Navy, III. 39-440; Titherington, SpanishAmerican War; Brooks, War with Spain.

Hart, Source Book, §§ 141-145, - Contemporaries, IV. §§180196 ; MacDonald, Select Statutes, nos. 128-131 ; Old South Leaftets, no. 114 ; Hill, Liberty Documents, ch. xxiv. ; Caldwell, Territorial Development, 213-255 ; Appleton's Annual Cyclopadia, 1898-1903. See N. Eng. Hist. Teachers' Ass'n., Historical Sources, §92.

F. P. Dunne, Mr. Dooley in Peace and War,-Mr. Dooley in the Hearts of his Countrymen; Stephen Crane, Wounds in the Rain.

Leslie's Official History of the Spanish-American War; Harper's Weekly; Harper's Pictorial History of the War with Spain; Collier's Weekly; Century; Scribner's ; McClure's. 


\section{CHAPTER XXXV.}

\section{WHAT AMERICA HAS DONE FOR THE WORLD}

The history of our beloved country can not be understood unless we think of it as the story of the progress of great ideals and principles. Having followed it to the 487. The end of the nineteenth century, let us now consider what American America has accomplished which will be transmitted to posterity.

The United States has taught the world how to make a great modern nation out of a variety of races and peoples. According to the federal census of 1900 , in the total "continental" population of 76 ,000,000 people, about $10,000,000$ were born outside this country, 16,000,000 were children of foreigners, and 9,000,000

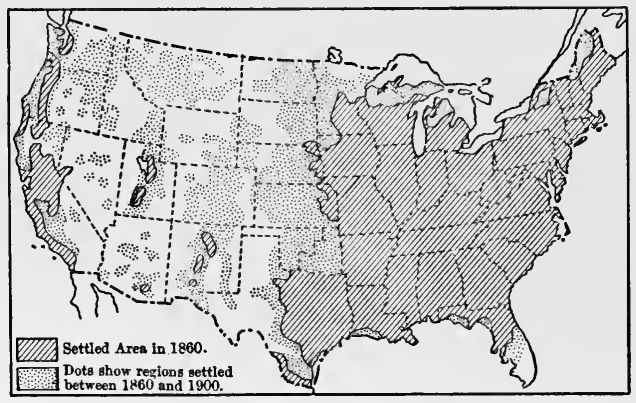

Settled Area in 1900. negroes. Yet all the elements of this enormous population had a common set of political traditions and methods, and, with few exceptions, held themselves to be Americans and devoted only to this country.

About 43,000,000 Americans lived in the valleys of the Mississippi and of the Great Lakes. This middle West has come to 
have the most people, the most votes, and the most influence in national affairs; but the East with its seaports and connection with Europe, and the far West with its farms, mines, and workshops, are closely united. Even the old sectional feeling between North and South seems almost spent, and one American race and spirit is developing throughout the broad land. The mixture of races is aided by the practice of moving freely from state to state. In 1900 14,000,000 persons born within the United States were living outside the state of their birth.

The United States grew from about 400,000 square miles in 1776 to $3,747,000$ square miles in 1900 by the following

488. Territorial expansion additions of territory to the original thirteen states: (1) the Northwest Territory, in part conquered by General George Rogers Clark in 1778, in part ceded by the treaty of 1783 ; (2) the country south of the Ohio River, in part previously occupied by the Kentuckians and Tennesseeans, but chiefly gained by clever diplomacy in 1782 ; (3) Louisiana, purchased from France in 1803; (4) Oregon, discovered in 1792, explored in 1805 , occupied as wild territory in 1811; (5) West Florida, conquered in 1810-1814; (6) East Florida, purchased in 1819; (7) Texas, annexed as a state in 1845; (8) New Mexico and California, conquered in 1846 and ceded by Mexico in 1848; (9) the Gadsden Purchase, bought from Mexico in 1853; (10) Alaska, bought in 1867 ; (11) the Hawaiian Islands, annexed by consent in 1898; (12) Christmas, Wake, Baker, Howland, Midway, and other islands, earlier discovered but added as wild territory in 1898; (13) Porto Rico, Guam, and the Philippines, conquered in 1898; (14) Tutuila and some other small Samoan islands, wild territory confirmed as our sole possession in 1899 .

These acquisitions, most of them brought in peacefully, have given to the United States a magnificent frontage on the Atlantic, on the Gulf of Mexico, on the Great Lakes, and on the Pacific, with outlying island possessions and naval stations. 


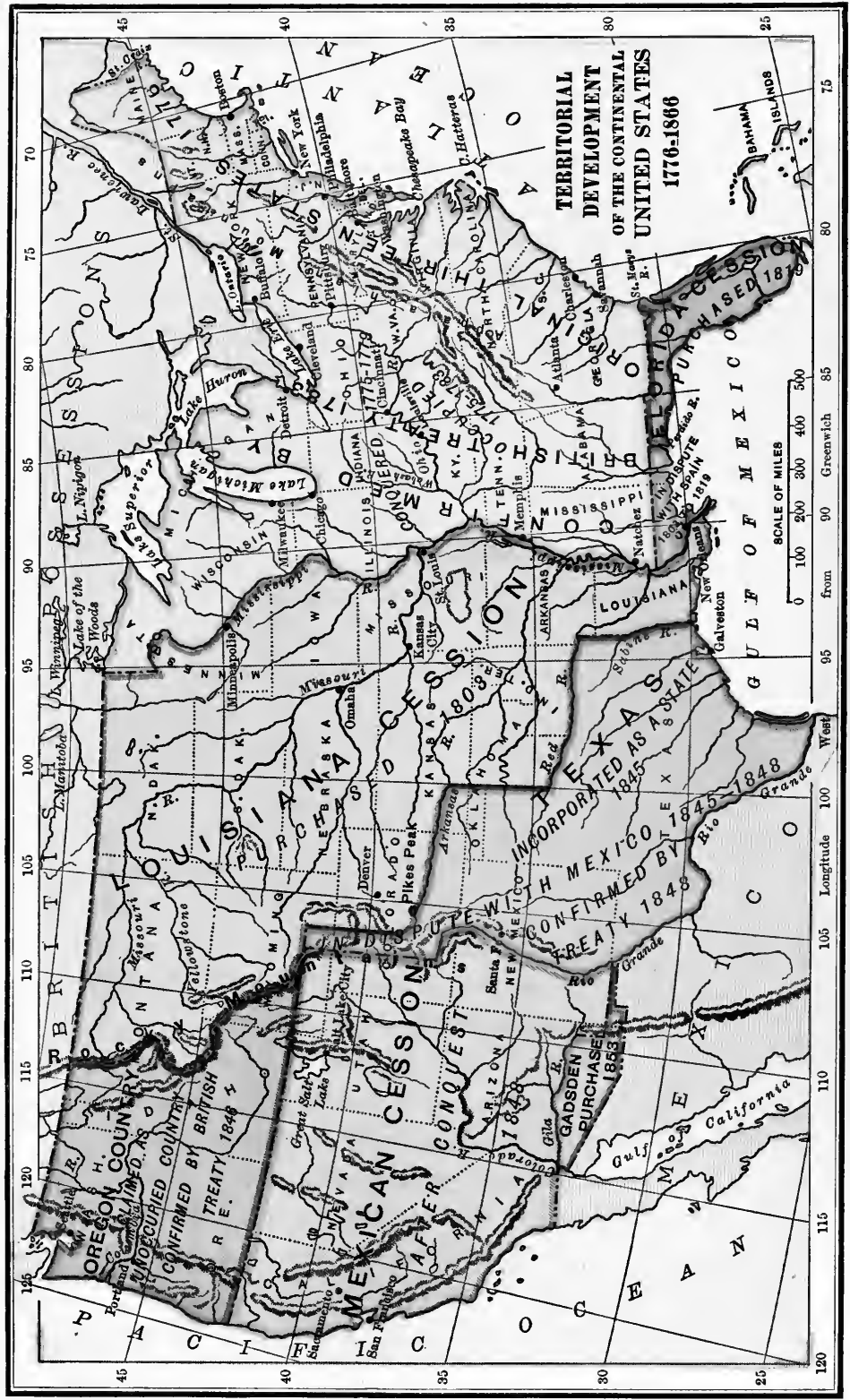


The United States in 1900 was far the strongest force in North America, the leading power in the West Indies, and was on the way, through its control of a canal, to dominate Central America; while from the Philippines she spoke with authority on Asiatic questions.

Much of the history of the United States is the story of the swift occupation of new territories. The English colonists 489. Recla lived practically on the seacoast, but during the Revolumation of tion began the long process of clearing the wilderness the frontier

just beyond the Appalachian ranges, and then of settling the country farther west. In 1787 the tide began to push into the Northwest. In 1800 Indiana and western Kentucky were the frontier; in 1810 the Mississippi River; in 1821 Missouri was admitted into the Union; in 1850 the extreme limits of settlement were the Missouri River and the lower Rio Grande. Already population was working backward from the Pacific coast, and by 1890 there was a continuous belt of states across the continent.

The Indian tribes were pushed aside by this onset of backwoodsmen. A series of bloody wars, which made both sides more ruthless, destroyed the red man's power before 1880, though the total number of Indians has not much diminished. As the wheatfield and cornfield advanced, the forests fell. Swamps were drained, roads created, streams bridged, houses built, schoolhouses provided. Never has mankind seen such a speedy and complete conquest of the wilderness.

This westward movement was in part an application of one of the greatest lessons which America has taught mankind, the 490. Perright of personal liberty, the right of every man and sonal liberty woman to be free from arbitrary arrests, from unfair trials, and from unaccustomed punishments; and the broader right to move about, to work where one will, to go from place to place, and to engage in the trade or business for which a man or woman is capable. 
To four classes of the American population these rights have not been freely given: (1) the tribal Indians, not settled on separate lands, are treated as a kind of big children; (2) the Chinese now in the country are subject to special restriction, and no more laborer's are allowed to come; Filipinos are practically not free to come to the main part of the United States, and in their islands are treated much like the Indians; (4) the negroes, for a century and a half held in bondage, are still under many practical and some legal disabilities.

The destruction of slavery was a great triumph for human freedom; for slavery was always a denial of the fundamental principles of American liberty; as Emerson says, "If you put a chain around the neck of a slave, you bind the other end around yourself." Slavery brought on the Civil War in 1861, and the Civil IVar destroyed slavery.

America has set for the world an example of toleration of both political and religious opinions. A man may speak his mind on any public question; he may call his neighbor's together in a public meeting; he may publish his doctrines in a newspaper; he is not subject to punishment for any opinion, unless he urges his friends to break the laws. The United States has enjoyed the same freedom in religion; for the first time in the history of the world men have been free to preach and practice any form of religion which does not interfere with the morals or welfare of the community.

Americans also have had the freest opportunity of education. The community provided public schools where all children might be educated at the expense of the state; though if any one preferred to pay for a private tutor or private school, secular or denominational, he might do so. Thus every child has had a chance to make the most of himself; and the state has found the advantage of bringing up people who know HART'S AMER. HIST. -34 


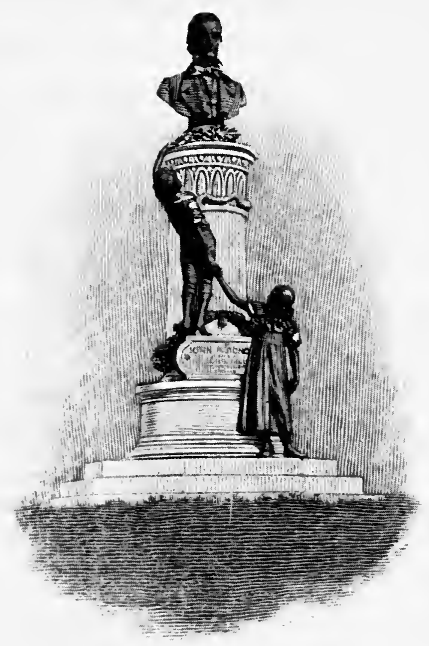

Statue to A Founder of Schools. James McDonough, New Orleans.

something, who can express their ideas, and who can reason. No other country in the world has made such a provision of endowed and public high schools, colleges, universities, and professional schools of science, law, medicine, and other suljects. No other country has had so many libraries or such widespread habits of reading. Most of these advantages can be enjoyed by women on the same terms as men, and the United States is the country which has employed the largest number of women teachers.

Among modern nations, the United States is celebrated for its use of labor-saving machinery and devices. Americans 492. Use of taught the world how to save farm labor, and American machinery farm machinery has been used the world over - mowers, reapers, and such marvels as the thirty-horse harvester, which goes through a field of wheat and delivers the grain ready thrashed in bags.

Machinery has also been employed here for manufactures to a greater degree than anywhere else. The willingness of the American workmen to accept, use, and even invent new machinery is one of the reasons for the prosperity of American manufactures. No other nation has made such elaborate use of electricity. Electric cars were first introduced into the United States; the telegraph and the telephone are American inventions; and the telephone has extended into the farms to make life brighter in the remotest corners of the country. The use 
of electric light is widely diffused; and the water powers of the southern and the western mountains light distant cities.

To America the world owes many forms of commercial organization. Railroad business has been rerolutionized by American cheap steel and American railroad management. The average trainload of freight, moved by one engineer, one fireman, one conductor, and a small train crew, was in

493. Busi. ness organization 1900 two or three times as large in America as in Europe. The best passenger trains in the world were run on the through routes in the United States. If we only had everywhere good stations, clean, handsome, and large, we should have little to learn from Europe about transportation.

American trusts, with all their difficulties and dangers, have shown a high degree of commercial skill. It is not an easy matter to induce a dozen large owners to unite in one company with one general manager, but there is sometimes a great saving in the expenses of management and of selling goods, in bookkeeping and the cost of manufacture.

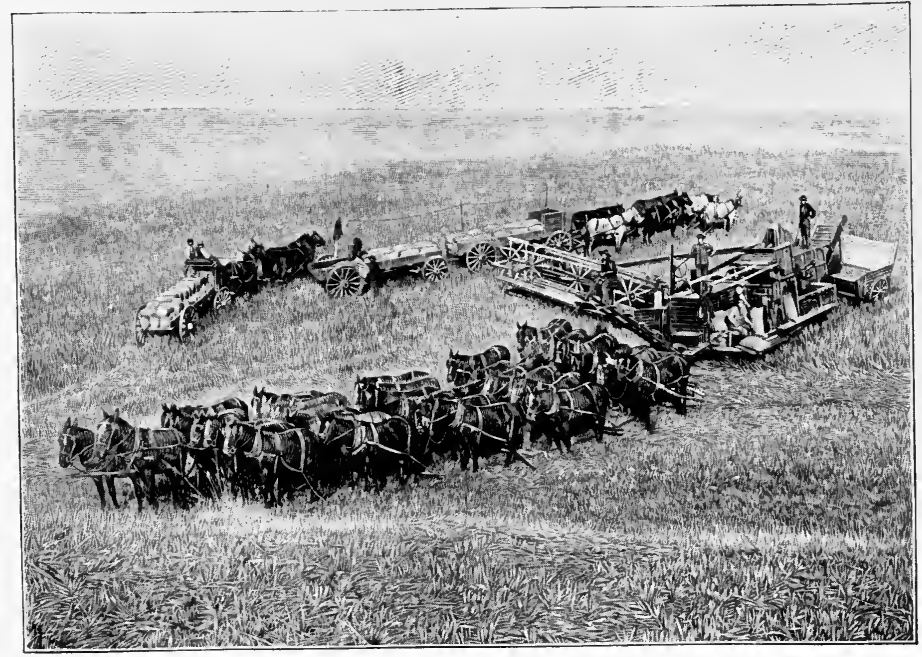

Thirty-horse Harvester。 (Used on Pacific slope.) 
Nowhere in the world has there been such a large area of rich and productive territory without any artificial barrier:s to trade and intercourse. From end to end of the United States there was in 1900 one post-office system, two telegraph companies, four large express companies, one system of currency, and one general system of transportation of through freight and through passenger cars. Neither state nor federal government could hinder free trade from one state to another; hence business inen and commercial travelers moved from one end to the other of the land, looking for goods and for customers; and freight was cheaply shipped wherever there was a market.

For many years the United States was free from the old mediæval idea of a guild controlling a whole trade, limiting 494. Free- the number of apprentices, and holding a monopoly of dom of labor employment in that trade. American boys and men have been allowed to choose their calling for themselves. The American principle is that a man is free to make his own contracts with his employer, except that laws may wisely limit the hours of labor, regulate child labor, and compel the employer to look out for the safety of his workmen.

On the other hand, for many years the American workman has been free to combine with his fellows in trades unions, and to strike if he feels like it. As workmen increase and employers organize, it is natural for the labor unions to be eager to enroll members, because their success depends on bringing into one society all the men who can do the work. Hence they feel that the nonunion man is acting against them; and in a strike they go so far as to accuse him of stealing their jobs, and of taking the bread out of their mouths.

The trades unions up to 1900 habitually made use of three devices which caused trouble in every strike: (1) they "picketed" the premises of employers, and tried to persuade nonunion applicants for work to keep away; (2) they called 
out men in "sympathetic strikes" - that is, strikes of men who have no grievance of their own, but wish to bring pressure to bear in aid of their brethren; (3) the "boycott" was freely used; for instance, when the employees of a street railway struck, the strikers often refused to trade with or consort with people who rode on cars conducted by nonmion men. All these methods may be, and sometimes have been, used to limit the American freedom to choose one's own employment, and to do business where one will.

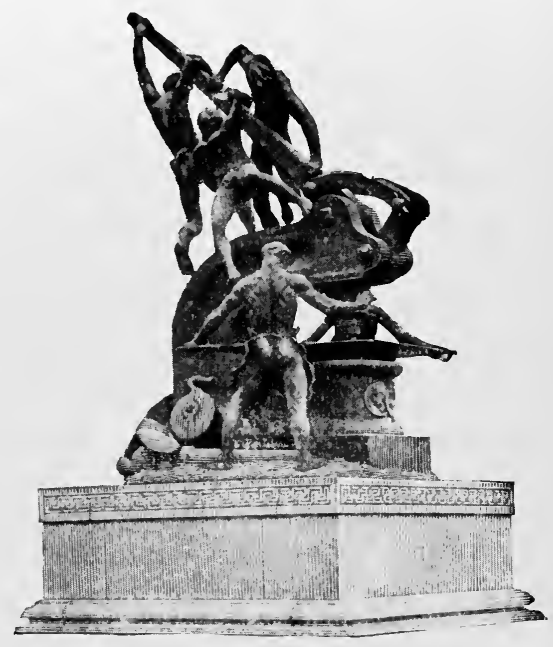

A Monument to Labor.

Designed by Tilden; San Francisco.

Americans have a freedom hardly known on the continent of Europe, to form societies for any legal purpose. Secret fraternities, such as the Masons, the Odd Fellows, and the Knights of Pythias, have millions of members. The churches are, from one point of view, social organizations 495. Freedom of for common benefits. There are now many regular meetings of business men, such as the Bankers' Association and the annual conference of manufacturers of bolts and nuts. Similar meetings are held by men of science and learning, among them the American Association for the Advancement of Science, the American Historical Association, and the National Educational Association. Ever since the war patriotic societies have thriven, such as the Grand Army of the Republic, the Loyal Legion, and the Daughters of the American Revolution. Similar societies have been organized in the 
South, such as the Daughters of the Confederacy. All these organizations, extending from state to state, tend to break up local boundaries, and to inake people feel that they belong to one country and have one purpose.

Business, social, and labor organizations are all good, so far as they do not prevent or dwarf the freedom of individual effort, which is the touchstone of the wonderful progress of our country. The one organization within the United States to which everybody belongs, which everybody ought to love most, which is supreme over every other society, corporation, or union, which comes first, and must be obeyed first, is the country itself - the "commonwealth," as expressed through the local governments, the state governments, and the national government at Washington.

Perhaps the largest contribution that America has made to the world is the proof, for the first time in history, that popular 496. Popu- government is possible for a nation of great extent, with lar govern- a large population. This success is in part due to some ment of the following peculiarities of our American form of government: (1) The breadth of the suffrage, which is based upon the idea that if a man has a vote he will think about public affairs; denial of the right to vote, by bribery, force, or fraud, is therefore a crime against civilization. (2) Equal representation of districts of equal population - a plain, comprehensible method, which keeps people satisfied. (3) Party machinery and party politics, which help to keep government moving, so long as they are not worshiped for themselves. (4) Frequent elections, making it possible to bring public opinion to bear in a quick and effective way.

The part of American government which has been most 497. Fed- imitated by other countries is our federal system, which eral govern- has in various ways shown itself both strong and fleximent ble:-

(1) The national government has had a well-balanced Con- 
gress, the best civil service in the country, and judges and courts of great dignity and weight.

(2) Each state has organized itself according to its own constitution. In practice the state governments are very much

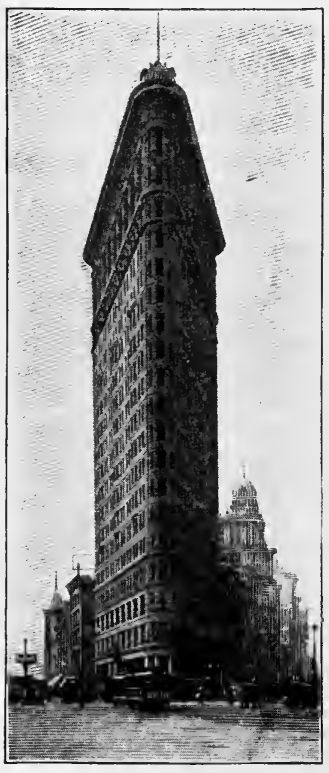

Flatiron Building, New

YoRK, BUILT IN 1902。

Height, 286 feet.

alike, each possessing an elective governor, a legislature of two houses, and judges (usually elective), with power to declare statutes void because unconstitutional; and the states furnish a good example of the wisdom of leaving local matters to local authorities, which must take the consequences of their own mistakes, each for itself.

The cities have grown so large that they often overshadow the states which create them; at present they have little to teach the world because they have not learned to choose their officers and carry on their affairs for purely municipal purposes; they are torn in two by state and national party spirit.

In many ways the treatment of the territories by the United States has been admirable; but we had in 1900 many kinds of dependencies, some of which were very hard to manage:

(1) the "territories," including

498. Government of dependencies Hawaii, which have had about as good government as the neighboring states; (2) Indian Territory, Alaska, and the small Pacific islands, under various kinds of paternal government, directed from Washington; (3) the Indian reservations, under the special wardship of the national government; (4) Porto Rico, with a special type of territorial government; (5) the Philippine Islands, which have been subject to special 
legislation; the Filipinos have not yet attained the moderate self-government provided for Hawaii and Porto Rico.

These differences and limitations are hard to reconcile with the general principles of free and equal popular government. Either we must look forward to granting all these dependent people as large a degree of self-government as our organized territories, or else we must give up the idea that "governments derive their just powers from the consent of the governed."

Of what advantage to us has been our study of American History? Does it pass simply as a tale that is told, or has it a lesson

499. summary: the meaning of American history which will help Americans to lead happier lives and to be more useful in their day and generation? As we follow the story all the way from our seafaring and sea-fighting ancestors, the most important lessons are the three principles which the French Revolution tried to express in the republican motto, "Liberty, Equality, Fraternity."

Equality in the United States means an equal privilege before the law for every man, woman, and child. It is the just boast of our country that all people who have their own way to make enjoy a better chance here, in the United States, than anywhere else in the world.

Liberty means in the United States, not the freedom to do whatever one likes, but-with due respect to the rights of others - to take part in life as one judges best, to think and to act for oneself. That is what has made the great inventors, educators, and statesmen: they have worked out their own problems. Laws or customs must not deny even to the ignorant child or man the chance to do the best that is in him; nor must they tie the hands of the quick and the able.

Fraternity means combination; and in the whole history of America, perhaps the most wonderful thing is the spirit of orderly union. The Pilgrims on the Mayflower agreed to act together, and to obey the majority; the patriots of the Revo. 
lution made state and national governments, which could provide for the general welfare; the Federal Convention enlarged and strengthened the Union; the spirit of union saved the government from destruction by the Civil War, and has brought the two sections together again.

Liberty, equality, and fraternity are all means to one end - the supremacy of law and order as the protector of the individual. Perhaps the greatest lesson of American history is that the only safe and sure way to bring about changes and reforms is by an appeal to the moral sense of the nation, by the long course of political discussion, by ballots rather than by bullets. As Lincoln put it in his first inaugural: "Why should there not be a patient confidence in the Works, II ultimate future of the people. Is there any better or equal hope in the world?" Ours be Lowell's pledge of patriotism : -

"O Beautiful! my Country! . .

What were our lives without thee?

What all our lives to save thee?

We reck not what we gave thee;

We will not dare to doubt thee,

But ask whatever else, and we will dare !"

\section{TOPICS}

(1) Why do Americans move so freely from state to state? (2) Why has the United States grown so rapidly in population? Suggestive

(3) Why have the Indians lost their importance? (4) Whence came the American ideas of personal liberty? (5) Whence came the American ideas of religious toleration? (6) Whence came the American ideas of freedom of opinion and speech ? (7) Why do American workmen accept new machinery? (8) Why is American railroad management superior to foreign? (9) Why can not a man contract to make himself a slave? (10) Why does the government come before any religious, social, or business organization in its right to the allegiance of Americans? (11) Why is the suffrage so broadly extended in America? (12) What are 
Search topics

Geography

Secondary authorities

Sources the good things about party government? (13) What are the defects of party government? (14) Why is city government harder to carry on well than state or national government?

(15) How many of the people of the United States are of English, Scotch, or Welsh descent? (16) Number of children educated in private schools. (17) Number of children educated in church schools. (18) Picketing in strikes. (19) Sympathetic strikes. (20) Use of the boycott by workmen. (21) Use of the black list by employers. (22) Limitations on the right of free speech. (23) What limitations are there on the suffrage?

\section{REFERENCES}

See maps, pp. 561, 567 .

C. I). Wright, Practical Sociology; James Bryce, American Commonwealth; Alexander Johnston, American Politics; A. B. IIart, Actual Government; Emlin McClain, Constitutional Law; F. A. Cleveland, Growth of Democracy; F. J. Goodnow, Politics and Administration; B. A. Hinsdale, American Government; R. L. Ashley, American Federal State.

Herbert, Why the Solid South; Riis, Children of the Poor, How the Other Half Lives; Booker Washington, Up from Slavery. 


\section{CHAPTER XXXVI.}

\section{THE TWENTIETH CENTURY}

Aт the beginning of the twentieth century the President of the United States was William McKinley, who was reëlected

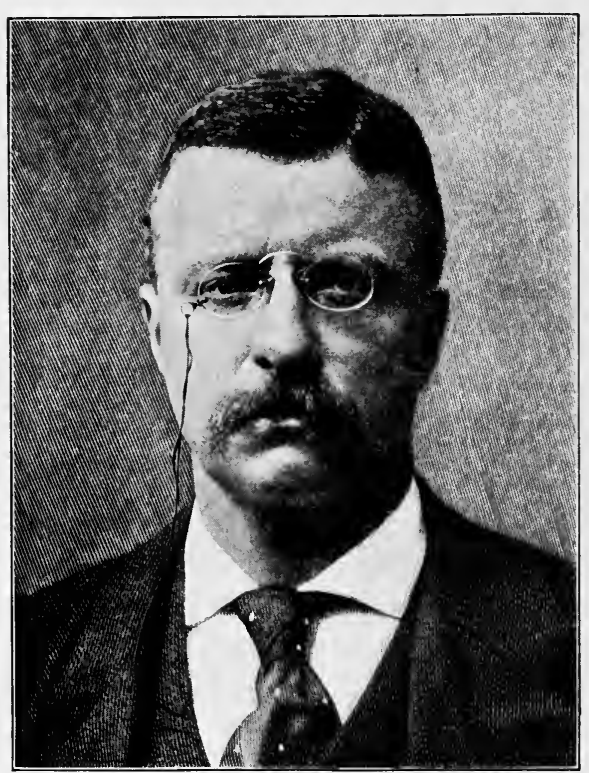

Copyright, 1898, by Pach Bros., N.Y.

Theodore Roosevelt, in 1903. in 1900 over Bryan, by an dent Rooseelectoral vote velt of 292 to $15 \%$, and began his second ter'm with a prestige and influence which no President had enjoyed for many years; but he was shot by an obscure assassin and died September 14, 1901, lamented by all his countrymell. He was succeederl by VicePresident Roosevelt. Theodore Roosevelt was born in New York in 1858, of Dutch descent. $\mathrm{He}$ graduated from Harvard College in 1880, and entered politics in the New York legislature in 1883, where he distinguished himself as a fighter for cheaper fares on the New York elevated roads. Then he raised cattle in 
North Dakota, and wrote books on open-air life and American history. From 1889 to 1895 he was the leading spirit of the National Civil Service Commission. In 1897-1898 he was Assistant Secretary of the Navy, but entered the army, and was one of the few men who in the Spanish War attracted popular attention by military services on land. His reputation in the war practically made him governor of New York (1899), and Vice President (1901). Roosevelt's distinguishing qualities have been the courage to hold and express an opinion, a quick resolution and firmness of decision, and uncommon openness and directness.

As President, Roosevelt had an opportunity to improve the civil service. 84,000 persons were already in the classified 501. Interservice, open to competitive examination. In 1904; out nalaffairs of 271,000 persons in the civil service, 143,000 were (1901-1904) classified or subject to examination; 7000 were subject to confirmation by the Senate, and 85,000 were country postmasters and clerks. President Roosevelt improved the consular service and practiced a system of promoting good diplomats from one post to another. In the southern states he followed the practice of forty years by nominating some colored men to office. To an outburst of denunciation from the South, he replied in a public letter that he would not "shut the door of opportunity" on the members of the negro race.

In 1902 a desperate strike of the anthracite coal miners of Pennsylvania threatened to leave the eastern states without necessary fuel: President Roosevelt came forward as a mediator, and by consent of both sides appointed a commission which settled the strike. He was much aroused on the subject of trusts and monopolies, and through the attorneygeneral brought suit under the act of 1890 (\$ 462) to prevent the "merger," or consolidation, of the Great Northern, Northern Pacific, and Chicago, Burlington, and Quincy railroads; and the Supreme Court in 1904 held that the merger 
was illegal. A more stringent anti-trust act was passed in 1903, under which the government may require corporations which do an interstate business to submit their accounts to the government; for half the evils of trusts and combinations can be prevented if the trusts can be made to tell the public what they are doing. Toward the Philippines and Cuba Roosevelt favored a liberal commercial policy; and he visited with his severe official displeasure a few officers convicted of torturing or otherwise abusing the Filipinos.

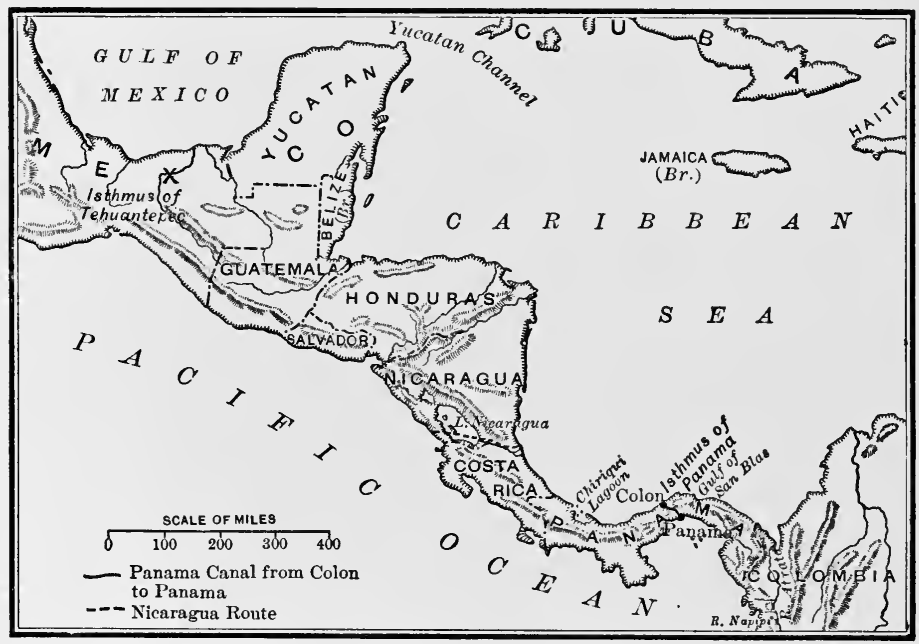

The Chief Isthmian Canal Routes.

In 1898 the battleship Oregon was compelled to steam fifteen thousand miles from San Francisco to join Sampson's fleet in the West Indies; and this incident again called attention to the need of an isthmian canal. The breakdown of the

502. The isthmian canal Panama Company ( $\$ 451)$ did not leave the field entirely (1899-1903) free, for the company still owned the land and the right to finish the canal; but it convinced the people of the United States that the only way to get a canal was for the United States 
to build it. The Nicaragua Canal Company asked Congress to take their route off their hands. As a basis for intelligent action, Congress in 1899 authorized a special commission of experts, which reported (1900) in favor of the Nicaragua route, because they had been unable to come to satisfactory terms with the French Panama Company for its holdings on that route.

Since the British government and people during the Spanish War showed the warmest sympathy with the United States, and a desire to remove all causes of friction between the two English-speaking countries, this seemed a favorable moment for disposing of the Clayton-Bulwer treaty. By the HayPauncefote treaty (November 18, 1901), Great Britain gave up fully all claims to any share in the construction or control of a canal from the Atlantic to the Pacific. The United States was at last free to construct a canal, and public sentiment demanded action. The French company offered to sell its property and its rights for $\$ 40,000,000$, and Congress passed an act (June 28, 1902) anthorizing the President to accept those terms and to complete the canal at Panama; but if he could not secure control of the necessary land strip from Colombia "within a reasonable time and upon reasonable terms," he was to construct the canal on the Nicaragua route. He therefore negotiated a treaty drawn by a representative of Colombia which would have given the United States sufficient control over the line of the canal; but Colombia refused to ratify it (September 14, 1903). A few weeks later an insurrection broke out in Panama, a new republic was set up, November 3, 1903, and was recognized by the United States, November 6 ; and on February 23, 1904, a treaty with Panama was ratified for the construction of the canal.

After the adjustment of the government of the Philippine 503. Elec- Islands -under Governor William H. Taft in 1903, and tion of

the settlement of the Isthmus question in 1904, both political parties bent their energies to the approaching presi- 
dential election. The sudden death of Senator Marcus A. Hanna, the intimate friend of President McKinley, removed one of the great leaders of the Republican party. President Roosevelt from the first seemed likely to be renominated, and when the Republican convention met in Chicago in June, 1904, he was unanimously renominated, and with him Senator Fairbanks of Indiana was put on the ticket for Vice President. The platform of the party declared for protection, called attention to recent acts passed by a Republican Congress for the regulation of corporations, and promised "new laws insuring reasonable publicity" of the transactions of corporations.

The Democratic convention, held at St. Louis in July, 1904, declared against executive usurpation, exploitation of the colonies, and tariffs favorable to trusts and special interests; and also pronounced in favor of an isthmian canal. Nothing was said on the platform as to the currency, but the Democratic candidate for the presidency, Judge Alton B. Parker of New York, before the convention adjourned, telegraphed his firm adherence to the gold standard.

The campaign turned principally upon the record of President Roosevelt and the principles announced in several speeches by Judge Parker; the main issues being imperialism, the tariff, and the relations of the two great parties to the trusts. In the election in November, Judge Parker carried the "Solid South" except Missouri and one elector in Maryland. Roosevelt carried all the other states in the Union, and had 336 electoral votes to 140 for Judge Parker, on a popular plurality of about 2,500,000 votes. The Socialist candidate, Eugene V. Debs, received 402,000 votes; the People's party candidate, Thomas E. Watson, had 118,000 votes; and the Prohibition candidate, Silas Swallow, had 259,000 votes. 
• 


\section{APPENDIX A}

\section{BRIEF LIST OF BOOKS}

(These books, costing about $\$ 25$, are well adapted for constant use on the teacher's desk.)

I. Methods and Materials

American Historical Association, Committee of Seven, The Study of History in Schools. (N.Y. Macmillan. 1839. \$0.50.)

New England History 'Teachers' Association, Historical Sources in Schools. (N.Y. Macmillan. 1902. \$0.60.)

New England History Teachers' Association, A History Syllabus for Secondary Schools. (Bost. Heath. 1904. \$1.20.) Part IV., on American History, sold separately, \$0.15.

Channing, E., and Hart, A. B., Guide to the Study of American History. (Bost. Ginn. 1896. \$2.00.)

\section{Also one of the two following books :}

(1) Bourne, H. E., The Teaching of History and Civics in the Elementary and the Secondary School. (N.Y. Longmans. 1902. \$1.50.)

(2) Hinsdale, B. A., How to Study and Teach History, with Particular Reference to the History of the United States. (International Education Series. Rev. ed. N.Y. Appleton. 1902. \$1.50.)

II. Collections of Sources

Hart, A. B., ed., American History told by Contemporaries. (4 vols. N.Y. Macmillan. 1897-1901. \$8.00.)

Also one of the two following combinations of volumes :

(Caldwell, H. V., Survey of American History. (Chic. Ainsworth. $1900 . \$ 1.10$.)

Hart, A. B., ed., Source-Book of American History. (N.Y. Macmillan. 1900. \$0.60.)

(1) Hart, A. B., and Channing, Edward, eds., American History Leaflets. (33 Nos. pub. N.Y. Simmons. 1892- . \$0.10 each.) Hill, Mabel, ed., Liberty Documents, with Contemporary Exposition and Critical Comments drawn from Various Writers. (N.Y. Longmans. 1901. \$2.00.)

William MacDonald, ed., Select Documents Illustrative of the History of the United States, 17\%6-1861. (N.Y. Macmillan. 1898. \$2.25.)

William MacDonald, ed., Select Charters and other Documents

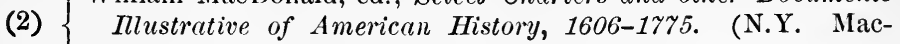
millan. 1899. \$2.00.)

William MacDonald, ed., Select Statutes and other Documents Mlustrative of the History of the United States, 1861-1898. (N.Y. Macmillan. 1903. \$2.00.) 
iII. Colonial Perion

One of the three following books:

(1) Fisher, G. P., The Colonial Era. (American History Series. N.Y. Scribner. 1892. \$10\%.)

(2) Lodge, H. C., A Short History of the English Colonies in America. (N.Y. Harper. 1881. \$3.00.)

(3) Thwaites, R. G., The Colonies, 1492-1750. (Epochs of American History. Rev. ed. N.Y. Longmans. 1897. \$1.25.)

\section{Revolutionary and Constitutional Period}

One of the two following books :

(1) Channing, Edward, The United States of America, 1765-1865. (N.Y. Macmillan. 1897. \$1.50.)

(2) Stanwood, Edward, A History of the Presidency. (Bost. Houglton. 1898. \$2.50.)

One of the two following combinations of volumes :

(Hart, A. B., Formation of the Union, 1750-18\%9. (Epochs of American History. Rev. ed. N.Y. Longmans. 1897.

(1) $\$ 1.25$.

Wilson, Woodrow, Division and Reunion, 1829-1889. (Epochs of American History. Rev. ed. N.Y. Longmans. $₫ 898$. $\$ 1.25$.

(Sloane, W. M., The French War and the Revolution. (American History Series. N.Y. Scribner. 1893. \$1.00.)

(2) Walker, F. A., The Making of the Nation, 1783-181\%. (American History Series. N.Y. Scribner. 1895. \$1.00.)

Johnston, Alexander, History of American Politics. (4th ed. rev. by W. M. Sloane. N.Y. Holt. 1898. \$0.80.)

\section{Civil War and Subsequent Period}

Dodge, 'T. A., A Bird's-eye View of our Civil War. (Rev. ed. Bost. Houghton. 1897. \$1.25.)

Morse, John T., Abraham Lincoln. (2 vols. American Statesmen Series. Rev. ed. Bost. Houghton. 1900. \$2.50.)

One of the three following volumes :

(1) Hart, A. B., Actual Government as applied under American Conditions. (N.Y. Longmans. 1903. \$2.00.)

(2) Ashley, R. L., The American Federal State. (N.Y. Macmillan. 1902. $\$ 2.00$.)

(3) Bryce, James, The American Commonwealth. (Abridged ed. N.Y. Macmillan. 1896. \$1.75.) 


\section{APPENDIX B}

\section{GENERAL BIBLIOGRAPHY}

(Titles marked with an asterisk denote books especially desirable for a school library, besides those mentioned in the Brief List.)

Adams, C. F., Charles Francis Adams (Amer. Statesmen). Bost. 1900. Adams, C. F., Three Episodes of Massachusetts History. 2 vols. Bost. 1892.

* Adams, Henry, History of the United States during the Administrations of Jefferson and Madison. 9 vols. N.Y. 1889-1891.

Adams, Henry, John Randolph (Amer. Statesmen). Bost. 1900. Allen, Walter, Ulysses S. Grant (Riverside). Bost. 1901.

* American Annual Cyclopadia, 1861-1875. 15 vols. N.Y. 1862-1876. Ames, H. V., ed., State Documents on Federal Relations. Nos. 1-4. Phil. 1900-1902.

Ammen, Daniel, The Atlantic Coast (Navy in Civil War). N.Y. 1883. Andrews, C. M., Colonial Self-Government (Amer. Nation). N.Y. 1904. Appletons' Anuual Cyclopadia, 1876-. N.Y. 1877-.

Arber, Edward, ed., Story of the Pilgrim Fathers. Lond. 1897.

Babcock, K. C., Rise of American Nationality (Amer. Nation). N.Y.

Bancroft, Frederic, William H. Seward. 2 vols. N.Y. 1900.

Bancroft, George, History of the Formation of the Constitution. 2 vols.

N.Y. $188 \%$.

Bancroft, George, History of the United States. Bost. 10 vols. 18341874.

Barnes, James, David G. Farragut (Beacon). Bost. 1899.

Bassett, J. E., Federalist System (Amer. Nation). N.Y.

* Bigelow, John, Samuel J. Tilden. 2 vols. N.Y. 1895.

Birney, William, James G. Birney. N.Y. 1890.

Botume, E. H., First Days amongst the Contrabands. Bost. 1893.

Bourinot, J. G., Story of Canada. N.Y. 1896.

Bourne, E. G., Spain in America (Amer. Nation). N.Y. 1904.

Bowne, E. S., A Girl's Life Eighty Years Ago. N.Y. 1887.

Brady, C. 'T., Stephen Decatur (Beacon). Bost. 1900.

* Brigham, A. P., Geographic Influences in American History. Bost. 1903.

Brooks, E. S., Story of our War with Spain. Bost. 1899.

Brooks, Noah, Short Studies in Party Politics. N.Y. 1895.

* Brooks, Noah, Washington in Lincoln's Time. N.Y. 1895.

* Brown, W. G., Andrew .Jackson (Riverside). Bost. 1900.

Brown, IV. G., The Louer South in American Histıry. N.Y. 1902.

Brown, W. G., Stephen Arnold Douglas (Riverside). Bost. 1902.

Browne, W. H., George Calvert and Cecilius Calvert (Makers of Amer.).

N.Y. 1890.

* Bruce, Henry, General Houston (Makers of Amer.). N.Y. 1891.

Bruce, Henry, General Ojlethorpe (Makers of Amer.). N.Y. 1890. 
Bruce, P. A., Economic History of Virginia. 2 vols. $\quad$ N.Y. 1896.

* Bryant and Gay, Popular History of the United States. 5 vols. N.Y. 1878-1898.

Burton, Richard, John Greenleaf Whittier (Beacon). Bost. 1901.

* Cable, G. W., Creoles of Louisiana. N.Y. 1884.

Cable, G. W., Negro Question. N.Y. 1890.

Cairnes, J. E., Slave Power. N.Y. 1862.

Caldwell, H. W., ed., American Territorial Development. Chic. 1900.

Caldwell, H. W., ed., Great American Legislators. Chic. 1900.

Caldwell, H. W., ed., Survey of American History. Chic. 1900.

Callahan, J. M., Cuba and International Relations. Balt. 1899.

* Cambridge Modern History. (Vol. VII. The United States.) N.Y. 1903.

Carpenter, E. J., American Advance. N.Y. 1903.

* Carpenter, F. B., Six Months at the White House. N.Y. 1866.

Century Co., Battles and Leaders of the Civil War. 4 vols. N.Y. 18881889.

* Chadwick, F. E., Causes of the Civil War (Amer. Nation). N.Y.

Chamberlain, N. H., Samuel Sewall. Bost. 1897.

Chamberlin, J. E., John Brown (Beacon). Bost. 1899.

* Channing, Edward, Jeffersonian System (Amer. Nation). N.Y.

* Channing, Edward, Town and County Government in the English Colonies. Balt. 1884.

Chesnutt, C. W., Frederick Douglass (Beacon). Bost. 1899.

Cheyney, E. P', European Background (Amer. Nation). N.Y. 19014

Cist, H. M., Army of the Cumberland (Campaigns of Civil War). N.Y. 1882.

Colby, C. W., ed., Selections from the Sources of English History. Lond. 1899.

Conant, C. A., Alexander Hamilton (Riverside). Bost. 1901.

Coppée, Henry, General Thomas (Great Commanders). N.Y. 1893.

Cox, J. D., Atlanta (Campaigns of Civil War). N.Y. 1882.

Cox, J. D., March to the Sea (Campaigns of Civil War). N.Y. 1882.

* Curtis, G. T., Constitutional History of the United States. 2 vols. N.Y. $1889-1896$.

* Dana, C. A., Recollections of the Civil War. N.Y. 1898.

Dana, R. H., Jr., Two Years before the Mast. Various eds.

Davies, H. E., General Sheridan (Great Commanders). N.Y. 1895.

Dawes, A. L., Charles Sumner (Makers of Amer.). N.Y. 1892.

* Dewey, D. R., Financial History of the United States (Amer. Citizen). N.Y. 1903.

Doubleday, Abner, Chancellorsville and Gettysburg (Campaigns of Civil War). N.Y. 1882.

Douglass, Frederick, Life and Times. Rev. ed. Bost. 1893.

* Doyle, J. A., English Colonies in America. 3 vols. pub. N.Y. 1889.

Du Bose, J. W., Life of William Lowndes Yancey. Birm., Ala. 1892.

* Dunning, W. A., Civil War and Reconstruction. N.Y. 1898.

Dunning, W. A., Reconstruction (Amer. Nation). N.Y. 
Eggleston and Seelye, Tecumseh and the Shawnee Prophet. N.Y. 1878.

* Eggleston, Edward, Beginners of a Nation. N.Y. 1896.

* Eggleston, Edward, Transit of Civilization. N.Y. 1901.

Eggleston, G. C., American War Ballads. 2 vols. N.Y. 1889.

* Eggleston, G. C., A Rebel's Recollections. N.Y. 1878.

Elliott, S. B., Sam Houston (Beacon). Bost. 1900.

Elson, H. W., Side Lights on American History. 2 vols. N.Y. 1899-1900.

Farrand, L., Basis of American History (Amer. Nation). N.Y. 1904.

Fiske, John, American Revolution. 2 vols. Bost. 1891.

* Fiske, John, Beginnings of Nevo England. Bost. 1889.

* Fiske, John, Critical Period of American History. Bost. 1888.

* Fiske, John, Discovery of America. 2 vols. Bost. 1892.

* Fiske, John, Dutch and Quaker Colonies. 2 vols. Bost. 1899.

Fiske, John, Mississippi Valley in the Civil War. Bost. 1900.

Fiske, John, New France and New England. Bost. 1902.

* Fiske, John, Old Virginia and her Neighbours. 2 vols. Bost. 1897.

Fithian, P. V., Journal and Letters, 1\%6\%-1\%\%4. Princeton, 1900.

Force, M. F., From Fort Henry to Corinth (Campaigns of Civil War).

N.Y. 1881.

Force, M. F., General Sherman (Great Commanders). N.Y. 1899.

Ford, P. L., The Many-sided Franklin. N.Y. 1899.

* Ford, P. L., The True George Washington. Phil. 1902.

Ford, W. C., National Problems (Amer. Nation). N.Y.

Foster, J. W., Anerican Diplomacy in the Orient. Bost. 1903.

* Foster, J. W., Century of American Diplomacy. Bost. 1900.

* Frothingham, R., Rise of the Republic of the United States. Bost. 1872.

Garrison, G. P., Texas (Amer. Commonwealths). Bost. 1903.

Garrison, G. P., Westward Extension (Amer. Nation). N.Y.

Gay, S. H., James Madison (Amer. Statesmen). Bost. 1900.

Gilman, D. C., James Monroe (Amer. Statesmen). Bost. 1900.

Gordy, J. P., History of Political Parties in the United States, 2 vols. pub. N.Y. 1900-1902.

Goss, W. L., Recollections of a Private. N.Y. 1891.

Gould, A. B., Louis Agassiz (Beacon). Bost. 1901.

Grant, Anne, Memoirs of an American Lady. Albany. 1876.

* Grant, U. S., Personal Memoirs. 2 vols. N.Y. 1885-1886.

Graydon, Alexander, Memoirs of a Life chiefly passed in Pennsylvania. Harrisburg. 1811.

Greene, E. B., Provincial America (Amer. Nation). N.Y. 1905.

Greene, F. V., General Greene (Great Commanders). N.Y. 1893.

Greene, F. V., The Mississippi (Campaigns of Civil War). N.Y. 1882.

* Greene, G. W., Historical View of the American Revolution. Bost. 1865. Griffis, W. E., Sir William Johnson (Makers of Amer.). N.Y. 1891.

Hale, E. E., Jr., James Russell Lowell (Beacon). Bost. 1899.

Hapgood, Hutchins, Paul Jones (Riverside). Bost. 1901.

Hapgood, Norman, Abraham Lincoln. N.Y. 1899.

Hapgood, Norman, Daniel Webster (Beacon). Bost. 1899.

* Hart, A. B., Foundations of American Foreign Policy. N.Y. 1901. 
Hart, A. B., Practical Essays on American Government. N.Y. 1893. Hart, A. B., Salmon Portland Chase (Amer. Statesmen). Bost. 1900. Hart, A. B., Slavery and Abolition (Amer. Nation). N.Y.

* Hart, A. B., ed., Source Readers in American History. 4 vols. N.Y. 1902-1903.

* Hart, A. B., ed., The American Nation; a History from Original Sources by Associated Scholars. 28 vols. N.Y. 1904-. Volumes sold separately, and mentioned in this book by the names of the authors.

Helper, H. R., Impending Crisis. N.Y. 1857.

Herbert, H. A., Why the solid South? Balt. 1890.

Higginson, T. W., Army Life in a Black Regiment. New ed. Bost. 1882.

Higginson, T. W., Book of American Explorers. Bost. 1877.

Higginson, T. W., Francis Higginson (Makers of Amer.). N.Y. 1891.

* Higginson, T. W., Larger History of the United States. N.Y. 1886.

Hinsdale, B. A., Old Northwest. N.Y. 1888.

Hodges, George, William Pern (Riverside). Bost. 1901.

Hollis, I. N., The Frigate "Constitution." Bost. 1900.

Holst, Hermann von, John C. Calhoun (Amer. Statesmen). Bost. 1900. Hosmer, J. K., Appeal to Arms (Amer. Nation). N.Y.

Hosmer, J. K., Louisiana Purchase. N.Y. 1902.

Hosmer, J. K., Mississippi Valley. Bost. 1901.

Hosmer, J. K., Outcome of the Civil War (Amer. Nation). N.Y.

Hosmer, J. K., Samuel Allams (Amer. Statesmen). Bost. 1900.

Hosmer, J. K., Thomas Hutchinson. Bost. 1896.

*Houston, D. F., Nullification in South Carolina. N.Y. 1896.

Hovey, Carl, Stonevall Jackson (Beacon). Bost. 1900.

Howard, G. E., Preliminaries of the Revolution (Amer. Nation). N.Y. 1905.

Howard, O. O., General Tayior (Great Commanders). N.Y. 1892.

Hughes, R. M., General Johnston (Great Commanders). N.Y. 1893.

Humphreys, A. A., From Gettysburg to the Rapidan (Campaigns of Civil War). N.Y. 1883.

Humphreys, A. A., Virginia Campaign of '64 and'65 (Campaigns of Civil War). N.Y. 1883.

* Hunt, Gaillard, James Madison. N.Y. 1902.

Johnson, B. 'T., General Washington (Great Commanders). N.Y. 1894.

* Johnston, Alexander, American Orations. 4 vols. Rev. ed. N.Y. 18961897.

Jones, J. B., A Rebel War Clerk's Diary. Phil. 1866.

Keasbey, L. M., Nicaragua Canal and Monroe Doctrine. N.Y. 1896.

Kendall, Elizabetl, Source-Book of English History. N.Y. 1900.

King, Grace, Jean Baptiste Le Moyne, Sieur de Bienville (Makers of Amer.). N.Y. 1892.

* Landon, J. S., Constitutional History and Government of the United States. Rev. ed. Bost. 1900.

* Larned, J. N., History for Ready Reference. 6 vols. Springfield, Mass. 1894-1901.

Latané, J. H., America the World Pover (Amer. Nation). N.Y. 
* Latané, ア. H., Diplomatic Relations of the United States and Spanish America. Balt. 1900.

Lecky, W. E. H., American Revolution (ed. J. A. Woodburn). N.Y. 1898. Lee, Fitzhugh, General Lee (Great Commanders). N.Y. 1894. Lighton, W. R., Lewis and Clark (Riverside). Bost. 1901. Linn, IV. A., Horace Greeley. N.Y. 1903.

Linn, W. A., Story of the Mormons. N.Y. 1902.

* Locke, M. S., Anti-Slavery in America, 1619-1808. Bost. 1901.

* Lodge, H. C., Alexander Hamilton (Amer. Statesmen). Bost. 1900.

* Lodge, H. C., Daniel Webster (Amer. Statesmen). Bost. 1900.

* Lodge, H. C., George Washington (Amer. Statesmen). 2 vols. Bost. 1900.

Lodge, H. C., Story of the Revolution. 2 vols. N.Y. $1898 . \quad$ Also new ed., in 1 vol., 1903 .

Longstreet, James, From Manassas to Appomattox. Phil. 1896.

Lothrop, 'T. K., William Henry Seward (Amer. Statesmen). Bost. 1900. Lucas, C. P., Historical Geography of the British Colonies. Vol. V. Pt. i. Oxford. 1901.

McCall, S. W.. Thaddeus Stevens (Amer. Statesmen). Bost. 1900.

McCarthy, C. H., Lincoln's Plan of Reconstruction. N.Y. 1901.

* McCrady, Edward, History of South Carolina. 4 vols. N.Y. 1897-1902. McCulloch, Hugh, Men and Measures of Half a Century. N.Y. 1888. MacDonald, William, Jacksonian Democracy (Amer. Nation). N.Y. McDougall, M. G., Fugitive Slaves. Bost. 1891.

McLaughlin, A. C., Confederation and Constitution (Amer. Nation). N.Y. 1905.

McLaughlin, A. C., Lewis Cass (Amer. Statesmen). Bost. 1900.

* Maclay, E. S., History of American Privateers. N.Y. 1899.

Maclay, E. S., History of the United States Navy. 3 vols. N.Y. 1901-1902.

* McMaster, J. B., History of the People of the United States from the Revolution to the Civil War. 5 vols. pub. N.Y. 1883-.

Macy, Jesse, Political Parties in the United States. N.Y. 1900.

Mahan, A. 'T., Admiral Farragut (Great Commanders). N.Y. 1892.

Mahan, A. T., Gulf and Inland Waters (Navy in Civil War). N.Y. 1883. Mahan, A. T., War of 1812. Bost. 1905.

Major, R. H., Prince Henry the Navigator. Lond. 1868.

Markham, C. R., Christopher Columbus (Great Explorers). Lond. 1892.

Mathes, J. H., General Forrest (Great Commanders). N.Y. 1902.

Matthews, Brander, Poems of American Patriotism. N.Y. 1882.

* May, S. J., Antislavery Confict. Bost. 1869.

Merwin, H. C., Aaron Burr (Beacon). Bost. 1899.

Merwin, H. C., Thomas Jefferson (Riverside). Bost. 1901.

Michie, P. S., General McClellan (Great Commanders). N.Y. 1901.

* Moore, Frank, Diary of the American Revolution. 2 vols. N.Y. 1860.

More, P. E., Benjamin Franklin (Riverside). Bost. 1900.

* Morse, J. 'T., Alexander Hamilton. 2 vols. Bost. 1876.

Morse, J. T., Benjamin Franklin (Amer. Statesmen). Bost. 1900.

* Morse, J. T., John Adams (Amer. Statesmen). Bost. 1900.

Morse, J. T., John Quincy Adams (Amer. Statesmen). Bost. 1900. 
* Morse, J. T., Thomas Jefferson (Amer. Statesmen). Bost. 1900. Myers, Gustavus, History of Tammany Hall. N.Y. 1901.

* Nicolay, J. G., Outbreak of Rebellion (Campaigns of Civil War). N.Y 1881.

Noyes, A. D., Thirty Years of American Finance. N.Y. 1898.

* Old South Leaflets. General series. 150 nos. pub. Bost. 1888-.

* Olmsted, F. L., Seaboard Slave States. New ed. 2 vols. N.Y. 1904.

* Page, T. N., The Oid South. N.Y. 1892.

Palfrey, F. W., Antietam and Fredericksburg (Campaigns of Civil War). N.Y. 1882.

Paris, Comte de, History of the Civil War. 4 vols. Phil. 1875-1888.

Parkman, Francis, Conspiracy of Pontiac. Rev. ed. 2 vols. Bost. 1870.

Parkman, Francis, Count Frontenac and New France under Louis XIV. Bost. 1877.

* Parkman, Francis, Half-Century of Confict. 2 vols. Bost. 1892.

* Parkman, Francis, The Jesuits in North America. Bost. 1867.

* Parkman, Francis, La Salle and the Discovery of the Great West. Rev. ed. Bost. 1887.

* Parkman, Francis, Montcalm and Wolfe. 2 vols. Bost. 1884.

Parkman, Francis, Old Régime in Canada. Rev. ed. Bost. 1895.

Parkman, Francis, Oregon Trail. Rev. ed. Bost. 1892.

Parkman, Francis, Pioneers of France in the New World. Rev. ed. Bost. 1887.

Parton, James, General Jackson (Great Commanders). N.Y. 1893.

Paxson, F. L., Independence of the South American Republics. Phil. 1903.

Payne, E. J., ed., Voyages of the Elizabethan Seamen. 2 vols. Oxford. 1893-1900.

Peck, C. H., Jacksonian Epoch. N.Y. 1899.

Pellew, George, John Jay (Amer. Statesmen). Bost. 1900.

Pennypacker, I. R., General Meade (Great Commanders). N.Y. 1901.

Phillips, U. B., Georgia and State Rights. Wash. 1902.

* Pike, J. S., Prostrate State. N.Y. 1874.

Pond, G. E., Shenandoah Valley in 1864 (Campaigns of Civil War). N.Y. 1883.

Quincy, Edmund, Josiah Quincy. Bost. 1867.

* Quincy, Josiah, Figures of the P'ast. Bost. 1883.

Raymond, R. W., Peter Cooper (Riverside). Bost. 1901.

Reddaway, W. F., The Monroe Doctrine. Cambridge, Eng. 1898.

* Rhodes, J.F., History of the United States from the Compromise of 1850. 5 vols. pub. N.Y. $1893-$.

Riddle, A. G., Recollections of War Times. N.Y. 1895.

* Riis, J. A., Children of the Poor. N.Y. 1892.

Riis, J. A., How the Other Half Lives. N.Y. 1890.

Roosevelt, Theodore, Gouverneur Morris (Amer. Statesmen). Bost. 1900.

Roosevelt, Theodore, Naval War of 1812. 3d ed. N.Y. 1883.

Roosevelt, Theodore, Thomas H. Benton (Amer. Statesmen). Bost. 1900.

* Roosevelt, Theodore, Winning of the West. 4 vols. N.Y. 1889-1896. 
Ropes, J. C., Army under Pope (Campaigns of Civil War). N.Y. 1881. * Ropes, J. C., Story of the Civil War. 2 vols. . N.Y. 1894-1898. Royce, Josiah, California (Amer. Commonwealths). Bost. 1886. * Sanborn, F. B., Life and Letters of John Browon. Bost. 1885. Sanborn, F. B., Ralph Waldo Emerson (Beacoul). Bost. 1901. Sanborn, J. B., Congressional Aid of Railways. Madison. 1899. Sato, Shosuki, History of the Land Question. Balt. 1886.

* Schouler, James, History of the United States under the Constitution. 6 vols. Rev. ed. N.Y. 1895-1899.

Schouler, James, Thomas Jefferson (Makers of Amer.). N.Y. 1893.

* Schurz, Carl, Henry Clay (Amer. Statesmen). 2 vols. Bost. 1900.

Schwab, J. C., Confederate States : a Financial and Industrial History. N.Y. 1901.

* Scudder, H. E., Men and Manners in America One Hundred Years Ago. N.Y. 1876.

Seaver, J. E., Narrative of the Life of Mrs. Mary Jemison. 6th ed. N.Y. 1898.

Sedgwick, Ellery, Thomas Paine (Beacon). Bost. 1899.

Sedgwick, H. I., Samuel de Champlain (Riverside). Bost. 1902.

* Semple, E. C., American History and its Geographic Conditions. Bost. 1903.

Sewall, Samuel, Diary, 1674-1729. 3 vols. Bost. $1878-1882 . \quad$ (Mass. Hist. Soc., Collections. 5th series, V-VII.)

Shaler, N. S., Kentucky. Bost. 1885.

Shaler, N. S., Nature and Man in America. N.Y. 1891.

Shaler, N. S., ed., United States of America. 2 vols. N.Y. 1894.

Sharpless, Isaac, Quaker Government in Pennsylvania. 2 vols. Phil. 1898-1899.

* Shelton, J. de F., Salt-Box House. N.Y. 1901.

Shepard, E. M., Martin Van Buren (Amer. Statesmen). Bost. 1900.

* Sherman, W. T., Memoirs. 2 vols. Rev. ed. N.Y. 1886.

* Siebert, W. H., Underground Railroad. N.Y. 1898.

* Smedes, S. D., Memorials of a Southern Planter. 4th ed. N.Y. 1890. Smith, T. C., Liberty and Free Soil Parties in the Northwest. N.Y. 1897.

Smith, T. C., Parties and Slavery (Amer. Nation). N.Y.

Soley, J. R., Admiral Porter (Great Commanders). N.Y. 1903.

Soley, J. R., The Blockade and the Cruisers (Navy in Civil War). N.Y. 1883.

* Sparks, E. E., Expansion of the American People. Chic. 1900.

* Sparks, E. E., Men who made the Nation. N.Y. 1901.

Spring, L. W., Kansas (Amer. Commonwealths). Bost. 1885.

Stanwood, Edward, American Tariff Controversies. 2 vols. Bost. 1903.

Stevens, J. A., Albert Gallatin (Amer. Statesmen). Bost. 1900.

Stockton, F. R., Buccaneers and Pirates of our Coasts. N.Y. 1898.

Storey, Moorfield, Charles Sumner (Amer. Statesmen). Bost. 1900.

Straus, O. S., Roger Williams. N.Y. 1894.

* Sumner, W. G., Alexander Hamilton (Makers of Amer.). N.Y. 1890. 
Sumner, W. (i., Audrew Jackson (Amer. Statesmen). Bost. 1900.

Summer, IV. (i., Robert Morris (Makers of Amer.). N.Y. 1892.

* 'Taussig, F. W., Tariff History of the United Stutes. 4th ed. N.Y. 1898.

*'Thayer, J. B., John Marshall (Riverside). Bost. 1901.

'Thurston, R. II., Robert Fultom (Makers of Amer.). N.Y. 1891.

*'Thwaites, R. (i., Daniel Boone. N.Y. 1902.

Thwaites, R. G., Fither Marquette. N.Y. 1902.

'Thwaites, R. G., France in America (Amer. Nation). N.Y. 1905.

'Titherington, IR. II., Spanish-American War of 189S. N.Y. 1900.

*'Trent, W. I'., Robert E. Lee (Beacon). Bost. 1899.

'Trevelyan, G. ()., American Revolution. 2 pts. pub. N.Y. 1899-1903. 'Trowbridge, John, Samuel Finley Breese Morse (Beacon). Bost. 1901. 'Tucker, (i. F., The Montoe Doctrine. Bost. 1885.

'Tuckerman, Bayard, P'ter Stuycesant (Makers of Amer.). N.Y. 1893. 'Turner, F. J., Rise of the New West (Amer. Nation). N.Y.

*'I'wichell, J. II., John Irinthrop (Makers of Amer.). N.Y. 1891.

'Tyler, L. (i., England in America (Amer. Nation). N.Y. 1904.

*'Tyler, M. ('., American Literature cluring the Colonial Time. 2 vols. N.Y. 1897.

*'Tyler, M. C., Literary History of the American Revolution. 2 vols. N.Y. 1897.

'Tyler, M. C., P’atrick IIenry (Amer. Statesmen). Bost. 1900.

Van 'Tyne, C. Il., American Revolution (Amer. Nation). N.Y. 1905.

Walker, F. A., (reneral IIuncock (Great Commanders). N.Y. 1894.

Walker, G. L., Thomas Hooker (Makers of Amer.). N.Y. 1891.

Ward, J. II., Bishop White (Makers of Amer.). N.Y. 1892.

Warner, C. 1)., Captain John Smith (Amer. Worthies). N.Y. 1881.

* Washington, B 'T., Up fiom Slavery. N.Y. 1901.

Webb, A. S., The Peninsula (Campaigns of Civil War). N.Y. 1881.

* Weeden, W. B., Economic and Social History of New England. 2 vols. Bost. 1891.

* Wenclell, Barrett, Cotton Mather (Makers of Amer.). N.Y. 1891.

Wilkeson, Frank, Recollections of a Private Soldier. N.Y. 1887.

Wilson, J. G., General Grant (Great Commanders). N.Y. 1897.

* IVilson, Woodrow, History of the American People. 5 vols. N.Y. 1902.

Winsor, Justin, Cartier to Frontenac. Bost. 1894.

* Wiusor, Justin, Christopher Columbus. Bost. 1891.

Winsor, Justin, Mississippi Basin. Bost. 1895.

* Winsor, Justin, ed., Narrative and Critical History of America. 8 vols. Bost. 1886-1889.

* Winsor, Justin, Westuard Movement. Bost. 1897.

Winthrop, John, The History of New England from 1630 to 1649. 2 vols Bost. 182:)-18:6. Corrected edition, 185:3.

* Wister, Owen, Ulysses S. Grant (Beacon). Bost. 1900.

Woolman, John, Journal. Various editions.

Wright, C. 1)., Outline of Practical Sociology (Amer. Citizens). N.Y. 1899.

Wright, M. J., General Scott (Great Commanders). N.Y. 1894. 


\title{
APPENDIX C
}

\section{DECLARATION OF INDEPENDENCE}

\author{
(Agreed to, July 4, 1776)
}

[From a faesimile of the original parchment]

Is Congress, July 4, 1776

THE UNANIMOUS DECLARATION OF THE THIREEN UNITED

STATES OF AMERICA

รTahın in the Conrse of human events, it becomes necessary for one people to dissolve the political bands which have conneeted them with another, and to assume among the powers of the earth, the separate and equal station to which the Laws of Nature and of Nature's God entitle them, a clecent respert to the opinions of mankind requires that they should declare the causes which impel them to the separation. - We hold these truths to be self-eviclent, that all men are ereated equal, that they are endowed by their Creator with certain unalienable Rights, that among these are Life, Liberty and the pursuit of Happiness. - That to secure these rights, Govermments are instituted among Men, deriving their just powers from the consent of the governed. - That whenever any Form of Government becomes destructive of these ends, it is the Right of the Pcople to alter or to abolish it, and to institute new Government, laying its foundation on such principles and organizing its powers in such form, as to them shall seem most likely to effect their Safety and Happiness. Prudence, indeed, will dictate that Govermments long established should not be changed for light and transient canses; and accordingly all experience hath shewn, that mankind are more disposed to suffer, while evils are sufferable, than to right themselves by abolishing the forms to which they are accistomed. But when a long train of abuses and usurpations, pursuing invariably the same Object evinces a design to reduee them nnder absolute Despotism, it is their right, it is their duty, to throw off such Government, and to provide new Guards for their future seeurity. - Such has been the patient sufferance of these Colonies; and such is now the necessity which constrains them to alter their former Systems of Government. The history of the present King of Great Britain is a history of repeated injuries and usurpations, all having in direet object the establishment of an absolute Tyranny over these States. To prove this, let Faets be submitted to a candid world. - He has refused his Assent to Laws, the most wholesome and necessary for the publie good. - He has forbidden his Governors to pass Laws of immediate and pressing impor- 
tance, unless suspended in their operation till his Assent should be obtained; and when so suspended, he has ntterly neglected to attend to them. - He has refused to pass other Laws for the accommodation of large districts of people, unless those people would relinquish the right of Representation in the Legislature, a right inestimable to them and formidable to tyrants only. - He has called together legislative bodies at places unusual, uncomfortable, and distant from the depository of their public Records, for the sole purpose of fatiguing them into compliance with his measures. - He has dissolved Representative Houses repeatedly, for opposing with manly firmness his invasions on the rights of the people. - He has refused for a long time, after such dissolutions, to cause others to be elected; whereby the Legislative powers, incapable of Annihilation, have returned to the People at large for their exercise; the State remaining in the mean time exposed to all the dangers of invasion from without, and convulsions within. - He has endeavoured to prevent the population of these States; for that purpose obstructing the Laws for Naturalization of Foreigners; refusing to pass others to encourage their migrations hither, and raising the conditions of new Appropriations of Lands. - He has obstructed the Administration of Justice, by refusing his Assent to Laws for establishing Judiciary powers. - He has made Judges dependent on his Will alone, for the tenure of their offices, and the amount and payment of their salaries. - He has erected a multitude of New Offices, and sent hither swarms of Officers to harrass our people, and eat out their substance. - He has kept among us, in times of peace, Standing Armies without the Consent of our legislatures. - He has affected to render the Military independent of and superior to the Civil power. - He has combined with others to subject us to a jurisiliction foreign to our constitution, and unacknowledged by our laws; giving his Assent to their Acts of pretended Legislation : - For quartering large bodies of armed troops among us : - For protecting them, by a mock Trial, from punishment for any Murders which they should commit on the Inhabitants of these States:For cutting off our Trade with all parts of the world:- For imposing Taxes on us without our Consent:- For depriving us in many cases, of the benefits of Trial by Jury :-For transporting us beyond Seas to be tried for pretended offences :- For abolishing the free System of English Laws in a neighbouring Province, establishing therein an Arbitrary government, and enlarging its Boundaries so as to render it at once an example and fit instrument for introducing the same absolute rule into these Colonies:-For taking away our Charters, abolishing our most valuable Laws, and altering fundamentally the Forms of our Governments : - For suspending our own Legislatures, and declaring themselves invested with power to legislate for us in all cases whatsoever. He has abdicated Government here, by declaring us out of his Protection and waging War against us. - He has plundered our seas, ravaged our Coasts, burnt our towns, and destroyed the Lives of our people. - He is at this time transporting large Armies of foreign Mercenaries to compleat the works of death, desolation and tyranny, already begun with circumstances of Cruelty $\&$ perfidy scarcely paralleled in the most barbarous ages, and totally unworthy the Head of a civilized nation. - He has constrained our fellow Citizens taken Captive on the high Seas to bear Arms against their Country, to become the executioners of their friends and Brethren, or to fall themselves by their 
Hands. - He has excited domestic insurrections amongst us, and has endeavoured to bring on the inhabitants of our frontiers, the merciless Indian Savages, whose known rule of warfare, is an undistinguished destruction of all ages, sexes and conditions. In every stage of these Oppressions IVe have Petitioned for Redress in the most humble terms: Our repeated Petitions have been answered only by repeated injury. A Prince, whose character is thus marked by every act which may define a Tyrant, is unfit to be the ruler of a free people. Nor have We been wanting in attentions to our Brittish brethren. We have warned them from time to time of attempts by their legislature to extend an unwarrantable jurisdiction over us. We have reminded them of the circumstances of our emigration and settlement here. We have appealed to their native justice and magnanimity, and we have conjured them by the ties of our common kindred to disavow these usurpations, which, would inevitably interrupt our connections and correspondence. They too have been deaf to the voice of justice and of consanguinity. We must, therefore, acquiesce in the necessity, which denounces our Separation, and hold them, as we hold the rest of mankind, Enemies in War, in Peace Friends. -

$\mathfrak{e x} \varepsilon$, thırefure, the Representatives of the unitıo statıs of. Amcrica, in General Congress, Assembled, appealing to the Supreme Judge of the world for the rectitude of our intentions, do, in the Name, and by Authority of the good People of these Colonies, solemnly publish and declare, That these United Colonies are, and of Right ought to be, free and Entependent states; that they are Absolved from all Allegiance to the British Crown, and that all political connection between them and the State of Great Britain, is and ought to be totally dissolved; and that as Free and Independent States, they have full Power to levy War, conclude Peace, contract Alliances, establish Commerce, and to do all other Acts and Things which Independent States may of right do. - And for the support of this Declaration, with a firm reliance on the protection of divine Providence, we mutually pledge to each other our Lives, our Fortunes and our sacred Honor.

JOHN HANCOCK.

[Signatures of representatives of the thirteen States, aftixed August 2, 1776.] 


\section{APPENDIX D}

\section{CONSTITUTION OF THE UNITED STATES OF AMERICA (1787) ${ }^{1}$}

(SUbmitted Sept. 17, 1787; iN Force April 30, 1789.)

The following text of the Federal Constitution, including the Amendments thereto, is reprinted with the accompanying notes from American History Leaflets, No. 8, for which the original parchment rolls were compared.]

We the People of the United States, in Order to form a more perfect Union, establish Justice, insure domestic Tranquility, provide for the common defence, promote the general Welfare, and secure the Blessings of liberty to ourselves and our Posterity, do ordain and establish this Constirution for the United States of America.

ARTICLE. I.

SeCrion. 1. All iegislative Powers herein granted shall be vested in a Congress of the United States, which shall consist of a Sente and House of Representatives.

SEction. 2. [\$ 1.] The House of Representatives shall be composed of Members chosen every second Year by the People of the several States, and the Electors in each State shall have the Qualifications requisite for Electors of the most numerous Branch of the State Legislature.

[§2.] No Person shall be a Representative who shall not have attained to the Age of twenty five Years, and been seven Years a Citizen of the United States, and who shall not, when elected, be an Inhabitant of that State in which he shall be chosen.

[§3.] Representatives and direct Taxes shall be apportioned among the several States which may be included within this Union, according to their respective Numbers, [which shall be determined by adding to the whole Number of free Persons, $]^{2}$ including those bound to Service for a Term of Years, and excluding Indians not taxed, [three fifths of all other Persons] ${ }^{3}$ The actual Enumeration slaall be made within three Years after the first Meeting of the Congress of the United States, and within every subsequent

1 There is no title in the original manuseript.

2 Modified by Fourteenth Amendment.

3 Superseded by Fourteenth Amendment. 
Term of ten Years, in such Manner as they shall by Law direct. The Number of Representatives shall not exceed one for every thirty Thonsand, but each State shall have at Least one Representative; [and until such enumeration shall be made, the State of New Hampshire shall be entitled to chuse three, Massachusetts eight, Rhode-Island and Providence Plantations one, Connecticut îve, New-York six, New Jersey four, Peunsylvania eight, Delaware one, Maryland six, Virginia ten, North Carolina tive, South Carolina five, and Georgia three.] ${ }^{1}$

[§ 4.] When vaeancies happen in the Representation from any State, the Executive Authority thereof shall issue Writs of Election to fill such Vacancies.

[§5.] The House of Representatives shall chuse their Speaker and other Officers; and shall have the sole Power of Impeachment.

Section. 3. [\$ 1.] The Senate of the United States shall be composed of two Senators from each State, chosen by the Legislature thereof, for six Years; and each Senator shall have one Vote.

[\$2.] Immediately after they shall be assenbled in Consequence of the first Election, they shall be divided as equally as may be into three Classes. The Seats of the Senators of the first Class shall be vacated at the Expiration of the second Year, of the second Class at the Expiration of the fourth Year, and of the third Class at the Expiration of the sixth Year, so that one third may be chosen every seeond Year; and if Vacancies happen by Resignation, or otherwise, during the Recess of the Legislature of any State, the Executive thereof may make temporary Appointments until the next Meeting of the Legislature, which shall then fill such Vacaneies.

[§3.] No Person shall be a Senator who shall not have attained to the Age of thirty Years, and been nine Years a Citizen of the United States, and who shall not, when elected, be an Inhabitant of that State for which he shall be chosen.

[\$4.] The Vice President of the United States shall be President of the Senate, but shall have no Vote, unless they be equally divided.

[§5.] The Senate shall chuse their other Officers, and also a President pro tempore, in the Absence of the Vice President, or when he shall exercise the Office of President of the United States.

[§ 6.] The Senate shall have the sole Power to try all Impeachments. When sitting for that Purpose, they shall be on Oath or Affirmation. When the President of the United States is tried, the Chief Justice shall preside: And no Person shall be convicted without the Concurrence of two thirds of the Members present.

[§ 7.] Judgment in Cases of Impeachment shall not extend further than to removal from Office, and disqualification to hold and enjoy any Office of honor, Trust or Profit under the United States : but the Party convieted shall nevertheless be liable and subject to Indictment, Trial, Judgment and Punishment, according to Law.

Section. 4. [\$ 1.] The Times, Places and Manner of holding Elections for Senators and Representatives, shall be prescribed in each State by the Legislature thereof; but the Congress may at any time by Law make or alter such Regulations, except as to the Places of chusing Senators.

1 'Temporary clause. 
[§ 2.] The Congress shall assemble at least once in every Year, and such Meeting shall be on the first Monday in December, unless they shall by Law appoint a different Day.

Section. 5. [\$1.] Each House shall be the Judge of the Elections, Returns and Qualifications of its own Members, and a Majority of each shall constitute a Quorum to do Business; but a smaller Number may adjourn from day to day, and may be authorized to compel the attendance of absent Members, in such Mamer, and under such Penalties as each House may provide.

[§ 2.] Each House may determine the Rules of its Proceedings, punish its Members for Disorderly Behaviour, and, with the Concurrence of two thirds, expel a Member.

[§3.] Each House shall keep a Journal of its Proceedings, and from time to time publish the same, excepting such Parts as may in their Judgment require Secrecy; and the Yeas and Nays of the Members of either House on any question shall, at the Desire of one fifth of those Present, be entered on the Journal.

[§4.] Neither House, during the Session of Congress, shall, without the Consent of the other, adjourn for more than three days, nor to any other Place than that in which the two Houses shall be sitting.

Section. 6. [\$ 1.] The Senators and Representatives shall receive a Compensation for their Services, to be ascertained by Law, and paid out of the Treasury of the United States. They shall in all Cases, except Treason, Felony and Breach of the Peace, be privileged from Arrest during their Attendance at the Session of their respective Houses, and in going to and returning from the same; and for any Speech or Debate in either House, they shall not be questioned in any other Place.

[§2.] No Sellator or Representative shall, during the Time for which he was elected, be appointed to any civil Office under the Authority of the United States, which shall have been created, or the Emoluments whereof shall have been encreased during such time; and no Person holding any Office under the United States, shall be a Member of either House during his Continuance in Office.

Section. 7. [\$ 1.] All Bills for raising Revenue shall originate in the House of Representatives; but the Senate may propose or concur with Amendments as on other Bills.

[§ 2.] Every Bill which shall have passed the House of Representatives and the Senate, shall, before it become a Law, be presented to the President of the United States; If he approve he shall sign it, but if not he shall return it, with his Objections to that House in which it shall have originated, who shall enter the Objections at large on their Journal, and proceed to reconsider it. If after such Reconsideration two thirds of that House shall agree to pass the Bill, it shall be sent, together with the Objections, to the other House, by which it shall likewise be reconsidered, and if approved by two thirds of that House, it shall become a Law. But in all such Cases the Votes of both Houses shall be determined by yeas and Nays, and the Names of the Persons voting' for and against the Bill shall be entered on the Journal of each House respectively. If any Bill shall not be returned by the President within ten Days (Sundays excepted) after it shall have been presented to him, the same shall 
be a Law, in like Manner as if he had signed it, unless the Congress by their Adjournment prevent its Return, in which Case it shall not be a Law.

[§3.] Every Order, Resolution, or Vote to which the Concurrence of the Senate and House of Representatives may be necessary (except on a question of Adjournment) shall be presented to the President of the United States; and before the same shall take Effect, shall be approved by him, or being disapproved by him, shall be repassed by two thirds of the Senate and House of Representatives, according to the Rules and Limitations prescribed in the Case of a Bill.

Section. 8. The Congress sliall have Power $[\S 1$.$] To lay and collect Taxes,$ Duties, Imposts and Excises, to pay the Debts and provide for the common Defence and general Welfare of the United States; but all Duties, Imposts and Excises shall be uniform throughout the United States;

[§ 2.] To borrow Money on the credit of the United States;

[§ 3.] To regulate Commerce with foreign Nations, and among the several States, and with the Indian Tribes;

[§4.] To establish an uniform Rule of Naturalization, and uniform Laws on the subject of Bankruptcies throughout the United States ;

[§ 5.] To coin Money, regulate the Value thereof, and of foreign Coin, and fix the Standard of Weights and Measures;

[§6.] To provide for the Punishment of counterfeiting the Securities and eurrent Coin of the United States;

[§ 7.] To establish Post Oftices and post Roads ;

[§8.] To promote the Progress of Science and useful Arts, by securing for limited Times to Authors and Inventors the exclusive Right to their respective Writings and Discoveries;

[§ 9.] To constitute Tribunals inferior to the supreme Court;

[§ 10.] To define and punish Piracies and Felonies committed on the high Seas, and Offences against the Law of Nations;

[\$11.] To declare War, grant Letters of Marque and Reprisal, and make Rules concerning Captures on Land and Water;

[§ 12.] To raise and support Armies, but no Appropriation of Money to that Use shall be for a longer Term than two Years;

[§13.] To provide and maintain a Navy ;

[§ 14.] To make Rules for the Government and Regulation of the land and naval Forces;

[§15.] To provide for calling forth the Militia to execute the Laws of the Union, suppress Insurrections and repel Invasions;

[§16.] To provide for organizing, arming, and disciplining, the Militia, and for governing such Part of them as may be employed in the Service of the United States, reserving to the States respectively, the Appointment of the Officers, and the Authority of training the Militia according to the discipline prescribed by Congress;

[§ 17.] To exercise exclusive Legislation in all Cases whatsoever, over such District (not exceeding ten Miles square) as may, by Cession of particular States, and the Acceptance of Congress, become the Seat of the Government of the United States, and to exercise like Authority over all Places purchased by the Consent of the Legislature of the State in which the same shall be, for 
the Erection of Forts, Magazines, Arsenals, dock-Yards, and other needful Buildings; - And

[§ 18.] To make all Laws which shall be necessary and proper for carrying into Execution the foregoing Powers, and all other Powers vested by this Constitution in the Government of the United States, or in any Department or Officer thereof.

Section. 9. [\$1.] [The Migration or Importation of such Persons as any of the States now existing shall think proper to admit, shall not be probibited by the Congress prior to the Year one thousand eight hundred and eight, but a Tax or duty may be imposed on such Importation, not exceeding ten dollars for each Person.] ${ }^{1}$

[§ 2.] The Privilege of the Writ of Habeas Corpus shall not be suspended, unless when in Cases of Rebellion or Invasion the public Safety may require it.

[§ 3.] No Bill of Attainder or ex post facto Law shall be passed.2

[§4.] No Capitation, or other direct, Tax shall be laid, unless in Proportion to the Census or Enumeration herein before directed to be taken.

[§5.] No Tax or Duty shall be laid on Articles exported from any State.

[\$6.] No Preference shall be given by any Regulation of Commerce or Revenue to the Ports of one State over those of another: nor shall Vessels bound to, or from, one State, be obliged to enter, clear, or pay Duties in another.

[§ 7.] No Money shall be drawn from the Treasury, but in Consequence of Appropriations made by Law; and a regular Statement and Account of the Receipts and Expenditures of all public Money shall be published from time to tine.

[§ 8.] No Title of Nobility shall be granted by the United States: And no Person holding any Oftice of Profit or Trust under them, shall, without the Consent of the Congress, accept of any present, Emolument, Office, or Title, of any kind whatever, from any King, Prince, or foreign State. ${ }^{3}$

Section. 10. [\$ 1.] No State shall enter into any Treaty, Alliance, or Confederation; grant Letters of Marque and Reprisal; coin Money; emit Bills of Credit; make any Thing but gold and silver Coin a Tender in Payment of Debts; pass any Bill of Attainder, ex post facto Law, or Law impairing the Obligation of Contracts, or grant any Title of Nobility.

[§ 2.] No State shall, without the Consent of the Congress, lay any Imposts or Duties on Imports or Exports, except what may be absolutely necessary for executing its inspection Laws: and the net Produce of all Duties and Imposts, laid by any State on Imports or Exports, shall be for the Use of the Treasury of the United States; and all such Laws shall be subject to the Revision and Controul of the Congress.

[§3.] No State shall, without the Consent of Congress, lay any Duty of Tonnage, keep 'Troops, or Ships of War in time of Peace, enter into any Agreement or Compact with another State, or with a foreign Power, or engage in War, unless actually invaded, or in such imminent Danger as will not admit of delay. 4

1 Temporary provision.

2 Extended by the first eight Amendments.

3 Extended by Ninth and Tenth Amendments.

4 Extended by Thirteenth, Fourteenth, and Fifteenth Amendments. 
ARTICLE. II.

Section. 1. [\$ 1.] The executive Power shall be vested in a President of the United States of America. He shall hold his Office during the Term of four Years, and, together with the Vice President, chosen for the same Term, be elected, as follows

[§ 2.] Each State shall appoint, in such Manner as the Legislature thereof may direct, a Number of Electors, equal to the whole Number of Senators and Representatives to which the State may be entitled in the Congress: but no Senator or Representative, or Person holding an Office of Trust or Profit under the United States, shall be appointed an Elector.

[The Electors shall meet in their respective States, and vote by Ballot for two Persons, of whom one at least shall not be an Inhabitant of the same State with themselves. And they shall make a List of all the Persons voted for, and of the Number of Votes for each; which List they shall sign and certify, and transmit sealed to the Seat of the Government of the United States, directed to the President of the Senate. The President of the Senate shall, in the Presence of the Senate and House of Representatives, open all the Certificates, and the Votes shall then be counted. The Person having the greatest Number of Votes shall be the President, if such Number be a Majority of the whole Number of Electors appointed; and if there be more than one who have such Majority, and have an equal Number of Votes, then the House of Representatives shall immediately chuse by Ballot one of them for President; and if no Person have a Majority, then from the five highest on the List the said House shall in like Manner chuse the President. But in chusing the President, the Votes shall be taken by States, the Representation from each State having one Vote; A quorum for this Purpose shall consist of a Member or Members from two thirds of the States, and a Majority of all the States shall be necessary to a Choice. In every Case, after the Choice of the President, the Person having the greatest Number of Votes of the Electors shall be the Vice President. But if there should remain two or more who have equal Votes, the Senate shall chuse from them by Ballot the Vice President.] ${ }^{1}$

[§3.] The Congress may determine the Time of chusing the Electors, and the Day on which they shall give their Votes; which Day shall be the same throughout the United States.

[\$ 4.] No Person except a natural born Citizen, or a Citizen of the United States, at the time of the Adoption of this Constitution, shall be eligible to the Office of President; neither shall any Person be eligible to that Office who shall not have attained to the Age of thirty five Years, and been fourteen Years a Resident within the United States.

[§ 5.] In Case of the Removal of the President from Office, or of his Death, Resignation, or Inability to discharge the Powers and Duties of the said Office, the Same shall devolve on the Vice President, and the Congress may by Law provide-for the Case of Removal, Death, Resignation, or Inability, both of the President and Vice President, declaring what Officer shall then act as

1 Superseded by Twelfth Amendment. 
President, and such Officer shall act accordingly: until the Disability be removed, or a President shall be elected.

[§ 6.] The President shall, at stated Times, receive for his Services, a Compensation, which shall neither be encreased nor diminished during the Period for which he shall have been elected, and he shall not receive within that Period any other Emolument from the United States, or any of them.

[§ 7.] Before he enter on the Execution of his Office, he shall take the following Oath or Affirmation:-

"I do solemnly swear (or affirm) that I will faithfully execute the Office of "President of the United States, and will to the best of my Ability, preserve, "protect and defend the Constitution of the United States."

Section. 2. [ $\$ 1$.$] The President shall be Commander in Chief of the Army$ and Navy of the United States, and of the Militia of the several States, when called into the actual Service of the United States; he may require the Opinion, in writing, of the principal Officer in each of the executive Departments, upon any Snbject relating to the Duties of their respective Offices, and he shall have Power to grant Reprieves and Pardons for Offences against the United States, except in Cases of Impeachment.

[§ 2.] He shall have Power, by and with the Advice and Consent of the Senate, to make Treaties, provided two thirds of the Senators present concur; and he shall nominate, and by and with the Advice and Consent of the Senate, shall appoint Ambassadors, other public Ministers and Consuls, Judges of the supreme Court, and all other Officers of the United States, whose Appointments are not herein otherwise provided for, and which shall be established by Law: but the Congress may by Law vest the Appointment of such inferior Officers, as they think proper, in the President alone, in the Courts of Law, or in the Heads of Departments.

[§3.] The President shall have Power to fill up all Vacancies that may happen during the Recess of the Senate, by granting Commissions which shall expire at the End of their next Session.

Section. 3. He shall from time to time give to the Congress Information of the State of the Union, and recommend to their Consideration such Measures as he shall judge necessary and expedient; he may, on extraordinary Occasions, convene both Houses, or either of them, and in Case of Disagreement between them, with Respect to the 'Time of Adjournment, he may adjourn them to such Time as he shall think proper; he shall receive Ambassadors and other public Ministers; he shall take Care that the Laws be faithfully executed, and shall Commission all the Officers of the United States.

Section. 4. The President, Vice President and all civil Officers of the United States, shall be removed from Office on Impeachment for, and Conviction of, Treason, Bribery, or other high Crimes and Misdemeanors.

\section{ARTICLE. III.}

Section. 1. The judicial Power of the United States, shall be vested in one supreme Court, and in such inferior Courts as the Congress may from time to time ordain and establish. The Judges, both of the supreme and inferior 
Courts, shall hold their Offices during good Behaviour, and shall, at stated Times, receive for their Services, a Compensation, which shall not be diminished during their Continuance in Office.

Section. 2. [§1.] The judicial Power shall extend to all Cases, in Law and Equity, arising under this Constitution, the Laws of the United States, and Treaties made, or which shall be made, under their Authority ; - to all Cases affecting Ambassadors, other public Ministers and Consuls; - to all Cases of admiralty and maritime Jurisdiction; - to Controversies to which the United States shall be a Party; - to Controversies between two or more States; - between a State and Citizens of another State ${ }^{1}$ - between Citizens of different States, - between Citizens of the same State claiming Lands under Grants of different States, and between a State, or the Citizens thereof, and foreign States, Citizens or Subjects.

[§ 2.] In all Cases affecting Ambassadors, other public Ministers and Consuls, and those in which a State shall be Party, the supreme Court shall have original Jurisdiction. In all the other Cases before mentioned, the supreme Court shall have appellate Jurisdiction, both as to Law and Fact, with such Exceptions, and under such Regulations as the Congress shall make.

[§ 3.] The Trial of all Crimes, except in Cases of Impeachment, shall be by Jury; and such Trial shall be held in the State where the said Crimes shall have been committed; but when not committed within any State, the Trial shall be at such Place or Places as the Congress may by Law have directed.

Section. 3. [\$ 1.] Treason against the United States, shall consist only in levying War against them, or in adhering to their Enemies, giving them Aid and Comfort. No Person shall be convicted of Treason unless on the Testimony of two Witnesses to the same overt Act, or on Confession in open Court.

[§ 2.] The Congress shal! have Power to declare the Punishment of Treason, but no Attainder of Treason shall work Corruption of Blood, or Forfeiture except during the Life of the Person attainted.

\section{ARTICLE. IV.}

Section. 1. Full Faith and Credit shall be given in each State to the public Acts, Records, and judicial Proceedings of every other State. And the Congress may by general Laws prescribe the Manner in which such Acts, Records and Proceedings shall be proved, and the Effect thereof.

Section. 2. [\$1.] The Citizens of each State shall be entitled to all Privileges and Immunities of Citizens in the several States. ${ }^{2}$

[§ 2.] A Person charged in any State with Treason, Felony, or other Crime, who shall flee from Justice, and be found in another State, shall on Demand of the executive Authority of the State from which he fled, be delivered up, to be removed to the State having Jurisdiction of the Crime.

[§ 3.] [No Person held to Service or Labour in one State, under the Laws thereof, escaping into another, shall, in Consequence of any Law or Regulation therein, be discharged from such Service or Labour, but shall be delivered up on Claim of the Party to whom such Service or Labour may be due. $]^{8}$

1 Limited by Eleventh Amendment. $\quad 2$ Extended by Fourteenth Amendment. 8 Superseded by Thirteenth Amendment so far as it relates to slaves. 
Section. 3. [\$1.] New States may be admitted by the Congress into this Union; but no new State shall be formed or erected within the Jurisdiction of any other State; nor any State be formed by the Junetion of two or more States, or Parts of States, without the Consent of the Legislatures of the States concerned as well as of the Congress.

[§ 2.] The Congress shall have Power to dispose of and make all needful Rules and Regulations respecting the Territory or other Property belonging to the United States; and nothing in this Constitution shall be so construed as to Prejudice any Claims of the United States, or of any particular State.

Section. 4. The United States shall guarantee to every State in this Union a Republican Form of Government, and shall protect each of them against Invasion; and on Application of the Legislature, or of the Executive (when the Legislature cannot be convened) against domestic Violence.

\section{ARTICLE. V.}

The Congress, whenever two thirds of both Houses shall deem it necessary, shall propose Amendments to this Constitution, or, on the Application of the Legislatures of two thirds of the several States, shall call a Convention for proposing Amendments, which, in either Case, shall be valid to all Intents and Purposes, as Part of this Constitution, when ratified by the Legislatures of three fourths of the several States, or by Conventions in three fourths thereof, as the one or the other Mode of Ratification may be proposed by the Congress; Provided [that no Amendment which may be made prior to the Year One thousand eight hundred and eight shall in any Manner affect the first and fourth Clauses in the Ninth Section of the first Article; and ${ }^{1}$ that no State. without its Consent, shall be deprived of its equal Suffrage in the Senate.

\section{ARTICLE. VI.}

[§1.] All Debts contracted and Engagements entered into, before the Adoption of this Constitution, shall be as valid against the United States under this Constitution, as under the Confederation. ${ }^{2}$

[§ 2.] This Constitution, and the Laws of the United States which shall be made in Pursuance thereof; and all Treaties made, or which shall be made, under the Authority of the United States, shall be the supreme Law of the Land; and the Judges in every State shall be bound thereby, any Thing in the Constitution or Laws of any State to the Contrary notwithstanding.

[§ 3.] The Senators and Representatives before mentioned, and the Members of the several State Legislatures, and all executive and judicial Officers, both of the United States and of the several States, shall be bound by Oath or Affirmation, to support this Constitution; but no religious Test shall ever be required as a Qualification to any Office or public Trust under the United States. 
ARTICLE. VII.

The Ratification of the Conventions of nine States, shall be sufficient for the Establishment of this Constitution between the States so ratifying the Same.

[Note of the draughtsman as to interlineations in the text of the manuscript.]

Attest

WILLIAM JACKSON. Secretary.
Dove in Convention by the Unanimous Consent of the States present the Seventeenth Day of September in the Year of our Lord one thousand seven hundred and Eighty seven and of the Independance of the United States of Ameriea the Twelfth In Witness whereof We have hereunto subscribed our naines.

$$
\begin{gathered}
\text { Go WASHINGTON- } \\
\text { Presidt and deputy from Virginia. }
\end{gathered}
$$

[Signatures of members of the Convention.] 1

\section{[AMENDMENTS.]}

ARTICLES in addition to and Amendment of the Constitution of the United States of America, proposed by Congress, and ratified by the Legislatures of the several States, pursuant to the fifth Article of the original Constitution.2

\section{[ARTICLE I.] ${ }^{8}$}

Congress shall make no law respecting an establishment of religion, or prohibiting the free exercise thereof; or abridging the freedom of speech, or of the press; or the right of the people peaceably to assemble, and to petition the Government for a redress of grievances.

\section{[ARTICLE II.]}

A well regulated Militia, being necessary to the security of a free State, the right of the people to keep and bear Arms, shall not be infringed.

\section{[ARTICLE III.]}

No Soldier shall, in time of peace be quartered in any house, without the consent of the Owner, nor in time of war, but in a manner to be prescribed bv law.

\section{[ARTICLE IV.]}

The right of the people to be secure in their persons, houses, papers, and effects, against unreasonable searches and seizures, shall not be violated, and no Warrants shall issue, but upon probable cause, supported by Oath or affirmation, and particularly describing the place to be searched, and the persons or things to be seized.

1 These signatures have no other legal force than that of attestation.

2 This heading appears only in the joint resolution submittling the first ten amendments.

8 In the original manuscripts the first twelve amendments have no numbers. 


\section{[AR'TICLE V.]}

No person shall be held to answer for a capital, or otherwise infamous crime, unless on a presentment or indictment of a Grand Jury, except in cases arising in the land or naval forces, or in the Militia, when in actual service in time of War or public danger; nor shall any person be subject for the same offence to be twice put in jeopardy of life or limb; nor shall be compelled in any criminal case to be a witness against himself, nor be deprived of life, liberty, or property, without due process of law; nor shall private property be taken for public use, without just compensation.

\section{[ARTICLE VI.]}

In all criminal prosecutions the accused shall enjoy the right to a speedy and public trial, by an impartial jury of the State and district wherein the crime shall have been committed, which district shall have been previously ascertained by law, and to be informed of the nature and cause of the accusation; to be confronted with the witnesses against him; to have compulsory process for obtaining witnesses in his favor, and to have the Assistance of Counsel for his defence.

\section{[ARTICLE VII.]}

In suits at common law, where the value in controversy shall exceed twenty dollars, the right of trial by jury shall be preserved, and no fact tried by a jury shall be otherwise re-examined in any Court of the United States, than according to the rules of the common law.

\section{[ARTICLE VIII.]}

Excessive bail shall not be required, nor excessive fines imposed, nor cruel and unusual punishments inflicted.

\section{[ARTICLE IX.]}

The enumeration in the Constitution, of certain rights, shall not be construed to deny or disparage others retained by the people.

\section{[ARTICLE X.]}

The powers not delegated to the United States by the Constitution, nor prohibited by it to the States, are reserved to the States respectively or to the people. 1

\section{[ARTICLE XI.] ${ }^{2}$}

The Judicial power of the United States shall not be construed to extend to any suit in law or equity, commenced or prosecuted against one of the United States by Citizens of another State, or by Citizens or Subjects of any Foreign State.

1 Amendments First to Tenth appear to have been in force from Nov. 3, 1791.

: 2 Proclaimed to be in force Jan. 8, 1798. 


\section{[ARTICLE XII.] 1}

The Electors shall meet in their respective states, and vote by ballot for President and Vice-President, one of whom, at least, shall not be an inhabitant of the same state with themselves; they shall name in their ballots the person voted for as President, and in distinct ballots the person voted for as Vice-President, and they shall make distinct lists of all persons voted for as President, and of all persons voted for as Vice-President, and of the number of votes for each, which lists they shall sign and certify, and transmit sealed to the seat of the government of the United States, directed to the President of the Senate; - The President of the Senate shall, in the presence of the Senate and House of Representatives, open all the certificates and the votes shall then be counted; - The person having the greatest number of votes for President, shall be the President, if such number be a majority of the whole number of Electors appointed; and if no person have such majority, then from the persons having the highest numbers not exceeling three on the list of those voted for as President, the House of Representatives shall choose immediately, by ballot, the President. But in choosing the President, the votes shall be taken by states, the representation from each state having one vote; a quorum for this purpose shall consist of a member or members from two-thirds of the states, and a majority of all the states shall be necessary to a choice. And if the House of Representatives shall not choose a President whenever the right of choice shall devolve upon them, before the fourth day of March next following, then the Vice-President shall act as President, as in the case of the death or other constitutional disability of the President. - The person having the greatest number of votes as Vice-President, shall be the Vice-President, if such number be a majority of the whole number of Electors appointed, and if no person have a majority, then from the two highest num. bers on the list, the Senate shall choose the Vice-President; a quorum for the purpose shall consist of two-thirds of the whole number of Senators, and a majority of the whole number shall be necessary to a choice. But no person constitutionally ineligible to the office of President shall be eligible to that of Vice-President of the United States.

\section{ARTICLE XIII.2}

Section 1. Neither slavery nor involuntary servitude, except as a punishment for crime whereof the party shall have been duly convicted, shall exist within the United States, or any place subject to their jurisdiction. SEcTion 2. Congress shall have power to enforce this article by appropriate legislation.

\section{ARTICLE XIV. ${ }^{8}$}

Section 1. All persons born or naturalized in the United States, and subject to the jurisdiction thereof, are citizens of the United States and of the State

1 Proclaimed to be in force Sept. 25, 1804.

2 Proclaimed to be in force Dec. 18,1865 . Bears the unnecessary approval of the President.

3 Proclaimed to be in force July 28, 1868. 
wherein they reside. No State shall make or enforce any law which shall abridge the privileges or immunities of citizens of the United States; nor shall any State deprive any person of life, liberty, or property, without due process of law; nor deny to any person within its jurisdiction the equal protection of the laws.

Section 2. Representatives shall be apportioned among the several States according to their respective numbers, counting the whole number of persons in each State, excluding Indians not taxed. But when the right to vote at any election for the choice of electors for President and Vice President of the United States, Representatives in Congress, the Executive and Judicial officers of a State, or the members of the Legislature thereof, is denied to any of the male inhabitants of such State, being twenty-one years of age, and citizens of the United States, or in any way abridged, except for participation in rebellion, or other crime, the basis of representation therein shall be reduced in the proportion which the number of such male citizens shall bear to the whole number of male citizens twenty-one years of age in such State.

Section 3. No person shall be a Senator or Representative in Congress, or elector of President and Vice President, or hold any office, civil or military, under the United States, or under any State, who, having previously taken an oath, as a member of Congress, or as an officer of the United States, or as a member of any State legislature, or as an executive or judicial officer of any State, to support the Constitution of the United States, shall have engaged in insurrection or rebellion against the same, or given aid or comfort to the enemies thereof. But Congress may by a vote of two-thirds of each House, remove such disability.

Section 4. The validity of the public debt of the United States, anthorized by law, including debts incurred for payment of pensions and bounties for services in suppressing insurrection or rebellion, shall not be questioned. But neither the United States nor any State shall assume or pay any debt or obligation incurred in aid of insurrection or rebellion against the United States, or any claim for the loss or emancipation of any slave; but all such debts, obligations and claims shall be held illegal and void.

Section 5. The Congress shall have power to enforce, by appropriate legislation, the provisions of this article.

\section{ARTICLE XV.1}

Section 1. The right of citizens of the United States to vote shall not be denied or abridged by the United States or by any State on account of race, color, or previous condition of servitude. -

Section 2. The Congress shall have power to enforce this article by appropriate legislation. -

1 Proclaimed to be in force Mar. 30, 1870. 


\section{APPENDIX E}

\section{PROCLAMATION OF EMANCIPATION \\ (JANUARY 1, 1863)}

[From the facsimile in Nicolay and Hay, Abraham Lincoln, A History, VI, 422.]

BY THE PRESIDENT OF THE UNITED STATES OF AMERICA:

\section{A Proclamation.}

Whereas, on the twenty second day of September, in the year of our Lord one thousand eight hundred and sixty two, a proclamation was issued by the President of the United States, containing, among other things, the following, to wit:

"That on the first day of January, in the year of our Lord one thousand eight hundred and sixty-three, all persons held as slaves within any State or designated part of a State, the people whereof shall then be in rebellion against the United States, shall be then, thenceforward, and forever free; and the Executive Government of the United States, including the military and naval authority thereof, will recognize and maintain the freedom of such persons, and will do no act or acts to repress such persons, or any of them, in any efforts they may make for their actual freedom.

"That the Executive will, on the first day of January aforesaid, by proclamation, designate the States and parts of States, if any, in which tise people thereof, respectively, shall then be in rebellion against the United States; and the fact that any State, or the people thereof, shall on that day be, in good faith, represented in the Congress of the United States by members chosen thereto at elections wherein a majority of the qualified voters of such State shall have participated, shall, in the absence of strong countervailing testimony, be deemed conclusive evidence that such State, and the people thereof, are not then in rebellion against the United States."

Now, therefore I, Abraham Lincoln, President of the United States, by virtue of the power in me vested as Commander-in-chief, of the Army and Navy of the United States in time of actual armed rebellion against [the] authority and government of the United States, and as a fit and necessary war measure for suppressing said rebellion, do, on this first day of January, in the year of our Lord one thousand eight hundred and sixty three, and in accordance with my purpose so to do publicly proclaimed for the full period of one hundred days, from the day first above mentioned, order and designate as the States and parts of States wherein the people thereof respectively, are this, day in rebellion against the United States, the following, to wit: 
Arkansas, Texas, Louisiana, (except the Parishes of St. Bernard, Plaquemines, Jefferson, St. John, St. Charles, St. James, Ascension, Assumption, Terrebonne, Lafourche, St. Mary, St. Martin, and Orleans, including the City of New Orleans) Mississippi, Alabama, Florida, Georgia, South-Carolina, North-Carolina, and Virginia, (except the forty eight counties designated as West Virginia, and also the counties of Berkley, Accomac, Northampton, Elizabeth-City, York, Princess, Ann, and Norfolk, including the cities of Norfolk \& Portsmouth); and which excepted parts are, for the present, left precisely as if this proclamation were not issued.

And by virtue of the power, and for the purpose aforesaid, I do order and declare that all persons held as slaves within said designated States, and parts of States, are, and henceforward shall be free; and that the Executive government of the United States, including the military and naval authorities thereof, will recognize and maintain the freedom of said persons.

And I hereby enjoin upon the people so declared to be free to abstain from all violence, unless in necessary self-defence; and I recommend to them that, in all cases when allowed, they labor faithfully for reasonable wages.

And I further declare and make known, that such persons of suitable condition, will be received into the armed service of the United States to garrison forts, positions, stations and other places, and to man vessels of all sorts in said service.

And upon this act, sincerely believed to be an act of justice, warranted by the Constitution, upon military necessity, I invoke the considerate judgment of mankind, and the gracious favor of Almighty God.

In witness whereof, I have hereunto set my hand and caused the seal of the United States to be affixed.

Done at the city of Washington, this first day of January, in the [.. s.] year of our Lord one thousand eight hundred and sixty three, and of the Independence of the United States of America the eightyseventh.

Abraham Lincoln

By the President; William H. Seward, Secretary of State 


\title{
APPENDIX F
}

\section{JOINT RESOLUTION FOR INTERVENTION IN CUBA (Approved April 20, 1898)}

\author{
[From the United States Statutes at Large, XXX, 738]
}

Joint Resolution For the recognition of the independence of the people of Cuba, demanding that the Government of Spain relinquish its authority and government in the Island of Cuba, and to withdraw its land and naval forces from Cuba and Cuban waters, and directing the President of the United States to use the land and naval forces of the United States to carry these resolutions into effect.

Whereas the abhorrent conditions which have existed for more than three years in the Island of Cuba, so near our own borders, have shocked the moral sense of the people of the United States, have been a disgrace to Christian civilization, culminating, as they have, in the destruction of a United States battle ship, with two hundred and sixty-six of its officers and crew, while on a friendly visit in the harbor of Havana, and can not longer be endured, as has been set forth by the President of the United States in his message to Congress of April eleventh, eighteen hundred and ninety-eight, upon which the action of Congress was invited: Therefore,

Resolved by the Senate and House of Representatives of the United States of America in Congress assembled, First. That the people of the Jsland of Cuba are, and of right ought to be, free and independent.

Second. That it is the duty of the United States to demand, and the Government of the United States does hereby demand, that the Government of Spain at once relinquish its anthority and government in the Island of Cuba and withdraw its land and naval forces from Cuba and Cuban waters.

Third. That the President of the United States be, and he hereby is, directed and empowered to use the entire land and naval forces of the United States, and to call into the actual service of the United States the militia of the several States, to such extent as may be necessary to carry these resolutions into effect.

Fourth. That the United States hereby disclaims any disposition or intention to exercise sovereignty, jurisdiction, or control over said Island except for the pacification thereof, and asserts its determination, when that is accomplished, to leave the government and control of the Island to its people. 


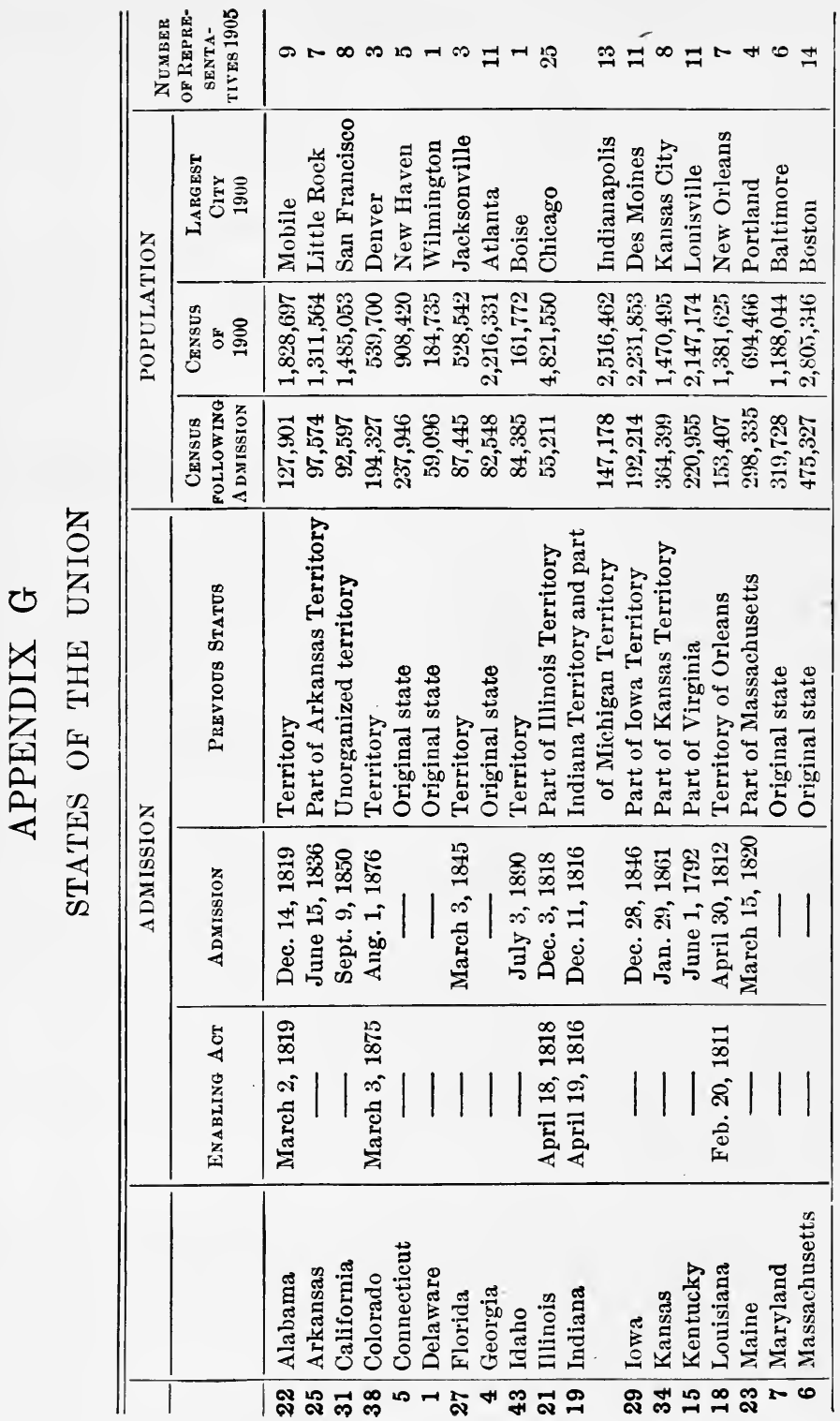




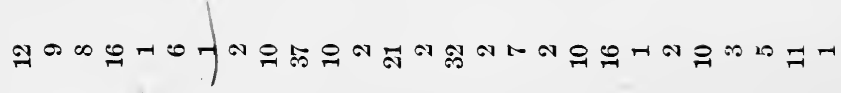

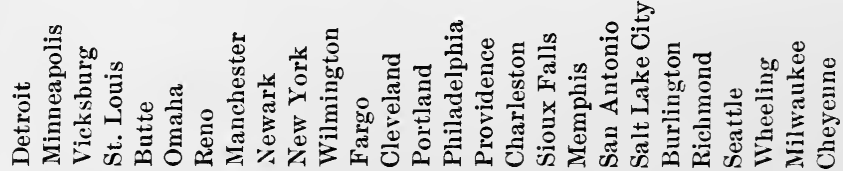

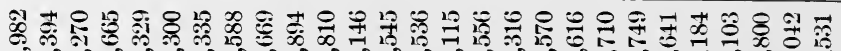

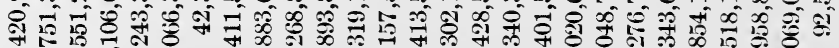

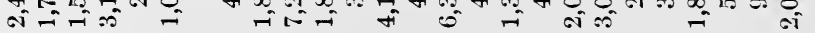

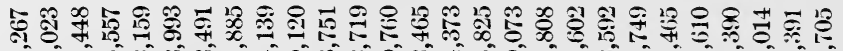

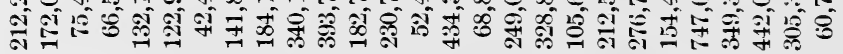

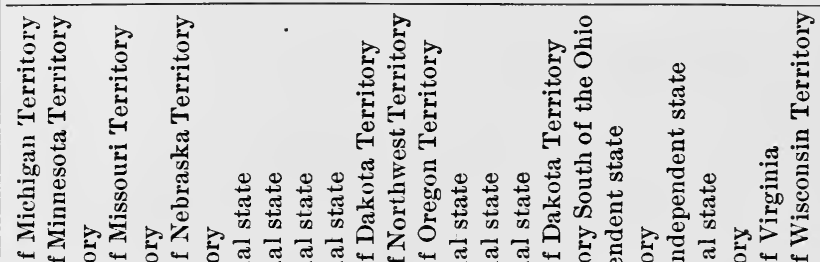

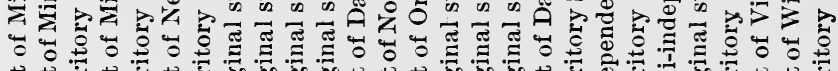

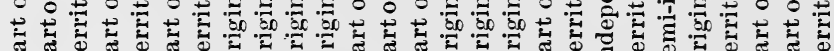

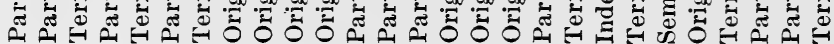

\begin{tabular}{|c|c|c|}
\hline 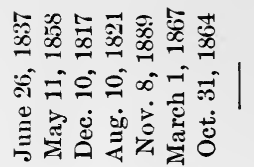 & 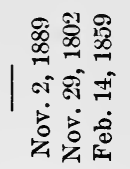 & 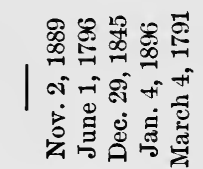 \\
\hline
\end{tabular}

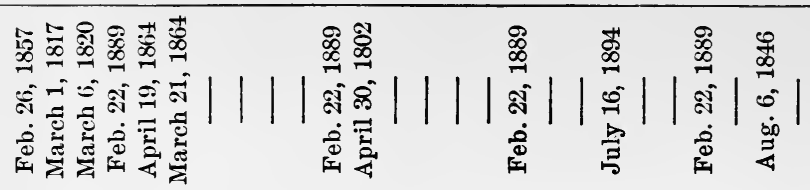

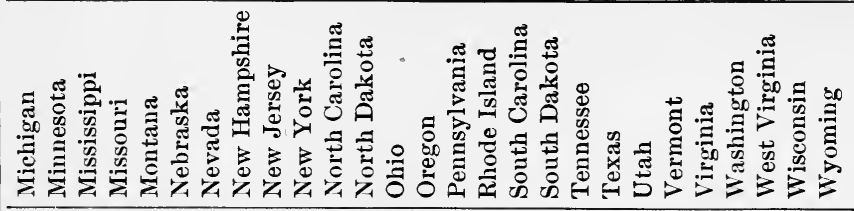

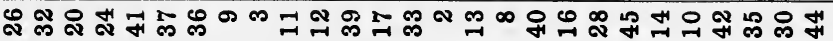




\section{INDEX}

Diacritic marks : $\bar{a}$ as in late; $\breve{a}$ as in fat; ä as in far; â as in eare ; $\mathfrak{a}$ as in last; a as in fall; $\mathrm{e}, \mathrm{eh}$ as in cask, chasm; $\mathrm{g}$ as in ice; $\bar{e}$ as in me; $\mathrm{e}$ as in met, berry; $\mathrm{e}$ as in veil; $\tilde{\mathrm{e}}$ as in term; $\mathrm{g}$ as in gem; $\overline{\mathrm{g}}$ as in go; $\mathrm{i}$ as in $t i n ; \hat{\mathrm{i}}$ as in police; $\mathrm{N}$, the French nasai ; $\bar{o}$ as in note; ó as in not; $\delta$ as in son; ô as in for : 0 as in $d o$; $s$ as in news; th as in the; $\check{\mathrm{u}}$ as in tune; $\mathrm{u}$ as in nut; $\mathrm{u}$ as in rude $(=0)$; $\underline{u}$ as in $f u l l ; \overrightarrow{\mathrm{u}}=$ French $u ; \overline{\mathrm{y}}$ as in $m y$. Single italic letters are silent.

A bolitionists, 298, 347-351.

in election of 1844,358 .

underground railroad, 373,378 .

Aca'dia, 66, 125, 128, 129.

Acts of Trade, 103 ; see Navigation Acts.

Adams, Charles Francis, 440, 460.

Adams, Henry, 530 .

Adams, John, biography, 254, 255.

Constitution, 218.

Declaration of Independence, 157, 158.

defends British soldiers, 142 .

on democracy, 226.

President, 254-259, 263.

Vice President, 235, 246.

Adams, John Quincy, President, 310-313, 330, 332.

representative in Congress, $311,349$.

Secretary of State, $306,308,301$.

Adams, Samuel, 155, 156, 144, 145, 149, 151.

Agamen'ticus, 60.

Agriculture, see Farming.

Å-ğ $u$ ï-näl'do, 553, 554, 556, 557, 558.

A $i \mathrm{x}$-lä-Çha-pèll $l e^{\circ}$, treaty of, 127.

Al-a-bä'ma, 298, 301, 406, xxx.

Alabama, 439 ; claims, 505, 506.

Al'a-mance, battle of, 144 .

À'lä-mō, 331.

Alaska, purchased, 499.

Al'ba-ny (al' -), settled, 67 .

Albany Congress, 128.

Al'be-marle settlement, 84 .

Al'ger, Russell A., 554 .

Al-gon'quin Indians, 27, 66.

Alien and Sedition acts, 256, 257.

Al'le-ghe-ny River, 127.

Allen, Ethan, 153.

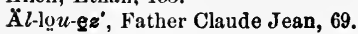

Al-ta-ma-ha' (al-) River, 108.

Amendments to federal Constitution, 287, $238,259,492,495,503,509$.

America, origin of name, 35 .

American party, 388.
American system, of Clay, 297.

Am 'i-das, Phili î, 40.

Amnesty, 467, 494, 504.

Anæsthesia, discovery of, 429.

A narchists, 536.

Anderson, Major Robert, 405, 411, 414.

An'dersonville prison, 473 .

Än'dré, Major John, 177.

An'dros, Sir Edmund, 87, 88.

Annap'olis (Md.) Convention, 206.

Annapolis, N.S., 66, 122.

An'tho-ny, Susan B., 340 .

An-tie'tam, battle of, 451 .

Anti-Federalists, 214, 245.

Anti-masonic party, 313 .

Antino'mians, in Massachusetts, 55 .

Anti-Rent disturbances, 354 .

Antislavery people, 201,347 ; see Slavery.

$\Lambda$-pä'che Indians subdued, 526 .

Appalä'chian Mountains, 20.

Appomat'tox, 485 .

Architecture, 530, 575; see Church buildings, and Honses.

Är'gall, Capt. Samuel, 66.

A rgenti'na, independence of, $307,308$.

A rizona, territory, 501.

Ar'kan-sas, $374,415, \mathrm{xxx}$.

Armā'da, Spanish, 41 .

Army, in Civil War, 437, 438, 460, 473.

in Revolution, $167,172,178,184$.

in Spanish War, 554.

in War of 1812, 279, 280, 283, 286.

Army of the Potomac, 443, 447-452, 462, 463, $474,475,484$.

Arnold, Benedict, 154, 170, 177-179.

A-roos'took War, 356.

Irt, 230,530 .

Arthur, Chester A., 520, 519.

Articles of Confederation, 189, 191, 202-204, $161,162,1 \mathrm{~S} 2,1 \mathrm{~S} 3,260$.

Articles of Confederation, New England, 61.

As'bury, Francis, Bishop, 230. 
A sh'burton treaty, 856.

A sia, mediæval trade with, 14-16, 33.

Ä-siěn'tō, 114.

A ssembly, colonial, 111, 112, 48.

A ssociation of 1774,150 .

Associations, $573,574$.

Astor, John Jacob, 222, 269.

Asto'ria, Oregon, 269, 283.

As'trolabe, 14:

A sylums, 388, 339.

A tlanta, captured, 478.

Austin, Moses and Stephen F., 830 .

Australian ballot, 539.

A yllon (īl-yōn'), Lucas Vásquez de, 36.

A-zöreș', discovered, 16.

Az'tecs, 26, 36.

Back'woods'men, 193, 194, 568.

Bacon, Nathaniel, 84.

Baker Island, 561.

Bal-bō'a, Vasco Nunez de, 86.

Ballot reform, 539.

Bal'ti-more, city, 220, 283, 415.

Bältimore, Lord, 55, 56, 108, 109.

Bancroft, George, 342, 425.

Bank, United States, 242, 243. second, 304, 318, 319, 329, 335 .

Bank of North Amerlca, 196.

Banks, national, 442.

savings, 515.

state, $224,318,334,335,428,442$.

Banks, Gen. Nathaniel P., 461.

Baptists, 59 ; see Churches.

Bar'bary wars, 265.

Barlow, Joel, 227.

Bar'lowe, Arthur, 40.

Barnburners, 372.

Battle above the Clouds, 465 .

B $a \bar{y}^{\prime} \mathrm{o} u$ Män-chäc', 265.

Beane, Wllliam, 143.

Bear Flag Republic, 365.

Beau're-gard (bō'), General, 413, 442, 445.

Bel'knap, Willianı W., 507.

Bell, Alexander Graham, 532

Bell, John, 402, 408.

Bennington, battle of, 170 .

Ben'tonville, battle of, 484 .

Be'ring Sea controver'sy, 546.

Berke'ley, Sir William, 80, 84, 92.

Ber'lin Decree, 272.

Bes'se-mer steel, 518.

Bethleheu, Pa., 82, 518.

Biddle, Nicholas, 318.

Bienville, Céloron de (sā-lo-rôn' d' byănvēl'), 12 i.

Biglow Papers, 363, 425

Bĭ-lŏx'ĭ, 124.

Birney, James G., 347, 858.

Bishop's Palace, 143.

Black, Jeremiah, 405, 411.
Black Hawk War, 392.

Black Hills, discovery of gold in, 500

Black Warrior, 354.

Blackbeard, pirate, 104.

Blä'densburg, battle of, 283 .

Blaine, James G., 522, 525, 545, 546, 511, 519.

Blair, Montgomery, 412, 413.

Bland, Richard P., 513.

Blennerhas'set Island, 270.

Blockade runners, 438, 479.

Bol'i-var, Gen. Simon, 307.

Bon Homme Ruchard (bo-nǒm'rē-shär'), 175.

Bŏnne'ville, Benjamin L. E., 356.

Boone, Daniel, 143, 144, 160.

Boonsboro, founded, 160.

Border Ruffians, 388.

Boston, 52, 53, 220, 423, 507, 539.

in Revolution, 142, 145, 146, 153, 154, 156.

Tea Party, 145, 156.

Boundaries, of colonies, 108, 109.

of United States, 184, 305, 307, 355, 360, $361,506$.

Bouquet (boo-kā'), Colonel, 132.

Boxers, in China, 561.

Boycott, 573.

Braddock, Gen. Edward, 129.

Bradford, William, 51, 94.

Bragg, Gen. Braxton, 445, 463-466.

Bran'dy-wine, battle of, 171.

Brant, Joseph, 179.

Bra-zil', discovered, 35 ; Independent, 808.

Breck'in-ridge, John C., 402, 403.

Bre-d ̈̈', peace of, 73 .

Bridges, 223, 517, 539.

British, 126 ; see Great Britain.

Brook Falm community, 341, 342.

Brooks, Preston, 389.

Brown, Gen. Jacob, 283, 286.

Brown, John, 388, 397, 398.

Brush, Charles F., 532.

Bryan, William J., 547, 557, 579.

Bryant, William Cullen, 342.

Bǔeh-ăn'an, James, 384, 359, 394, 395, 404, $405,410,416$.

Bu'ell, Gen. Don Carlos, 444, 445.

Bue 'na Vis'ta, battle of, 364.

Buffalo Exposition, 545.

Bull Run, 442, 443, 450.

Bunker Hill, battle of, 154 .

Bur-goyne, Gen. John, 170, 171.

Burke, Edmund, 135, 146, 110.

Bur'lin-game treaty, 500 .

Burns, Anthony, 378.

Burnside, Gen. Ambrose F., 451, 468, 466.

Burr, Aaron, 258, 270, 271.

Butler, Gen. Benjamin F., 455, 447.

Butler, John, 179.

Bũtte, Montana, 500 .

Byl'lynge, 80.

Byrd, Col. William, 94, 100. 
Cabinet, 237.

Cable, submarine, 518.

Cable, George W., 530.

Cab'ot, John and Sebastian, 35, 34.

Ca-bräl', Pedro Alvarez de, 33, 34.

Caho'kia, 124, 181.

Cal-houn', John C., 321, 306. in Congress, 279, 294, 304. nullification, $313,319-322$. slavery, 345,374 . tariff, 304, 312.

Tyler's Secretary of State, 357. Vice President, 310.

California, acquired, 361,36 i -367 . gold in, 369,370 . slavery question, $372-375$.

Calvert, George and Cecil, 55, 56.

Calvin, John, 96.

Camden, battle of, 178 .

Căm'er-on, Simon, 412, 437.

Camp meeting, 282, 296.

Canada, 66, 74, 126, 130, 154. in War of $1812,280-284,286$.

Canals, 224, 294, 295, 326, 325, 534; see Panama Canal.

Cape Bret'on, 126, 130.

Capital of U.S., 238, 239, 283, 377, 422.

Car-nĕg'ie, Andrew, 529.

Carolina, 84, 85, 108.

Carpethaggers, 504, 505.

Căr'roll, Charles, 149.

Car'ter-et, Sir George, 80.

Car-tha-gẽ'na, 41, 126.

Cartier, Jacques (zhảk kar-tyā'), 88, 34.

Carver, John, 51.

Cä'så dẹ Cōn-träc-tä-cï-ōn', 74.

Cass, Lewis, 372, 880, 405.

Catholics, 55, 56, 69; 8ee Churches.

Caucus, 309, 540.

Ca-vi't te, 553.

Ca-yu'gas, 68 ; see Iroquols.

Cedar Creek, battle of, 479,480 .

Census, see Population.

Centennial Exposition, 511.

Central America, 26, 37, 308; see Panama.

Cer ro Gor'do, battle of, 364 .

Cervera (thâr-vā'ra), Admiral, 555.

Chām'bersburg, captured, 475.

Champion Hill, battle, 461.

Cham-plain', Samuel de, 66.

Chan' cellorsville, battle of, 462.

Charles I., 49, 52, 60, 62.

Charles II., 77, 84.

Charleston, 85, 125, 220, 422.

exposition, 545.

in Civil War, 405, 413, 466, 484.

in Revolution, $167,177,179$.

Charlestown, 53.

Çhärties, Ft., 125.

Chase, Phllander, Bishop, 295.

\section{INDEX}

Chase, Sal'mon P., Chief Justice, 497.

Secretary of Treasury, 412,480 .

Senator, $375,387$.

Chase, Samuel, 263.

Chăt'ham, Earl of (Pitt), 129, 135, 141, 165, 166.

Chattanoo'ga, in Civil War, 463-166.

Chĕr-o-kees', 27, 132, 133, 179, 331, 332.

Cherry Valley, N.Y., 180.

Ches'a-peake, 272, 280, 281.

Çhi-ca'go, 289, 333, 507, 539.

portage, $24,71,72$.

World's Fair, 545.

Chickamau'ga, battle of, 463,464 .

Chick'a-saws, 27, 132, 332.

Chï'le, difficulty with, 522,545 .

independence of, 307,308 .

Chillicòth'è, 244.

China, Boxer outbreak, 561, 562.

treaty with, 371.

Chinese immigration, $500,518,519$.

Chip'pa-wa, battle of, 283.

Choc'taws, 27, 132, 332.

Christian Commission, 470.

Christmas Island, 561.

Church buildings, 83, 96, 230-232, 529, 530 .

Churches, 96, 97, 116, 230-232, 340, 341, 426. in West, $295,296$.

Church'ill, Winston, 530.

Ci'bō-lä, cities of, 37 .

Cincinnä'ti, 244, 423.

Cities, 220, 422, 423, 514, 515, 538, 539, 575.

Civil Rights Acts, 495, 504 .

Civil service, $263,318$. reform, 503, 520, 538, 580 .

Civil War, 413-422, 433-489. cost of, $487,488$. northern opposition to, 472.

Clark, George Rogers, 180, 181.

Clark, William, 268, 269.

Classified service, $520,538,580$.

Clay, Henry, 297, 306. compromises, $299,819,874$. presidential candidate, $309,810,820,858$. tariff, $304,312,319$.

U. S. Bank, 819 .

War of $1812,279$.

Clay'bourne, William, 56.

Clayton-Bulwer treaty, 366, 367, 398, 522, 582.

Clem'ens, S. L., 530.

Clermont, 274.

Cleveland, 244, 423, 428, 518.

Cleveland, Grover, 525, 526, 537, 540, 541, $543,546,560$.

Cliff d wellings, 25.

Clinton, De Witt, 294.

Clinton, George, 217, 270, 284.

Clinton, Sir Henry, 174, 177.

Coal mining, 289, 427, 428. 
Coinage, 242, 334, 508, 513, 548.

Cold Harbor, battle of, 474, 475 .

Colleges, 93, 116, 228, 296, 339, 423, 424, 528, $529,570$.

Co-lōm'bï-ä, independence of, 307, 308. treaties with, $366,552$.

Colonial trade, 74, 75, 103, 114 ; 8ee Navigation Acts.

Colonles, English, 40, 45-63, 74-163. government, $75,103,110-113,118$. life and industry, 91-105, 114-116. people, 91.

See names of colonies.

Col-o-rä'do, admitted, 501, xxx.

Columbla, S.C., captured, 484.

Columbia College, 116.

Columbla River discovered, 268.

Colunıblan exposition, in Chlcago, 545.

Columbus, Christopher, 3i-35, 43.

Commerce, colonial, 101-105, 114.

growth, 222, 223, 233, 303, 304, 392.

Indlan trade, 104.

neutral, 250-252, 271-273, 278.

Pacific, 370, 371.

under Confederation, 199.

under Constitution, $211,213,242,572 ; 8 e e$

Tarlff, and Inter'state commerce.

Commerclal panles and crises, 311, 334, 335, $393,507,543$.

Commercial treatles, 197, 252, 272, 286, 303, $330,871,545,560$.

Committees of Correspondence, 145.

Communal societies, 340-342.

Compromise of $1820,299$.

Compromise of $1850,374-377$.

Compromises of the Constitution, 210.

Concord, battle of, 151, 152.

Confederacy, Southern, 406-422, 433-489.

government, 406, 439, 440.

military strength, $436,437$.

Confederates, punishment of, 491-493.

Confederation, 189-204.

defects, 202-204.

Confiscation, in Civil War, 455, 456.

In Revolution, 166, 185.

Congress, Albany, 128.

Congress, Continental, 149-163, 172, 179, 182, 185.

Congress, Stamp-Act, 140.

Congress of the Confederation, 189-206, 213, 235.

Congress under the Constitution, 211-213, 235-243.

powers over slavery, 383 .

reconstruction by, 494-497, 503 .

Connect'icut, colony, 57, 60, 77, 79, 87-89, 107.

western claims, 182, $192,244$.

Connecticut Compromise, 210, 211.

Constitution, 280, 281.
Constitution of U.S., xiv. amendments to, 237, 238, 259, 492, 495, $503,504$.

analysis of, $212,213$.

making of, 206-218.

ratification, 213-217.

theories of, 322,323 .

Constitutional Union party, 402.

Constitutions of the states, $159,160,422,540$.

Continental Congress, First, 149, 150.

Second, 152, 153, 156-163, 172, 179, 182, 185.

Contraband, 250.

"Contrabands," slaves, 455, 456.

Convention, federal, 206-214, 217, 218.

Conventlons, party, 226, 320 .

Conway Cabal, 173.

Cooper, James Fenimore, 342.

Cooper, Peter, 327.

"Copperheads," 472.

Corinth, captured, 445.

Corn-wal'lis, Lord Charles, 177-179.

Cō-ro-nä'dō (-tho), Francisco Vasquez de, 37.

Corporations, 224, 515, 516, 532, 533, 571. control of, $535,548,581$.

Cor'tez, Hernando, 36.

Corwill amendment, 409.

Cotton, 221, 222, 420, 430, 527.

Cotton gin, 222.

Council, colonial, 111.

Council for New England, 52, 53, 57, 59.

County government, 112, 297.

Cou-reurs' de bols (bwä), 74.

Courts, 111, 112, 238.

Cowpens, battle of, 178 .

Crater, at Petersburg, 475.

Crawford, William H., 306, 309, 310.

Creeks, 27, 132, 331, 332.

war with, 279.

Cre-dït' Mo-bï-lier' (-lyā'), 507.

Crèvecœur (krāv-ker'), Ft., 72.

Crime of 1873,508 .

Criminals, 225, 338.

Crit'ten-den, John J., 410.

Cromwell, Oliver, 60 .

Crown Point, fortified, 126.

Cro-zä $t^{\prime}$, Anthony, 124, 125.

Cuba, proposed annexation, $377,378,884$. relations to U.S., $551-560$. revolts against Spain, 507, 521, 551-557.

Cum'berland Road, 294.

Currency, see Coinage, and Paper money.

Cush'Ing, Caleb, 371.

Custer, Gen. George A., 502.

Cutler, Manasseh, 195.

Cut'tyhunk, 42.

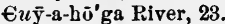

Dakota territory, 501.

Dale, Sir Thomas, governor, 48.

Danish West Indies, 499. 
Dare, Virginia, 40.

Dã-ri-ěn', town in South America, 36 .

Dart'moǔth College, 116, 306.

Dăv'enport, Rev. .John, 57.

Davis, Jefferson, biography, 439, 440.

Buchanan and, 404.

captured, 486.

held for treason, $491,497$.

President of confederacy, 406, 439, 440.

resolutions of 1860,401 .

secession views, 408, 409.

Deane, Sllas, 174.

Dear'born, Ft., 289.

Debs, Eugene V., 537, 583.

Debtors' laws, 200, 225, 338.

Declaration of Independence, 157-159, xi.

Declaration of Rights, 149.

Deerfield, attacked, 125.

De Grässe, Admiral, 179.

De Kălb', Baron, 167, 178.

Delaware, 68, 81, 84, 107, xxx.

Delfs-hä'ven, 50 .

De Lō me, Spanish minister, 552.

Democracy, in America, 110, 226, 227, 316, 421.

Democratic Clubs, 250, 253.

Democratic party, earliest, 246,253 ; see Republican party (Democratic).

Jacksonian, 336, 380.

recent issues, $525,540,541,547,583$.

slavery and, 388, 389, 401-403.

Denver, founded, 427.

Dependencies, government of, 575,576 .

Deposit Act of 1836, 334.

Deş-er-ět', state of, 394 .

De Sö'to, Ferdinando, 37.

Des Plaines' River, 24.

D'Es-tă $i \mathrm{~N} g$, Admiral, 177.

De-troit', founded, 124.

in War of $1812,280,282$.

Dew'ey. Admiral George, 553, 554.

Diaz (dé'äs). Bartholomew, 31.

Dickinson, John, 141, 149, 161, 207.

Dingley tariff, 547 .

Dinwid'die, Gov. Robert, 127.

Direct tax, 442, 541 .

Discovery of America, 17, $3 \mathrm{i}-43$.

aids to, 14.

causes, 13-16.

District of Columbia, 239, 377

Dix, Dorothea, 338, 339.

Dixie's Land, 109.

Dǒn'elson, Ft., captured, 444, 476.

Dǒn'gan, Gov. Thomas, 80.

Dooley, Mr., 530.

Dorr, Thomas W., 855.

Don̆g'las, Stephen A., blography, 386.

I.incoln and, 396, 397, 416.

presidential candidate, 401-403, 850, 389.

slavery views, 355-387, 395-397, 401.
Draft, in North, 437, 460 ; riots, 472.

in South, 473.

Drake, Sir Francis, 39-41.

Dred Scott decision, 391, 392.

Dress, 92, 102, 13s, 139, 228.

Du-āne', William John, 329.

Dun-mōré, Gov. John Murray, 144.

Dunne, Finley Peter, 530.

Uu-pont', Admiral S. F., 443.

Uụ-quesne' (-kän'), Ft., 127, 129.

Dustin, Hannah, 124.

Dutch, colonies, $67,68,73,78$. freedom from Spain, 39, 67, 63 .

in Connecticut valley, 57,60 .

in Revolutionary War, 175.

settlers, 67, $80,91,220$.

Dutch West India Company, 67, 78.

Eads, Capt. James B., 534.

Early, Gen. Jubal A., 475, 477.

Eaton, Theophilus, 57.

Ed'ison, Thomas A., 532.

Education, 92, 93, 227, 228, 339, 840, 423, 424, $528,529,569,570$.

in Northwest, 296.

Edwards, Rev. Jonathan, 115.

Elections, see Voters, and Presidential elections.

Electoral Commission, 512.

Electoral Count A ct, 538.

Electric devices, 532, 570 ; see Telegraph.

El'i-ot, John, 86.

Elizabeth, Queen, 40.

Emancipation proclamations, 459, 492, xx vii.

Embargo Act, 278, 275.

Em'erson, Ralph Waldo, 425, 842.

Emigrant aid companies, 387 .

England, changes in government, $29,60,77$, $88,126$.

claim to North America, 42, 73, 75 .

colonies of, see Colonies, and Colonial.

discoveries, 35, 38, 39, 42, 43.

war with France, 66, 122-133.

war with Spain, 38-43.

See also Great Britain.

Enumerated goods, 103.

Eph'rata, Pa., settled, 82.

Equality, 576.

Era of good feeling, 306.

Ěr icsson, John, 447.

Erie Canal, 294, 295.

$\breve{E} \mathbf{r}^{\prime}$ ikson, Leif, 31.

Er'skine, British minister, 277.

European basis of American history, 13-17, $28,29$.

Ev'ans, Oliver, 222, 225.

Ew'ell, Gen. Richard S., 477.

Executive Departments, organized, 237.

Ex'eter, N.H., settled, 59.

Exploration, of coast, see Discovery. 
Exploration, of interior, 263, 269, 356, 501. Expositions, 511, 545.

Express companies, 430.

Fairbanks, Charles W., 583.

Fair Oaks, battle of, 448 .

Farmer's Alliance, 542.

Farming, 98-100, 221, 420, 421, 527. machinery, 326, 428, 570 .

Făr' ragut, David G., 446, 478, 479.

Federal Convention, 20C-214, 217, 218.

Federalist, 214.

Federalist party, 214, 246, 25ł-259, 806.

Fer'gǔson, Maj. Patrick, 178.

Filipĩ'nos, 563, 569.

Fillmore, Millard, 375, 378, 389.

Finance, in Civil War, 441, 442.

in Revolution, 185, 186.

in War of $1812,284$.

recent, $498,513$.

under Confederation, 196, 199.

under Constitution, 213, $239-243$.

See also Public Debt, Tariff, etc.

Fire eaters, 384.

Fisher, Ft., captured, 479.

Fisheries, 101, 184, 222, 303, 506.

Fiske, John, 530.

Fitch, John, 225.

Fitz-hügh', Col. William, 100.

Five Nations, see Iroquois.

Flag, Confederate, 466.

United States, 189, 159.

Fletcher, Gov. Benjamin, 105.

Florida, British, 130, 131, 155, 181, 184.

discovery of, 36.

French in, 38.

purchased by U.S., 807.

Seminole war, 332.

Spanish, 36, 38, 130, 184, 307.

state in U.S., $374, \mathrm{xxx}$.

Floyd, John B., 405.

Foote, Andrew H., 444.

Forests of United States, 20, 22, 527 .

Forrest, Gen. Nathan B., 466.

Fort Astoria, Sumter, etc., see Astoria, Sumter, etc.

Fort Wayne, 24, 290.

Forty-niners, 370.

Foundations of A merican History, 13-29.

Fox, Charles James, 135.

France, ally of U.S., 174-179, 184, 185, 187, 249.

changes in government, $29,249,257$.

claim to North A merica, 42, 73, 75.

colonies, 65, 66, 69-75, 131, 265-267.

depredations on U.S. commerce, 251,255 , $257,272,273,278,330$.

discoveries, 37, 38, 66, 69-73.

Mexican empire, 499

spoliation claims, 330 .
France, treaties with, 174, 257.

war with Engiand, 66, 122-133, 174-187, $249,271$.

war with Iroquois, 66.

war with U.S., 257.

X. Y. Z. controversy, 255, 256.

Franklin, battle of, 484 .

Franklin, state of, 194.

Franklin, Benjamin, blography, 117, 118.

Declaration of Independence, 157.

Federal Convention, 207, 210, 212.

minister to France, 174, 183, 185.

plan of union, 128,161 .

writings of, 117, 229.

Fraternity, 576.

Freebooters, 38, 39.

Free coinage, 513 ; see Colnage and Silver.

Free Democrats, 380, 389.

Freedman's Bureau, 492, 503.

Freeman's Farm, batties at, 170 .

Freeport doctrine, 397 .

Free-soil party, 372, 380 .

Fré-mont', John C., 357, 365, 389, 456, 480.

French, see France.

French and Indian War, 127-131.

French settlers, 85, 91, 124, 125.

Fre-neau' (-nō'), Philip, 228.

Frŏb'isher, Sir Martin, 38.

Fron'te-nac, Ft., 71, 129.

Frôn-te-nảc', Governor, 71.

Fugitive Siave Act, of $1793,273,873$. of $1850,377-379,459$.

Fugitive slaves, $373,378,379$.

Fulton, Robert, 274.

Fur trade, 68, 73, 86, 222.

Gabriel insurrection, 347 .

Gadsden Purchase, 566.

Gage, Gen. Thomas, 146, 150, 153.

Găl'iatin, Aibert, 262, 27 .

Gä'ma, Väs'co dä, 33, 43.

Garfield, James A., 520, 464.

Garrison, William Llojd, 348, 349.

Gāspé Peninsula, 20.

Gaspee, 144.

Gates, Gen. Horatio, 170, 171, 173, 178.

Genêt (zh'-nä'), Edınond, 249,' 250.

¿̇ěn'o-a, trade routes, 15 .

Geography of U.S., 17-28, 29.

George III., 135, 136, 151, 165.

Georgia, colony, 108, 132, 177.

Indian troubles, $244,331,332$.

western claims, 182, 192, 245.

German settlers, 82, 91, 108, 125, 143, 193, $220,500$.

Gerinantown, founded, 82 ; battle, 171.

Ġe-rŏn'i-mo, Indian chief. 28.

Ḡër'ry, Elbridge, 212, 25:.

Gerrymander, 316.

Gettysburg, battle of, 462,463 . 
$\bar{G} h$ ent, treaty of, 285.

Gid'dings, Joshua R., 349.

Gillbert, Sir Humphrey, 38, 40.

Girty, Simon, 180.

Glad'stone, on the Confederacy, 457.

Gnä'den-hüt-ten, 183.

Goffe, William, $7 \mathbf{7}$.

Gold, mining, 369, 370, 427, 500 .

money, see Coinage.

Good Hope, Ft., at Hartford, Conn., 57, 60.

Good'year, Charles, 429.

Gordon, Gen. John B., 477.

Gor'ğěs, Ferdinando, 60.

Gorman, Arthur P., 543.

Gor sŭch, 378.

Gosnold, Bartholomew, 42, 46.

Gould, Jay, 533.

Governınent, colonial, 75, 103, 110-113, 118 ; see names of colonies.

dependencies, $575,576$.

military, 471, 497, 503.

state, $160,316,422,538-540,575$.

territorial, 195.

U. S., 1S9-218, 235-243, 574, 575 .

Governors, colonial, 111, 112, 153.

Gra-nä'da, 17.

Grangers, 512.

Grant, Ulysses S., biography, 475, 476, 503. campaigns in East, 474-476, 485, 486. campaigns in West, 444-446, 460, 461, 465. President, 502-508, 501.

presidential candidate, $502,505,511,519$.

protects Confederates, 491 .

Gray, Capt. Robert, 268.

Grayson ordinance, 192.

Great Britain, 126; see England.

boundary controversies, $355,361,506$.

depredations on U.S. commerce, 250,251 , 271-273.

difficulties with (1783-Ss), 197-199.

during Civil War, 440, $41,459,460$.

Isthınian canal, $366,367,393,582$.

treaties (1783) 184, (1794) 251, 252, (1814) 285, (1818) 303, (1871) 506.

Venezuelan boundary, 546 .

wars with France, 126-133, 174-187, 249, 271.

wars with U.S., 150-187, 277-287.

Great Plains, 21.

Greeley, Horace, 343, 459, 505.

Green, Duff, 318.

Greenback Labor party, 513.

Greeuback party, 512.

Greenbacks, 47i, 498, 508, 513.

Greene, Gen. Nathanael, 178, 186.

Greenville, treaty of, 244.

Grenville, George, 138.

Griffon (grē-füs'), 71.

Guam (gwämı), 557.

Guä-nä-hän', 32 .
Guerrière (gâr-ryâr'), 280.

$\overline{\mathrm{G}} u \mathrm{i}-\mathrm{a} ' \mathrm{n} a$, Dutch, 68 .

$\overline{\mathbf{G}} u$ il' ford, battle of, 178.

Gu'ten-bĕrg, prìnter, 14.

Hadley, Mass., attacked, 86.

Hāgue Conference, 561.

Hail Columbia, 256.

Hāi $i^{\prime}$ tí, 33, 133, 266.

Hak'luyt, Richard, 42.

Halleck, Gen. Henry W., 445, 450, 474.

Ham'ilton, Alexander, and Adams, 258.

biography, 239, 240.

Burr and, 270.

Constitution, 206, 207, 210, 214, 217.

Jefferson and, 239, 243, 245, 246.

Secretary of the Treasury, 239-243.

Washington and, 253.

Hamilton, Henry, 180, 181.

Hampton Roads conference, 486.

Hancock, John, 140, 222, 142, 150, 215, 216.

Hancock, Winfield S., 519, 520.

Hanna, Marcus A., 563, 583.

Harmar, Gen. Josiah, 243.

Harnden, William F., 430.

Harpers Ferry, 397, 451.

Harriman, E. H., 533.

Harris, Joel Chandler, 530.

Harrison, Benjamin, 540, 541, 546.

Harrison, William H., 279, 281, 282, 286, 353

Harte, Bret, 530.

Hartford, 57, 60; Convention, 285.

Harvard College, 93.

Hat'teras, Ft., captured, 443.

Ha-van'a, captured by British, 130 .

Hā'ver-hill, Mass., attacked, 124.

Hä-wa'ian Islands, $370,560,561$.

Hawkins, Sir John, 39.

Hawthorne, Nathaniel, 425, 342.

Hay, John, 557, 562, 582.

Hay-Panncefote treaty, 582.

Hayes, Rǔth'erford B., 511-513, 519, 521.

Hayne, Robert Y., 319.

Henderson, Richard, 160 .

Hen'nepin, Father, 72.

Henry, Ft., captured, 444.

Henry, Patrick, 137, 140, 149, 155, 180, 216.

Henry VII., 35.

Henry the Navigator, Prince, 16.

Her'kimer, Gen. Nicholas, 170.

Hessian soldiers, 166, 169, 170.

IIIIl, Gen. A. P., and Gen. D. H., 477.

IIill, James J., 533.

llilton Head, $443,444$.

Ilispanio'la, 33.

Hobson, Lient. Richmond P., 555.

Ho-ģhěl'a-ga (St. Lawrence), 38.

Hoe, Richard, 429.

Holland, or the Netherlands, see Dutch.

Hōlmeş, Oliver Wendell, 425. 
Holy Alliance, 307,308 .

Homestead Act, 500 .

Hood, Gen. John B., 478, 484.

Hooker, Gen. Joseph, 462, 465.

Hooker, Rev. Thomas, 57.

Hopkins, Esek, 175.

Hopkinson, Joseph, 256.

House of Representatives, 211, 235, 538, xxx.

Houses, 91, 92, 143, 223, 230, 295.

Hoùs'tòn, Sam, 331, 406, 408.

Howe, Elias, 429.

Howe, Sir William, 167-172, 174.

Howells, W. D., 530.

Howland Island, 561.

Hudson, Henry, 67, 73.

Hudson Bay, 73, 74, 125.

Hudson River, explored, 67.

Hudson's Bay Company, 73.

Hū'ğue-not colonists, 38, 85, 91, 143, 220.

Hull, Gen. William, 280.

Humanitarian reform, 338-351.

Hunter, Gen. David, 456.

Hurons, Indians, 69.

Hutchinson, Anne, 55, 59.

Hutchinson, Thomas, 140, 144, 146.

I-ber-vīll $e^{\circ}$, Sieur (syẽr) d', 124.

I'daho, 501, 527, xxx.

Illinoir', 182, 298, 301, xxx.

French in, 72, 73.

1-lo-i'lo, 557 .

Immigration, 333, 419, 500, 536.

Impeachment of President Johnson, 497.

Impending Crisis, 401.

Implied powers, 213, 243, 246, 267, 306.

Impressments, 251, 271, 280, 285.

Incas, 26.

Income tax, 442, 544.

Indented servants, 99.

Indents, 185.

Independence, $155-160$.

Independent treasury, 335, 359.

Independents (sect), 49,60 .

Indian Territory established, 332 .

Indian Wars, in aid of French, 122-125, 127129.

in New England, 57, 58, 86, 87, 125.

in New York, 78.

in Virginia, $48,84$.

Pontiac's, 132.

with U.S. (1789-94) 243, 244, (1811) 278 , $279,(1832) 332,(1872-76), 501,(1886) 526$.

Indiana, state, 298. 301, xxx.

territory, 244, 273, 298 .

Indians, aboriginal life, 23-28.

behavior in slavery, 99 .

controversy with Georgia, 331, 332.

government, 28.

in Revolution, 167. 170, 179, 180, 183.

relations with whites, $74,75,568,569$.
Indians, removal of, $331,332,563$.

Severalty Act, 526 .

trade, 104.

" tribes," 28.

warfare, 27, 28, see Indian Wars.

See also names of tribes.

Industrial exhibitions, 511,545 .

Industries, 221-225, 323, 427-431, 570.

in South, 527, 528.

Initiative, $5 \mathbf{4 0 .}$

Insane, care of, $225,339$.

Insurance companies, 515.

Intercolonial wars, 122-133.

Internal improvements, 293, 294, 326, 327, $533,534$.

Interstate commerce, 199, 534, 535 .

Intolerable Acts, 146.

Inventions, $222,224,225,323,326,428,429$, $530-532,570$.

I'owa, $374, \mathbf{x x x}$.

Iron, $289,323,427,428,518,528$.

Ir-o-quois', 68, 69, 27, 66, 123, 129, 132, 179. 180.

Irrigation, 526, 527.

Irving, Washington, 342 .

Isabella, town in Haiti, 33 .

Isabella of Castile, 16, 31, 32 .

Island No. 10, captured, 444.

Isthmian Canal, 366, 367, 393, 499, 581, $5 \$ 2$.

Jackson, Andrew, biography, 310, 317.

general, 279, 283, 286, 307.

President, 316-320, 32i-336.

presidential candidate, $310,313,320$.

Jackson, Dr. Charles T., 429.

Jackson, James, 277.

Jackson, Gen. Thomas J. ("Stonewall "), $442,449,450,462,477$.

Jamāi'ca, 33, 60 .

James, Capt. George S., 414.

James II. of England, 87, 88.

Jamestown, 47-49, 84 .

Japan, treaty with, 371.

Jasper, Sergeant, 167, 169.

Java, 281.

Jay, John, 149, 183, 200, 214, 238.

treaty with Great Britain, 251, 252.

Jefferson, Thomas, biography, 261, 262.

Declaration of Independence, 157.

Hlamilton and, 239, 243, 245, 246.

Kentucky Resolutions, 256.

on National Bank, 243.

on slavery, 226.

on treaty with France, 249.

ordinance for western territory, 194.

President, 258, 261-2i i.

Vice President, 254.

Washington and, 253.

writings of, 229.

Jesuits in America, 66, 69, 71. 
Jews, 97, 231.

Jogues (zhōg), Fatber Isaac, 69.

Johns Hopkins University, 529.

Johnson, Andrew, governor, 444.

President, 494, 495, 497.

Vice President, 480.

Johnson, Sir William, 123, 129, 132.

Johnston, Gen. Albert Sidney, 445.

Johnston, Gen. Joseph E., 478, 442, 448, 477, 484,456 .

Joliet (zho-lyā'), Louis, 71.

Jones, John Paul, 175.

Juan (hoo-än') de Fu'ca, Strait of, 23.

Ka-naw' $h$ a River, 144.

Kan'kakee River, 72.

Kansas, 387, 388, 395, 407, xxx.

Kansas-Nebraska Bill, 387.

Karl-sef'nï, 31.

Kaskas'kia, 124, 181.

Keär'ney, Dennis, 519.

Keär'ny, Stephen W., 364.

Kemble, Fanny, 343, 344.

Ken-e-saw' Mountain, battle of, 477.

Kent Island controversy, 56.

Kentucky, in Revolution, 180, 181.

settled, 143,144,160,161,183,193, 194, $293,301$.

state, $245, \mathrm{xxx}$.

Kentucky Resolutions, 256, 257.

Key, Francis S., 283.

Kidd, Capt. William, 105.

King George's War, 126.

King Phillp's War, 86, 87.

King William's War, 122.

Kings Mountain, battle of, 178.

Kitchen Cabinet of Jackson, 318.

Knights of Labor, 519.

Knights of the Golden Circle, 472.

Know-nothings, 388.

Knox, Henry, 237.

Knoxville, in Civil War, 463, 466.

Koo'te-nāi River, 360.

Kos-çi-n̆s'ko, Thaddeus, 167.

Ku Klux Klan, 505.

Labor, 99, 100, 221, 428, 518, 519, 535-537, $570-572$.

La-çhïne' Rapids, named, 38.

Ladies' aid societies, 470.

La-drōnes , discovered, 36.

La-fã-yět $t 2^{\prime}$, Marquis de, 167, 179, 186.

Laird rams, 460.

Lake Erie, battle of, 281.

Lä Plä'ta, independence of, $3117,308$.

La Sålle', Robert Cavalier, Slẽur de, 70-73.

Laudonnière (lo-do-nyâr'), 38.

Jaurens, Henry, 183, 206.

Iaw, John, 125.

Lawrence, Kan., sacked, 388.
Lěad'ville, Colo., 500.

Le Boẽuf, Ft., 127.

Lecomp'ton constitution, 895.

Lee, Annah, 231.

Lee, Gen. Charles, 169, 174.

Lee, Fitzhugh, 552.

Lee, Gen. Henry, 178.

Lee, Richard Henry, 157.

Lee, Gen. Robert E., blography, 476, 477. captures Brown, 398.

in Civil War, 448-452, 462, 463, 474-477, 485,486 .

Legislature, colonial, 111 ; 88в Government.

Leif the Lucky, 31.

Leìs'ler, Jacob, 89.

Le'land Stanford University, 529.

Le-ōn', Pōn'ce (-thā) de, 36.

Leopard, 27\%, 273.

Lesseps, Ferdinand de, 521.

Lewis, Meriwether, 268, 269.

Lexington, battle of, 151, 152.

Libby prison, 473.

Liberal Republicans, 505.

Li-be'ri-a, 298.

Liberty, 568, 569, 572, 573, 576.

Liberty, 142.

Liberty party, $358,372$.

Libraries founded, 340,529 .

Life, American colonial, 91-105.

during Civil War, 470-473.

in 1780-1800, 220-233.

in 1861, 420-431.

in the South, 343, 421, 424, 473.

in the West, 292-296, 301, 333.

Indian, 23-28.

Lincoln, Abraham, biography, 396, 457, 458.

death, 487.

debates with Douglas, 396, 397.

elected President, 403, 481.

emancipation, 456-459, 498.

on secesslon, 409, 410, 412.

on the Union, 159.

President, 411-414, 433, 438, 441, 456-459, 474, 486, 493, 497.

representative in Congress, 363, 373.

Lincoln, Gen. Benjamin, 177.

Lin'otype machine, 531.

Literature, 93-96, 105, 228, 229, 842, 343, 424-426, 530.

Livingston, Robert R., 157, 266, 267, 269.

Local government, 112, 113.

in West, 296, 297.

See al*o Cities.

Locke, John, 85.

Logan, Indian chief, 144.

London Company, 45-50.

Long, Maj. Stephen II., 356.

Long Island, battle of, $167-169$.

settled, $57,67,79$.

Longfellow, Henry W., 424. 
Longstreet, Gen. James, 463, 477.

Lookout Mountain, battle, 465 .

"Loose Construction," 246.

Lō'pęz (-pās), in Cuba, 378.

Lord Dunmore's War, 144.

Lords of Trade, $77,103,137$.

Louisburg, 126, 127, 129.

Lọ $u$-ï sï-ä'na, province, 72, 73, 124-127, 130, 265-267.

Purchase, 266, 267, 269.

state, $268,301, \mathbf{x x x}$.

Lou'is-ville, $183,423$.

Lovejoy, Elịjah, 349 .

Lō $w^{\prime}$ ell, F. C., 225.

Loweli, James Russell, 348, 363, 425, 342.

Loyalists (Tories), 166, 167, 177-180, 185, 186.

Lundy, Benjamin, 293.

Lundys Lane, battle of, 283.

Ly-ce'um, 340.

Lyon, Capt. Nathaniel, 415, 444.

McClellan, Gen. George B., 443, 447-451, 480, 481.

MeClernand, Gen. .Tohn A., 461.

McCormick, Cyrus II., 428, 326.

MacDon'ough, Com. Thomas, 283.

Mclowell, Gen. Irvin, 442, 443, 448, 449.

Macedonian, 281.

Mack'ina c mission, 69 .

McKinley, William, 562, 563, 547, 552, 556, $560,579$.

McKinley tariff, $541,542,543$.

Ma-comb', Gen. Alexander, 283.

Macon Bill No. 2, 278.

Madison, Doliy, 277.

Madison, James, and the Constitution, 207209, 211, 214, 216.

President, 27i-250, 284, 294.

Virginia Resolutions, 256.

Ma-drid', treaty of, 73.

Magazines, 229, 296, 342, 425.

Ma-gel'lan, Fernando, 36, 34.

Ma-hăn", Alfred T.. 530.

Ma-ho'ning River, 24.

Maine, and Massachusetts, 60, 87, 107.

boundary controversy, $355,356$.

probibition law, 340.

settlements in, 42, 43, 46, 60 .

state, $299, \mathrm{xxx}$.

Maine, destroyed, 552.

Maivern Hiil, battle of. 449 .

Mand eville's Traveix. 16.

Ma-nil'a, 130, 553, 554, 556, 558.

Mann, Horace, 339.

Manufactıres, 136, 222, 224, 225; (1812-16) $279,303,304$; (1810) $323 ; 428-430,531,570$. in South, 527, 528.

Marcy, William L., 380, 384.

Ma-ri-et'ta, $O$., founded, 196.

Măr'i-on, Gen. Francis, 178, 177, 186.
Mar-quette'(-kět'), Father Jacques, 71.

Marshall, James W., 369.

Marshall, John, 805, 832, 255.

Maryland, colony, 55, 56, 78, 108, 109.

insurrections in, 60,84 .

ratifies articles of confederation, 182, 183.

Mason, George, 212.

Mason, James M., 441.

Mason, Capt. John, 57.

Mason, John Y., 884.

Mason and Dixon's line, 109.

Massachusetts, colony, 52-55, 59-62, 77, 79, 86-ss, 107, 109.

education in, 93,339 .

in Revolution, 137, 142, 145, 146, 149-154.

Plymouth colony added to, 107.

Silays's Rebellion, 200.

western claims, 182, 191, 192.

Măth'er, Cotton, 94, 96.

Maxim, Hiram, 531.

Maximilian, of Mexico, 499.

Mayflower, 50, 51.

Meade, Gen. George G., 462, 463, 474.

Meade, Bishop Wiiliam, 426.

Necklenburg Jeciaration, 156.

Memphis, captured, 445.

Mé-nẹn'dęz (dāth), 38.

Merchant, colonial, 101.

Merit system, 588.

Merrimac and Monitor, 447, 448.

Merritt, Gen. Wesley A., 554.

Met'acom, 86.

Mexico, independence, 307, 308.

Indians in, 26.

Napoleon III. and, 499.

Spanish, 36, 37.

war with U.S., 361-367.

Mī-äm'Y River, 127.

Niamis, Ft., Mich., 72.

Michigan, 69, 374, xxx1.

Midnight judges, 263.

Midway Island, 561.

Mii'an Decree, 272.

Miles, Gen. Nelson A., 556.

Military Academy founded, 339.

Military government. in Civil War, 471, 497. of southern states, 503 .

Milligan, Dr., 471.

Milwau'kee, 423.

Minms, Ft., 279.

Mining, 289, 427, 500.

Minnesota, 407, xxxi.

Mint, established, 242.

Min'u-it, Peter, 67.

Minutemen, 150, 152.

Miạnelon (më-k'-lôn'), 181.

Missionary Ridge, hattle of, 465,466 .

Missionary societies, 339.

Mississippi, 245, 298, 301, xxxi.

Mississippi River, discovered, 37. 
Mississippi River, explored, 71, 72. jetties, 534 .

right to navigate, $197,252,266$. valley, $20,21$.

Missouri, 298, 299, xxxi.

Missouri compronise, $299-301,385,387,391$.

Mo-bïle', founded, 124.

forts captured, $283,478,479$.

Mo'doc Indians, 501.

Mo'hawks, 65 ; see Iroquois.

Molasses Act, 115, 138.

Money, see Coinage, and Paper money.

Monitor, 447, $44 \mathrm{~S}$.

Mon'moŭth, battle of, 174.

Mo-non-ga-he'la R., 290.

Món-roe', James, 266, 267, 306-309.

Monroe Doctrine, 308. 309.

Montï'na, 500, 501, 527, xxxi.

Mont-calm', Marquis de, 130.

Mon-te-rey', battle of, 364 .

Montgơm'ery, Gen. Richard, 154.

Mont-re-al ${ }^{\prime}, 38,66$.

captured, 130, 154

Môvts, Siẽ $u r$ de, 65,66 .

Moravians, 82, 94, 96, 108.

Morgan, Gen. Daniel, 178.

Morgan, Gen. John, raid in Ohio, 466.

Mormons, 341, 394, 395, 527.

Morrill tariff, 441.

Morris, Gouverneur, 212.

Morris, Robert, 169, 196, 197.

Morse, Samuel F. B., 429.

Morton, Dr. William T. G., 429.

Moș'by, Col. .John S., 466.

Motley, John Lothrop, 425.

Mō $u l^{\prime}$ trie, Col. William, 167.

Mounds, 25.

Mount Desert Island, settled, 66 .

Mount Vernon, Washington's home, 236.

Mugwumps, 525.

Mūh'lenberg, Frederick, 235.

Mur'freesboro, battle of, 446 .

Museums, founding of, 340.

Mus-ko'gee Indians, 27.

Napoleon, 257, 265, 282.

Louislana, 265-267.

seizes U. S. ships, 272, $273,278$.

Napoleon III., in Mexico, 456, 499.

Narragan'sett Indians, 57, 61, 87.

När-vä'éz (-ãth), Panfilo de, 36.

Nashville, founded, 183.

in Civil War, 444, 484.

Nashville Convention, 374.

Nătch-1̌-tǒçhes', Ft., 125.

National debt, see Public debt.

National road, 294.

Natural resources of U.S., 17-25, 29, 289, $426,427$.

Naum'kēag settlement, 52 .
Nau-voo', 341, 894.

Naval Academy founded, 339.

Navigation, about 1450,14

Navigation acts, 60, 75, 77, 103, 136.

Navy, in Civil War, 438, 439, 443-448, 452. $466,478,479$.

in Revolution, 175.

in W ar of $1812,280,281$.

in war with France, 257.

Jefferson and, 265, 271.

modern, 541, 553-555.

Nebraska, 385-387, 501, xxxi.

Negro Seamen Act, 407.

Negroes, see Slavery.

after Civil War, 492, 494, 495, 569.

colonization of, 298.

schools, 528 .

suffrage, 495, 496, 503-505, 540.

troops in Civil War, 460.

Netherlands, see Dutch.

Nentrality, 249-252, 271-278.

Ne-vä'da, 501, xxxi.

New Albion, 39 .

New Amsterdam, 67, 68, 78, 79.

New England, Councll for, 52, 53, 57, 59 .

Indian wars in, 57, 58, 86, 87, 125.

settled, 50-55, 57-63.

slave trade, 114,115 .

struggle for charters, $86-89$.

War of 1812, 284, 285.

See also names of separate states.

New England Confederation, 61, 87.

New England Primer, 96.

New France, 66, 74; see Canada.

New Gra-nä'da, 307, 366.

New Hampshire, 59, 87, 107, xxxl.

New Haven, 57, 61, 77.

New Jersey, 80, 107, xxxi.

New Mexico, 366, 372-375, 381.

New Netherland, 67, 68, 78 .

New Or'le-ans, 125, 130, 266, 267, 422.

battle of, 283.

captured in Civil War, 447.

New Sweden, 68.

New York (city), draft riots, 472.

growth, 79, 220, 295, 423, 538 .

in Revolution, 145, 167, 169, 184.

Tweed Ring, 514.

New York (state), "A ntl-Rent," 854.

colony, 78-80, S9, 107, 109.

In Revolution, 141, 170.

settled, 67,68 .

western claims, 182, 191.

New York Harbor, discovered, 37, 67.

Newark, settled, 80 .

Newburg Addresses, 184.

New' foundland, 40, 125.

Newport, founded, 59 .

in Revolution, 169, 175, 177.

Newspapers, 94, 229, 343. 
Ni-ca-rä'gua Canal, $866,393,522,581,582$.

Ni-co-lę $t^{\prime}$, Jean (zhä̀), 69.

Nic'olls, Gov. Kichard, 79.

Niña (nēn'yã), 32.

Nominating conventions, $226,320$.

Non-importation, 140, 142, 147, 272.

Normal school, first, 339.

North, Lord, 153, 165, 166, 174, 183.

North Carolina, colony, 84, 85, 108, 123. in Revolution, 143, 144, 156, 177, 178. western claims, 182, 192, 194 .

North Dakota, 527, xxxi.

Northwest Ordinance, 195 .

Northwest passage, 38 .

Northwest Territory, 195, 243, 244.

Nova Scotia, 125, 153.

Nullification, 257, 313, 319-323.

of Fugitive Slave Act, $379,381$.

O'berlin College, $340,349$.

O'gle-thorpe, George, 108, 126.

Ohio, admitted, 245 , xxxi. settled, 193, 244, 289, 293, 301.

Ohio Company, 127.

Ohio Company of Associates, 195, 193.

Oil wells, 427, 528 .

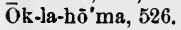

$0 l \mathrm{~m}$ 'sted, Frederick Law, 530.

Olney, Richard, 546.

O-nei'das, 68; see Iroquois.

On-on-dä'gas, 68 ; $8 e e$ Iroquois.

O-pěq'uan Creek, battle of, 479.

Orange, Ft., 67.

Orders in Council, 272.

Ordinance of $1787,195$.

Ŏr'e-gǒn, 360, 361, 372, 407, xxxi. explored, $268,269$.

joint occupation, $303,356$.

O-ris'ka-ny, battle of, 170 .

Or'le-ans, Island of, 265.

Orleans, Territory of, 268.

Os-a-wat'o-mie (-wǒt'-), fight, 388.

Osgood, Samuel, 237.

Ost-end' Manifesto, 384.

Os-we'go, Ft., captured by French, 129.

Otis, James, 137.

O'wen, Robert, 341.

Pactic Ocean, discovered, 36.

Pacific rallroads, 393, 502, 535.

Page, Thomas Nelson, 530.

Paine, Thomas, 156, 191.

Păk'en-ham, Gen. Edward M., 283.

Päl'ma, Gen. Tomas Estrada, 560.

Pä'lo Äl'to, battle of, 364 .

Pä'lōs, 32.

Pan-a-mä' Canal, 366, 367, 521, 522, 581, 582.

Panama Congress, 311.

Panama republic, 582.

Pan-American Congress, 545, 311.
Pan-American policy of Blaine, 522 .

Pa-n $a \overline{\mathbf{y}}^{\prime}, 557$.

Panics, 311, 334, 393, 507.

Paper blockade, 250.

Paper money, 115, 185, 186, 200, 498, 508.

in Clvil War, 442, 471, 473.

Paris, peace of (1763), 130.

treaty of (1782), 183, 184.

Parish, government of, 112.

Parker, Judge Alton B., 583.

Parker, Theodore, 348.

Parkman, Francis, 425.

Parliament, 60, 77, 103, 111, 115, 126, 138-141, $146,153,174$.

Parson's Cause, 137.

Partles, see Federalist, Democratic, etc.

Party management, 226, 227, 316, 320, 422, 540 .

Patent, defined, 40.

Păt'er-son, William, 207.

Pa-troons', 68, 354.

Peace Congress (1861), 410.

Pea Ridge, battle of, 444 .

Pemberton, Gen. John C., 461.

Peninsular Campaign, 447-450.

Penn, William, S0-84, 94, 107, 109, 113.

Pennsylvania, 50-84, 109, 193, xxxi.

Whisky Insurrection, 252, 253.

Pensaco'la, 124, 307.

Pensions, 541.

People's party, 542 .

Pep'per-ell, William, 126.

$\mathrm{Pe}^{\prime}$ quot War, $57,58$.

Per-di'do River, 265.

Perkins, Jacob, 225.

Pěr'ry, Com. Matthew C., 371.

Perry, Oliver H., 281.

Personal Liberty Bills, 379, 381.

Pe-ru', 26, 36, 37, 307, 308.

Petersburg, siege of, 475, 484, 485 .

Pet'i-gru, James L., 408.

Philadelphia, 82, 83, 107, 220, 238, 239, 423, 514.

Centennial exposition, 511.

in Revolution, 145, 152, 171, 174.

Philip, King, Indian, 86, 87, 28.

Phil'ip-pine Islands, acquisition of, 556-558, 563.

discovered, 36.

government, 558, 559, 575 .

Phillips, Wendell, 348.

Phillips academies, 228.

Phips, William, 101, 122.

Photography, 429.

Pickering, Timothy, 195, 255.

Pickett, Gen. George E., 463.

Pierce, Franklin, 380, 384, 388.

Pike, Lieut. Zeb'ulon, 269.

Pikes Peak, discovered, 269.

Pilgrims, 49-51.

Pinckney, Charles C., 255, 277. 
Pi-ne'da, 86, 84.

Pìn'ta, 32.

Pirates, 104, 105, 263.

Pitt, William (Chatham), 129, 185, 141, 165, 166.

Pittsburg, 143, 289, 423, 428.

Pittsburg Landing, battle near, 445.

Pí-zär'ro, Francisco, 86.

Planter, colonial, 100, 108.

Plassey, battle of, 129.

Platt Amendment, 559.

Plattsburg, battle of, 283.

Plym'oǔth Colony, 50, 60, 61, 77, 107.

Plymouth Company, 45, 46, 62.

Pocahon'tas, 47.

Poe, Edgar Allan, 342.

Point Pleasant, battle of, 144.

Pokanokets, Indians, 86.

Pōlk. James K., 35̃s-367, 377.

Pollard, Edward Albert, 344.

Polo, Marco, 15.

Pon'ti-ac, 132, 28.

Pony express, 430.

Poor Richard's Almanac, 117.

Poor whites, 343, 421.

Pope, Gen. John, 444, 450.

Pope's bull of $1493,33$.

Pop'ham, Chief-justice, 46.

Popular sovereignty, 372, 385.

Population (1700) 91, (1754) 128, (1776) 167, (1790) 220, (1S20) 2s9, 290, (1860) 419, 420 , (1900) 565, 568; see also Life.

Port Gibson, captured, 461.

Port IIudson, capt'ired, 461.

Port Royal, N.S., founcied. 66.

captured by English, 66, 122, 125.

Port Royal, S.C., French in, 38

Portages, Indian, 23, 24.

Porter, Capt. David, 283.

Porter, Com. David D., 446.

Pōrtōlä'no, 14.

Pōr'to Rĩ̀ co, 33, 556-559.

Portugal in 1450-1500, 29.

discoveries, 16, 33-35.

Post Office, 152, 430, 518.

Po-to-si', in Peru, 37.

Powell, Major, 501.

Pow-ha-tăn', 47, 28.

Prairies, 20, 21.

Preëmption Act, 335.

Pres'cott, Col. William, 154.

Prescott, William H., 342, 425.

President, 212, 235-238.

Electoral Count Act, 538 .

Presidential Succession A ct, 538.

Presidential election (1789) 235, (1792) 246, (1796) 254, (1800) 258, (1804) 270, (1808) 277, (1812) 284, (1816) 306, (1820) 306, (1824) 309, 310, (1828) 313, (1832) 320, (1536) 334, (1840) 353, (1844) 358, (1848)
$871,872,(1852) 380,(1856) 389,(1860)$

403, (1864) 480, 481, (1868) 502, (1872)

505 , (1876) 511, 512, (1880) 520, (1884) 525,526 , (1888) 540, (1892) 543, (1896) 547, (1900) 579, (1904) 583.

Presque 1sle, fort at, 127.

Princeton, battle of, 169 .

Princeton College, 116.

Pring, Martin, 42.

Printing, first in U.S., 94.

Prisoners, in Civil War, 433, 473.

in Revolution, 172.

Privateering, 104, 175, 257, 283-285.

Proclanation line of 1763, 131, 132.

Proctor, Senator, 552.

Prohibition, 340, 583.

Proprietary, or proprietor, 56, 110, 111.

Providence, founded, 59.

Provincial Congress, 150, 153, 159.

Prü-dhŏmme', 'Ft., 72.

Public debt, (1776-84) 185, 186, 196, (1790) 240, 241, (1812-14) 262, 284, (1835) 334, (1861-66) 442, 498, (1598) 544, 563.

Public lands, 182, 191-193, 290, 832-335, 500, 527.

grants to railroads, $393,502,516$.

Pueb'los (pwěb'), 26.

Pū'gèt Sound, 23.

Pu-lăs'kì, Casimir, Count, 167.

Puritans, 49, 52, 53, 60, 89, 84, 96.

Putnam, Gen. Israel, 154.

Putnam, Rufus, 195.

Quakers, 61, 62, 77, 80-85, 232.

Quartering Act, 139.

Queběc' (city), attacked by Arnold, 154 . attacked by English, 125.

captured by English, 66, 130.

founded, 66 .

Quebec (province), 131, 144, 153.

Quebec Act, 144, 154.

Queen Anne's War, 125.

Quin'cy (-zǐ), Josiah, 284.

Quì-vi'rä (kế-), explored, 37.

Railroads, control of, 533-535.

growth, 327-329, 325, 392, 393, 430, 431, $502,515-519$.

Improvements in, 531, 571.

Raisin RIver, battle of, 281.

Rạ'leĭgh, Sir Walter, 40.

R.undolph, Edmund, 149, 209, 212, 216.

Randolph, Ed ward, 86, 87, 103.

Randolph, John, 301, 304.

lankin, John, 347.

Reciprocity, 522, 545.

Rè-cōn-cen-trä'dōs, 551.

Reconstruction, 491-497, 503-505, 509.

Redemptioners, 99.

Reed, Thomas B., 538, 552. 
Referen'dum, 540.

Reformation, Protestant, 87.

"Regulators" of North Carolina, 143.

Religion, see Churches.

Rè nā $i$ s-sānç̧e', 13.

Republican party (Democratic), 253, 306 ; see Democratic.

Republican party (later), 389, 402, 403, 525, $540,541$.

Requisitions, 185, 191.

Rè-sā'ca de lï Päl'ma, battle of, 864.

Restoration of Charles II., 77.

Re-vēre', Paul, 150.

Revolution, American, 135-188.

Revolution in England, 88.

Rhett, Colonel, 104.

Rhode Island, colony, 59, 77, 87-89, 107.

Dorr Rebellion, 354, 355.

Rhodes, James Ford, 530.

Rlbault, Jean (zhäN rē-bō'), 38.

Richmoud, in Civil War, 439, 448, 485.

River and harbor bills, $327,533$.

Roads, 223, 224, 290-295, 325, 356.

Ro-a-nōke' Island, 40.

Robertson, James, 144.

Robinson, Rev. John, 49.

Rochambeau (ro-shäv-bö'), Count de, 179.

Roch'ester, N.Y., founded, 290.

Rock'e-fel-ler, John D., 515.

Rocky Mountains, 21.

Rōoș'evelt, Theodore, 579-533, 560, 538, 555.

Ro'șe-crăns, Gen. William S., 445, 463-465.

"Rough Riders," 555.

Rule of $1756,251$.

Rumsey, James, 225.

Russian A merica, 308, 309, 499.

Rutledge, John, 149.

Ryşwick, treaty of, 122.

Sä'ga, Icelandic, 31.

St. Au'gus-tïne, 38, 74, 125, 126.

St. Clair, Gen. Arthur, 195, 243.

St. Croix settlement, 66 .

St. Germain (săs-zhâr-măs'), treaty of, 66.

St. Joseph, Ft., 124, 182.

St. Lěg'er, Col. Barry, 170.

St. Louis, 290, 423, 545.

St. Louis, Ft., 73.

St. Marys settlement, 56.

St. Pierre (săn-pyâr'), 131.

St. Xăv'i-er (sānt zăv'i-er) mission, 69.

Salem, Mass., 52, 98, 146.

Salt Lake City, 394.

Sä-mō'a Islands, 560, 561.

Sampson, Admiral William T., 554, 555.

San Francisco, 423.

San Gabriel, battles near, 365 .

Sän Ill-de-fōn'so, treaty of, 265.

Sän Juan (hoo-än') Island, 506.

San Juan de Ulloa (ool-yō'a), 39.
San Juan Hill, battle of, 555 .

Sän Mär-tïn', Gen. José de, 307.

Sän Säl-va-dör', 32.

Sandys, Sir Edwin, 48.

Sanitary Counmission, 470.

Sän'ta Än'na, General, 330, 363, 364, 365.

Santa Fé, $37,364$.

Santa $\vec{M} \ddot{a}-r{ }^{\prime} a, 32$.

Sän-tï-ä'go dẹ Cuba, 555.

Sān' to Đo-mīn'go, 33, 41, 507.

Saratō' 'ga, surrender at, 170.

Saụlt Ste. (sānt) Mā'rie, 69, 534.

Savannah, founded, $10 \mathrm{~S}$.

in Revolution, 177, 179.

taken by Sherman, 481 .

Say and Seal, Lord, 57 .

Saybrook, founded, 57 .

Sealawags, 504.

Sehe-něc'ta-dy, attacked, 122.

Schle y, Admiral Winfield s., 555.

Seho'field, Gen. John A., $4 \triangleleft 4$.

Schools, see Education.

Sehu $\bar{y}^{\prime}$ ler, Gen. Philip, 170.

Sehuyl'kill River, 172.

Sci-o'to Company, 193.

Scotch settlers, 80, 85, 91, 108.

Scotch-Irish settlers, 82, 91, 143, 193, 220.

Scott, Gen. Winfield, 283, 320, 364, 380, 411.

Seabury, James, 230.

Seafaring, colonial, 101, 108, 104.

Seal fishery difficulty, 546 .

Secession, 404-412, 415-41T, 488.

effect of, 493, 494.

Sectionalism, 336, 343-351, 566.

Sedition Act, 256, 257.

Sẻm'1-noles, 132, 307, 332.

Senate, 235.

Sěn'e-cas, 68 ; see Iroquois.

Separatists, 49, 60 .

Se-rä'pis, captured by Jones, 175 .

Seven Pines, battle of, 448.

Seven Years' War, 129-131.

Severalty Act, 526 .

Se-viēr', John, 144, 178, 194.

Sev'ille, 33, 74.

Sew'ard, William H., 377, 375, 403, 404, 409.

Secretary of State, $411,413,499$.

Sē $y^{\prime}$ mōur, Horatio, 502.

Shä'draeh, 378.

Shafter, Gen. WIlliam R., 555, 556.

Shakers, 231, 341.

Sharpsburg, battle near, 451.

Shays's Rebellion, 200.

Shenand $o^{\circ} a h, 439$.

Shenandoah valley, $449,479$.

Shěr'i-dan, Gen. Philip H., 479, 480, 485.

Shermal1, John, 401, 513, 585, 543.

Sherman, Roger, 157.

Sherman, Gen. William T., 481-484, 445, $446,461,465,477,478,486$. 
Sherman, march to the sea, 481, 482.

Sherman Act (silver), 543.

Sherman $\Lambda$ nti-Trust Law, 535.

Shi'loh, battle of, 445 .

Ships (1450) 14, (15S8) 41, (1700) 122 .

growth of shipping, 101, 392, 439.

subsidy acts, 392,541 .

See Steamboats.

Sǐ-ěr'ra Le-o'ne, 16.

Si-ěr'ra Ne-vii'da. 22.

Silver, coinage, $242,334,508,513,542,543$, 547.

mines, 427,500 .

Sioux Indians, 72, 501.

Sitting Bull, 501.

Six Nations, 123 ; see Iroquois.

Slade, William, 349.

Slater, Samuel, 225.

Slave insurrections, 100,347 .

Slave trade, colonial, $39,114,115$.

foreign, prohibited, 201, 274 .

in Constitution, 211.

in District of Columbia, prohibited, 377.

Slavery, abolished in North, 201, 202.

abolished in South, 455-460, 491-493.

abolished in territories, 456 .

agitation (1801-1807) 273, 274, (1808-1821)

298-301, (1830-1844) 347-351, (1846-1852)

$372-381$, (1853-1860) 383-392, 395, 397-

399 , (1860) 401-403, 406-410.

arguments for and against, 345-351.

colonial, 99, 100, 48, 85, 108 .

conditlon of slaves, 221, 343-345.

fugitive slaves, see Fugitive.

powers of Congress over, 388.

representation of slaves in Congress, 210, 211.

Spanish-American, 39.

Texan, 330, 331, 358.

Sli-dell', John, 361, 362, 441.

Smith, Caleb B., 412.

Smith, Gerrit, 347 .

Smith, Capt. John, 47, 94.

Smith, Joseph, 341.

Smuggling, colonial, 103, 104, 136.

Social reforms, 225, 226, 338-351.

Socialist party, $5 \mathrm{S3}$.

Soil, 17, 21, 29, 289.

Solid South, 520 .

Sons of Liberty, 140.

Sō'to, Ferdinando de, 87.

Sou-le', Pierre (pyâr), 384.

Sound Money Democrats, 547.

South America, discovered, 33.

independent, $307,308$.

Spanish in, 37 .

South Bend, settled, 290.

South Carolina, colony, 85, 108, 123, 125.

French in, 38.

nullification, 319-321.
South Carolina, Revolution in, 177-179.

secession, 404, 405, 411.

western claims, 182, 192.

South Dakota, 527, xxxi.

Spain, Black Warrior difficulty, 384.

boundary controversies with, $269,2 \pi 0$.

claim to North America, 42, 73, 75.

colonies, 36-38, 74, 124, 130, 307; see Cuba.

conditions in 1492, 17, 29.

discoveries, 31-33, 36, 37 .

in Revolution, 175, 181, 182, 184.

treaties (1795) 197, 252, (1819) 307, (1898) 557.

war with England, 38-43, 125, 126, 175, $181,182,184$.

war with U.S., 551-557, 563.

West Florida dispute, 269, 270.

Specie Circular, 334.

Specie payments, 508, 513.

Spice Islands, 16.

Spoils system, 227, 818 .

Spotswood, Gov. Alexander, 105.

Spottsylvania, battle of, 474 .

Stamp Act, 13s-141.

Stamp A ct Congress, 140.

Standard Oil Company, 515.

Standish, Capt. Miles, 51.

Stanton, Edwin M., 405, 411, 437.

Stanwix, Ft., treaty, 132.

Stark, Gen. John, 170.

Star-Spangled Banner, 283.

States, government of, $159,160,316,422,538$ $540,575$.

receive money from U.S., 335.

relations to U.S., 211, 213.

table of, $\mathbf{x x x}$.

See Secession, Reconstruction, etc., and names of the states.

Steamboats, 225, 274, 275, 293, 326, 392, 430, 517.

Steel making, 222, 518.

Stephens (stē venz), Alexander H., 406, 408, $409,486$.

Steu'ben, Baron von, 167.

Stevens, Thaddeus, 496, 498.

Stock watering, 517.

Stone, Lucy, 340.

Stone River, battle of, 446,452 .

Stony Point, captured, 17 .

Stōwe, Harriet Beecher, 379, 380.

Strā'ehey, William, 94.

"Strlct Construction," 246.

Strikes, 519, 536, 537, 572, 573, 580.

Stuart, Gen. J. E. B., 466, 477.

St $u \bar{y}^{\prime}$ ve-sant, Peter, 68, 78.

Suffrage, see Voters.

Sugar Act, 138.

Sullivan, Gen. John, 180.

Sumner, Charles, 389, 493, 507.

Sumter, Ft., 405, 411-415, 433, 466. 
Sumter, Gen. Thomas, 177, 186.

Supreme Court, 211, 213, 238, 304-306.

Sutter's Fort and Mill, 369.

Swan'sea, in Indian war, 86.

Swedish settlers, 68, 80, 91 .

Symmes Company, 193.

Taft, William H., 558, 559, 582.

Tallmadge, James, 299.

Tam'many Society, 226, 227.

Ta'ney, Roger B., 329.

Tap'pan, Arthur and Louis, 347.

Tariff, in the dependencies, 559 .

on imports from Cuba, 560 .

Tariff Acts (17S9) 241, (1816) 304, (1824) 311, 312 , (1828) 312, (1\$32) 319, 336, (1833) 321, (1842) 354, (1846) 359, (1857) 393, (1861) 441, (1883) 520, (1887-1894) 540544, (1897) 547.

Tarle'ton, Lleut.-Col. Bannastre, 177, 178.

Taxation, constitutional provisions, 211, 213. See Direct tax, Income tax, Tariff, etc.

Taylor, Zae $h$ 'ary, in Mexican War, 361, 362, 364.

President, 372-375.

Tea tax, 141, 142, 145, 174.

Te-cum' the, 278, 279, 282, 28.

Telegraph, electric, 429, 518 .

Telephone, 532, 570.

Teller Resolution, 553, xxix.

Temperance movements, 340 .

Tennessee, admitted, 245 , xxxi.

settled, 143, 144, 183, 193, 194, 289, 293, 301.

Tenure of Office Act, $497,538$.

Těr're Haute (höt'), settled, 290.

Territories, see Northwest Territory, Indiana, etc.

Territory, growth of, 566-568.

Tër'ry, Ell, 225.

Texas, $330,331,357-359,374$, $\mathbf{x x x i . ~}$

Thames (těmz), battle of, 282.

Thomas, Gen. George H., 464, 465, 444, 484.

Thomas, Senator, 299.

Three-fifths rule, 210, 211.

Ticondero ga, captured, 153.

tilden. Samuel J., 511, 512, 515.

Tippecanoe', battle of, 279 .

Tobaceo, in Virginia, 48, 49.

Toleration Act of 1649 (Md.), 56.

Tǒn'ty, 72 .

Toombs, Robert. 374, 40خ, 413.

Tōr-dẹ-sil'l'läs (-yäs), treaty of, 33.

Tories (loyalists), 166, 167, 177-180, 185, 186.

Tos-ca-nel'lï, 16.

Tous-săist $t^{\prime}$ L'O $u$-ver-tūre', 266.

Town government, colonial, 112, 113.

Town meetings, 112, 113, 51, 297.

Town'şhend, Charles, 137, 141, 142, 145.

Trade, see Commerce.

Trade routes, mediæval, 14-16.
Trades unions, 428, 519, 535-537, 572, 573.

Traf-al-gär', battle of, 272 .

Transportation, see liailroads, Canals, Steamboats.

Transylvania Company, 160, 161.

Treasury notes, 284.

Treaties, see Commercial treaties, and treaties by name.

Trent affair, 441.

Trenton, 20, 326 ; battle, 169.

Trip'o-lí, war with, 265.

Trist, N. P., $365,366$.

Trusts, 533, 535, 548, 571, 580, 581.

Try'on, Gov. William, 144.

Tu-lāne' University, 529.

Tür-gō $t^{\prime}$, Baron de, 136.

Turks, 15, 29.

Turner, Nat, 347 .

Turnpikes, 223.

Tuseara'was River, 183.

Tuscaro'ra Indians, 123.

Tu-tu-i'la, 561.

Twain, Mark, 530, 293.

Tweed Ring, 514, 515.

Tyler, John, 353-358.

Uncle Tom's Calin, 379, 380.

"Underground Railroad," 373.

Union, Franklin's plan of, 128.

of the thirteen colonies, 152,157, 159-163, 189.

See Secession.

United Colonies of New England, 61.

University of North Carolina, 228.

University of Pennsylvania, 116, 228.

University of Virginia, 339.

U'tah, 377, 394, 527, xxxi.

U'treeht, treaty of, 114, 125 .

Vall, Alfred, 429.

Vallan'digham, Clement L., 472.

Valley Forge, army at, 172.

Van Buren, Martin, 313, 318, 320.

President, 334, 335.

presidential candidate, $353,358,371,372$.

Vandā'lia Company, 144, 161.

Vanderbilt, Cornelius, 517.

Vanderbilt, William H., 533.

Ven-e-zue'la (-zwé'-) boundary, 546.

Ven'ice, trade routes of, 15.

Ve'ra Cruz (kroos), captured, 364.

Vermont', 109, 161, 227, xxxi.

Vèr-ra-za' no (-råt-sä'-), 37, 34.

Ve'şey, Denmark, 347.

Vespu'cius, Amĕr'icus, 35, 34.

Vicksburg, capture of, 460,461 .

Vin-cenneș', 124, 181.

Virginla, colony, 46-49, 60, 84, 127. named, 40.

Revolution in, 137, 140, 182, 183.

western claims, 182, 191, 192. 
Virginia Plan of Constitution, 207, 209, 210.

Virginia Resolutions (1798), 256.

Virginius, 507.

Voters, $110,262,316,539,540,574$. negro, 495, 496, 503-505, Ј40.

Wğ'băsh River, 24, 71.

Wäke Island, 561.

Walker, Robert J., 359.

War for Independence, 150-188.

War of 1812, 279-287.

Ward, Artemus, 425, 426.

Warren, Gen. Joseph, 154.

Wars, see Indian wars, and wars by name.

War'wick, Earl, 59.

War'wlek, R l., founded, 59.

Washingtou (city), 283, 422. treaty of, 506.

Washington (state), admitted, 527, xxxi.

Washington, Ft., 169.

Washington, George, blography, 173, 174, 208.

Constitution, 203, 207-209, 216.

death, 257.

farewell address, 253.

French and Indian War, 127.

President, 235-237, 243, 246, 249, 251-254

Revolution, 142, 151, 154, 167-174, 178, $179,184,186,187$.

writings of, $229,253$.

Washingto'nian societles, 340.

Wa-tau'ga settlement, 143, 144, 179.

Wat'ling (wǒt'-) island, 33.

Waxhaw Creek, battle of, 177 .

Wayne, Gen. Anthony, 177, 244.

Webster, Daniel, 322, 323, 812, 819, 356, 874.

Webster, Noah, 342.

Webster-A shburton treaty, 356.

Weed, Thurlow, 377.

Welles, Gideon, 412.

Wesley, John and Charles, 116.

West Florida, 265, 266, 269, 270 ; see Florida.

West Indles, 37, 60, 73.

West Point, in Revolution, 177.

Military Academy, 339.

West Virginla, 467, xxxi.

Western Reserve, 192, 244.

Western Union Telegraph Company, 518.

West'inghouse, George, 5:31.

Wey'moňth, George, 43.

Whal'ley, Edward, 77.

Wheelwright, John, 59.
Whig party, 353, 380, 381, 888, 389.

Whisky insurrections, 252, 253, 200.

Whisky Ring of 1875,507 .

White, John, 40.

White Plains, battle of, 169.

White' field, Rev. George, 116.

Whitman, Dr. Marcus, 356, 857.

Whitney, Eli, 221.

Whit'ti-er, John G., 348, 424.

Wigglesworth, Michael, 96.

Wigwam, 27, 501 .

Wilderness campaign, 474.

Wilderness Road, 160, 224.

Wilkes, Capt. Charles, 441.

Wilkinson, Gen. James, 270, 282.

Wil-lä'mette valley, 360 .

William IIl., 83, 93, 103, 107, 122.

William and Mary College, 98.

William Henry, Ft., eaptured, 129.

Williams, Roger, 58, 59.

Williamsburg, battle of, 448 .

Wilmington, Del., settled, 68 .

Wilınot Proviso, 363.

Wilson, William L., tariff, 543, 544.

Winthrop, John, 53, 54, 55, 94.

Wisconsin, 374, xxxi.

French in, 69, 71 .

Witchcraft in the colonies, $\mathbf{9 7}, \mathbf{9 8}$.

Wolfe, Gen. James, 130.

Woman suffrage, 540.

"Woman's Rights" movement, 340.

Wood, Gen. Leonard, 559.

Woolinan, John, 201.

Wright, Frances, 340 .

Writs of assistance, 136, 137.

Wy'eth, Nathaniel J., 356.

Wy-o'ming, 501, 527, xxxi.

Wyoming Valley, attack on, 179.

X. Y. Z. controversy, 255, 256.

Yale College, 93.

Yän'as-see Indians, 123.

Yellowstone valley, 501, 527.

York, Duke of, 78-81, 87.

Yorktown, surrender of, 179.

Yo-sěm'i-tē valley, 527.

Young, Brigham, 894.

Zen'ger, John Peter, 94.

Zol'licoffer, Gen. Felix K., 444.

$Z_{\mathcal{H}}$ 'nis (nyees), 25, 26. 
. 


$$
\text { , }
$$




\section{DAY USE}

RETURN TO DESK FROM WHICH BORROWED

\section{EDUCATION-PSYCHOLOGY}

\section{LBRARY}

This book is due on the last date stamped below, or on the date to which renewed.

Renewed books are subject to immediate recall.

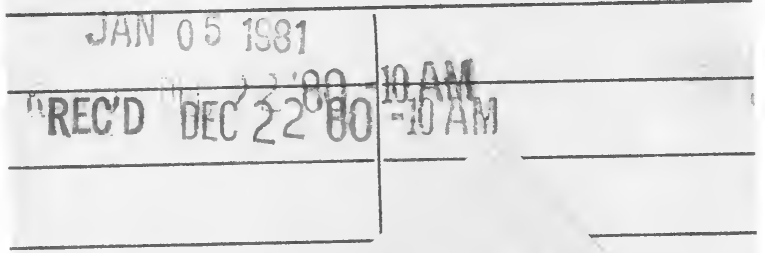




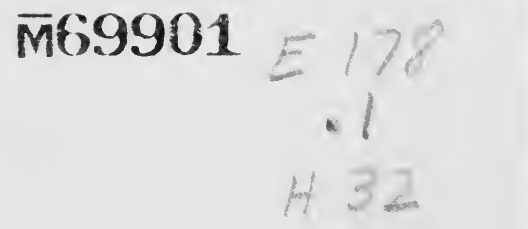

ratuc loos

THE UNIVERSITY OF CALIFORNIA LIBRARY 
